TULAJDONNEVEK ÉS SZÓTÁRAK 



\title{
Tulajdonnevek és szótárak
}

\author{
Szerkesztette: \\ FARKAS TAMÁS és SLÍZ MARIANN
}

ELTE Magyar Nyelvtudományi és Finnugor Intézet Magyar Nyelvtudományi Társaság

Budapest, 2020 


\section{Tulajdonnevek és szótárak}

Szerkesztette:

Farkas Tamás és Slíz Mariann

A tanulmányokat lektorálták:

Benő Attila, Berecz Ágoston, Bölcskei Andrea, Eőry Vilma, Farkas Tamás, Gerstner Károly, Hegedűs Attila, Hoffmann István, Juhász Dezső, Kiss Jenő, Kocán Béla, Laczkó Krisztina, Nagy Levente, Raátz Judit, Slíz Mariann, Szentgyörgyi Rudolf, Tóth Valéria, Uzonyi Pál, Vörös Ottó, Zoltán András

ISBN 978-963-489-236-6 (nyomtatott)

ISBN 978-963-489-237-3 (elektronikus)

DOI: $10.26546 / 4892373$

\section{Készült}

az ELTE BTK-n a Tématerületi Kiválósági Program és a Nemzeti Kulturális Alap támogatásával

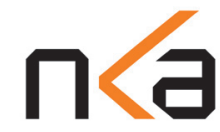

(C) A szerzők és a szerkesztők, 2020

A kötet elektronikus formában elérhető az ELTE repozitóriumában: https://edit.elte.hu az MTA REAL repozitóriumában: http://real.mtak.hu és a Magyar Elektronikus Könyvtárban: http://mek.oszk.hu

Müszaki szerkesztő: Szabó Panna

A borítótervezésben közremüködött: Forgács Katalin és Fülöp Evelin

Kiadta az ELTE Magyar Nyelvtudományi és Finnugor Intézete és a Magyar Nyelvtudományi Társaság.
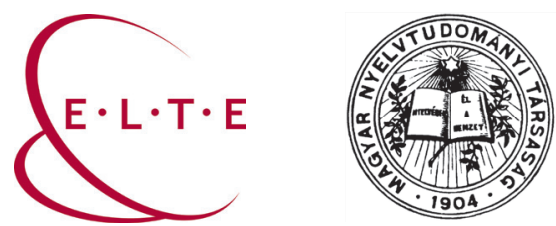


\section{Tartalom}

Elöszó

\section{Általános kérdések}

FARKAS TAMÁS: A tulajdonnevek szótári feldolgozásának alapkérdései

\section{Tulajdonnevek az egynyelvü szótárakban}

GERSTNER KÁROLY: Tulajdonnevek a történeti és etimológiai szótárakban 39

JUHÁSz DEZSŐ: Tulajdonnevek a tájszótárakban 53

MÁRTONFI ATTILA: Tulajdonnevek a helyesírási szótárakban 63

\section{Tulajdonnevek a többnyelvű szótárakban}

FÁBIÁN ZSUZSANNA: Tulajdonnevek az olasz-magyar szótárakban...................... 95

SZILÁGYI-KÓSA ANIKÓ: Tulajdonnevek a kulturális szótárakban ........................... 109

\section{Tulajdonnévszótári típusok}

KovÁCs ÉVA: A történeti helynévszótárak ....................................................... 133

N. FODOR JÁNOS: A történeti személynévszótárak ............................................ 145

SLÍZ MARIANN: A laikus keresztnévszótárak..................................................... 165

Magyar tulajdonnevek és magyarázataik más nyelvek szótáraiban

BENŐ ATTILA: Magyar tulajdonnevek a román névszótárakban ........................... 187

BAUKO JÁNOS: Magyar tulajdonnevek a cseh és szlovák névszótárakban............... 199

SEBESTYÉN ZSOLT: Magyar tulajdonnevek az ukrán névszótárakban ...................... 209

Tulajdonnevekkel összefüggő köznevek a szótárakban

BÁBA BARBARA: A Magyar földrajzi köznevek táráról ....................................... 223

TAKÁCS JUDIT: Köznevesült tulajdonnevek szótárainkban .................................. 231

Kötetünk szerzői ........................................................................................ 241 


\section{Contents}

Foreword

\section{General questions}

FARKAS, TAMÁs: The fundamental questions of processing proper names in dictionaries

\section{Proper names in monolingual dictionaries}

GERSTNER, KÁROLY: Proper names in historical and etymological dictionaries ...... 39

JuHÁSZ, DEZSŐ: Proper names in Hungarian dialect dictionaries .......................... 53

MÁRTONFI, ATTILA: Proper names in Hungarian spelling dictionaries ................... 63

\section{Proper names in multilingual dictionaries}

FÁBIÁN, ZSUZSANNA: Proper names in Italian-Hungarian bilingual dictionaries ..... 95

SZILÁGYI-KÓSA, ANIKÓ: Proper names in cultural dictionaries .............................. 109

\section{The types of name dictionaries}

KovÁCS, ÉVA: Historical place name dictionaries ........................................... 133

N. FODOR, JÁNOS: Historical personal name dictionaries .................................... 145

SLÍZ, MARIANN: Non-professional given name dictionaries ............................... 165

Hungarian proper names and their definitions in the name dictionaries of other languages

BENÖ, ATTILA: Hungarian proper names in Romanian name dictionaries ............. 187

BAUKO, JÁNOS: Hungarian proper names in Czech and Slovakian name dictionaries .... 199

SEBESTYÉN, ZSOLT: Hungarian proper names in Ukrainian name dictionaries ........ 209

\section{Common nouns connected to proper names in dictionaries}

BÁBA, BARBARA: On the Dictionary of Hungarian geographical common nouns ..... 223

TAKÁCS, JUDIT: Common nouns derived from proper names in Hungarian dictionaries ... 231

Authors of the volume 
FARKAS TAMÁS - SLÍZ MARIANN szerk., Tulajdonnevek és szótárak. ELTE Magyar Nyelvtudományi és Finnugor Intézet - Magyar Nyelvtudományi Társaság, Budapest, 2020. 7-8. DOI: 10.26546/4892373.1

\section{Előszó}

1. A tulajdonnevek és a szótárkészítés kapcsolatát gyakran jellemzi problematikusként a vonatkozó szakirodalom - eleve nem függetlenül a tulajdonnevek nyelven belüli sajátos helyének, szerepkörének, jelentésének kérdéseitől. Míg egyes szótárak elvszerüen igyekeznek kizárni a tulajdonneveket anyagukból, más szótárak megengedőbbek, esetleg kifejezetten befogadóak a tulajdonnevek irányában, s léteznek ezek típusainak feldolgozására specializálódott tulajdonnévszótárak is. A vonatkozó szótárak profilja, válogatási szempontjai, anyagának elrendezése és kidolgozásának módja ugyancsak többféle lehet, s ezek szintén számos megoldandó elméleti és gyakorlati kérdést vetnek fel a tulajdonnevek lexikográfiájával kapcsolatban.

A jelen tanulmánykötet ennek a sajátos alkalmazott nyelvészeti, illetve alkalmazott névtani problémakörnek a vizsgálatára fordítja figyelmét, a magyar névkutatás és a magyar szótártan vonatkozó fontosabb munkáit, eredményeit és jellemzőit állítva a középpontba. Célja, hogy bár nem teljes, de a korábbiaknál átfogóbb, vagy legalábbis sokszínűbb áttekintést nyújtson e területről, fontosabb és jellemzö szótári munkáiról, összetett problematikájáról, s hogy bizonyos vonatkozásokban a magyar tulajdonnevek szótári feldolgozásának szükebb értelemben vett témakörén túli kitekintést nyújtson olvasóinak.

2. A kötet első nagy fejezete, mely kivételesen egyetlen tanulmányból áll, a tulajdonnevek szótári feldolgozásának alapkérdéseit tárgyalja. FARKAS TAMÁS azt mutatja be, hogy miképpen kaphatnak helyet a tulajdonnevek a referenciamüvek alaptípusaiban, különösen a szótárakban és a szótártan történetében; s hogy milyen elvi és gyakorlati kérdésekkel, illetve lehetőségekkel kell számolniuk a szótárak készítőinek általában egy nyelv tulajdonneveinek a szótári feldolgozása során.

Az egynyelvủ szótárak fő típusainak körébe nyújt betekintést a kötet második nagy fejezete. GERSTNER KÁROLY tanulmánya azt tárgyalja, hogy miképpen jelennek meg a tulajdonnevek a magyar nyelv történeti és etimológiai szótáraiban, e két, egymással érintkező szótártípus hazai történetében. Hasonlóképpen vizsgálja JUHÁSz DEZsŐ a tulajdonnevek megjelenését a magyar tájszótárak (s részben a nyelvatlaszok) anyagában. MÁRTONFI ATTILA pedig egy speciálisabb szótártípus, a magyar helyesírási szótárak történetében követi nyomon a tulajdonnevek egyes típusainak, illetve példáinak felvételét.

A többnyelvű szótárak lexikográfiájának kérdéskörét érintik a kötet harmadik nagy fejezetének tanulmányai. FÁBIÁN ZsUZSANNA az olasz-magyar szótárak fontosabb képviselőinek elemzésén keresztül mutatja be azokat a kérdéseket, amelyek a kétnyelvű szótáraknak a tulajdonnevek szótári feldolgozásával kapcsolatos feladatait és megoldásait jellemzik. SZILÁGYI-KóSA ANIKÓ pedig egy speciális, az enciklopédia müfajához közel álló típus, az ún. kulturális szótárak müfajában vizsgálja a tulajdonnevek kezelésének további lehetőségeit és szempontjait.

A negyedik nagy fejezet a magyar tulajdonnévszótárak föbb típusainak körébe vezeti olvasóját. KovÁCS ÉVA tanulmánya a történeti helynévszótárak témaköréröl, annak fontosabb képviselőiről ad történeti ívü s napjainkig tartó áttekintést és jellemzést. 
N. FODOR JÁNOS írása a történeti személynévszótárak állományát mutatja be hasonló szempontból és tematikus jelleggel, az egyes nyelvtörténeti korszakok szerinti áttekintésben. SLÍZ MARIANN pedig a laikus keresztnévszótárak eddig kevés figyelemre méltatott témakörét és problémáit teszi módszeres elemzés tárgyává tanulmányában.

A kötet ötödik nagy fejezete a magyar tulajdonnevek lexikográfiai feldolgozását illető szokásos szakmai látókört igyekszik tovább bővíteni. A fejezet három tanulmánya arra fordítja figyelmét, hogy milyen módon és mértékben, illetve milyen (etimológiai) magyarázatokkal jelenik meg a magyar tulajdonnévanyag a szomszédos országok, illetve (állam)nyelvek szótáraiban. BENŐ ATTILA a román, BAUKO JÁNOS a cseh, illetve szlovák, SEBESTYÉN ZSOLT pedig az ukrán tulajdonnévszótárak anyagában teszi vizsgálatának tárgyává ezt a kérdést.

A tanulmánykötet utolsó nagy fejezete a tulajdonnevek állományával összefüggő köznevek irányába tágítja tovább a témakör kutatását. BÁBA BARBARA írása a magyar földrajzi köznevek szótári feldolgozásának már megvalósult példáját mutatja be. TAKÁCS JUDIT tanulmánya pedig a köznevesült tulajdonnevek szótárakba foglalásának kérdéskörét és további lehetőségeit tárgyalja.

3. A kötetben megjelent tanulmányok többsége elöadásként elhangzott a 2017. november 29-én, az ELTE Bölcsészettudományi Karán megtartott, Alkalmazott Névkutatás 2017. Nevek és szótárak címü konferencián. A konferencia szervezői az ELTE Magyar Nyelvtudományi és Finnugor Intézete, a KRE Magyar Nyelvtudományi Tanszéke és a Magyar Nyelvtudományi Társaság Névtani Tagozata voltak. A konferencia-előadások java, további tanulmányokkal kiegészülve, alkotja a jelen tanulmánykötet anyagát.

Az egyes tanulmányok szerzői a magyar nyelvtudomány, különösképpen a névkutatás, illetve a lexikográfia magyarországi és határon túli müvelői, jórészt egyúttal szótárak szerkesztői, szerzői. A kötetben szereplő 14 tanulmány anonim lektorálásáról két-két (olykor három) szakember gondoskodott, a kötet szakmai színvonalát biztosítandó. A szerzők rövid bemutatását a kötet végén, a további közremüködők felsorolását a kötet címnegyedében adjuk közre. Munkájukat ezúttal is köszönjük.

A kötet elkészítését, illetve hagyományos és szabad hozzáférésü, online megjelentetését az ELTE Bölcsészettudományi Karán megvalósuló Tématerületi Kiválósági Pályázat, valamint a Nemzeti Kulturális Alap pályázati támogatása tette lehetővé. Támogatásukért szintén köszönettel tartozunk.

A szerkesztők

\section{Foreword}

The volume entitled Proper names and dictionaries deals with a special field of applied linguistics or more exactly, applied onomastics. Studying the lexicographic processing of proper names, its types, opportunities, and wider problems, it focuses on the results of Hungarian onomastics and lexicography. The thematic chapters contain 14 peer-reviewed papers from authors who represent various scientific institutions of contemporary Hungarian linguistics. 
Általános kérdések 

FARKAS TAMÁS - SLÍZ MARIANN szerk., Tulajdonnevek és szótárak. ELTE Magyar Nyelvtudományi és Finnugor Intézet - Magyar Nyelvtudományi Társaság,

Budapest, 2020. 11-36. DOI: 10.26546/4892373.2

\section{A tulajdonnevek szótári feldolgozásának alapkérdései*}

1. A tanulmány témája. A szótárkészítés és a tulajdonnevek kapcsolatát gyakran szokás a probléma és problémák szavakkal jellemezni. Többek közt, például: „A tulajdonnevek - természetüknél fogva - állandó problémát okoznak a szótárkészítőknek" (PRÓSZÉKY 1997: 332); „A nevek szótári beillesztésének vagy azok kihagyásának problémája magával a lexikográfiával egyidős" (BROZOVIĆ RONČEVIĆtől idézi GLUŠACDOMORAT-DOMAZET 2018: 98); ,a szótárkészítés müvészetének egyik legnehezebben kezelhető problémája [...] a köznevek és a tulajdonnevek elhatárolása"1 (NICOLAISEN 1995: 386; saját fordítás - F. T.).

A jelen tanulmány ezt a sajátos - alkalmazott nyelvészeti, illetőleg alkalmazott névtani (vö. RAÁTZ 2015) - kérdéskört, a tulajdonnevek lexikográfiai feldolgozásának problematikáját tárgyalja áttekintő igénnyel. Figyelmét egyrészt a problémakör általános kérdéseire fordítja, másrészt konkrétabban szól a magyar lexikográfia és a magyar névkutatás vonatkozó eredményeiröl és sajátságairól.

A tanulmány bevezetésképpen felvázolja, hogy milyen módon jelenik meg e témakör a nemzetközi, s föleg a hazai lexikográfiai, illetve névtani szakirodalomban. Szól arról, hogy miképpen kapnak helyet a tulajdonnevek a referenciamüvek alaptípusaiban, különösen a szótárakban, s egyúttal a szótártan történetében.

Mindezeket követően fordítja figyelmét a tulajdonnevek szótári feldolgozásának elvi és gyakorlati lehetőségeire. Szól arról, hogy milyen fenntartások fogalmazódhatnak meg általában a neveknek a szótárakba való felvételével kapcsolatban. Számba veszi, hogy potenciálisan milyen különböző nyelvi, azaz nyelvészeti és névtani szempontú (s akár enciklopédikus jellegü) információk kapcsolódhatnak a tulajdonnevekhez a szótárak anyagában (bár egy-egy szótár ezeknek természetesen mindig csak egy részét foglalja magában). Tárgyalja azt, hogy milyen szempontok befolyásolják a nevek felvételét általában az egynyelvü, illetve a kétnyelvü szótárakba. Ezt követően szól a névszótárak lehetséges típusairól, majd a névszótári tartalmak, illetve struktúra meghatározásának speciális kérdéseiröl.

Összefoglalásképpen megállapítható, hogy a tulajdonnevek szótári feldolgozásai a hazai és a nemzetközi tudományosság, illetve a nagyközönség szempontjából egyaránt fontosak. Ezen irányok kapcsán is utal a tanulmány a magyar névtani lexikográfia aktuális helyzetére. Végezetül - bár esetünkben inkább a jövő lehetőségeként - igyekszik felhívni a figyelmet az elektronikus, illetve online névszótárak potenciális előnyeire, $\mathrm{s}$ általában a lexikográfiai feldolgozásokkal kapcsolatos tudományszervező munka, illetve tudománytámogatás fontosságára.

* Készült az ELTE Bölcsészettudományi Karán a Tématerületi Kiválósági Program támogatásával.

${ }^{1}$,What they were faced with was one of the most intractable problems in the art of dictionary making, i. e. the separation of the nouns and names." 


\section{A problémakör a modern lexikográfiai és a névtani szakirodalomban}

2.1. A nemzetközi szakirodalom reprezentatív munkáiban. A tulajdonnevek szótári kezelésének kérdéskörével egyaránt foglalkozik a nemzetközi lexikográfiai és névtani szakirodalom. A sokszerzős reprezentatív nemzetközi kézikönyvek sorából a Walter de Gruyter kiadó Handbücher zur Sprach- und Kommunikationswissenschaft (HSK.) sorozatának lexikográfiai és névtani kötetei (HAUSMANN et al. Hrsg. 1989-1990, EICHLER et al. Hrsg. 1995-1996), illetve az Oxford University Press (OUP) kézikönyvsorozatának megfelelő kiadványai (DURKIN ed. 2015, HoUGH ed. 2016) egyaránt önálló fejezetben, illetve egymást kiegészítő fejezetekben tárgyalják a témát (HSK. 5/2: SEIBICKE 1990a és 1990b, GREULE 1990, SCHMID 1990; HSK. 11/1: REICHARDT 1995, MÖLler 1995, EICHLER 1995; OUP: STYLES 2015, MCCluRE 2015, ill. GRANT 2016). Az említett kézikönyvekbeli fejezetekben egyrészt a témakör általános és elméleti kérdéseiről esik szó, másrészt és különösen pedig egyes konkrét - (elsősorban) a brit, illetve a német (és szláv) - területek hagyományos és aktuális névlexikográfiai gyakorlatának bemutatásáról. (A HSK. névtani kézikönyvében további fejezetekben is felmerülő módon: a nemzetközi névkutatás alapvető intézményrendszerét és tényezőit bemutató, illetve a köznevesülés összefüggéseit tárgyaló fejezetek sajátos alpontjaiként; VAN LANGENDONCK 1995: 280, NiCOLAISEN 1995: 386-388.) További példaként a szláv nyelvek névkutatására is kitekintve: a nagy szláv onomasztikai konferenciák egyikének egyenesen központi témája volt a névszótárak kérdésköre (vö. MAJTÁN red. 1983), de a témakör akár egy karcsú névelméleti összefoglaló munkában is önálló fejezetet érdemelhetett ki (kétnyelvü kiadásban 1. BLANÁR 2009: 58-62, ill. 131-135). Bár a tulajdonnevek lexikográfiájának problematikája mindkét szakterületen a kevésbé frekventált témák közé tartozik, az említett szakirodalmi tételek e kérdéskör relevanciáját és figyelemre érdemes voltát is jól jelzik számunkra.

2.2. A hazai lexikográfiai szakirodalomban. Ha témánkat A magyar szótárirodalom bibliográfiája címü - az 1. kiadást követően egy 2., javított és bővített kiadásban is megjelent -, átfogó igényü kiadvány alapján közelítjük meg (MAGAY szerk. 2004, 2011), akkor a magyar névszótárak témakörét hagyományosan alulreprezentáltnak, illetve kidolgozatlannak láthatjuk a hazai lexikográfia szempontjából. E bibliográfia 1. kiadása mindössze 7 , illetve 8 névszótárat tartalmaz, a különböző szótári alaptípusok (etimológiai, helyesírási, kiejtési, továbbá egyéb szótárak, szótárszerü müvek) kategóriáiba sorolva be őket (MAGAY szerk. 2004: 34, 44, 46, 48-50). A bibliográfia újabb kiadása ugyanakkor - a szerkesztőkhöz érkezett javaslatok nyomán - már nagyságrendekkel gazdagabb és árnyaltabb képet kínál. Egyrészt azáltal, hogy további névszótárakat vesz fel anyagába - részben időközben megjelent, részben a korábbi kiadásból kimaradt szakmunkákat -, s így már jó másfél tucat különböző névszótárat tartalmaz. Másrészt annak révén, hogy e tételek nagyobb részét immár egy önálló, Névszótárak címü kategóriában adja közre (a 2. kiadás egyetlen új kategóriája az egynyelvü szótárak körében: MAGAY szerk. 2011: 63-65, vö. még 44, 56-57, 59, 93).

Mindazonáltal a javított és bővített kiadás sem tudja igazán megoldani a felmerülő problémákat. Bár a szerkesztői szándék szerint a kötet rendszerezése „fölér egy szakszerü szótártipológiával” (MAGAY szerk. 2011: 19), a névszótárak támasztotta általános, illetve konkrét kihívásokat nem sikerül következetesen kezelnie, hiszen ugyanazon névszótári típus képviselői részben, illetve több esetben különböző szótártípusok alá 
sorolva kapnak helyet benne. Megjegyezhetjük továbbá, hogy a névszótárak, de különösen a névszótárszerü munkák köre - nem szólva itt a laikus és dilettáns utónévkönyvek bőséges kínálatáról - jóval gazdagabb a valóságban (vö. FARKAS 2012: 322-327, SLÍZ 2020a: 182). Az említett tényezők a névszótárak problémakörének több szempontból sajátos, nem könnyen kezelhetö, s akár nem is egyértelmüen megoldható kérdéseivel állnak összefüggésben.

Az utóbbi évek magyar lexikográfiai szakirodalmának egyes fontos munkáiban ugyanakkor célzott figyelmet kapott a tulajdonnevek szótári kezelésének kérdésköre is. A magyar egynyelvü szótárak, illetve szótártípusok történetét feldolgozó idegen nyelvü, többszerzős tanulmánykötetben (FÁBIÁN ed. 2012) külön fejezetet alkot a tulajdonnévszótárak témaköre (FARKAS 2012); egy további, tematikus szótártani tanulmánykötetben (FÁBIÁNSZÖLLÖSY szerk. 2015) pedig két kiváló írás is a tulajdonnevek bizonyos szótártípusokban való kezelésének problematikáját vizsgálja (egy- és kétnyelvü szótárakban, illetve írói szótárakban: UZONYI 2015, MÁRTONFI 2015).

2.3. A hazai névtani szakirodalomban. A magyar, illetve a külföldi névszótárak palettájának különböző részleteit - tematikus vagy a megjelenés ideje szerinti rendben, átfogó igénnyel - különösen KISS LAJOS és HAJDÚ MIHÁLY igyekezett több alkalommal is szemlézni és felmérni. A névkutató és lexikográfus KISS LAJOS egyrészt a magyar névtudományi konferenciákon elhangzott, az európai névkutatás fejlődését felvázoló plenáris előadásaiban adott következetesen számot a nemzetközi színtéren megjelent fontosabb névszótárakról és névtárakról (KISS 1970a, 1989), másrészt a helynév-etimológiai szótárak, illetve nyelvtörténeti szótáraink egyes típusai kapcsán tekintette át a fontosabb müveket és jellemzőiket (KISS 1991, 1994). HAJDÚ MIHÁLY elsősorban a személynévszótárak nemzetközi és hazai irodalmára fordított kiemelt figyelmet: e témakörnek szentelte a Magyar Névtani Dolgozatok egyik első füzetét (HAJDÚ 1977), egy újonnan megjelent névszótár ismertetését is széles látókörű szemlévé tudta alakítani (HAJDÚ 1998), s névtani nagymonográfiájában (HAJDÚ 2003: 327-330) és családnévszótárának bibliográfiájában (CsnE. 517-520) is részletes áttekintésüket adta az olvasónak. Számos hazai és külföldi névszótár, illetve szótárszerü munka ismertetése lát továbbá napvilágot a hazai szakfolyóiratok, elsősorban a Névtani Értesítő hasábjain is.

Több névszótárunk szerzője közölt cikket előzetes elképzeléseiről, az előmunkálatokról, a felmerülö kérdésekről tervezett vagy már készülőben lévő munkája kapcsán, több esetben próbaszócikkekkel együtt (pl. KISS 1970b, KÁZMÉR 1987, HAJDÚ 2008; akár később el nem készült szótárak esetében is, pl. PAPP 1960); ugyanők más munkáikban egyes kapcsolódó névtani problémákat igyekeztek tisztázni. Az elkészült és megjelent névszótárak pedig egy sor különböző lexikográfiai problémára adtak választ immár a gyakorlatban is. A kérdéskör átfogó jellegü elméleti kérdései viszont kevésbé kaptak teret szakirodalmunkban.

2.4. A témakör kutatásának újabb hazai eredményei. Általánosságban elmondható tehát, hogy a tulajdonnevek szótári feldolgozásának problematikája átfogó igényü, célzott figyelemben az utóbbi időkig nemigen részesült a hazai kutatásokban. Ezért állította az onomasztika és a lexikográfia e közös érdeklödési területét egynapos konferenciájának középpontjába az Alkalmazott Névkutatás címü konferenciasorozat 2017 öszén megtartott, Nevek és szótárak című alkalma. E rendezvény előadásainak többsége, további tanulmányokkal kiegészülve, biztosítja a jelen írást is magába foglaló tanulmánykötet 
(FARKAS-SLÍZ szerk. 2020) anyagát, mely ilyen értelemben újszerü kezdeményezésként vállalkozik e témakör módszeresebb vizsgálatára.

E kötet tanulmányait is számításba véve, a tulajdonnevek szótári kezelését illetően rendelkezésünkre áll jelenleg több alapvető szótártípusunk hazai irodalmának áttekintése. Az egynyelvű szótárak közül a történeti és etimológiai szótárak (GERSTNER 2020), a tájszótárak (JUHÁSZ 2020) és az írói szótárak (MÁRTONFI 2015), valamint a helyesírási szótárak (MÁRTONFI 2020), továbbá a többnyelvü szótárak vonatkozó gyakorlatának feldolgozása (különböző nyelvpárok vonatkozásában, német és orosz: UZONYI 2015: 76-82, olasz: FÁBIÁN 2020; illetve a kulturális szótárak típusában: SzILÁGYI-KÓSA 2020). (A legalapvetőbbnek tekinthető egynyelvü szótártípus, az értelmező szótárak kapcsán kevés mondanivalónk akadna, amint arról a későbbiekben még lesz szó.)

A fentebb már említett, angol nyelvü összefoglaló (FARKAS 2012) mellett a tulajdonnévszótárak több fő típusáról készült hasonló összegzés: tudománytörténeti jellegű áttekintés a történeti helynévszótárakról (KOVÁCS 2020, vö. még KERTÉSz 2000), illetve a történeti személynévszótárakról (N. FODOR 2020), s több tanulmány született a keresztnévszótárak egyes típusairól, illetve konkrét problematikájáról (általában: FARKAS 2006, a laikus keresztnévszótárakról: SLíz 2020a és 2020b, az online utónévkeresőkről: FARKAS 2019). Témánkhoz kapcsolódóan említendők azok a feldolgozások is (többségük a jelen kötetben), amelyek a környező országok és nyelvek szótáraiban vizsgálják meg a magyar tulajdonnevek közreadásának, illetve magyarázatainak módját (cseh, illetve szlovák: BAUKO 2020, ukrán: SEBESTYÉN 2020, román: BENŐ 2020, horvát: GLUŠACDOMORAT-DOMAZET 2018).

Végezetül pedig, a tulajdonnevek és lexikográfia kérdésköréhez tágabb értelemben kötődnek azok a tanulmányok (1. a jelen kötet anyagában), amelyek a tulajdonnevek állományához kapcsolódó bizonyos közszói kategóriák: a köznevesült tulajdonnevek (TAKÁCS 2020), illetve a földrajzi köznevek (BÁBA 2020) lehetséges szótári feldolgozásának témájával foglalkoznak.

\section{Tulajdonnevek a szótárban, enciklopédiában és enciklopédikus szótárban}

3.1. Szótár, enciklopédia és enciklopédikus szótár. A szótár és az enciklopédia (lexikon $)^{2}$ egyaránt szócikkeket tartalmaz, melyek tipikusan betürendben követik egymást. A felszíni hasonlóság mögött azonban alapvetö különbség áll: a szótár a nyelv, az enciklopédia pedig a világ alkotóelemeit igyekszik számba venni és bemutatni. A két megközelítés, illetve a két kategória között ugyanakkor nincs éles határ (vö. az Encyclopædia Britannica vonatkozó frappáns megfogalmazásával; idézi PAJZS 2015: 120). Ezt jelzi az enciklopédikus szótárként számon tartott típus - a „szótárba oltott enciklopédia” kategóriája - is, melynek alapja a szótári feldolgozás, bizonyos enciklopédikus információkkal kiegészülő módon. (A problémakörhöz l. FÁBIÁN-SzÖLLÖSY szerk. 2015 több tanulmányát, elsősorban - a tulajdonnevek kérdésére külön kitérve - FÁBIÁN 2015, kül. 28-33.) Egy-egy konkrét mü profilját a várható felhasználói igények, illetve a szerkesztői-kiadói

${ }^{2}$ A referenciaművek három fö típusát a szótár, enciklopédia (nem különböztetve meg a lexikontól), valamint enciklopédikus szótár terminussal jelölöm a továbbiakban. A tipológia és a terminológia ennél jóval problematikusabb a szakirodalomban (1. FÁBIÁN-SzÖLLÖSY szerk. 2015), ennek részleteivel itt azonban nem célom foglalkozni. (A fogalom- és terminushasználatban magam alapvetően FÁBIÁN 2015-öt tekintem iránymutatónak.) 
célok határozzák meg. A kidolgozás módja, mélysége, az egyes információtípusok aránya igen változó lehet, sokféle jó megoldást téve lehetővé a gyakorlatban.

3.2. Tulajdonnevek a referenciaművek egyes típusaiban. A szókészlet és a névkészlet (lexikon és onomasztikon) közt hasonlóságok, illetve kapcsolatok, kölcsönös meghatározottságok állnak fenn. Lényegesek szempontunkból a (köz)szó és a (tulajdon-) név jelentése közötti különbségek is, amelyeknek szintén megvannak a maguk lexikográfiai következményei.

A tulajdonnevekhez kapcsolható információk a referenciamüvekben egyfelől a név nyelvi oldalához (formájához, használatához, jelentéséhez) kötődhetnek, másfelöl a tulajdonnév konkrét, egyedi jelöltjéhez, enciklopédikus jellegü tartalmakként. Előbbiek a nevek esetében is a szótári, míg utóbbiak az enciklopédikus (lexikonszerü) feldolgozást igénylik. A minimális szótári értelmezéshez ugyanakkor az enciklopédikus jellegü információk egy részére is elengedhetetlenül szükség lehet, ami eleve nem idegen a szótár müfajától sem (MÁRTONFI 2015: 85). Mindezek kapcsán itt érdemes még megjegyeznünk: a szótár/enciklopédia különbségtétel szempontjából egy konkrét mü címe nem feltétlenül számít mérvadónak (vö. FÁBIÁN 2015: 19). Tartalmuk és jellegük alapján például az Irodalmi alakok nagy lexikona (TÓTFALUSI 2010-2011) ténylegesen enciklopédia, az igen gazdag tartalmú Keresztnevek enciklopédiája (KnE.) enciklopédikus szótár, a Családnevek enciklopédiája (CsnE.) pedig szótárnak tekinthető szakmunka. (Az utóbbi munkacíme egyébként: Mai családneveink lexikona, s az eredeti elképzelés szerint a híres névviselőkre vonatkozó, azaz enciklopédikus jellegü adatokat is közölt volna; vö. HAJDÚ 2008. A végső címét nyilván az egy évvel korábban ugyanezen kiadónál megjelent KnE. mintája határozhatta meg.)

A különböző szótárakban jobbára nem vagy csak kevéssé találunk tulajdonnévi szócikkeket, míg az enciklopédiákban ezek könnyen a többséget is alkothatják. Érdemes azonban már most elöre bocsátanunk: ha a tulajdonnevek nyelvi jelek - ami, úgy vélem, nem vonható itt kétségbe -, akkor szótári módon is kidolgozhatóknak kell lenniük. Igaz, ez a szótári kidolgozás egy sor sajátos kérdést vet fel (melyekről a későbbiekben bővebben esik majd szó). A tulajdonneveket elsősorban és célzottan speciális típusú szótárak, a névszótárak dolgozzák fel.

Az adott tulajdonnév fajtája, ha nem is egyértelmüen határozza meg, de jelentős mértékben befolyásolhatja a szótári/enciklopédikus feldolgozás valószínüségét. Az irodalmi müvek szereplőinek tulajdonnevei például inkább enciklopédikus feldolgozásban részesülnek (pl. TóTFALUSI 2010-2011), melyekben egyébként szintén elöfordulhatnak szótári jellegü információk (pl. Rejtő Jenő humoros névadásának a regényekből kiolvasható motivációi kapcsán; 1. RejtőLex.). Az írói neveknek is elképzelhető azonban szótári jellegü feldolgozása (vö. SEIBICKE 1990b: 1293-1294, 1. pl. PARROTT 2004), amellett, hogy írói nevek az írói szótárakban is helyet kaphatnak (bár ezt írói szótára válogatja; bővebben 1. MÁRTONFI 2015: 94-98). A keresztnevek ugyanakkor - már ha nem konkrét személyeket jelölnek - az enciklopédiákban kevésbé fordulnak elö, bizonyos szótártípusokban viszont - például a kétnyelvü szótárakban (vö. UZONYI 2015: 77-79, 81), s eleve a leggyakoribb névszótári típus, az utónévkönyvek anyagában - jellemzően megtalálhatóak.

3.3. Tulajdonnevek a szótárakban. A tulajdonnevek címszóként való felvételével kapcsolatban a szótárkészítők, illetve az egyes szótárak elött alapvetöen négyféle lehetőség áll (vö. MUFWENE 1988: 269; az egynyelvű szótárak alapvető típusainak körében, magyar viszonylatban 1. GERSTNER 2020, JUHÁsz 2020, MÁRTONFI 2015). Mégpedig: 
1. A szótár nem veszi fel, hanem elvszerűen kihagyja a tulajdonneveket. Ez az eljárásmód jellemzi elsősorban és általában a „leginkább esszenciális szótári műfajú” modern értelmező szótárakat (bár e szempontból a nemzetközi gyakorlat, illetve hagyomány sem egyöntetü, vö. UZONYI 2015: 72-76). Ezt indokolhatja egyebek mellett az a fajta nem ritka megközelítés, mely szerint a tulajdonneveket azonosítani lehet, de ,a szó szoros értelmében" értelmezni nem (MÁRTONFI 2015: 91). A további egynyelvü szótártípusok körében már változatosabb a gyakorlat, bár ezeknél is - különösen a modernebb munkákban - általában a tulajdonnevek mellőzése látszik jellemzőbbnek: többnyire külön indoklás nélkül, „,hagyományosan”, esetleg terjedelmi okokra hivatkozva, ugyanakkor nem feltétlenül teljes következetességgel valósítva meg azt (vö. UZONYI 2015: 72-73, 81).

2. A szótár nem hagyja ki elvszerüen, viszont külön függelékbe vagy pótkötetbe utalja a tulajdonneveket (illetőleg azok bizonyos típusait), ami a ritkább megoldási módok közé tartozik. Ez lehet a szükségszerü megoldás a később, kiegészítőleg elkészült munkák esetében, mint a PÁPAI PÁRIZ FERENC latin-magyar szótárának 1767. évi, BOD PÉTER-féle kiadásába bekerült latin-magyar keresztnévjegyzék esetében (1. FEKETE 1991). Ezt az utat választották később eleve, elviekben a 19. század végén a Magyar nyelvtörténeti szótár (NySz.) és a Magyar tájszótár (MTsz.) szerkesztői, az előszavakban ígért függelékek azonban nem készültek el. Így járt el viszont ténylegesen is a Régi magyar glosszárium (Gl.), függelékben közölve a forrásanyagában előforduló tulajdonneveket; A magyarországi középkori latinság szótára (MKLSz.) pedig eleve későbbi pótkötetbe utalta a neveket.

3. A szótár nem hagyja ki, éspedig törzsanyagába veszi fel a tulajdonneveket (pontosabban azok bizonyos típusait), rendszerint kisebb-nagyobb következetlenségekkel. Ezzel az eljárásmóddal a legtöbb egynyelvü szótári alaptípus számos képviselöjének esetében találkozunk (akár még 19. századi értelmező szótárainkban: CzF., Ball. is), különösen jellemző gyakorlatnak számít pedig a kétnyelvü szótárak körében (vö. UzONYI 2015: 76-82, FÁBIÁN 2020).

4. A szótár kifejezetten és csakis tulajdonneveket, azok valamely fajtáját, típusát vagy körét dolgozza fel. Ez a névszótárak kategóriája, mely a nyelvi elemek lexikográfiai szempontból sajátos jellegü szelekcióján, elkülönítésén alapul, s a szótárak alapvető típusaival részben együtt, más szempontokból viszont azoktól elválasztva lehet tárgyalható (vö. MAGAY szerk. 2011 fentebb már hivatkozott gyakorlatával is).

Ezen alapvető lehetőségek közül választhatnak tehát a tulajdonnevek címszóvá tételével kapcsolatban a szótárak készítői. A szótári előszók gyakran nem foglalnak állást expressis verbis ebben a kérdésben, rendszerint nem részletezik, $\mathrm{s}$ különösen nem indokolják vonatkozó döntésüket. A tényleges megvalósulás, az elvek gyakorlatra váltása pedig nem ritkán bizonyul következetlennek (akár az előszóban leírtakkal is ellentétesnek) az elkészült müvek esetében. Az, hogy a tulajdonnevek címszóként való felvételét valóban következetesen elhárító szótárak is tartalmazhatnak tulajdonneveket a szócikkek szövegében, illetve tulajdonnevek felhasználásával alakult további formákat a címszók sorában, mindezektől természetesen független kérdés, és jó indokokkal (többek közt a közszavak korai adatolásának igényével vagy a köznevesüléssel keletkezett lexémák felvételének szükségességével) magyarázható.

3.4. Tulajdonnevek a szótárak és a szótártan történetében. Az első lexikográfiai szakmunkaként számon tartott mü, az olasz PAOLO BENI 1612-ben Padovában megjelent munkája tíz pontban tárgyalja a tökéletes szótár ismérveit, elsősorban az egynyelvü 
szótárakra vonatkoztathatóan. E pontok közt szerepel az is, hogy egy szótár ne vegyen fel tulajdonneveket. (UZONYI 2015: 72.)

A lexikográfia történetének egy sor egynyelvü klasszikus szótári müve tipikusan, illetve többnyire mellőzi is a neveket. A SAMUEL JOHNSON-féle szótár (1755) például minden olyan szót, melynek a tulajdonnevekhez köze volt (pl. Benedictine, Calvinist), kihagyott az anyagból (GRANT 2016: 572). Az Oxford English Dictionary eredeti kiadásának (1884-1928) első szerkesztője, JAMES MURRAY a tulajdonneveket a szókészlettel ugyan ezernyi ponton érintkező, de a lexikográfia hatókörén kívüli kérdéskörnek tekintette (GRANT 2016: 572-573). A GRIMM testvérek nevével fémjelzett német nagyszótár (1852-1954) szintén elvszerüen, de a szótár jellege és célkitűzései szempontjából is mondott le a (ti. csak ritkán újfelnémet eredetü) hely- és keresztnévanyag felvételéröl; igaz, végül nem teljes következetességgel (UZONYI 2015: 76).

A régi szójegyzékek, nomenklatúrák, szótárak anyagában ugyanakkor értelemszerüen akadhattak tulajdonnevek, hiszen - adott értelemben a többnyelvü szótárak előzményeiként - a latin nyelv elsajátítását így szolgálhatták hathatósan (magyar viszonylatban 1. GERSTNER 2020: 39, vö. Gl. 793-805). A 16. századtól pedig egyre több képviselője akadt Európában a tulajdonnévszótárak korai típusának, s többek közt a CALEPINUS-féle szótárhoz is megjelent (1544-ben) függelékként egy onomasztikon (HAJDÚ 2003: 23).

A magyar szótártan utóbbi két évszázadára fordítva figyelmünket, érdemes szempontunkból kiemelni, hogy TELEKI JÓZSEF nagyívü - 1817-ben elkészült és 1821-ben megjelent - tervezetében, mely „egy tökéletes magyar szótár” elkészítésére vonatkozott, bővebben is foglalkozott a kérdéssel. A személyneveket és a helyneveket is szótárazandónak ítélte, de a közszavakétól elkülönülö közreadásukra tett javaslatot (TELEKI 1821: 17-18). HORVÁT ISTVÁN ezzel egyidőben tette szóvá egy „Magyar Onomasticon” hiányát, illetve elkészítésének fontosságát (HORVÁT 1821: 49); ennek gondolata a későbbiekben többeket és konkrétabban is foglalkoztatott (1. még MIKESY 1970, ill. N. FODOR 2020, KovÁCs 2020). Azt az elvi álláspontot ugyanakkor, miszerint a magyar nyelv teljes szótárának - a közszavak állományának különböző csoportjai mellett - a tulajdonnevek több fontos típusát is fel kellene dolgoznia, a 18. század végén már ARANKA GYÖRGY megfogalmazta (ARANKA 1795-1796/1978: 281).

A hazai gyakorlatban azután, fontosabb 19., majd 20. századi szótáraink között a tulajdonnevek kezelésének többféle módjára találunk példát, amint arról a fentebbiekben már esett szó. A magyar egynyelvü szótárak zöme nem vesz fel tulajdonnévi szócikkeket, vagy legalábbis jobbára nem vesz fel ilyeneket. A magyar szótártörténet legnagyobb, 21. századi vállalkozásának, A magyar nyelv nagyszótárának (NSzt.) - mint történeti érdekü, de alapvetően értelmező szótárnak - a 2000-es évek közepétől megjelenő kötetei is következetesen és elvszerüen mellözik a tulajdonneveket. Önmagában jelzésértékü, hogy a nagyszótár szerkesztési elveiről szóló tájékoztató mindössze hét sorban foglalja össze a tulajdonnévi címszavak problematikájával kapcsolatos tudnivalókat (Nszt. 1: 30-31). Tulajdonnévi érintettségü, illetve a tulajdonnév kategóriájához közel álló elemek mindenesetre, szükségszerüen, előfordulnak anyagában (MÁRTONFI 2015: 91-92).

A tulajdonnévszótárak területére fordítva figyelmünket megállapíthatjuk, hogy történetük nem egy töredékben, torzóban maradt vállalkozást ismer, s a megjelent munkák zöme egyéni, esetleg kisebb munkacsoporthoz kötődő szakmai teljesítményként született meg. Elkészítésük nagy munkát és többirányú szakmai felkészültséget igényel, az elkészült szótárak pedig több szempontból, illetve többféle szakterület számára, s nem ritkán az érdeklődő szélesebb közönségnek is jól hasznosítható anyagot kínálnak. 
Ehhez képest sajnálatosnak tünik, hogy megalkotásuk láthatólag kevéssé minősül (szakmai) közérdeknek, ahogyan általában a lexikográfiai tevékenység tudományos megbecsültsége is bőven hagy kívánnivalókat maga után. Legfontosabb tulajdonnévfajtáink alapvető (név)szótári feldolgozásai mindenesetre rendelkezésünkre állnak, bár számos feladat és lehetőség van még elöttünk ezen a téren is. (Mindezekről e tanulmány későbbi szakaszában esik még majd szó.)

\section{A tulajdonnevek szótári leírásának lehetőségei}

4.1. Fenntartások a tulajdonnevek felvételével kapcsolatban. A tulajdonnevek nyelvrendszerbeli elhelyezhetőségének kérdése nem feloldhatatlan probléma, mely azonban nyelvelméleti megközelítéstől függően is okoz több vagy kevesebb gondot a nyelvtudomány müvelőinek (vö. VÁRNAI 2005, kül. 64-68). Logikusnak látszik mindenesetre a gondolatmenet: ha a tulajdonnevek nyelvi jelek, akkor nyelvi sajátságokkal bírnak, és nyelvészeti szempontból is jellemezhetőknek kell lenniük, tehát (nem csupán enciklopédiába, hanem) szótárba (is) valók. (Az elvi kérdésekről részletesebben l. MUFWENE 1988, a gyakorlatiakról különösen MöLLER 1995.) Szótározhatóságuk, illetve szótározandóságuk megítélését azonban a tulajdonnevekkel kapcsolatos bizonyos alapvető kérdések, illetve fenntartások is befolyásolhatják. A jellemzőbbek az alábbiak:

1. Lexikai egységek-e a tulajdonnevek? Egyrészt kijelenthető, hogy a lexikon és az onomasztikon több vonatkozásában megkülönböztethető egymástól; többek közt a tulajdonnevek akár több önálló szóból is állhatnak, s a közszókéhoz hasonló módon (ti. szófajok szerint) nem kategorizálhatók (GRANT 2016: 575-576, MÖLlER 1995: 324, VÁRNAI 2005: 64-75). Másrészt azonban, tágabb értelemben a tulajdonnevek is tekinthetők lexikális egységeknek, tehát szótári módon is kidolgozhatók (MÁRTONFI 2015: 87).

2. Van-e jelentése a tulajdonnévnek? A tulajdonnév jelentésének mibenléte sokat vitatott problémaköre a vonatkozó kutatásoknak (összegző módon 1. pl. VAN LANGENDONCK 2007: 20-84, SLÍz 2015: 95-96, RESZEGI 2018). Ennek részleteibe itt nem bocsátkozván bele, azt a típusú megközelítést tarthatjuk célravezetőnek, mely szerint a tulajdonnévnek is van jelentése, bár a közszavakétól eltérően annak lényegét a nevek megkülönböztető és egyedileg azonosító, dentotatív szerepében határozhatjuk meg. A szótárak szempontjából mindehhez hozzátehetjük, hogy azok sem eleve csupán fogalmi jelentéssel bíró, hanem más típusú szavakat is felvesznek anyagukba. Mindezek alapján tehát a tulajdonnév szótárba is, jelentésével együtt is felvehető, s utóbbi megadásában az enciklopédikus jellegü meghatározások is helytállónak tekinthetők (vö. MöLLER 1995: 324). Igy a gyakorlatban, „lexikográfiai értelemben a lexikonszerü leírással megadható denotatív jelentést" is tekinthetjük a tulajdonnév jelentésének azok számos típusának, illetve szótári feldolgozásának esetében (HOFFMANN 2006: 445-446, 1. lábjegyzet).

3. A nyelvhez, közelebbről az adott nyelvhez tartoznak-e a tulajdonnevek? A kérdéssel kapcsolatban felvethető egyrészt, hogy a tulajdonnevek ismerete bizonyos értelemben helyek, személyek stb. ismeretét jelenti, s a nyelvet ezek nélkül is használhatjuk; azaz: a nevek nem a szorosabban vett nyelvi tudás részét képezik (MUFWENE 1988: 270, 274). Megjegyezhető másrészt, hogy a tulajdonnevek nem nyelvspecifikus elemek olyan módon, mint a közszavak; megalkotásukat követően bármely nyelvben univerzálisan használhatók (MÖLLER 1995: 324). Ugyanakkor a tulajdonnevek fordíthatóságának, nyelvek közötti megfeleltetésének problémája általában (1. pl. FARKAS 2009), illetve a tulajdonneveknek a kétnyelvü szótárakban való jellemző megjelenése a gyakorlatban 
(vö. UZONYI 2015: 76-82, FÁBIÁN 2020) szintén figyelmeztet arra, hogy a valóságban korántsem ilyen egyszerü a helyzet. Ezenkívül egy bizonyos tulajdonnévhez egy-egy adott nyelvben különböző, nyelvészetileg releváns információk kapcsolódhatnak, ami ugyancsak a nevek szótárazása melletti érvként veendő számításba (vö. MUFWENE 1988: 277, ill. 1. még alább).

4. További, gyakorlatias szempontok. Egy nyelv teljes szókészlete a gyakorlatban szótárazhatatlan, ám ez ugyanígy - sőt, akár még inkább - igaz a tulajdonnévkincsére. A nyomtatott szótárak esetében a terjedelmi megfontolások - a közszói és tulajdonnévi állomány együttes szótárazásából adódó egyéb problémák mellett - szintén a nevek kihagyása mellett szólhatnak. Ezt ugyanakkor olyan szempontok is befolyásolhatják, mint hogy van-e az adott nyelvnek megfelelö névszótára, ennek hiánya ugyanis értelmezhető lehet úgy, hogy az egyéb szótáraknak többféle feladatot kell magukra vállalniuk (l. a horvát etimológiai szótár példáján: BROZOVIĆ RONČEVIĆ 2008).

4.2. Nyelvi információk a tulajdonnevek szótári leírásában. A tulajdonnevekre vonatkozó nyelvi információk sokfélék lehetnek, egy adott szótár pedig - profiljának megfelelően - ezeknek csupán egy részét tartalmazza. Sajátos esetben akár gyakorlatias ajánlások is létezhetnek, melyek ezen információknak a minimális körét igyekeznek meghatározni. A nemzetközi helynév-standardizáció területén, ennek szempontjából egy helynév leírásában például a következők minősülnek a legszükségesebbeknek: a megnevezett hely pontos meghatározása (különböző tartalmi elemekkel); további (egyéb standardizált, illetve korábbi) nevek megadása; szükség és lehetőség szerint továbbá: nyelvtani nem, szám, határozott, illetve határozatlan forma, kiejtés, hangsúly, hanglejtés, valamint egyéb releváns nyelvi információk, melyek a név használatának jobb megértését szolgálják (MÖLLER 1995: 327-328).

Az alábbiakban a tulajdonnevek szótári leírásában számba vehető nyelvi információk releváns típusait igyekszem felvázolni, néhány rövid megjegyzés kíséretében.

1. A legalapvetőbb nyelvi információk, melyek a tulajdonnév jelentését, illetve lényegi használatát meghatározzák:

a) Tulajdonnévi volta: az adott nyelvben meglévő nyelvi elem (nyelvi egység), éspedig nem közszó (vö. MUFWENE 1988: 269, 275). Ez egyébként azt is jelenti, hogy ilyen értelemben egy megfelelö címmel közzétett puszta névlista (pl. [férfi/női] keresztnevek betürendes felsorolása) is szótárként értelmezhető.

b) A tulajdonnév típusa, fajtája: a definícióhoz tartozó megfelelö klasszifikációval; például helynév, illetve településnév; személynév, illetve utónév, közelebbről férfi vagy női (ill. akár gendersemleges) utónév. A fentebbi megjegyzéshez is kapcsolódva: az utóbbi információ segíthet például abban, hogy egy keresztnevet megfelelően értelmezzünk, illetve használhassunk (adott esetben például a névviselö, illetve a nyelvtani nemek szempontjából).

c) A tulajdonnév egyedi azonosító értéke: a tulajdonnévi jelentés lényegének megfelelöen, a névhez kapcsolódó enciklopédikus információk egy részét is tartalmazva; például helynév esetében a lokalizáció megadásával, konkrét személy nevének esetében a névviselő azonosításával. Utóbbi lehet releváns egy történeti névtár szempontjából, míg egy családnév- vagy keresztnévszótár általában nem tér ki hasonló információkra.

d) Másnyelvü megfelelő megadása: többnyelvü szótárakban alapvető, de más szótártípusokban is lehetséges nyelvi vonatkozású tájékoztatásként. 
e) A tulajdonnév nyelvi formája, névterjedelme: a tulajdonnévvel kapcsolatos lényegi információ, melyet tipikusan már a címszó maga közvetít, ide értve például, többek közt a tulajdonnév szerves részét képező névelő vagy köznévi utótag meglétét, illetve hiányát.

2. Történeti-etimológiai információk, melyek a tulajdonnevek szótárakba való felvételét és leírását is a legjellemzőbben (sőt, látszólag szinte tipikusan; vö. MöLLER 1995: 327) meghatározhatják:

a) A tulajdonnév nyelvi eredete, szerkezete, egykori közszói jelentések, névadási motivációk: a névcikkek tartalmát legtipikusabban domináló szótári információk (részben és bizonyos értelemben a közszói szócikkek jelentésmegadásai helyett szereplően).

b) Névtörténeti adatok: különösen a korai adatokra (speciális esetekben akár a keletkezés idejére, körülményeire is) vonatkozó információként.

c) Származéknevek és kapcsolódó nevek: ritkábban, sokszor csupán utaló jellegü elemekként (pl. a keresztnévszótárakban viszont gyakori tartalomként).

d) Köznévi származékok: a tulajdonneveket és a közneveket tartalmazó szótárakba is felvehetők (pl. freudi elszólás, fine china 'porcelán'; az adott helyröl származó lakosság megnevezései: Capetonians, Durbanites stb.; vö. MöLLER 1995: 327).

3. A nyelvi jellemzőkre, szabályokra vonatkozó információk (vö. MUFWENE 1988: 274 is), melyek potenciális köre erősen nyelvfüggő (a magyar esetében többük például eleve irreleváns):

a) Nyelvtani nem: ha az adott nyelvben létezik (nem csupán, de különösen a rendhagyónak számító esetekben releváns információként).

b) Szám: a többes számú tulajdonnevek kapcsán.

c) Névelöhasználat: a határozott névelővel használandó tulajdonneveknél.

d) Toldalékolás: bizonyos esetekben, mint például a magyar helységnevek hol? és hová? kérdésre válaszoló helyhatározóragjainak vonatkozásában.

e) Kiejtés: különösen idegen nyelvi eredetü, illetve régi(es) nevek esetében.

f) Hangsúly, hanglejtés: előbbi számos, utóbbi egyes nyelvek esetében.

g) Helyesírás, elválasztás: a megfelelő írásrendszerek esetében.

4. A névhasználati jellemzőkre vonatkozó információk, amelyek egyébként a további szótári (különösen: történeti-etimológiai) tartalmak szempontjából is fontosak lehetnek:

a) Névváltozatok: az adott nyelven belüli történeti, illetve szinkrón névváltozatok, különösen írás- és ejtésváltozatok, illetve a név alap-, sztenderdizált, normatív, hivatalos változata (utóbbiak bizonyos névfajták, így a helységnevek, utónevek esetében tipikusan fontos információként).

b) Névgyakoriság: elsősorban bizonyos névfajták (mint a család- és keresztnevek) esetében jellemző lehetőségként.

c) Nyelvföldrajzi elterjedtség: a fontosabb, hagyományos névfajták több kategóriájában lehetséges (bár a szótárakban inkább ritkán előforduló) tartalomként.

d) Szociokulturális háttér: különösen történeti vonatkozásban, illetve multikulturális társadalmakban jellemző információként (1. a nemzetközi szakirodalomban; pl. zsidó, hugenotta, normann személynevek, vö. MCCLURE 2015: 284).

e) További pragmatikai szempontok, használati, illetve stílusérték, asszociatív potenciál: az adott név használatát befolyásoló további tényezőkként (pl. az informális, illetve szlengnevek esetében; TSEPKOVA 2018: 210-212).

A utóbbiakban számba vett információk némelyike első ránézésre talán enciklopédikus jellegü tartalomnak tünhet. Mivel azonban olyan, az adott nyelvi elem használatára 
vonatkozó tájékoztatást adnak, melyek megfelelői a közszavakat feldolgozó szótárakban is természetszerüleg megtalálhatók, ezeket is nyelvi vonatkozású, azaz szótári jellegü információként kell számon tartanunk.

4.3. Egyéb, enciklopédikus jellegü tartalmak. Az enciklopédikus szótárak sokféle további, az adott tulajdonnévhez, illetve az általa jelölt egyedhez kapcsolható információt tartalmazhatnak. Ilyenek például a helynevek, illetve helységnevek esetében a földrajzi leírás, illetve a lakosságra vonatkozó információk; személynevek esetében a névviselő társadalmi hovatartozásának megadása vagy a híres névviselők életrajzi adatai. Ezek körét, egyáltalán felvételét, valamint részlességét természetesen ezekben az esetekben is az adott konkrét munka célja határozhatja meg.

\section{Tulajdonnevek az egy- és többnyelvü szótárakban}

5.1. A tulajdonnevek felvétele az egynyelvü szótárakba. Mint arról az eddigiekben már részletesebben esett szó, az egynyelvü szótárak alapvetően, illetve elsősorban közszói címszavakat tartalmaznak, s többnyire mellőzik a tulajdonnevek felvételét. Szemléletesen mutatják ezt azok az esetek, amelyek azt is jelzik, hogy egy-egy konkrét, egymással összefüggő és alakilag megegyező tulajdonnév és közszó több szempontból is elválasztható, illetve lexikográfiailag is megkülönböztetendő egymástól. Így például az Oxford English Dictionary címszavai közt ott szerepel a derby közszó, különböző jelentéseivel együtt, de a Derby tulajdonnevet (melynek ez a köznevesült formája) már nem találjuk meg a címszók sorában (STYLES 2015: 255). Az más kérdés, hogy egyes esetekben az értelmező szótárbeli jelentés megadásakor is történhet utalás egy-egy köznevesült forma tulajdonnévi hátterére, bár ez tipikusan nem feladata az adott szótártípusnak (a magyar értelmező szótárak példáján 1. TAKÁCS 2020: 233-234).

Ez a példa is azt mutatja, hogy a tulajdonnevek címszóként való felvételétől egyébként következetesen tartózkodó szótárak is tartalmazhatnak olyan címszavakat, amelyek közel állnak, illetve szorosan kötődnek a tulajdonnevek kategóriájához. A magyar nyelv nagyszótárának (Nszt.) példájára utalva vissza ezúttal, ide tartozhatnak a köznevesült névformákon túl a tulajdonnévi előtagú, de közszói értékü összetételek (pl. Achilles-ín); a jellegzetesen tulajdonnévként, illetve azok részeként használt közszók (pl. breki, bányászakadémia); illetve a tulajdonnevet tartalmazó állandósult szókapcsolatok (pl. [Boldogaszszony], önálló közszói használatának hiányát a szögletes zárójellel jelezve) is (MÁRTONFI 2015: 92-93, további magyar értelmező szótári típuspéldákra 1. UZONYI 2015: 73).

A tulajdonneveknek az egynyelvű szótárakba való felvételét (pontosabban felvételét vagy kizárását, illetve hogy milyen tulajdonneveket és milyen mértékben vesznek fel) többféle tényező befolyásolhatja. Ezek közé tartoznak:

1. Az adott nyelv lexikográfiai hagyományai: például az orosz kizáróbb, a német viszont nyitottabb, változatosabb, s egyúttal kevésbé következetes e szempontból (részletesebben 1. UZONYI 2015: 74-76).

2. Az adott szótártípus: a korábban elmondottak szerint az értelmező szótárak általában inkább kizáró, más szótártípusok potenciálisan megengedőbb jellegüek, vagy akár jellemzően befogadóak a tulajdonnevek irányában, mint a kiejtési vagy a helyesírási szótárak (a már említetteken túl, utóbbiakhoz 1. EWALD 2018 is). A szótártípus, illetve az adott szótár érdeklődése, profilja a felveendő tulajdonnevek fajtáit és konkrét egyedeit is nagyban meghatározhatja; például nyelvtörténeti jelentőségü nevek felvételét az etimológiai 
szótárban (vö. GERSTNER 2020), a helyi nyelvjárást és környezetet reprezentáló nevekét egy tájszótárban (vö. JUHÁSZ 2020), a kulturális és országismereti szempontból fontos tulajdonnevekét egy egynyelvü tanulószótárban (vö. UZONYI 2015: 75-76).

3. Szerzői szándék, szerkesztői, illetve kiadói döntés: számos további szempontot vehetvén figyelembe (pl. az elkészítendő szótár tervezett terjedelme, a szótár által ellátandó funkciók).

Az egyes tulajdonneveknek az egynyelvü szótárakba való bekerülését - ha az adott szótár meg is engedi ezt - mindezeken túl természetesen számos esetlegesség, következetlenség kísérheti (példáit 1 . az itt fentebb hivatkozott tanulmányokban is).

5.2. A tulajdonnevek felvétele a kétnyelvű szótárakba. A kétnyelvű szótárakban általánosan megszokott jelenség a tulajdonneveknek - elsősorban bizonyos személynévés helynévfajták képviselőinek, de egyes intézményneveknek is - a címszóként való megjelenése (vö. UZONYI 2015: 76-81). Ezek az adott név másnyelvü megfelelöjéről - ennek hiányában legalább (referenciális, denotatív) jelentéséröl -, illetve az adott név használatáról nyújtanak információt az olvasónak. A másnyelvü ekvivalens megadása mind az etimológiailag átlátszatlan tulajdonnevek (pl. a keresztnevek nagy többsége), mind a (legalább részben) közszói elemekből álló tulajdonnevek (pl. intézménynevek, uralkodói ragadványnevek) esetében releváns funkció (utóbbira 1. kül. FÁBIÁN 2020: 97-98, ill. 9. és 12. lábj.).

A felveendő tulajdonnevek körét persze jól meg kell válogatni, s bár bekerülésük többé-kevésbé esetlegesnek bizonyulhat, bizonyos szempontok jellemzően az adott tulajdonnevek felvétele mellett szólnak (a magyar, illetve az orosz, német és olasz nyelv viszonylatában 1. UZONYI 2015: 76-81, FÁBIÁN 2020: 97). A fontosabb szempontok:

1. A két nyelvben eltérő névforma (hang-, illetve betüsor), vagy akár az azonos forma mellett is eltérö kiejtés, hangsúly. Nem csupán, de különösen is az ún. hamis barátok, a két nyelvben ekvivalensnek tünő, ám eltérő jelentésű, használatú tulajdonnevek esetén.

2. Sajátos nyelvtani viselkedés (nyelvtani nem, grammatikai esetek) megléte.

3. A tulajdonnév fajtája, jelöltjének fontossága (általában, illetve az adott szótár profiljának szempontjából). Ezek sokféleképpen indokolhatják az adott nevek felvételét, még az olyan első ránézésre talán kevésbé érthető esetekben is, mint a keresztnevek, illetve idegen nyelvü ekvivalenseik megadása (tanulságos elemzéssel 1. UZONYI 2015: 77-79).

4. S végül, természetesen a szerzői, szerkesztői, kiadói szándék, illetve a szótár esetleges speciális profilja (pl. útiszótár, szakszótár) is nagyban meghatározza a tulajdonneveknek az adott szótárba való bekerülését.

E témakör kapcsán érdemes megjegyeznünk, hogy az ekvivalensek kérdése nem mindig magától értetődő, illetve egyértelmü. Így például a Pál keresztnév orosz szótári ekvivalense lehet a Пал és а Павел, az olasz Luigi keresztnévnek a magyar Lajos és az Alajos, a Buda magyar helységnév német megfelelője a Buda és az Ofen is. (A példák forrása, illetve magyarázata: UZONYI 2015, FÁBIÁN 2020. Eltekintünk itt ugyanakkor attól a kérdéstöl, hogy a szótárazandónak ítélhető ekvivalensek körén túlmenően egyegy keresztnévnek további egyedi megfelelői is számba vehetők lehetnek; vö. FARKAS 2009: 27-32.) A kétnyelvü szótárak körében sajátos helyet elfoglaló kulturális szótárak pedig tipikusan nem is az adott tulajdonnév ekvivalensének megadására, mint inkább a név jelentésének, illetve denotátuma jelentőségének magyarázatára törekednek (SZILÁGYI-KÓSA 2020). 


\section{Tulajdonnevek a névszótárakban}

6.1. A névszótárak típusai. A tulajdonnévszótárak lehetséges típusait különböző szempontok alapján határozhatjuk meg:

1. Jellemzően lexikográfiai megközelítéssel, a fö szótártípusok szerint (elsősorban: történeti és etimológiai, de akár egyéb típusú, pl. kiejtési szótárak).

2. Névtani szempontból, a feldolgozott névfajták szerint, névszótárakként (helynévszótár, keresztnévszótár stb.). Ez tủnik a jellemzőbb megközelítésnek, mely azért is indokolt, mert az egyes névfajták nagymértékben különböznek egymástól, így szótári feldolgozásaikat eltérö tartalmak, jelleg, illetve problematika jellemzi, s az egyes névfajták is rendszerint különálló szótári feldolgozásban részesülnek. (Nem véletlen, hogy a nemzetközi lexikográfiai kézikönyvek is fő névfajták szerinti fejezetekben tárgyalják a tulajdonnévszótárak kérdéskörét: HAUSMANN et al. Hrsg. 1989-1990. 2: 1267-1296, DURKIN ed. 2015: 255-291.) Tipikusan önálló munkákként jelennek meg például a keresztnévszótárak és a családnévszótárak, míg a két névfajta együttes feldolgozására jóformán csak az elképzelés szintjén idézhetünk példát (vö. TUCKER 2008). E névszótári típusok mellett léteznek, ám jóval ritkábbak azok a névszótárak, amelyek a tulajdonnevek szélesebb körét, többféle fajtáját dolgozzák fel együttesen saját szempontjaik szerint (pl. a névkiejtési szótárak; 1. MAGAY 1970, ill. 1974). Egyes névszótárak több fő szótártípus jellemzöit egyesítik magukban.

3. A szótárak forrásanyaga, profilja, jellege, célja, célközönsége alapján beszélhetünk továbbá szinkrón vagy diakrón, deskriptív vagy preskriptív szempontú (ill. normatív), tudományos célú vagy ismeretterjesztő jellegű stb. névszótárakról (vö. MAGAY 2015).

Összességében tehát többféle kereszteződő szempont lehetséges, melyek alapján elvileg a névszótárak igen változatos tipológiájával számolhatnánk. Ugyanakkor nem minden elképzelhető típus fordul elö a valóságban, nem is lennének egyformán relevánsak, szükségesek, illetve megvalósíthatók (a családnévszótárak lehetséges tipológiájának példáján 1. BRENDLER 2002).

Önmagában az egyes névfajták szótári feldolgozásának is igen eltérő esélyei vannak a gyakorlatban. Egyértelmüen a keresztnévszótárak alkotják a legnagyobb érdeklődésre számot tartó, s így egyúttal a leggyakoribb névszótári típust. A családnévszótárak már jóval ritkábbak, más személynévfajták pedig még kevésbé kapnak, illetve kaphatnak önálló, szótári jellegü feldolgozást. A személynevek melletti másik fő névfajtát magukba foglaló helynévszótárak képezik a tulajdonnévszótárak hasonlóképp jellemző további nagy kategóriáját. Az egyéb névfajták esetében a névszótári feldolgozások azonban már jóval ritkábbnak számítanak (vö. SEIBICKE 1990b).

Az egyazon típust képviselő egyes névszótárak konkrét tartalmuk, jellegük, kidolgozottságuk alapján természetesen szintén változatos képet mutatnak. Ennek legszemléletesebb példáját, természetesen, a keresztnévszótárak különösen gazdag palettája (vö. HAJDÚ 1977, FARKAS 2006, SLÍZ 2020a) szolgáltatja.

6.2. A névszótári tartalmak és struktúrák. A névlexikográfia területén a szótári struktúra kialakításában, a tartalom megválogatásában és elrendezésében sajátos kérdésekkel és megoldásokkal is találkozhatunk. (Több vonatkozásukhoz, áttekintő igénnyel, a főbb névfajták szótári feldolgozásai kapcsán 1. STYLES 2015, MCCLURE 2015.)

Mindenekelőtt két alapvető müfaj különbségével kell számot vetnünk: a névtári és a névszótári jellegű feldolgozás és közzététel lehetőségével. A névtár a nevek jelöltjei 
(a denotátumok) szerinti megközelítést alkalmazza: személynévtárak esetén a személyek, helynévtárak esetén a megnevezett helyek szerinti, a földrajzi elvet is figyelembe vevő elrendezést. A névszótár ugyanakkor a jelölök (az egyes névformák, azaz a nyelvi szempontú megközelítés) szerinti, tisztán betürendes közzétételi módot követi. Előbbi típus az adattári, utóbbi a szótári jellegü munkákhoz köthető. A két tipikus müfaj közt azonban számos érintkezést, átmeneti lehetőséget, illetve konkrét munkát ismerünk. (A kérdéskörhöz 1. pl. PAPP 1966, KovÁCS 2020.)

Szótári szempontból egészen egyedi elrendezéseket tesz lehetővé a keresztnévanyag közzététele. A férfi és a női keresztneveket elkülönítő hagyományok, illetve névjogi szabályozás esetén - mint Magyarországon - a keresztnévkincs jellemzően kétfelé, férfi és női nevekre oszlik. Ennek megfelelően, célszerüségből is, a keresztnévszótári feldolgozások szintén eleve kétfelé, akár külön kötetekre is oszthatják anyagukat. A keresztnévanyag közzétételének további sajátos módja lehet a névnapok szerinti elrendezés. De akad példa a keresztnévanyag etimológiai, illetve jelentéstani szempontú, avagy a szociokulturális jelleg és konnotációk szerinti tagolására és közzétételére is. (FARKAS 2006: 248, MCCLURE 2015: 274.)

A szótárba bekerülő névanyag megválogatása sokféle szempont alapján történhet. Befolyásolja ezt az adott névfajta, illetve a feldolgozandó névállomány jellege, a szótár célkitüzése és profilja, az egyes nevek bármely értelemben vett jelentősége, a kapcsolódó szakirodalom fejlettsége, s további kifejezetten gyakorlatias tényezők és megfontolások, de esetlegességek is (1. még TUCKER 2008: 196-198). A tartalmi elemeket, a szótárba felvett információk típusait is hasonló vonatkozások határozzák meg.

A szócikkesítés szempontjából természetesen alapvető feladat a poliszémia, a szinonímia és a homonímia jelenségének a tulajdonnevek körében megfelelő értelmezése, illetve az ezzel összefüggő gyakorlati problémák megoldása. Ugyanakkor már az alak vagy a jelentés alapján történő szócikkesítés kérdése is elsőrendü fontosságú lehet, amint azt legszemléletesebben helynévszótáraink mutatják. KISS LAJOS ismert és elismert munkája, a Földrajzi nevek etimológiai szótára (FNESz.) e szempontból tulajdonképpen inverze a közszavak állományát feldolgozó szótáraknak, ugyanis a szócikkek szervező elve az azonos denotátumra való vonatkozás: az azonos helyekre vonatkozó különböző neveket egy szócikken belül dolgozza fel. A debreceni helynévkutatók későbbi szótári vállalkozása, a Korai magyar helynévszótár (KMHsz.) ezzel szemben az egyébként jellemző szótári megközelítést képviseli, mely az egyes névalakokat alapul véve építi fel szócikkeinek sorát. (A problémakörre 1. HOFFMANN 2006: 445-447.)

A címszó kiválasztása, illetve meghatározása többféle szempont mérlegelését igényelheti a történeti jellegü névszótáraknál (részletesebben 1. HoFFMANN 2006), s általában minden olyan névállomány szótári feldolgozásánál, melyek esetében nem indulhatunk ki egyszerüen a sztenderd névváltozatokból. Szerepet játszhat ebben olyan nyelvészeti jellegü szempont, mint az etimológia, de névhasználati tényezők, mint a névgyakoriság kérdései is. A bokrosítás lehetőségeit és esetleges alkalmazását az adott szótár jellege, anyaga és készítőinek szándékai határozzák meg.

A lemmatizáció, illetve a kialakítandó betürend kapcsán vethet fel kérdéseket egyes névszerkezetek (pl. a tipikusan több szóból álló intézménynevek vagy címek, a határozott névelöt tartalmazó tulajdonnevek), illetve bizonyos nyelvek sajátos grammatikai jellemzőinek megléte (dél-afrikai példákon 1. MöLLER 1995: 325-326).

Végezetül érdemes röviden említést tenni a névszótárak járulékos részeiről is. Egyrészt fontosnak kell tartanunk a szótárral és használatával kapcsolatban eligazító, szakszerü, 
egyúttal azonban gyakorlatias és felhasználóbarát szótári bevezetőket. Ezek jelentőségét olykor a szakma is alábecsüli, a laikus névszótárak esetében viszont különösen szembesülhetünk a hiányukkal (legszembetünőbben természetesen a keresztnévszótárak körében). Másrészt külön érdemes itt szólnunk a névszótárak mutatóinak lehetőségeiről. E téren elsősorban a névelemmutatók, illetve a névvégmutatók előnyeire utalhatunk. Ezeket a számítógépes szótárkészítés korában már könnyen el lehet készíteni, s függelékként csatolni az alapmühöz (1. pl. az ezredelőn megjelent névtörténeti szótárainkban: ÁSznt., KMHsz.). Névvégmutató feldolgozások, az egykori technológiai lehetőségek híján vagy a terjedelem okán is, később külön szótári müként születtek meg (mint a CsnSz.-hez másfél évtizeddel később elkészült CsnVégSz., vagy az ÚCsnT.-hez eredetileg tervezett, de meg nem jelent a tergo változat esetében).

\section{Feladatok és lehetőségek a tulajdonnevek szótári feldolgozásában}

7.1. A megfelelő információk közvetítésének szükségessége. A tulajdonnevek szakszerü szótári feldolgozásai megbízható adatokat és információkat nyújtanak mind a tudományosság különböző területei, mind az érdeklődő szélesebb közönség számára.

Ahogyan a tulajdonnevek lexikográfiájának láthatólag legjellemzőbb összetevője a nevek történeti-etimológiai szempontú vizsgálata, úgy szótári feldolgozásaik további tudományos hasznosíthatóságát is legszemléletesebben ezekkel példázhatjuk. A történeti hely- és személynévanyag elemeivel kapcsolatos információk általában számos nyelvtörténeti tanulsággal járnak, köztük a szókincs kutatásának, s így egyúttal más szótáraknak a szempontjából is: korábbi adatolásra, akár addig ismeretlen közszavak kimutatására, korábbi adataink és ismereteink újraértékelésére biztosíthatnak újabb lehetőségeket (az angol lexikográfia példáin 1. GRANT 2016: 573-574, 576-583). A történeti névanyag nyelvtudományon kívüli felhasználására a legjobb példákat pedig a történettudomány szolgáltatja. E vonatkozásaik alapján is fontos feladat - különösen korai nyelvemlékeink és nyelvtörténeti korszakaink, illetve eddig kevésbé vagy módszeresen még nem vizsgált forrásaink esetében - a névtörténeti adatok feltárása, egyebek mellett módszeres és jól használható szótári típusú feldolgozása. Fontos eredmény ezért magyar vonatkozásban például, hogy az utóbbi két évtizedben az Árpád- és Anjou-kori magyar tulajdonnévanyagot reprezentatív igénnyel feldolgozni szándékozó történeti szótárak is készültek (ÁSznt., SLÍz 2011 és 2017, ill. HA., KMHsz.), bár további teendőkkel (mint az Árpádkori névállomány etimológiai szótári feldolgozásában) e téren is számolnunk kell még (vö. még N. FodOR 2020, KovÁcs 2020).

Fontos feladat továbbá, hogy a nagyközönség számára is színvonalas, megbízható és megfelelően használható szótári feldolgozások álljanak rendelkezésre. Ezek általános értelemben vett ismeretterjesztő szerepükön túlmenően további, gyakorlatias funkciókat is betölthetnek. Erre adnak példát a helységnév-azonosító szótárak (legreprezentatívabb képviselőjük: LELKES 2011), különösen pedig a leginkább közhasználatúnak, gyakorlati célúnak számító névszótári típus, a szülők névválasztását segíteni hivatott utónévkönyvek kínálata. Utóbbiak közt számos laikus, akár kifejezetten szakszerütlen, dilettáns, sőt áltudományos munka található, a keresztnévszótárakban szóba jöhető félrevezető információk és tartalmak, illetve az elkövethető hibák széles palettáját produkálva (részletesebb elemzésüket 1. SLíz 2020a, 2020b; persze hasonló a helyzet az online utónévkeresők körében is, 1. FARKAS 2019: 65-74). Mindez amellett is hangsúlyozandó, hogy ugyanakkor szakszerü magyar utónévkönyvek (mint a MUnk. és különböző kiadásai; speciális profillal 
FEKETE 2007; KnE., FERCSIK-RAÁTZ 2017a és 2017b), illetve az MTA Nyelvtudományi Intézetében készült, online elérhető Utónévkereső (Unk.) is rendelkezésére áll az érdeklődőknek. A keresztnévszótárak területén ellátandó feladat továbbá a kifejezetten a nemzeti és etnikai kisebbségek névadását, névválasztását támogató névkönyvek biztosítása (ezekről l. RAÁTz 2005, FARKAS 2019: 74-75). Ez - a jogszabályi elvárásnak eleget téve, ugyanakkor változó kidolgozottságban - rendelkezésére áll a hazai nemzeti és etnikai kisebbségeknek (S. DÁVID szerk. 2004, BRENNER-ERB-KNIPF 2015; utóbbi immár egy 2., átdolgozott és bővített kiadást képviselve a német kisebbség vonatkozásában). Ezekhez képest bizonyos fáziskéséssel, de a határon túli magyarság sajátos szempontjainak megfelelöen is készült már utónévkönyv, azonban a paletta itt még igen hiányos (romániai magyar vonatkozásban 1. J. KovÁCS 2018; szlovákiai viszonylatban elökészületben, vö. BAUKO 2016; máshonnan hasonló munkáról nincs tudomásunk). Az utóbbi kiadványok egyúttal a viszonylag ritkának számító kétnyelvü névszótárak sajátos típusát is képviselik.

A magyar tulajdonnévanyaggal kapcsolatos alapvető, rendszerezett és szakszerü információkat a nemzetközi színtéren, idegen nyelven is fontos elérhetővé, illetve hozzáférhetővé tenni. Ennek lehetnek jó eszközei az idegen nyelvü, illetve kétnyelvü, legalábbis idegen nyelvü bevezetővel és tájékoztatóval ellátott, reprezentatív anyagú névszótárak. Ezen a téren azonban viszonylag kevés munkát tudunk felmutatni. Készült kétnyelvü keresztnévszótár a szinkrón magyar keresztnévkincsről (angol-magyar: HAJDÚ 1983, román-magyar: J. KovÁCS 2018), és német nyelven is közzétett bevezetője (illetve latin forrásszövegei) révén az Árpád-kori személynévtár (ÁSznt.) tartalma is hasznosítható lehet a magyarul nem tudó külföldi kutatók számára. A családnévszótárak palettájáról kétnyelvü, bár szükös információtartalmú sajátos munka állhat az angolul olvasó érdeklödők rendelkezésére (CsnVégSz., a CsnSz. a tergo feldolgozásaként). A helynévszótárak kategóriáját pedig legújabb helységnévazonosító szótárunk képviseli e színtéren (LELKES 2011; angol és német nyelvü használati útmutatóval). Bizonyos mértékü idegen nyelvi útmutatással néhány további névszótári jellegü munka (névszótár, -adattár, mutatókötet) is rendelkezik (1. FARKAS 2015: 38). Mindezeken túl pedig különösen jó lehetőséget nyújthatnak az olyan lehetséges nemzetközi projektek, amelyek más nyelvek névkincse mellett magyar anyag szótári feldolgozására is vállalkoznak. Ennek kínálja jó példáját a Dictionary of Medieval Names from European Sources (DMNES.) címü online nemzetközi keresztnévszótári projekt, melynek magyar szerkesztője és magyar modulja is van (bővebben 1. UCKELMAN-SLíZ 2015). A magyar névtani lexikográfiának ezekben az irányokban szintén lennének még feladatai, elősegítendő a magyar nyelvü, s főleg a magyar eredetü tulajdonnévanyag jobb megismerését és helytállóbb értelmezését, kezelését a nemzetközi szakirodalomban, különösen a kárpát-medencei térségben, a szomszédos országok és nyelvek szakirodalmában, egyúttal névszótáraiban (vö. az aktuális körképpel, a jelen kötetben: BENÖ 2020, BAUKO 2020, SEBESTYÉN 2020).

7.2. Az elektronikus, illetve online szótárak lehetőségei. A szótárak készítésének, közzétételének és használatának területén részben lezajlott, részben folyamatban lévő paradigmaváltás része, hogy a hagyományos, papíralapú szótárak mellett egyre nagyobb szerepet kapnak az elektronikus, illetve digitalizált, s még inkább az informatizált, többnyire online hozzáférhető munkák. Ezek számos jellemző előnnyel bírhatnak (vö. pl. GAÁL 2015, PAJZS 2015): 
1. Jobb (szélesebb körü, könnyebb, gyorsabb) hozzáférést biztosítanak az adott szótári munkához (különösen az interneten könnyen megtalálható és szabad eléréssel használható szótárak esetében).

2. A papírszótárakat jellemző terjedelmi korlátok nem érvényesek rájuk, ami egyrészt a szótári anyag, tartalom, másrészt a szótár, a szócikkek kevésbé tömör és kötött szerkesztési-közzétételi módjait tekintve nagyobb fokú szabadságot, jobb áttekinthetőséget és további új lehetőségeket teremt.

3. Célszerübb (gyorsabb, hatékonyabb, akár egyénre szabott) felhasználást (kereshetöség, megjelenítés) biztosítanak anyagukban.

4. Könnyebben (gyorsabban, jobb rendszerességgel) bővíthető, frissíthető, fejleszthetö a tartalmuk.

5. Sokoldalúan bővíthetők, összekapcsolhatók más elektronikus tartalmakkal, alkalmazásokkal - a tulajdonnévszótárak esetében különösen az alábbi irányokban, illetve vonatkozásokban:

a) További szótárak, névszótárak, a megfelelö tartalmakkal összefüggésben (pl. gördített etimologizálás esetén).

b) Kapcsolódó névadattárak, adatbázisok (és akár forrásanyagok) az adatok vonatkozásában.

c) Statisztikai információk, illetve ezek vizuális megjelenítését lehetővé tevő alkalmazások (pl. aktuálisan is generálható diagram, grafikon).

d) Névatlaszok, illetve térinformatikai alkalmazások, a kapcsolódó adatok nyelvföldrajzi képének (területi elterjedtség, sürüség és gyakoriság) megjelenítésére.

e) További, enciklopédikus jellegü információk, tartalmak (pl. híres névviselők, helytörténeti vonatkozások), a felhasználói érdeklődés, igények sokoldalúbb, multifunkcionális kielégítésére.

Az elektronikus, elsősorban online szótárak tehát számos előnnyel rendelkezhetnek a hagyományos, papíralapú szótárakkal szemben. Ezekkel a lehetőségekkel a magyar tulajdonnévszótárak területén azonban egyelöre mérsékelten sikerült élni.

A legjellemzőbb eredmény e téren, hogy több - papíralapon is megjelent - névszótárunk egyúttal digitális formában, szabadon elérhetöo, (pdf fájlként) le is tölthető az internetről, anyagukban így egyúttal szabadszavas kereséssel is kutathatunk. Az informatizált szótári jellegủ feldolgozások tipikus és egyelőre lényegében kizárólagos hazai képviselői, nem meglepő módon, a széles körủ érdeklődést kielégíteni szándékozó utónévkeresők. A müfaj aktuális képviselői szakszerüségük, információgazdagságuk, praktikusságuk, valamint naprakészségük és ismertségük alapján igen változatos palettát alkotnak (bövebb elemzéssel 1. FARKAS 2019: 65-74). Példájuk jól jelzi, hogy a fentebb említett elönyök, könnyebbségek - ebben a szótártípusban a szótári alaptartalmak máshonnan való viszonylag egyszerü átemelhetőségével együtt - az amatör, szakszerütlen munkáknak is nagymértékben kedveznek. Tanulságosnak látszik ugyanakkor az is, hogy míg az MTA Nyelvtudományi Intézetében fejlesztett Utónévkereső (Unk.) a legsokoldalúbb, tartalmát és szakszerűségét tekintve egyaránt a legjobb magyar online utónévkereső alkalmazás, többféle gyakorlatias szempontból (mint a folyamatos fejlesztés és naprakészség, a kiegészíto alkalmazások, illetve a széles körü ismertség hiányosságai alapján) mégsem tudja teljes mértékben kibontakoztatni a benne rejlő lehetőségeket.

A szótári tartalmakhoz kapcsolt kiegészítő alkalmazásokra ugyancsak az utónévkeresők közt találunk jó példát: a nem igazán szakszerü, de folyamatosan és sikeresen fejlesztett Magyar Keresztnevek Tára (MKT.) oldalán - a népességnyilvántartás statisztikai 
adatsoraira épülően - a felhasználó által kiválasztott nevek divatjának időbeli alakulását látványosan bemutató grafikon egy kattintással elóállítható. A térinformatikai, illetve térképes megjelenítés lehetőségei egyelöre az online névtárak és névatlaszok példáin szemléltethetők (TMCsA., ill. MNH., EHA.). Ezek a megfelelő online névszótárhoz is hasonlóképpen kapcsolódhatnának, ha állna ilyen a rendelkezésünkre (vö. a nemrég zárult német családnévatlasz-, illetve az ennek folytatásaképpen is közel 25 [!] éves időtartamúra tervezett elektronikus német családnévszótár-projekt példájával; bővebben 1 . BÁRTH 2019: 156-158).

7.3. Zárásképpen. Az egyes nyelvekre vonatkozó kutatások kiterjedtségének és színvonalának jellemző mutatója szótárirodalmának gazdagsága - állapíthatjuk meg általában, s így a tulajdonnevek szótári feldolgozásának témaköre kapcsán is (vö. HoFFMANN 2006: 452). A hazai, illetve magyar nyelvü lexikográfiai munkálatok támogatásának terén azonban sok tennivaló akadna még, melyek az elöttünk álló lehetőségek jobb kihasználását segíthetnék. E komoly szakértelmet követelö, s igencsak idő- és munkaigényes területen a stabil és hosszabb távon tervezhető szakmai és intézményi háttér, a kiszámítható anyagi és erkölcsi támogatás, illetve az ezeket biztosító tágabb tudományos és társadalmi környezet közremüködésére nagy szükség lenne. Különösen akkor, ha valóban nagyívü, továbbá az egyes szótárak elkészítése mellett azok folyamatos fejlesztését (elektronikus, online szótárak esetében már csupán a fenntartását is) biztosító szótári projekteket szeretnénk célul magunk elé tüzni. Ezek vonatkozásában, egyfelöl, nem tünnek éppen kedvezőnek a körülmények. Másfelöl viszont, az egyre nagyobb számban és egyre inkább hozzáférhetővé váló (digitalizált) forrásanyagok, a vonatkozó kutatások eddigi bőséges eredményei és színvonala, valamint napjaink informatikai lehetőségei jó alapot és lehetőségeket biztosíthatnak e speciális terület müvelői és várható újabb, ígéretes jövőbeli eredményei számára is.

\section{Felhasznált források}

ÁSznt. = FEHÉRTÓI KATALIN, Árpád-kori személynévtár 1000-1301. Akadémiai Kiadó, Budapest, 2004.

Ball. = BALlagi MóR, A magyar nyelv teljes szótára 1-2. Franklin, Pest, 1867-1872.

BRENNER KOLOMAN - ERB MARIA - KNIPF ERZSÉBET 2015. A magyarországi német utónevek jegyzéke. 2., átdolgozott és bővített kiadás. Magyarországi Németek Országos Önkormányzata, Budapest. http://ldu.hu/attachments/file/55c1da40ce468a37560000b8 (2020. 05. 31.)

CzF. = CZuCZOR Gergely - FogARAsi JÁNOS, A magyar nyelv szótára 1-6. Emich Gusztáv / Athenaeum, Pest/Budapest, 1862-1874.

CsnE. = HAJdú MiHÁLY, Családnevek enciklopédiája. Leggyakoribb mai családneveink. A magyar nyelv kézikönyvei 17. Tinta Könyvkiadó, Budapest, 2010.

CsnSz. = KÁZMÉR MiKLós, Régi magyar családnevek szótára XIV-XVII. század. Magyar Nyelvtudományi Társaság, Budapest, 1993.

CsnVégSz. = Régi magyar családnevek névvégmutató szótára XIV-XVII. század. Szerk. FARKAS TAMÁS - F. LÁNCZ ÉVA ANNA. ELTE Magyar Nyelvtudományi és Finnugor Intézet - Magyar Nyelvtudományi Társaság, Budapest, 2009.

S. DÁvID EMESE szerk. 2004. Nemzeti és etnikai kisebbségek utónévkönyve. Aranyhal Könyvkiadó, Budapest. 
DMNES. = Dictionary of Medieval Names from European Sources. Főszerk. UCKELMAN, SARA L. http://dmnes.org (2020. 05. 31.)

EHA. $=$ Erdélyi Helynévtörténeti Adattár és interaktív névföldrajzi atlasz. Szerk. BÁRTH M. JÁNOS. SzABÓ T. ATTILA helynévgyüjtése alapján. http://eha.elte.hu (2020. 05. 31.)

FEKETE ANTAL 2007. Keresztneveink, védöszentjeink. 3., javított és bővített kiadás. Szent István Társulat, Budapest.

FERCSIK ERZSÉBET - RAÁTZ JUdit 2017a. Keresztnevek. A legfontosabb tudnivalók a leggyakoribb nevekröl. Az ékesszólás kiskönyvtára 46. Tinta Könyvkiadó, Budapest.

FERCSIK ERZSÉBET - RAÁTZ JUDIT 2017b. Örök névnaptár. A mai magyar keresztnevek legteljesebb gyüjteménye. Müszaki Könyvkiadó, Budapest.

FNESz. = KISS LAJOS, Földrajzi nevek etimológiai szótára 1-2. 4., bővített és javított kiadás. Akadémiai Kiadó, Budapest, 1988.

G1. = Régi magyar glosszárium. Szótárak, szójegyzékek és glosszák egyesitett szótára. Szerk. BERRÁr Jolán - KÁroly SÁndor. Akadémiai Kiadó, Budapest, 1984.

HA. = Helynévtörténeti adatok a korai ómagyar korból 1-4. Közzéteszi HofFMANN IsTVÁN RÁCZ ANITA - TÓTH VALÉRIA. A Magyar Névarchívum Kiadványai 1, 3, 25, 43. KLTE Magyar Nyelvtudományi Tanszék / Debreceni Egyetemi Kiadó, Debrecen, 1997-2017.

HAJDÚ MiHÁLY 1983. Magyar-angol, angol-magyar keresztnévszótár / Hungarian-English, English-Hungarian Dictionary of Christian Names. ELTE Magyar Nyelvészeti Tanszékcsoport, Budapest.

KMHsz. = Korai magyar helynévszótár 1000-1350. 1-. Szerk. HofFMAnN IsTVÁN. A Magyar Névarchívum Kiadványai 10. Debreceni Egyetem Magyar Nyelvtudományi Tanszék, Debrecen, 2005-.

KnE. = FERCSIK ERZSÉBET - RAÁTZ JUDIT, Keresztnevek enciklopédiája. A leggyakoribb női és férfinevek. A magyar nyelv kézikönyvei 16. Tinta Könyvkiadó, Budapest, 2009.

J. KovÁCs MAGDA 2018. Magyar-román, román-magyar összehasonlitó keresztnévszótár / Dicţionar comparativ maghiar-român, român-maghiar al numelor de botez. AESZ-füzetek 16. Anyanyelvápolók Erdélyi Szövetsége, Sepsiszentgyörgy.

LELKES GYÖRGY 2011. Magyar helységnév-azonositó szótár. Argumentum - KSH Könyvtár, Budapest.

MAGAY TAMÁs 1974. Idegen nevek kiejtési szótára. Akadémiai Kiadó, Budapest.

MKLSz. = A magyarországi középkori latinság szótára 1-. Kiad. HARMATTA JÁNOS etc. Akadémiai Kiadó etc., Budapest, 1987-.

MKT. = Magyar Keresztnevek Tára. http://magyarnevek.hu (2020. 05. 31.)

MNH. = Magyar Nemzeti Helynévtár. Szerk. HOFFMANN ISTVÁN - TÓTH VALÉRIA. http://mnh. unideb.hu (2020. 05. 31.)

MTsz. = Magyar tájszótár 1-2. Szerk. SzINNYEI JÓZSEF. Hornyánszky, Budapest, 1893-1901.

MUnk. = LADÓ JÁNOS - BíRÓ ÁGNES, Magyar utónévkönyv. Vince Kiadó, Budapest, 1998.

Nszt. = A magyar nyelv nagyszótára $1-$. Főszerk. ITTZÉS NóRA. MTA Nyelvtudományi Intézet, Budapest, 2006-.

NySz. = Magyar nyelvtörténeti szótár a legrégibb nyelvemlékektöl a nyelvújításig 1-3. Szerk. SZARVAS GÁBOR - SiMONYI ZSIGMOND. Hornyánszky, Budapest, 1890-1893.

Parrott, Jeremy 2004. Change all the Names. A Samuel Beckett Onomasticon. The Kakapo Press, Szeged.

RejtőLex. = Rejtő lexikon. RejtöJenö 27 nagyregényének világa 2500 szócikkben. Főszerk. FARKAS ANDRÁs. Quattrocento, Budapest, 2012.

SLíz MARIANN 2011. Anjou-kori személynévtár (1301-1342). Históriaantik, Budapest. 
SLíz MARIANN 2017. Anjou-kori személynévtár (1343-1359). Magyar Nyelvtudományi Társaság, Budapest. https://doi.org/10.26546/5061158

TMCsA. = Történeti magyar családnévatlasz. Szerk. N. FODOR JÁNOS. http://www.csaladnevatlasz. $\underline{\mathrm{hu}}(2020.05 .31$.

TóTFALUSI ISTVÁN 2010-2011. Irodalmi alakok nagy lexikona. 1. Mitoszok és mondák. 2. Magyar irodalom. Argumentum, Budapest.

ÚCsnT. = HAJdÚ MiHÁLY, Újmagyarkori családneveink tára XVIII-XXI. század. I. Adatok. Szerzői kiadás, Budapest, 2012.

Unk. = Utónévkeresö. Készítette RAÁTZ JUDIT - SASS BÁLINT. http://corpus.nytud.hu/utonevportal (2020. 05.31.)

\section{Hivatkozott irodalom}

ARANKA GYÖRGY 1795-1796/1978. A jó szótár követelményeiről. In: ÉDER ZOLTÁN, Benkö József nyelvészeti munkássága és az Erdélyi Magyar Nyelvmüvelö Társaság. Akadémiai Kiadó, Budapest. 275-284.

BÁBA BARBARA 2020. A Magyar földrajzi köznevek táráról. In: FARKAS TAMÁs - SLÍz MARIANN szerk., Tulajdonnevek és szótárak. ELTE Magyar Nyelvtudományi és Finnugor Intézet - Magyar Nyelvtudományi Társaság, Budapest. 223-230. https://doi.org/10.26546/4892373.14

BÁRTH M. JÁNOS 2019. Az európai névföldrajzi kutatások és digitális névadatbázisok az online térben. Nemzetközi kitekintés. Névtani Értesitő 41: 153-163. https://doi.org/10.29178/ NevtErt.2019.8

BAUKO JÁNOS 2016. Alkalmazott névtudomány, anyanyelvi keresztnévtervezés Szlovákiában. Magyar Nyelvőr 140: 267-278.

BAUKO JÁNOS 2020. Magyar tulajdonnevek a cseh és szlovák névszótárakban. In: FARKAS TAMÁS SLíz MARIANN szerk., Tulajdonnevek és szótárak. ELTE Magyar Nyelvtudományi és Finnugor Intézet - Magyar Nyelvtudományi Társaság, Budapest. 199-207. https://doi.org/10.26546/ $\underline{4892373.12}$

BENÖATTILA 2020. Magyar tulajdonnevek a román névszótárakban. In: FARKAS TAMÁS - SLÍZ MARIANN szerk., Tulajdonnevek és szótárak. ELTE Magyar Nyelvtudományi és Finnugor Intézet Magyar Nyelvtudományi Társaság, Budapest. 187-197. https://doi.org/10.26546/4892373.11

BLANÁR, VINCENT 2009. Vlastné meno vo svetele teoretickej onomastiky / Proper Names in the Light of Theoretical Onomastics. Matica slovenská, Martin.

BRENDLER, SiLVIO 2002. On the Lexicography of English Surnames (LES). Some problems and prospects. In: Boullón Agrelo, ANA IsABEl ed., Actas do XX Congreso Internacional de Ciencias Onomásticas, Santiago de Compostela, 20-25 setembro 1999. Fundación Pedro Barrié de la Maza, A Coruña. 1299-1306.

BROZOVIĆ RONČEVIĆ, DUNJA 2008. How to treat the proper name in an encyclopaedic dictionary. In: Brylla, Eva - WAHLBerg, MATS eds., Proceedings of the 21st International Congress of Onomastic Sciences. Uppsala, 19-24 August 2002. Institut för språk och folkminnen, Uppsala. 4: 48-57.

DURKIN, PHILIP ed. 2015. The Oxford Handbook of Lexicography. Oxford University Press, Oxford. https://doi.org/10.1093/oxfordhb/9780199691630.001.0001

EICHLER, ERNST 1995. Methoden und Probleme der Namenlexikographie: Slavisch und Deutsch-Slavisch. In: EICHLER, ERNST et al. Hrsg., Namenforschung / Name Studies / Les noms propres. Ein internationales Handbuch zur Onomastik / An International Handbook of 
Onomastics / Manuel international d'onomastique. Handbücher zur Sprach- und Kommunikationswissenschaft 11/1-2. Walter de Gruyter, Berlin - New York. 1: 329-334. https://doi. org/10.1515/9783110114263.1

EICHLER, ERNST et al. Hrsg. 1995-1996. Namenforschung / Name Studies / Les noms propres. Ein internationales Handbuch zur Onomastik / An International Handbook of Onomastics / Manuel international d'onomastique. Handbücher zur Sprach- und Kommunikationswissenschaft 11/1-2. Walter de Gruyter, Berlin - New York.

EWALD, PETRA 2018. Namen im Orthographiewörterbuch. In: HeUSER, RITA - SCHMUCK, MiRJAM Hrsg., Sonstige Namenarten. Stiefkinder der Onomastik. De Gruyter, Berlin-Boston. 407-432. https://doi.org/10.1515/9783110547023-018

FÁBIÁN ZSUZSANNA 2015. A szótár, illetve a lexikon és az enciklopédia megkülönböztetése az „enciklopédikus szótár" műfajának tükrében. In: FÁBIÁN ZSUZSANNA - SZÖLLÖSY ÉVA szerk., Szótár, lexikon, enciklopédia. Kérdések és feladatok. Segédkönyvek a nyelvészet tanulmányozásához 172. Tinta Könyvkiadó, Budapest. 17-38.

FÁBIÁN ZSUZSANNA 2020. Tulajdonnevek az olasz-magyar szótárakban. In: FARKAS TAMÁS - SLÍZ MARIANN szerk., Tulajdonnevekés szótárak. ELTE Magyar Nyelvtudományi és Finnugor IntézetMagyar Nyelvtudományi Társaság, Budapest. 95-107. https://doi.org/10.26546/4892373.6

FÁBIÁN, ZSUZSANNA ed. 2012. Hungarian Lexicography II. Monolingual and Special Dictionaries. Lexikográfiai füzetek 6. Akadémiai Kiadó, Budapest.

FÁBIÁN ZSUZSANNA - SZÖLLŐSY ÉVA szerk. 2015. Szótár, lexikon, enciklopédia. Kérdések és feladatok. Segédkönyvek a nyelvészet tanulmányozásához 172. Tinta Könyvkiadó, Budapest.

FARKAS TAMÁS 2006. Keresztnévkönyvek - keresztnévtárak - keresztnévszótárak Magyarországon. In: MÁrTONFi ATTILA - PAPP KornéLIA - Slíz MARIANN szerk., 101 irás Pusztai Ferenc tiszteletére. Argumentum Kiadó, Budapest. 246-252.

FARKAS TAMÁS 2009. A tulajdonnevek fordításának alapkérdéseiről. Diadal vagy Viktória, Eugén vagy Jenö? Forditástudomány 11/2: 22-35.

FARKAS, TAMÁs 2012. Proper Name Dictionaries in Hungary. In: FÁBIÁN, ZsuZsANNA ed., Hungarian Lexicography II. Monolingual and Special Dictionaries. Lexikográfiai füzetek 6. Akadémiai Kiadó, Budapest. 307-329.

FARKAS TAMÁS 2015. A nemzetközi névkutatás és magyar kapcsolatai. In: FARKAS TAMÁS - SLÍZ MARIANN szerk., Magyar névkutatás a 21. század elején. Magyar Nyelvtudományi Társaság ELTE Magyar Nyelvtudományi és Finnugor Intézet, Budapest. 23-47.

FARKAS TAMÁS 2019. Keresztnévszótárak és utónévportálok. A magyar keresztnévanyag feldolgozása online és határok nélkül. In: VÖRÖs FERENC szerk., A nyelvföldrajztól a névföldrajzig X. Nevek a nyelvpolitikai küzdötérben. A 2019. június 8-i révkomáromi névföldrajzi tanácskozás elöadásai. Savaria University Press, Szombathely. 63-80.

FARKAS TAMÁS - SLÍZ MARIANN szerk. 2020. Tulajdonnevek és szótárak. ELTE Magyar Nyelvtudományi és Finnugor Intézet - Magyar Nyelvtudományi Társaság, Budapest. https://doi.org/ $\underline{10.26546 / 4892373}$

FEKETE ANTAL 1991. Keresztneveink nyomában. (Bod Péter névjegyzékének vizsgálata.) A Magyar Nyelvtudományi Társaság Kiadványai 191. Magyar Nyelvtudományi Társaság, Budapest.

N. FODOR JÁNOS 2020. A történeti személynévszótárak. In: FARKAS TAMÁS - SLíz MARIANN szerk., Tulajdonnevek és szótárak. ELTE Magyar Nyelvtudományi és Finnugor Intézet - Magyar Nyelvtudományi Társaság, Budapest. 145-164. https://doi.org/10.26546/4892373.9

GAÁL PÉTER 2015. Nyelvi és enciklopédikus információk az online szótárakban. In: FÁBIÁN ZSUZSANNA - SZÖLLÖSY ÉVA szerk., Szótár, lexikon, enciklopédia. Kérdések és feladatok. Segédkönyvek a nyelvészet tanulmányozásához 172. Tinta Könyvkiadó, Budapest. 127-135. 
GERSTNER KÁROLY 2020. Tulajdonnevek a történeti és etimológiai szótárakban. In: FARKAS TAMÁs SLíz MARIANN szerk., Tulajdonnevek és szótárak. ELTE Magyar Nyelvtudományi és Finnugor Intézet - Magyar Nyelvtudományi Társaság, Budapest. 39-52. https://doi.org/10.26546/ $\underline{4892373.3}$

GluŠac, MAJA - Domorad, BernardicA - Domazet, Betina 2018. A magyar névanyag a horvát szótárakban. In: VÖRÖS FERENC - LEHOCKI-SAMARDŽIĆ ANNA szerk., A nyelvföldrajztól a névföldrajzig IX. Név és társadalom a magyar nyelvterület peremén. Savaria University Press Glotta Nyelvi Intézet, Szombathely-Eszék. 97-109.

Grant, Alison 2016. Names and Lexicography. In: Hough, CARol ed., The Oxford Handbook of Names and Naming. Oxford University Press, Oxford. 572-584. https://doi.org/10.1093/ oxfordhb/9780199656431.013.25

Greule, AlBrecht 1990. Ortsnamenwörterbücher. In: HAUSMANN, FranZ J. et al. Hrsg., Wörterbücher / Dictionaries / Dictionnaires. Ein internationales Handbuch zur Lexikographie / An International Encyclopedia of Lexicography / Encyclopédie internationale de lexicographie. Handbücher zur Sprach- und Kommunikationswissenschaft 5/1-2. Walter de Gruyter, Berlin New York. 2: 1276-1284. https://doi.org/10.1515/9783110124200.2

HAJDÚ MiHÁLY 1977. Keresztnévszótárak repertóriuma. Magyar Névtani Dolgozatok 3. ELTE Magyar Nyelvészeti Tanszékcsoport Névkutató Munkaközössége, Budapest.

HAJdú MiHÁLY 1998. Fercsik Erzsébet - Raátz Judit, Hogy hívnak? Könyv a keresztnevekröl. [Recenzió.] Névtani Értesitö 20: 134-139.

HAJdú MihÁLY 2003. Általános és magyar névtan. Személynevek. Osiris Kiadó, Budapest.

HAJDÚ MIHÁLY 2008. Beszámoló a készülő „Mai családneveink lexikona” munkálatairól. Névtani Értesitö 30: 167-184.

HAUSMANN, FrAnZ J. et al. Hrsg. 1989-1990. Wörterbücher / Dictionaries / Dictionnaires. Ein internationales Handbuch zur Lexikographie / An International Encyclopedia of Lexicography / Encyclopédie internationale de lexicographie. Handbücher zur Sprach- und Kommunikationswissenschaft 5/1-2. Walter de Gruyter, Berlin - New York.

HOFFMANN ISTVÁN 2006. Címszóválasztás nyelvtörténeti szótárakban. In: MÁRTONFI ATTILA PAPP Kornélia - SLíz MARIANN szerk., 101 irás Pusztai Ferenc tiszteletére. Argumentum Kiadó, Budapest. 445-452.

HoRVÁT IsTVÁN 1821. Veszprém Vára Nevéről. A’ Tekéntetes Veszprémi Káptalan Nagy Érdemü Tagaihoz Tisztelet Jeléül. Tudományos Gyüjtemény 5/3: 37-70.

Hough, CAROL ed. 2016. The Oxford Handbook of Names and Naming. Oxford University Press, Oxford. https://doi.org/10.1093/oxfordhb/9780199656431.001.0001

JUHÁSZ DEZSŐ 2020. Tulajdonnevek a tájszótárakban. In: FARKAS TAMÁS - SLíZ MARIANN szerk., Tulajdonnevek és szótárak. ELTE Magyar Nyelvtudományi és Finnugor Intézet - Magyar Nyelvtudományi Társaság, Budapest. 53-62. https://doi.org/10.26546/4892373.4

KÁZMÉR MiKLós 1987. Régi magyar családnevek szótára XIV-XVII. század. Magyar Nyelv 83: 59-71.

KERTÉSZ GYULA 2000. Magyar helységnévtárak, helynévlexikonok és szótárak. (Történeti tipológiai áttekintés.) Történeti statisztikai füzetek 12. Központi Statisztikai Hivatal Könyvtár és Dokumentációs Szolgálat, Budapest.

KISS LAJOS 1970a. Az európai névtudomány fontosabb eredményei. In: KÁZMÉR MIKLÓS - VÉGH JózSEF szerk., Névtudományi elöadások. II. névtudományi konferencia. Budapest 1969. Nyelvtudományi Értekezések 70. Akadémiai Kiadó, Budapest. 16-26.

KISS LAJOS 1970b. A Földrajzi nevek etimológiai szótárának tervezete. Magyar Nyelvőr 94: 334344. 
KISS LAJOS 1989. Az európai névtudomány utóbbi másfél évtizede. In: BALOGH LAJOS - ÖRDÖG FERENC szerk., Névtudomány és müvelödéstörténet. A IV. magyar névtudományi konferencia elöadásai Pais Dezső születésének 100. évfordulóján (Zalaegerszeg, 1986. október 8-10.). A Magyar Nyelvtudományi Társaság Kiadványai 183. Magyar Nyelvtudományi Társaság, Budapest. 18-31.

KISS LAJOS 1991. A helynevek eredetét magyarázó szótárak típusairól. In: SzÉKELY GÁBOR szerk., Első Magyar Alkalmazott Nyelvészeti Konferencia. Nyiregyháza, 1991. május 3-4. Nyíregyházi Főiskola, Nyíregyháza. 1: 292-298.

KISS LAJOS 1994. Nyelvtörténeti szótáraink típusai. Magyar Nyelv 90: 392-412.

KOVÁCS ÉVA 2020. A történeti helynévszótárak. In: FARKAS TAMÁS - SLÍZ MARIANN szerk., Tulajdonnevek és szótárak. ELTE Magyar Nyelvtudományi és Finnugor Intézet - Magyar Nyelvtudományi Társaság, Budapest. 133-144. https://doi.org/10.26546/4892373.8

MAGAY TAMÁS 1970. A névkiejtési szótár problematikája. In: KÁZMÉR MIKLÓS - VÉGH JÓZSEF szerk., Névtudományi elöadások. II. névtudományi konferencia. Budapest 1969. Nyelvtudományi Értekezések 70. Akadémiai Kiadó, Budapest. 359-362.

MAGAY TAMÁS 2015. Szótár, enciklopédia és tipológia. In: FÁBIÁN ZSUZSANNA - SZÖLLÖSY ÉVA szerk., Szótár, lexikon, enciklopédia. Kérdések és feladatok. Segédkönyvek a nyelvészet tanulmányozásához 172. Tinta Könyvkiadó, Budapest. 9-16.

MAGAY TAMÁS szerk. 2004. A magyar szótárirodalom bibliográfiája. [1. kiadás.] Lexikográfiai füzetek 1. Akadémiai Kiadó, Budapest.

MAGAY TAMÁS szerk. 2011. A magyar szótárirodalom bibliográfiája. 2., javított és bővített kiadás. Lexikográfiai füzetek 1. Akadémiai Kiadó, Budapest.

MAJTÁN, MILAN red. 1983. VIII. slovenská onomastická konferencia (Banská Bystrica-Prešov [Dedinky] 2. - 6. júna 1980). Jazykovedný ústav Ludovíta Štúra SAV - Pedagogická fakulta v Banskej Bystrici - Pedagogická fakulta Univerzity Pavla Jozefa Šafárika v Prešove, Bratislava Banská Bystrica - Prešov.

MÁRTONFI ATTILA 2015. Kisenciklopédia a szótárban? A tulajdonnevek (írói) szótári kidolgozása. In: FÁBIÁN ZSUZSANNA - SZÖLLÖSY ÉVA szerk., Szótár, lexikon, enciklopédia. Kérdések és feladatok. Segédkönyvek a nyelvészet tanulmányozásához 172. Tinta Könyvkiadó, Budapest. 85-99.

MÁRTONFI ATTILA 2020. Tulajdonnevek a helyesírási szótárakban. In: FARKAS TAMÁS - SLíZ MARIANN szerk., Tulajdonnevek és szótárak. ELTE Magyar Nyelvtudományi és Finnugor IntézetMagyar Nyelvtudományi Társaság, Budapest. 63-91. https://doi.org/10.26546/4892373.5

McClure, Peter 2015. Personal and Surname Dictionaries. In: Durkin, PhILIP ed., The Oxford Handbook of Lexicography. Oxford University Press, Oxford. 271-291. https://doi.org/10.1093/ oxfordhb/9780199691630.013.17

MiKESY SÁNDOR 1970. Személynévkutatásunk első szakaszához. Magyar Nyelv 66: 197-207.

MöLler, LuCIE A. 1995. Methods and Problems in Proper Name Lexicography. In: EICHLER, ERNST et al. Hrsg., Namenforschung / Name Studies / Les noms propres. Ein internationales Handbuch zur Onomastik / An International Handbook of Onomastics / Manuel international d'onomastique. Handbücher zur Sprach- und Kommunikationswissenschaft 11/1-2. Walter de Gruyter, Berlin - New York. 1: 324-328. https://doi.org/10.1515/9783110114263.1

Mufwene, SAlikoko S. 1988. Dictionaries and Proper Names. International Journal of Lexicography 1/3: 268-283. https://doi.org/10.1093/ijl/1.3.268

NiCOlaisen, WilHelm F. H. 1995. Name and Apellative. In: Eichler, ERNST et al. Hrsg., Namenforschung / Name Studies / Les noms propres. Ein internationales Handbuch zur Onomastik / An International Handbook of Onomastics / Manuel international d'onomastique. Handbücher 
zur Sprach- und Kommunikationswissenschaft 11/1-2. Walter de Gruyter, Berlin - New York. 1: 384-393. https://doi.org/10.1515/9783110114263.1

PAJZS JÚLIA 2015. Szótár és enciklopédia az online világban. In: FÁBIÁN ZSUZSANNA - SzÖLLŐSY ÉvA szerk., Szótár, lexikon, enciklopédia. Kérdések és feladatok. Segédkönyvek a nyelvészet tanulmányozásához 172. Tinta Könyvkiadó, Budapest. 120-135.

PAPP LÁSZLÓ 1960. Beszámoló az Árpád-kori személynévszótár munkálatairól. In: MIKESY SÁNDOR - PAIS DEZSÖ szerk., Névtudományi vizsgálatok. A Magyar Nyelvtudományi Társaság névtudományi konferenciája 1958. Akadémiai Kiadó, Budapest. 126-131.

PAPP LÁSZLÓ 1966. Szinkrón anyagú névtárak készítése. In: ORSZÁGH LÁSZLÓ szerk., Szótártani tanulmányok. Tankönyvkiadó, Budapest. 55-76.

PRÓSZÉKY GÁBOR 1997. Szótárírási szempontok a számítógépes nyelvi programok korában és korábban. In: KISS GÁBOR - ZAICZ GÁBOR szerk., Szavak - nevek - szótárak. Írások Kiss Lajos 75. születésnapjára. MTA Nyelvtudományi Intézet, Budapest. 326-335.

RAÁTZ JUDIT 2005. Nemzetiségi utónévkönyvek. [Recenzió.] Névtani Értesitő 27: 322-328.

RAÁTZ JUdiT 2015. Alkalmazott névtan. In: FARKAS TAMÁS - SLíz MARIANN szerk., Magyar névkutatás a 21. század elején. Magyar Nyelvtudományi Társaság - ELTE Magyar Nyelvtudományi és Finnugor Intézet, Budapest. 227-247.

REICHARDT, LUTZ 1995. Arbeits- und Darstellungstechniken der Namenforschung: Namenbücher. In: EICHLER, ERNST et al. Hrsg., Namenforschung / Name Studies / Les noms propres. Ein internationales Handbuch zur Onomastik / An International Handbook of Onomastics / Manuel international d'onomastique. Handbücher zur Sprach- und Kommunikationswissenschaft 11/1-2. Walter de Gruyter, Berlin - New York. 1: 304-312. https://doi.org/10.1515/9783110114263.1

RESZEGI KATALIN 2018. A tulajdonnevek jelentésszerkezete funkcionális kognitív keretben. $M a-$ gyar Nyelvjárások 56: 5-23. https://doi.org/10.30790/mnyj/2018/01

SCHMID, WOLFGANG P. 1990. Gewässernamenwörterbücher. In: HAUSMANN, FRANZ J. et al. Hrsg., Wörterbücher / Dictionaries / Dictionnaires. Ein internationales Handbuch zur Lexikographie / An International Encyclopedia of Lexicography / Encyclopédie internationale de lexicographie. Handbücher zur Sprach- und Kommunikationswissenschaft 5/1-2. Walter de Gruyter, Berlin - New York. 2: 1284-1291. https://doi.org/10.1515/9783110124200.2

SEBESTYÉN ZSOLT 2020. Magyar tulajdonnevek az ukrán névszótárakban. In: FARKAS TAMÁS - SLíz MARIANN szerk., Tulajdonnevek és szótárak. ELTE Magyar Nyelvtudományi és Finnugor IntézetMagyar Nyelvtudományi Társaság, Budapest. 209-219. https://doi.org/10.26546/4892373.13

SEIBICKE, Wilfried 1990a. Personennamenwörterbücher. In: HAUSMANn, FranZ J. et al. Hrsg., Wörterbücher / Dictionaries / Dictionnaires. Ein internationales Handbuch zur Lexikographie / An International Encyclopedia of Lexicography / Encyclopédie internationale de lexicographie. Handbücher zur Sprach- und Kommunikationswissenschaft 5/1-2. Walter de Gruyter, Berlin - New York. 2: 1267-1275. https://doi.org/10.1515/9783110124200.2

SEIBICKE, WiLfried 1990b. Weitere Typen des Namenwörterbuchs. In: HaUsmanN, Franz J. et al. Hrsg., Wörterbücher / Dictionaries / Dictionnaires. Ein internationales Handbuch zur Lexikographie / An International Encyclopedia of Lexicography / Encyclopédie internationale de lexicographie. Handbücher zur Sprach- und Kommunikationswissenschaft 5/1-2. Walter de Gruyter, Berlin - New York. 2: 1291-1296. https://doi.org/10.1515/9783110124200.2

SLÍZ MARIANN 2015. Általános névtani kérdések. In: FARKAS TAMÁS - SLÍZ MARIANN szerk., Magyar névkutatás a 21. század elején. Magyar Nyelvtudományi Társaság - ELTE Magyar Nyelvtudományi és Finnugor Intézet, Budapest. 93-114. 
SLíz MARIANN 2020a. A laikus keresztnévszótárak. In: FARKAS TAMÁS - SLÍZ MARIANN szerk., Tulajdonnevek és szótárak. ELTE Magyar Nyelvtudományi és Finnugor Intézet - Magyar Nyelvtudományi Társaság, Budapest. 165-184. https://doi.org/10.26546/4892373.10

SLíz, Mariann 2020b. Hungarian non-professional dictionaries of first names. Methodological problems caused by the lack of lexicographic and onomastic knowledge. International Journal of Lexicography. https://doi.org/10.1093/ijl/ecaa009

StYles, TANia 2015. Place-name Dictionaries. In: Durkin, PhILIP ed., The Oxford Handbook of Lexicography. Oxford University Press, Oxford. 255-270. https://doi.org/10.1093/oxfordhb/ $\underline{9780199691630.013 .16}$

SZILÁGYI-KÓSA ANIKÓ 2020. Tulajdonnevek a kulturális szótárakban. In: FARKAS TAMÁS - SLÍZ MARIANN szerk., Tulajdonnevek és szótárak. ELTE Magyar Nyelvtudományi és Finnugor Intézet - Magyar Nyelvtudományi Társaság, Budapest. 109-130. https://doi.org/10.26546/ $\underline{4892373.7}$

TAKÁCS JUDIT 2020. Köznevesült tulajdonnevek szótárainkban. In: FARKAS TAMÁS - SLíz MARIANN szerk., Tulajdonnevek és szótárak. ELTE Magyar Nyelvtudományi és Finnugor Intézet Magyar Nyelvtudományi Társaság, Budapest. 231-240. https://doi.org/10.26546/4892373.15

TELEKI JÓZSEF 1821. Egy tökélletes magyar szótár' elrendeltetése, készítése módja. In: HoRVÁT ISTVÁN kiad., Jutalomfeleletek a' magyar nyelvröl, a' Magyar Nemzeti Muzeum 1815. 1816. 1817. esztendei kérdéseire. Trattner, Pest.

TSEPKOVA, ANNA V. 2018. A Dictionary of Secondary Toponymic Nominations as an Educational Guide to a Foreign Language and Culture. Onomástica 4: 203-216.

TUCKER, KEN 2008. A new approach to personal name dictionaries. The proposed Canadian forenames and surnames dictionary. In: Brylla, EVA - WAHLBERG, MATS eds., Proceedings of the 21st International Congress of Onomastic Sciences. Uppsala 19-24 August 2002. Institutet för språk och folkminnen, Uppsala. 4: 195-224.

UCKelman, SARa L. - Slíz Mariann 2015. Többnyelvü névtani lexikográfia: a Dictionary of Medieval Names from European Sources elnevezésű nemzetközi szótári projekt. Névtani Értesitö 37: 203-220.

UZONYI PÁL 2015. A tulajdonnevek kezelése az egy- és kétnyelvű szótárakban. In: FÁBIÁN ZSUZSANNA - SzÖLLÖSY ÉVA szerk., Szótár, lexikon, enciklopédia. Kérdések és feladatok. Segédkönyvek a nyelvészet tanulmányozásához 172. Tinta Könyvkiadó, Budapest. 71-84.

VAN LANGENDONCK, WILlY 1995. International Onomastic Organizations. Activities, Journals, and Collections. In: EICHLER, ERNST et al. Hrsg., Namenforschung / Name Studies / Les noms propres. Ein internationales Handbuch zur Onomastik / An International Handbook of Onomastics / Manuel international d'onomastique. Handbücher zur Sprach- und Kommunikationswissenschaft 11/1-2. Walter de Gruyter, Berlin - New York. 1: 277-280. https://doi. org/10.1515/9783110114263.1

VAn LANGENDONCK, Willy 2007. Theory and Typology of Proper Names. Trends in Linguistics. Studies and Monographs 168. Mouton de Gruyter, Berlin - New York. https://doi. org/10.1515/9783110197853

VÁRNAI JUDIT SZILVIA 2005. Bárhogy nevezzük... A tulajdonnév a nyelvben és a nyelvészetben. Segédkönyvek a nyelvészet tanulmányozásához 42. Tinta Könyvkiadó, Budapest.

FARKAS TAMÁS

ORCID: https://orcid.org/0000-0002-7732-2302

ELTE Eötvös Loránd Tudományegyetem

Bölcsészettudományi Kar 


\section{TAMÁS FARKAS, The fundamental questions of processing proper names in dictionaries}

It is commonplace to approach the relationship between lexicography and proper names with the words "problem" and "problems". The current study provides a comprehensive overview of this unique question, the lexicographic processing of proper nouns, within applied linguistics and applied onomastics. While detailing general questions and tendencies the study focuses on Hungarian results and characteristics of research into the topic. The introduction details how the question has been raised in the lexicographic and onomastic literature. This is followed by an overview how proper names have appeared in various subcategories of reference works, especially in dictionaries and the history of lexicography. The next section focuses on the theoretic and practical problems and solutions to the lexicographic processing of proper names. The study details the general arguments that are raised in connection with including names in dictionaries. The study lists what types of lingual, linguistic, and onomastic information (even of an encyclopaedic nature) can be listed next to a proper name in a dictionary. (Each dictionary only contains a sub-set of these, and differences can arise in different languages.) The study then examines the aspects that define the inclusion of proper names in monolingual and bilingual dictionaries. Unique questions pertaining to the possible types of name dictionaries, their structure and formation are also examined. The lexicographic processing on proper names is a vital question of national and international academic discourse, and is of interest to the general public as well. The tendencies of contemporary lexicography should thus be reviewed in light of these tasks. Finally, the study highlights the potential advantages of digital and online name dictionaries and highlights the importance of organisational lexicographic and academic work. 


\section{Tulajdonnevek az egynyelvü szótárakban}



FARKAS TAMÁS - SLÍZ MARIANN szerk., Tulajdonnevek és szótárak. ELTE Magyar Nyelvtudományi és Finnugor Intézet - Magyar Nyelvtudományi Társaság, Budapest, 2020. 39-52. DOI: 10.26546/4892373.3

\section{Tulajdonnevek a történeti és etimológiai szótárakban*}

1. Általános szótárak és tulajdonnevek. A köznév (nomen appellativum) és a tulajdonnév (nomen proprium) közötti alapvetö különbség évezredek óta ismert. Egyszerüen fogalmazva: az első általánosít, az utóbbi egyedít. Ennek következtében szókészleti helyzetük is eltérő, és az idők folyamán lexikográfiai kezelésük is különbözővé vált. Bár nem tartozik szorosan e cikk témájához, igen röviden érinteni kell a magyar szótártörténet kezdeteit.

A magyar nyelv és főleg a magyar szótörténet szempontjából jelentős szójegyzékek, nomenklatúrák és szótárak (pl. Schlägli szójegyzék; Pesti Gábor: Nomenclatura sex linguarum; Gyöngyösi szótártöredék; Murmellius: Lexicon; stb.) mindkét szótípust tartalmazzák, mondhatni természetes módon. A középkor müveltségét meghatározó latin nyelv szavainak elsajátítását szolgálták ezek a müvek is, illetve a latin szavak tükrözték a szükebb és tágabb világ valóságelemeit is. Ezek közé nemcsak köznevek, hanem tulajdonnevek is tartoztak. A kezdetben csak latin nyelvü szójegyzékek idővel kiegészültek más nyelvek szavaival is, megteremtve ezáltal a későbbi két- vagy többnyelvű szótárak alapjait. A szójegyzékekben található tulajdonnevek közül föleg a helynevek voltak fontosak, hiszen egy-egy ország vagy város megnevezése a latinban és az egyes nemzeti nyelvekben lényegesen eltérő lehetett, ami az adott földrajzi objektum azonosítását is megnehezítette vagy akár lehetetlenné is tette. A gyakorlati célú lexikográfiai müvek - egyszerüen szólva a mai értelemben vett két- vagy többnyelvủ szótárak - Murmelliustól kezdve (1533) Szenci Molnár Alberten (1604) és Pápai Páriz Ferencen át (1708) a mai napig tartalmaznak személy- és helyneveket magyar és megfelelö idegen nyelvi formában.

Minden írott (illetve a 19. század végétől kezdve rögzített hangzó) nyelvi megnyilvánulás az idő múlásával a nyelvek történeti vizsgálatának anyagaként használható. Ilyen nyelvi anyagnak tekinthetők az egyes múltbeli korszakokban vagy napjainkban készült, az adott társadalmi, gazdasági és müveltségi ismereteket lexikálisan tükröző két- és többnyelvü, az értelmezö, a táj- és különféle szakszótárak, melyek - amint arra fentebb utaltam - akár tulajdonneveket is tartalmazhatnak. Az ilyen jellegü szótárak akár csak érintőleges vizsgálata kívül esik ennek a tanulmánynak a keretein (igyekezetem szerint jól megokolt kivétel az alábbi 2. pontban tárgyalt CzF.). Írásomban ugyanis csak azokkal a szótárakkal foglalkozom, amelyek a különféle primer forrásokból származó lexikális anyagukkal - beleértve az említett szótártípusokat is - nyelvi-kronológiai(-etimológiai) tekintetben a tudományos kutatás számára szekunder, ám rendkívül fontos forrásul szolgálnak. Hasonló okokból nem foglalkozom a mai magyar lexikográfia legjelentősebb munkálatával, A magyar nyelv nagyszótára (Nszt.) folyamatosan megjelenő köteteivel sem. Ez az évtizedek óta várt kézikönyv alapvetően értelmező szótár, amely azonban történeti perspektívájú abban az értelemben, hogy alak- és jelentésváltozatait az 1772-től (egyelőre) 2010-ig publikált különféle jellegü forrásokból származó idézetekkel mutatja be.

* A tanulmány az 124127-es számú NKFIH-pályázat (Új magyar etimológiai szótár. Második ütem) támogatásával készült. Köszönöm anonim lektoraim javaslatait, amelyek révén írásom tartalmasabb és értékesebb lett. 
Ezen idézetekben természetesen tulajdonnevek is szerepelnek, ám ezek nem érintik egyegy címszó jelentéseinek értelmezését, és - értelemszerüen - semmiféle közvetlen etimológiai vagy nyelvtörténeti vonatkozásuk sincs. (Az előzőekben említett szótártípusok történeti áttekintéséhez vö. FÁBIÁN ed. 2011, 2012; MURÁTH szerk. 2014.)

2. A CzuCzor-Fogarasi-féle szótár és a tulajdonnevek. Mielőtt rátérnék arra, hogy a szorosan vett történeti és etimológiai szótárak miként kezelik a tulajdonneveket, ilyen összefüggésben szólni érdemes a 19. század közepének kiemelkedő lexikográfiai alkotásáról, a CZUCZOR-FOGARASI-féle szótárról. A magyar nyelv szótára (CzF.) a Magyar Tudós Társaság (ma: MTA) 1844. december 16-ai nagygyülési határozata értelmében csupán értelmező szótárként készítendő el, de a végső változat szócikkei számos esetben tartalmaznak nyelvtörténeti és etimológiai megjegyzéseket is. Ezért néhány sorban foglalkozom azzal, hogy ezek az utalások miként jelennek meg a szótárban.

A CzF. 1. kötetének 3. lapján olvashatunk ,a szótárba tartozó egyes szókról”. Témánk szempontjából a következő szakaszt kell kiemelni: „Családok, nemzetek, országok, tartományok, városok, hegyek, vizek, helységek stb. tulajdonneveik, mivel a szófejtegetésben felvilágosítást adhatnak, szinte felveendők, mint: magyar, cseh, Örs, Sajó, Pécs stb." [kurziválások az eredetiben - G. K.]. Ennek megfelelően - csupán földrajzi helyzetükre utalva - kisebb települések nevét is megtalálhatjuk. Ilyenek például: Abácsfalva 'falu Udvarhely székben'; Abád 'falu Heves megyében'; Leányvár 'faluk Esztergom és Zemplén, puszta Tolna m.[egyében]'; stb. A nagyobb városok közül csak kettőt említek, melyeknél a szócikk bizonyos történeti és (gyakran nem helytálló) etimológiai vonatkozásokat is közöl:

Buda: (1), Magyarország iker fővárosainak egyike. [...] Nevét Kézai krónikája szerént Buda fejedelemtől, Ethele (Attila) testvérétől vette.

Debreczèn, Dẻbrẻczèn: (1), tősgyökeres magyar városaink egyik legnagyobbika, Bihar megyében. [...] Némelyek szerint a tót dobra zem (jó föld) vagy dobrá tzená (jó vásár) szókból származott volna.

Csupán megemlítem, hogy természetesen megtaláljuk a szótárban a Bakony-t, a $B a$ laton-t, a Duná-t és más földrajzi objektumok nevét is.

A személynevek közül is lássunk néhányat:

András: Közvetlenül Andreas-ból vétetett, mely hellen elemzés szerint jelent férfiast, erőst. Máskép: Andorás, Andris, Andor, Endre, kicsinezve: Andriska, Andorka; elötéttel Bandri, Bandi.

Álmos: 1) Alunni kivánó, aki alhatnék. [...] 2) Sok alvást szerető, gyakran aluvó, illetőleg tunya. [...] 3) Álmok fejtegetésével foglalkodó. [...] 4) Mint fó és személynév Ügek fiának és Árpád vezér apjának neve, melyet a névtelen jegyző főképen az álom szóból elemez, minthogy, úgy mond, születése anyjának álmában jósoltatott meg. Bíborban született Koszta leirása szerént: Salmutzes. [...] Régi oklevélben (1270-ből) előfordúl Álmod (Olmud) is mint személynév. Álmosnak neveztetett Kálmán király testvére is.

Ilona: (hellén eredetü, am. világító, fényes, $\varepsilon \lambda \varepsilon v \eta$ am. fáklya vagy $\varepsilon \lambda \eta$

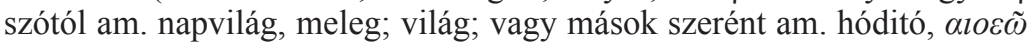


igétől); női kn. tt. Ilonát. Helena. [...] Kicsinyezve: Ilonka, Ilu, Iluska, Ilka, Ikó, Ila, Pila.

Veronika: (1) női keresztnév, a görög phereniké szótól, mely am. győzelemhozó, győzelmes.

Amint a fentiekből kiviláglik, a CzF. szerkesztői a népneveket is a tulajdonnevek közé sorolták, és számos ilyen szó hosszabb-rövidebb szócikkekben meg is található a szótárban.

3. A tulajdonnevek a történeti lexikográfiában. A továbbiakban a ténylegesen nyelvtörténeti és etimológiai szótárakat tekintem át a tulajdonnevek kezelése szempontjából. A 3.1. részben a nyelvtörténeti, a 3.2. részben a (történeti és) etimológiai kézikönyvekről írok. (Ezen szótártípusok általános jellemzéséhez vö. KISS 1994.)

\subsection{Nyelvtörténeti szótárak}

3.1.1. A magyar történeti lexikográfia kezdetei a 19. század közepéig nyúlnak vissza. JERNEY JÁNOS történész a korabeli kutatásokat hátráltató helyzetként értékelte, hogy nem állt rendelkezésükre olyan gyüjtemény, amely a különféle oklevelekben és krónikákban található magyar szavakat tartalmazná. Ezt a hiányosságot megszüntetni akarván adta közre a Magyar nyelvkincsek Árpádék korszakából címü, két füzetből álló művét. Az Előszóban a következőket írja: „E’ hézagot kívántam betölteni, midőn az árpádiak korszakát a' XIV-dik század első évéig fölkarolva, a' hely-, határ-, vidék-, hegy-, völgy-, erdö-, folyó-, család-, személy-, hivatal-, eszköz- 's egyébb ide vonatkozó, bármirészben magyar szóértelmet tartalmazó neveket és szólásformákat összegyüjtvén, szótáralakban körülbelöl mintegy ötezer vezérszóval ellátva közrebocsátom” (JERNEY 1854: V). A felsorolásból látható, hogy a feldolgozott szóanyag lexikális jellege eléggé vegyes.

Találunk benne közszavakat, sőt ezeknek különféle jelezett vagy ragozott alakjait is:

Adjon: Oggun 1 Hb.cs [cs = cselekvő ige] (mond: agygyon).

Áldomás: Aldamas, Aldumás Bknj [Béla király névtelen jegyzője] 16, 22 „Et in eodem loco (Tarczal hegyen) more paganismo, occisso equo pinguissimo, magnum aldamas fecerunt”. „Et more paganismo fecerunt aldumás” pogány szertartásu áldozat, mely lakomából állott főleg.

Párkány: Parcan 1295 „Ad erteriorem munitionem castr (Gimus), quae vulgariter Parcan dicitur" vár külső része, Nitrában.

Teremté: Terumteve $1 \mathrm{Hb}$ (m: terüntevé [Sic! - G. K.]) cs.

A szótári anyag túlnyomó része tulajdonneveket tartalmaz, amelyek között természetesen igen sok olyat találunk, amely valamilyen közszóból keletkezett. A személynevekre vonatkozóan a következőket írja JERNEY: „Szótárunkban nem kevés oly anyagra találand a' figyelmes olvasó, melyből az ős magyar nép szokása, gondolkozása és életmóda tanulságos vonásokban tünik föl. Ime sajátságos férfi nevek például, Alacsony, Bekegő, Bikacső, Bors, Büszke, Csekelő, Haragos, Irgalom, Irigy, Jólegény, Kemény, Kenő, Kevély, Keverék, Lipe, Lusta, Lökő, Maradék, Medve, Nőetlen, Ortó, Öklelő, Rigó, Serkentő, Szegény, Szomorka, Tagadó, Tekerő, Titok, Vendég, Vénlegény, Villám, Zúzó, a’ nőnevek közt továbbá: Ajándok, Banya, Csókadó, Drága, Gyönyörü, Játék, Jobbcsecsü, Kecs, 
Kúpcsecs, Liliom, Szép, Szerelmes, Szerető, Tükör, Utáló, Viola 'stb. sokkal jellemzőbbek, semhogy a' népéletre belülök eredményeket nem vonhatnánk" (JERNEY 1854: IX) - ehhez különösebb hozzáfüznivalónk nincs.

A személynevekhez kapcsolódóan, de már a helynevekre utalva írja a szerző a következőket: „Nem levén czélom magyar Onomasticon írása [...], azon személyneveket, melyek kéttelenül görög vagy római eredetü martyrologiai nevekböl alakulván, magyarban jelentéssel nem bírnak, minők például: Csepán, Deső, Isop, Jákó, Mikó, Pető (Stephanus, Desiderius, Josephus, Jacobus, Nicolaus, Petrus) stb végképen mellőztem; ellenben mint helynevet besorolám az ilyekből magyar ragok hozzájárultával alakultakat, minők: Jánosd, Miháld, Samud stb.” (JERNEY 1854: VIII). A helynevek között a településnevek mellett víz- és dülőneveket is szép számban találunk:

Adony: Odun 1208 szn; Odon 1262 hn; Addon 1279 hn Fejérben.

Ágas-halom: Agosholm 1229 VR 358 § hrhegy [hrhegy = határhegy] Kolosmben Erdélyben.

Árok-töve: Aruktue 1055 hr [hr = határ].

Barcs: Barch 1248, „Ad stagnum Barch,” tó Csallóközb.

Esk-üllő: Esculeu Bknj 27 ,In loco illo, qui dicitur Esculeu, fidem cum juramento firmaverunt, et a die locus ille nuncupatus est Esculeu, eo, quod ibi juraverunt" most Esküllö fu [fu = falu] Dobokában Erdélyben.

Fejér-Körös: Feyerkeres 1299 fó [fó = folyó] Békésben.

Az adatokat évszám követi, de a források megadása általában hiányzik: JERNEY ezt helytakarékossággal indokolta. Ha egy-egy adat a Halotti beszédből, Anonymustól, Kézaitól vagy a Váradi regestrumból származik, a lelőhelyre utalás nem marad el. Ilyen módon ez a szótár korlátozottan használható, de mindenképpen fontos mü a tulajdonnevek kutatását tekintve. Ezt az erényét még az sem kisebbíti, hogy eredetmagyarázat egyik szócikkben sem található.

3.1.2. 1865-ben a Magyar Tudományos Akadémia megbízta a nyelvész és történész MÁTYÁS FLÓRIÁNt egy nyelvtörténeti szótár összeállításával. Az MTA tagja össze is gyüjtötte $z s$ betüig a Magyar nyelvtörténeti szótárba szánt anyagot, ám a közzététel a borul igénél abbamaradt. Ennek oka a mü iránti érdektelenség volt, a második füzetből alig kelt el néhány tucat. A szótár címszavai elsősorban közszavak, azonban ezek szócikkeiben is találunk személy-, illetve helynévi adatokat:

Aczél: 1. Személynév. Ioannes dictus Achyl. 1340, C. D. VIII. 4. 474.; 2. Helynév. Achelkirtus possessio. 1386. C. D. VIII. 4. 268.

Agyag: ,Vadit ad quemdam [Sic! - G. K.] locum Ogyoguozuw vocatum” 1262. C. D. VII. 3. 46.

Bika: 1. férfinév. „Beko et Bika cum uxoribus filiis et filiabus.” 1198. Mon. 11. 194. 2. taurus.

Bogár: 1. személynév. „Artifices hy sunt: filius Buhte, bogar filius Boda” 1211. Mon. 8. 108. [...] 2. insectum, musca.

Ezek mellett olyan címszavak is szerepelnek, amelyek csupán tulajdonnévként adatolhatók: 
Aladár: Férfinév. Filiis Ivanca de Peeth, nec non filiis Aladarii fratris eorumdem. 1295. C. D. VII. 2. 183.

Antal: Férfi keresztneve, Antonius. „Castrenses de villa Mogorey, una cum Antalo filio Vytalus de Maach.” 1277. Mon. 9. 94.

Bora: Barbara. Ozthan Bornemizza Boranak adak az feldeth. 1554. R. M. Ny. E. III. 11.

A fenti példákból látható, hogy a szócikkek megfelelnek a filológiai elvárásoknak: az egyes adatokat évszám és forrásmegjelölés követi, így az adatokat ellenőrizni lehet. MÁTYÁS FLÓRIÁN müve is heterogén tartalmú, köz- és tulajdonneveket egyaránt közlö szótár, ami nem meglepő, hiszen az adott korban ez általános jelenség volt. (Csak az érdekesség kedvéért: a Béla névre vonatkozó adatok és különféle fejtegetések öt hasábot töltenek meg.)

3.1.3. A 19. század vége felé jelent meg SzARVAS GÁBOR és SimONYI ZSIGMOND szerkesztésében a Magyar nyelvtörténeti szótár (NySz.). Az 1. kötet ii. lapján a 3. pontban azt olvashatjuk, hogy a szótárból „ki kell rekeszteni [...] b) a tulajdonneveket, kivéve a keresztneveket, népneveket, s azokat, melyek egy-egy köznévnek magyarázatául szolgálhatnak (pl. Alsó-Ör, Felső-Ör sat.); [...]”. A xvii. lapon már az áll, hogy a szótárhoz csatolandó függelékben fognak majd állni a keresztnevek és „,népnevezetek”. Ennek ellenére a szótári szócikkek között találunk népneveket is, ám csupán néhányat, azokat is csak kiismerhetetlen szempontok szerint válogatva. Mondhatni, természetesen címszóként szerepel a magyar, és érthető a tót és a kun (az NySz.-ben kún) szerepeltetése is, bár az utóbbi népnév adatolása mindössze egy-két szólásra korlátozódik. A magyar nyelv (és nép) történetét tekintve ugyanígy várható lenne a magyar írásbeliségből jól adatolható besenyö, cseh, német, szász és egyéb népnév felvétele is, ezeket azonban hiába keressük a szótárban. - Az NySz. végül is nem tartalmazza azt a függeléket, amelyben ígérete szerint a kereszt- és népneveket sorolta volna föl (1. még az OklSz.-ról írottakat).

3.1.4. Az NySz. pótlékaként elkészített Magyar oklevélszótár (OklSz.) bevezetésében (Az anyag kiaknázásának elvei; különösen: XI-XIII) ZOLNAI GYULA hosszasan foglalkozik a tulajdonnevek kezelésének kérdésével. Mivel szótárát a régi közszók gyüjteményének tekintette (miként a szótár anyagának jelentős részét összegyüjtő SzAMOTA ISTVÁN is), a tulajdonneveket kihagyta a szótárból, de kijelenti: „A tulajdonnevek történelmi és hangtörténeti fontosságát egyetlen nyelvész sem vonta kétségbe, de helyesen jár el a nyelvtudós, ha a neveket tudatosan különválasztja a szóktól, s mikor szótárt készít, nem vegyít ebbe olyan elemeket, melyeknek tárgyalása külön neveskönyvbe (onomasticon), illetőleg a történeti hangtanba való" (OklSz. XI) (a kurziválások az eredetiben - G. K.). Álláspontjának megfelelően az OklSz.-ban csak akkor szerepelnek hely- és személynévi adatok, ha azok magyar közszókat tartalmaznak, ez utóbbiak szócikkébe sorolva öket. Az eljárás bemutatására álljanak itt néhány szócikkből megfelelő adatok:

Bérc: 1258: ad locum qui dicitur Kuzepberch; 1338: In loco Meggyesmaalberchy dicto; 1448: In ascensu cuiusdam montis wlgo Zeenheghetew Bercz vocati; stb.

Bükk: 1203/1254: In loco qui dicitur Bycfeu; 1337: A quodam loco Bykzad vocato; stb. 
Hév (hő): 1288/1326: In fluuio Heuyo constructum; 1394/1446: Iuxta quendam monticulum wlgo Hewhalom vocatum; stb.

Nyak: 1379: Tendendo per idem Berch in vno loco Babolna naka nominato.

Só: 1200 k.: Usque ad fluuium Souyou; 1411: in loco Thalaborsowa vocato; stb.

A fenti, viszonylag jól érzékelhető szerkezetü helynevekkel szemben vannak olyanok is, amelyek önálló szócikket kaptak. Ezekről ZOLNAI a következőket írja: „Beretytyó-t, Erdély-t - megvallom - elvemtöl eltéröleg vettem föl külön cikkekben, csupán azért, mert teljes bizonyossággal kimutatott alkotó elemeik (berek+jó, erdö+elv) anynyira elhomályosodtak már, hogy a szótár minden használója bizonyára mai egybeforrt alakjuk szerint s nem alapszavaiknál keresné őket, azonban az alapszóknál is megtalálja az olvasó a szükséges utalásokat” (OklSz. XII). Úgy gondolom, helyeselhető ez a szerkesztési gyakorlat.

A szótárba - általános kivételként - felvett keresztnevekkel kapcsolatban a következőket olvashatjuk: „A keresztnevek ugyanis mintegy a tulajdonnév és köznév határán állanak, természetüknél fogva minden más névnél jóval sürübben fordulnak meg ajkunkon, nyelvünk természetéhez legjobban simultak, s nagyobbára teljesen magyaros alakot öltöttek, úgyhogy tanulságos fejlődésük föltüntetését szótáram céljához sokkal közelebb állónak tarthattam" (OklSz. XII). Ezzel egyben az NySz. ígéretét is beváltotta az OklSz. Lássunk néhány példát keresztnévi szócikkekből:

András: 1225: Endre; 1242 k.: Endere; 1282 k.: Andreas; 1321/1323: Kenchesandrasfolua; 1336: Scenth-anduryas; 1602: Andor; stb.

Bálint: 1558 k.: ? Baint; 1577: Walent, Walint; 1584: Balynth; stb.

Ërzsëbet: 1244 k.: Ersebyth; 1334: Scentelsebeth; 1451: Zenthersebeth; stb.

Az Ok1Sz. a - $d$ és - $d i$ képzős származékokat (a származékságra való utalással) szintén a megfelelő alapszó szócikkében közli, mivel a szerkesztő szerint ezek a szavak „csupán hely- és személynevekül szolgáltak, melyeknek ennélfogva közszói minőségük alig lehetett” (XIII). A következő szavak illusztrálják ezt a szintén elfogadható eljárást:

Balog: 'balkezes; rosszindulatú' - 1230: Villa Bolugd; 1234: Ad caput arbustorum Bolugd.

Bárány: 1266/1297: Villa Barand; 1358: Possessionum [...] Barand.

Szamár: 1171: In uilla Zamard; 1211: ad stagnum Somardy.

Összességében elmondhatjuk, hogy az Ok1Sz. jól átgondolt elvek alapján közöl tulajdonneveket egy olyan szótárban, amely alapvetően köznevek szótörténeti adatait tárja az olvasók elé.

3.1.5. A történeti szótárak keletkezési időrendjében haladva röviden szólni kell a SZILY KÁLMÁN szerkesztette különleges müről, A magyar nyelvújítás szótáráról is. Mint közismert, a 18-19. század fordulójának legjelentősebb nyelvi és kulturális mozgalma, a nyelvújítás számos új szóval gazdagította időlegesen vagy tartósan a magyar szókészletet. 
A mű szerzője a következőket írja az előszóban: „Íme, a mit igértem, kedves olvasóim, előttetek fekszik ,a magyar nyelvújítás krónikája“, szótári alakban. Semmi egyéb, mint krónika; se nem teljes, se nem tökéletes” (NyÚSz. VI). Az egyes szócikkekből megtudhatjuk, ki, mikor és mely müvében (esetleg levelében) használta először az adott szót, illetve számos esetben azt is, hogy milyen más javaslatok születtek egy-egy fogalom, jelentés megnevezésére. A két kötetből álló, gazdag szómutatót tartalmazó szótár címszavainak túlnyomó többsége természetesen közszó, de a tulajdonneveket is érintette a nyelv iránt elkötelezettek magyarítási buzgalma, így ilyen lexikális anyag is színesíti a szótárt. Lássunk néhány példát előbb a helynevek köréből:

Budapest: Széchenyitől (1831: Világ, 331) idéz SzILY: „fővárostok nevét Budapestre kellene változtatni, melly kevés év, sőt hónap mulva olly megszokottan s könnyen hangzanék mint Bukarest" (NyÚSz. 424) - Pest, Buda és Óbuda 1873-as egyesítésekor vált ez a név az ország fővárosának hivatalos nevévé.

Tátrafüred: a németül Schmecks-nek nevezett településnek 1839-ben az ott alapított fürdőről a Nagyszalóki fürdö, 1842-ben a Tátrai-fürdő magyar nevet ajánlották. Ebböl alakult a Tátrafüred, mégpedig a következöképpen: „1846 július 31-ikén az akkor ott (Schmecksen) mulató közönség nevezte el e helyet, a regényes Balaton-Füred pendantjáúl” (NyÚSz. 584).

A német Leipzig magyarításaként keletkezett Lipcse szócikkét talán érdemes teljes terjedelmében közölni:

Lipcse: Sá nd or I s t ván 1791 (Sokféle 2:112). - A 112. lapon Liptse, holott u. o. 104. lapon meg Lájptzig és még 4: 34 is Liptsét rekeszben Lajptziggal magyarázza. Bizonyosan a régi Lipsia és a liptómegyei Lipcse csengett a fülében. Így ő Jenát Jenőnek, Bolognát Abonynak, Thebaet Tabánynak, Bern-et Berénynek akarta nevezni. Még furcsább: Dresda Darázsd, Kopenhága: Kappanhágó; Stockholm: Istókhalma; Solothurn: Szólótorony; Julius Caesar: Gyula császár; Kalendarium Julianum: Gyulai Kalendárium. (Sokféle 2: 110-115; 4: 233; 12: 220-243). Vö. Adal. 301.Dugonics (Jólánka 1:599) egész komolyan állítja, hogy Riga régente Rigó volt (NyÚSz. 210).

A személynevekkel több szócikk is foglalkozik, de a Keresztnevek címszó (NyÚSz. 172) alatt jó néhány olyat találhatunk, amelyek ebben az időszakban keletkeztek: Aranka $(\sim$ lat. Aurelia), Bódog ( lat. Felix), Frigyes ( ném. Friedrich), Gyözö ( lat. Victor $)$ stb. A szócikk végén a következőket írja SzILY: „Érdekes lenne kikutatni, hogy az újabb időkben kik nevezték magukat legelöször Álmos, Árpád, Attila, Béla, Elemér, Géza, Gyula, Jenö, Kálmán, Ödön, Szabolcs, Tihamér, Zoltánnak stb."

Ismert lehet, hogy az Etelka (NyÚSz. 83, 172) és Jolánka (NyÚSz. 492) női nevet Dugonics András alkotta, a Szilárd (NyÚSz. 308) pedig előbb köznévként gyökeresedett meg (Szemere Pál leleménye az 1816 elötti időből).

A NyÚSz. nagy érdeme, hogy a dolog természeténél fogva hiányos anyag bemutatásával lehetővé tette a nyelvújítás korának mind a köz-, mind a tulajdonnevek állományát érintő szótörténeti feltárását. 
3.1.6. A magyar történeti szótárak között kiemelkedő helyet foglal el a SzABÓ T. ATTILA által elindított Erdélyi magyar szótörténeti tár (SzT.). Ez a monumentális szótár valójában SzABÓ T. ATTILA erdélyi helynévtörténeti gyüjtésére épül, melyet az egykori kolozsvári kutató eleve egy más, nem szótári jellegü nagy munkában szándékozott közreadni.

A müfaj jellegzetességeiből fakadó módon ebben a szótárban is elökerül az a kérdés, hogy milyen szóanyag kerüljön be az egyes szócikkekbe. Az alaphelyzet itt is világos: csak közszavak alkotnak önálló szócikkeket. Tulajdonnevek azonban közvetett módon jelen vannak ebben a szótárban is. Más történeti (és etimológiai) szótárakhoz hasonlóan köznevesüléssel létrejött szavakat itt is találunk; pl.:

asztrakán: 'prémfajta' - 1807: (Vásárolt) 3 Astragánt; 1809: ásztrokányal; 1838: Asztrakán; stb.

atilla: 1851: Atilla; 1857: átilla.

fukar: 1722: fukár, fukar.

Bizonyos összetételekben és jelzős szerkezetekben álló tulajdonnevek is szerepelhetnek címszóként; pl.:

Péter-alma: 'almafajta' - 1697: Bán Ferencz hagyot két Almafát ... edgyik Péter alma, másik mosolygó.

Mátyás király barna pénze: 'bronzdénár' - 1637/1639: Matthjas kiralj barna penze njom M. 3 p. 34.

János király tallérja: 'Szapolyai János pénze' - 1584: Bakj pal ... Illie(n) ezwst marhakat Newez vala ... wgy mint Serlegeket, Mosdot, poharokot János kiralj tallért es egj eoregh maiczos parta eowet; 1611: Egj János kiralj tallér, egj mas Rendbelj talleral egiwt nio(m) p. 14 f. 2. d. 62 .

Számos olyan címszó is található az SzT.-ben, amely helynévböl jött létre - $i$ képzővel, különösen olyan nevekböl, amelyek alaki viselkedése nyelvtörténeti szempontból is érdekes; pl.:
alfalvi: 'gyergyóalfalusi' - 1610: Alfalj; 1647: Alfalvi; 1658: Alffaluj. bonchidai: 1591: Bonczidai; 1717: Bonczhidai.
borgói: 1670: Borgai; 1757: Borgoi.

A legtöbb (feltehetőleg több ezer) tulajdonnév számos közszói szócikkben az Án (= állatnév), Hn (= helynév) és Szn (= személynév) szakaszokban található, és ezzel gazdag tárházát kapjuk az értékes szótörténeti adatoknak. Lássunk néhány példát erre a megoldásra is:

borjú: Hn. 1695: az Borjú Ret; 1757: A Bornyu Mező, a holl az egész Falunak Bornyai Szoktak Nyaralni; 1765/1801: a Borjú motsár; 1768: A Bornyu kútnál; 1850 k.: Borjú gyepü.

boros: Szn. 1497: Johannem Boros de Zenthgrazia; 1569: Boros Kristóf; 1685: Boros Borka. 
csákó1: 'szétálló, felfelé görbülő' - Án. 1805: Második Pár ökör . . . a Tsáko Tsábéli, a Jámbor hojszbéli; 1807: Csákó fekete szarvú... ŭszŏ.

diós: Hn. 1526: dyoskerth vocitatus; 1672: az Dijos berekben; 1687: Az Diós Irtoványban; 1716: A Diós veremben; 1725: az diós bungordban; stb.; Szn. 1584: Diós Balinth.

macska: Hn. 1604: Az maczka vereon aloll az szekeres fejebe az keozen eghette(m) zenet; 1726: Az Matska nyuzo domb alat; 1805: A' Matska lik nevü helyben; 1811: Matska szék oldala nevü hellyben; 1864: Macska Mály.

Az SzT.-ben található (közvetett vagy közvetlen) tulajdonnév-állományt gazdagnak mondhatjuk. Ez egyrészt a feldolgozott források jellegéböl fakad, hiszen a különféle birtokösszeírások, peres eljárások jegyzőkönyvei, városi-községi tanácsi hivatalos iratok, anyakönyvek, adásvételi szerződések, misszilisek stb. ezrével tartalmaznak hely- és személyneveket egyaránt. Másrészt ez a szótár kifejezetten törekedett a címszó-gazdagításra, és ezáltal olyan címszavak is keletkeztek, amelyek a korábbi (és nagyrészt a mai) magyar lexikográfiában nem állnak ilyen helyzetben. Ilyenek általában a jelzős szerkezetek, az - $i$ képzős alakok (hacsak nincs jelentésbeli többletük) stb. Ám SzABÓ T. ATTILA ezzel az eljárással (és egyéb szerkesztési megoldásokkal) arra törekedett, hogy minél több olyan nyelvi anyagot mentsen meg és tegyen közzé, amely más formában hozzáférhetetlen lenne a szakemberek vagy az érdeklődő laikus olvasók számára.

3.1.7. A magyar történeti szótárak sorában fontos helyet foglal el egy, a maga nemében egyedülálló szótár. Ez a BERRÁR JOLÁN és KÁROLY SÁNDOR szerkesztette Régi magyar glosszárium (Gl.), mely az alcíme szerint Szótárak, szójegyzékek és glosszák egyesített szótára. Lexikográfiai és nyelvtörténeti jelentőségét nem lehet eléggé hangsúlyozni, hiszen nélküle igen nehézkes lenne a sokféle helyen örzött, nem is mindig megfelelö formában publikált lexikális anyag felhasználása. Az 1290 körül keletkezett Vatikáni glosszákkal és az 1610 körüli időből származó Herbolarium Vincentiae-vel jelölhető időhatárok közötti ötvenhét forrás is tartalmaz természetesen tulajdonneveket, és ezeket a Gl. is közli: elkülönítve a közszavaktól, a szótár végén, mintegy függelékként. (A szótár közszói részében bizonyos szintagmák tagjaként is előfordulnak tulajdonnevek, amelyekre az adott tulajdonnév szócikkében mindig utalás történik.) Ha egy-egy tulajdonnév - $i$ vagy -beli képzővel is előfordul, ez az alak a közszavak között szerepel címszóként, természetesen utalással a megfelelő névre, illetve a névnél utalást találunk a közszói címszóra.

Sajátosnak tünik a szerkesztőknek az az eljárása, hogy a tulajdonneveket nem a ma megszokott köznyelvi alakjukban teszik meg címszónak, hanem a forrásokból adatolható korabeli, sokszor latinos formában. Ez a megoldás az egyénneveknél kevésbé okoz gondot az azonosíthatóság tekintetében, hiszen az Asveros, illetve a Jovis viszonylag könnyen „transzformálható” a ma használt Ahasvérus, illetve Jupiter formára. Viszont az Udalrikus vagy a Korlát esetében már gondban lehetnénk, ha a címszóként álló nevek után nem állna ott németül a ,jelentésük”, vagyis a mai magyar névformával azonosítható német megfelelö. Ilyen módon az első esetben az Ulrich, a második esetben a Konrad névnek a korabeli (meglehet, hibásan lejegyzett, esetleg népetimológiás) alakjával van dolgunk. A személynevek között (érthető módon) viszonylag számos adata van a János és a Mária keresztnévnek. 
A helynevek közt természetesen sok olyat találhatunk, amelynek korabeli és mai névformája (ejtésformája) azonos: Ázsia, Balaton, Garam, Hollandia, Székesfehérvár stb. Több olyan helynév is van, amelyet ma már nem használunk, de történelmi ismereteink segítségével lokalizálni tudjuk őket: Antverpia, Athénás, Florencia, Helvécia, Slézia stb., de a német megfelelök itt is segítségünkre vannak.

A helynevek közül a német értelmezések nélkül viszont számosat aligha tudnánk mai megfelelöikkel azonosítani. Lássunk ezekre is néhány példát: Aretopolis 'Bern', Argentína 'Straßburg' [!], Briganton 'Bregenz', Gedanon 'Gdańsk', Leopolia 'Lemberg' stb.

A Gl. köznévi része mellett a tulajdonneveket bemutató szócikkek is jól használható adalékokat tartalmaznak a magyar történeti onomasztikai kutatások számára.

3.2. Etimológiai szótárak. A tisztán történeti szótárak után áttérünk az etimológiai szótárakra. Ezek közül a hangsúlyosan tudományos igények kielégítésére törekvő szótárak a szóeredeztetés mellett szótörténeti adatokat is közölnek, hiszen megalapozott etimológiát általában nem lehet szótörténet nélkül felállítani.

3.2.1. Időrendben haladva a GOMBOCZ-MELICH-féle Magyar etymologiai szótárral (EtSz.) kell kezdenünk. Ennek a kézikönyvnek sajátos módon nincs bevezetője, melyből a különféle szerkesztési elvekre, megoldásokra vonatkozó információkat szerezhetnénk. A füzetekben megjelenő szótár hátsó borítójának külső oldalán azt olvashatjuk, hogy a köznyelv szavain kívül felveszik a tájszavakat, „valamint a tulajdonnevek közül is azokat, amelyeknek világos az eredetük s amelyeknek nyelvészeti vagy történeti fontosságuk van". Ezzel követik azt a lexikográfiai gyakorlatot, amelyet már a CzF.-ben, majd (kicsit szükebb körre kiterjedően) az OklSz.-ban is tapasztalhattunk. Az EtSz. A, Á kezdetü részében a következő hely- és személyneveket találjuk: $A b a$ szn., Ábel, Ábrahám, Abrud hn., Acintus szn., Acsa hn., Ádám, Adolf, Adorján, Aglënt szn., Ágnës, Ágosta hn. (Augsburg), Ágoston, Ágota, Ajton, Akastyán-hegy, Ákos, Aladár, Alajos, Alap szn., Albërt, Álmos, Alpár szn., Amadé, Amália, Ambrus, Ancilla szn., Anda szn., András, Angyalos szn., Anianus, Anna, Antal, Apaj szn., Apalin szn., Apostol hn., Apsa szn., Arad, Árbusz szn., Ardán Ardány hn., Ardó hn., Arnold, Áron, Árpád, Árva hn., Ata szn., Aténás, Athlamos szn., Atilla, Atlanti(-tenger), Auguszt szn., Ausztria, Azariás szn. Ezeknek vagy sosem volt magyar köznévi alapjuk, vagy pedig elhomályosult morfémaszerkezetekké váltak (Ardó, Arpád), és így lehettek tulajdonnévvé. A 102 lapon 53 tulajdonnév áll címszóként; ez mindenképpen nagy számnak mondható egy alapvetően köznévi etimológiai szótárnak szánt müben. Más kezdőbetűket tekintve nyilván más (jobbára alacsonyabb) számokat kapunk, de több más tényező mellett feltehetőleg a tulajdonnevek túlzott felvétele is oka lehetett annak, hogy az EtSz. torzóban maradt.

Tulajdonneveket, föleg helyneveket a szótár köznévi szócikkeiben, a szótörténeti adatoló részben is találunk, gyakran csupán az illető adat forrására utalva, a konkrét adat közlése nélkül; pl.:

apa: 1141-61 Apa szn.

apró: 1145/1443: aprokwrthwel hn.

berek: 1138 berekzeg hn.

bika: 1193 biquacut hn.

bodnár: 1388 Bodnar szn. 
3.2.2. Második etimológiai szótárként a BÁRCZI GÉZA szerkesztette Magyar szófejtő (SzófSz.) szótárt kellene megvizsgálni. Erről a megjelenése idején hiánypótló müről szerkesztője a következőket írja: „Ez a szófejtő szótár nem a szakembereknek, hanem elsősorban a müvelt magyar közönségnek szól” (SzófSz. V). Ennek következtében a szócikkek alapvetően a legfontosabb etimológiai információk közlésére szorítkoznak. A szótörténet pusztán annyiból áll, hogy közli az első adat keletkezési idejét és forrását. Ha egy-egy szó első adata személy- vagy helynévből származik, erre a hn. (= helynév), illetve szn. (= személynév) rövidítés utal, majd következik az első köznévi adat évszáma, lelőhelye, pl.:

alma: [hn. összet. 1236/1239. OklSz., kn. 1225. OklSz.]

bíz: [szn. szárm. 1211. MNy. 31: 159, kn. XIV. sz. v. BesztSzj.]

hős: [szn. 1206. NySz., kn. XIV. sz. v. BesztSzj.]

mocsár: [hn. v. kn. 1231/1397. OklSz. kn. 1342. Nyr. 42: 364$]$

ösvény: [hn. 1222. Ok1Sz., kn. XV. sz. e. f. JókK. NySz.]

A SzófSz. - mint láthatjuk - magától értetődő módon elismeri a tulajdonnevek fontosságát a szótörténetben, de céljainak megfelelően a mintegy 350 lapos szótár csupán utal ezekre a megfelelö szócikkekben.

3.2.3. A magyar történeti lexikográfia eddigi legnagyobb alkotása a BENKŐ LORÁND föszerkesztésében megjelent A magyar nyelv történeti-etimológiai szótára (TESz.). A mintegy háromezer lapon található, a 130 000-et meghaladó lexikális adat (szóalakok és jelentések), valamint a szócikkekben található idegen nyelvi adatok óriási száma, az etimológiai kifejtések megalapozottsága nemzetközi tekintetben is a müfaj legjobbjai közé emelték ezt a szótárt. Ez a kézikönyv már a címében is hangsúlyozza a szótörténet és az etimológia egységét, és ezt a szócikkek felépítésében is jól láthatjuk. Az egyik előzménytől, az EtSz.-től eltérően azonban semmilyen tulajdonnév nem áll címszóként: „Szótárunkban a magyar szókészletnek csak a köznévi elemeit dolgoztuk föl. A magyar tulajdonneveket (hely- és személyneveket) - mind elvi, mind gyakorlati meggondolások alapján - kirekesztettük; ezeknek történeti-etimológiai feldolgozása egy vagy több külön névtár feladata. A tulajdonnevek kirekesztése természetesen csak a címszóanyagra vonatkozik; az egyes szavak történeti dokumentációjában ezek magától értetődően nagy számban szerepelnek, hiszen a régi magyar köznevek jelentős része korai nyelvemlékeinkben hely- és személynévként fordul elö" (TESz. 1: 8). Ám a tulajdonnevek sokkal következetesebben szerepelnek a szótörténeti adatoló szakaszban, mint az EtSz.-ben. Erről a következőket olvashatjuk: „Az alakváltozatok dokumentálására a címszó származékait [...] és tulajdonnévként előforduló adatait is felhasználjuk. A származékok sz. (= származék) jelzést kapnak, a tulajdonnévi adatokat pedig szn. (= személynév), illetőleg hn. (= helynév = földrajzi név) jelzéssel látjuk el" (TESz. 1: 19). A szóalakokat többé-kevésbé jól meg lehet állapítani a tulajdonnevek esetében is, de az alakokhoz kapcsolódó jelentések elvonása ezekből már sok esetben nehézségekbe ütközik. Erre vonatkozólag a következő tájékoztatást kapjuk: „Ha a forrás nem teszi lehetővé a jelentés teljesen egyértelmű meghatározását, vagy pedig tulajdonnév alapján tüntetjük fel valamelyik jelentés első felbukkanását, akkor erre a bizonytalanságra az értelmezés szövege elé tett kérdőjellel hívjuk fel a figyelmet" (TESz. 1: 19). (Természetesen mindig szerepel az illető jelentés első biztos 
adata is.) A tulajdonnevek nemcsak a címszavak alakváltozatai között szerepelnek, hanem az Sz: rövidítéssel bevezetett, a kiemelt származékokat közlö szakaszban is; pl.:

acél: 1135 k.: ? „Tornatores: . . Acil” szn. (PRT. 8: 270); 1229/1550: ? Acél szn. (VárReg. 360.) - J: 1135 k.: ? 'edzhető vasféleség, vasötvözet; Stahl' \# (1. fent), 1395 k.: 'ua.' (1. fent) - Sz: os 1335: Acilus hn. (OklSz.).

ág: 1158/1323/1403: ? „que terminatur ... ab oriente . . . Voduez, et Agifei” hn. (Karácsonyi: Szt. István 81); 1193: egerag hn. (ÓMOlv. 55) J: 1158/1323/1403: ? 'folyó ága; Flußarm' \# (1. fent), 1193: 'ua.'(1. fent) Sz: as 1141-61: ? Agus szn. (Ok1Sz.); 1229/1550: Agosholm hn. mn. (VárReg. 358.)| azat 1510: Kewzepagazath hn. (Ok1Sz.).

bátor': 1138/1329: „Hec sunt nomina seruorum Bahatur ...” szn. (MNy. 32: 132); [1177]/1202-3/15. sz.: Batur hn. (Györffy 1: 598); 1180 k./1213. sz.: ? Buatir szn. (PRT. 8: 270); 1230: Baatur hn. (Györffy 1: 848); 1323: Bathorighaz hn. (Györffy 1: 710) - J: 1138/1329: ? 'merész, hős; mutig' \# (1. fent), 1372 u./1448 k.: 'ua.' (1. fent).

A példák számát bőven szaporíthatnánk, de az itt megadottakból is világosan látszik, hogy a tulajdonnevek a szavak adatolásának kronológiájában tapasztalható fontosságuk miatt kellő súllyal szerepelnek a szótörténeti adatok között.

3.2.4. A tudományos igényű magyar etimológiai szótárak sorában (egyelőre) utolsó a német metanyelvü Etymologisches Wörterbuch des Ungarischen (EWUng.), melynek föszerkesztője szintén BENKÖ LORÁND volt. Gyakran - és tévesen - a TESz. német fordításaként emlegetik ezt a kézikönyvet, jóllehet attól több lényeges tekintetben is eltér; ennek taglalása nem feladata ennek a cikknek. Az természetesen igaz, hogy a TESz.-ben felhalmozott szótörténeti adatok közül igen sok megtalálható az EWUng.ban is, ami nyilvánvalóan teljesen érthető dolog. Ám semmi esetre sincs szó az adatok mérlegelés nélküli ,átlapátolásáról”: a szerkesztés során alapos rostálás történt, illetve új adatok is beépültek az új szótárba. Amiben szintén hasonlóság van a TESz. és az EWUng. között, az a tulajdonnévi adatok azonos módon való kezelése. Lássuk ehhez a TESz.-ből idézett példák EWUng.-beli megfelelöit (A = származék; ON = helynév; $\mathrm{PN}=$ személynév; $\mathrm{B}=$ jelentés). (Ha az adat után nem áll forrásjelölés, az azt jelenti, hogy az adat a TESz.-ből származik.)

acél: 1086 ? Acil PN (DHA 240); 1229/ Acel PN; 1335 Acilus A, ON A: os 1335 ON.

ág: [1131-41]/ ? Agus PN; 1193 egerag ON; - A: as [1131-41] PN (?), $1229 / \mathrm{ON} \mid \sim$ azat $1510 \mathrm{ON}$.

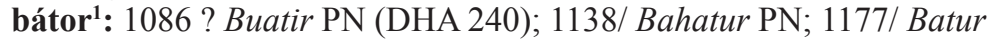
ON; 1230 Baatur ON; - B: 1086 ? 'mutig' \# (t), 1138/ 'ds'.

Elmondhatjuk tehát, hogy a tulajdonnevek szótörténeti felhasználását tekintve az EWUng. is eleget tesz azoknak a magas elvárásoknak, amelyeket a TESz. óta támasztanak a szakemberek egy jó történeti és etimológiai szótárral szemben. És csupán megemlítve: ugyanez érvényes az MTA Nyelvtudományi Intézetében készülő Új magyar etimológiai szótárra is, hiszen a tulajdonnevek kezelését tekintve nem tér el az említett két szótártól. 
3.2.5. A tényszerüség kedvéért meg kell említeni a ZAICZ GÁBOR föszerkesztésében készült Etimológiai szótárt (ESz.) is. A SzófSz.-hoz hasonlóan ez is a müvelt nagyközönség igényeit szándékozik kielégíteni. A szótörténet ebben is rendkívül szikár: lényegében az első adat évszámára szorítkozik, és csupán akkor jelöli egy-egy adat tulajdonnévi jellegét, ha az kronológiailag elsőként adatolható. Ebben a szótárban nem találunk különbséget a személynévi és helynévi adat között, egységesen a tn. (= tulajdonnév) rövidítést alkalmazzák a szerkesztők, és a tulajdonnévi adat esetleges származék volta is jelöletlen marad; pl.:

farag: [1357 tn., 1416 u.]; vö. TESz.: helynévi származék.

féreg: [1152 tn., 1372 u.]; vö. TESz.: személynévi származék.

kard: [1319 tn., 1405 k.]; vö. TESz.: személynévi származék.

4. Összegzés. Összefoglalva a fentieket elmondhatjuk, hogy a magyar szókészlet eredetével foglalkozó szótárak között (beleértve a CzF.-et is) világos különbséget tapasztalhatunk. A 19. századi ihletésü kézikönyvek (CzF., EtSz.) - bár deklaráltan közneveket dolgoznak fel - különféle indokokkal tulajdonneveket is felvesznek címszavaik sorába, és igyekeznek megfelelő etimológiát adni hozzájuk. Velük szemben a modern(ebb) szótárak a tulajdonnevek fontosságát meg nem tagadva csupán a köznévi címszók adatolásában használják ezeket, a tulajdonnévi jellegből fakadó bizonytalanságokat kellő óvatossággal kezelve. Ám ilyen módon is (különösen a TESz., de jelentős mértékben az EWUng. is) gazdag tárházát jelentik annak a müvelődéstörténeti szempontból is színes és fontos lexikális anyagnak, amelyet tulajdonneveknek nevezünk.

\section{Felhasznált források}

CzF. = CzUCzor Gergely - Fogarasi JÁnos, A magyar nyelv szótára 1-6. Emich Gusztáv / Athenaeum, Pest/Budapest, 1862-1874.

ESz. = Etimológiai szótár. Magyar szavak és toldalékok eredete. Főszerk. ZAICZ GÁBOR. A magyar nyelv kézikönyvei 12. Tinta Könyvkiadó, Budapest, 2006.

EtSz. = GOMBOCZ ZOLTÁN - MELICH JÁNOS, Magyar etymologiai szótár 1-17. füzet. MTA, Budapest, 1914-1944.

EWUng. = Etymologisches Wörterbuch des Ungarischen 1-2. Hrsg. LORÁND BENKÖ. Akadémiai Kiadó, Budapest, 1993-1995.

Gl. = Régi magyar glosszárium. Szótárak, szójegyzékek és glosszák egyesitett szótára. Szerk. BERRÁr JolÁn - KÁroly SÁNDOR. Akadémiai Kiadó, Budapest, 1984.

JERNEY JÁNOS 1854. Magyar nyelvkincsek Árpádék korszakából 1-2. K. n., Pest.

MÁTYÁs FLóRIÁN 1868-1871. Magyar nyelvtörténeti szótár[-kisérlet] 1-3. K. n., Pest/Pécs.

NySz. = Magyar nyelvtörténeti szótár a legrégibb nyelvemlékektöl a nyelvújításig 1-3. Szerk.

SZARVAS GÁBOR - SiMONYI ZSIGMOND. Hornyánszky, Budapest, 1890-1893.

NyÚSz. = SZILY KÁLMÁN, A magyar nyelvújitás szótára a kedveltebb képzők és képzésmódok jegyzékével 1-2. Hornyánszky, Budapest, 1902-1908.

OklSz. = Magyar oklevél-szótár. Régi oklevelekben és egyéb iratokban elöforduló magyar szók gyüjteménye. Gyüjt. Szamota István. Szerk. Zolnai GyUla. Hornyánszky, Budapest, 1902-1906. 
SzófSz. = BÁRCZI GÉZA, Magyar szófejtő szótár. Királyi Magyar Egyetemi Nyomda, Budapest, 1941.

SzT. = Erdélyi magyar szótörténeti tár 1-14. Föszerk. SzABÓ T. ATTILA etc. Kriterion Könyvkiadó etc., Bukarest etc., 1975-2014.

TESz. = A magyar nyelv történeti-etimológiai szótára 1-3. Főszerk. BENKÖ LORÁND. Akadémiai Kiadó, Budapest, 1967-1976.

\section{Hivatkozott irodalom}

FÁBIÁN, ZSUZSANNA ed. 2011. Hungarian lexicography I. Bilingual dictionaries. Lexikográfiai Füzetek 5. Akadémiai Kiadó, Budapest.

FÁBIÁn, ZsUZSANNA ed. 2012. Hungarian Lexicography II. Monolingual and Special Dictionaries. Lexikográfiai Füzetek 6. Akadémiai Kiadó, Budapest.

KisS LAJOS 1994. Nyelvtörténeti szótáraink típusai. Magyar Nyelv 90: 392-412.

MURÁTH JUDIT szerk. 2014. Hungarian lexicography III. LSP Lexicography. Lexikográfiai Füzetek 7. Akadémiai Kiadó, Budapest.

GERSTNER KÁROLY

ORCID: https://orcid.org/0000-0003-1945-2667

Nyelvtudományi Intézet

Pázmány Péter Katolikus Egyetem

Bölcsészet- és Társadalomtudományi Kar

\section{Károly Gerstner, Proper names in historical and etymological dictionaries}

The fundamental difference between common nouns (nomen appellativum) and proper names (nomen proprium) has been known for thousands of years. Put simply, the former generalizes, the latter individualizes. As a result, their place in the lexicon is different, and their lexicological consideration has also parted ways. The study touches on how the outstanding lexicographic work of the $19^{\text {th }}$ century, the Czuczor-Fogarasi dictionary, references proper names. While the dictionary is fundamentally an explanatory dictionary, its entries often contain historical or etymological information. Beyond reference books that do not deal directly with proper names, dictionaries focusing on the history of other parts of speech also list several proper names, as the importance of these in the history of both society and language is evident to researchers. Based on the above, the study first provides an overview of the methods applied in historical dictionaries (e.g., Magyar oklevélszótár [Dictionary of Hungarian deeds], Erdélyi magyar szótörténeti tár [Historical dictionary of Transylvanian Hungarian]) and etymological dictionaries (e.g., Magyar etymológiai szótár [Etymological dictionary of Hungarian], A magyar nyelv történeti-etimológiai szótára [Historical and etymological dictionary of Hungarian]). Both dictionary types are rich repositories of data for the lexical material known as proper names. 
FARKAS TAMÁS - SLÍZ MARIANN szerk., Tulajdonnevek és szótárak. ELTE Magyar Nyelvtudományi és Finnugor Intézet - Magyar Nyelvtudományi Társaság, Budapest, 2020. 53-62. DOI: 10.26546/4892373.4

\section{Tulajdonnevek a tájszótárakban}

1. A tanulmány tárgyáról, forrásairól. Hogy mit kezdenek a tájszótárak a tulajdonnevekkel, az elég esetlegesnek tünik. A legkövetkezetesebb és legegyszerübb megoldás a hárítás: ha a szerző vagy szerkesztő az előszóban, illetve a bevezetőben kijelenti, hogy tulajdonneveket nem vesz fel a szótárába. A nyitás a nevek felé azonban már sokféle lehet; ezeknek a megoldásoknak a típusait igyekszem körvonalazni, egy rövid jövőbeli kitekintéssel.

Külön foglalkozom a három fö tájszótártípus: az általános tájszótárak, a regionális szótárak és a tájszó-tárak névkezelésével. Az általános tájszótárakból mindet bevonom a vizsgálatba, a másik két kategóriában válogatok a müvek közül. (A tájszótárak állományát mintegy kéttucatnyira becsüljük, müfaji határaik azonban nem mindig élesek; még akkor sem, ha a címben szerepel a tájszótár megjelölés.) A szótárak után röviden kitérek - mintegy függelékszerüen - a nyelvjárási atlaszok névkezelésére is.

A névtani információk forrásai a szócikkeken kívül az előszók/bevezetők és bizonyos függelékek lehetnek. A bevezetők többnyire utalnak arra, hogy felvesz-e az adott mü tulajdonneveket a szócikkek közé, és ha igen, miféléket. Van azonban olyan szótár is, amely bár nyit a nevek felé, de erről a bevezetőben elmulaszt nyilatkozni. Emiatt nem kerülhettem el, hogy - előzetes tájékoztatás hiányában - egyszerüen átlapozzak bizonyos szótárakat.

2. Az általános tájszótárak tanúsága. Az általános tájszótárak közös jellemzője, hogy szóanyagukat az egész nyelvterületről gyüjtik, illetve közlik. A következőkben ezen müveket tárgyalom a tulajdonnevek kezelése szempontjából.

2.1. Magyar tájszótár (Tsz., Magyar Tudós Társaság 1838). Első tájszótárunkat, amelyet a Magyar Tudós Társaság jegyez, feltehetőleg DöBRENTEI GÁBOR és VÖRÖSMARTY MiHÁLY rendezte sajtó alá. Még nem előzte meg kidolgozott lexikográfiai koncepció, és ez a tulajdonnevek kezelésében is megmutatkozik: sem a DÖBRENTEI GÁBORtól való Előbeszéd, sem a SCHEDEL [TOLDY] FERENCtől származó Utóirat nem tér ki a kérdésre, de a mü tartalmaz hely- és személyneveket. Néhány szócikk a szótár elejéről (betühü közlésben):
Ábri, Abrahám, kicsinyitve. Székely szó Albisban. Szabó Elek.
Ábris, Ábrahám. Kemenesali szó, Vas várm. Lévai Lászó.
Bábi, Barbara vagy Biri. Kezdi széki szó. Szabó Elek.
Bencze, 1) Benedek; 2) nyúl. Kemenesali szó, Vas várm. Lévai Lászó.
Bera, Albert. Palócz szó. Szeder Fábián.
Bora, Boris, Borbála. Palócz szó. Szeder Fábián.

SZABÓ ELEK nemcsak a székely szók közzétételében serénykedett, hanem gyakran kalandos - Ázsiába vivő - magyarázatokat is illesztett a tulajdonnévi adatközlések végére. Lássunk erre is néhány szórakoztató példát: 
Bene, Dálnokban ezen nevezetet viselő katonák vagynak, - ázsiai származásu szó. Kezdi székben divatos. Szabó Elek.

Csernáton, két nevezetes falu ugyanazon völgyben és patak mellett Kezdi székben. Az ázsiai nagy tengerszigetek közül China felé egyiknek neve Ternatani. Kezdi széki szó. Szabó Elek.

Csia, nemes familia’ vezeték nevezete. Czofalván T. Lisznyóban. Chinának egy tenger-szeme Csiaonak neveztetik. Kezdi széki szó. Szabó Elek.

Csik, székely nemes, és katonaság' vidéke, a’ hol vagyon az első székely gyalog ns. regiment' stabja; fenyős erdős helyekkel és havasos hegyekkel körül kerített kies szép hely, - az, hol sokkal több a' szurok, mint a' méz. A' chinai birodalomnak kebelében termő fák között, viasz-termő fa is iratik, mellynek a’ neve Csikha, a’ fa viasz gyánta és szurok lévén; tehát az illyetén fa Csikha nevet viselve, Csíkban is az efféle fa tevén a' bővebbi lételt; - innen a' Csík nevezet sem csíktól jön le, a’ mely ottan nem is lehetett, nem lévén nádas tók; hanem a viaszt termő fákról, ’s következőleg ázsiai nevezetből."”

2.2. Magyar tájszótár (MTsz. 1-2, SZINNYEI szerk. 1898). SZINNYEI a szótár bevezetőjében a következőket írja: „Ezek [ti. az alak szerinti tájszavak] teszik a szótár főrészét, a mely után külön-külön jegyzékbe foglalva következnek: a dajkanyelv (gyermeknyelv) szavai, a keresztnevek nyelvjárási változatai, az állatok tulajdonnevei $\mathrm{s}$ az állat-hivogató és üzö szavak." (1: IV). Ezek a megígért függelékek azonban nem készültek el, a 2. kötetben sem találhatók.

2.3. Új magyar tájszótár (ÚMTsz. 1-5, B. LŐRINCZY főszerk. 1979-2010). A szótár előszava így nyilatkozik: „Tulajdonneveket és tulajdonnévi származékokat általában nem vettünk fel, kivéve a nyelvjárási jellegü csillagneveket, a tulajdonnévi eredetü növényés állatneveket (pl. bánfipál-alma, ilonabogár) és tárgy megnevezéseket (pl. árpádvilla, debreceni csengó). Tulajdonnévi címszónk csupán néhány van (pl. Derecske, Kossuth, Pilátus), ezeket érdekes és jellegzetes frazeológiai egységek miatt alakítottuk ki." (1: 12). Ezek közül a Derecske szócikkét idézem:

Derecske fn. Sz: Megjöttek Derecskéröl (Sarkad 793): dér borít mindent. || SzamSz.

2.4. Nagy magyar tájszótár (NMTsz., KISS G. főszerk. 2019). Az ÚMTsz.-hez hasonló, elhárító állásponton van legújabb általános tájszótárunk is: „Megjegyezzük, hogy gyüjtésünk a köznevekre terjedt ki, a korábbi tájszógyüjteményekben szép számmal található tulajdonneveket - például földrajzi neveket - nem vettük fel gyüjteményünkbe" (10). Tulajdonnévi eredetü köznevek azonban az ÚMTsz.-hez hasonlóan előfordulnak az NMTsz.-ben is (1. pl. az ilonabogár, katibogár, katalin, katalinka, katóka, katókabogár, katókavirág típusú tájszavakat).

3. A regionális szótárak tanúsága. A regionális szótárak a tájszavakon kívül köznyelvi szavakat is az állományukba vesznek, ha azok az adott táj vagy település szókincsének szerves részét alkotják. A következőkben e szempontból tárgyalom a vizsgálatra kiszemelt forrásmüveket. 
3.1. Szamosháti szótár (SzamSz. 1-2, CSÜRY 1935-1936). CSÜRY BÁlINT klasszikus tájszótára korát megelőző teljesítmény volt a két világháború között. Az ezer oldalt meghaladó két kötetével egy kistáj népi nyelvhasználatának reprezentatív gyüjteményét adja. (Kevés nyelvjáráskutató volt képes megközelíteni ezt a teljesítményt mennyiségi és minőségi szempontból.) A tulajdonnevek felvételét is melegen támogatta. Ezt írja:

„Különös tekintettel voltam a tulajdonnevekre s ezek közt a földrajzi nevekre. Szótáramban gazdag anyagot talál a kutató helynevekre, határrésznevekre vonatkozólag is. Íme egypár: Erge, Galambos-erge, Kútergéje, Sebes ásvány (ér és pataknevek), Daru-kiáltó, Ördöngös, Zsaró, Csató, Ölyü-szeg, Setét-szeg, Kender-átó, Tömeg, Ravaszodu, Láz, Gaz, Nagy-gaz, Varga-gaz, Kétrét-gaz, Harminc-öl, Öt-apróföld, Nyolc-apróföld, Három-ér, Három-hold, Hat-fa, Hat-hold, Húsz-tó stb. (határnevek).

A helység-, falu- és városnevek közt különös tekintettel voltam azokra, melyeket a nép a köznyelvi alaktól eltérően ejt, mint pl. Kórógy (Kóród), Majtiny (Majtény), Szakmár (Szatmár), Pettyin (Pettyén), Józsipháza (Józsefháza), Odorján (Adorján), Vároja (Szinyérváralja), Nomény Nominy (Namény) stb. A Szamosháton divatos keresztneveket becéző változataikkal egyetemben nemcsak nyelvi, hanem néprajzi érdekességüknél fogva is mind fölvettem. A családneveket már csak válogatva vettem föl. A gúnyneveket tanulságos voltuknál fogva szintén felöleltem.” (12.)

A nevek felvételének oka tehát lehet a kiejtésbeli eltérés, a morfológiai változatosság (pl. beceneveknél), a néprajzi vonatkozások vagy egyéb motivációs sajátságok (pl. gúnyneveknél). Példaként idézzük a Darukiáltó és a Kendereskert szócikkét:

Darukiáltó Darukijátóú hn. (Vizenyős, lápos hely, régen a darvak tanyája.) (Kölcse.)

Kendereskert Kendereskērt hn. (Szárazberek).

3.2. Ormánysági szótár (OrmSz., KERESZTES szerk. 1952). Az OrmSz.-nak sem a szótári hagyatékot jegyző KISS GÉZA Bevezetőjében, sem pedig a kéziratot sajtó alá rendező KERESZTES KÁLMÁN előszavában (A szerkesztő bevezetése) nem találtam érdemi kitérőt a tulajdonnevek kezelésére. Hogy mégis vannak a szótárban ilyen szócikkek, arról az átlapozáson kívül a bevezetések után álló (számozatlan oldalon található) rövidítésjegyzék tájékoztat. A lista élén rögtön két ilyet olvashatunk: „csn. = családnév”, „dn. = dülőnév”. Történeti adatok felhasználására utal a következő rövidítésfeloldás: „r. csn. = régi családnév; (1561-i dicalis jegyzékből, 1696-i dicalis adólajstromból, 1741-i conscriptio domestica[-]ból és az 1808-i Tanubizonyságtevő levélből kiírt családnevek).” Lássunk ezek után néhány tulajdonnévi szócikket:

Ádámbörce Ádámbörci dn. (földhát; Palkonya). Vö. b ö r c .

Almás dn. (Kórós, Csehi). L. F a rk a s - , N a g y -, V a d a 1 m á s .

Atak Középkori elpusztult falu. Vö. A t a k i m e ző, N a g y a t a k .

Babér Gyakori ökörnév (1. ö k ö r ).

Balázs szn. 'a nagyotakaró ember neve a közmondásokban, szólásokban': Úgy böcsü, mim Balázs a gatyáját. - Neki Balázs, lāt ád Isten 
(törik, szakad, ennek a dolognak menni kell)! Vö. B a lás. L. S z e n t B a lá z s .

Barahó r. csn. l. c s a lád.

Bárcás gyakori ökörnév (1. ö k ö r ).

Amint a példákból is látszik, a szócikkek közé kihalt falunevek és állatnevek is bekerültek, illetve a frazémák tulajdonnevei is címszóvá válhattak.

3.3. Szlavóniai (kórógyi) szótár (SzlavSz. 1-3, PENAVIN 1968-1978). PENAVIN OLGA mestere és példaképe CSÜRY BÁLINT volt, szótárának elöképe pedig a SzamSz. Bevezetőjében ezt írja: „A népnyelv egész szókincsének összegyüjtésére törekedtem, azaz felvettem a közszókat [ti. a köznyelvi szókat - J. D.] és a tájszókat is, éppen úgy, mint már Csüry Bálint tette a Szamosháti szótárban. [...] Indulatszókat, állathívogató és terelö szókat, földrajzi neveket, dülő neveket [!], utcaneveket, családneveket, csúfneveket, keresztneveket (becéző alakjukkal is) felvettem, noha nem törekedhettem teljességre, mert nagyon felduzzasztották volna a szótár anyagát, csak a valamilyen szempontból érdekesebbeket szemeltem ki.” (8.) Széles tehát a nevek merítési köre, változatos az anyag, emellett viszont a szemelvényesség dominál. Néhány példa a szócikkek közül:

Dakóbokra Dakóubokrả hn. Kórógyi határrész neve.

Dávidka Dáovityká Dáovitykó ${ }^{u}$ szn. „kis Dávid”.

Devetke Devetke szn. csúfnév Szentlászlón.

Dezsővőgyi Dezsővö ${ }^{\prime \prime} g y i$ hn. szentlászlói határrész neve.

Fiastyúk Fijästyúk Fijästik fn. „,csillagkép, a Pleiades része”.

Gyönyörü Gyönyörü Harasztiban a Kürtös család egyik ágának csúfneve.

György György férfi személynév (Gyurà, Gyurkà - a fiatalok beceneve, Gyuri fiatalok és öregek beceneve).

3.4. A moldvai magyar tájnyelv szótára (MMTnySz. I/1-2, II, PÉNTEK szerk. 2018). A szótár szerkesztője, PÉNTEK JÁNOS így helyezi el a művet a tájszótárak között: „Az MMTnySz. szándékom szerint a regionális szótáraknak abba a típusába tartozik, amelynek mintájaként a Szamosháti szótárat szokás említeni” (I/1: 7). Ugyanakkor már az Előszó első bekezdésében megjegyzi: „Az eredetileg »enciklopédikus« szándékot is szerényebbre kellett fognom. Be kellett látnom: ha nem számolok a realitásokkal, akkor számomra is - mint egy évszázada több elődöm számára - a szótár továbbra is terv marad, vagy az utánam következő nemzedék(ek)re testálom a folytatását” (I/1: 5).

Ami a nevek felvételét illeti: „A köznévi elemek mellett kisebb számban, szintén a források függvényében, tulajdonnevek is kerültek a szótárba: személynevek (családés keresztnevek, becenevek), helynevek, településnevek stb. Különösen a kicsinyítő és becéző formák miatt a keresztnevekre a CsángA. anyagának gyüjtése idején is fokozottabban odafigyeltek, hozzátartoznak az anyaghoz, nem tehettem meg, hogy lemondjak róluk.” (I/1: 9.) Míg a személynevekre a CsángA., addig a helynevekre föleg HALÁSZ PÉTER gyüjtései, idevágó publikációi szolgáltatták a forrást. (Erre a „Hn.” rövidítés feloldásakor is történik utalás a 10. lapon.) Lássunk néhány példát! 


\begin{abstract}
Albény (ált.) településnév; nume de localitate; place-name: Albeni. Megj. Bogdánfalva része.

Albert Álbert (Di), Albét (Esz) férfi kn. prenume bărb.; male forename. CsángSz.

Alexandru Álëkszándru (Tn) férfi kn.; prenume bărb.; male forename. Kics. Álëkszándruska. (Tn) HPHn.

Babos (Kr) csn.; nume de fam.; surname. Hn. Babosok szántó (Kr).
\end{abstract}

4. A tájszó-tárak tanúsága. Tájszótáraink legnagyobb és legváltozatosabb csoportját azok alkotják, amelyek - a szakirodalmi hagyományokat követve - megelégszenek a tájszónak minősíthető lexémák szótárazásával. A tulajdonnevek felvételét illetően három típusba sorolhatók (a határok lehetnek életlenek is).

4.1. Névkizáró szótárak. A legtisztább eset a nevek teljes kizárása. Ebbe a csoportba tartoznak például a következők: KISS JENÖ Mihályi tájszótára (MihTsz.), HEGEDÜS ATTILA Kisnémedi tájszótára (KisnTsz.), SzABÓ JÓzSEF és Sz. BozÓKI MARGIT Koppány menti tájszótára (KmTsz.) és PESTI JÁNOS Alsómocsoládi tájszótára (AmTsz.). A hárítások egyszerüek és egyértelműek, nemigen kívánnak illusztrációt. A lényeg: a neveknek névtárakban, névgyüjteményekben van a helyük.

4.2. Névbefogadó szótárak. A másik alaptípust a névbefogadó szótárak jelentik. Jól szemlélteti ezt IMRE SAMU Felsőőri tájszótára (FTsz.). Idézzük a nevekre vonatkozó állásfoglalását: „A közszavak mellett felvettem szótáramba néhány tulajdonnevet is. Így például olyan, Felsőőrben gyakori vagy legalábbis jól ismert családneveket, melyek bizonyos hangtani sajátságokat igen pregnánsan tükröznek, vagy meglehetősen szokatlan hangfejlődést mutatnak; pl.: Bedenëk 'Benedek', Pongorác 'Pongrácz', Adrán 'Adorján', Bukics 'Vukics', Prunnër 'Brunner' stb.' (13.)

A helynevekkel kapcsolatban IMRE SAMU megjegyzi, hogy azokat már publikálta, de a korábbi közlése nem volt teljes: „Ebben a közleményben azonban csak a határrészek elnevezései, a dülőnevek szerepelnek, a belső településsel kapcsolatos nevek (községrészek neve, utcanevek) nem. Szótáramba - mintegy pótlásként - felvettem ezeket az adatokat is. A népi utcanevek regisztrálását azért is fontosnak tartottam, mert néhány évvel ezelőtt az addigi házszámos rendszerrel szemben hivatalosan is megtörtént az utcák elnevezése, sajnálatos módon a helyi hagyományok szinte teljes kizárásával, egykét fordítástól eltekintve lényegében csupa német nevekkel. Így az eredeti népi magyar elnevezések egy-két nemzedéken belül minden bizonnyal teljesen feledésbe mennek. [...] Felvettem a szótárba egy-két egyéb földrajzi objektumnak, például hídnak az elnevezését is. Ezt pedig azért tartottam fontosnak, mert ezek a nevek régebben általános használatúak voltak, de a Pinka folyó szabályozásával, új mederbe való terelésével mint létesítmények megszüntek, s nevük is rövidesen el fog tünni." (13.)

A nyelvterület peremén, szigethelyzetben, erős asszimilációs folyamatok közepette érthető a nyelvi leletmentés fontossága, így az indokok nagyon hasonlóak, mint amit fentebb PÉNTEK JÁNOStól olvashattunk a moldvai magyar tájszótár bevezetőjében. Figyelembe kell venni továbbá azt a körülményt, hogy a 20. század 50-es, 60-as éveiben nem volt egyszerü dolog eljutni ezekre a nyelvszigetekre és ott kiterjedt gyüjtést végezni, 
majd az összegyült anyagot megfelelö módon tudományosan is közzétenni. Így minden efféle gyüjtés és közzététel - hézagossága ellenére - felbecsülhetetlen értékü.

4.3. Sajátos névbefogadó szótárak. A névbefogadó tájszó-tárak közé is sorolhatók, de sajátos alcsoportként is kezelhetők azok a müvek, amelyek névanyagát valamely eddig nem említett tényező (is) meghatározza.

4.3.1. Kiskanizsai szótár (KiskSz., MARKÓ 1981). MARKÓ IMRE LEHEL a szótárát átmeneti jellegü alkotásnak tekinti: „Szótáram [...] középhelyet foglal el a regionális teljes szótárak (CSÜRY BÁLINT, BÁLINT SÁNDOR) és a szorosan vett tájszótárak (IMRE SAMU) típusa között" (8). Az átmenetiség okaként (hogy ti. elég sok köznyelvivel megegyező szót is szerepeltet) a passzív gyüjtési módszert jelöli meg: „A majdnem négy esztendő alatt naponként, folyamatosan végeztem a gyüjtést. Ennyi idő alatt szavaknak a százezreit lehetne lejegyezni példamondatokkal együtt. Én azonban a passzív módszerrel való gyüjtést választottam. A kívülálló óvatossága késztetett erre, mivel a szókincs nem nyelvjárásomból való. Kerültem még a lehetőségét is annak, hogy kérdéseimnek nem megfelelö feltevésével, kiejtésemnek elütő jellegével megzavarjam mind a szemantikai, mind a fonetikai spontaneitást.” (7-8.) Feltehetőleg ez a gyüjtési alapelv határozza meg a tulajdonnevek kezelését is: ami a spontán diskurzusban felbukkan, szótári egység lehet, de célzott gyüjtést és feldolgozást a szerzőtől elvárni nem lehet. Idézzünk néhány tulajdonnévi szócikket:

Reza Rëza szn. a Teréz beceneve.

Szent György-nap Szen Györ-nap fn. szent György ünnepe (ápr. 24.). M e g j. Ezen a napon zöld ágat tüznek a kapura, mert akkor a boszorkányok nem tudnak a házba menni, s nem tudják az állatokat megrontani.

Szüzanya Szüzanya fn. Szüz Mária. Jaj Szüzanyám, në haggy el!

Tölös $\sim$ dn. a temető melletti erdőszél, régebben sok tölgyfa állt benne.

Új-hegy Uj-högy dn. a homokkomáromi szőlöhegy része.

Úrnapja Urnaptya fn. 'az oltári szentség ünnepe'. A is vütte az eget Urnaptyán.

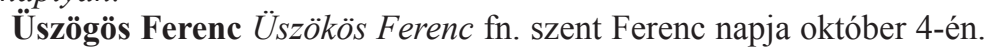
Üszökös Ferencko nëm szabad vetnyi, mer akko üszökös lëssz a búza.

Vadalmás Vadómás dn. Lazsnakpuszta melletti erdőrész.

A szerző az egyházi ünnepnapok neveit tulajdonnévnek tekinti, és a helyi nyelvjárási ejtésmód mellett különös figyelmet fordít a jeles napokhoz füződő néphagyományokra is.

4.3.2. Büki tájszótár (BükiTsz., BALOGH 2004¹ , 2016²). BALOGH LAJOS hosszú évtizedeken keresztül dolgozott szülöfaluja, a Vas megyei Bük tájszavainak összegyüjtésén. A munkát szótára első kiadása (2004) után sem hagyta abba, így a 2016-os bővített kiadás már jóval gazdagabb anyagot tartalmaz. Saját statisztikája szerint a 2824 szócikkből 250 a tulajdonnévi (BükiTsz. ${ }^{2}$ 30). Ez megközelíti a tíz százalékot, ami átlagon felüli névtani figyelmet jelent. Idézem a szótár bevezetőjének a tulajdonnevekre vonatkozó részét: „A tájszótárak többsége csak közszavakat tartalmaz, tulajdonneveket nem. Kivételesen eltértem ettől a gyakorlattól azzal, hogy bevettem a szótárba a környezö községek nevét is, elsősorban azért, mert a népi név hangalakjában és morfológiai szerkezetében sok esetben eltér a hivatalos névtől. Például a népi név Kál, a hivatalos név Sajtoskál, 
a népi név $B u ̈$, a hivatalos név $B o ̈$, így tehát valójában ezek a tulajdonnevek is tájszónak, táji névváltozatnak tekinthetők. Egyúttal megadom a települések hová? kérdésre felelő határozóragos alakját. Ezzel kívánom föltüntetni, hogy az adott település [ti. neve - J. D.] a helyi használatban külső vagy belső helyviszonyragot kap-e.” (24.)

A szerző azzal a megjegyzéssel, hogy a tulajdonnevek helyi ejtésmódja vagy morfológiai viselkedése számos regionalizmust hordozhat, így alkalmas lehet tájszói minősítésre, még nem hozott merőben új attitüdöt a magyar tájszótár-irodalomba, de azzal, hogy következetesen beépítette a szomszédos települések neveit, illetve mindegyiknek közölte a hová? kérdésre felelő ragos alakját, valószínüleg egyedülálló elvárással bővítette a nevek iránt nyitott tájszótárak módszertanát. Azzal is többletet rótt ki a maga számára, hogy a Vas megye földrajzi nevei című adattárból átemelte a Bükre vonatkozó dülöneveket, a történeti adatokkal és népi névmagyarázatokkal, megjegyzésekkel együtt (BükiTsz. ${ }^{2}$ 25). BALOGH LAJOS tehát a büki helynevek minél teljesebb körü és minél részletesebben dokumentált szerepeltetésével igyekezett bővíteni a szótárát.

4.3.3. Palóc tájszótár (PTsz., TÓTH 1978¹, 2007²). BALOGH LAJOShoz hasonlóan TÓTH IMRE is évtizedeken át gyarapította tájszógyüjteményét; Ipoly menti palóc tájszótára (1978) később bővítve, Palóc tájszótár címmel jelent meg (2007). A bevezetésben (20) részletesen foglalkozik müve tulajdonnévi anyagával. Viszonylagos teljességgel közli a kiemelt település, a szülöfalu, Bernecebaráti ragadványneveit és külterületi helyneveit. A helyneveket a hozzájuk tartozó történeti adatokkal, tárgyi és néprajzi megjegyzésekkel, a 70-es évek állapotát rögzítő múvelési ági besorolással HÁLA JÓZSEFtől vette át (Földrajzi nevek az Ipoly mentén). Erősen válogatva néhány más Ipoly menti település helynevei is a szótárba kerültek; ezek közlését valamilyen néprajzi vagy nyelvi érdekesség indokolja.

A többi tájszótártól eltérően nagy jelentőséget tulajdonít a ragadványneveknek; eredet és fajta (motiváció) szerint öt típusba sorolja őket, példákkal szemléltetve: „,keresztnévből keletkeztek: Albert, Laci, Misa stb., 2. vezetéknévből származók: Balyog, Hinö, Lajtos stb., 3. foglalkozásból vagy tisztségből adódtak: Bíró, Vótbírójék, Harangozó, illetve Bába, Tojásos, Tyúkász stb., 4. csúfnév: Csendes, Fingos, Fityisz stb., 5. lakóhelyet vagy származást jelölők: Fölysők, Budaj, Huntyi, Letovai stb. Akadnak ma már megfejthetetlen keletkezésü és hangalakú (esetleg eltorzított) ragadványnevek is.” (20.) Ugyanott névszociológiai, névlélektani megjegyzést is tesz: „A ragadványnevek túlnyomó többségét valóban megkülönböztetésre használják, s azok használatáért az érintettek nemigen neheztelnek.” „Végül egy-két jellegzetes családi név mellett szerepelnek még a szótárban azok a becenevek is, amelyek Ladó János Magyar utónévkönyvében nem találhatók."

5. Rövid kitekintés a nyelvatlaszokra. Tanulmányomnak nem szerves része a tájszótárakkal sok rokon vonást mutató másik fontos dialektológiai forráscsoportnak, a nyelvatlaszoknak a névtani szempontú szemlézése. Egy hasonló próbálkozásom már volt, amikor A romániai magyar nyelvjárások atlasza (RMNyA.) névállományát, névkezelési gyakorlatát tekintettem át (JUHÁSz 1999). Már akkor felmerült bennem, hogy módszeresen össze kellene gyüjteni minden nyelvatlasz tulajdonneveit. Ez a „feltérképezés" - a teljes címszókészlet számbavételével - időközben megtörtént SZABÓ PANNA doktori (PhD) értekezésében (2018), de még nem látott napvilágot, és részletes értékelése is várat magára. Addig is, amíg ez a célzott tanulmány meg nem születik, érdemes egy figyelemfelhívó pontban kitérni a témára. Lássuk először azt, hogy milyen névfajták milyen egyedekkel képviseltetik magukat a nyelvjárási atlaszokban! 
A tájszótárakkal ellentétben a helynevek jelenléte az atlaszokban csak jelképes: $M a$ ros, Kolozsváron, Kolozsvárra, Marosvásárhelyen, Marosvásárhelyre, Szamos. A hangtani realizációk felderítése mellett a Kolozsvár és a Marosvásárhely városnév a helyhatározóragok viselkedése, azaz a morfológia okán került a kérdőívbe.

A jóval nagyobb arányú személynévi jelenlét fő mozgatórugója is a morfológiai sajátságok egy részének rendszertani és táji jellegü feltárása. Az egyik ilyen nyelvtani részrendszer a kicsinyítés-becézés. A következő keresztnevek kicsinyítő-becéző alakjairól készültek térképek: András, Anna, Aurél, Béla, Erzsébet (Erzsi), Ferenc, Gizella, György (Gyuri), Gyula, Ilona, Irén, István (Pista), János (Jani), Jolán, József (Józsi), Júlia, Károly, Katalin (Kati, fiatal-idős megoszlásban is), Lajos, László, Magdolna, Margit, Mária (Mari), Mihály, Miklós, Pál, Péter, Sándor, Zoltán, Zsuzsanna.

A másik morfológiai részrendszer a nevek ragozása, jelezése (különös tekintettel a határozóragokra). Íme a példák: Erzsiék, Erzsiéké, Erzsiékhez, Erzsiéknél, Erzsiéktől, Erzsihez, Erzsinél, Erzsitöl, Ferenchez, Ferencnél, Ferenctöl, Ferihez, Ferinél, Galambosékhoz, Józsiék, Józsiéké, Józsiékhoz, Józsiéknál, Józsiéktól, Józsihoz, Józsinál, Józsitól, Mihályé, Mihálytól, Pistánál (okosabb, fiatalabb), Pistáék földje, Sándorékhoz, Sándoréknál, Sándoréktól, Terinél.

A ritkább tulajdonneveket egy napnév (Szent Heverdel napja) és néhány csillagnév (ill. égitestnév) képviseli: Esthajnalcsillag, Fiastyúk, Göncölszekér, Hajnalcsillag, Hold (ill. udvara van a Holdnak), Kaszás (Orion), Nagy Göncöl, Sarkcsillag, Tejút.

Ezek a térképlapok egyenként és tematikusan is vizsgálhatók. (A legtöbb az RMNyA.ból való.) A tájszótárakkal való összehasonlításra feltehetőleg a keresztnevek becealakjai kínálnak legtöbb lehetőséget.

6. Pillantás a jövőbe. A fenti, részben mintavételszerű szemlézés után hogyan lehet még szélesebb körü, lehetőleg teljességre törekvő névtani számbavételt elvégezni? Ennek nyilván több útja és módja lehetséges. A neveket mellőző tájszótárak kizárása után következhet egy hagyományos, „manuális” gyüjtés, amely az érintett szótárak átlapozásával először listázza a tulajdonnévi szócikkeket. A szócikkek „,beltartalma” rögzíthető akár hiánytalanul, betűhűen is, egy későbbi sokoldalú feldolgozás számára, de készülhet rögtön onomatodialektológiai adatbázis is, jól megtervezett szempontrendszer alapján. Ebben a hangalaki realizáció után a fő névfajták megjelölésétől kezdve a lokalizáláson át a névfajtákra jellemző paraméterek megadása (dülőneveknél pl. térszínforma, müvelési ág, hová? kérdésre felelő alak, becézőneveknél az alapnév stb.), a nyelvtörténeti adatok és a néprajzi, helytörténeti vonatkozások stb. rögzítése következne. A paraméterek száma és struktúrája folyamatosan bővíthető, alakítható.

A névtani adatbázis optimális esetben beilleszkedhet egy olyan egyetemesebb dialektológiai adatbázisba, amely minden tájszótár minden szócikkét feldolgozza. Ha ilyen létesülne, nyilván összhangba kellene hozni az általánosabb nyelvjárástani szempontokat, kategóriákat a névtaniakkal. Egy ilyen „összmagyar”, egyesített tájszótár körvonalait KISS JENŐ már fölvázolta (1. KISS J. 2008). A minden tájszótárra kiterjedő, kritikai elemeket is tartalmazó lexikográfiai értékelés egyik „,mellékterméke” lehetne egy segédlet a leendő tájszótárak összeállítói számára, hogy milyen kötelező és ajánlott részfeladatokat végezzenek el részben a gyüjtés, részben pedig a szerkesztés során, és milyen típushibákat kerüljenek el. (Ilyen módszertani észrevételekre és ajánlásokra 1. pl. KISS J. 1995, 1998; HEGEDÜS 1996.) 


\section{Felhasznált források}

AmTsz. = PeSTI JÁNOS, Alsómocsoládi tájszótár. [Alsómocsolád Község Önkormányzata stb.], Alsómocsolád, 2008.

BükiTsz. ${ }^{1}=$ BALOGH Lajos, Büki tájszótár. Vasi Szemle Szerkesztősége, Szombathely, 2004.

BükiTsz. ${ }^{2}$ = BALOGH LAJOS, Büki tájszótár. Bük Város Önkormányzata - Magyar Nyugat Könyvkiadó, Bük-Vasszilvágy, 2016.

FTsz. = IMRE SAMU, Felsőőri tájszótár. Akadémiai Kiadó, Budapest, 1973.

KiskSz. = MARKÓ IMre LeHEL, Kiskanizsai szótár. Akadémiai Kiadó, Budapest, 1981.

KisnTsz. $=$ HEGEDÜs ATTILA, Kisnémedi tájszótár. ELTE Magyar Nyelvtörténeti és Nyelvjárási Tanszék - MTA Nyelvtudományi Intézet, Budapest, 1992.

KmTsz. = SZABÓ JÓZSEF [- Sz. BOZÓKI MARGIT], Koppány menti tájszótár. Wosinsky Mór Megyei Múzeum, Szekszárd, 2000.

MihTsz. = Kiss JENÖ, Mihályi tájszótár (Rábaköz). Nyelvtudományi Értekezések 103. Akadémiai Kiadó, Budapest, 1979.

MMTnySz. = A moldvai magyar tájnyelv szótára. I/1. Moldvai magyar-közmagyar rész. A-K. I/2. L-Zs. II. Közmagyar - moldvai magyar rész. A-Zs. Szerk. PÉNTEK JÁNOS. Erdélyi MúzeumEgyesület, Kolozsvár, 2016-2018.

MTsz. = Magyar tájszótár 1-2. Szerk. SzINNYEI JóZSEF. Hornyánszky, Budapest, 1893-1901.

NMTsz. = Nagy magyar tájszótár. 55000 népies, tájnyelvi és archaikus szó magyarázata. Főszerk. KISS GÁBOR. Tinta Könyvkiadó, Budapest, 2019.

OrmSz. = Ormánysági szótár. KISS GÉZA szótári hagyatékából szerk. KERESZTES KÁLMÁN. Akadémiai Kiadó, Budapest, 1952.

PTsz. ${ }^{1}=$ TÓTH IMRE, Ipoly menti palóc tájszótár. Bernecebaráti és vidéke tájnyelve az 1930-1940-es évek fordulóján. A Magyar Nyelvtudományi Társaság Kiadványai 176. Magyar Nyelvtudományi Társaság, Budapest, 1987.

PTsz. ${ }^{2}$ = TÓTH IMRE, Palóc tájszótár. Az Ipoly menti palóc tájszótár 2., javított, bővített kiadása. Nap Kiadó, Budapest, 2007.

SzamSz. = CsÜRY BÁLINT, Szamosháti szótár 1-2. Magyar Nyelvtudományi Társaság, Budapest, $1935-1936$.

SzlavSz. = Penavin OlgA, Szlavóniai (kórógyi) szótár 1-3. Forum, Újvidék, 1968-1978.

Tsz. = Magyar tájszótár. A’ Magyar Tudós Társaság, Buda, 1838.

ÚMTsz. = Új magyar tájszótár 1-5. Főszerk. B. LŐRINCZY ÉVA. Akadémiai Kiadó, Budapest, 1979-2010.

\section{Hivatkozott irodalom}

HeGEDÜS ATTILA 1996. A tájszók szótárazásának néhány kérdése. Magyar Nyelv 92: 476-479.

JuHÁsz DEZSŐ 1999. A romániai magyar nyelvjárások atlasza névtudományi jelentőségéről. Névtani Értesitö 21: 395-400.

KISS JENŐ 1995. Észrevételek a hazai regionális lexikográfiáról. Magyar Nyelv 91: 170-178.

KISS JENŐ 1998. A tájszavak és a tájszótárak - régi kérdéskör, új problémák. Magyar Nyelvőr 122: $427-437$. 
KISS JENŐ 2008. Az első tájszóközlésektől az egyesített digitális tájszótárig. Magyar Nyelvőr 132: 27-36.

SZABÓ PANNA 2018. Nyelvföldrajzi vizsgálatok a magyar nyelvterület nyugati felén a dialektológiai atlaszok alapján. Doktori (PhD) értekezés. ELTE BTK, Budapest. Kézirat. https://doi. org/10.15476/ELTE.2018.071

JUHÁSZ DEZSÖ

ORCID: https://orcid.org/0000-0003-1508-9688

ELTE Eötvös Loránd Tudományegyetem

Bölcsészettudományi Kar

\section{DEZSő JuHÁsz, Proper names in Hungarian dialect dictionaries}

Roughly two dozen dictionaries of regional Hungarian exist, but the borders of the genre are fuzzy. The approaches these dictionaries employ in the handling of proper names are generally incidental, and changeable. The most consistent and simplest attitude is to omit them from the dictionary. In these cases, the author or editor states that proper names are not listed in the dictionary in the Preface or Foreword. When names are listed, they are handled in a variety of ways; it is these this study aims to summarise while briefly touching upon future possibilities. The approaches used in the three main types of regional dictionaries - general dialect dictionaries, dialect dictionaries of certain regions and dictionaries of dialect words - are examined separately. All published general dialect dictionaries are surveyed while the other two categories are examined through selected examples. The different approaches are illustrated through example entries. The majority of entries for proper names contain micro-toponyms, while some contain anthroponyms including family names and nicknames. Rarely the names of animals, stars or planetary bodies also appear. The examination of name dictionaries is followed by a short appendix providing an overview of how names are dealt with on language atlases. 
FARKAS TAMÁS - SLÍZ MARIANN szerk., Tulajdonnevek és szótárak. ELTE Magyar Nyelvtudományi és Finnugor Intézet - Magyar Nyelvtudományi Társaság, Budapest, 2020. 63-91. DOI: 10.26546/4892373.5

\section{Tulajdonnevek a helyesírási szótárakban}

1. A vizsgálat korpusza. A téma 114 évet fog át, ennyi ideje, 1906-ban jelent meg ugyanis az első magyar helyesírási szótár. Nem meglepő, hogy minden helyesírási szótárban szép számmal előfordulnak tulajdonnevek. Jelen írás figyelembe veszi az összes köznyelvi helyesírási szótárat. Így tehát nem foglalkozik a szaknyelvi helyesírási szótárakkal, illetve az átírási szótárakkal, valamint a kifejezetten iskolai célra készült munkákkal (bár a korai magyar helyesírási szótárak jobbára inkább a diákokat célozhatták meg). Tekintettel van ugyanakkor a feldolgozott munkákhoz kapcsolódó szabályzatra, illetve magyarázó függelékre is a tulajdonnévi vonatkozások szempontjából. Tekintsük először tehát át a feldolgozott forrásokat időrendben, néhány alapvető jellemzőjük vagy egyedi sajátságuk megjegyzésével:

KELEMEN BÉla 1906. A magyar helyesirás kis szótára. A hivatalos iskolai helyesírás alapján. Athenaeum, Budapest. 6×14 cm, 172 lap (szótár: 5-159). [Közvetlen szemrevételezésre az 1914. évi, 6. kiadás került; ez az 1907. évi, 2. kiadás utánnyomásának tekinthető. A kötethez függelék is tartozik.]

HORVÁTH ENDRE 1913. A magyar helyesírás szótára és szabályai. Az iskolai helyesirás alapján. Athenaeum, Budapest. $14 \times 21 \mathrm{~cm}, 288$ lap (szótár: 5-258). [A kötethez szabályzat is tartozik.]

BALASSA JÓZSEF 1929. Az egységes magyar helyesirás szótára és szabályai. Budapesti Korrektorok és Revizorok Köre, Budapest. 12×17 cm, L+288 lap (szótár: 1-288). [Bevett rövidítése: NyomdH. A kötethez szabályzat is tartozik. $]^{1}$

BOGNER JÓZSEF 1939. A magyar helyesirás szabályai és szótára. Jugoszláviai Magyar Népkönyvtár. Globus Nyomda, Petrovgrád [= Nagybecskerek]. $12 \times 18 \mathrm{~cm}, 115$ lap (szótár: 26-111).

MAgYAR TUdOMÁNYOS AKAdÉMIA 1950. A magyar helyesirás szabályai. 9., átdolgozott és bővített kiadás. Akadémiai Kiadó, Budapest. $14 \times 20$ cm, 185+4 lap (szótár: 47-185). [A szótár a szabályzat mellékleteként jelent meg. Bevett rövidítése: AkH. 1950.]

MAGYAR TUdOMÁNYOS AKAdÉMIA 1954. A magyar helyesírás szabályai. 10., átdolgozott és bővített kiadás. Akadémiai Kiadó, Budapest. $14 \times 20$ cm, 268 lap (szótár: 89-265). [A szótár a szabályzat mellékleteként jelent meg. Bevett rövidítése: AkH. 1954.]

${ }^{1}$ A szótári apparátus itt utal először lexikográfiai szempontból professzionális munkára. - A kiadvány szoros kapcsolatban van a BALASSA szerkesztette, de e helyt külön be nem mutatott $A$ magyar nyelvtan és helyesírás kézikönyve. Kis magyar nyelvtan és helyesírás szabályai és szótára címü, a Lingua Kiadónál feltehetöleg az 1940-es években év nélkül, négyszer kiadott, helyesírás terén a NyomdH.-nál szükebb anyagú kézikönyvvel. Továbbá lényegében e két nagyon hasonló kötetből kompilált munka a következő, BALASSA nevét még csak meg sem említő szótár: BODRITS ISTVÁN szerk. 1953. A magyar helyesírás szótára. I. rész. Nyelvtan és helyesirási útmutató. II. rész. Szótár. Testvériség-Egység Könyvkiadóvállalat, Újvidék. 12×17 cm, LXXIX+260 lap. 
Deme LÁszló - FÁBIÁn PÁl 1961. Helyesírási tanácsadó szótár. Terra, Budapest. 14×20 cm, 827 lap (szótár: 17-814). [Közvetlen szemrevételezésre az 1977. évi, 7. kiadás került, ez az 1970. évi, 4. kiadás utánnyomásának tekinthető. Bevett rövidítése: HTSz.] ${ }^{2}$

Szabó T. Attila - BAlogh Dezsö - GÁlffy Mózes - Kelemen Béla szerk. 1978. Magyar helyesirási szótár. Kriterion Könyvkiadó, Bukarest. 12×17 cm, 718 lap (szótár: 103-718).

MAGYAR TUdOMÁNYOS AKADÉMIA 1984. A magyar helyesírás szabályai. 11. kiadás. Akadémiai Kiadó, Budapest. 14×20 cm, 388 lap (szótár: 129-375). [A szótár a szabályzat mellékleteként jelent meg. Bevett rövidítése: AkH. 1984.]

Deme LÁszló - FÁBIÁN PÁL 1988. Helyesírási kéziszótár. Akadémiai Kiadó, Budapest. 14×20 cm, 687 lap (szótár: 13-674). [Bevett rövidítése: HKsz.]

Deme LÁszló - FÁBiÁn PÁl - TÓTh ETELKA 1999. Magyar helyesírási szótár. Akadémiai Kiadó, Budapest. 16×24 cm, XI+587 lap (szótár: 1-574). [DEME-FÁBIÁN 1988 közvetlen utóda, lényegében felújított kiadása. Bevett rövidítése: MHSz.]

LACZKÓ Krisztina - MÁRTONFi AtTiLA 2004. Helyesírás. Osiris Kiadó, Budapest. $14 \times 20 \mathrm{~cm}$, 1539 lap (szótár: 425-1497). [A kötet első része: Tanácsadó, a második része: Szótár. Bevett rövidítése: $\mathrm{OH}$.

BÁRÁNY MARGit 2009. Akadémiai helyesirási szótár. Akadémiai Kiadó, Budapest. $13 \times 20 \mathrm{~cm}$, 1415 lap. $^{3}$

MAgYAR TUdOMÁNYOS AKADÉMIA 2015. A magyar helyesírás szabályai. 12. kiadás. Akadémiai Kiadó, Budapest. 14×20 cm, 611 lap (szótár: 141-577). [A szótár a szabályzat mellékleteként jelent meg. Bevett rövidítése: AkH. 2015.] ${ }^{4}$

TÓTH ETELKa 2017. Magyar helyesirási szótár. A magyar helyesirás szabályai tizenkettedik kiadása szerint. Akadémiai Kiadó, Budapest. 16×24 cm, VIII+586 lap. [Érdemben eltér DEMEFÁBIÁN-TÓTH 1999-től, önálló münek tekinthető. Ajánlott rövidítése: MHSz. ${ }^{2}{ }^{5}$

2. A vizsgált kategóriák. A vizsgálat az MTA 2015 tulajdonnévi kategóriáit veszi alapul: személynevek, állatnevek, tárgynevek, földrajzi nevek, csillagászati nevek, intézménynevek, márkanevek, kitüntetés- és díjnevek, címek, egyéb tulajdonnevek. A feldolgozás is ezt a rendet követi, szemben a névtanban megszokott személynév, földrajzi név stb. sorrenddel. Minthogy a személy-állat-tárgy kategóriák szemantikailag is szorosabban összetartoznak, ez a megközelítés ontológiai szempontból is erősen indokolható.

A szótárak átnézése a következő általános tanulságokkal szolgált:

1. A szótárak folyamatosan bővülnek, nőnek, ezért nő a bennük feldolgozott tulajdonnévi anyag is.

2. A szótári apparátus folyamatosan csiszolódik, kikristályosodik. Az eleinte némiképp zavaros apparátus először túlbonyolódik, majd a nyolcvanas években letisztul. Az ötvenes évektől kezdődően egyértelmüen szerves fejlődésről beszélhetünk.

3. Egyre több tulajdonnévtípus, tulajdonnévi kategória jelenik meg a szótárakban (részletesen 1. alább).

${ }^{2}$ E helyesírási szótár elkészítése során sok, a helyesírási szabályzatban taglalhatónál finomabb részletkérdést szabályozott a helyesírási bizottság (FÁBIÁN szerk. 1962, újrakiadása: FÁBIÁN szerk. 1972).

${ }^{3}$ A kiadvány alig tekinthető helyesírási szótárnak, híján van bárminemü struktúrának, puszta szó(alak)felsorolás. A benne található hibák száma is igen nagy.

${ }^{4}$ A szabályzatban nem mutatkoztak érdemi változások, így alapvetően csupán a szótári részt mutatjuk be.

${ }^{5}$ Az azonos cím ellenére DEME-FÁBIÁN-TóTH 1999-hez képest igen sok a változás. Az alábbiakban csak ilyen változásokat mutatunk be. 
3. A részletes adatok. Tekintsük át tehát az egyes tulajdonnévi kategóriákat időrendben a szótárak konkrét példáin. A példák kiválasztása szemléletességre és típusonként teljességre törekvő, ugyanakkor az alábbiak éppen ezért nem tekinthetők puszta adatközlésnek: a beszédes példák megfelelő összeválogatása adja magát az elemzést. Minthogy kiragadott példákat mutatunk be, az egyes szótárak tipográfiájától eltekintünk - inkább zavaró, mint informatív lett volna reprodukálásuk. Azokat a példákat, amelyeket egy adott szótár törölt az előzménykiadványhoz képest, áthúzás jelöli a továbbiakban.

3.1. Személynevek. Személynevek mindegyik szótárban előfordulnak.

KELEMEN 1906-ban utónevek, egyelemü nevek (hírességek, fiktív személyek nevei) és teljes nevek jelennek meg, ragozási mintával:

Adél (Adélnak v. ritkb. Adélnek)

Aeschylus v. Aiskhylos

Aesopus (Ezópus); aesopusi mese

A függelékben:

Petöfi Sándor, Baróti Szabó Dávid

József, Vince

Szent István, Nagy Lajos
Anyégin (nem: Onegin)

gróf Andrássy Gyula

Bacchus v. Bakkhos

a Habsburg család

Isten: Úr, Teremtö, Megváltó

HORVÁTH 1913-ban családneveket, illetve összetételeket is találunk:

Abaffy nemescsalád; Abafi Lajos, iró

Ábrahám

Achilles, Achilles-in, Achilles-sarok

A szabályzatban:

Csokonai Vitéz Mihály

Semsei Semsey Andor gróf

Nagy Lajos

Kis Károly

Vak Béla

Szent István

szent András adonáj v. Adonáj zs: Uram! Jehova

Adorján v. Andor

Bocskay-család, Bocskay brigadéros

BALASSA 1929:

Ábel, tn, -t, -je

Ágh, csn

Achilles, th, $-t$, - $e$

A szabályzatban:

Vörösmarty Mihály

Baróti Szabó Dávid

Vitéz Nagy János

a nagy Napóleon

a kis Kovács

Végzet

Hadúr

Isten: Gondviselés, Mindenható, Megváltó

Hóditó Vilmos

Szent István

Isten: Úr, Mindenható, Örökkévaló, Megváltó

Nagy Lajos

Szüz Mária

Boldog Margit 


\section{BOGNER 1939:}

Achilles

Adél (nem Adéle)

Aeshylus v. Aiskhylos
Ágoston: Augusztinus

Ármány isten neve

Balogh; Baloghy

A szabályzatban:

Puncsec, Sztojadinovics, Hajdukvelykovics, Szveti Hubert és nem Punčec, Sveti Hubert

Boldog Krizinus, Nagy Frigyes, Hatalmas Dusán, Oroszlánszívü Richárd Achilles és nem Achill; Ovidius és nem Ovid; Homérosz és nem Homér Zeus, Hadur, Wotan, Dajbog Mindenható, Megváltó, Üdvözitö Ady Endre, Szabó Dezsö, Jovánovics Milán

MTA 1950:

Achilles; Achilles-sarka valakinek Ádám Ágost: Augustus Aiskhylos v. Aeschylus Allah, Allahot, Allahhal Amade (csn.); Amadé (kn.) Anonymus tn. Apafi

Árpád-család Árpád-ház Árpád-házi Árpád-kori Atilla v. Attila (hun király) Attila v. Atilla megváltó; a Megváltó (= Krisztus) Messiás (= Krisztus)

A szabályzatban:

Petőfi Sándor, Ady Endre, Móricz Zsigmond

Hadúr, Jupiter, Zeus

Könyves Kálmán, Nagy Péter, Hóditó Vilmos, Bölcs Salamon, Szent László Isten, Mindenható, Szentlélek, Szentháromság, Boldogasszony a nagy Napóleon, a tengerjáró Kolumbus

MTA 1954:

Achilles-sarka valakinek
Ádám
Adolf
Ady Endre
Aeneas

Allah, Allahot, Allahhal Anatole France Anjou, Anjouk Anonymus Attila

A szabályzatban bemutatott kategorizáció: család- és keresztnevek; történelmi személyek nevének állandó jelzője; a mitológia és a vallás személynévként használt nevei.

\section{DEME-FÁBIÁN 1961:}

Ábel, Ábellal v. Ábellel Achilles l. Akhilleusz
Achilles-sarka valakinek

Adrien, Adriennel 
Ady: Ady Endre, Adyval, az Adyak és

Adyk; - adyas v. adys, Ady Endré-s;

$\mapsto$ Ady-vers; - Ady-versbeli
Aiszkhülosz, Aiszkhülosszal; - aisz-

khüloszi; elv.: Aisz-khü-losz

Aiszóposz, Aiszóposszal; - aiszóposzi,

de: Ezópus fabulái, ezópusi mesék

SZABÓ T. et al. 1978:

ádám-: ádámcsutka, ádámkosztüm

Adonisz, Adonisszal; adoniszi

Albert, Alberttal v. Alberttel

Allah, Allahot, Allahhal

Aeneas, Aenesszal; aeneasi

Aiszkhülosz, Aiszkhülosszal; aiszkhü-

loszi; elv.: Aisz-khü-losz

Arany: Arany János, Arannyal,

Aranyt; aranyi; Arany János-i,

Arany-szerü, Arany-vers

A szabályzatban bemutatott kategorizáció: vezetéknevek és keresztnevek; asszonynevek; történelmi személyek nevének állandó jelzője; a mitológia és a vallás fogalomkörébe tartozó, személynévként használt nevek.

MTA 1984:

Achilles-sarka valakinek; de:

Akhilleusz

Áchim L. András

Adrienn, Adriennel, Adriennél

Ady: Ady Endre, az Adyak és Adyk;

adyas v. adys, Ady Endré-s; Ady-

-vers; Ady-versbeli; Ady Endre utca

Aeneas, Aeneasszal

Allah, Allahot, Allahhal

Amadé (keresztnév), Amadéval

A szabályzatban bemutatott kategorizáció: családnevek (vezetéknevek) és keresztnevek (utónevek); asszonynevek; a mitológia és a vallás személynévként használt nevei.

DEME-FÁBIÁN 1988:

Ábel, Ábellal v. Ábellel

Achilles-sarka valakinek; de: Akhilleusz

Adrienn (keresztnév), Adriennel, Adriennél

Ady: Ady Endre, Adyval, az Adyak és

Adyk, adyas v. adys, Ady Endré-s;

Ady-vers, Ady-versbeli; Ady Endre

utca

Aiszkhülosz, Aiszkhülosszal, aiszkhü-

loszi; elv.: Aisz-khü-losz

Aiszóposz, Aiszóposszal, aiszóposzi;

de: Ezópus fabulái, ezópusi mesék

DEME-FÁBIÁN-TóTH 1999 nem mutat változást DEME-FÁBIÁN 1988-hoz képest.

LACZKÓ-MÁRTONFI 2004: csak itt található az idegen nevek kiejtésére vonatkozó utalás.

Abdullah: Abdullahhal, abdullahi

Abbado [abbádó] Abbadóval, abbadói

I Claudio Abbado

Abe Kóbó: Abe Kóbóval, Abe Kóbó-i

|| Abe Kóbó-regény
Ábel: Ábellel, ábeli

Achilles-[ahillesz-] \{A-chil-les- $\} \rightarrow$

Akhilleusz || Achilles-ín, Achilles-

-in-szakadás, Achilles-sarok 
Adamis: Adamissal, adamisi $\|$ Adamis Anna

Adonáj: Adonájjal, adonáji

Adonisz (utónév) Adonisszal, adoniszi $\| \rightarrow$ | valóságos
Adónisz 'Kinürasz király és leánya, Mürrha fia' (latinul Adonis) Adónisszal, adóniszi || adóniszi kólon, adóniszi sor

Afanaszjevics $\| \rightarrow \mid$ Bulgakov

A kötet Tanácsadó részében bemutatott kategorizáció: családnevek; utónevek; házassági nevek; becenevek; ragadványnevek; müvésznevek, írói álnevek; a mitológia és a vallás személynévként használt nevei; nickek.

BÁRÁNY 2009:

$\begin{array}{ll}\text { Ábel } & \text { Ady Endré-s } \\ \text { Achilles, Akhilleusz } & \text { Ady Endre utca } \\ \text { Achilles-ín } & \text { Adyk } \\ \text { Achilles-sarok (valakinek az Achilles- } & \text { Ady-kötet } \\ \quad \text {-sarka) } & \text { Ady-kutatás } \\ \text { Áchim L. András } & \text { adys } \\ \text { Adolfka } & \text { Ady-vers } \\ \text { Ady } & \text { Ady-versbeli } \\ \text { Ady Endre } & \text { Akhilleusz }\end{array}$

MTA 2015:

Abigél, Abigéllel v. Abigéllal Achilles-in; Achilles-in-szakadás -vers; Ady-versbeli; Ady Endre utca

Achilles-sarka valakinek; de: Akhilleusz

Adrienn, Adrienn-nel, Adrienn-nél Ady: Ady Endre, az Adyak és Adyk; adyas v. adys, Ady Endré-s; AdyAeneas (görögül Aineiasz), Aeneasszal Allah, Allahot; Allahhal Amadé (utónév), Amadéval

TÓTH 2017:

Achilles; elv.: A-chil-les; l. Akhilleusz

Adrienn (utónév), Adrienn-nel, AdriAchilles-in; Achilles-in-szakadás enn-nél

Achilles-sarok, Achilles-sarka valakinek

Áchim: Áchim L. András; elv.: Ady: Ady Endre, Adyval, adyas v. adys, Ady Endré-s; Ady-vers, Ady-versbeli; Ady Endre utca Á-chim; Áchim-ügy

3.2. Állatnevek. Az állatnevek írása talán a leghektikusabb a különféle helyesírási szótárakban. 1913-ban jelennek meg először, de 1950-ig a szótárakban csak kis kezdőbetüs példák vannak (pl. bodri). 1929 óta a szabályzatokban előfordulnak nagy kezdőbetüs állatnevek. Szótárakban nagy kezdőbetüs állatnévi példák csak 2004 óta bukkannak fel (BÁRÁNY 2009 kivételével). 
KELEMEN 1906-ban egyáltalán nem találhatók állatnevek.

HORVÁTH 1913-ban megjelenik néhány, kis kezdőbetüs példa:

bodri

riska

BALASSA 1929 ellentmondásos - a szótárban kis, a szabályzatban nagy kezdőbetűvel ad példákat:

bodri

A szabályzatban:

Bodri Ráró

BOGNER 1939 csak a szabályzatban említ állatneveket:

Bimbó, Morzsa, Pici, Sárga

MTA 1950 is BALASSA 1929 kettősségét követi.

riska (tehén)

A szabályzatban:

Bodri, Sajó, Cirmos, Villám, Fecske,

Csákó, Bimbó

MTA 1954 csak a szabályzatban hoz állatneveket:

Bimbó, Bodri, Cirmos, Csákó, Fecske,

Sajó, Villám

DEME-FÁBIÁN 1961-ben nincs állatnévi példa.

SzABÓ T. et al. 1978 csak a szabályzatban hoz állatneveket:

Bimbó, Bodri, Cirmos, Csákó, Fecske,

Sajó, Villám

MTA 1984 ismét csak a szabályzatban foglalkozik a kérdéssel:

Bimbó, Csákó; Fecske, Villám; Bodri,

Zsoli; Cili, Cirmos

DEME-FÁBIÁN 1988-ban sincs állatnévi példa.

DEME-FÁBIÁN-TóTH 1999 nem mutat változást DEME-FÁBIÁN 1988-hoz képest.

LACZKÓ-MÁRTONFI 2004:

Bodri: Bodrival, bodris

Ráró: Ráróval, rárós 
A szótár Tanácsadó részében:

Bakróházi Mirr-murr Szepi Józsefvárosi Kócos Pajtás Mihály

Bimbi, Cimi, Cindri, Csuppi, Susu, Szipa, Szuszmók, Tunyó Akela, Bagira, Bambi, Csí, Kele
Amazon, Báró, Bundás, Gyanús, Holló, Ilyesmi...

Bodri kutya, Cili cica, Ráró lovam, Riska tehén, Pityu papagáj,

Kavicska teknös

BÁRÁNY 2009-ben nincs állatnévi példa.

MTA 2015:

Bodri: Bodri kutya, Bodrival

Cirmos (állatnév); de: cirmos cica

TóTH 2017:

Bodri, Bodrival: Bodri kutya, Bodrival

Cirmos (állatnév); de: cirmos cica

3.3. Tárgynevek. Tárgynevekre példát először 1999-ből találni (pl. Szent Korona). A tárgynévi kategória 2004-től egyértelmü csupán. KELEMEN 1906, HoRVÁTH 1913, BALASSA 1929, MTA 1950, MTA 1954, DEME-FÁBIÁN 1961, SZABÓ T. et al. 1978, MTA 1984 és DEME-FÁBIÁN 1988 tehát nem vesz fel tárgynévi kategóriát.

DEME-FÁBIÁN-TÓTH 1999-ben jelennek meg először a tárgynevek, bár gyanítható, hogy a nagy kezdőbetüs írásmód valójában a szakralitásra utal, s nem tárgynév voltuk miatt kapnak nagy kezdőbetüt:

Szent Jobb (nemzeti ereklye)

Szent Korona-tan

Szent Korona (nemzeti ereklye)

Kategóriaként LACZKÓ-MÁRTONFI 2004 tárgyalja elsőként a tárgyneveket:

Szent [...] Szent Jobb

Szent Korona || Szent Korona-tan
Titanic [titanik] titanicos || Titanic-

-katasztrófa

A kötet Tanácsadó részében bemutatott kategorizáció: hajónevek; mozdonyok, léghajók, repülőgépek neve; ürjármüvek és más ürobjektumok neve; vonatjáratok neve; hálózati számítógépek neve.

BÁRÁNY 2009:

Szent Jobb (nemzeti ereklye)

Szent Sir

Szent Korona (nemzeti ereklye)

MTA 2015:

Excalibur (Artúr kardja; fegyvernév)

Szent Jobb (nemzeti ereklye)

Szent Korona (nemzeti ereklye); Szent

Korona-tan

A szabályzatbeli kategorizáció LACZKÓ-MÁRTONFI 2004-et követi.

TóTH 2017 pontosan követi MTA 2015-öt. 
3.4. Földrajzi nevek. Földrajzi nevek mindegyik szótárban előfordulnak.

KELEMEN 1906 országok, vizek, földrészek, közterületek, települések, megyék neveit mutatja be:

$\begin{array}{ll}\text { Abesszinia (Abisszinia); abessziniai } & \text { Al-Duna; aldunai } \\ \text { Ádriai-tenger } & \text { Andrássy-úti } \\ \text { Afrika; afrikai } & \text { Bács-Bodrog vármegye; de: } \\ \text { Akácfa-utca } & \text { bácsmegyei } \\ \text { az Akropolis } & \text { Grác [-ban, -ot]: gráci } \\ \text { Alcsút, községnév; alcsúti } & \end{array}$

A függelékben:

Rákóczi-út, Múzeum-körút, KirályArany János utcai, Deák Ferenc téri -utca, Petöfi-tér

Arany János utca, Deák Ferenc tér, Budapest; budapesti Ferenc József hid

Duna

Ferenc-körúti, Lónyay-utcai, BudaMagyarország; magyarországi Magas Tátra utcai

Fekete-tenger

bécsiutcai, királyutcai

HORVÁTH 1913-ban települések, megyék, országok, térszínek, vizek, közterületek stb. nevei találhatók meg:
Abaúj-Torna vármegye v. megye, abaújmegyei v. abaújtornamegyei Abbazia (-ban, -ba) (v. Abbázia) Abesszinia, abessziniai Abruzzók: az Appeninek fennsíkja Afrika, Dél-Afrika, délafrikai Al-földr:: Al-Duna, az Alföld

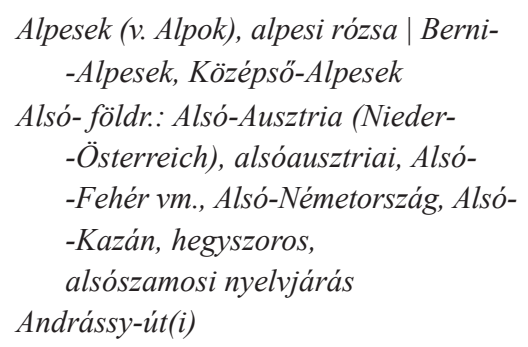

A szabályzatban bemutatott kategorizáció: helységnevek; megyék neve; országok, földterületek, világrészek és szigetek neve; hegységek neve; vizek neve; utcák, terek, városrészek neve; épületek, hidak, szobrok neve.

BALASSA 1929:

\author{
Abbazia, ..ában; abbaziai \\ Abesszínia, abesszíniai \\ Abony, hn, -ban: abonyi
}

Adria, Adriai tenger [Adriai-tenger]

Afrika, afrikai; Dél-Afrika, Észak-

-Afrika, délafrikai, északafrikai 
A szabályzatban:

Angolország
Székesfehérvár, Balatonfüred, Duna-
földvár, Magyaróvár
Bécs-Újhely, Majna-Frankfurt, Baden-
-Baden
Észak-Amerika, Dél-Afrika, Nyugat-
-Magyarország, Kelet-Európa
északamerikai, délafrikai,
nyugatmagyarországi
Zala (vár)megye, Fejér (vár)megye
Erzsébet körút, Váci ucca, Ferenc Jó-
zsef tér
Atlanti óceán, Földközi tenger, Fekete
tenger, Vörös tenger

Belváros, Viziváros, Józsefváros

Lánchíd, Margithid, Erzsébethíd

Margitsziget, Csepelsziget

Gellérthegy, Sashegy, Hármashatár-

-hegy

Ferenc József hid

margitszigeti, józsefvárosi

Petöfi téri, Deák Ferenc uccai

Duna

Budapest; budapesti

Tátra

Gellérthegy

\section{BOGNER 1939:}

Abesszinia, abessziniai

Adria, adriai-tenger

Afrika, afrikai, Délafrika, délafrikai Alcsi, az alcsi bíró (nem: az alcsii bíró)

alföld, de: az Alföld

Algír, algíri

A szabályzatban:

Petrovgrád, Noviszád, Lyubisa

Bácska Palánka és nem Bačka Palanka

sziboticai Danicsityev út és nem suboticai Daničićev put

MTA 1950:
Alpesek v. Alpok; alpesi tájék Altaj hegység; urálaltaji nyelvek Amerika; Észak-Amerika; amerikai, észak-amerikai tér: Petöfi-tér, Szabadság-tér; [...] Petöfi-téri, Vörösmarty-téri, de: szabadságtéri, szénatéri

Karagyorgye tér Jugoszlávia, Sumadija, Száva, Alföld,

Dunántúl, Balaton, Nis,

Kragujevác, Délszerbia
Alföld, Nagy-Alföld, Kis-Alföld

alföldi, nagyalföldi, kisalföldi

Algir

algíri

Alpesek v. Alpok

Bakony, Hernád, Balaton

Sztálin-út, Rákóczi-tér, Marx-tér 
MTA 1954:

$\begin{array}{ll}\text { Abesszinia } & \text { afrikai } \\ \text { abesszíniai } & \text { Afrika-kutató } \\ \text { Adria } & \text { Albán Népköztársaság } \\ \text { Adriai-tenger } & \text { Alföld: Nagyalföld, Kisalföld } \\ \text { adriai-tengeri halászat } & \text { Alpokv. Alpesek } \\ \text { Afganisztán } & \text { Alsó-: Alsódabas } \\ \text { Afrika } & \text { Antarktisz: elv.: An-tark-tisz }\end{array}$

A szabályzatban bemutatott kategorizáció: országok neve; országrészek, tájegységek neve; vármegyék neve; közigazgatási egységek többelemü neve; helységnevek; városrészek neve; utcák és terek neve.

\section{DEME-FÁBIÁN 1961:}

Abbázia, Abbáziában;-abbáziai

Abesszinia, Abessziniában;-abessziniai

Adria, az Adrián; - adriai

Adriai-tenger, az Adriai-tengeren; adriai-tengeri, Afrika, Afrikában; - afrikai $\mid \rightarrow$ Afrika-kutatás, Afrika- -vadász; - Afrika-vadászi felszerelés $\mid \leftarrow$ Dél-Afrika, Észak-

-Afrika; - dél-afrikai, észak-afrikai

Albán Népköztársaság

Algír (arabul Al-Dzsazáir), Algírban;

- algíri

SZABÓ T. et al. 1978:

Abesszinia; abessziniai

Adeni-öböl; adeni-öböli

Afrika; afrikai; Afrika-kutató; Dél-

-Afrika; dél-afrikai

Alexandria, Alexandriába; alexandriai;

elv.: Ale-xand-ria

alföld: nagy alföld, román alföld, termékeny alföld; Nagyalföld, Németalföld; Szlovák-alföld Amerikai Egyesült Államok; amerikai egyesült államokbeli; röv.: USA, USA-beli

Antwerpen; antwerpeni

A szabályzatban bemutatott kategorizáció: országok neve; államnevek; országrészek, tájegységek neve; vármegyék neve; közigazgatási egységek többelemü neve; települések neve, helységnevek; városrésznevek; utcák és terek neve.

MTA 1984:

Abesszinia (történeti név); ma: Etiópia Adriai-tenger, adriai-tengeri

Afganisztán, afganisztáni

Afrika, afrikai; Afrika-kutatás | Közép-

-Afrika, közép-afrikai alföld (=síkság); de: az Alföld (magyar tájegység); Havasalföld (történeti tájnév), Kisalföld, Német-alföld; Pó-alföld; Szlovák-alföld 
Algériai Szultánság (történeti), algériai szultánságbeli

Alpok, az Alpokban; Keleti-Alpok; az osztrák Alpok
Alsó-: Alsóörs, alsóörsi; Alsó-Ausztria, alsó-ausztriai

Antarktisz, antarktiszi: elv.: Ant-arktisz v. An-tark-tisz

A szabályzatban bemutatott kategorizáció: egyelemü földrajzi nevek; országnevek, országrésznevek, tájnevek; helységnevek, helységrésznevek; kötőjellel kapcsolt földrajzi nevek; államnevek, gazdasági földrajzi körzetnevek; államrészek nevei; közterületek nevei.

DEME-FÁBIÁN 1988:

Abbázia (szerbhorvátul Opatija), abbáziai

Abesszinia (történelmi név); ma: Etiópia

Abház ASZSZK

Adriai-tenger, adriai-tengeri

Adyliget, adyligeti
Afrika, afrikai; Afrika-kutatás |

Közép-Afrika, közép-afrikai

Aggteleki-cseppköbarlang (= Ba-

radla)

Aix-en-Provence, aix-en-provence- $i$

Albán Szocialista Népköztársaság, al-

bán szocialista népköztársasági

Algír (város; arabul Ed-Dzáir), algíri

\section{DEME-FÁBIÁN-TÓTH 1999:}

Abbázia (horvátul Opatija), abbáziai Abesszinia (tört.); ma: Etiópia

Aggteleki-cseppköbarlang (névváltozat Baradla)

Abhá ASZSZK

Albán Köztársaság, albán köztársasági

LACZKÓ-MÁRTONFI 2004 - megjelennek határon túli magyar tulajdonnevek és tulajdonnévtípusok: ${ }^{6}$

Aachen [áhen] \{Aa-chen\} Aachenben, aacheni

Abaligeti-barlang

Abaúj-Torna vármegye: Abaúj-Torna vármegyében, Abaúj-Torna vármegyei

Abbázia (horvátul Opatija), Abbáziában, abbáziai

Ábrahámhegy (település) Ábrahámhegyen, ábrahámhegyi
Ábrahám-hegy (hegy) Ábrahám-hegyen, Ábrahám-hegyi

Ada község: Ada községben, Ada községi

Afgán Iszlám Állam: afgán iszlám állami

Aggteleki Nemzeti Park: aggteleki nemzeti parki

Ajtósi Dürer sor: Ajtósi Dürer sori Akadémiatelep $\| \rightarrow \mid$ Régiakadémiatelep

A kötet Tanácsadó részében bemutatott kategorizáció: országnevek és államnevek; víznevek, domborzati nevek, terület- és tájnevek, tengerfenék-domborzati nevek; utcanevek.

${ }^{6}$ Az Ada község például a magyarországitól eltérően az Ada város mint központ körüli járást, kistérséget jelöli. 
BÁRÁNY 2009:

Abbázia
Abesszínia (történelmi)
abesszíniai
Abrudbánya
Abruzzók
Afrika

MTA 2015: afrikai

Afrika-kutatás

Afrika-kutató

Afrika-utazó

Alcsi-Holt-Tisza

TÓTH 2017 alapvetően DEME-FÁBIÁN-TÓTH 1999-et követi, de vannak kisebb változtatások, például:

Afrika, afrikai; Afrika-térkép |Közép-Afrika, közép-afrikai

3.5. Csillagászati nevek. Csillagászati nevek mindegyik szótárban előfordulnak.

\section{KELEMEN 1906:}

göncölszekér (csill. munkákban: a

Göncölszekér)

\section{HORVÁTH 1913:}

göncöl, göncölszekér, kisgöncöl

hold, holddal (csill. munkákban: a

Hold, de pl. a Szaturnusznak nyolc holdja van)

A szabályzatban:

Merkúr

BALASSA 1929:

göncölszekér (vö szekér); a Nagy-

-Göncöl és a Kis-Göncöl
Ajka, ajkai

Ajkai járás, ajkai járási

Alaszka, alaszkai

Alcsi-Holt-Tisza, alcsi-holt-tiszai

Algír (város; arabul Ed-Dzáirr), algíri

Alma-Ata l. Almati 
A szabályzatban:

Mars

Jupiter

Nagy-Göncöl

\section{BOGNER 1939:}

Mars

A szabályzatban:

Jupiter, Vénus, Fiastyúk

MTA 1950:

föld; a Föld (mint égitest)

Göncölszekér

A szabályzatban:

Vénus

Föld

MTA 1954:

Göncölszekér; de: Göncöl szekere hold (égitest), holdja, holddal

Mars (égitest)

DEME-FÁBIÁN 1961:

föld, földje, földdel; csillagászati szakmunkákban: a Föld

Göncölszekér; de: Göncöl szekere

hold, holdja, holddal; csillagászati szakmunkákban: a Hold

Mars (isten és bolygó), Marssal, a Marson;-marsi és marsbeli

SzABÓ T. et al. 1978:

föld, földje, földdel; csillagászati szakmunkákban: a Föld

Göncölszekér; de: Göncöl szekere hold (égitest), holdja, holddal [...] (csillagászati szakmunkákban): a Hold tudományos munkákban: Föld, Nap,

Hold

Göncöl szekere

hold; a Hold (égitest)

Nap

Venus (istennö és bolygó); de: Vénusz:

a murányi Vénusz

nagy medve; de: a Nagymedve

(csillagkép)

nap (égitest), napja; csillagászati szakmunkákban: a Nap

Venus (istennö és bolygó), Venusszal,

a Venuson; - venusi és venusbeli

Vénusz: a milói Vénusz, a murányi

Vénusz

Mars (isten és bolygó), Marssal, a Marson; marsi és marsbeli;

Mars-lakó; de: marslakó

(=különleges) figura

Nagymedve (csillagkép); de: nagy medve 
nap (égitest), napja; csillagászati

szakmunkákban: a Nap
Venus (istennö és bolygó), Venusszal, a Venuson; venusi és venusbeli Vénusz: a milói Vénusz

MTA 1984:

Föld (tulajdonnévként)

Göncölszekér; de: Göncöl szekere

hold (égitest), holdja, holddal; de tulajdonnévként: a Hold

Mars (isten és bolygó), Marssal; marsi és marsbeli

Merkúr (bolygó)

A szabályzatban:

Ikrek, Fiastyúk, Orion, Tejút, Merkúr, Plútó, Vénusz

\section{DEME-FÁBIÁN 1988:}

Föld (tulajdonnévként)

Göncölszekér; de: Göncöl szekere

hold (égitest), holdja, holddal; [...] de tulajdonnévként: a Hold

Mars (isten és bolygó), Marssal, marsi és marsbeli

Merkúr (bolygó), merkúri

nagy medve; de: a Nagymedve

(csillagkép)

\section{DEME-FÁBIÁN-TÓTH 1999:}

nap (égitest), napja; de: a Nap (tulajdonnév)

\section{LACZKÓ-MÁRTONFI 2004:}

Göncölszekér: göncölszekéri

Hold (csillagászati tulajdonnévként) Holdon, holdi || Hold-Föld-távolság

Mars $^{2}$ 'a Naprendszer negyedik bolygója' Marson, marsi $\|$ marsbeli, Mars-év, Mars-expedició, Mars-kutatás, Mars-szonda marslakó 'ürlény; fura alak' Mars-lakó 'Marson élö lény' nap (égitest), napja; de tulajdonnévként: a Nap

Vénusz (bolygó és istennő neve; latinosan: Venus), vénuszi és vénuszbeli; a milói Vénusz, a murányi Vénusz nap (égitest), napja; de tulajdonnévként: a Nap

Venus (istennö), Venusszal, venusi; de: a milói Vénusz, a murányi Vénusz

Vénusz (bolygó), a Vénuszon, vénuszi; Vénusz-felszín
Merkúr: merkúri

Nagy Medve (latinul Ursa maior) nagy medvei

Nap (csillagászati tulajdonnévként) napi || Nap-Föld-távolság | Nap típusú csillag

Vénusz 'a Naprendszer második bolygója'vénuszi || Vénusz-expedició, Vénusz-felszín, Vénusz-rakéta 
A kötet Tanácsadó részében bemutatott kategorizáció: a naprendszer bolygói; csillagképek.

BÁRÁNY 2009:

Föld (tulajdonnévként)

Mars (isten/bolygó)

Göncöl

Merkúr (bolygó)

Göncölszekér

Mérleg (csillagkép)

Göncöl szekere

Nagymedve (csillagkép)

Hold (égitest: a Föld holdja)

Nap

Vénusz (bolygó és istennö neve ma-

vénuszdomb

gyarosan)

vénuszi

Vénusz-átvonulás

Vénusz-rakéta

vénuszbeli

MTA 2015:

Föld (csillagászati tulajdonnévként) földi; Föld körüli pálya

Göncölszekér; de: Göncöl szekere

hold (égitest), holdja, holddal; de tulajdonnévként: a Hold

Mars (isten és bolygó), Marssal;

marsi és marsbeli

Merkúr (bolygó)

Nagy Medve; Nagy Medve-beli

nap (égitest), napja; de csillagászati tulajdonnévként: Nap

Vénusz (istennö és bolygó neve magyarosan), vénuszi és vénuszbeli; milói Vénusz

TÓTH 2017:

Föld (csillagászati tulajdonnévként);

Nagy Medve (csillagkép); Nagy

Föld körüli pálya

Medve-beli

Hold (csillagászati tulajdonnév), holdbeli v. holdbéli; Hold-Föld-távolság

Mars (bolygó), marsbeli; Mars-év,

Mars-kutatás, Mars-szonda

nap (égitest), napja; de csillagászati tulajdonnévként: Nap

Vénusz (istennö és bolygó neve magyarosan), Vénuszon, vénuszi és vénuszbeli; Vénusz-felszín | milói Vénusz

3.6. Intézménynevek. Intézménynevek mindegyik szótárban elöfordulnak.

\section{KELEMEN 1906:}

akadémia (mint köznév): ellenben: a

Magyar Tudományos Akadémia $=a z$

Akadémia 
A függelékben:

Magyar Tudományos Akadémia

Természettudományi Társulat

Első Hazai Takarékpénztár

\section{HORVÁTH 1913:}

akadémia (akademia): föiskola, tudósok társasága; az Akadémia úgy döntött; van két akadémiája;

A szabályzatban:

Vatikán

Nemzeti Szinház

a kir. Kúria

Magyar Tudományos Akadémia, Nemzeti Múzeum, de: az nem akadémia, de ez múzeum

BALASSA 1929:

akadémia, Magyar Tudományos

A szabályzatban:

Magyar Tudományos Akadémia

Kisfaludy Társaság

Természettudományi Társulat

Nemzeti Szinház

Szépmüvészeti Múzeum

BOGNER 1939:

akadémia $g$ = tudós társaság, szakirányú felsöiskola, az Akadémia,

Szerb Tudományos Akadémia,

A szabályzatban:

Királyi Báni Hivatal, Proszvéta Konviktus, Nemzeti Szinház, Első Horvát Takarékpénztár, Fekete Sas

MTA 1950:

Akadémia $=$ A Magyar Tudományos Akadémia; röv.: M. Tud. Akadémia nem hivatalos használatban: nemzeti szinház, székesfehérvári áll. Föreáliskola

a Magyar Tudományos Akadémia röv.: M. T. Akadémia

operaház, az Operaház

Pesti Hazai Első Takarékpénztár

Budapesti grafikai és rokoniparosok fönökegyesülete (mivel nagyon hosszú)

Radich Béla és Társa

Kovács Árpád és Fia

Akadémia (M. T. Akadémia)

Magyar Általános Hitelbank

Bethlen Kollégium

a m. kir. Adóhivatal, a IV. ker. elöljáróság, a központi állampénztár

Magyar Tudományos Akadémia, röv. M. T. Akadémia
Alkotmányozó Gyülés opera, operák; az Opera

Operaház 
A szabályzatban:

Magyar Tudományos Akadémia

Közegészségügyi Intézet

Magyar Nyelvtudományi Társaság

Országos Tervhivatal

MTA 1954:

Akadémia $=$ a Magyar Tudományos Akadémia; röv.: MTA, névelövel: az MTA

A szabályzatban:

Magyar Dolgozók Pártja

Pedagógus Szakszervezet

Magyar Tudományos Akadémia

Ipari Tervezö Intézet

\section{DEME-FÁBIÁN 1961:}

Akadémia (= a Magyar Tudományos Akadémia), az Akadémiában és az Akadémián; - akadémiai

kórház $\mid \leftarrow$ [...] János Kórház és Rendelöintézet (rövidebben: János-

-kórház; [] Benczúr utcai Kórház opera, operája, operái; de: az Opera (= a budapesti operaház) pályaudvar; röv.: pu. $\mid \leftarrow$ [...] Keleti pályaudvar, Gömöri pályaudvar

SzABÓ T. et al. 1978:

pályaudvar: [...] Északi pályaudvar Nemzeti Színház; nemzeti színházi

A szabályzatban:

Román Kommunista Párt

Románia Szocialista Köztársaság Akadémiája

Magyar Tudományos Akadémia

Párttörténeti Intézet

\author{
Szabadság Szálló \\ bölcsészettudományi kar, szentesi \\ földmüvesszövetkezet, mezötúri \\ gépállomás
}

Államvasutak, röv.: MÁV

opera, operája; de: az Opera

Operaház

\section{Oktatásügyi Minisztérium}

Eötvös Loránd Tudományegyetem

Petöfi Sándor Gimnázium

Rudas fürdö, a Rudas fürdöben; - Rudas fürdö $i$

szálló (fn.), szállója, szállói $\mid \leftarrow[\ldots]-$

Gellért-szálló, Opera-szálló (nem

hivatalos nevekként)

szálloda, szállodája, szállodái $\mid \leftarrow A s-$ toria Szálloda, Duna Szálloda, Gellért Szálloda, Opera Szálloda, Park Szálloda (hivatalos intézménynevekként)

szálloda, szállodája, szállodái [...]

Napoca Szálloda

Babeş-Bolyai Tudományegyetem

Nyelvtudományi Intézet

Kriterion Könyvkiadó

Egyetemi Könyvtár

Állami Magyar Színház 
MTA 1984:

akadémia (= föiskola), akadémiája,

opera, operája, operái; de: az Opera akadémiái; de: az Akadémia (=a

(= a budapesti operaház)

Magyar Tudományos Akadémia)

Állami Biztositó (intézménynév); röv.: ÁB

étterem: Kárpátia étterem, Kis Rabló étterem

fürdö [...] Lukács fürdö pályaudvar; röv.: pu. [...] Kelenföldi pályaudvar, a szolnoki pályaudvar szálló (fn.), szállója, szállói; [...] Volga Szálló szálloda, szállodája, szállodái; [...] Gellért Szálloda

kórház [...] Mentőkórház, Sport-

kórház, Margit Kórház, Tétényi

Úti Kórház (intézménynevek)

A szabályzatban bemutatott kategorizáció: hivatalos, teljes és cégszerü nevek; intézmények alárendelt egységei; pályaudvarok, megállóhelyek, repülőterek, mozik, vendéglök, eszpresszók, üzletek, fürdők, temetők stb.; intézményszerü rendezvények, kiállítások, vásárok.

\section{DEME-FÁBIÁN 1988:}

ÁFÉSZ = Általános Fogyasztási és Értékesitési Szövetkezet; de: egy falusi áfészben

Air France (repülőtársaság), az Air

France-szal

Akadémia (= a Magyar Tudományos

Akadémia), az Akadémiában és az Akadémián, akadémiai

állami áruház; de: Úttörö Állami Áruház

államvasutak; de: Magyar Államvasutak; röv.: MÁV

étterem: Kárpátia étterem, Kis Rabló étterem, Vörös Rák étterem

fürdö [...] Lukács fürdö kórház [...] Benczúr Utcai Kórház, Fövárosi János Kórház és Rendelöintézet, [...] Mentőkórház, Sportkórház, Tétényi Úti Kórház Opera (= a budapesti operaház) operaház; de: Magyar Állami Operaház pályaudvar; röv.: pu. [...] Budapest Nyugati pályaudvar, Kelenföldi pályaudvar, rendezö pályaudvar; a szolnoki pályaudvar szálló (fn.), szállója, szállói; [...] Erzsébet Szálló szálloda, szállodája, szállodái; szállodaipar | Nemzeti Szálloda, Volga Szálloda

\section{DEME-FÁBIÁN-TÓTH 1999:}

állami áruház

kórház [...] Madarász Utcai Gyermekkórház és Rendelöintézet, Mentőkórház, Sportkórház, Szent Imre Kórház pályaudvar; röv.: pu. [...] Kelenföldi pályaudvar, Nyugati pályaudvar, rendezö pályaudvar, a szolnoki pályaudvar szálló (fn.), szállója, szállói; [...] Stadion Szálló

szálloda, szállodája, szállodái; szállodaipar | Astoria Szálloda, Nemzeti Szálloda 
LACZKÓ-MÁRTONFI 2004:

Ágoston-rend

Akácos kisvendéglö: Akácos kisvendéglöi
Akadémia 'Magyar Tudományos Aka- démia'akadémiai || az Akadémia levelezö tagja, az Akadémia ren- des tagja

A kötet Tanácsadó részében bemutatott kategorizáció: hivatalos nevek; rövid alakok; alárendelt egységek; intézményszerű rendezvények, kiállítások, vásárok.

BÁRÁNY 2009:

Adó-és Pénzügyi Ellenörzési Hivatal Ágoston-rend

Ágoston-rendi
Adó- és Pénzügyi Ellenörzési Hivatal
l. Nemzeti Adó- és Vámhivatal; röv.: $A P E H$
Alitalia (légitársaság), az Alitaliánál

MTA 2015 igen bő választékot ad:

Agrártudományi Egyetem (intézménynévként)

Akadémia (a Magyar Tudományos Akadémia)

akadémia (= föiskola), akadémiája, akadémiái; de: az Akadémia (=a Magyar Tudományos Akadémia) operaház; de: Magyar Állami Operaház; rövid névváltozattal: Operaház v. Opera

TóTH 2017:

$$
\begin{aligned}
& \text { adóhivatal; Nemzeti Adó- és Vámhiva- } \\
& \text { tal; röv.: } N A V \\
& \text { ÁÉSZ = Áltatur Fogyasztúsi és Ér- } \\
& \text { tékesitési Szövetkezet; de: egy fa- } \\
& \text { tusiáfészen } \\
& \text { Akadémia (= a Magyar Tudományos } \\
& \text { Akadémia), az Akadémiában és az } \\
& \text { Akadémián, akadémiai; az Aka- } \\
& \text { démia levelezö tagja } \\
& \text { úllami árúz } \\
& \text { államvasút; de: Magyar Államvas- } \\
& \text { utak; röv.: MÁV } \\
& \text { étterem, étterme; étteremlánc | Bíró } \\
& \text { Háza Etterem és Panzió, Bíró Háza }
\end{aligned}
$$

étterem és panzióbeli, Kárpátia étterem, Kis Rabló étterem kórház [...] intézménynév részeként:

Sportkórház, Szent Margit Kórház pályaudvar; röv.: pu. [...] rendezö pályaudvar, szolnoki pályaudvar;

Kelenföldi pályaudvar, Nyugati pályaudvar szálló (fn.), szállója, szállói; [...]

Kastélykert Szálló szálloda, szállodája, szállodái; [...] |

Erzsébet Szálloda

3.7. Márkanevek. Márkanevek 1961 óta fordulnak elő a helyesírási szótárakban; Kelemen 1906, HoRVÁTH 1913, BALASSA 1929, MTA 1950 és MTA 1954 tehát nem mutat be márkaneveket.

Először DEME-FÁBIÁN 1961-ben tünnek fel: 
Ford, Forddal $\mid \rightarrow$ Ford-gyár $\mid \leftarrow$ van egy Fordja
Pobeda, Pobedával: beült a Pobedába $\rightarrow$ Pobeda autó

SzABÓ T. et al. 1978:

autó [...] Dacia autó

MTA 1984:

autó [...] Škoda autó

Mercédesz (nöi név), Mercédesszel; de: egy Mercedes (márkanév)

A szabályzatban:

Ultra, Trabant, Fabulon, Vegacillin; Alfa Romeo, Coca-Cola narancsital, meggylé; kecskeméti barack, tokaji bor ${ }^{7}$

Omnia kávé, Panangin tabletta, Odol fogkrém; Tomi Mat mosópor

DEME-FÁBIÁN 1988:

Alfa Romeo (autómárka)

autó [...] Moszkvics autó, Škoda autó,

Ford, Forddal; Ford-gyár | van egy

Fordja

Wartburg kombi autó

Mercedes (márkanév), Mercedesszel

Coca-Cola, Coca-Colát, Coca-

Colával, coca-colás; Coca-Cola-

-szerü

DEME-FÁBIÁN-TÓTH 1999:

autó [...] FIAT v. Fiat autó, Opel

autó, Škoda autó

LACZKÓ-MÁRTONFI 2004:

Adidas [adidasz] adidasos

Kalasnyikov: kalasnyikovos

Adobe [edobi] $\{A \cdot d o-b e\}$ adobes

A szótár Tanácsadó részében:

Sony

Sába sonka

Piros Arany

Benetton

Egyél Egyet!

Hohes C

Visa Electron

${ }^{7}$ L. a 193. pont második bekezdésének állásfoglalását: „A nem márkanévként használt, többnyire a termék anyagára vagy származási helyére utaló nevekben a tagokat kis kezdőbetűvel írjuk: narancsital, meggylé; kecskeméti barack, tokaji bor; stb. - Címkén, hirdetésen stb., alakulatkezdő helyzetben az első tagot természetesen nagybetüvel kezdjük: Kecskeméti barack stb." 
BÁRÁNY 2009:

Mercedes (márkanév)

MTA 2015:

Excel (= táblázatkezelö program);

Excel-tábla

TÓTH 2017:

Alfa Romeo (autómárka), Alfa

Romeó-s

autó $[\ldots]$ Škoda autó

Mercédesz (utónév), Mercédesszel; de: Mercedes (márkanév), Mercedesszel

Ford, Forddal; Ford modell $\mid$ Henry

Ford

3.8. Kitüntetésnevek és díjnevek. Kitüntetés- vagy díjnév elöször 1913-ban tünik fel (KELEMEN 1906-ban tehát még nem), de ekkor még csak a kis kezdőbetüs térdszalagrend. 1950-től tulajdonnévi példák is megjelennek.

HORVÁTH 1913 és BALASSA 1929:

térdszalag(rend)

MTA 1950:

Kossuth-dij

Szabadság-érdemrend

MTA 1954:

Kossuth-dij

Kossuth-dijas

DEME-FÁBIÁN 1961:

Kossuth-dij

térdszalagrend

SZABÓ T. et al. 1978:

Állami Díj; állami dijas

térd [...] térdszalagrend

dij [...] Nobel-dij

MTA 1984:

dij [...] Jászai Mari-díj, Nobel-dij; Állami Díj

díjas; Jászai Mari-dijas, Nobel-dijas;

SZOT-dijas; állami dijas

Kossuth-dij, Kossuth-dijas

A szabályzatban bemutatott kategorizáció: tulajdonnévi előtagúak; több különírt közszóból állók; kitüntetések és díjak fokozatai, típusai. 
DEME-FÁBIÁN 1988:

dij [...] Jászai Mari-dij, Kossuth-dij, Nobel-dij; Állami Díj

Kossuth [...] Kossuth-dij, Kossuth-dijas

dijas; Jászai Mari-dijas, Nobel-dijas;

SZOT-dijas; állami dijas

DEME-FÁBIÁN-TóTH 1999 hűen követi DEME-FÁBIÁN 1988-at.

LACZKÓ-MÁRTONFI 2004 - az altípusok jelentős bővülése a rendszerváltás hozta robbanásszerü nyelvhasználati változás következtében:

Corvin-lánc: Corvin láncos

dij [...] Bartók Béla-Pásztory Ditta-

-dij, Baumgartner-dij, [...]

Grammy-dij [...] | Állami Dij, [...]

Mécs László irodalmi dij

A szótár Tanácsadó részében:

Citromdij (névvé vált dijtípus)

Eötvös Loránd-emlékérem; Alföld-dijj;

MIE-emlékérem

kémiai Nobel-dij; béke-Nobel-dij

Gundel-dij, de: Gundel müvészeti dij

a Francia Köztársaság Becsületrendje; Állami Díj

BÁRÁNY 2009:

Kossuth-dij

MTA 2015:

Akadémiai Aranyérem

dij [...] Sajtódij, Toleranciadíj; Jászai

Mari-dij, Nobel-dij; Állami Díj;

Pro Universitate dij, Pro Urbe dij pro [...] Pro Urbe Dij

térdszalag || térdszalagrend,

térdszalagsérülés

Életfa dijj; Pro Cultura Hungarica emlékplakett tanári Delfin dij

Magyar Köztársasági Arany Érdemkereszt

Budapest Tájfutó Sportjáért dij

Kossuth-dijas

dijas; Jászai Mari-dijas, Nobel-dijas; állami dijas

A szabályzat sokat merít LACZKÓ-MÁRTONFI 2004-ből.

То́тн 2017:

Akadémiai Aranyérem

dij [...] tulajdonnév részeként: Sajtódij, Toleranciadij; Jászai Mari-dij, Kossuth-dij, Nobel-dij; Állami Díj; Pro Universitate dij, Pro Urbe dij dijas; Jászai Mari-dijas, Nobel-dijas; állami dijas

Kossuth-dij, Kossuth-dijas 
3.9. Címek. Címek mindegyik szótárban előfordulnak.

KELEMEN 1906:

az Odisszea v. Odysseia

A függelékben:

Magyar Nyelvtan

Törökországi Levelek

Budapesti Közlöny

Vasárnapi Újság

A kösziviu ember fiai

Zalán futása vagy Zalán Futása

Buda halála vagy Buda Halála

HORVÁTH 1913:

Friss Ujság

Odisszea (Odyssea): Odisszeus (Odys-

Vasárnapi Ujság

seus) bolyongásait leíró eposz címe

A szabályzatban:

Utazás a föld körül

Vasárnapi Ujság

a Falu rossza [!]

Kewlari búcsú

Magyar Nyelvör

BALASSA 1929:

szózat; a Szózat

A szabályzatban:

Budapesti Szemle

Magyarország és a Nagyvilág

A köszivü ember fiai

Fenn az ernyö, nincsen kas

Pesti Napló

A falu rossza

Zalán futása

Gondolatok a könyvtárban

BOGNER 1939:

szózat; a Szózat

A szabályzatban:

A Két Fogoly, Hitel, Világ, Ifjúság,

Kalangya, A Mi Irodalmunk, de:

„A mi irodalmunk"

MTA 1950:

Szózat (Vörösmarty költeménye)

A szabályzatban:

Szabad Nép, Szabad Ifjúság, Társadalmi Szemle, Élet és Tudomány, Magyar Nyelv

«Az acélt megedzik», "A fordulat éve», «Ismét magyar lett a magyar»

Buda Halála, Az Ifjú Gárda, Nemzeti Dal 
MTA 1954:

Odisszea

A szabályzatban:

Szabad Nép

A leninizmus kérdései

DEME-FÁBIÁN 1961:

Aeneis, az Aeneisszel; - aeneisi nemzeti dal; de: a költö maga mondta el a Nemzeti dalt

népszabadság; de: Népszabadság (újságcím)

SzABÓ T. et al. 1978:

biblia [...] Biblia (irodalmi mü)
Nemzeti dal

Elöszó

Népszava (újságcim); de: a nép szava Odisszea (hösköltemény; görögösen

Odüsszeia), az Odisszeában; odisszeai
Odisszea (hösköltemény; görögösen

Odüsszeia), az Odisszeában;

odisszeai

MTA 1984:

$\begin{array}{cc}\text { Nép-: Népszabadság, Népszava (újság- } & \text { odisszea (= hányattatás, bolyongás); } \\ \text { címek); Népszinház; Nép-sziget } & \text { de: Odisszea (hösköltemény; gö- } \\ & \text { rögösen: Odüsszeia) }\end{array}$

A szabályzatban bemutatott kategorizáció: állandó címek - újságok, hetilapok és folyóiratok címe; egyedi címek - költői müvek, könyvek, értekezések, cikkek, képek, szobrok, zenemüvek, müsorszámok stb.

DEME-FÁBIÁN 1988:

Aeneis, az Aeneisszel, aeneisi; Aeneis-beli hös

Aida (zenemü), Aida-beli

nemzeti dal; de: a költö maga mondta el a Nemzeti dalt

Nép-; Népszabadság, Népszava (újságcímek); Népszinház; Nép-sziget

odisszea (= hányattatás, bolyongás);

de: Odisszea (hösköltemény; gö-

rögösen Odüsszeia)

szózat, szózata; Szózat (verscím)

DEME-FÁBIÁN-TÓTH 1999:

szózat, szózata; de: Szózat (verscím)

LACZKÓ-MÁRTONFI 2004:

A Dunánál címü vers

Aeneis [éneisz] \{Ae-ne-is\} aeneisi

Agnus Dei

Aida [ajda] $\{$ Ai-da $\}$ aidai $\|$ Aida-

-elöadás

A Hét

Ajurvéda: Ajurvéda-beli || ájurvédikus 
A kötet Tanácsadó részében bemutatott kategorizáció: állandó címek; melléklet- és rovatcímek, tévé- és rádiómüsorok állandó címei; internetes portálok címei; egyedi címek.

BÁRÁNY 2009:

Aeneis

A közúti közlekedés szabályai (rendelet cime)

MTA 2015:

Aeneis, aeneisi; Aeneis-beli hös

Nemzeti alaptanterv; röv.: NAT

\author{
Odüsszeia, Odüsszea-beli \\ szózat, szózata; de: Szózat (verscím)
}

TóTH 2017:

Aeneis, az Aeneisszel, aeneisi; elv.: Ae-ne-is; Aeneis-beli hös

Aida (zenemü), Aida-beli; Aida-

-bemutató

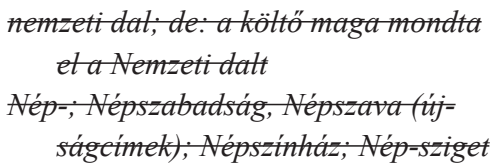

3.10. Egyéb tulajdonnevek. Az egyéb tulajdonnevek megjelenése - a dolog természetéből adódóan - meglehetősen ad hocnak tünik.

KELEMEN 1906, HORVÁTH 1913 és BALASSA 1929 egyike sem foglalkozik egyéb tulajdonnevekkel. Az MTA 1950-ben csak a szabályzatban jelennek meg egyéb tulajdonnevek. Az akadémiai helyesírási szabályzat 1879-1950 közötti kiadásaiban ugyanis - némileg eltérő szövegváltozatokkal - szerepel az alábbi kitétel: „Természettudományi munkákban az é g i te s te k és j e g y e k neveit egyöntetüség és könnyebb érthetőség kedvéért nagy kezdőbetüvel írják: Merkur, Venus, Föld (Tellus), Nap (Sol), Kaszás, Fiastyúk, Kos, Bika; - a földtanban a képződmények neveit: Kréta, Köszén, Jura, Trias stb.,valamint más tárgyi tulajdonneveket is, ha különös kiemelésük szükségesnek mutatkozik, pl. a kőzettanban a kőzetek, az ásványtanban az ásványfajok, a vegytanban az elemek nevét stb. [kiemelések az eredetiben]" (MTA 1943: 42).

MTA 1954: ekkortól 1984-ig két eseménynév, a Nagy Októberi Szocialista Forradalom és a Nagy Honvédö Háború tulajdonnévként, kivételesen, nagy kezdőbetüvel íródik. A manapság elég gyakori nagy kezdőbetüs eseménynévírást a helyesírási szabályzatok legfeljebb eltürik, a szótárak semmiképp se propagálják.

DEME-FÁBIÁN 1961:

Nagy Honvédö Háború; - nagy hon-

Nagy Októberi Szocialista Forradalom védö háborúbeli

SzABÓ T. et al. 1978:

Nagy Honvédö Háború; nagy honvédő $\quad$ Nagy Októberi Szocialista Forradalom háborúbeli

MTA 1984 visszavonja ez utóbbiak tulajdonnévi státusát:

nagy honvédö háború

nagy októberi szocialista forradalom 
DEME-FÁBIÁN 1988 óta a szótárakban időről időre fel-feltünnek számítógépes programozási nyelvek nevei:

Algol nyelv (a számitástechnikában)

DEME-FÁBIÁN-TÓTH 1999:

Pascal nyelv (számitógépi programnyelv)

Komplex kézikönyv lévén LACZKÓ-MÁRTONFI 2004 a többinél részletesebben mutatja be a tulajdonnévi kategóriákat és alkategóriákat; ezekről több helyütt tettünk említést. Az e pontban tárgyalt típusok is megjelennek a szótári részben:

$\begin{array}{cc}\text { BASIC [bézik] \{BA.SIC\} 〈Beginner’s } & \text { nagy [...] nagy honvédö háború [...] } \\ \text { All-purpose Symbolic Instruction } & \text { nagy októberi szocialista forrada- } \\ \text { Code 'Kezdök Általános Célú } & \text { lom } \\ \text { Szimbolikus Utasitáskódja'〉 } & \text { Pascal }^{2} \text { (programnyelv) [paszkál] } \\ \text { BASIC-kel, BASIC-es } \| \text { BASIC- } & \text { pascali } \| \text { Pascal-program } \mid \text { Pascal } \\ \text {-program } \mid \text { BASIC nyelv } \| \rightarrow \mid \text { Vi- } & \text { nyelv }\end{array}$

BÁRÁNY 2009 és MTA 2015 nem foglalkozik egyéb tulajdonnevekkel.

То́тн 2017:

Pascal nyelv (programnyelv)

4. Összegzés. A magyar helyesírás történetében eddig 15 (önálló münek tekinthető) szótár jelent meg, az első 1906-ban. Ezeket tekintettük át a tulajdonnevek feldolgozása szempontjából. Általánosságban megállapíthattuk, hogy minden szótár tartalmaz tulajdonneveket, toldalékolási tudnivalókkal. A szótárak mérete egyre nő, így a tulajdonnévi állomány is bővül. Ezzel párhuzamosan a szótári apparátus is folyamatosan érlelödik, fejlődik, az 1950-es szabályzat óta egyértelmüen szervesen.

A bemutatott tulajdonnévi kategóriák is fokozatosan számosodnak: személynevek, földrajzi nevek, csillagászati nevek, intézménynevek és címek mindegyik szótárban elöfordulnak. Kitüntetés- vagy díjnév elöször 1913-ban tünik fel, előbb csak kis kezdőbetüvel, 1950-től tulajdonnévi példákkal is. Márkanevek 1961 óta fordulnak elő a helyesírási szótárakban. Állatnevek 1913-ban jelennek meg először, de - noha 1929 óta a szabályzatokban előfordulnak nagy kezdőbetüs állatnevek - 1950-ig a szótárakban kizárólag kis kezdőbetüvel; nagy kezdőbetüs állatnévi példák szótárban csak 2004 óta bukkannak fel. Tárgynevekre példát először 1999-ből találni, bár a nagy kezdőbetű itt inkább a szakralitás jelölöje, a tárgynévi kategória 2004-től egyértelmü csupán.

A kisbetü-nagybetű átcsapás nem csupán a helyesírási szótárak, hanem az akadémiai helyesírás egész történetén végigvonul. Az 1832-es első szabályzat még az intézményneveket is csak korlátozottan tartotta tulajdonnévnek, például: magyar tudós Társaság. Az eltelt szűk két évszázad során folyamatosan nőtt a nagy kezdőbetűs, azaz a helyesírás által tulajdonnévnek tartott elemek aránya. Ezt is tükrözheti az állatnevekről és díjnevekről tett fenti megfigyelés. Ennek a fajta elmozdulásnak a hátterében álló okok ugyanakkor 
vélhetőleg elsősorban közéletiek (a 19. század elején a minden főnevet nagy kezdőbetüvel írni rendelő német helyesírástól való minél nagyobb elkülönböződés igénye) és szociálpszichológiaiak (a dolgoknak tulajdonított szubjektív fontosság ikonikus megjelenítése), így ezek elemzése szétfeszítené egy nyelvészeti tárgyú írás kereteit.

\section{Felhasznált források}

BALASSA JÓZSEF 1929. Az egységes magyar helyesírás szótára és szabályai. Budapesti Korrektorok és Revizorok Köre, Budapest.

BÁRÁNY MARGIT 2009. Akadémiai helyesirási szótár. Akadémiai Kiadó, Budapest.

BOGNER JÓZSEF 1939. A magyar helyesírás szabályai és szótára. Jugoszláviai Magyar Népkönyvtár. Globus Nyomda, Petrovgrád [= Nagybecskerek].

DEME LÁSZLÓ - FÁBIÁN PÁL 1961. Helyesirási tanácsadó szótár. Terra, Budapest.

DEME LÁSZLó - FÁBIÁN PÁL 1988. Helyesirási kéziszótár. Akadémiai Kiadó, Budapest.

DeME LÁsZló - FÁBIÁN PÁL - Tóth ETELKA 1999. Magyar helyesírási szótár. Akadémiai Kiadó, Budapest.

HORVÁTH ENDRE 1913. A magyar helyesírás szótára és szabályai. Az iskolai helyesírás alapján. Athenaeum, Budapest.

KELEMEN BÉLA 1906. A magyar helyesírás kis szótára. A hivatalos iskolai helyesirás alapján. Athenaeum, Budapest.

LACZKÓ KRISZTINA - MÁRTONFI ATTILA 2004. Helyesírás. Osiris Kiadó, Budapest.

MAgYAR TUDOMÁNYOS AKADÉMIA 1943. A magyar helyesirás szabályai. 8., átdolgozott és bővített kiadás. Akadémiai Kiadó, Budapest.

MAGYAR TUDOMÁNYOS AKADÉMIA 1950. A magyar helyesírás szabályai. 9., átdolgozott és bővített kiadás. Akadémiai Kiadó, Budapest.

MAgYar TudOMÁNYOS AKAdÉMIA 1954. A magyar helyesírás szabályai. 10., átdolgozott és bővített kiadás. Akadémiai Kiadó, Budapest.

MAgYar TUdOMÁNYOS AKAdÉMIA 1984. A magyar helyesírás szabályai. 11. kiadás. Akadémiai Kiadó, Budapest.

MAgYar TudomÁNYOs AKAdÉmia 2015. A magyar helyesírás szabályai. 12. kiadás. Akadémiai Kiadó, Budapest.

Szabó T. Attila - Balogh Dezső - GÁlffy Mózes - Kelemen Béla szerk. 1978. Magyar helyesirási szótár. Kriterion Könyvkiadó, Bukarest.

TóTH ETELKA 2017. Magyar helyesírási szótár. A magyar helyesirrás szabályai tizenkettedik kiadása szerint. Akadémiai Kiadó, Budapest.

\section{Hivatkozott irodalom}

FÁBIÁN PÁL szerk. 1962. A Helyesírási Bizottság újabb határozatai. MTA I. Osztály Közleményei 19: 277-87.

FÁBIÁN PÁL szerk. 1972. A Helyesírási Bizottság 1959-1961. évi határozatai. In: TIMKÓ GYÖRGY szerk., Helyesírási és tipográfiai tanácsadó. 2. kiadás. Nyomdaipari Egyesülés, Budapest. 60-72.

MÁRTONFI ATTILA

ORCID: https://orcid.org/0000-0001-9972-4305

Budapest 


\section{Attila Mártonfi, Proper names in Hungarian spelling dictionaries}

The paper provides a review of every spelling dictionary of the Hungarian standard, excluding terminological, transcriptional, and educational works, however, considering attached regulatory sections and appendices. The general observations are the following: Every spelling dictionary contains proper names. Over time, dictionaries have become more and more detailed; hence the onomastic material within them has also grown. The lexicographical apparatus has become richer over time. While it was slightly chaotic at the beginning of the examined period, then it became overcomplicated and was finally cleaned up made the 1980s. Organic development can be observed from the 1950s. At times, new onomastic categories appeared in the dictionaries. Anthroponyms, toponyms, astronomical names, names of institutions, and titles occur in every dictionary. Names of honors, prizes, or awards appeared for the first time as proper names in 1950. Brand names have been present in dictionaries since 1961. The occurrence of the names of animals is the most hectic: dictionaries between 1913 and 1950 handled them as common nouns. Since 1929 regulations have considered them proper names; the first capitalized examples in dictionaries only appeared in 2004. The names of objects have been listed since 1999, however the first cases were capitalized because of their sacred nature. The category has been used consciously since 2004 . Miscellaneous proper names also appear ad hoc in the dictionaries. 



\section{Tulajdonnevek a többnyelvü szótárakban}



FARKAS TAMÁS - SLÍZ MARIANN szerk., Tulajdonnevek és szótárak. ELTE Magyar Nyelvtudományi és Finnugor Intézet - Magyar Nyelvtudományi Társaság, Budapest, 2020. 95-107. DOI: 10.26546/4892373.6

\section{Tulajdonnevek az olasz-magyar szótárakban}

1. Problémafelvetés és célkitüzés. A tulajdonnév megjelenése a szótárakban - mondhatni - az egyik „klasszikusa” a lexikográfia problémáinak: megkerülhetetlen feladat, de (a sokféle implikáció miatt) valószínüleg nem is lehet egyértelmű és minden lexikográfus, illetve szótárhasználó által kívánatosnak és helyesnek tartott módszert találni hozzá. Ugyanakkor a névtan számára is problémaként jelentkezik ebben a vonatkozásban elsősorban az, hogy alapkategóriájának, azaz magának a tulajdonnévnek a meghatározása nem tud minden felmerülő részkérdésre választ adni (így például bizonyos kategóriákat a tulajdonnevek csoportjába beilleszteni vagy éppenséggel innen kizárni, továbbá az újonnan jelentkező névfajtákat ${ }^{1}$ a rendszerben elhelyezni és terminológiailag is besorolni stb.).

Mivel olasz-magyar vonatkozásban tudomásom szerint még nem született átfogó vizsgálat a „tulajdonnév a szótárban” kérdésköréről, ${ }^{2}$ ebben a tanulmányban kísérletet teszek annak a felvázolására, hogy a kétnyelvü, olasz-magyar irányú szótárakból milyen szótárírói elmélet és gyakorlat bontakozik $\mathrm{ki}^{3}{ }^{3}$ A vizsgálat az összes, száz oldalnál hoszszabb olasz-magyar szótárra kiterjed (így tizennégy általános és hat szakszótár anyaga került a korpuszba). A szótárírók által alkalmazott módszert, gyakorlatot egyrészt az elöszavakból és a szótári apparátusból, másrészt a szótárak $L$ betüs címszavaihoz tartozó szócikkek áttekintéséből kinyert adatok alapján igyekszem feltárni (időnként azonban a szótárak más helyeiről vett példákat, eseteket is megemlítek).

2. Köznév és tulajdonnév, egynyelvü és kétnyelvü szótárban. A köznév és a tulajdonnév elkülönítésére, az utóbbi meghatározására (azaz egy átfogó definíció megalkotására) és alkategóriáinak felsorolására már számos kutató tett kísérletet (álljon most itt hivatkozásként csupán HAJDÚ 2003: 49-59; KÁLMÁN 1973, 1989²: 7-12; J. SOLTÉSZ 1979: 22-43; VÁRNAI 2005: 20-37; VAN LANGENDONCK 20074; SLÍz 2015: 94-99). Úgy

${ }^{1}$ Az olasz tulajdonnevek körében (1993 óta) megjelent például a törvénynév mint névfajta: a törvényjavaslatok és később esetleg meg is szavazott törvények neve latinos, -um végü alakban. Ezekben a leggyakrabban a törvény benyújtójának a nevét alakítják a törvény nevévé. Az első ilyen törvénynév az 1993-ban született Mattarellum: ezt - ironikus célzattal - egy Giovanni Sartori nevű politológus találta ki (a törvényjavaslat benyújtója ugyanis Sergio Mattarella, Olaszország mai köztársasági elnöke volt). További ilyen nevek: Tatarellum, Porcellum, Vassalum, Italicum, Rosatellum stb. Ez a nyelvi fejlemény elsősorban a hírközlés számára jelent kommunikációs könnyebbséget, ezért az újságírók körében igen népszerü, így gyorsan elterjedt. (L. mindehhez: CAFFARELLI 2008, 2018a, 2018b; GoMEZ GANE 2015).

${ }^{2}$ Francia-olasz viszonylatban a helynevekhez 1. FARINA (2006), az utónevekhez pedig FARINA (2008). Speciális megközelítésü, azaz az olasz tulajdonneveket (csak) a magyar helyesírási szótárban vizsgálja VIG (2006) tanulmánya, melynek megállapításai ezért ebben a vizsgálatban nem hasznosíthatók.

${ }^{3}$ Magyar-olasz irányú szótárból sokkal kevesebb van, mint ellenkező irányú párjából, tehát ezek elemzéséből nehezebb lenne általánosító jellegü következtetéseket levonni.

${ }^{4}$ Erről recenzió: CAPRINI 2008, FARKAS 2010. 
tünik azonban, hogy - a nyelv jelölő funkciójának bonyolultsága és a konkrét esetek sokfélesége miatt, továbbá a változó világban a tulajdonnevek számának növekedése és a névfajták szaporodása okán is - talán csak egy általános és leegyszerüsített definíciót lehet megadni: tulajdonnév az, ami egyedet, egy bizonyos referenst jelöl, identifikál, azonosít. Igy aztán tulajdonnév lehet köznévi elemeket is tartalmazó (sőt: csak ilyenekböl álló) szószerkezet ${ }^{5}$ is; köznév és tulajdonnév nem stabilak és állandóak, hanem kölcsönösen átválthatnak egymás kategóriájába, illetve a névfajták is egymáséba; ${ }^{6}$ előfordulhat továbbá, hogy egy névfajtát az egyik nyelvben a tulajdonnevek közé sorolnak, de egy másikban köznévnek számítanak (ilyenek a népnevek); stb.

Megjegyzendő még az is, hogy a régebbi szótárakban olykor a mai általános gyakorlattól eltérő tipográfiai megoldásokat alkalmaztak, és ezek megnehezítik annak megállapítását, hogy az átmeneti kategóriák vonatkozásában mi a szerzó álláspontja. Vizsgált anyagunkban például a BENKÖ-féle szótár (B.) még minden címszót nagy kezdőbetüvel ír, és a szócikket ponttal zárja; a KöRösIben (Kör.) pedig a teljes címszó csupa nagybetüvel van szedve. A tulajdonnevek írásmódjára oly jellemző szókezdő nagybetü tehát e munkákban nem jöhet szóba a tulajdonnevet azonosító eszközként.

A szótár (mint müfaj) meghatározása szintén bonyolult és nem is egészen egyértelmü, illetve eltérő lehet a különböző nyelvek, lexikográfiai iskolák, hagyományok felfogásában, besorolásában. (Ennek a problematikának is igen terjedelmes a szakirodalma.) Közismert, hogy a nyelvek számának tekintetében a szótár lehet egynyelvü, illetve két- vagy többnyelvü. Az egynyelvü értelmező szótár esetében fontos a lexikontól és az enciklopédiától való megkülönböztetés (1. ehhez pl. FÁBIÁN-SzÖLLÖSY [2015] szerkesztett kötetének több tanulmányát: MAGAY 2015: 9-16, FÁBIÁN 2015: 17-38, ITTZÉS 2015: 39-47, UZONYI 2015: 71-84). Az egynyelvü értelmező szótár a felsorolt szavak jelentését ugyanazon a nyelven írja le. Mivel a referenseket, egyedeket jelölö tulajdonneveknek - olyan értelemben, mint a közszavaknak - nincs jelentésük, tulajdonképpen nem kerülhet(né)nek be a szótárakba. A lexikon is egynyelvü, de igen lényeges különbség az, hogy ebben a szó által jelölt referens van leírva. A lexikonban lehet tehát tulajdonneveket felsorolni és referensüket leírni. A határvonalat azonban több okból is nehéz meghúzni, illetve vannak enciklopedizáló nemzeti-nyelvi hagyományok (pl. a franciáké), amelyek a tulajdonneveket illetően befogadó álláspontot képviselnek (l. erről FARINA 2006, 2008).

A tulajdonnevek bizonyos alkategóriáinak azonban mindenképpen helyük van a kétnyelvü szótárakban (1. ehhez pl. SvENSÉN 2009: 73-75). Ennek a szótártípusnak ugyanis nem a szavak jelentésmegadása a feladata, hanem két nyelv ekvivalens elemeit kell felsorolniuk, függetlenül attól, hogy köznévröl vagy tulajdonnévről van-e szó (pl. asztal tavola/table, London - Londra/Londres).

${ }^{5}$ A „Mária a gyermek Jézussal” toposz különböző olasz festménycímeiről szóló tanulmányában ENZO CAFFARELLI a több- és vegyes elemü tulajdonnevekről azt írja, hogy ezek természetüket tekintve nem tulajdonnevek, hanem olyan szintagmák, amelyek tulajdonnévi funkciót töltenek be (CAFFARELLI 2016: 31-32). CAFFARELLI érvelése alapján az antonomáziákat is besorolhatjuk a tulajdonnevek körébe, hiszen a referenst pontosan azonosító funkciójuk nem vonható kétségbe (pl. a haza bölcse = Deák Ferenc) .

${ }^{6}$ Az olasz névtan ezt a jelenséget a transonimia szakszóval jelöli. A Rivista Italiana di Onomastica 2018/1. kötetében a föszerkesztő egy külön rovatban (Osservatorio transonimico) számol be különböző, ilyen jellegü kategóriaváltásokról; pl. márkanévböl személynév: Nutella, Dior, Denim, Fanta stb. (CAFFARELLI 2018a: 462-468). 
A tulajdonnévi alkategóriák közül nem kell bekerülniük a kétnyelvü szótárba azoknak, amelyeket (koronként is változóan) „nem szokás lefordítani, áttenni” két nyelv között, hanem a másik nyelvi közegben is eredeti változatukban szerepelnek (1. ehhez HAJDÚ 2003: 143-145, FARKAS 2007; az olasz-francia szótárak tulajdonnévanyagáról szóló elemzésben pedig FARINA [2006] a helynevekröl és FARINA [2008] a személynevekröl). Ilyenek ma például tipikusan a személynevek, a hajónevek vagy a márkanevek. A régiségben kialakult, immár tradicionálisan kétféle megnevezéseknek azonban be kellene kerülniük a szótárba (pl. ol. Cristoforo Colombo - m. Kolombusz Kristóf, fr. Descartes - ol. Cartesio; uralkodók neve: ol. Riccardo Cuor di Leone - m. Oroszlánszívü Richárd, ol. Enrico l'Uccellatore - m. Madarász Henrik).

Annak, hogy egy kétnyelvű szótárba milyen és mekkora tulajdonnévi kör kerül be, mérlegelés, válogatás tárgyának kell lennie a szótáríró részéről. Számos aspektusra tér ki az orosz-magyar, illetve a német-magyar szótárakat ebből a szempontból elemző tanulmányában UZONYI PÁL (2015). Szinte kötelező felvenni a másik nyelvben eltérő tulajdonneveket (pl. ol. Venezia - m. Velence, ol. Napoli - m. Nápoly, ném. Mainz - ol. Magonza, ném. München - ol. Monaco di Baviera, ném. Aachen - ol. Aquisgrana stb.), még akkor is, ha esetleg csak a hangsúlyban különböznek (Milano - Mílánó) ${ }^{7}$. A személynevek körében az utónevek, a földrajzi nevek körében az ország-, város-, víz- és hegynevek mellett esetleg további névfajták is bekerülhetnek a kétnyelvü szótárba. (És természetesen attól függetlenül, hogy tulajdonneveknek tartjuk-e öket, a népneveknek is be kell kerülniük a kétnyelvü szóanyagba. ${ }^{8}$ ) Fontos (lenne!) az intézménynevek felvétele is: ezek a legtöbbször szintagmaszerkezetüek, gyakran csak köznévi elemekből állnak, és esetükben a két nyelv közötti ekvivalencia sem referenciálisan, sem nyelvileg nem elörelátható, nem kitalálható. ${ }^{9}$ Külön kérdéskör a köznevesült tulajdonnevek (eponimák, pl. fregoli), illetve a tulajdonnevekből képzett (gyakran rendhagyó) melléknévi származékalakok (pl. a városlakók melléknévi megnevezése: Siena senese, Tokio edochiano) megjelenítése a szótárban (mindehhez l. UZONYI 2015).

FARINA az olasz-francia szótárak vizsgálata kapcsán említ a kétnyelvü szótárakba mindenképpen felveendő eseteket. Ilyen például az ol. Ginevra, amely női személynév és helynév ('Genf') is, vagy az ol. Andrea, amely az olaszban elsősorban férfit jelöl ('András'), tehát (az - $a$ végződés ellenére) nyelvtanilag hímnemü ${ }^{10}$ (FARINA 2008: 499, 500).

3. Tulajdonnevek az olasz-magyar szótárakban. ${ }^{11}$ Az alábbiakban bemutatjuk, hogy az átvizsgált $L$ betüs szótári szakaszokból milyen konkrét, illetve általánosabb következtetéseket lehet levonni a tulajdonneveket illetően.

${ }^{7} \mathrm{Az}$ aláhúzások a hangsúly helyét jelölik.

${ }^{8}$ Mint közismert, a népnevek tulajdonnévi státusa vitatott: a különböző (nyelvű) filológiákban más lehet a besorolásuk (az olaszban például korábban tulajdonnév és nagy kezdőbetủvel írandó volt, ma viszont a köznévi státus felé mozdul el, és általánossá vált a kis kezdőbetűs írásmódjuk). A besorolás koronként is változhat (ahogy az a magyar nyelvtudományban történt).

${ }^{9} \mathrm{Pl}$. Accademia della Crusca (a híres firenzei Crusca-Akadémia neve) nem lehet csak di vagy cruschese stb.

${ }^{10}$ Olaszországban csak pár éve adható hivatalosan nőknek is (a belső keletkezésü ol. női változat: Andreina).

${ }^{11}$ A tanulmányban a szótárakra a szerzői nevek kezdőbetűivel és - szükség esetén - a kiadások sorszámával történik hivatkozás (feloldásukat l. a bibliográfiában az egyes tételek végén). 
3.1. A szótáríró hozzáállása a „tulajdonnevek a szótárban” kérdésköréhez. A szótáríró viszonyulása a kérdéskörhöz elsősorban és expliciten akkor ragadható meg, ha müve előszavában (vagy egy használati útmutatóban) megvilágítja koncepcióját. Ebből a szempontból vizsgált olasz-magyar szótáraink közül csak egyben (HI.) nincs egyáltalán előszó és/vagy bevezetés. Vizsgálatunkból az tünik ki továbbá, hogy ezekben a szerkesztési koncepciót is ismertető bevezető fejezetekben (melyek terjedelme az általános olasz-magyar nagyszótárak esetében a tíz oldalt is elérheti) nem esik szó a tulajdonnevekről (így természetesen ezek esetleges fajtáiról ${ }^{12}$ sem). Mindössze egyik szakszótárunkban (J.) van a tulajdonnevek felvételét említő áttételes utalás. ${ }^{13}$

A tulajdonnevekkel kapcsolatos koncepció leírásának hiányát bizonyos tekintetben pótolja azonban az, ha a szerző a szólistában a tulajdonnévi címszavakat megfelelő rövidítésekkel látja el. Ennek a módszernek az alkalmazásáról a szótár rövidítésjegyzékéből bizonyosodhatunk meg. Lehet a rövidítés az expliciten tulajdonnévre utaló, összefoglaló jellegü $t n$, $t u l$, de a - már a névfajtákat megkülönböztető - $f n$, földr 'földrajzi név' vagy hn 'helynév', szn 'személynév' stb. is. A vizsgált szótárak közül időrendben elsőként KÖRÖSIé (Kör.) alkalmazta ezt a módszert, nála a következő, ide vonható kategóriák és rövidítések szerepelnek: N. pr. - Nome proprio - Tulajdonnév, és ennek több alcsoportja: N. pr. bibl. - bibliai, N. pr. mitologico - mitológiai, N. pr. storico-történelmi tulajdonnév, továbbá N. pr. etnografico - etnográfiai tulajdonnév ${ }^{14}$ is. A földrajzi nevek rövidítése azonban nem ennek a (N.pr. szakasszal bevezetett) sorozatnak a mintáját követi: azokat KÖRÖSI a Geogr. = Geografia - Földrajz rövidítéssel látta el (1. pl. a Londra vagy a Lorena címszónál). A későbbi szótárírók közül HERCZEG alkalmazza újra ezt a módszert (a H1.-ben: $t n$ = tulajdonnév - sostantivo proprio; a H2.-ben: tn és földr; a HJ1.-ben: a helyneveknél tul földr, a személyneveknél csak $t u l$.). Elöfordul azonban az is, hogy

${ }^{12}$ Itt jegyzem meg, hogy a már említett antonomáziák (ol. appellativi) jelenléte a kétnyelvü szótárakban feltétlenül szükséges lenne. Nemcsak azért, mert kollokációs-idiomatikus jellegük okán két nyelv között ezek nem kitalálhatók, hanem azért is, mert gyakran csak a szótárban amúgy is helyet kapó köznévi elemeket tartalmaznak (pl. l'Eroe dei due mondi - Garibaldi: csak a HJ1.ben szerepel), vagy vegyes típusúak (pl. il poverello di Assisi - Assisi Szt. Ferenc, ez szerepel is a Kőr., H2., HJ1. szótárakban, de hiányzik még az 1952-es H1.-ből). - Kollokációs jelleg alatt például a lehetséges szinonimák közötti rögzülést értem (pl. Nagy Károly olaszul csak Carlo Magno lehet, itt a grande 'nagy' szinonima nem választható; ugyanígy: Kis Pipin - Pipino il Breve, bár breve jelentése ma 'rövid'; babiloni fogság - cattività babilonese, és nem használható az amúgy szinonima prigionia szó; stb.).

${ }^{13}$ „Az idegen eredetű közszavak és tulajdonnevek írásában »A magyar helyesírás szabályai« [...] figyelembevételével jártunk el.” (JuHÁsz 1997. Előszó).

${ }^{14}$ Szó szerinti jelentése: 'etnográfiai/néprajzi tulajdonnév'; ha 'népnév' lenne a jelentés, akkor „helyesen”, azaz a mai nyelvészeti terminológia szerint nome (proprio) etnico lehetne, és olyan esetek tartoznának ide, mint az italiano 'olasz' vagy svedese 'svéd' stb. Ezek az olaszban régebben tulajdonnévi státusúak is lehettek, tehát gyakori volt a nagybetüs írás: ma már kihalóban van ez a szokás. - Lehetséges, hogy Körösi az általa forrásként használt, elöször 1896-ban kiadott Rigutini-Bulle-féle olasz-német szótárból vette át a N. pr. etnografico rövidítést (ezzel vannak minősítve ott a hol kicsi, hol nagy kezdőbetủvel felvett népnevek; pl. eschimese, etrusco, Gallo, levita, Londinese, Svevo, Turcomanno), amelyet azután Körösi talán nem is használt fel saját munkájában (mi legalábbis nem találtunk rá példát), a népneveket ugyanis rendszerint csak az agg. 'melléknév' és sost. 'fönév' szófaji minősítésekkel látja el. 
a tágabb, elsősorban a köznévi lexikára vonatkozó, ún. használati köri rövidítések is bevezetnek tulajdonneveket is (pl. mit - mitológia, müv - müvészetek, tört - történelmi, földr - földrajz, vall - vallási ${ }^{15}$ stb.). Ilyen módszert alkalmaz például a H1., hiszen például csill - csillagászat rövidítéssel bevezetve feltünik az Andromeda - Andromeda csillagkép ekvivalens, mit - mitológiai rövidítéssel az Eros - szerelem istene. Fel lehet természetesen venni tulajdonneveket minden minősítő bevezetés nélkül is a szótárba; ez igen gyakori például a H1.-ben (Erode - Heródes, Etiopia - Abesszínia stb.). További lehetőség a szótáríró számára az az eljárás, ha a szótár a törzsanyagába nem vesz ugyan be, de a szótárban (függelékként, listákban) mégis közread tulajdonneveket. ${ }^{16} \mathrm{Ez}$ a módszer különösen azon szótárírók által lehet kedvelt „öszvérmegoldás”, akik szem előtt tartják a már vázolt elvi kritériumot, azaz hogy a szótárba ne kerüljenek be ,,jelentés nélküli” tulajdonnevek. Ennek az eljárásnak az alkalmazására (névetimológiák megadása céljából) legtöbbször egynyelvü szótárakban és az utónevek esetében kerül sor. A tulajdonnevek jelenléte (a legtöbbször jelentősen különböző ekvivalensek okán) a kétnyelvü szótárakban azonban talán még indokoltabb. Vizsgált kétnyelvü szótáraink közül azonban egyik sem alkalmaz ilyen függelékes módszert.

A nyelvtudás szempontjából fontos (mert gyakran nem szabályos), földrajzi nevekből (városnevekből, országnevekből) képzett mellékneveket (pl. Firenze - fiorentino) mindegyik szótár felvesz, mégpedig a legtöbbjüket a címszólistába illesztve. Csak az N.ben vannak ilyen a szavak, a kétirányú kötet közepére bekötve, külön kilistázva (Olasz tartományok és lakóik, illetve Fontosabb olasz városok és lakóik).

3.2. A szóanyagok vizsgálata. Az $L$ kezdőbetüs szakaszok ${ }^{17}$ vizsgálata alapján az első leszögezendő tény az, hogy - a várakozásnak megfelelően - a nagy terjedelmủ és általános kétnyelvü szótárak (Kőr., H2., HJ1.) tartalmazzák a legtöbb tulajdonnévi címszót. A nagyszótári kategórián belül feltünő, hogy a H1. nagyszótárban még alig van tulajdonnév a H2.-höz képest, tehát HERCZEG Gyula föszerkesztő nagyobb számú tulajdonnévnek a szótárba való beemeléséről csak később, a szótár második, javított kiadásakor döntött, valószínüleg a kritikák hatására is. (HERCZEG forrásként használt szótárait említve a recenzens KOLTAY-KASTNER JENÖ ugyanis például megjegyezte, hogy [a forrás] „Palazzi nem veszi fel a keresztneveket és város- meg tartományneveket s pótlásuk a HERCZEGszótárban nem történt meg a szükséges következetességgel"; KOLTAY-KASTNER 1954: 531). Arra is érdemes továbbá felfigyelni, hogy a HJ1. az 1967-es, illetve függelékkel 1978-as, kétkötetes H2.-nek az egykötetes, 2000-ben kiadott változata: az oldalszám alapján kiszámított kb. 40\%-os terjedelmi csökkenést ${ }^{18}$ azonban nem kísérte a tulajdonnevek hasonló arányú redukálása, azok száma a kisebb volumenü kötetben majdnem

${ }^{15}$ Például a Cicerone - Cicero ekvivalencia minősíthető lenne a tört, vagy a Gesù - Jézus a vall. rövidítéssel stb.

${ }^{16}$ Ilyen müre olasz egynyelvü példa lehet a (kis) Garzanti- vagy a Zingarelli-szótár. A helynevek kétnyelvü (francia-olasz) szótári jelenlétét elemző tanulmányában FARINA (2006: 186-191) is két külön szótárírói gyakorlatként említi a tulajdonnevek függelékben vagy törzsanyagban való elhelyezését, és tanulmányában határozottan az utóbbi mellett foglal állást.

${ }^{17}$ Megjegyezzük és hangsúlyozzuk, hogy egyetlen betü áttekintéséből természetesen csak részkövetkeztetéseket lehet levonni.

${ }^{18}$ A H2. (két kötet, függelékkel) összesen 1781 oldal, a HJ1. pedig 1065 oldal. (Az oldalak tipográfiailag - a tükör nagysága, betűtípus és -méret, két oszlop stb. - nagyon hasonlóak.) 
változatlan maradt. ${ }^{19}$ Ez talán utalhat arra, hogy a kétnyelvü kommunikációban (és így a nyelvtanulásban) az idők során felértékelődtek a tulajdonnevek, és - felismerve ezt - a szótárírók igyekeznek ezt az igényt is kielégíteni.

Nehéz lenne megmondani, hogy mi (lenne) a személynevek és a helynevek kívánatos mennyisége, illetve aránya a kétnyelvü szótárban. Itt most csak a tényeket tudjuk leszürni olasz-magyar szótáraink vizsgálatából. Címszóként összesen 34 különbözö személynevet, ${ }^{20}$ illetve $51^{21}$ különböző helynevet ${ }^{22}$ tudtunk megszámolni az $L$ betü alatt. A számszerü személynévi sorrend nagyszótárainkban így alakul: a Kör.-ben $20 \mathrm{db}$, a H2.-ben $24 \mathrm{db}$, a HJ1.-ben $19 \mathrm{db}$; a földrajzi névi pedig így: a Kör.-ben $23 \mathrm{db}$, a H2.-ben 42 db, a HJ1.-ben 39 db. Tehát míg az 1912-es kiadású Kőr.-ben a személy- és helynevek aránya kb. azonos (20 és 21), addig a H2.-ben (1967) és a HJ1.-ben (2000) a földrajzi nevek száma kb. a kétszerese a személynevekének.

Tanulságos gyakorisági szempontból is áttekinteni a szótárakba felvett tulajdonneveket. (A csak egy-két szótárban elöfordulókról még külön szólunk.)

A személynevek gyakorisági sorrendje a következö:

8 szótárban szerepel: Lucifero - Lucifer (B., Kör., U., KSzV., Kir., H1., H2., HJ1.);

7 szótárban szerepel: Luigi - Lajos (Kör., KSzV., Kir., H1., H2., HJ1.) és Alajos (U., $\mathrm{KSzV}$., H2., HJ1.); 23

6 szótárban szerepel: Lazzaro - Lázár (Kör., U., KSzV., Kir., H2., HJ1.);

5 szótárban szerepel: Leopoldo - Lipót (Kör., KSzV., Kir., H2., HJ1.), Lorenzo - Lörinc (Kör., KSzV., Kir., H2., HJ1.);

${ }^{19}$ A HJ1.-ből a következő, a H2-ben még szereplő személynevek hiányoznak: Lattanzio, Lemure, Lenin, Longino, Licurgo. Kihagyásuk tehát magyarázható a latin, illetve az orosz kultúra oktatásának háttérbe szorulásával a HJ1. kiadásakor, a „rendszerváltozás” utáni időkben. A helynevek körében a HJ1.-ből kimaradt a Laterano, Leida 'Leyden', Livorno, Loreto, Lucca, de újként fel van véve a Liechtenstein és a Limburgo.

${ }^{20}$ Ezek közül vitatható a lemure 'halottak kísérő szelleme, hazajáró lélek (a rómaiaknál)' tulajdonnévi státusa: vizsgált anyagunkban ezt csak a H2. veszi fel tulajdonnévként. A Kör.-ben is szerepel ugyan, de (valószínűleg?) köznévként (LÈ·MURI m. pl. hazajáró lelkek; rémek, lidércek). Régebbi és mai olasz egynyelvü szótárainkban a szó köznévként (kisbetűvel) címszó.

${ }^{21}$ Nem számoltuk most ide a lago 'tó' köznév szócikkében felsorolt tulajdonnévi példákat, de ezekről később még esik szó.

${ }^{22}$ A vegyes státusú luna - hold ekvivalencia tulajdonnévi, illetve köznévi státusa így alakul a (B. és Kör. nélkül) vizsgált szótárakban: minden szótár kisbetűvel, azaz köznévként veszi fel a luna címszót, ez alól csak csak az SzTGy. idegenforgalmi szótára („Termini geografici” lista) kivétel, ahol nagybetüs tulajdonnévként áll. Ami az ekvivalenseket illeti: Hold (H2., L.); Hold, hold (HJ1., HI.). A HJ2. a legrészletezőbb: luna 1. csill. Luna - Hold; 2. hold, piena telihold; 3. di miele mézeshetek.

${ }^{23}$ A Luigi név két magyar megfelelővel áll négy szótárunkban. Az ekvivalens Lajos és Alajos változatok gyakoriságának változása a 19. század elejétől napjainkig a névsorrend megváltoztatásán keresztül jól tükröződik az olasz-magyar szótárakban (KSzV. és Kir.: Alajos, Lajos; H2. és HJ1.: Lajos, Alajos). A párhuzamos, de ritkább és régiesebb olasz Lodovico csak négy korábbi szótárunkban bukkan fel címszóként (Kör., U., KSzV., Kir.), az ekvivalens azonban némileg meglepő módon mindegyikben Lajos (és sehol sem áll ekvivalensként Alajos). Az ol. Ludovico névváltozat csak a H2. és HJ1.-ben van jelen, Lajos ekvivalenssel. 
4 szótárban szerepel: Leone - Leó (KSzV., Kir., H2., HJ1.), Lucia - Lucia (Kör., H2., HJ1.) és Luca (Kir.), Luisa - Lujza (KSzV., Kir., H2., HJ1.), Lutero - Luther (Kör., Kir., H2., HJ1.), Lodovico - Lajos (Kör, U., KSzV., Kir.);

3 szótárban szerepel: Laoconte - Laocoonte (Kör.) és Laokoon (H2.) és Laokoón (HJ1.), Lena - Léni/Magda/Magduska (Kör.) és Lenke (H2., HJ1.), Livio-Liviusz (Kör.) és Livius (H2., HJ1.), Luigia - Lujza (Kör., KSzV., Kir.), Luca - Lukács (Kör., U., Kir.).

Itt említjük meg, hogy éppen olasz-magyar vonatkozásban fontos lehetne egy sajátos személynévtípusnak, a leggyakoribb, legismertebb becézett személyneveknek a kétnyelvü szótárba való felvétele. Az olasz személynévrendszert ugyanis a becézökicsinyítő alakok burjánzása „szervező erőként” hatja át, amennyiben igen gyakori ezek önállósulása (pl. Gianni, Checcho, Pina), akár családnévként is (pl. Giovanni - Vanni, Domenico - Ménico, Rinaldo - Naldi stb.). Olasz becézők/kicsinyítök és magyar ekvivalenseik megadására vizsgált anyagunkban néhány (csak nőket jelölő) példát találtunk: Lena - Léni/Magda/Magduska (Kör.) és Lenke (H2., HJ1.); Lisa - Liza/Liszka (Kör.); Lisetta - Liza (H2.) és Liza/Lizácska (HJ1.).

A helynevek gyakorisági sorrendje a következő:

8 szótárban szerepel: Lituania - Litvánia (KSzV., Kir., H2., HJ1., HJ2., HI., L., N.), Londra - London (Kör., U., Kir., H2., HJ1., HJ2., HI., L.);

7 szótárban szerepel: Lettonia - Lettország (Kir., H2., HJ1., HJ2., HI., L., N.), Lussemburgo - Luxemburg (KSzV., Kir., H2., HJ1., HJ2., HI., L.);

6 szótárban szerepel: Lapponia - Lappföld (Kör., KSzV., Kir., H1., H2., HJ.) és Lappország (Kör.), Lipsia - Lipcse (Kör., KSzV., Kir., H2., HJ1., HJ2.), Lombardia - Lombardia (KSzV., Kir., H2., HJ1., HI., L.), Lorena - Lotharingia (Kör., U, Kir., H2., HJ1.) és Lotaringia (KSzV.);

5 szótárban szerepel: Lete - Lethe (Kör.) és Léte (KSzV.) és Léthé (H1., H2., HJ1.), Libano - Libanon (Kör., Kir., H2., HJ1., HJ2.), Libia - Libia (Kir., H2., HJ1., HJ2., L), Lubecca - Lübeck (Kör., KSzV., Kir., H2., HJ1.), Lubiana - Laibach (Kör., KSzV., Kir., H2., HJ1.) és Ljubjana (H2., HJ1.), Lucerna - Luzern (Kör., KSzV., Kir., H2., HJ1.);

4 szótárban szerepel: Lazio - Latium (Kör., Kir., H2.) és Lazio (H2., HJ1.), Liguria Liguria (Kör., H2., HJ1., L.), Lisbona - Lisszabon (Kir., H2., HJ1., HJ2.), Lungarno - az Arno partján levö utca (Kör.) és Arno-part (H1., H2., HJ1.);

3 szótárban szerepel: Lacedemonia - Lacedaemonia, Spárta (Kör.), Lacedonia - Lakedaimon, Spárta (H2., HJ1.), Laterano - Laterán (H1., H2. $\left.{ }^{24}\right)$, Leningrado - Leningrád (Kir., H2., HJ1.), Liegi - Lüttich (Kir., H2.) és Liège (H2., HJ1.), LioneLyon (Kör., H2., HJ1.), Lipari - Lipari-szigetek (Kir.) és a Lipari-szigetek (H2., HJ1.), Losanna - Lausanne (Kir., H2., HJ1.), Lungotevere - a Tiberis-part (H1., H2., HJ1.).

Ebben a csoportban is megfigyelhetö, hogy archaikusabb név(változatok), illetve a latinos müveltséghez tartozó szavak csak a régebbi, illetve a legnagyobb terjedelmú

${ }^{24}$ Furcsa ennek a fontos szónak a későbbi kimaradása a HJ1.-ből, annál is inkább, mert a melléknévi lateranense - lateráni is eltűnt. 
szótárakban vannak jelen: Lamagna - Németország (Kőr., KSz., V.), Lazio - Latium (Kör., H2.). ${ }^{25}$ Szokatlan (vagy csak sajtóhiba?) a H1. megoldása a Lete szónál: nincs magyar nyelvi ekvivalens, hanem az enciklopédiába illö feledés folyója az alvilágban megjegyzés szerepel. HERCZEG későbbi szótáraiba azután bekerül a Léthé ekvivalens, de a kiegészítő magyarázat is megmarad; megjegyzendő, hogy már a Kör.-ben is hasonló volt a megoldás: Lete - Lethe (alvilági folyó). A csak a H2. függelékében felbukkanó Lario - a Comói-tó (a latinoknál) ekvivalenshez 1. még alább a lariano melléknévvel kapcsolatos megjegyzéseket. A Lubiana városnév (HJ1.) magyar ekvivalenseként ma már kissé anakronisztikusan hat a régies Laibach megfeleltetés.

Külön szólunk a lung(o)- kezdetü, a folyópartokat jelölö összetételekröl. Négy ilyen szó (amely két olasz és két magyar folyó parti útjait jelöli) szerepel vizsgált szótárainkban: Lungarno - az Arno partján levö utca (Kör.) és Arno-part (H1., H2., HJ1.), Lungotevere - a Tiberis-part (H1., H2., HJ1.), Lungodanubio - Duna-part (H2., HJ1.), Lungotibisco - a Tisza-part (H2., HJ1.). Mint látjuk, KöRÖSI magyarázó, enciklopédikus jellegü ekvivalenciát ad meg (ez a módszer egyébként általában is jellemzi szótárát, 1. ehhez FÁBIÁN 2011: 386-387), míg HERCZEG szükszavúbb, továbbá Róma folyójának a latinos (és nem az olasz Tevere) nevét használja. A magyar ekvivalenseknél a névelöhasználat különbségére nem találunk magyarázatot.

Nem szóltunk eddig arról, hogy az olasz és a magyar nyelv strukturális különbségei miatt (miszerint az olaszban a jelző és a gyakran prepozícióval kapcsolt bővítmény követi a jelzett szót, a magyarban viszont fordított a sorrend) olasz kezdésủ vizsgálatnál tulajdonképpen egy-egy földrajzi köznévi címszó (pl. monte - hegy) alá is be lehet sorolni földrajzi neveket. Tipikusan ilyen eset ebben az $L$ betüs vizsgálatban a lago 'tó' köznév szócikke, melynél öt szótárban valóban fel is bukkannak szintagmaszerkezetü tulajdonnevek: a Kör.-ben il Lago Maggiore - a Lago Maggiore, a H2.-ben kilenc példa sorakozik (köztük négy nem olasz vonatkozású), a HJ1.-ben viszont már csak három (il Lemano v. di Ginevra - a Genfi-tó, il $\sim$ di Costanza - a Bodeni-tó, il $\sim$ di Garda - a Garda-tó). A kisebb szótárak közül az FV.-ben il $\sim$ di Como - a Comói-tó, a HI.-ben pedig di Garda - Garda-tó fordul elö.

Az $L$ betüs címszavak sorában felbukkanhat még önálló címszóként a lariano, illetve a lemano melléknév is, márpedig ezek szintén lehetnek összetett tónevek részei. A Lariano a Comói-tóval kapcsolatos, és csak a H2. függelékében (lariano - a Comóitóra vonatkozó), illetve a HJ1.-ben szerepel címszóként: lariano - Como-tavi, Comói tónál v. tó környékén levő v. élö; a lemano pedig a Genfi-tóhoz kapcsolódik, és címszó a Kör. (-Léman-tó, a genfi-tó), a KSzV. és a Kir. (- Genfi-tó) szótárában. (Itt jegyzendő meg, hogy a H2.-ben mind a Como, mind a lago szócikkében szerepel a lago di Como szintagma, ez a ,hiba” azonban ki van javítva a HJ1.-ben, ahol a szókapcsolat a lago szócikkéből eltűnt, és csak a Como alatt szerepel.)

Több tulajdonnév tartozik a mindössze egy szótárban előfordulók körébe; ezek felvételét csak megpróbálhatjuk magyarázni. A személynevek körében: néhány bibliai vagy antik név csak a Kör.-ben (Lotte - Lót, Lucio - Luciusz), míg mások (Lattanzio -

${ }^{25}$ Igen körültekintő a függelékben szereplő Lazio címszónál a H2.: két fö jelentést vesz fel, és a földr-val jelölt elsőn belül további kettő a rég. Latium, illetve a mai Lazio tartomány ekvivalensü. Második azután a sp minősítésű La Lazio - a Lazio labdarúgó-csapat ekvivalencia: ezt a „,rendhagyó nyelvtani nem" miatt (ti. -o végü szó, de egy bizonyos szabály miatt mégis nőnemü) igencsak célszerü felvenni a kétnyelvű szótárba. 
Lacatantius, Licurgo - Likurgosz, Longino - Longinus) csak a H2. szótárában bukkannak fel. A ma már archaikus Lisabella - Izabella, Lamberto - Lambert utónevek, illetve a Lisa - Liza, Liszka becézö csak KöRÖSInél (Kör.) szerepel. Minden bizonnyal ideológiai okokból szerepel egyetlen szótárban (H2.) a Lenin - Lenin ekvivalencia. ${ }^{26}$ A helynevek körében: a Laurana - Lovrana helynévi ekvivalencia csak KöRÖSI szótárában fordul elö, nyilván a szerző fiumei tartózkodásának lenyomata. Ugyanakkor a csak a H2.-ben szereplö Lucca - Lucca, ${ }^{27}$ Livorno - Livorno, Loreto - Loreto ekvivalenciák (azonosságuk okán) feleslegesnek tünnek (nyilván ezért is maradtak ki később HJ1.-ből). Nem világos, hogy mi motiválta a Limburgo - Limburg szópár HJ1.-be való bekerülését. Hiányolhatjuk esetleg mai szótárainkból a csak a Kör.-ben felbukkanó Lesbo-Leszbosz megfelelést.

Térjünk át most a kis terjedelmű szótárakra: ezek közül a B., a HR. és az FV. semmilyen tulajdonnevet sem tartalmaz címszóként, és további négy szótárban (HJ2., HI., N., L.) sincs címszói személynév, csak helynév (ezek körében a közösek: Londra, Lussemburgo, Lettonia). Bár nem releváns mértékben, de a kis szótáraknál is megfigyelhető tehát a helynevek gyakoribb jelenléte a személynevek rovására. Ezt talán a szótárak jellege magyarázhatja: az útiszótárakban valószínüleg a helyneveknek juthat nagyobb szerep.

Lássuk végül a szakszótárakat. A vizsgálatból az rajzolódik ki, hogy ezek tulajdonnévanyagában az az összetett névtípus a domináns, amelynek az első (tehát a vizsgálatban: $L$ betűvel kezdődő) eleme köznév, és csak a rendszerint di prepozícióval kapcsolt második elemük tulajdonnév (mégpedig rendszerint családnév): leggi di Gossen - gosseni törvények ${ }^{28}$ (J.); lampada Davy - Davy-lámpa; legge di Avogadro - Avogadro-törvény; legge di Boyle-Mariotte - Boyle-Mariotte törvény; legge di Bragg - Bragg-törvény; legge di Raoult - Raoult-törvény; lumaca di Pascal - Pascal-csiga, Pascal-féle csiga (F): ${ }^{29}$ linea del Piave - (átv.) végsö határ (SzV). Szerepel még (az SzTGy.-ben) a Linate - Miláno egyik repülőtere, Linate ekvivalencia is. Úgy tünik, ennél a szótártípusnál is elsősorban a szótár terjedelmével arányos a felvett tulajdonnevek és tulajdonnév jellegü szintagmák mennyisége.

${ }^{26}$ Italianista körökben közismert, hogy Herczeg Gyulát 1952-es szótára (H1.) megjelenése után ideológiai jellegü támadások érték, karrierje törést is szenvedett (1. ehhez pl. FRIED 2009a, 2009b). Ennek kompenzálására irányuló megnyilvánulás lehet az ilyen jellegű szóanyagnak a szótár második kiadásába való beemelése. Még inkább felmerül ez a gondolat, ha azt is figyelembe vesszük, hogy az olasz(os) változat tulajdonképpen Lenino, azonban Herczegnél a semmilyen ekvivalenciális nehézséget nem jelentő Lenin - Lenin szópár áll, ráadásul még az ordine di Lenin - Lenin-rend, illetve a seguace di Lenin - Lenin hive, követöje ekvivalenciák is szerepelnek a szócikkben. A H1.-ből és a H2.-ből egyaránt hiányzik ugyanakkor a Stalino Sztálin ekvivalencia (viszont a H1.-ben és a H2.-ben is szerepelnek e személynevekből képzett fönevek, melléknevek és igék).

${ }^{27}$ A Kör.-ben a ma mindenképpen furcsa Lucca - Lukka ekvivalencia szerepel.

${ }^{28}$ A szótárban ez a magyar ekvivalens áll, de használatosak a Gossen törvénye(i) változatok is (Google-keresés).

${ }^{29}$ Az F. magyar-olasz párjában a következő (szintén vegyes típusú) tulajdonnevek állnak az $L$ betü alatt: Leonard-átalakitó, Leonard-transzformátor, Lewis-bázis, Lewis-sav, Linz-Donauwritz eljárás, Lorentz-erö. 
4. Összefoglaló megjegyzések. A tulajdonneveknek az olasz-magyar szótárakban való megjelenése a vizsgált részek tükrében meglehetősen esetlegesnek tünik, bár - kronologikusan, illetve típusok szerint is szemlélve - kirajzolódnak bizonyos tendenciák és törekvések.

Az idők változásával függ össze az a bizonyos nevek kapcsán már említett tény, hogy a felvett személynevek a régebbi szótárakban az akkor szokásos (archaikusabb) változatukban állnak, az újabbakban pedig a mai variánsban. Ugyanígy jól látható, hogy a régebbi szótárak a latin oktatásának tudatában vettek fel nagyobb számban a klasszikus kultúrához (vagy a katolikus valláshoz) tartozó neveket. Ezekre ma már csak magasabb müveltségi szinten (illetve bizonyos diszciplínákon belül) van szükség, és legfeljebb a nagyszótárakba férnek be.

Idő- és típusfüggetlennek látszik viszont az (európai) országokat jelölő földrajzi nevek és a belölük képzett melléknevek felvétele; ezek legtöbbje mindegyik szótárunkban megtalálható.

Kívánatos lenne, ha az elemzés tükrében kirajzolódó véletlenszerüséget felváltaná bizonyos kisebb névtípusoknak a szótárba való szisztematikus beemelése. Mint láttuk, ilyennek tekinthető az európai országok névpárjainak (immár általánosnak tekinthető) felvétele. Hasonlóan lehetne eljárni például az utónevek körében ${ }^{30}$ a szótár kiadása idején leggyakoribb, bizonyos számra korlátozott (pl. első 100 leggyakoribb) utónév felvételével is. ${ }^{31}$ Nagyobb figyelmet kellene arra is fordítani, hogy az adott szótártípusokhoz is más és más fajtájú tulajdonnevek illenek (pl. egy iskolai szótárba több történeti személy- és helynév, müalkotások és intézmények, esetleg múzeumok neve; egy útiszótárba helynevek, látványosságok, intézmények neve stb.). Külön is hangsúlyozandó az a negatív tény, hogy intézménynevek igen kis számban szerepelnek a szótárakban. Lévén szó kétnyelvü szótárakról, szisztematikusabban kellene figyelembe venni a kontrasztív szempontokat mind a fonetika, mind a nyelvtan és a szintaxis területén is. A szakszótárakban viszonylag kevés tulajdonnevet találtunk, és ezek között a legnagyobb számban a szintagmaszerkezetü, vegyes típusú tulajdonnevek ${ }^{32}$ fordulnak elő.

\section{Felhasznált források}

B. = BENKÖ KÁROLY - DONÁTH IMRE - KAVULYÁK GYÖRGY - SZÍGYÁRTÓ ZOLTÁN, Olaszmagyar szótár (Dizionario italiano-ungherese). Mohovich, Fiume, 1887.

F. = FóRIS ÁGOTA, Olasz-magyar müszaki-tudományos szótár. Vocabolario tecnico-scientifico italiano-ungherese. Dialóg Campus Kiadó, Budapest-Pécs, 2005.

FV. = FÁBIÁN ZSUZSANNA - VÁSÁRHELYI JÚLIA, Olasz-magyar, magyar-olasz útiszótár. Akadémiai Kiadó, Budapest, 2006.

${ }^{30}$ Így el lehetne kerülni a vizsgálatból kitűnő olyan feltünő hiányokat, mint hogy a gyakori és kultúrtörténeti szempontból is fontos Leonardo utónév csak két szótárunkban szerepel (Kör.: Lénárd, Kir.: Lénárt ekvivalenssel).

${ }^{31}$ Ma már nem kell ebben a vonatkozásban a megérzésre hagyatkozni, hiszen évekre lebontott utónév-gyakorisági listák segíthetik a szótárírót. Az adott referenciaszámnak az előszóban való közlése is fontos, nem lexikográfiai jellegű információ lehetne a szótárhasználó számára.

${ }^{32}$ Ez közismerten azért van, mert termékek, eljárások, felfedezések elnevezésében gyakran fordul elő a ki- és feltalálók személyneve. 
H1. = HeRCZEG GYULA, Olasz-magyar szótár. Vocabolario italiano-ungherese 1-2. Akadémiai Kiadó, Budapest, 1952.

H2. = HeRCZEG GYULA, Olasz-magyar szótár. Vocabolario italiano-ungherese 1-2. 2., bővített kiadás. Akadémiai Kiadó, Budapest, 1967.

HI. = HESSKY ESZTER - IKER BERTALAN, Olasz-magyar, magyar-olasz kisszótár. Grimm Kiadó, Szeged, 2011.

HJ1. = HERCZEG GyULA - JUHÁSZ ZSUZSANNA, Olasz-magyar szótár. Vocabolario italianoungherese. Akadémiai Kiadó, Budapest, 2000.

HJ2. = HERCZEG GYULA - JUHÁSZ ZSUZSANNA, Olasz-magyar kisszótár. Dizionario italianoungherese. Akadémiai Kiadó, Budapest, 2003.

HR. = HoNTI REzSÖ, Magyar-olasz, olasz-magyar szótár. Lingua Kéziszótárak. K. n., Budapest, é. n.

J. = JUHÁsZ ZsuZSANNA, Olasz-magyar közgazdasági szótár. Aula, Budapest, 1997.

Kir. = KirÁly RUdOLF, Olasz-magyar szótár. Dizionario italiano-ungherese. Szent Istvántársulat, Budapest, 1944.

Kör. = KÖRÖSI SÁNDOR, Olasz-magyar szótár (Dizionario italiano-ungherese) 1-2. Lampel, Budapest, 1912.

KSzV. = KOLTAY-KASTNER JENÖ - SZABÓ MiHÁly - VirÁNYI ElEMÉR, Olasz-magyar szótár (Dizionario italiano-ungherese). 2. kiadás. Danubia, Pécs, 1940.

L. = LINGEA olasz ügyes szótár. Lingea Kft. Kiadó, Komárom, 2015.

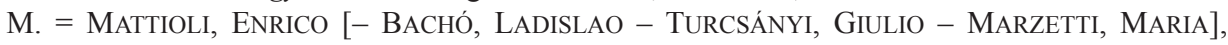
Dizionario militare italiano-ungherese e ungherese-italiano. Istituto Poligrafico dello Stato, Roma, 1937.

N. = NAGY MÁRIA, Magyar-olasz, olasz-magyar zsebszótár. Akadémiai Kiadó, Budapest, 2006.

SzTGy. = SZOKÁCS KINGA - TERMELNÉ GYÖRKE JUDIT, Olasz-magyar idegenforgalmi szótár. Dizionario italiano-ungherese del turismo. Budapesti Gazdasági Főiskola, Kereskedelmi, Vendéglátóipari és Idegenforgalmi Főiskolai Kar, Budapest, 2003.

SzV. = SZIGETINÉ DEMETER MARGIT - VEPERDI ANDRÁS, Olasz-magyar katonai szótár. Zrínyi Miklós Nemzetvédelmi Egyetem, Budapest, 2003.

TM. = TuLOK MAGDA - MAKKAY JÁNOS, Régészeti kifejezések szótára. Dizionario di terminologia archeologica. Enciklopédia Kiadó, Budapest, 2009.

U. = URBANEK SÁNDOR, Olasz-magyar szótár. Dizionario italiano-ungherese. Mohovich, Fiume, 1915.

\section{Hivatkozott irodalom}

CAfFarelli, Enzo 2008. Permettete un Caffarellum? Rivista Italiana di Onomastica 14: 290-291.

CAFFARELLI, ENZO 2016. Le „Madonne col bambino” nella pittura italiana (secc. XII-XIX). Il Nome nel testo 18: 29-41.

CAfFARELl, ENZO 2018a. Osservatorio transonimico. Rivista Italiana di Onomastica 24: 462468.

CAfFARelli, EnZo 2018b. Rosatellum, Dimaiellum, Mazziottellun, Grillellum... Rivista Italiana di Onomastica 24: 445.

CAPRINI, RITA 2008. Van Langendock, Willy: Theory and Typologie of Proper Names. [Recenzió.] Rivista Italiana di Onomastica 14: 484-491. 
FÁBIÁN ZSUZSANNA 2011. Száz éves Körösi Sándor olasz-magyar nagyszótára. In: SzEGEDI ESZTER - FALVAY DÁVID szerk., ,, Ritrar parlando il bel”. Tanulmányok Király Erzsébet tiszteletére. L'Harmattan Kiadó, Budapest. 373-388.

FÁBIÁN ZSUZSANNA 2015. A szótár, illetve a lexikon és az enciklopédia megkülönböztetése az „enciklopédikus szótár" müfajának tükrében. In: FÁBIÁN ZSUZSANNA - SZÖLLÖSY ÉVA szerk., Szótár, lexikon, enciklopédia. Kérdések és feladatok. Segédkönyvek a nyelvészet tanulmányozásához 172. Tinta Könyvkiadó, Budapest. 17-38.

FÁBIÁN ZSUZSANNA - SzÖLLŐSY ÉVA szerk. 2015. Szótár, lexikon, enciklopédia. Kérdések és feladatok. Segédkönyvek a nyelvészet tanulmányozásához 172. Tinta Könyvkiadó, Budapest.

FARINA, ANNICK 2006. Toponomastique et lexicographie bilingue. In: D’ACHILLE, PAOLO - CAFFARELLI, ENZO szerk., Quaderni internazionali di RIOn 2: Lexicography and Onomastics. Società Editrice Romana, Roma. 179-192.

FARINA, ANNICK 2008. En voiture Simone, tes articles ont fait Gilles! Les prénoms dans les dictionnaires. In: D’ACHILle, PAOLO - CAFFARElli, ENZO szerk., Quaderni internazionali di RIOn 3: Lexicography and Onomastics 2. Società Editrice Romana, Roma. 497-510.

FARKAS TAMÁS 2007. A tulajdonnevek fordíthatóságáról és napjaink fordítási hibáiról, közszók és tulajdonnevek példáján. Névtani Értesitö 29: 167-188.

FARKAS TAMÁS 2010. Willy Van Langendonck: Theory and Typology of Proper Names [A tulajdonnevek elmélete és tipológiája]. [Recenzió.] Névtani Értesitő 32: 237-241.

FRIED ILONA 2009a. Italianisztika és állambiztonság. Betekintő 2009/4. http://www.betekinto.hu/ sites/default/files/betekinto-szamok/2009_4_fried.pdf (2020.05. 10.)

FRIED IlONA 2009b. Árnyak a Bródy Sándor utcában. Élet és Irodalom 53: 26.

GOMEZ GANE, YORICK 2015. Dal Mattarellum all'Italicum: produttività dei suffissi pseudolatini -um ed -ellum. Rivista Italiana di Onomastica 21: 742-774.

HaJdú MiHÁLy 2003. Általános és magyar névtan. Személynevek. Osiris Kiadó, Budapest.

ITTZÉS NÓRA 2015. A nyelvi, illetve az enciklopédikus-lexikális elemek szerepe a szótári értelmezésben. In: FÁBIÁN ZSUZSANNA - SzÖLLŐSY ÉVA szerk., Szótár, lexikon, enciklopédia. Kérdések és feladatok. Segédkönyvek a nyelvészet tanulmányozásához 172. Tinta Könyvkiadó, Budapest. 39-47.

KÁlmán BÉla 1973. A nevek világa. Gondolat Kiadó, Budapest.

KÁlmÁn BÉla 1989². A nevek világa. Csokonai Kiadó, Debrecen.

KOLTAY-KASTNER JeNŐ 1954. Herczeg Gyula: Olasz-magyar szótár I-II. Budapest, Akadémiai Kiadó, 1952. [Recenzió.] MTA I. Osztály Közleményei 5: 527-541.

MAGAY TAMÁs 2015. Szótár, enciklopédia és tipológia. In: FÁBIÁN ZSUZSANNA - SZÖLLŐSY ÉVA szerk., Szótár, lexikon, enciklopédia. Kérdések és feladatok. Segédkönyvek a nyelvészet tanulmányozásához 172. Tinta Könyvkiadó, Budapest. 9-16.

SLÍZ MARIANN 2015. Általános névtani kérdések. In: FARKAS TAMÁs - SLíZ MARIANN szerk., Magyar névkutatás a 21. század elején. Magyar Nyelvtudományi Társaság - ELTE Magyar Nyelvtudományi és Finnugor Intézet, Budapest. 93-114.

J. Soltész KATALIN 1979. A tulajdonnév funkciója és jelentése. Akadémiai Kiadó, Budapest.

SVEnsÉn, Bo 2009. A Handbook of Lexicography. The Theory and Practice of Dictionary-Making. Cambridge University Press, Cambridge.

UZONYI PÁL 2015. A tulajdonnevek kezelése az egy- és kétnyelvü szótárakban. In: FÁBIÁN ZsUZSANNA - SZÖLLŐSY ÉVA szerk., Szótár, lexikon, enciklopédia. Kérdések és feladatok. Segédkönyvek a nyelvészet tanulmányozásához 172. Tinta Könyvkiadó, Budapest. 71-84. 
VAn LANGENDONCK, WiLly 2007. Theory and Typology of Proper Names. Trends in Linguistics. Studies and Monographs 168. Mouton de Gruyter, Berlin - New York. https://doi.org/10.1515/ $\underline{9783110197853}$

VÁRNAI JUdiT SzILVIA 2005. Bárhogy nevezzük... A tulajdonnév a nyelvben és a nyelvészetben. Segédkönyvek a nyelvészet tanulmányozásához 42. Tinta Könyvkiadó, Budapest.

VIG ISTVÁN 2006. Olasz tulajdonnevek a magyar helyesírási szótárban. BÁR. Társadalomtudományi és müvészeti folyóirat. Különszám. 8: 169-178.

FÁBIÁN ZSUZSANNA

ORCID: https://orcid.org/0000-0003-3597-8773

ELTE Eötvös Loránd Tudományegyetem

Bölcsészettudományi Kar

\section{ZsuZSAnNa Fábián, Proper names in Italian-Hungarian bilingual dictionaries}

The study examines the theoretical and practical approach employed in the case of proper names in Italian-Hungarian bilingual dictionaries over 100 pages in length. Fourteen general and six topical dictionaries are examined. The authors' methodological approaches are discerned through an examination of prepositions, the dictionary apparatus, the list of entries, and entries themselves. The examined corpus contains data collected through a review of entries under the letter L. Beyond highlighting specific data, the study examines the tendencies that can be discerned in how proper names have been listed in dictionaries over a little more than the past century, and names the shortcomings and inconsistencies that should be overcome in the future. 

FARKAS TAMÁS - SLÍZ MARIANN szerk., Tulajdonnevek és szótárak. ELTE Magyar Nyelvtudományi és Finnugor Intézet - Magyar Nyelvtudományi Társaság,

Budapest, 2020. 109-130. DOI: 10.26546/4892373.7

\section{Tulajdonnevek a kulturális szótárakban}

1. Egy speciális szótártípus: a kulturális szótár. Az általános lexikográfiai szakirodalomban a szótárakat különböző dichotómiák alapján szokták osztályozni: egy- vagy többnyelvü, szinkrón vagy diakrón, általános vagy szaknyelvi, a standard nyelvet vagy egy-egy nyelvváltozatot bemutató (nyelvjárási, csoportnyelvi stb., vö. MAGAY 2015: 10). A nyelvészeti szótárak osztályozása a bennük található lexikai egységek alapján is lehetséges: pl. archaizmusokat, neologizmusokat, idegen szavakat, szakszavakat, tabuszavakat, eufémizmusokat feldolgozó szótárak.

A kulturális szótárak a felsorolt szempontok szerint deskriptívek, tipikusan kétnyelvüek, a kiválasztott szókincs szinkrón bemutatására törekednek, és speciálisak, hiszen a szókincsnek csak egy meghatározott szeletére fókuszálnak. Terjedelmükben korlátozottak (azaz nem teljesek; vö. MAGAY 2015: 11). Tartalmukban inkább az enciklopédiákhoz állnak közel, hiszen szócikkeikben kevés a nyelvi, annál több a kulturális információ. MAGAY TAMÁS (2015: 15) szótárosztályozási rendszerében a kulturális szótárak a kétnyelvü, (enciklopédikus elemekkel bővített vagy) enciklopédikus, illetve hibrid szótárak kategóriájába tartozhatnak.

FÁBIÁN ZSUZSANNA (2015: 21) a terminológiai sokféleségből kiemeli az enciklopédikus szótár fogalmát, amely esetében „a szótárba »oltották be« az enciklopédiát”. Az enciklopédikus szótár fogalma annál is inkább találó lehet a kulturális szótárak esetében, mert ezekben a szerzők a tulajdonnevekkel kapcsolatban enciklopédikus ismereteket (is) közölnek (vö. FÁBIÁN 2015: 29).

A magyarországi kulturális szótárak a jelenleg ismert formájukban leginkább az országspecifikus lexikonokra vagy útikönyvekre hasonlítanak (pl. a közel 1300 oldalas, német nyelvü Franciaország-lexikonra [SCHMIDT et al. 2006]). A kulturális szótárakban ugyanis elsősorban a címszóval jelzett fogalom definíciója, leírása, körülírása található.

A Corvina Kiadónak a 21. század küszöbén indított sorozatában angol-magyar (BART 1998, 2002, 2018), amerikai-magyar (BART 2000, 2017), japán-magyar (GY. HORVÁTH 1999, 2018), német-magyar (GYÖRFFY 2003, 2018), francia-magyar (ÁDÁM 2005), orosz-magyar (SOPRONI 2008), olasz-magyar (SZTANÓ 2008), sőt egy nyelv(terület) helyett egy városra fókuszáló (római) kulturális szótárt (LUKÁCS 2018) is találunk. ${ }^{1}$ Fordított irányú, magyar kulturális szótárak is születtek francia, angol és német nyelven (BART 2005, 2015, 2016).

A kulturális szótárak kiadásába más (határon túli) kiadók is bekapcsolódtak. BENŐ ATTILA (2009) román-magyar, PÉNTEK JÁNOSsal közösen pedig (PÉNTEK-BENÖ 2013) magyar-román kulturális szótárt is megjelentetett. BALOGH F. ANDRÁs ugyanebben a sorozatban német-magyar (2017) kulturális szótárt adott közre, amelyben a kisebbségi német népcsoportok (svábok, szászok, cipszerek stb.) kultúrája és szókincse jelenik meg.

\footnotetext{
${ }^{1}$ Az említett évszámok az egyes kiadásokra utalnak. A tanulmány mindegyik szótárnak csak a legutóbbi kiadását vizsgálja a továbbiakban.
} 
Kissé meglepő módon magyar szerzőtől, ÓDOR LÁSzLÓtól jelent meg német nyelvü svájci kulturális szótár a nyelvközösség nem svájci részének címezve (ÓDOR 2010), amelyben a szerző a svájci németek és nyelvhasználatuk jellegzetességeit foglalja össze kb. 2000 rövid szócikkben. A szerző később a német kulturális szótárakkal rokon müvet is megjelentetett (ÓDOR 2016) - immár a teljes német nyelvterületről, esszészerüvé duzzadt szócikkeket füzve össze.

A müfaj újszerüségének megfelelően a szakirodalomban alig találunk említést a kulturális szótárak mibenlétéről; ezek közt említendő LUKÁCS ANDRÁS angol, német, francia és olasz szótárakat összehasonlító elemzése (2010).

A kulturális szótárak - más speciális szótárakhoz hasonlóan - címükben utalnak arra, hogy miben térnek el az általános szótáraktól: „kulturálisan” meghatározott szavakat, kifejezéseket tartalmaznak. „A nyelv és kultúra számos különböző szegmensét felölelö címszóállományt nehéz összefoglalóan jellemezni. A kulturális szótárak szerzőinek koncepciójához valószínüsíthetően akkor járunk a legközelebb, ha a lexikográfiai és fordítástudományi szaknyelvben is ismert kultúra-specifikus szavak felöl közelítjük meg a címszóválogatást." (LUKÁcs 2010: 39.)

Ezeket a lexikai elemeket gyakran a reáliák (vagy ekvivalens nélküli lexémák) körébe szoktuk sorolni, melyek nyelvi közvetítése különös nehézséget okoz, hiszen ,egyegy nyelvközösségre sajátosan jellemző jeltárgyat” jelölnek (KLAUDY 1994: 25).

A kulturális szótárak tehát sajátos kulturális töltetü, kultúrafüggő lexémákat tartalmaznak: ide tartoznak azok a nyelvi elemek, amelyekben „,kifejeződik egy adott kultúrközösség sajátos élmény- és ismeretanyaga, tárgyai, fogalmai, mentális, emotív sémái, amelyek az adott kulturális kontextusban speciális jelentéssel bírnak" (VALLÓ 2000: 45).

Ez indokolja, hogy a kulturális szótárakban a címszavakat nem pusztán azok nyelvi megfelelöje követi, hanem tulajdonképpen egyfajta értelmezés: „A kulturális szótárban tehát nem a címszavak forditását olvashatjuk, hanem magyarázatát - ahol is a magyar magyar-áz szó, az etimológia felől nézve, különösen találó: kifejtjük magyarul, mit jelent nagyjából egy olyan idegen szó vagy név, amelynek különben nincs pontos vagy hozzávetőleges magyar szótári megfelelője.” (GYÖRFFY 2018: 6; a kiemelések az eredetit követik.)

Mivel a címszóállomány mindig a forrásnyelvi kultúra (vagy kultúrák) adottságaitól függ, valószínüleg lehetetlen objektív kritériumokat találni a lemmaválasztáshoz; ez ráadásul nagyban függ a szótárírók (többségükben gyakorlott fordítók) megítélésétől, tapasztalataitól, egyéni ízlésétől is.

Nem teljesen egységes a nyelv és kultúra, illetve ország összefüggésének kezelése sem a különböző kulturális szótárakban. Az angol kulturális szótár (BART 2018) természetszerüleg tartalmaz brit/kelta (ír, skót) nyelvi elemeket, ugyanakkor nem terjed ki az angol nyelvű országok mindegyikére. Ez annál is inkább indokolt, mert az amerikai kulturális szótár (BART 2017) külön kötetben jelent meg, természetesen az amerikai szónak az (angol nyelvü) Amerikai Egyesült Államokra vonatkozó jelentésében, Amerika többi részét figyelmen kívül hagyva. Ugyanakkor a német kulturális szótár (GYÖRFFY 2018) az összefüggő német nyelvterület (Németország, Ausztria, Svájc) egészéről tartalmaz címszavakat, vagyis a német szó jelentése a címben: 'német nyelvü'.

A továbbiakban néhány kulturális szótár összehasonlításával igyekszem bemutatni a kulturális szórákban szereplő tulajdonnévanyagot. Az összehasonlításban szereplő szótárak: angol (BART 2018), amerikai (BART 2017), francia (ÁDÁM 2005), német (GYÖRFFY 2018), olasz (SZTANÓ 2008). 
2. A kulturális szótárak cím- és lemmaválasztásáról. A korábban megjelent (első kiadású) kulturális szótárak címében - a hagyományos szótárakhoz hasonlóan - nyelvpárok szerepelnek: angol-magyar, francia-magyar, német-magyar stb. Az újabb kiadású szótárak már csak a forrásnyelvet viselik címükben: Amerikai kulturális szótár (BART 2017), Német kulturális szótár (GYÖRFFY 2018). BART ISTVÁN idegen nyelvü sorozatában a nyelvpár alcímként jelenik meg: La Hongrie et les Hongrois. Magyarfrancia kulturális szótár (BART 2005).

BART ISTVÁN (2018) az angol-magyar szótár előszavában nem a szótár szavai, hanem a szavak által bemutatott valóságszeletek felöl közelíti meg a szótár célját: „A brit élet és életforma jellegzetes szokásait és hagyományait, a mindennapi élet és az ünnepnapok rítusait gyüjti össze ez a szótár, továbbá bemutatja az ezekhez tartozó tárgyakat, vagyis a brit életforma kellékeit” (BART 2018: 7). A szerző hangsúlyozza, hogy szótárában elsősorban olyan szavakat mutat be, amelyek jelentése (és valószínüleg konnotációja) a kétnyelvü szótárakból nem ismerhető meg. Az előszóból nem derül ki, hogy a tulajdonnevek milyen szerepet játszanak a szótárban.

Hasonló elvek alapján válogatta be a címszavakat az amerikai kulturális szótárába is, a válogatásban a szavak mögöttes jelentése és hangulata játszotta a legfontosabb szerepet. „Nos, mi [...] föként olyan egyszerü fogalmakat, tényeket és tárgyakat - szavakat! - szerepeltetünk (és próbálunk megvilágítani) ebben a szótárban, melyek az amerikai életformát - történelmet és hétköznapokat - tükrözik, jellegzetes amerikai értékek és hagyományok jelennek meg bennük, és ekképpen részét, mondhatni kötőanyagát alkotják az amerikai kultúrának" (BART 2017: 6). A tulajdonnevek szerepéről itt sem esik szó.

ÁDÁM PÉTER francia kulturális szótárát az előszóban „Land und Leute típusú kislexikonnak” nevezi (ÁDÁM 2005: 5). A szócikkek témáinak felsorolása: „évszám, sanzoncím, történelmi évforduló, népszokás, borelnevezés, híres csata, rejtett irodalmi idézet, nagy történelmi személyiség, közhely, szállóige" stb. (ÁDÁM 2005: 5) utal arra, hogy a szótár szócikkei között több tulajdonnevet is találunk.

GYÖRFFY MIKLÓS német kulturális szótára előszavában ugyancsak a „kulturális felhangú" szavakat jelöli meg szótára tartalmaként. Ezen olyan lexikai elemeket ért, amelyeknek ,vannak ugyan szótári megfelelöi(k), [...] mégis tartalmaznak lefordíthatatlan jelentésárnyalatot vagy jelentéstöbbletet” (GYÖRFFY 2018: 6). A szerző a lemmaválogatás bemutatásakor részletesen kitér a tulajdonnevek szerepére. Miután megjegyzi, hogy a „tulajdonnevek egy részének jelentős és persze eleve lefordíthatatlan kulturális konnotációja van" (GYÖRFFY 2018: 7), bemutatja a feldolgozott tulajdonnevek kiválasztásának módszerét. „Személyneveket és földrajzi neveket csak akkor szerepeltetek címszóként, ha azok valamilyen körülhatárolható értelemben fogalommá, esetleg köznévvé váltak. Kivételt csupán a történelmi és földrajzi tartományok, régiók, tájegységek nevével, valamint néhány német nagyváros [...] nevezetességeinek, helyszíneinek elnevezésével tettem [...].” (GYÖRFFY 2018: 7.) Ezenkívül megtalálhatók a szótárban olyan, tulajdonnevekből keletkezett „kulturális címszavak és fogalmak”, amelyek a német, osztrák és svájci történelemmel, müvészettel, tudománnyal stb. kapcsolatosak, és nincs célnyelvi megfelelöjük (GYÖRFFY 2018: 7).

Az olasz-magyar kulturális szótár előszavában a szerző a müfajt így határozza meg: „A kulturális szótár először is szótár” (SzTANÓ 2008: 6). Szócikkei nagyjából egy útikalauz anyagát ölelik fel, csak nem földrajzi, hanem betürendes elrendezésben. Az elöszó alapján a lemmák között kevés tulajdonnevet várhatunk: „Személyneveket nemigen vettünk fel, hacsak nem váltak fogalommá” (SZTANÓ 2008: 6). Hasonlóan jár el a szerző 
a hely- és intézménynevekkel. A szerző több esetben a tulajdonnévi címszavaknál (is) utal a címszóhoz hasonló funkciójú magyar (vagy más: francia, amerikai) tulajdonnevekre, egyfajta ekvivalenciaként: pl. a Cuore címü ifjúsági regény szócikkében: „az olaszok Pál utcai fiúkja" (SZTANó 2008: 90).

Egyedül az olasz-magyar kulturális szótárban van névmutató (SZTANÓ 2008: 302304), amely szándéka szerint nem a címszavakat tartalmazza, hanem a szócikkekben szereplö tulajdonneveket.

A tulajdonnevek aránya a kulturális szótárakban a fentieknek megfelelően változó. Az $A$-nál szereplő címszavakat részletesen áttekintve és átszámolva az alábbi eredményeket kaptuk. A számolásnál csak a pusztán tulajdonnévi címszavakat, illetve a teljes szócikkeket vettük figyelembe, azokat a címszavakat tehát nem, amelyek után csak egy utalás található, pl. Academy $\rightarrow$ Royal Academy of Arts (BART 2018: 10). Nem számoltuk kétszer, ha ugyanazt a fogalmat jelölö nyelvi forma két alakban is szerepelt a címszavak között: ABA, illetve American Bar Association (BART 2017: 7).

1. táblázat: Tulajdonnevek aránya az $A$ alatti címszavak között ${ }^{2}$

\begin{tabular}{|l|c|c|c|}
\hline Szótár nyelve & $\begin{array}{c}\text { Szócikkek } \\
\text { száma (db) }\end{array}$ & $\begin{array}{c}\text { Tulajdonnevek } \\
\text { száma (db) }\end{array}$ & $\begin{array}{c}\text { Tulajdonnevek } \\
\text { aránya (\%) }\end{array}$ \\
\hline angol & 108 & 42 & 38,9 \\
\hline amerikai & 128 & 63 & 49,2 \\
\hline francia & 111 & 35 & 31,5 \\
\hline német & 62 & 42 & 67,7 \\
\hline olasz & 98 & 34 & 34,7 \\
\hline
\end{tabular}

A táblázatból láthatjuk, hogy a tulajdonnevek aránya a szócikkek 1/3-a és $2 / 3$-a között mozog; a német szótárban találjuk arányosan a legtöbb tulajdonnévi címszót. Összehasonlításképpen: a szigorúan korpuszalapú, elexico nevü német online szótárban a címszavak 1,2\%-a tulajdonnév: 3689 tulajdonnév szerepel a 300000 címszó között. Ezek legnagyobb része családnév (1334) és helységnév (1065), a többi pedig tájnév (332), utónév (267) és országnév (189) (KLOSA et al 2010: 658). ${ }^{3}$

\section{Földrajzi nevek a kulturális szótárakban}

3.1. Angol kulturális szótár. Az angol kulturális szótár bővelkedik különböző típusú földrajzi nevekben. Ezek sorában természetesen előfordulnak vízrajzi nevek. A Severn folyónév szócikkében elsősorban földrajzi ismeretek olvashatók: ,a sziget leghosszabb $(290 \mathrm{~km})$ folyója, amely Északkelet-Walesben ered, és a Bristol Channelbe ömlik; ha bore (tidal wave) van rajta, utolsó szakaszán a dagálytól visszafelé folyik a vize." Az Avon folyónév mellett olvashatjuk: „több angliai folyócska neve, melyek közül Shakespeare [...] okán a Stratford városán átfolyó a legismertebb.”

${ }^{2}$ A számlálás a 2. pontban számba vett, a tanulmányban feldolgozott kiadások alapján történt.

${ }^{3}$ Az elexico az Institut für Deutsche Sprache projektjének keretében készült online szótár, a jelenkori német köznyelv szóanyagát tartalmazza: https://www1.ids-mannheim.de/lexik/elexiko.html. (2020. 05. 02.) 
A hegyneveknek a forrásnyelvben használatos formája mellett nem feltétlenül található meg a magyar megfelelője: a Pennines leírása szerint „a skót határtól [...] Derbyshire-ig, 400 km hosszan dél felé húzódó hegység”. A szócikkből hiányzik a magyar megfelelö (Pennine-hegység).

Az Albion címszónál a következő etimológiai, stilisztikai megjegyzéseket olvashatjuk: „Nagy-Britannia régi (talán kelta eredetü), ma már leírhatatlanul poétikus neve.” Az Ireland országnév több, egymással utalásokkal összekapcsolt változatban is előfordul a szótárban. Közülük a leghosszabb szócikk, az Ireland tulajdonképpen a rendkívül terhelt angol-ír viszony történetét és mai állapotát foglalja össze dióhéjban: ,a hate-love viszony Írország és Anglia között kölcsönös.” A rokon szócikk, az Eire objektív földrajzi és történelmi adatokat közöl az Ír Köztársaságról, míg az Erin nyelvi információkat ad meg: „Írország költői neve, ír nyelven.”

A településnevek közül a másodlagos jelentéssel (is) bírók kaptak helyet a szótárban: a John o'Groats földrajzi névként egy északkelet-skóciai kis helységet jelöl (,,a szigetek legészakibb települése"), másodlagos jelentése azonban egy állandósult szókapcsolatból derül ki: „from Land's End to John o'Groats” ('az ország egyik végétől a másikig'). A szótárban természetesen a Land's End is kapott külön szócikket.

Városrészek is szerepelnek a szótárban szócikkel: a Mayfair a városrész neve a felső tízezer (upper class) beszédmodorával fonódott egybe, ezért ennek a (szociolingvisztikai) összefüggésnek a magyarázata tölti ki a szócikk nagy részét. A Soho szócikk is leginkább a városnegyed történetével és funkcióváltásaival ismertet meg, kiegészítve némi etimológiai magyarázattal: „a so-ho eredetileg vadászkiáltás volt, ugyanis valamikor királyi vadaskert terült el ezen a környéken.’"

A szótárban számos, jelentős konnotációval bíró mikrotoponima is található. Falls Road: „Belfast katolikus részének főutcája, mely robbantásokról, merényletekről és az itt lezajlott összecsapásokról lett nevezetes." A The Mall (lemmaként: Mall, The) utcanév szócikke a hely földrajzi elhelyezkedéséröl, növényzetéről, egykori és mai funkcióiról tudósít, miközben számos további földrajzi (és egyéb) névhez utalja tovább az olvasót (Buckingham Palace, Trafalgar Square, illetve Royal Society).

Fiktív földrajzi nevek is felbukkannak a szótárban: Ambridge képzeletbeli angol falu, a The Archers címü végeérhetetlen rádiójáték-sorozat (afféle Szabó család) helyszíne.

A szótárban a névanyagban gyakran elöforduló földrajzinév-elemeket is találunk: az ír Kil „helynevek jellegzetes előtagja, jelentése 'egyház' ('templom’), pl. Kilkenny”.

3.2. Amerikai kulturális szótár. Az amerikai kulturális szótárban a földrajzi nevek számos fajtája előfordul. A víznevek között például: Great Lakes. A szócikk a tavak rövid földrajzi bemutatásával kezdődik: „öt hatalmas, édesvizü tó láncolata az USA és Canada határán (nagyság szerint: Superior, Huron, Michigan, Erie, Ontario)", majd a tórendszernek a gazdaságban betöltött szerepét ismerteti. A szócikk a tulajdonnév magyar megfelelöjét (Nagy tavak) nem tartalmazza.

A folyónevek közül álljon itt példaként a Mississippi River, amelynek szócikke az előzőhöz hasonlóan épül fel: földrajzi bemutatást tartalmaz (,az USA legnagyobb folyója a Missouri és az Ohio összefolyásából"), és a régió életében betöltött szerepét hangsúlyozza. A szócikk továbbirányítja az olvasót az Ol'Man River tulajdonnévhez, amely „Oscar Hammerstein száma a Mississippiröl, amelynek neve indián nyelven »Nagy Víz«".

A Rocky Mountains a földrajzi információkon túl (,Alaszkától Új-Mexikóig terjedő, csaknem 5000 km hosszú hegylánc az USA nyugati részén, gerince alkotja a kontinens 
vízválasztóját”) az Aspen helységnévre utal tovább. Aspen nem méreténél fogva került a szótárba, hanem mert régen és ma is „különleges” helynek számított: „,hajdan ezüstbányászok lakták, ma a világ legelegánsabb síterepe."

A szótár számos helység- és helységrésznevet tartalmaz. A New Orleans magyarázata a település földrajzi elhelyezkedésének és legfontosabb nevezetességeinek (French Qarter és jazz) összefoglalásából áll, megadja a város nem hivatalos elnevezését is („közkeletü nevén a Big Easy”). A Georgetown szócikkben a „Washington legelőkelőbb elövárosa" megjelölés mellett a hely mai megjelenésének a bemutatása alkotja a magyarázat nagy részét. A terjedelmesebb a Harlem szócikk, amelyet a szótárban megelőz a Harlem Globetrotters és a Harlem Renaissance, a városrész nevéhez füződő szegénység és etnikai problémák bemutatására helyezi a hangsúlyt, illetve röviden ismerteti a hely történetét, emellett megemlíti a tulajdonnév holland eredetét (Nieuw Haarlem). A nagyon rövid Manhattan szócikk csak a városrész helyét jelöli meg, nem utal tovább a Hell's Kitchen szócikkre (vö. „Manhattan közepén [...] elterülö utcák”), ahonnan azonban van utalás a Manhattan-re. A Camp David, vagyis az elnöki nyaraló neve is helyet kapott a szótárban; hajdani politikai szerepe a róla elnevezett Camp David-i egyezmény (1978) aláírásának helyszíneként nem szerepel a szótárban.

A mikrotoponimák között számos utca- és hídnevet találunk. A Central Park szócikke New York City legnagyobb közparkjának a történetéről és mai funkcióiról szolgál információkkal. A Basin Street szócikke a New Orleans-i utca és a jazz kapcsolatára helyezi a hangsúlyt.

A Golden Gate Bridge szócikkében a San Francisco-i öböl hídjának magyar nevét (fordítását) is megtaláljuk: Aranykapu; ezenkívül méreteit és építésének idejét is olvashatjuk.

Az amerikai kulturális szótárban fiktív helynevek is elöfordulnak, például a Gotham. Magyarázataként ez áll: ,,az angol 'Rátót'”, vagyis az együgyü, buta emberek lakóhelye. A fiktív helynév szócikkében angol-amerikai összevetés is található: „Amerikában elevenebben él a szó, ugyanis [...] New York zsurnalisztikus szinonimája ma is."

3.3. Francia kulturális szótár. A francia-magyar kulturális szótárban szintén találkozunk - történelmi, kulturális vagy más szempontból jelentős - földrajzi nevekkel, bár arányuk lényegesen alacsonyabbnak tünik, mint a többi hasonló kulturális szótárban.

A történelmi országnevek csoportját képviseli a Gaule : Gallia. A szerző a magyar megfelelő megadása után részletesen ismerteti a gall és francia népnevek, illetve a Gallia és Franciaország közötti bonyolult összefüggéseket, az országnév mai értelmezését. A modern országnevek közül megtaláljuk például a Martinique címszót, mely definícióval kezdődik: „A sziget 1635-től francia gyarmat, sokáig a cukornádtermesztés egyik központja." Hajdani francia fennhatósága okán a Canada is címszóként szerepel a szótárban: ,,az ott élő franciák és az ott beszélt (erősen archaikus) francia nyelv miatt változatlanul része a franciák tágabb horizontjának."

A tájnevek közül megtaláljuk a szótárban az Alsace-t: „Talán az egyetlen igazi région.” A szócikk tömören, mégis sok szempontot figyelembe véve tudósít a Franciaország többi részétől nagyon eltérő tájegység történetéről, vallási és főként (bonyolult) nyelvi helyzetéröl. A Camargue is szerepel a szócikkek között, meghatározásaként ezt olvashatjuk: „Sós taváról (Vaccarès), különleges madár- és növényvilágáról, valamint szilaj ló- és bivalytenyésztésről ismert, kb. 85 ezer hektárnyi tavas-mocsaras síkság a Rhône deltájában Provence-ban.” A Jardin de (la) France szócikke definíciószerűen 
adja meg a címszó jelentését: „Franciaország virágoskertje.” Csak ezután derül ki, hogy „a franciák a Loire völgyét értik rajta”.

A szótár szerint a valós és fiktív földrajzi nevek határán található az Occitanie: „A valamikor a langue d'oc nyelven, illetve e nyelv különböző dialektusain beszélő déli országrész (fantázia)neve [...]. A szót, amelynek nincs valóságos történelmi referenciája (ilyen nevü ország vagy országrész politikai egységként sohasem létezett), ma is hallani."

Gyakori címszavak a helységnevek, pl. Domrémy (Domrémy-la-Pucelle), ahol Jeanne d'Arc született, és ahonnan országmentö útjára indult. A szócikkben a településnek a történelmi hősnő életében játszott szerepéről olvashatunk (de földrajzi elhelyezkedéséről nem). A Paris nem szerepel címszóként, a Paris intra muros (lat.) viszont igen, ez a „sajtóban gyakran használt közigazgatási kifejezés, a boulevards extérieurs által közrefogott húsz párizsi kerület együttesen".

A mikrotoponimák közül megtaláljuk a Champs-Élysées (avenue des) szócikket, amelyben a sugárút különbözö háborús helyzetekben betöltött (szimbolikus) szerepe jelenik meg hangsúlyosan.

Természetesen jelentős épületek is helyet kaptak a szótárban. A Notre Dame de Paris meghatározása szerint ,az ország harmadik legfontosabb székesegyháza”. A szótáríró ezután ismerteti azon jeles irodalmi és történelmi vonatkozásokat, amelyek a templomhoz (és nevéhez) kapcsolódnak.

3.4. Német kulturális szótár. A német kulturális szótárban a vízrajzi nevek között számos folyónevet találunk. Természetesen a legnagyobbakét: Elbe, mellette a magyar névformát: Elba, majd az Elba legfontosabb földrajzi adatait és jelentőségének bemutatását. Hasonlóan épül fel a Rhein (Rajna) szócikke, itt azonban a folyónév latin, francia és holland névformáit is megtaláljuk. A Donau (azaz 'Duna') nem szerepel címszóként.

Németország egyik tengere, a Nordsee (azaz 'Északi-tenger') nem található meg címszóként a szótárban, az Ostsee viszont igen, talán azért is, mert két magyar megfelelője van: „Keleti- v. Balti-tenger”. A Neusiedler See címszónál megfeleltetést lehet olvasni: „A Fertő tó német neve.”

A német nyelvterület hegynevei közül szerepelnek az egyes országok legmagasabb csúcsai. Großglockner: ,,az osztrák Alpok legmagasabb hegycsúcsa: 3798 m magas.” Hasonlóan épül fel a Zugspitze szócikke is: „Németország legmagasabb hegycsúcsa (2963 m) az Alpokban." Történelmi vagy irodalomtörténeti szempontból jelentős hegységek, csúcsok, sziklák neveit is ismerteti a szótár. A Loreley egy „132 m magas sziklaorom a Rajna-mentén Mainz és Koblenz között”, amelyet Heinrich Heine tett halhatatlanná.

A szótár számos tájnevet sorakoztat fel. Már a tájnevek áttekintéséből kiviláglik, hogy a szótár a címében szereplő német alatt a német nyelvü országokat, illetve az egykori német nyelvü közép-európai területet érti. Ezek között vannak a mai német nyelvű országok területén találhatók, pl. Breisgau (D), Graubünden (CH), Lausitz (D), Mühlviertel (A). A Breisgau szócikk földrajzi meghatározást (,,délnémet tájegység, amely a Rajna felső folyása és a Schwarzwald között található") és rövid történelmi bemutatást tartalmaz, majd ismerteti a forrásnyelvi nyelvhasználók számára evidens $i . B r$. (= im Breisgau) rövidítést. A Mühlviertel szócikke hasonlóan épül fel: a rövid földrajzi definíciót (,,300-1300 m magas felső-ausztriai középhegység a Dunától északra; a Cseh-erdő déli nyúlványa") a név jelentésének megadása ('malomnegyed'), majd ennek magyarázata követi. Egyes tájnevek köznévi jelentésük miatt kerültek be a szótárba: pl. az Emmenthal, amelynek jelentése után ('az Emme folyó völgye') megtudhatjuk, hogy „,[i]tt, illetve itteni eljárás 
szerint készül az ementáli sajt"; a köznév immár illeszkedett a magyar helyesíráshoz. Az Elsass szócikkben megtaláljuk a magyar megfelelőt is (Elzász).

A településnevek között nagy számban fordulnak elő az egykor német nyelvü területek városai. Pl. Hirschberg (a lengyelországi Jelenia Góra): a sziléziai város ,egykori” német neve. Marienbad, a mai csehországi Mariánské Lázně német neve mellett a fürdővárosnak a német kultúrtörténetben betöltött szerepét ismerjük meg, különös tekintettel a híres fürdővendégekre: Wagnerre, Lisztre és Goethére. Breslau: Wrocław, a szócikk ismerteti a lengyelországi város lassan feledésbe merült magyar történelmi nevét is (Boroszló). A fenti településnevekhez csatlakoznak a korábban Magyarország részét képező német városok névpárjai, pl. „Bartfeld Bártfa (ma Bardejov, Szlovákia) német neve”, Neusohl (Besztercebánya, Banská Bystrica)". Hasonlóan önálló címszóként szerepel a Hermannstadt (Nagyszeben, ma Sibiu/Románia) stb. Ezekben az esetekben tehát a mai hivatalos nyelvi névalak mellett a korábban használatos német és magyar megfelelöket is megtaláljuk, amelyek névpárokat alkotnak, illetve párhuzamos nevekként jelennek meg a szótárban.

Mai magyarországi városoknak gyakran van (volt) német elnevezése is, ezeket is nagy számban tartalmazza a szótár: Fünfkirchen (Pécs), Güns (Köszeg), Raab (Györ), Ödenburg (Sopron), Ofen (Buda). Ezekben a szócikkekben a német név etimológiáját, illetve kialakulásának motivációját is megadja a szerző.

A mikrotoponimák közül sok városrész és utca nevét megtaláljuk a szótárban: általában azokat, amelyeket valamilyen esemény, látványosság, intézmény vagy irodalmi mü tett ismertté. Az egyik bécsi külváros neve, a Grinzing a borozóiról, a másiké, a Döbling pedig (nekünk) Széchenyi István miatt nevezetes. Az épületnevek szintén a teljes német nyelvterületet reprezentálják. Ezek a szócikkek az épületnevek „fordításával” kezdődnek, majd azt követi az épület rövid bemutatása (magyarázata), pl. Brandenburger Tor: „Brandenburgi kapu”, Kapuzinergruft: „kapucinus kripta”.

A címszavak között homonim német nevek is előfordulnak, amelyeknek egy szócikkben találjuk meg különböző megfelelőit. Ilyen a Marburg: „,a Lahn folyó mellett (an der Lahn) fekvő, ma is így nevezett egyetemi város mellett ez (volt) a szlovéniai Maribor német neve is (an der Drau, azaz 'a Dráva mellett' jelzői értékủ határozóval). Interlingvális homonimákra, pontosabban egy homográf névpárra külön utalást olvashatunk. Eger: „,a magyar város nevével írásban tökéletesen megegyező, csak kiejtésében ('éger') eltérő német városnév", a mai csehországi Cheb német megnevezése.

3.5. Olasz kulturális szótár. Bár vízrajzi és hegyneveket hiába keresünk az olasz kulturális szótárban, a szótár az egyéb földrajzi nevek különböző típusait tartalmazza.

Az országnevek közül - Olaszország ,érdekeltsége” okán-megtalálható az Abissinia: „Abesszínia, más néven Etiópia, az olasz gyarmatosítási törekvések egyik fő célpontja.”

A tájnevek között különösen fontos az észak-olaszországi régió, Alto Adige neve, amelynek megfelelője nem magyar, hanem német („németül Südtirol”), bár a szócikk szövegében előfordul a dél-tiroli melléknév is. A jelentős konnotációval bíró tulajdonnevek közé tartozik a Trinacria: „Szicília antik neve, ma a sziget önazonosságának és függetlenségének egyik kifejezője, érzelmi töltése kb. olyan, mint nálunk a 'Hungária', 'Magyar hon', 'Szittyaföld' szavaknak." A történelmi áttekintés mellett megismerhetjük a szó eredetét is: a görög trinakrios ('három hegyfok') átvétele.

Több városnév szerepel a szótárban: Bari, Fiume, Trieste. A városnevek szócikkei az adott város közigazgatási szerepét, földrajzi bemutatását és rövid történetét tartalmazzák. Pl. Bari: „Puglia tartomány székhelye.” A Fiume szócikkből hiányzik a ma horvátországi 
város hivatalos nyelvi megnevezése (Rijeka), így a névpár tagjainak azonos jelentéséről ('folyó') sem esik szó, annál inkább a város mozgalmas történetéről. Trieste szócikke szintén nem tartalmazza a többnyelvü és -nemzetiségü város többi nevét: horvátul és szlovénül Trst, németül Triest, magyarul Trieszt. Ehelyett a helység földrajzi helyének leírása olvasható: ,a Szlovéniába beékelődő olasz földnyelven fekvő város.”

Az itáliai városok közül jó néhánynak van - az olaszok számára közismert - ragadványneve; a szótár ezeket is számba veszi. Città del Santo (Padova, 'szent [Antal] városa', Bologna la Grassa ('kövér'), Dotta ('tanult, tudós', Bologna, illetve Padova), Superba („Genova állandó jelzője”). Az Urbe városnév Róma latin nevéből, az Urbs-ból származik, ,az $\sim$ n kizárólag Róma értendő”.

A földrajzi nevek címszavai között vannak fiktív nevek is, pl. Cuccagna: „Dínomdánom ország, Eldorádó". A név a középlatin cocaniá-ból alakult ki, amely pedig a német Kuchen ('sütemény, édesség') szóra vezethető vissza. A Cuccagna szinonimája a Bengodi, jelentésében nem, csak használatának gyakoriságában különbözik az előzőtől.

\section{Személynevek a kulturális szótárakban}

4.1. Angol kulturális szótár. Az angol kulturális szótárban természetesen számos személynév is található a történelem és a müvészetek, különösen az irodalom területéröl.

Az Arthur, King szócikk a brit nemzeti történelem egyik legismertebb szereplöjét mutatja be néhány mondatban, némiképp homályban hagyva, hogy valós történelmi alaknak tartja-e: ,az alak történelmi előképe alkalmasint brit (kelta) király lehetett, aki az angolszász hódítók ellen küzdött az V. században.” Az Albert, Prince szócikk a névviselő családjáról („Viktória királynő férje, a Saxe-Coburg and Gotha német hercegi család sarja”) és az angol kultúrában betöltött szerepéről tudósít („olyan nagy befolyása volt a királynőre, hogy általa tkp. az ő szellemisége formálta az egész Victorian kort").

A valós személyek neve mellett számos fiktív, mesebeli vagy irodalmi alak nevét is tartalmazza a szótár. John Bull a „tipikus angol” szatirikus figurája, a fiktív személynév mellett az alak kialakulásának története és a hozzá füződő képzetek olvashatók. A szótáríró a tárgyalt nevet magyar személynévnek is megfelelteti („,kb. Bika Berci”).

Klasszikus mesealakok angol neve (megfelelöje) is megtalálható a szótárban: Little Red Ridinghood a mesebeli Piroska. A nagyon régi és rendkívül sok változatban élő történetet a szótáríró Charles Perrault-hoz köti, és legjellemzőbb mondatait, a kislánynak a nagymamához intézett kérdését és a farkas válaszát idézetként, forrásnyelvi alakban közli. Travers mesealakjának neve, a Mary Poppins még címszó volt a szótár korábbi kiadásában, a felújított kiadásban azonban már nem szerepel. A szintén fiktív Dr Dolittle személynév szócikke a gyermekkönyvek doktor bácsiját mutatja be néhány sorban, itt a névkiegészítö is a címszó része.

Agatha Christie regényeinek detektív hősei is szócikket kaptak az angol kulturális szótárban: Miss Marple éppúgy, mint Hercule Poirot: nevük a krimikből ismert alakban szerepel címszóként, rövid bemutatásuk regénybeli viselkedésükre korlátozódik. Különös névtani helyzetet mutat be a Laurel and Hardy szócikk, amelynek címszavában az angol nézők számára az ismert színészek (Stan Laurel és Oliver Hardy) családneve, magyar megfelelöként pedig ugyanezen (szintén jól ismert) személyek magyarban ismert neve áll: Stan és Pan.

A szótár gyakori családnévelemeket is tartalmaz szócikként: a Mac skót és ír családnevek elötagja (,jelentése: son of'), az $O$ ' ír patronimikumok előtagjaként 'unoká'-t, 'leszármazott'-at jelent, a Gil jelentése 'valakinek a fia'. 
A szótárban ugyancsak megtalálható az erős konnotációjú Kevin. A jellegzetesen ír utónév a Kenneth-nek a változata, az „,angolokban durva és erőszakos modorú, iskolázatlan fiatalember képét idézi fel".

4.2. Amerikai kulturális szótár. A szótárban számos valódi személynév található; a híres névviselők között sok a politikus, katona, sportoló, színész.

Van ugyan Lincoln, Abraham címszó, mögötte azonban nem áll szócikk, csak utalások sora, többek között az Honest Abe szócikkre, melyben a következő definíció olvasható: „Lincoln elnök szeretetteljes beceneve, amely egész jogi és politikai pályáján elkísérte." A politikusok nevei közül elsősorban az amerikai elnököké bukkan fel a szótárban. Pl. George Washington: ,az Egyesült Államok első elnöke virginiai földbirtokos volt." Andrew Jackson hivatalos neve mellett ragadványneve is szerepel („Old Hickory”: 'elnyühetetlen'), Thomas Jefferson: ,,az Egyesült Államok harmadik elnöke.” A politikában jelentős személyek nevei között találjuk a Hoover J., Edgar-t, az FBI megteremtőjének nevét; a bemutatásban a közéletben betöltött funkcióit és legfontosabb tulajdonságait egyaránt megismerjük. A Harriet Tubman szócikkből megtudjuk, hogy a név viselője rabszolgának született, mielőtt politikai pályára állt; az ő ragadványneve csak magyar alakban olvasható: „fekete Mózes”.

A személynevek között több sportoló nevét is megtaláljuk: Yogi Berra a New York Yankees híres baseball játékosa, Jack Dempsey „legendás hírü amerikai ökölvívó” az 1920-as években. A sportolók személynevei után álló rövid bemutatások ugyanazon minta alapján épülnek fel.

Az amerikai kultúrát indián személynevek is reprezentálják: Crazy Horse ,az Oglala $\rightarrow$ Sioux törzs fönöke”, Hiawatha „legendás indián törzsfö, az Iroquois League megalapítója”.

A híres személyiségek neve a családnévvel kezdődően szerepel a szótár betürendjében, például a Presley, Elvis szócikk esetében is. A személynév melletti magyarázat: ,a rock'n'roll első nagy sztárja." Az amerikai müvészetet különböző müvészeti ágakban tevékenykedő hírességek reprezentálják. Houdini Harry híres „szabadulóművész”, a szócikkben fény derül magyar származására (eredeti neve: Weisz Erik).

A szótárban természetesen fiktív nevek is előfordulnak, közülük sokan híressé vált filmek szereplöi, pl. Tarzan. A Batman címszó után magyar megfeleltetés is olvasható: „a Denevérember, [...] az alvilág réme, polgári nevén Bruce Wayne.” Innen utalás irányít a Spider Man szócikkhez (ott azonban Spiderman alakban szerepel), onnan további utalás található a Superman szócikkhez, így füzve össze a csodálatos képességű figurákat.

4.3. Francia kulturális szótár. Különböző típusú személynevekkel találkozunk a francia kulturális szótárban: szentek nevétől mai politikusok nevéig. A szentnevek a valós személynevek közé sorolandók. A francia kulturális szótárban nyilvánvalóan más „releváns” szenteket találunk, mint akikkel a magyar egyház- és kultúrtörténetben szoktunk találkozni. A 3. században élt hittérítő, Saint-Denis neve mellett vértanúságának története, ünnepnapja és ikonográfiai hagyományai olvashatók. A szócikk a magyar megfelelővel kezdődik: Szent Dénes. A magyar megfelelő (Szent Ottília) nélkül áll a Sainte-Odile címszó, Elzász védőszentjének neve.

Felvett egyházi név az abbé Pierre, amely mellett szintén megadja a szótár a magyar megfelelőt: Péter apát, majd a névviselő polgári nevét is: Henri Grouès. „A szókimondó kapucinus neve, amelyet egész Franciaország ismer, a szegényekkel és hajléktalanokkal való önzetlen törödés és együttérzés szinonímája [sic!].” 
A személynevek közé sorolhatjuk a szótár Roland címszavát is: „Ha fiktív személy, ha nem, az első nemzeti hős." A szócikk nagy részét a vele kapcsolatos történelmi eseményről szóló francia nyelvü idézet és annak magyar fordítása teszi ki.

A történelmi kollektív neveket képviseli a Carolingiens és a Mérovingiens, mindkét címszó magyar megfelelőjét is megtaláljuk (Karolingok, illetve Merovingok). Ugyancsak mindkét szócikkben van utalás a név eredetére (etimológiájára), majd a szerző ismerteti az uralkodócsaládnak a francia történelemben betöltött szerepét. Az utóbbi szócikkben annak magyarázatát is megtaláljuk, hogy miért lett a Louis, egészen XVIII. Lajosig, ,a francia uralkodók hagyományos keresztneve".

Meglehetősen hosszú szócikket kapott de Gaulle, illetve teljes nevén Charles de Gaulle ,[k]atona és államférfi, a XX. század egyik legnagyobb politikusa, karizmatikus történelmi személyiség". Az 1970-ben elhunyt államférfi életútját jelen időben mutatja be a szótár szerzője, ezzel is felerősítve a politikus máig tartó, élő hatását. A szócikket 13 további szócikkre történő utalás zárja.

A modern kor nagy személyiségei közül megtaláljuk többek között a Bocuse, Paul címszót, neve mellett felsorolást alkotnak a meghatározások: „Az egyik leghíresebb francia séf, a klasszikus francia konyhamüvészet hagyományának képviselője és megújítója, a francia becsületrend kitüntetettje és [...] az ,„évszázad szakácsa«.”

A Platini, Michel címszót interkulturális metaforával magyarázza a szótáríró: „A francia Puskás Öcsi.” A név jelentésének leírásában más híres labdarúgók is szerepet kapnak: „Méltó francia megfelelője Zamorának, Pelènek és Maradonának. Minden idők egyik legnagyobb labdarúgója.” Hasonló metaforára (modifikációra) a fiktív nevek bemutatásánál is találunk példát: Toto „a francia viccek Mórickája”.

A fiktív élőlények nevei közül bekerült a szótárba a mesebeli Tarasque neve: „A legenda szerint Tarascon környékén élö tüzokádó sárkányforma kétéltü szörny.” A szörnyhöz kapcsolódó mai hagyományok bemutatása egészíti ki a név bemutatását.

4.4. Német kulturális szótár. A német kulturális szótár számos személynevet tartalmaz. Közöttük elöfordulnak jelentős személyiségek nevei a legkülönbözőbb történelmi korokból, ezeket (néhány kivételtől eltekintve) definíciószerü meghatározás követi. Pl. Arminius v. Armin der Cherusker: „egy nyugati germán néptörzs, a keruszkok vezére volt.” Barbarossa: „Rőtszakállú [...] I. Frigyes (Friedrich von Hohenstaufen) középkori német-római császár olasz előneve.” Eckermann, Johann Peter: „1823-tól gazdája haláláig Goethe hüséges »famulusa«, segítőtársa, beszélgetőpartnere volt."

A szótárban külön szócikket kapott a Karl germán eredetü utónév, itt nem egy bizonyos névviselöre utalva. A szócikk a név jelentésén túl ('legény, fiú, fickó') utal a név európai elterjedtségére és az európai uralkodóházak névadásában betöltött szerepére, illetve a földrajzinév-adásban megmutatkozó jelentőségére.

A személynevek egy része több névviselőre utal. A (Brüder) Grimm címszó a G betűhöz lett besorolva, jelentése: 'Grimm-testvérek' (a két Grimm fivér utóneve nem szerepel a szócikkben.) A Fugger családnév szócikkében a családtagok közül Jakob Fugger szerepel utónévvel is. A szócikk megemlíti a családnévből kialakult Fuggerei tulajdonnevet is („lakótelep a szegényeknek”), de a családnévböl alakult magyar közszót (fukar) nem.

Az uralkodócsaládok nevei közül megtaláljuk a szótárban a Habsburger családnevet, melynek magyar megfelelője („Habsburgok”) után rövid bemutatást olvashatunk: „európai uralkodócsalád, amely a svájci Aargauban található Habsburgról kapta a nevét." 
Ugyancsak a történeti nevek csoportjába tartozik a (Kaspar) Hauser, a névviselő a leghíresebb németföldi farkasgyerek (a szótárban „lelencgyerek”) volt a 19. század első felében. A szócikk megemlíti a személynévből kialakult pszichológiai terminust (KasparHauser-komplexus) és a névviselő regényes történetének müvészi feldolgozásait.

A szótár fiktív nevekben is bővelkedik: megtalálhatók benne a Grimm testvérek mesegyüjteményének alakjai: (Frau) Holle a magyar megfelelöjével (Holle anyó) szerepel; a Hänsel und Gretel szócikkéből megtudjuk, hogy a Jancsi a Hänsel becenévi megfelelője, a Juliska mellett viszont „,az alliteráció is szólhatott”, az ugyanis nem a Gretel (Margarete) fordítása. További irodalmi (mitológiai) nevek a szótárból: Kriemhild és Siegfried, Nibelungen; ez utóbbinál (behelyettesítve) a magyar megfelelő: „Nibelungok”.

A szótár meghatározása szerint egyfajta átmenetet képez a személy- és a tárgynevek között az Ötzi: ,'Ötz-völgyi lelet', [...] egy újkőkori vadász fagyban konzerválódott teteme, azaz gleccsermúmiája." A néhai vadászt megtalálásának helyéröl nevezték el (becézőképzővel).

4.5. Olasz kulturális szótár. Az olasz kulturális szótár személynevei között találunk történelmi neveket, pl. Regina Margherita: ,az első olasz királyné, I. Umberto felesége.” A szócikk természetesen említi a személynév és a pizzafajta (pizza margherita) közötti kapcsolatot, és a királynő nevéből képzett más (földrajzi) neveket is. Címszóként szerepel a kalandos életü Anita Garibaldi neve is: ,a Risorgimento hősének [...] a felesége.”

Számos egyházi személy nevét is megtaláljuk a szótárban. Padre Pio (,,az egyik legnépszerübb szent Olaszországban") kapucinus szerzetes élete és vallási tevékenysége hosszú szócikket kapott. Civil nevén Francesco Forgione, ,szerzetesi nevén Pio da Pietralcina"; ennek utónévi tagja az egyházi megszólításával (Padre) forrt össze. Természetesen pápák nevei is bekerültek a szótárba. Papa Sisto „a római nép körében rendkívül népszerü V. Sixtus", a Papa Buono XXIII. János ragadványneve; az előbbinek a szócikkből kiderül az eredeti civil neve, az utóbbinak nem.

Nem minden személynév mellett áll a leginkább magától értetődő információ. A Verdi szócikk ,a híres zeneszerző” politikai tevékenységét és szimpátiáit tárgyalja: ,a Risorgimento szimpatizánsa volt."

A nem valós személynevek csoportjába tartozik a Pierino, ,az olasz viccek Pistikéje", a magyar kulturális szótárban - a szótáríró utalása szerint - Móricka (lenne) a megfelelője.

Ugyancsak fiktív név a Signor Rossi: ,az átlagos kisember átlagos neve.” A Signor Bianchi („Kovács úr, azaz a tökéletesen átlagos ember”) szócikkben kis névtani esszét olvashatunk a gyakoribb itáliai családnevekről. Ezek szerint az átlagos nápolyit Espositónak hívják, az északi átlagembert inkább Fumagalli-nak. A Brambilla szócikk („,Lombardiában rendkívül elterjedt vezetéknév") hasonlóan mutatja be a név gyakoriságát.

\section{Egyéb névfajták a kulturális szótárakban}

5.1. Angol kulturális szótár. A további névfajták közül szinte mindegyiknek van képviselöje a kulturális szótárban: híres épületek nevei, intézménynevek, tárgynevek, üzlet- és márkanevek, fajtanevek, címek, eseménynevek stb.

Az Ark Royal eredetileg a ,spanyol armadát legyőző (1588) angol flotta zászlóshajójának a neve volt", később több anyahajót is így neveztek el. A szótár nem füz jelentéstani vagy etimológiai magyarázatot a névhez. 
A Big Ben a londoni parlament északi tornyának óráját, illetve harangját jelöli; itt is a névhez kapcsolódó hagyományokat ismerhetjük meg, a névelemek jelentését vagy eredetét nem.

Valószínüleg az intézménynevek alkotják az egyéb nevek legnépesebb csoportját: ezek mindegyike hordoz valamiféle jelentéstöbbletet, illetve reáliák a szónak abban az értelmében, hogy nincs célnyelvi megfelelöjük. Megtaláljuk az intézménynevek között iskolák, oktatási intézmények elnevezését, pl. Oxford University. A tulajdonnév magyarázataként az egyetem történetét, hajdani és jelenlegi jellegzetes oktatási és szociális rendszerét ismerhetjük meg. A The Garrick szócikk a londoni színházi és irodalmi világ híres (kizárólag férfiak előtt nyitva álló) klubjának nevét értelmezi, megadva a név eredetét: Garrick híres 18. századi színész volt.

Az intézménynevek közé sorolandók az egyházak nevei, pl. Congregational Church, amely a nagy-britanniai református egyház elnevezése. Itt a szótáríró megadja az egyháznak, illetve híveinek forrás- és célnyelvi szinonim elnevezéseit is (puritánok, Independent, kongregacionalisták, Pilgrim Fathers). Ugyancsak intézménynév a Football Association; az angol futballvilág legfontosabb szervezetének a neve mellett a közkeletü rövidítése is megjelenik (FA). A szócikk további tulajdonnevekre is tartalmaz utalást: Football League, Premier League. Az intézmények, szervezetek között természetesen helyet kaptak a legfontosabb politikai pártok elnevezései is: Conservative Party, Labour Party, National Front. A pártok alakulási évszámán, rövid történetén kívül megismerhetjük szavazóikat, legfontosabb képviselöik névsorát, ugyanakkor a neveknek itt nincs magyar fordítása.

A szótár tulajdonnévi címszavai között számos betüszó is helyet kapott. A $D L R$ címszónál annyi derül ki, hogy az a Docklands Light Railway vasút nevének rövidítése; jelentése a Docklands címszónál válik világossá.

Számos üzlet- és márkanév is helyet kapott a szócikkek között. A Fortnum and Mason cégnévvel kapcsolatban definíciószerűen közli a szerző, hogy „minden bizonnyal a legelőkelőbb élelmiszerüzlet Londonban”. A Disprin márkanevet az adott gyógyszer használatának bemutatása követi: „a minden háznál megtalálható legközönségesebb (enyhe) fejfájás-csillapító; vízben oldva szokás bevenni.” A Jaguar márkanév (a magyar olvasók számára valószínüleg ismeretlen rövidített alakban: Jag) szintén az autómárkához kapcsolódó asszociációkat gyüjti össze („nőfogó”: crumpet catcher). A fajtanevek közül szerepel a szótárban például a Conference: „nyújtott alakú, sárgásbarna, őszi körtefajta” vagy a Granny Smith: „,nagy, zöld alma; ausztrál fajta.”

A kulturális szótárban sok cím szerepel önálló címszóként: ezek többnyire nevezetes sajtótermékek, irodalmi müvek vagy dalok (slágerek) címei. Önálló szócikket kapott a Lord's Prayer, itt a címszó után - szinte kivételesen - a magyar megfelelő áll: „Miatyánk", ezt az ima forrásnyelvi szövege követi. A közismert sajtótermékek közül megtaláljuk többek között a The Times-t. A viszonylag hosszú szócikk összefoglalja az újság hosszú és bonyolult történetét, bemutatja olvasóközönségét és jelentőségét.

Eseményneveket is felsorakoztat a szótár, például a Midsommer-t, ezt a „nyári napforduló eredeti pogány rítusait a keresztény máz alatt is megőrző germán Nap-ünnep"-et, amelynek hagyományos dátumán kívül ősi szokásait is megismerhetjük a szócikkből.

5.2. Amerikai kulturális szótár. Az egyéb nevek kategóriájában előfordul számos intézménynév, például a Guggenheim Museum és a Disneyland, amelyek személynévből keletkeztek másodlagos névadással. A Met címszó a Metropolitan Opera szócikkéhez irányít; ez utóbbi az operaház történetéről tudósít. 
A politikai pártok és mozgalmak nevei közül megtalálhatjuk a szótárban többek között a Democratic Party-t, a Republican Party-t és a Tea Party-t. Ezekben a szócikkekben a pártok rövid története, legmeghatározóbb elveik és képviselőik szerepelnek.

Természetesen számos amerikai márkanevet is felvonultat a szótár. A Cadillac $(C a d d y)$ a General Motors státuszszimbólumnak számító autójának vevőkörét mutatja be, ugyanakkor utal a névadás motivációjára is: ,a Detroit-ot megalapító és elsőül kormányzó francia Cadillac báró nevét viselő michigani városkában készül."

Eseménynevekben is bővelkedik az amerikai kulturális szótár. Az amerikai történelmet meghatározó fontos események elnevezései címszóként jelennek meg a szótárban. A Civil War megadja a név bevett déli szinonimáit (War Between the States, War of Secession), és összefoglalja a háború legfontosabb céljait és lépéseit. A történelmi eseményt jelölő címszó horderejére utal, hogy 11 további szócikkre található benne utalás. A Declaration of Independence esetében megtaláljuk a magyar tulajdonnévi megfelelőt: Függetlenségi Nyilatkozat, majd létrejöttének rövid leírását, a szócikk nagy részét azonban egy hosszabb idézet teszi ki.

Amerika újabb történetéből is találunk eseményneveket: a Nine Eleven vagy 9/11, definíciója szerint „,a New York-i World Trade Center ikertornyai ellen intézett 2001-es terrortámadás dátuma (szeptember 11.), illetve ma már magának az eseménynek a szinonimája” (tkp. inkább a neve). A szócikkből megtudjuk, hogy „a nine-eleven »odacsapni« értelemben igeként is használatos". A Great Depression (nagy világválság) szócikke - a szócikkek nagy részéhez hasonlóan - ugyancsak nem tartalmazza a tulajdonnév magyar megfelelőjét, de leírja az esemény legfontosabb lépéseit és következményeit.

A jellegzetesen amerikai ünnepek is helyet kaptak a szótár szócikkei között. A Halloween szócikke például az ünnep eredetéről, hajdani és mai szokásairól számol be részletesen: „október 31, Mindenszentek napjának előestéje.” Itt az amerikai és angol szokások egybevetésére is találunk példát.

Az amerikai kultúra európai „,kisugárzásának” jeleként a címek között számos - a filmiparral és a könnyüzenével kapcsolatos - címszót találunk. Az Easy Rider szócikke a filmcím magyar megfelelőjével (fordításával) kezdődik: Szelíd motorosok. A film egymondatos (tkp. kétnyelvü) összefoglalása mögül kiviláglik a szótáríró enyhe iróniája: „,in search of fun and freedom, amin a rock, a drug és a sex értendő.” Helyenként a címszavak magyarországi vonatkozásai is előbukkannak a szócikkekből. Pl. a Dallas esetében: „minden idők (nálunk is) legsikeresebb, máig ismételt televíziós soap operája.” A Reader's Digest folyóirat címe szintén címszó lett: itt egyfajta magyar köznyelvi meghatározást is találunk (,az olvasók zanzája”), majd az amerikai olvasói szokásokról kapunk tájékoztatást: „változatlanul a »müvelt« középosztály egyik legkedveltebb olvasmánya, és számai évekig elhevernek a nappalikban, sokan gyüjtik is."

5.3. Francia kulturális szótár. Földrajzi és személyneveken kívül számos egyéb névfajtával is találkozhatunk a szótárban.

Irodalmi és más müvek címei itt is előfordulnak. A Robert-nek nevezett szótár szócikke szerzőjének, Paul Robert-nek a nevével kezdődik: „legendás figurája a francia szótárirodalomnak.” A szótáríró életútjának rövid ismertetése után a Grand Robert egynyelvü nagyszótárt és annak rövidített, nálunk is ismert változatát, a Petit Robert-t említi a szerző. Bár a Roland személynévnél nem volt rá utalás, Chanson de Roland címszó is szerepel a szótárban; itt a szerző nem adja meg a középkori lovagi ének nevének magyar megfelelöjét (Roland-ének). 
A címek és az intézménynevek közötti átmenetnek tekinthetjük a Gault-Millau étteremkalauz nevét; definíciója: „A legjobb éttermek és vendéglők évről-évre kiadott népszerü és sürűn idézett kalauza."

Jelentős intézmények nevei is gazdagítják a szótár címszóállományát. A Louvre szócikke többszörös definícióval kezdődik: „A világ legnagyobb szépmüvészeti múzeuma, építészeti értékeinél és történelmi presztízsénél fogva az ország egyik legismertebb müemléke." Ez követi az épület építéstörténete. Hasonlóan megtaláljuk a címszavak között a Sorbonne-t; a szócikk a „nagyhírü felsőoktatási intézmény” rövid történetét mutatja be, majd röviden utal a mai francia felsőoktatásban betöltött szerepére. A franciaországi pártok neve is helyet kapott a kulturális szótárban. A Front National teljes nevével szerepel címszóként, míg a francia kommunista párt betüszóként: $P C F$, amelyet teljes neve (Parti Communiste Français) követ.

A szótár számos márkanevet tartalmaz. A Chanel $n^{\circ} 5$ esetében a címszót tömör definíció követi: „A világ leghíresebb parfümje.” A parfüm történetén túl utalást találunk híres használóira is. A Perrier név magyarázata is definíció: „Buborékos ásványvíz, a francia ásványvízpiac legismertebb terméke." Emellett természetesen megjelennek a névhez füződő asszociációk: „egy kicsit jelképe is a francia bisztrók hangulatának.” Az utalások között természetesen elsősorban a konkurens márkákat találjuk (Evian, Vittel, Volvic stb.).

A francia autómárkák nevei is címszóként szerepelnek. Míg azonban a Peugeot ,autómárka” és a Renault „francia autómárka, illetve autógyár”, addig a Citroën-t személynévi lemmaként találjuk meg (Citroën, André): „Francia nagyiparos; [...] 1919-ben létesítette autógyárát."

5.4. Német kulturális szótár. Az egyéb nevek között nagy hangsúllyal szerepelnek a szótárban politikai intézmények, szervezetek, pártok nevei. Az ausztriai és németországi pártok ismert betüszavas rövidítéseikkel találhatók meg. Némelyiknél a német nevet magyar megfelelöje követi, másoknál a szócikk szövegében később következik a magyar elnevezés. Az FPÖ: „Freiheitliche Partei Österreichs [...]. Magyarul Osztrák Szabadságpárt néven emlegetik őket.” A CDU: ,a Christlich-Demokratische Union (Kereszténydemokrata Unió) rövidítése.” A szótár az újabb szervezeteket is tartalmazza, pl. AfD: „Alternative für Deutschland (Alternatíva Németországnak); Új keletü német politikai párt, amelyet 2013-ban alapítottak."

A pártok nevein kívül történetileg jelentős szervezetek is megjelennek a szótárban: Hitlerjugend v. Hitler-Jugend; itt magyar megfelelő vagy fordítás helyett a név magyarázata olvasható: „a német nemzetiszocialista párt ifjúsági szervezete volt 1926-tól 1945-ig." Ehhez hasonlóan a német rendszerváltásban fontos szerepet játszó Gauck-Behörde neve is hosszabb magyarázatot kapott: „1990-ben létrehozott német állami hatóság." Ebben a szócikkben utalás van a Stasi mozaikszóra, amelynek szócikkében a szótáríró köznévnek tartja a szervezet nevét: „az NDK titkosszolgálatának, a Staatssicherheitsdienstnek hírhedt köznévvé vált rövidítése."

A modern élet sok más intézménye is helyet kapott a szótárban. Ezek közül sok inkább csak betüszóként ismert: $A D A C, A D N, D A A D, N D R$; ezek feloldása minden esetben megtalálható a szócikkek élén: Allgemeiner Deutscher Automobil Club, Allgemeiner Deutscher Nachrichtendienst, Deutscher Akademischer Austauschdienst (,Német Akadémiai - azaz felsőoktatási - Csereszolgálat”, ,,a Norddeutscher Rundfunk (Észak-német Rádió) rövidítése. Regionális német televízió- és rádiócsatorna”. 
Kulturális intézmények, föleg múzeumok nevével is gyakran találkozhatunk: die Albertina („,bécsi múzeum”), Albertinum („drezdai múzeum”), Kunsthistorisches $M u$ seum („Bécs híres szépmüvészeti [szó szerint: müvészettörténeti] múzeuma”). A GoetheInstitut szócikkében az intézménynév fordítása, majd magyarázó körülírása található: „Goethe Intézet; a német nyelv és kultúra külföldi ápolására és a nemzetközi kulturális együttmüködés elömozdítására."

A szótár erős történeti szemléletéből adódóan történelmi események neve is kereshetö benne, pl. Hermannsschlacht („Hermann csatája”), Nürnberger Prozess („,nürnbergi per”), Siebzehnter Juni (,Június tizenhetedike, az 1953-as szovjetellenes kelet-berlini munkásfelkelés emléknapja").

A szoros magyar-német gazdasági kapcsolatnak megfelelően a kulturális szótár számos (a magyar nyelvterületen is ismert) cég- és márkanevet tartalmaz: Adidas $A G, B M W$, DB, Grundig AG, Krupp, Lufthansa, Mozartkugel, Nescafé stb.

A betü- vagy mozaikszóból álló cégnevek feloldását (és ezzel gyakran a név magyarázatát) mindig megtaláljuk az adott szócikkben; pl. Aldi: az 'ALbrecht DIskont' rövidítése." $V W$ : Volkswagen, ,a népautót jelentő szó, az autómárka neve alighanem a legismertebb német szó a világon."

Címek nagy számban fordulnak elő a szótárban: föként sajtótermékek és irodalmi müvek címe; pl. Bild-Zeitung, Spiegel, Stern, FAZ. A folyóiratok nevét általában nem fordítja le a szótáríró: (Der) Spiegel „a legrégibb és legnépszerübb német hírmagazin, amely 1947 óta jelenik meg Hamburgban”, ugyanakkor a cím közszói jelentését közli: „Címe magyarul azt jelenti: 'A tükör'."

A müalkotások címei a német nyelvü irodalom különböző korszakait és müfajait reprezentálják: Erlkönig, Faust, Götz von Berlichingen, Hammerklaviersonate, Hildebrandslied, Kleiner Mann, was nun?, Merseburger Zaubersprüche stb.

A mücímek kategóriájának perifériáján megtalálható még a szótárban: der Heidelberger Chatekismus (,,a legfontosabb német evangélikus katekizmus”) vagy a Köchelverzeichnis (,Köchel-jegyzék”).

5.5. Olasz kulturális szótár. Olasz szempontból jelentős történelmi események nevei közül megtaláljuk a szótárban például a Grande Guerra címszót. A szócikk nem tartalmazza a név szó szerinti fordítását ('nagy háború'), csak a név magyarázatát: ,,az olasz szóhasználatban mindig az első világháborút jelenti”, majd ismerteti az I. világháború olasz szempontból jelentősebb eseményeit. A Risorgimento címszó melletti jelentés „szó szerint 'feltámadás' (de megkülönböztetendő Krisztusétól, amely resurrezione)"; ezt követi a részletesebb magyarázat: ,az olasz nemzet, illetve az ország területi és politikai egysége megteremtésének időszaka."

Az olasz kulturális szótárban is megtaláljuk intézmények, szervezetek neveit. Politikai szervezetek, pártok közül a Brigate Rosse nevet magyar megfelelöjével (Vörös Brigádok), olasz rövidítésével ( $B R$ ) és annak kiejtésével együtt. Jóval békésebb, aktuális szervezetként kapott a szótárban helyet az Alleanza Nazionale; a névnek itt nincs magyar megfelelője, csak egyfajta definíciója: ,jobboldali politikai párt”. A Forza Italia definíciója: „Silvio Berlusconi [...] által 1994-ben alapított, középjobb orientációjú erőket összekovácsoló mozgalom, majd párt." Megjegyzésként olvashatjuk a név jelentését: „Már a labdarúgó-mérkőzéseket felidéző neve is kész program (Hajrá Olaszország).”

Az intézménynevek között fontos szerepet játszanak a múzeumok nevei is. Az $A$-hoz besorolva találjuk az Ambrosiana címszót, mellette zárójelben az intézmény teljes nevét 
(Biblioteca e Pinacoteca Ambrosiana) és meghatározását: „,könyvtár és képtár Milánóban.” Sportszervezetek neveit is megtaláljuk a szótárban. Az Inter címszó után a teljes olasz név következik: Football Club Internazionale Milano, majd a név létrejöttének magyarázata: internazionale ('nemzetközi'), mert a klub a Milannal ellentétben külföldi játékosokat is szerződtetett.

A Barilla az egyik világszerte ismert olasz márka. A szócikk utal arra, hogy a cégnév és a márkanév megegyezik, bár a cégnek további márkái (és márkanevei) is vannak. Több jármümárka nevét is tartalmazza továbbá a szótár: Alfa Romeo, Ferrari, FIAT, Vespa stb. A FIAT esetében a szócikk megadja a betüszó feloldását (Fabbrica Italiana di Automobili di Torino), majd a legfontosabb típusokat (Balilla, Topolino), amelyekhez külön utalások vezetnek. A cég- és márkanév itt is egybeesik: „a legismertebb olasz gépkocsigyártó vállalat [...] és az általa gyártott autók neve.”

Sok különböző müfajú alkotás címe is megjelenik a szótárban. Természetesen filmcímek, például az Amarcord, amelynek szócikke nyelvi magyarázatot is tartalmaz: „Federico Fellini egyik leghíresebb filmjének [...] a címe romagnai dialektusban. Olaszul a mi ricordo, azaz 'emlékezem' igének felel meg." A Bambino di Roma egy szobor neve, amely a gyermek Jézust ábrázolja: ,,a leghíresebb ereklye Rómában.” A Pinocchio a szócikk meghatározása szerint: „Carlo Collodi (valódi nevén: Lorenzini) meseregénye.” Bár a mü teljes címe Le avventure die Pinocchio - Storia di un burattino, a címszó a főhős (fiktív) neve: Pinocchio. A többi kulturális szótárhoz hasonlóan az olasz is megemlékezik a nyelv nagyszótáráról. A Battaglia (,az olasz nyelv nagyszótára”) nevét szintén egykori föszerkesztőjéröl kapta.

A szótár az esetlegesen előforduló homonim címszavak esetében a következőképpen jár el. A Cinquecento ('500') az olaszban egyrészt köznév (?), az 1500-as évek, vagyis a 16. század elnevezése, másrészt egy ismert Fiat-típus (,hivatalosan Nuovo Cinquecento"), amely nevét $500 \mathrm{~cm}^{3}$-es motorjáról kapta. A szócikkben hangsúlyosan szerepel a tulajdonnévi használat, valamint az autómárka ipartörténeti jelentősége.

\section{Speciális kulturális szótárak}

6.1. Svájci kultúra németeknek. ÓDOR LÁSZLÓ (2010) Helvetismen [Helvétizmusok] címü kulturális szótára - a szerző ajánlása értelmében - egyrészt a nem svájci német nyelvüeknek szól, hogy jobban megértsék Svájcot, a svájci német nyelvjárást és a svájciakat, másrészt a svájciaknak, hogy jobban megértsék saját egyedülállóságukat, harmadrészt a magyaroknak is, „Európa örök vendégeinek”, hogy lássák, mindenütt vannak különbségek (ÓDOR 2010: V).

A szerző magyar-német szakot végzett bölcsész, aki 1990-1994 között Magyarország svájci nagykövete volt, de elötte és utána is a nemzetközi kapcsolatokkal foglalkozott; munkásságának alapvető eleme a kultúrkomparatisztika. Diplomáciai munkásságából táplálkozó szótára egynyelvü, alcíme szerint a svájci államszövetség német kulturális szótára.

Az elöbbiekben bemutatott szótárakkal összehasonlítva ez az egyetlen, amely nem szótárszerüen, két hasábba van tördelve, de a betürendbe szedett (svájci német) címszavai és azok (német) megfelelői, illetve magyarázatai egynyelvü szótárt alkotnak. A „szócikkek" sokszor egyetlen szóból, a standard német ekvivalensből állnak.

A szótárban számos földrajzi nevet találunk. Például vízrajzi neveket, mint az Aare, melynek rövid szócikke a folyó útját mutatja be Bern vidékétől a Rajnáig. A Freiburg városnév magyarázata is egyetlen mondatból áll: „,város és kanton a Kelet- és Nyugat-Svájc 
közötti nyelvhatáron.” Előfordul, hogy egy adott hely egy másik (nem német) nyelven ismertebb; ekkor a (korántsem közismert) svájci német megfelelö csak követi a közismert nevet: Lago Maggiore: Langensee.

A svájci szótárban alig-alig fordulnak elő személynevek. Közöttük Svájc történelmének jeles alakjait találjuk, szintén a családnevek (vagy névkiegészítők) szerint betürendbe sorolva: Winkerlied, Arnold: „,a svájci ügy önfeláldozó hőse”; Bruder Klaus: „Niklaus von Flüe, [...] a bölcs 15 . századi remete a mai átlagsvájci tartását, élet- és gondolkodásmódját fejezte ki” (a tanulmány szerzőjének fordítása).

Természetesen jellegzetes svájci szervezetek és pártok neveit is megtaláljuk a szótárban. Az FDP - a németországi betüszóval ellentétben - egy svájci párt nevének rövidítése: Freisinnig-demokratische Partei ('Szabadelvü Demokrata Párt'). Az LdU (Landesring der Unabhängigen: 'a függetlenek gyürüje') egy kelet-svájci párt neve; a párt központja Zürichben található. A Liga Rumantscha Svájc rétoromán lakosságának kulturális és politikai szervezetét jelöli; ekvivalens német nevet (pl. Rätoromanische Liga) nem ad meg a szótár. A svájci intézménynevek gyakran rövidítésükkel szerepelnek a szótárban, ezek feloldása adja meg a név magyarázatát; pl. TCS: „a svájci Touring Club rövidítése."

6.2. Egy város tulajdonnevei. LUKÁCS ANDRÁS 2018-ban megjelent római kulturális szótára nem egy nemzet vagy nyelv kultúráját igyekszik magyarázatokkal ellátni, hanem egy városét. A szótár tehát sok jellegzetesen római kifejezést (nyelvjárásit is) tartalmaz, emellett római hely- és épületneveket, intézmény- és személyneveket, valamint címeket is.

Az Accademia d'Ungheria in Roma intézménynév megfelelöje a Római Magyar Akadémia. A szócikk az intézet rövid történetét és helyszínét is bemutatja.

Ebben a szótárban is gyakoriak a rövidítések, pl. AS Roma: „teljes nevén Assoziazione Sportiva Roma [Róma Sportegyesület].” A betüszó feloldásán túl a köznyelvben használt névalakot is tartalmazza a szócikk: La Roma.

A fordítói szokásoknak megfelelően az uralkodók nevének pontos magyar ekvivalensét is megadja a szótár: Vittorio Emanuele II: II. Viktor Emánuel.

Róma kulturális örökségének megfelelően sok címszó nem olasz, hanem latin nyelvű. Ilyen pl. az „Ara Pacis teljes nevén Ara Pacis Augustae [...] 'Augustus békeoltára””. Az olasz címszót gyakran a latin megfelelő követi, mert az a magyarban is ismertebb. Így épül fel a Tevere szócikke, amelyben a címszó ekvivalense: ,latinban Tiberis, magyarban mind az olasz, mind a latin alak használata elfogadott."

A szótárban „meglepetésként” magyar címszó is található, a Triznya kocsma: „Triznya Mátyás (1922-1991) történész-festőmüvész és felesége, Szőnyi Zsuzsa (19242014) lakásán a hatvanas évektől egészen az ezredfordulóig vasárnaponként, majd később szombatonként rendszeresen összegyültek a magyar emigráció Rómában élő, illetve oda látogató tagjai."

7. Összefoglalás. A kulturális szótárak - mint egy speciális szótártípus képviselői - az egy- és kétnyelvü általános szótárakhoz képest sok tulajdonnevet tartalmaznak, hiszen az egyes országokra vonatkozó - leginkább kulturális - ismeretek átadásában a tulajdonnevek (az adott kultúra híres személyiségeinek és emblematikus helyszíneinek nevei, valamint a helyekhez, személyekhez köthető események elnevezése, intézmény- és márkanevek) kitüntetett szerepet kapnak. 
A kulturális szótárak tipikusan kétnyelvüek: a címszó „szokásos” esetben a forrásnyelven jelenik meg, míg definíciója, meghatározása, illetve körülírása, magyarázata célnyelven (jelen esetben: magyarul) olvasható, ugyanakkor a szócikkek tulajdonképpen az egynyelvü értelmező szótárak mintájára épülnek fel.

A kulturális szótárakban csak ritkán találunk 1 : 1 megfeleltetést (hozzárendelést), ami a többi szótárban a legáltalánosabb és elsődleges eljárásnak számít: „Käsmarkt 'Késmárk', a felvidéki szász város német neve (ma Kežmarok, Szlovákia)" (GYÖRFFY 2018: 148).

A kulturális szótárakban előforduló legtöbb tulajdonnévnek inkább definíció(szerü) értelmezése van, ennek tekinthetjük például, ha az Act of Union címszó mellett a következőket olvashatjuk: ,a parlament által 1707-ben hozott törvény [...], mely $\rightarrow$ Great Britain néven egységes királyságnak nyilvánította Angliát, Walest és Skóciát” (BART 2018: 11). Gyakori ez az eljárás a földrajzi neveknél: „Mariahilferstraße Bécs legnagyobb és legismertebb bevásárlóutcája, amely a magyar bevásárlóturizmus fő célpontja volt a Kádár-korszakban" (GYÖRFFY 2018: 191).

Más esetekben a tulajdonnév által jelölt fogalom elsődleges meghatározása nélkül, körülírás, magyarázat formájában ismerteti a szerző a címszó által megnevezett helyet, személyt, intézményt stb.: „Liberal Democratic Party 1988-ban alakult a $\rightarrow$ Labour Partyból kivált $\rightarrow$ Social Democratic Party (SDP) és a klasszikus $\rightarrow$ Liberal Party egyesülése révén" (BART 2018: 189).

A szótárak eltérő nyelvismeretet feltételeznek, illetve várnak el az olvasóktól. Sok esetben rövidebb-hosszabb idézetek is a névmagyarázat részét képezik, ezek az angol (BART 2018) és az amerikai (BART 2017) kulturális szótárban csak forrásnyelven olvashatók, a franciában (ÁDÁM 2005) azonban az idézeteket következetesen fordításuk követi szögletes zárójelben.

A kulturális szótárak szócikkeinek felépítése kevéssé emlékeztet a klasszikus szótárakéra: közös bennük, hogy kevés nyelvtani információt tartalmaznak, annál több leírást, magyarázatot. A nyelvtani információk közül a francia és az olasz szótár következetesen közli a fönevek nemét, míg a németben ez csak ritkábban jelenik meg, mert a német tulajdonnevek egyik fontos morfológiai jellegzetessége, hogy a nemüket eláruló névelő nélkül használják öket. Pl.

Arlecchino m. ,a commedia dell'arte egyik legjellegzetesebb alakja” (SZTANÓ 2008: 134), hímnemü;

Heure $f$. de verité (l’ ): „A közszolgálati France 2 tévécsatorna népszerü müsora" (ÁDÁM 2005: 119), nőnemü;

e Augsburger Bekenntnis, e Augustana: ,ágostai hitvallás” (GYÖRFFY 2018: 25), nőnemü.

A szócikkek helyenként a nevek pluralia tantum jellegére is utalnak, ha az eredeti (forrásnyelvi) tulajdonnevek többes számban használatosak, vagy így váltak tulajdonnévvé:

Halles (les ): „Az egykori vásárcsarnokot [...] 1853 és 1870 között építették" (ÁDÁM 2005: 118).

A szótárak a személyneveket általában (az adott forrásnyelvi névsorrendtől eltérően) a családnevekkel kezdődően közlik, pl. King, Jr. Martin Luther (BART 2017: 124), uralkodók 
esetén a keresztnév a cím előtt áll, pl. Albert, Prince (BART 2018: 13, az olasz szótárban azonban Regina Elena (SZTANÓ 2008: 239), Papa Lambertini (SZTANÓ 2008: 207).

A kulturális szótárakban a tulajdonnevek közvetítésének (VERMES [2005] osztályozása szerinti), illetve a tulajdonnévpárok tagjai közötti kapcsolatnak mind a négy típusával találkozhatunk. (A szótárakban szereplő szócikkek címszavai természetesen nem szövegekbe ágyazva jelennek meg, így csak a szócikkek felépítéséböl következtethetünk a közvetítés lehetséges fajtájára.)

Átvitt név esetén az eredeti (forrásnyelvi) tulajdonnév átvitel útján, változatlan alakban jelenik (jelenne meg) meg a célnyelvben a célnyelvi névforma nélkül (már ha létezik ilyen), a szótárak definiálást vagy körülírást alkalmaznak. Pl. Suhrkamp: ,,a legtekintélyesebb német nyelvü szépirodalmi és társadalomtudományi könyvkiadó Frankfurt am Mainban.” A szótárakban gyakran találkozunk átvitellel üzlet- és márkanevek esetében.

Behelyettesítésnek tarthatjuk, amikor a forrásnyelvi tulajdonnév konvencionális (történetileg alakult) célnyelvi megfelelöje jelenik meg a szócikkben. Ez különösen gyakori a célnyelvi nyelvhasználó közösség számára többé-kevésbé ismert (vagy akár a közösségek számára „közös”) földrajzi nevek esetében. Pl. Thüringen: „Türingia” (GYÖRFFY 2018: 293). A célnyelvi megfelelő (különösen az olasz szótárakban) néhány esetben más nyelvből kölcsönzött; pl. Adriano: „latinul és magyarul Hadrianus” (LUKÁCS 2018: 9). Hagyományosan ide tartoznak az uralkodók (pápák) nevei is.

Szükebb értelemben vett fordítást találunk általában a (több szóból álló) intézményneveknél, amikor a forrásnyelvi tulajdonnév lexémáit többé-kevésbé pontosan, de a célnyelv morfológiai-szintaktikai szabályainak figyelembevételével célnyelvi megfelelökkel helyettesítjük: Accademia d'Ungheria in Roma: „Római Magyar Akadémia” (LUKÁCS 2018: 7), SPD: Sozialdemokratische Partei Deutschlands: Német Szociáldemokrata Párt" (GYÖRFFY 2018: 279).

Modifikációt feltételezünk azon névpároknál, ahol a célnyelvi megfelelő konvencionálisan nem áll kapcsolatban a forrásnyelvivel, csak annak funkcióját jelzi. Pl. Signor Bianchi: „Kovács úr, azaz a tökéletesen átlagos ember” (SzTANÓ 2008: 262).

A fenti eljárások egy-egy név esetében keveredhetnek is (vö. LuKÁcs 2012): Barbarossa: „Rőtszakállú ( $\rightarrow$ Rotbart) I. Frigyes”, a Frigyes behelyettesítés, a Rőtszakállú szükebb értelemben vett fordítás eredménye.

Mint láttuk, a kulturális szótárak olyan enciklopédikus lexikográfiai müvek, amelyek az egyes idegen nyelvek és nyelvhasználó közösségeik fontos és/vagy jellegzetes kulcsszavait tartalmazzák, amelyek nem elhanyagolható része tulajdonnév. Ezen tulajdonnevek bemutatása a vizsgált szótárakban éppoly különböző, mint a lemmaállomány kiválasztásának szempontjai, a tulajdonnevek nyelvi közvetítésének elvei azonban a legtöbb esetben megfelelnek a fordítási hagyományoknak.

\section{Felhasznált források}

ÁDÁM PÉTER 2005. Francia-magyar kulturális szótár. 2. kiadás. Corvina Kiadó, Budapest.

BALOGH F. ANDRÁs 2017. Német-magyar kulturális szótár. Szász, sváb, landler, cipszer és bukovinai német nyelvü kultúra a történelemben és mindennapokban. Anyanyelvápolók Erdélyi Szövetsége, Sepsiszentgyörgy.

BART, ISTVÁN 2005. La Hongrie et les Hongrois. Magyar-francia kulturális szótár. Corvina Kiadó, Budapest. 
BART, ISTVÁN 2015. Hungary \& The Hungarians. Magyar-angol kulturális szótár. 4. kiadás. Corvina Kiadó, Budapest.

BART, IstVÁN 2016. Ungarn Land und Leute. Magyar-német kulturális szótár. 3. kiadás. Corvina Kiadó, Budapest.

BART IsTVÁn 2017. Amerikai kulturális szótár. 2. kiadás. Corvina Kiadó, Budapest.

BART IsTVÁN 2018. Angol kulturális szótár. 3. kiadás. Corvina Kiadó, Budapest.

BENÖ ATTILA 2009. Román-magyar kulturális szótár. Anyanyelvápolók Erdélyi Szövetsége, Sepsiszentgyörgy.

PÉNTEK, JÁNOS - BENŐ, ATTILA 2013. Dicționar cultural maghiar-român. Anyanyelvápolók Erdélyi Szövetsége, Sepsiszentgyörgy.

GYÖRFFY MiKLÓs 2018. Német kulturális szótár. 2. kiadás. Corvina Kiadó, Budapest.

Gy. HoRVÁTH LÁszLÓ 2018. Japán kulturális szótár. 2. kiadás. Corvina Kiadó, Budapest.

LUKÁCS ANDRÁs 2018. Róma. Kulturális szótár. Corvina Kiadó, Budapest.

ÓDOR, LÁSZLó 2010. Helvetismen. Deutsches Kulturwörterbuch der Schweizerischen Eidgenossenschaft. Martin Meidenbauer Verlagsbuchhandlung, München.

ÓDOR LÁSZLÓ 2016. Új német-magyar olvasmányos kulturális szótár esszé. K. n., h. n.

SOPRONI ANDRÁs 2008. Orosz-magyar kulturális szótár. Corvina Kiadó, Budapest.

SZTANÓ LÁSZLó 2008. Olasz-magyar kulturális szótár. Corvina Kiadó, Budapest.

\section{Hivatkozott irodalom}

FÁBIÁN ZSUZSANNA 2015. A szótár, illetve a lexikon és az enciklopédia megkülönböztetése az „enciklopédikus szótár” müfajának tükrében. In: FÁBIÁN ZSUZSANNA - SzÖLLÖSY ÉVA szerk., Szótár, lexikon, enciklopédia. Kérdések és feladatok. Segédkönyvek a nyelvészet tanulmányozásához 172. Tinta Könyvkiadó, Budapest. 17-38.

KLAUDY KINGA 1994. A forditás elmélete és gyakorlata. Angol, német, francia, orosz forditástechnikai példatárral. Scholastica Kiadó, Budapest.

Klosa, ANNETTE - SCHNÖRCH, UlRICH - Schoolaert, SABINE 2010. Stichwort, Stichwortliste und Eigennamen in elexico. In: DyKSTRA, ANNE - SCHOONHEIM, TANNEKE szerk., Proceedings of the XIV EURALEX International Congress. 6-10 July 2010. Fryske Akademy - Afûk, Leeuwarden/Ljouwert. 653-663. http://www.euralex.org/elx proceedings/Euralex2010/052 Euralex_2010_3_KLOSA\%20SCHNORCH\%20SCHOOLAERT_Stichwort, $\% 20$ Stichwortliste $\% 20$ und $\% 20$ Eigennamen $\% 20$ in $\% 20$ elexiko_Einflusse $\% 20$ der $\% 20$ Korpusbas.pdf (2020. 05. 02.)

LUKÁCS ANDRÁs 2010. A kulturális szótár mint müfaj. Forditástudomány 12/1: 38-49.

LUKÁCS ANDRÁS 2012. Müfajspecifikus megfeleltetési stratégiák az útikönyvek forditásában. Doktori $(\mathrm{PhD})$ értekezés. ELTE, Budapest. Kézirat. http://doktori.btk.elte.hu/lingv/lukacsandras/diss.pdf (2020. 05. 02.)

MAGAY TAMÁs 2015. Szótár, enciklopédia és tipológia. In: FÁBIÁN ZSUZSANNA - SZÖLLŐSY ÉVA szerk., Szótár, lexikon, enciklopédia. Kérdések és feladatok. Segédkönyvek a nyelvészet tanulmányozásához 172. Tinta Könyvkiadó, Budapest. 9-16.

SCHMIDT, BERNHARD et al. 2006. Frankreich-Lexikon. Schlüsselbegriffe zu Wirtschaft, Gesellschaft, Politik, Geschichte, Kultur, Presse- und Bildungswesen. Zweite Ausgabe. Erich Schmidt Verlag, Berlin.

VALLÓ ZSUZSA 2000. A fordítás pragmatikai dimenziói és a kulturális reáliák. Forditástudomány 2/1: 34-49. 
VERMES AlBert PÉTER 2005. Proper names in translation. A relevance-theoretic analysis. Névtani Értesítö 27: 311-314.

SZILÁGYI-KÓSA ANIKÓ

ORCID: https://orcid.org/0000-0003-4680-105X

Károli Gáspár Református Egyetem

Bölcsészet- és Társadalomtudományi Kar

\section{ANIKó SZILÁGYI-KóSA, Proper names in cultural dictionaries}

The study examines the occurrence of proper names in cultural dictionaries based on a few examples. The genre of cultural dictionary is relatively new and particularly Hungarian. These dictionaries are bilingual, specialized dictionaries that present the culturally bound vocabulary of particular (source) languages, often taking into account the interests and knowledge of the target language readers. In the dictionaries selected for analysis (English, American, French, German, and Italian), the proportion of proper names ranges from approximately $30 \%$ to $60 \%$. There are many types of proper names. These can be grouped into three categories: toponyms, anthroponyms, and other names (of institutions, brands, etc.). On the one hand, the cultural dictionaries contain very little grammatical information in the entries of proper names. On the other hand, there are several definitions, descriptions, while ways of transmitting names (unchanged transfer, replacement, translation, and modification) can also be encountered. 


\section{Tulajdonnévszótári típusok}



FARKAS TAMÁS - SLÍZ MARIANN szerk., Tulajdonnevek és szótárak. ELTE Magyar Nyelvtudományi és Finnugor Intézet - Magyar Nyelvtudományi Társaság,

Budapest, 2020. 133-144. DOI: 10.26546/4892373.8

\section{A történeti helynévszótárak*}

1. Bevezetés. A szótárak egy-egy nyelv kimunkáltságának legfontosabb mutatói közé tartoznak, s ezáltal ,a lexikogáfiai munkák gazdagsága, pontossága, sokfélesége, frissessége az adott nyelv kutatóinak, összességében pedig a nyelvtudományának is fontos értékméröje" (HOFFMANN-TóTH 2015: 195). A magyarság történetének fontos forrásaiként számon tartott régi helyneveknek a lexikográfiai feldolgozottságát, konkrétan a magyar helynévkincs közreadásának két tipikus müfaját, a történeti helynévszótárakat és a helynévtárakat, illetve azok sajátosságait legutóbb HOFFMANN IsTVÁN ismertette a 2017. november 29-én megrendezett Alkalmazott Névkutatás 2017. Nevek és szótárak címü szimpóziumon. Előadásában a 19. század első felétől, a magyar helynévszótár létrehozására tett első törekvések megfogalmazásától tekintette át azokat a munkákat (elsősorban szótárakat, névtárakat), amelyekben a helynevek hol kisebb, hol nagyobb szerepet kaptak, végigtekintve ezáltal azt az utat, hogy miként is jutott el a magyar nyelvtudomány, illetve a szótárirodalom a legújabb, korai helynévanyagot feldolgozó helynévszótárakig. Jelen írásomban erre támaszkodva mutatom be a helyneveket érintő, a 19. század második felében kibontakozó és napjainkban is lendületesen folyó szótárírói munkálatokat, illetve az e neveket részletesen is tárgyaló lexikográfiai munkákat, azok típusait és jellegzetességeit.

2. Törekvések a magyar helynévkincs közreadására. 1817-ben gróf TELEKI JÓZSEF, a reformkor egyik legnagyobb társadalomtudósa fogalmazta meg elsőként egy magyar helynévszótár létrehozásának igényét az Egy tökéletes magyar szótár elrendeltetése, készítés módja címü pályamunkájában. Az 1821-ben megjelent müben arról értekezett, hogy a magyar nyelv létrehozandó szótárának a magyar személynevek mellett mindenképpen tartalmaznia kell a helyneveket is. Ezt a törekvést a következőképpen fogalmazta meg: „Eggy hasonló második tóldalékban lehetne a' nevezetesebb hazai vidékek, városok, helységek, vizek, hegyek 'sa't. és az olly idegen tartományok, országok, városok 'sa't. nevezeteit, mellyeknek nyelvünkben különös eredeti nevök vagyon, felvenni. Ezek tulajdonképen inkább a' földeirási [!] Lexiconokba tartoznának, mivel mindazáltal azok nélkül a' közbeszédben sem lehetünk el, és különösen a' hazaiak nemzésének megvisgálálása [!], nyelvünk egész alkotásába, nagy világot önthet, azokat a’ nyelvünk gyarapodását tárgyazó szótárunkban egészszen elmellőznünk nem lehet, sőt a 'szónemzés' vóltaképen való kifejtésének tekintetéből kénytelenek leszünk, a' hazai helységek vizek és erdők közül némelly kevésbe nevezetesekröl is említést tenni." (TELEKI 1821: 18; kiemelések törölve - K. É.) A TELEKI által elképzelt helynévtár azonban - bár a magyar nyelvnek azóta több, teljesnek szánt szótára is napvilágot látott - máig sem készült el (vö. HOFFMANN-TÓTH 2015: 195). Az, hogy TELEKI a tökéletes magyar szótár toldalékának szánta a helyneveket tartalmazó részt, azt jelezheti, hogy a 19. század első felében a magyar tudományosság képviselőinek igen hiányos képük lehetett a magyar helynévkincs nagyságáról. A teljes magyar helynévanyag - a mai ismereteink szerint - milliós

\footnotetext{
* Készült az MTA-DE Magyar Nyelv- és Névtörténeti Kutatócsoport programja keretében.
} 
nagyságrendre rúg, amelynek összegyüjtése és közreadása rendkívül idö- és munkaigényes feladat (vö. HoFFMANN-TóTH 2015: 196), ahogyan ezt például a skandináv nyelvek vagy a finn nyelv sok évtizedes, söt évszázados kutatómunkával létrehozott, több millió helynévadatot tartalmazó helynévarchívumai is mutatják (vö. HOFFMANN 2010: 225).

2.1. 19. századi előzmények. A helynevek iránti érdeklődés az egész 19. századon végigvonult, s a TELEKI-féle tökéletes szótár igénye valamelyest realizálódni látszott a szótárirodalomban. KRESZNERICS FERENC szócsaládokat bemutató Magyar szótár gyökérrenddel és deákozattal címü kétkötetes munkájában is helyet kaptak ugyan a helynevek, de csak minimális információval közölve őket: a szerző tájékoztatja az olvasót a helyek fajtájáról (pl. víz, szabad puszta, falu, szabad királyi város), valamint lokalizálja a helyeket LIPSZKY JÁNOS Repertoriuma alapján (vö. KRESZNERICS 1831-1832. 1: L). A nagyobb magyar helységek nevei mellett olvashatjuk latin megfelelöjüket, valamint frazeologizmusokban való használatukat. Jól mutatja mindezt a Deb-szócsaládba sorolt Debrecen példája az 1. ábrán.

TELEKI JÓZSEF munkáját vette alapul a Magyar Tudományos Akadémia kezdeményezésére a CZUCZOR GERGELY és FOGARASI JÁNOS által készített, 1862-1874 között hat kötetben megjelent A magyar nyelv szótára $(\mathrm{CzF})$. Ebben a kiváló történeti forrásként használható szótárban a helynevek már nyelvileg jóval gazdagabb kifejtést kaptak: a kiejtési változatok és a frazeologizmusokban szereplő helyragos alakok mellett a névfejtés is előtérbe kerül, amint azt a 2. ábra ugyancsak Debrecen példáján kitünően szemlélteti.

1. ábra

A Deb- szócsalád KRESZNERICS munkájában
2. ábra

A Debrecen szócikke a CzF.-ben
DEB.

DEB.

DEBELLA. Nagy magas leángról mondatik. Sz. D.

DEBERKE. Scaphium, orca. PP.

DEBREC2EN. Debrecinum. M. A. Sz. KV. Bihar Vben. Debreczenbe pipáert, Sregedre dobánydrt. tun. Dug. 1. R. p. 294.

Kis Debreczen. E. RF. belso Szolnok Vben.

Dabreczoni szappan.

DEBREK (Kis, lapos, nagy). E. RP. belso Szolnok vben.

DEBREN. B. F. közép Szolnok Vben.

DEBRETE. $P$. Borsod Yben.

DEBRO ( $\mathrm{Al}$, föl).. FF. Heres Vben.

Debród. F. Ábauj Yben.
DEBRECZÉN, DÉBRÉCZG்N, (1), tösgyökeres magyar virosaink egyik legn:agjoblikn, Bihar megythen; helyr. Debreczèn-be, -besu, -böl. Debreczen maja egy vârmegye. Népszó. Debrcczenbe pipáterl, Szegedre dohúnyert. $\mathrm{Km}$. Betekintelt., mine bolond Istök Debreczenbe. Km. Régiesen és más tajejtéssel is: Dälnöczzin.

Némelyek szerint a tót dobvci zem (jó föld) vagy dobrd bzena (jo váshr) szokbobl származott volna. Egyebirint több helynevekkel rokon gyökii, milyenek Debrö, Döbro, Debrek, Debren, Debrete, Debrb̈l, Döbör, Dübrög ćs a szalamcgyci Döbröcze, melyekhez ismét hasonló a faediongt, hödönt jelentb debcske, «zo.

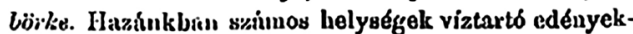
töl , illetölẹ döbönïs kutaktól vették neveiket, mint:

Noha címében viseli a szótár megjelölést FÉNYES ELEK közismert Magyarország geographiai szótára címü munkája (1851), és valóban csakis helyneveket, közelebbről településneveket tartalmaz, mégsem tekinthető helynévszótárnak (ugyanakkor becses helytörténeti forrásként tartható számon). A helynevek adatolása, nyelvi leírása helyett ebben ugyanis a helyek természeti adottságairól, történetéről, gazdasági-társadalmi képéről kapunk részletes információt.

A történeti névanyag feltárásában az első komoly próbálkozásnak JERNEY JÁNOS Magyar nyelvkincsek Árpádék korszakából (1854) című művét tarthatjuk. KISS LAJOS 
véleménye szerint JERNEY ezzel a munkájával „megvetette alapját a magyar történeti lexikográfiának" (1994: 393). A két füzetből álló kötet Árpád-kori oklevelekben, krónikákban és egyéb írott forrásokban (pl. imádságokban) elöforduló hely- és személyneveket, valamint közszavakat tartalmaz szótárszerü elrendezésben. A tulajdonneveket magában foglaló első részben a szerző ekképp fogalmazta meg törekvését: ,„az árpádiak korszakát a' XIV-dik század első évéig fölkarolva, a' hely-, határ-, vidék-, hegy-, völgy-, erdö-, folyó-, család-, személy-, hivatal-, eszköz- 's egyébb ide vonatkozó, bármirészben magyar szóértelmet tartalmazó neveket és szólásformákat összegyüjtvén, szótáralakban körülbelöl mintegy ötezer vezérszóval ellátva közrebocsátom” (1854: V). A címszavakat a nevek betühív adatai, majd az évszám és a lokalizálás követi, a forrásjelölés ugyanakkor igen gyakran hiányzik. A kötetben etimológiai fejtegetések nem kaptak helyet. A szócikkek felépítését láthatjuk például a 3. ábrán szereplő Ér példáján.

A 19. század tudósai közül mindenképpen ki kell emelnünk PESTY FRIGYES nevét, aki talán a legtöbbet tette a helynevek ügyéért. E tevékenysége csúcsaként tekintett egy magyar helynévszótár létrehozására. E tervezett sorozat első kötete 1888-ban, a halála elötti évben jelent meg Magyarország helynevei történeti, földrajzi és nyelvészeti tekintetben címmel. PESTY úgy vélte, hogy nem elég csupán saját korának helynévanyagát vizsgálnia: a kutatást ki kell terjesztenie az okleveles helynévanyagra is, hiszen ,„a névnek legrégibb alakja legbiztosabb kúlcsul szolgál a név megfejtésére, leginkább megóv téves magyarázatoktól" (1888: V). Munkájában ennek megfelelöen egyrészt saját korábbi, 1864-1865-ös országos gyüjtésére, másrészt pedig oklevelekre és más történeti forrásokra támaszkodott. A magyarok mellett az idegen eredetü helyneveket is bevonta a kutatásba. A történettudomány képviselöjeként nem csupán a történeti és a földrajzi szempontokat tartotta szem előtt: helynévmagyarázataiban igyekezett nyelvészeti szempontokat, eredményeket is figyelembe venni (munkásságához bövebben 1. SzABÓ T. 1944/1988: 38-48). A történeti szemlélet megjelenését jól mutatja a 4. ábrán szereplö Ecsér szócikke.

A 19. század végi történeti földrajzi érdeklődéshez kapcsolódik ORTVAY TIVADAR Magyarország régi vízrajza a XIII-ik század végéig (1882) címü müve. A helynevek egyik fontos csoportját, a vízneveket tartalmazó szótárszerü munka 4100 olyan folyó- és állóvíznek a nevét mutatja be, amely történeti forrásokból származik. A szócikkekben a címszót követően a víznév alakváltozatait, a víz jellegét (folyó, halastó, csermely stb.) és pontos helyét olvashatjuk, néhol pedig a név etimológiájáról is kapunk információt. A névalakoknak nincs pontos dokumentálása, a források kezelése ugyanakkor igen gondos.

A 19. századi helynévszótár-írói törekvések betetőzője lehetett volna a Magyar oklevélszótár (OklSz.), amely azonban jórészt figyelmen kívül hagyta a tulajdonneveket. Amint a címlapja (Pótlék a Magyar nyelvtörténeti szótárhoz) és alcíme (Régi oklevelekben és egyéb iratokban elöforduló magyar szók gyüjteménye) is jelzi, ez a régi közszavakat tartalmazó szótár a Magyar nyelvtörténeti szótár (NySz.) kiegészítéséül szolgált, ám csak bizonyos személyneveket (pl. kereszneveket) vett fel anyagába. A keresztneveken túl azonban közszói elemük révén helynevek is bekerültek a szótárba. A helynevekben található közszók szócikkeiben helynévi adatok tömege szerepel ugyan: például az ér címszó alatt találjuk többek között az Érhát (1109: Erhat, terra), a Feket ere (1211: Fekethereh, stagnum), a Kökény ere (1211: Cucen Hereh) és az Ér (1240: Er, fluvius) stb. helyneveket; lokalizálásuk viszont hiányzik, és ez nagymértékben megnehezíti a hasznosításukat. E nyelvtörténeti szótárba kivételesen elhomályosult összetételek (pl. Berettyó, Erdély) is bekerültek. 
3. ábra

Az Ér szócikke JERNEYnél (1854)

Er: Her 1216 VR $313 \S, \mathrm{Er}$

1217 uo $45 \S$ hn Biharban; 1225, "Ad venam Er"6 Veszprémben; 1229 no 358 §,Per vallem nomine Er" völgy Kolosmben; Eer 1249, ,Ad rivum qui dicitur Eer6 fó Baranyában; 1265; , $\operatorname{Eer} 1265$ fó Szatmárban; 1268 viz Komáromban; 1269 ,A quadam vena, quae Er vocalur" Csallokizzben; 1270 ,In quodam fluviolo, qui vulgariter Er vocatur" fó Gö́mörben Sajo körül; 1272 „In trat quamdam vallem, qaae Her vocatur" völgy Nitrában; 1274 fo $; 1283$,Vadit per fluvium qai vocatur Er"' fó Borsodban.
4. ábra

Az Ecsér szócikke PESTYnél (1888)

Ecsér, pus»ta, mely Kövágó-Ö̈rshöz tarto\%ik Y/alı megyëben. Mint falu említtetik 1476. évben Echyr néven. Akkor ugyanis gulaesi Bede György és Emericus de Fichyr maga és testrérei György, Péter és Kelemen nevében ellentmondott gersei Petö György és Jámosinak Guláes helységébe való beigtatásinak. ('l'eleki, Hunyadiuk kora XI. k. 557. lap.) Egy 1617, evi oredeti bevallisbun emlittetik nemes Eeséry Laizár. Régi gót ialésü templomanak és tornyinak tekintelyes romjai $m a$ is láthatók. Közvetlenuil a Balaton partjän srintén épületromok nyúlnak be a vizbe. A nép ezeket na is Paloninah: neveri. K. Ör's határúbun van Eesér nevïi szöllölnegy, melyen zamatos fehér bor terem. Ugyanitt ecséri erröö.

2.2. Lexikográfiai munkák a 20. században és napjainkban. A 20. század elején egy jó ideig nem látjuk megjelenni a helynévszótár elkészítésére vonatkozó célkitüzést; egyedül MELICH JÁNOS munkásságában mutatkozott meg ilyen törekvés. MELICH és a 20. század első felének egy másik kiemelkedő tudósa, GOMBOCZ ZoLTÁN a Magyar etymologiai szótár címủ próbadolgozatukkal 1914-ben megnyerték a Magyar Tudományos Akadémia magyar szófejtő szótár megírására hirdetett pályázatát. A szerzők szótárukban (EtSz.) a teljes magyar szókészlet közreadását igyekeztek megvalósítani, amelyben nemcsak a köznyelvi szókincs, hanem a tájszavak, valamint a régi magyar hely- és személynevek jelentős része is helyet kapott volna. A szavak valamennyi alakváltozatát szándékoztak szótárukban rögzíteni. A tulajdonnevek közül azokat kívánták felvenni a szótárba, amelyeknek biztos vagy biztosnak látszó etimonjuk van, amelyek a magyar hangtörténet számára fontosak (pl. Kolozsvár, Maros stb.), illetve amelyek megfejtéséhez fontos történeti vagy müvelődéstörténeti kérdések kapcsolódnak (pl. Erdély, Buda stb., vö. KISS 1994: 407). Sajnos azonban nem sikerült befejezniük ezt a magas tudományos színvonalú, hatalmas anyagot feldolgozni kívánó munkát, amely 30 év alatt a betürend egyharmadánál, a geburnus címszónál tovább nem jutott.

A történeti helynevek feldolgozása szempontjából MELICH JÁNOS egy másik nagy munkája, A honfoglaláskori Magyarország (1925-1929) is komoly jelentőséggel bír. Ez a mü ugyan nem szótár, és célkitüzésében sem szerepel az erre való törekvés, de mivel MELICH a nyelvtudomány segítségével, a földrajzi nevekből levonható tanulságokra alapozva kívánta megállapítani azt, hogy „milyen nyelvü népeket találtak a IX. század második és a X. század első felében a honfoglaló magyarok az általuk elfoglalt Magyarország területén" (1925-1929: 1), a munka legnagyobb részében helyneveket tárgyal. Ilyenkor a nevek szótárszerü elrendezésben, a szócikkekben az alakváltozatok, 
a lokalizáció és a források pontos megadásával szerepelnek, ezzel mintegy mintát is adva az efféle adatfeltárás számára.

A 20. század középső harmadában a magyar történeti helynévkutatásnak két vonulata erősödött meg. Egyrészt előtérbe került a korai szórványemlékek iránti érdeklődés, amely elsősorban az egyes oklevelek feldolgozásában, monografikus bemutatásában nyilvánult meg. A veszprémvölgyi apácakolostor alapítólevelének szórványait PAIS DEZSÖ (1939), a zobori apátság 1111. és 1113. évi oklevelét pedig KNIEZSA ISTVÁN vizsgálta (1949). BÁRCZI GÉZA a Tihanyi alapítólevél szórványainak nyelvtörténeti tanulságait foglalta össze nagy részletességgel és alapossággal (1951). SZABÓ DÉNES a dömösi prépostság adománylevelének helyesírásával, később hely- és vízrajzával foglalkozott (1937, 1954). Ezek a 20. század középső harmadában készült feldolgozások a nyelvi elemekhez általános magyar nyelvtörténeti szempontok szerint közelítettek.

Ezzel a vonulattal egy időben SzABÓ T. ATTILA jóvoltából az újabb kori helynévanyag közreadásának igénye is felerősödött. Erdély kiváló tudósa tanítványai és munkatársai segítségével kívánta hazája korabeli élönyelvi és történeti helyneveit egybegyüjteni és kiadni. E munka komoly eredményeket hozott, melyeket kötetek egész sorában publikáltak: SzABÓ T. ATTILA nevéhez füződik többek között a Közép-Szamos vidéke (1932), Dés (1937a), Gyergyó (1940), Kalotaszeg (1942) és a Töki-völgy (1945) helyneveinek adattárba rendezése és kiadása, továbbá Szásznyíres (1937b) és Kolozsvár (1946) helyneveinek tanúsága alapján, a névanyag közreadása mellett ezekre alapozott település-, népiség- és népesedéstörténeti következtetések megfogalmazása. A munka kiteljesedését azonban Romániában a korszak politikai viszonyai lehetetlenné tették (erről bővebben 1. BALASSA 1996: 67-78). Ezek az adattárak általában egy-egy település névkincsét adják közre denotátumok, azaz a megjelölt helyek szerinti elrendezésben, gyakran nem szócikkes formában. A kalotaszegi névanyag például az egyes források szerinti időrendben szerepel. A szásznyíresi kötet ugyan szócikkeket tartalmaz, de ezek nem betürendet, hanem lokális rendet mutatnak. Ezen elrendezési elvek miatt e munkákat helynévtáraknak tekinthetjük.

Az 1960-as években BÁRCZI GÉZA kezdeményezésére új lendületet vett a helynévgyưjtő munka, amelyben számos kiváló szakember vett részt, például VÉGH JÓZSEF, ÖRDÖG Ferenc, Balogh lajos, Pesti JÁnos, Hajdú Mihály, JaKab LÁszló, Kálnási ÁRPÁD, SEBESTYÉN ÁRPÁD és MEZŐ ANDRÁs. A gazdag névanyagot tartalmazó Zala megyei névkötet (ZMFN.) 1964-es megjelenését követően az ország mintegy kétharmad részére vonatkozóan több tucatnyi földrajzinév-gyüjtemény látott napvilágot, mint például a Somogy (SMFN.), a Baranya (BMFN.), a Tolna (TMFN.) vagy a Heves (HMFN. 1-4.) megyei helynévtárak. Ezekben a névtárakban sok százezernyi helynévadat található nagyrészt hasonló elvek és módszerek szerint közreadva (denotátumok szerinti elrendezést követve). Ugyanilyen szerkesztési elv alapján, de szócikkszerủen, címszó alá rendezve közlik a névanyagot a Debreceni Egyetemen készült névgyüjtemények. MEZŐ ANDRÁS, JAKAB LÁSZLÓ, KÁLNÁSI ÁRPÁD és SEBESTYÉN ÁRPÁD munkájaként öt járási kötet jelent meg Szabolcs-Szatmár-Bereg megye területéről (SzSzBMFN.). Kiváló regionális helynévgyüjtemények is készültek ez idő tájt: közülük KovÁTS DÁNIELnek a Sárospatak (BALASSAKOVÁTS 1997), az abaúji Hegyköz (KovÁTS 2000), valamint a Sátoraljaújhely (KovÁTS 2008) helyneveit feldolgozó szótárjellegü munkáit emelhetjük ki. E sort persze tovább folytathatnánk, hiszen számos kisebb-nagyobb helynévgyüjtemény látott napvilágot.

A helynévkiadványok újabb generációját képviseli a gazdag történeti anyagot tartalmazó, BÁBA BARBARA szerkesztésében megjelent Hajdú-Bihar megye helynevei sorozat első kötete, A Hajdúböszörményi és a Hajdúhadházi járás helynevei (2015) címú 
munka (HBMHn. 1). E kötet a címben jelzett térség öt településének (Hajdúdorognak, Hajdúböszörménynek, Téglásnak, Hajdúhadháznak és Bocskaikertnek) a teljes, okleveles források és élőnyelvi gyüjtések alapján egybeállított helynévanyagát tartalmazza, településenkénti elrendezést követve. A névtár a névadatokat a megjelölt helyek szerint csoportosítva tárgyalja, vagyis a legfőbb rendező elve - a hasonló helynévtárak általános gyakorlatához igazodva - a denotátum azonossága. A szócikkek szerkezetileg négy nagyobb egységből épülnek fel. A címszó után a történeti és élőnyelvi névadatok sora következik, majd pedig a megnevezett helyre és a névre vonatkozó információkat öszszegző leíró részt olvashatjuk. Ezeket követően a névadatok forrásait, illetve a szócikkek végén a megnevezett hely térképi azonosítóját találhatjuk meg (HBMHn. 1: 9-14). A kiadvány különlegessége, hogy az adatok közreadásában időben visszafelé halad. Mindezt jól szemlélteti az 5. ábrán szereplö, hajdúböszörményi Veréb-sár határrésznév szócikke. A kötet fontos újítása az is, hogy a könyv végén látványos helynévatlaszt, a szócikkek között pedig számos informatív ábrát, képet tartalmaz.

\section{5. ábra: A Veréb-sár szócikke a HBMHn.-ben}

Veréb-sár 1. 2011: Veréb-sár, 1959: Verébsár, 1951: Verébsárhoz, 1897: Verébsár, 1890: Verébsár, 1889: Veréb sár, 1871: Veréb sár, 1857: Verébsár, [1848k.]: Verébsár, 1839: Verébsár, 1808: Verébszar, 1806: Veréb szar, 19. sz. első fele: Verébszar, 1803: Verébszar, diverticulum, [1799-1803]: Verebszar, 1796: Verébsár, 1786: Veréb sár, 1781: Ökrös Nagy András a Verébsártól nádat hozott, 1776: Verebsar, 17671779: Verébsár, [1750]: Praedium Verébsár, 1738: Veréb Sáron tul Nánás felöl, 1703: Inde ac locum Verébsár dictum ingadunt. - Víz- állásos, nádas rész Hajdúvidtől délnyugatra. Korábban önálló birtokként, majorként jelölik. A hagyomány szerint Rákóczi serege a Verébsárnál táborozott. Nevének előtagjában madárnév szerepel, de a névadás pontos indítékát nem ismerjük. Egyes forrásokban Verébszar néven tünik fel. - H. FEKETE 1959: 47, 116, HbT. 1786, [1857], 1871 1890a, 1889, 1890b, 1897a, HnT. 1767-1779a, 1776a, b, LIPSZKY, Map., LIPSZKY, Rep., MoT. [1779-1803], [19. sz.], SzmT. [1750], VÁLyi 1796-1799: 1/267. - T15-G3H2.

A helynév-etimológiai munkák között szintén találunk történeti helynévszótár jellegü kiadványokat. A mintegy 13300 szócikket tartalmazó, a magyar és a jelentősebb külföldi helynevek eredetét magyarázó nagy ívü munka, KISS LAJOS Földrajzi nevek etimológiai szótára című műve (FNESz.) viszont kevésbé tekinthető ilyen jellegünek, mivel minimális történeti adatközlésre szorítkozik, egy-egy névformának csupán a legelső adatát adja meg. Sokkal inkább tekinthető történeti szótárnak MEZŐ ANDRÁs és NÉMETH PÉTER 1972-ben megjelent, Szabolcs-Szatmár megye történeti-etimológiai helységnévtára címü munkája, amely a gazdag névanyagot szócikkszerüen, címszó alá rendezve közli. Ezt a hagyományt követik több évtized múltán a nyíregyházi SEBESTYÉN ZSOLT munkái, aki a történelmi Magyarország északkeleti térségének helynévanyagát dolgozta fel. 2008-ban Kárpátalja teljes területét érintő történeti helynévgyüjtést adott közre, amely hat vármegye (Bereg, Ung, Ugocsa, Máramaros, Szabolcs, Szatmár) 476 egykori és mai településéről tartalmaz helyneveket, településneveket és mikrotoponimákat. A későbbiekben az e munkában megkezdett kutatási irányt mintegy folytatva SEBESTYÉN ZSOLT egy-egy szükebb régió, először a történelmi Bereg (2010), Máramaros (2012) és Ung (2014) vármegye településneveit vonta alapos vizsgálat alá, majd pedig a Felső-Tisza vidékének folyóvízneveit (2017) dolgozta fel. Ezek a munkák a ma is létező helységek 
nevei és ezek etimológiája mellett MEZŐ ANDRÁs és NÉMETH PÉTER kötetéhez hasonlóan az elpusztult települések megnevezéseivel is foglalkoznak.

A Debreceni Egyetemen az Árpád-kori Magyarország egyes vármegyéinek helyneveiröl készültek történeti-etimológiai szótárak: BÉNYEI ÁGNES és PETHŐ GERGELY (1998) Győr, Póczos RiTA (2001) Bodrog és Borsod, RÁCZ ANITA (2005, 2007) Bihar vármegye településneveinek, TÓTH VALÉRIA pedig (2001a és 2001b) Abaúj és Bars vármegye valamennyi helynévfajtájának (azaz a településnevek mellett a víz- és a határneveknek) az összegyüjtését és nyelvi elemzését végezte el. Ezekben a kötetekben a szerzők a korai ómagyar kor helynévanyagát dolgozták fel - elsősorban GYÖRFFY GYÖRGY történeti földrajzi munkájának (Gy.) eljárását követve - ugyancsak vármegyénkénti rendben. A kronológiai határokat tekintve a bihari kötet tünik ki, amely tágabb időkeretet vesz alapul, mivel nem a korai ómagyar kor zárópontjaként tekintett 1350-es évig, hanem a 16. század végéig tartalmazza a helyneveket. E munkákban a szócikkeket a nevek jelentése és szerkezete határozza meg: egy-egy szócikkben a morfológiai szempontból megegyező névadatok szerepelnek, még akkor is, ha azok nem azonos denotátumra vonatkoznak. A címszót a név jelöltjének, denotátumának meghatározása, lokalizálása követi, majd pedig az adatközlő rész, ahol az egyes adatok időrendben szerepelnek. Ezek után a nevek eredetét és történetét magyarázó részt olvashatjuk.

A következőkben a történeti helynévszótárak két kiemelkedő sorozatát mutatom be részletesebben, amelyek a Debreceni Egyetemen a Magyar Névarchívum Kiadványai címü sorozat részeiként láttak napvilágot. Mind a Helynévtörténeti adatok a korai ómagyar korból (HA.), mind pedig a Korai magyar helynévszótár (KMHsz.) sorozat kötetei a korai ómagyar kori Kárpát-medence szélesebb térségeire kiterjedő helynévanyagot dolgozzák fel. A Helynévtörténeti adatok a korai ómagyar korból sorozat idáig megjelent négy kötete HOFFMANN ISTVÁN, RÁCZ ANITA és TÓTH VALÉRIA kiadásában GYÖRFFY GYÖRGY történeti földrajzi munkájának nem településnévi anyagát tartalmazza, vármegyei bontásban szótárrá szerkesztve, ezzel megkönnyítve GYÖRFFY adatainak hozzáférhetőségét és hasznosítását. Az első kötet 1997-ben látott napvilágot, és 15 Árpád-kori vármegye (Abaúj, Arad, Árva, Bács, Baranya, Bars, Békés, Bereg, Beszterce vidéke, Bihar, Bodrog, Borsod, Brassó vidéke, Csanád, Csongrád) helynévanyagát közli. Az 1999-ben megjelent második kötet további hét (Doboka, Erdélyi Fehér, Fogarasföld, Esztergom, Fejér, Gömör, Győr), a 2012-es harmadik kötet pedig kilenc vármegye (Heves, Hont, Hunyad, Keve, Kis-Hont, Kolozs, Komárom, Krassó, Kraszna, Küküllő) nem településnévi anyagát adja közre. A sorozat 2017-ben megjelent negyedik darabjában nyolc vármegye (Liptó, Máramaros, Moson, Nagy-szigeti ispánság, Nógrád, Nyitra, Pest, Pilis) helynévkincse szerepel. A szerkesztők céljuk megvalósítása érdekében, azért tudniillik, hogy az adattár „,a korai ómagyar kor okleveleinek helyet jelölő kifejezéseiről a maguk teljességében tájékoztatást nyújtson" (HA. 1: 9), nemcsak a helyneveket, hanem a helyet jelölö köznévi kifejezéseket is felvették szótárukba. A területi elrendezés - követve GYÖRFFY módszerét - lehetőséget ad egy-egy vidék mikrotoponímiai állományának együttes bemutatására. A jelentéstani, valamint névszerkezeti szempontok szerint kialakított szócikkekben a címszó után a név denotátumának meghatározása, lokalizálása, majd pedig az adatközlő rész szerepel, ahol a betühíven, pontos évszámmal és hivatkozással szereplö adatok időrendben követik egymást. A kialakított utalásrendszer nagymértékben megkönnyíti az értelmezést és a keresést. A kötetek emellett többféle mutatót (név- és szóalakmutatót, címszó- és névelemmutatót, valamint névvégmutatót) is tartalmaznak. Az egyes megyék névanyaga helynévtérképeken is megjelenik. 
A Korai magyar helynévszótár (KMHsz.) szótárterve az 1350 előtti források teljes helynévállományát kívánja feldolgozni. A szótár készítői arra vállalkoztak, hogy közzétegyék „az 1350 előtti időből fennmaradt forrásokban található magyarországi helyneveket és helyeket jelölö kifejezéseket szótári formában" (KMHsz. 1: 6). A 2005-ben HOFFMANN ISTVÁN szerkesztésében megjelent első kötet - GYÖRFFY történeti földrajzi munkája (Gy.) alapján - Abaúj-Csongrád vármegyék névállományát tartalmazza betürendes elrendezésben. Jelenleg a második és a harmadik kötet szerkesztése zajlik. A helynévszótárak általános szerkesztési elvét követve a szótár azonos szócikkeibe a morfológiai szempontból (alaki azonosság alapján) egyező névadatok kerülnek. A legalább egy morfémányi eltérést mutató nevek, névváltozatok külön szócikkben szerepelnek, még akkor is, ha denotátumuk azonos. Ennek értelmében külön szócikkben találjuk meg a lexémányi eltérést mutató névformákat (pl. Acsa-Acsatelke), a képzős és képzőtlen, illetve a különböző képzőkkel alakult változatokat (pl. Horvát-Horváti), valamint a birtokviszony jelölt és jelöletlen névformáit is (pl. Hölgytelek - Hölgytelke). A szócikkekben a címszót követően a hely azonosítása következik, majd pedig szerepelnek (betühív formában, forrásmegjelöléssel) az adatok. A jellemző többnevüséget, alakváltozatokat gazdag utalási rendszer segít bemutatni. Az adatok írásformák szerint vannak csoportosítva, azon belül pedig az első előfordulás szerint követik egymást.

A helynévszótárak főbb szerkesztési elvét láthatjuk a Pest megyei Rákos-nak a HA. 4. kötetéből való példáján (6. ábra), illetve a KMHsz. Okor szócikkét bemutató 7. ábrán.

6. ábra

A Rákos szócikke a HA.-ban
7. ábra

Az Okor szócikke a KMHsz.-ben
Rákos 1. 'Szadánál eredő, Pestnél balról a Dunába torkolló vízfolyás' [1200k.], Chron. saec. XIV.: Racus, fl. (Gy. 4: 497, 550, 555), +1245/ 278: Bakus [f: Rakus], fl. (Gy. 4: 497, 536), 1259, 1325, 1350: Rakus, fl. (Gy. 4: 497, 516, 532, 533, 535, 556), 1325, 1338: Rakws, fl. (Gy. 4: 497, 516, 537). 2. 'a Duna és a Rákos patak között fekvő, Pesttől É-ra és K-re húzódó mező' 1244/333, +1278/330, 1286 [2a], [1286] [2a], [1286]/291, 1286]/326/372, 1289, 1299 [5a], 1300, [1300], 1307, 1310 [о: 1307], 1318: Rakus, camp., loc. 1277, 1298/440, 1299/303//437, Chron. saec. XIV.: Racus (Gy. 4: 550, 551, 672), 1310 [о: 1307]: Ratus [o: Racus], camp. (Gy. 4: 551), Chron. saec. XIV.: Rakos $\sim$ Rachus (Gy. 4: 550).
Okor I. 1. 'az Almával párhuzamosan folyó, a Körössel egyesülő víz Baranya vm.-ben' +1183 / 326/363, 1257, 1274, [1275], 1279, 1283, 1287/ 468, [1292-97], [XIII. vége], 1304/360, 1311, 1330, 1346 (Cs. 2: 512, A. 4: 583, 589): Okur, fl., flum. (Gy. 1: 248, 341, 351, 371, 375, 382, 384, 387, 389-90), [+1235]/350/404: Wkur (Gy. 1: 248, 389), 1287/468: Okwr (Gy. 1: 341), 1294/488: Okor, fl. (Gy. 1: 311), 1332-7/PR.: Vkur (Gy. 1: 341). Vö. Nagy-Okor, Okor (II.1.). II. 1. 'település Baranya vm. ÉNy-i részén az Okor patak mellett' 1257, 1346, 1347: Okur, t. (Gy. 1: 341, A. 4: 589, 5: 70-2). L. Okrimindszent. Vö. Okor (I.1.). 2. 'település Bodrog vm. középső részén Csaszkutától D-re' *1192/374/425: Ocor, 1198 P./PR.: Ocur (Gy. 1: 725).

3. Digitális adatbázisok. Amint az a fentiekből világosan kirajzolódik, a magyar helynévkincs közreadásának két tipikus müfaját különböztethetjük meg: egyrészt helynévtárak, másrészt helynévszótárak formájában jelentek meg az e feladatot vállaló munkák. A prototipikus kiadványok mellett - ahogyan erről már a korábbiakban is szó esett számos átmeneti változatot is találunk e téren. Jogosan merül fel ezzel kapcsolatban a kérdés, hogy miben ragadhatjuk meg e müfajok lényegét, és milyen további lehetőséget bizto- 
sítanak ezek a kutatás számára. Amint láttuk, a helynévtárak általában egy-egy település névkincsét adják közre denotátumok szerinti elrendezésben, lokális rendet követve, általában címszókiemelés nélkül. Ezzel lehetőséget adnak a települések névanyagának mint rendszereknek a vizsgálatára, a belső rendszerösszefüggések felderítésére, és kiválóan használhatók helytörténeti, topográfiai kutatásokhoz, mivel az egyes helyek megnevezéseinek változása jól követhető bennük. Ezzel szemben a helynévszótárakban nyelvi, pontosabban morfológiai jelleg szerint látjuk az adatokat címszó alá sorolva, amelyek betürendben követik egymást. A szótárak az adatokat általában nagyobb térségek szerint adják közre (nem pedig településenként), és ezekben a nyelvterület egészének a vizsgálata kerül elötérbe. Ezzel szorosan összefügg, hogy a névanyaguk átfogó nyelvi szempontú vizsgálatokra (pl. a névrendszer változásainak bemutatására, névtipológiai elemzésekre) könnyebben használható. E két közlési forma tehát jól kiegészíti egymást, és mindkettőnek megvannak az elönyei. Emellett e kétféle közlési forma kölcsönösen át is alakítható egymásba; e téren a digitális közzététel, illetve a régebbi anyagok digitalizálása teremt új lehetőséget, ezáltal pedig a hatalmas adatmennyiség könnyebben kezelhetővé válik. A két müfaj kapcsolata ilyen módon tehát digitális adatbázisokon keresztül valósulhat meg a legeredményesebben, amelyek igen gyakran ma már az újonnan közreadott névtárak és névszótárak alapjául is szolgálnak, de régebbi névtárak tudományos feldolgozását szintén elősegíthetik.

A magyar helynévkutatás e hatalmas forrásanyagot egyrészt a széles körü társadalmi igényeknek, másrészt pedig a tudományos kutatásnak a szolgálatába kívánja állítani. Ezáltal a magyar helynévkincs maradandó formában bárki számára hozzáférhetővé válhat(na), és a további kutatásokhoz, a nyelvészeti igényü feldolgozásokhoz is segítséget nyújt(ana). Ennek az összetett célnak igyekszik megfelelni a Debreceni Egyetem Magyar Nyelvtudományi Tanszékének névkutatói kezdeményezésére kialakított Magyar Nemzeti Helynévtár (MNH.) online adatbázisa. E hatalmas, egyre bővülő digitális adatbank az egész magyar nyelvterület helynévállományának a befogadására és kezelésére alkalmas (erröl részletesebben 1. HOFFMANN-TÓTH 2015). Az Eötvös Loránd Tudományegyetem Magyar Nyelvtörténeti, Szociolingvisztikai, Dialektológiai Tanszékének kutatói szintén ezt a törekvést tartották szem előtt, amikor SzABÓ T. ATTILA kéziratos gyüjtéseit tették hozzáférhetővé nyomtatott és digitális formában egyaránt. A 2001-2010 között megjelent 11 kötetes szótárszerü munka adatainak (ETH.) könnyebb kezelését és hasznosítását a BÁRTH M. JÁNOS szerkesztette Erdélyi Helynévtörténeti Adattár és Interaktív Névföldrajzi Atlasz (EHA.) online adatbázisa teszi lehetővé.

\section{Felhasznált források}

BALASSA IVÁN - KovÁTs DÁNIEL 1997. Sárospatak határának helynevei. Rákóczi Múzeum Baráti Köre, Sárospatak.

BÉNYEI ÁGNES - Pethő Gergely 1998. Az Árpád-kori Győr vármegye településneveinek nyelvészeti elemzése. A Magyar Névarchívum Kiadványai 2. Debreceni Egyetem Magyar Nyelvtudományi Tanszék, Debrecen.

BMFN. = Baranya megye földrajzi nevei 1-2. Szerk. Pesti JÁNOS. Baranya Megyei Levéltár, Pécs, 1982.

CzF. = CZuCZOR GERGELY - FogARAsi JÁnOS, A magyar nyelv szótára 1-6. Emich Gusztáv / Athenaeum, Pest/Budapest, 1862-1874. 
EHA. = Erdélyi Helynévtörténeti Adattár és interaktív névföldrajzi atlasz. SzABÓ T. ATTILA helynévgyüjtése alapján. Szerk. BÁRTH M. JÁNOS. http://eha.elte.hu (2020. 05. 25.)

ETH. = Szabó T. Attila Erdélyi Történeti Helynévgyüjtése 1-11. Szerk. HAJDÚ MiHÁLY et al. Magyar Nyelvtudományi Társaság, Budapest, 2001-2010.

EtSz. = GOMBOCZ ZOLTÁN - MELICH JÁNOS, Magyar etymologiai szótár 1-17. füzet. MTA, Budapest, 1914-1944.

FÉNYES ELEK 1851. Magyarország geographiai szótára, mellyben minden város, falu és puszta, betürendben körülményesen leiratik. 1-2. K. n., Pest.

FNESz. = KISS LAJOS, Földrajzi nevek etimológiai szótára 1-2. 4., bővített és javított kiadás. Akadémiai Kiadó, Budapest, 1988.

Gy. = GYÖRFFY GYÖRGY, Az Árpád-kori Magyarország történeti földrajza 1-4. Akadémiai Kiadó, Budapest, 1963-1998.

HA. = Helynévtörténeti adatok a korai ómagyar korból 1-4. Közzéteszi HofFMANN ISTVÁN RÁCZ ANITA - TÓTH VALÉRIA. A Magyar Névarchívum Kiadványai 1, 3, 25, 43. KLTE Magyar Nyelvtudományi Tanszék / Debreceni Egyetemi Kiadó, Debrecen, 1997-2017.

HBMHn. 1. = Hajdú-Bihar megye helynevei 1. A Hajdúböszörményi és a Hajdúhadházi járás helynevei. Szerk. BÁBA BARBARA. A Magyar Névarchívum Kiadványai 35. Debrecen, Debreceni Egyetemi Kiadó, 2015.

HMFN. = Heves megye földrajzi nevei $1-4$. Szerk. PAPP LÁSZLÓ - VÉGH JÓzSEF etc. A Magyar Nyelvtudományi Társaság Kiadványai 125, 144-145, 181. Magyar Nyelvtudományi Társaság, Budapest, 1970-1988.

JERNEY JÁNOS 1854. Magyar nyelvkincsek Árpádék korszakából 1-2. K. n., Pest.

KMHsz. = Korai magyar helynévszótár 1000-1350. 1-. Szerk. HofFMANN IstváN. A Magyar Névarchívum Kiadványai 10. Debreceni Egyetem Magyar Nyelvtudományi Tanszék, Debrecen, 2005-.

KovÁts DÁNIEl 2000. Az abaúji Hegyköz helynevei. Kazinczy Ferenc Múzeum, Sátoraljaújhely.

KovÁts DÁNIEL 2008. Sátoraljaújhely helynevei és történeti topográfiája. [Sátoraljaújhely Önkormányzata], Sátoraljaújhely.

KRESZNERICS FERENC 1831-1832. Magyar szótár gyökérrenddel és deákozattal 1-2. Egyetemi Nyomda, Buda.

MeLICH JÁNOS 1925-1929. A honfoglaláskori Magyarország. Magyar Tudományos Akadémia, Budapest.

MEZÖ ANDRÁS - NÉMETH PÉTER 1972. Szabolcs-Szatmár megye történeti-etimológiai helységnévtára. Szabolcs-Szatmár Megyei Tanács V. B. Mủvelődésügyi Osztálya, Nyíregyháza.

MNH. = Magyar Nemzeti Helynévtár. Szerk. HofFMANN IsTVÁN - TÓTH VALÉRIA. http://mnh. unideb.hu (2020. 04. 05.)

NySz. = Magyar nyelvtörténeti szótár a legrégibb nyelvemlékektöl a nyelvújitásig 1-3. Szerk. SZARVAS GÁBOR - SIMONYI ZSIGMOND. Hornyánszky, Budapest, 1890-1893.

OklSz. = Magyar oklevél-szótár. Régi oklevelekben és egyéb iratokban előforduló magyar szók gyüjteménye. Gyüjt. Szamota István. Szerk. Zolnai GyUla. Hornyánszky, Budapest, 1902-1906.

ORTVAY TIVADAR 1882. Magyarország régi vízrajza a XIII-ik század végéig 1-2. A Magyar Tudományos Akadémia Könyvkiadó Hivatala, Budapest.

PESTY FRIGYes 1888. Magyarország helynevei történeti, földrajzi és nyelvészeti tekintetben 1. Magyar Tudományos Akadémia Történelmi Bizottsága, Budapest. 
Póczos RiTA 2001. Az Árpád-kori Borsod és Bodrog vármegye településneveinek nyelvészeti elemzése. A Magyar Névarchívum Kiadványai 5. Debreceni Egyetem Magyar Nyelvtudományi Tanszék, Debrecen.

RÁCZ ANITA 2007. A régi Bihar vármegye településneveinek történeti-etimológiai szótára. A Magyar Névarchívum Kiadványai 12. Debreceni Egyetem Magyar Nyelvtudományi Tanszék, Debrecen.

SEBESTYÉN ZsOlt 2008. Kárpátalja településeinek történeti helynevei. Bessenyei Könyvkiadó, Nyíregyháza.

SEBESTYÉN ZSOLT 2010. Bereg megye helységneveinek etimológiai szótára. Bessenyei Könyvkiadó, Nyíregyháza.

SEBESTYÉN ZSOLT 2012. Máramaros megye helységneveinek etimológiai szótára. Bessenyei Könyvkiadó, Nyíregyháza.

SEBESTYÉn Zsolt 2017. A Felsö-Tisza-vidék folyóvíznevei. Nyíregyházi Egyetem, Nyíregyháza.

SEBESTYÉN ZsOLT - ÚR LAJOS 2014. Ung megye helységneveinek etimológiai szótára. K. n., Ungvár.

SMFN. = Somogy megye földrajzi nevei. Szerk. PAPP LÁSZLÓ - VÉGH JÓZSEF. Akadémiai Kiadó, Budapest, 1974.

SzABÓ T. ATTILA 1932. Közép-Szamos vidéki határnevek. Erdélyi Tudományos Füzetek 50. Királyi Magyar Egyetemi Nyomda, Kolozsvár.

SzABÓ T. ATtILA 1937a. Dés helynevei. Füssy Irodalmi és Nyomdai Műintézet, Turda.

Szabó T. AtTILA 1937b. Nireş-Szásznyíres település-, népiség-, népesedés- és helynévtörténeti viszonyai a XIII-XX. században. Minerva, Kolozsvár.

SZABÓ T. ATTILA 1940. Gyergyói helynevek a XVII-XIX. századból. Egyetemi Magyarságtudományi Intézet, Budapest.

Szabó T. AtTila 1942. Kalotaszeg helynevei I. Adatok. Minerva, Kolozsvár.

SzABÓ T. ATTILA 1945. A szolnok-dobokai Töki völgy helynevei. Erdélyi Tudományos Füzetek 193. Erdélyi Múzeum-Egyesület, Kolozsvár.

Szabó T. AtTILA 1946. Kolozsvár települése a XIX. század végéig. Erdélyi Tudományos Intézet, Kolozsvár.

SzSzBMFN. = MEzŐ ANDRÁs etc., Szabolcs-Szatmár[-Bereg] megye földrajzi nevei 1-5. SzabolcsSzatmár megyei Népmüvelési Tanács - Nyíregyházi Tanítóképző Főiskola Nyelvészeti Tanszék etc., Nyíregyháza etc., 1967-1993.

TMFN. = Tolna megye földrajzi nevei. Szerk. ÖRDÖG FERENC - VÉGH JÓZSEF. Akadémiai Kiadó, Budapest, 1981.

TÓTH VALÉRIA 2001a. Az Árpád-kori Abaúj és Bars vármegye helyneveinek történeti-etimológiai szótára. A Magyar Névarchívum Kiadványai 4. Debreceni Egyetem Magyar Nyelvtudományi Tanszék, Debrecen.

ZMFN. = Zala megye földrajzi nevei 1-2. Szerk. PAPP LÁSZLÓ - VÉGH JózSEF / BALOGH LAJOS ÖRDÖG FERENC. Akadémiai Kiadó / Magyar Nyelvtudományi Társaság, Budapest, 1964-1986.

\section{Hivatkozott irodalom}

Balassa Iván 1996. Szabó T. Attila (1906-1987). Erdély nagy nyelvtudósa. Püski Kiadó, Budapest.

BÁRCZI GÉZA 1951. A tihanyi apátság alapitólevele mint nyelvi emlék. Nyelvészeti Tanulmányok 1. Akadémiai Kiadó, Budapest. 
HofFMANN ISTVÁN 2010. Sirkka Paikkala főszerk.: Suomalainen paikannimikirja [Finn helynévkönyv. Ismertetés.] Névtani Értesítö 32: 223-233.

HOFFMANN ISTVÁN - TÓTH VALÉRIA 2015. Magyar Nemzeti Helynévtár. Névtani Értesitő 37 : 195-202.

KISS LAJOS 1994. Nyelvtörténeti szótáraink típusai. Magyar Nyelv 90: 392-412.

KNIEZSA ISTVÁN 1949. A zobori apátság 1111. és 1113. évi oklevelei mint nyelvi (nyelvjárási) emlékek. Magyar Népnyelv 6: 3-50.

PAIS DEZső 1939. A veszprémvölgyi apácák görög oklevele mint nyelvi emlék. A Magyar Nyelvtudományi Társaság Kiadványai 50. Magyar Nyelvtudományi Társaság, Budapest.

RÁCZ ANITA 2005. A régi Bihar vármegye településneveinek nyelvészeti vizsgálata. A Magyar Névarchívum Kiadványai 9. Debreceni Egyetem Magyar Nyelvtudományi Tanszék, Debrecen.

SZABÓ DÉNES 1937. A dömösi prépostság adománylevelének helyesírása. Magyar Nyelv 33: 99109.

SZABÓ DÉNES 1954. A dömösi prépostság adománylevelének hely-és vízrajza. A Magyar Nyelvtudományi Társaság Kiadványai 85. Magyar Nyelvtudományi Társaság, Budapest.

SZABÓ T. ATTILA 1944/1988. A magyar helynévkutatás a XIX. században. In: SzABÓ T. ATTILA, Nyelv és település. Válogatott tanulmányok, cikkek VII. Európa Könyvkiadó, Budapest. 13-84.

TELEKI JÓZSEF 1821. Egy tökélletes magyar szótár' elrendeltetése, készítése módja. In: HoRVÁT ISTVÁN kiad., Jutalomfeleletek a' magyar nyelvröl, a' Magyar Nemzeti Muzeum 1815. 1816. 1817. esztendei kérdéseire. Trattner, Pest.

TÓTH VALÉRIA 2001b. Névrendszertani vizsgálatok a korai ómagyar korban. A Magyar Névarchívum Kiadványai 6. Debreceni Egyetem Magyar Nyelvtudományi Tanszék, Debrecen.

KovÁCs ÉvA

ORCID: https://orcid.org/0000-0002-9111-0728

Debreceni Egyetem

Bölcsészettudományi Kar

\section{ÉVA KovÁCS, Historical place name dictionaries}

The study examines the types and characteristics of lexicographic works that contain, or provide detailed analysis of toponymic data, from the first attempts to create a Hungarian dictionary of toponyms to the most recent dictionaries of early place names. The historical overview follows in the footsteps of István Hoffmann's lecture given at the Applied Onomastics 2017. Names and Dictionaries symposium on 29 November 2017. Two types of place name dictionaries are examined. The first are place name collections that contain the geographical names of a single settlement or place arranged according to the denotations. The second are place name dictionaries that list place names according to morphological characteristics under single entries. The two types of place name dictionaries play complementary roles as the information gleaned from both can be utilized in different ways. Place name collections can be used to study settlements as place name systems, the internal relationships of names within a space, and for research into local history and topography. Meanwhile, place name dictionaries can be used for comprehensive studies throughout the lingual region (e.g., the changes of the name system, name typology). Hungarian toponomastics aims to place the enormous amount of data into the service of the general public and academic research, a goal unachievable without the proper use of digital methods. 
FARKAS TAMÁS - SLÍZ MARIANN szerk., Tulajdonnevek és szótárak. ELTE Magyar Nyelvtudományi és Finnugor Intézet - Magyar Nyelvtudományi Társaság,

Budapest, 2020. 145-164. DOI: 10.26546/4892373.9

\section{A történeti személynévszótárak*}

1. Bevezetés. A személynévi adatok fontosságára legkorábban a történettudományi vizsgálatok kapcsán figyeltek fel a kutatók, így már a 19. század első felében megfogalmazódott egy történeti névtár (onomasztikon) létrehozásának a gondolata (HORVÁT 1821). A kérdés a 19. században megmaradt föként történészi körben, míg a nyelv- és névtörténeti kutatások 20. századi kibontakozásával párhuzamosan a nyelvészek is csatlakoztak egy ilyen jellegü munka szükségességét hangoztatók táborához (erre 1. pl. MELICH 1907: 169, SZABÓ T. 1940: 82, KNIEZSA 1943/2001²: 19). A legkorábbi forrásainkra épülö történeti személynévszótár létrehozásának ügyében a múlt század közepén már a nyelvtudomány vette át a kezdeményezést, ugyanakkor BENKÖ LORÁND arra is felhívta a figyelmet, hogy „régi személyneveinkkel foglalkozó szakembereinknek egy pillanatra sem szabad elfelejtkezniük arról, hogy elért eredményeik nem raktározódnak el a könyvek mélyén, hanem fontos és állandóan használatos segédeszközök lesznek a más tudományágakkal foglalkozó kutatók kezében” (BENKÖ 1949: 245). Ez a BENKÖ LORÁND által megfogalmazott jogos elvárás azonban az összetett és időigényes feladat eredendő nehézsége mellett egyfajta korlátja is lehetett a személynévtani korpuszok összeállitásának, hiszen valóban nagy tudományos felelősséggel jár egy vélhetően sokak által használt interdiszciplináris forrás összeállítása. Szintén hátráltatta a munkát a szótári alapelvek kezdeti kidolgozatlansága, az elvi alapvetések körüli bizonytalanság is. Bizonyára ezek a tényezők együttesen játszottak szerepet abban, hogy a korai személynevek nyelvészeti alapú forrásközlései és feldolgozásai kapcsán immár közel két évszázad után sem beszélhetünk minden téren megnyugtatóan elvégzett és befejezett feladatokról.

Az alábbiakban a személynevek gyüjtésének programszerü meghirdetésétöl, az elért eredmények bemutatásán és értékelésén keresztül a még elvégezendő feladatokig kívánom tudománytörténeti szempontból áttekinteni a kérdéskört. Az ismertetés kronologikus sorrendet követ, az egyes szótári produktumokat a felhasznált forrásanyaghoz kapcsolódó nyelvtörténeti korszakok szerint mutatom be, azokon belül tárgyalom az egyes személynévfajtákat.

2. Tervek és lépések „a magyar Onomasticon” létrehozása érdekében. Habár a korábbi két- vagy többnyelvű szótáraink (pl. MA., PPB.) tartalmaztak szórványosan tulajdonneveket, sőt akár már kisebb névjegyzéket is, melyek között történeti adatok is előfordultak (vö. SZATHMÁRI 1997, 1999; FEKETE 1991), a történeti személynevek rendszeres összegyüjtésének igénye - mint említettem - a 19. századi történeti kutatások kibontakozásával jelent meg. A kutatók hamar felismerték, hogy a tulajdonnevek nyelvi eredetének feltárása nélkül a régi magyar történelem nem ismerhető meg a maga teljességében.

\footnotetext{
${ }^{*}$ Készült az ELTE Bölcsészettudományi Karán a Tématerületi Kiválósági Program, a Magyar Tudományos Akadémia Bolyai János Kutatási Ösztöndíja, valamint a Nemzeti Kutatási, Fejlesztési és Innovációs Hivatal (NKFIH) 116414. nyilvántartási számú szerződése támogatásával.
} 
Egy korai adatokat tartalmazó személynévtár hiánya főként a történeti helynévvizsgálatok terén merült fel. HoRVÁT ISTVÁN történész már 1821-ben kijelentette, hogy „a’ magyar Onomasticon nálunk még gyermeki korban sincsen, bár haszna igen nagy lehetne a' Genealogia készítésben és a' perlekedés folytatásokban. E' nem képzelt tárgyról keveset mondani annyi még most, mint Nevetséget okozni..." (HORVÁT 1821: 49.) A megállapítást követően a század végéig azonban érdemi lépések alig történtek e téren. JERNEY JÁNOS (1854a) ugyan a Magyar nyelvkincsek Árpádék korszakából címü munkájában közöl névadatokat, de ez még nem tekinthető valódi névtárnak. Művét azzal a szándékkal adta ki, hogy „honi régiségeinkben” elszórtan található „magyar szók eddigelő egy halmazban nem birtoklásából” a kutatás számára adódó hiányosságot pótolja. A gyüjtés felső határaként az Árpád-ház kihalását jelölte meg. Müvében a tulajdonnévi szórványokon kívül közszavakat is közölt, többek között a Halotti Beszéd szavait is szócikkbe rendezte. Forrásai között nemcsak oklevelek, hanem Anonymus és Kézai gesztája, több krónika (a 14. századi krónikakompozíció, a Pozsonyi krónika és a Turóczi-krónika), illetve a Váradi Regestrum is szerepelt. A hely- és személyneveket a közszavakkal együtt betürendben közölte. Megadta az adat évszámát, de a lelöhelyet terjedelmi okokra hivatkozva nem tüntette föl. Ezt az eljárást azonban már kortársai is jogos kifogással illették (vö. JERNEY 1854b: 90). A vitatható gyüjtési és közlési mód ellenére pozitívumként kell elismerni azt, hogy a nyelvi adatokat a szerző megpróbálta azonosítani, címszóként megadva a szó 19. századi alakját. A közszó- és tulajdonnév-gyüjtemény a JERNEY kutatásai során feltárt adatokat tartalmazta, értelemszerüen teljességre nem törekedhetett.

JERNEY munkájának jelentőségét az adja, hogy „felismerte a nevek kutatásának fontosságát a nyelvi és történeti kérdések megoldásában" (BASKI 1986: 89). Hogy mennyire fontosnak tartotta egy történeti névtár létrehozását, ${ }^{1}$ jól példázza, hogy „,szózatot” fogalmazott meg ,írótársaihoz” a magyar onomasztikon elkészítése ügyében (JERNEY 1854b). Ebben kiemeli, hogy „helyneveink nagyrészben a’ személyekéből alakulván, és épen azért, míg tökéletes Onomasticonnal nem birunk, helyneveink iránt sem jöhetünk minden oldalról tisztába" (JERNEY 1854b: 83). Ez az érv később is gyakran elökerült mind történész, mind nyelvész kutatók munkáiban (pl. BENKŐ 1949: 118, 247-248; MIKESY 1970: 204; KRISTÓ 1976: 17; HAJDÚ 2003: 333; 1. még fenn, valamint TóTH 2013: 233). Azt, hogy a majdani névtárat nemcsak történeti, hanem etimológiai jellegünek képzelte el, néhány személynév (pl. Csanád, Göncöl, Pentele, Tihany, Ugocsa) részletes leírása mutatja.

A JERNEY munkáját követő évtizedekben az onomasztikon ügye történészi körökben ugyan rendre elökerült, lényeges előrelépés azonban e téren nem történt. 1861-ben az Árpádkori új okmánytárban ÉRDY JÁNOS megjegyzi egy névmagyarázat kapcsán, hogy ,a magyar onomasticon meg volt ugyan kezdve [...], de haladásnak épen nem akar indúlni!" (ÁƯO. 2: 247). CSÉPlŐ PÉTER, a Magyar Történelmi Társulat egyik fiatal tagja a Századok hasábjain a Magyar Onomasticon I. Vezetéknevek okmányainkban címü tanulmányában (CSÉPLŐ 1872) a családnevek minél korábbi (11. századi) jelenlétét próbálta minden áron igazolni az oklevelek alapján. A problémafelvető jellegű tanulmánynak csupán a megtévesztő címe utal egy majdani magyar névtárral való összefüggésre. Feltehetően azzal a szándékkal íródott, hogy a névtár gyüjtési körét elsődlegesen a „,vezetéknevekben" határozza meg, legalábbis a NAGY IMRE történésztől érkezett kritikai válasz ezt sugallja (NAGY I. 1872). NAGY IMRE a névtárral kapcsolatos munkálatokat a Történelmi

'„Egy magyar Onomasticon’ létrejöttét senki nálamnál hőbben nem kivánja, belátván ugyanis annak ugy nyelv- mint történelmi tekintetböl hasznos és fölötte fontos voltát” (JERNEY 1854b: 83). 
Társulat „különösen fiatalabb” tagtársainak a figyelmébe ajánlja, „minthogy erre hoszszabb idő kívántatik" (NAGY I. 1872: 341). Kiemeli, hogy egyelőre még az irányelvek sincsenek lefektetve, azaz nincs egyértelmüvé téve, hogy mit és hogyan tartalmazzon az onomasztikon. Azt azonban nem támogatja, hogy csupán a vezetéknevekre terjedjen ki, mivel a névtárnak a „helyneveink megmagyarázására is kulcsúl kell szolgálnia”, ezért szerinte a családnevek kialakulása előtti korszak névanyagát is föltétlenül szótárazni kell (NAGY I. 1872: 343). NAGY GYULA a vitához kapcsolódva tovább pontosította az irányelveket azzal, hogy a keresztnevektől elkülönített tárgyalását szorgalmazta azoknak a névadási módoknak, melyek ,a személyek különféle körülményeit és viszonyait meghatározván, öket egymástól elválasztották, s a melyekből fejlődtek aztán a család- vagy vezetéknevek” (NAGY GY. 1872: 488). Ez utóbbiak közé a „,nemzetségi neveket”, az „atyai neveket" (ti. a filius-os neveket), ,a birtokról vagy származási helyröl vett neveket”, a „mellékneveket” (pl. Kopasz, Garázda, Bátor), valamint a „literatus”-okat (pl. Páldeák, Jánosdeák) sorolta. Ennél tovább azonban nem jutott ez a kezdeményezés sem. (A magyar személynévkutatás első szakaszának történetéhez 1. még MIKESY 1970.)

A személynevek összegyüjtése és szótárba rendezése kapcsán a továbbiakban KUBÍNYI FERENC történész érdemeit kell kiemelnünk, aki elsőként próbálta meg tudományos alapon a korai magyar személynévi adatokat névtárba rendezni. Munkája azonban torzóban maradt, mindössze az első kötet látott napvilágot (1891), amely az Aaron címszóval kezdődik, és az Almus-sal zárul. A szerző müve tartalmát így írja le: a történeti névtár „magában foglalja a hazai krónikákban és oklevelekben elszórva fenmaradt mind azon személyneveket, melyek a régi magyaroknál, illetőleg a Magyarország területén lakott egyéneknél a honfoglalás idejétől kezdve a XIV. évszázad végéig használatban voltak, valamint - az illető kútfők megnevezésével - mind azon személyeknek lehető teljes névsorát, kik ama személyneveket a megjelölt időszakban viselték" (KUBÍNYI 1891: v).

Érdemei között kell említenünk azt, hogy megpróbálta az adatközlés módszerét kidolgozni. Munkájában nem tematikusan, személynévfajták szerint, hanem kronológiai szempontok alapján kívánta a neveket megjelentetni. Az adatközlésben a névvariánsok szerinti rendezőelvet követi, az adatok közötti összefüggéseket ezért csak bonyolult utalásokkal tudja jelezni. Külön szócikkben szerepelnek például az Ábrahám név különböző alak- és becenévi változatai (Ábrám, Ábrán, Ábrahám, Ábránk stb.). Címszóként a betühív átírású névalakot emeli ki, viszont a lehetséges olvasatokat is címszavasítja, melyek között utalások jelzik a kapcsolatot. Például az Ábrán v. Ábrány címszónál utal az Abran-ra, ahol tulajdonképpen az elöfordulás(ok) adata(i) található(k). Az adatok tartalmazzák a nevet viselő személy társadalmi állását, tisztségét, családi kapcsolatait, viszont nem az eredeti forrás szövegét idézve, hanem szabad átírásban (pl. „Akus, Gug fia, nyitrai várjobbágy”, 1235-1270; „Aladarius mester, a Csák nemzetségbeli Kata asszony jogi képviselője”, 1297). Többször hosszabb leírást is ad az adott személlyel kapcsolatban. Például Abba comes fia Miklós kapcsán megjegyzi, hogy „birtokaitól megfosztatott mely itéletet I. Lajos király helybenhagyva, hasonnevü fiára is kiterjeszté", majd a birtokot Kont Miklós nádornak adományozta (KUBÍNYI 1891: 27). Ezzel nyilván a személyek azonosíthatósága felé tesz egy komoly lépést, de kérdés, hogy egy onomasztikonnak feladata-e ilyen részletes személyleírás közlése. Az adatok személyekhez rendelését azonban a fentiek mellett sem várhatjuk a szerzőtöl, hiszen ez archontológiai és genealógiai kutatás nélkül kivitelezhetetlen vállalkozás lett volna. A szerző a fentieken túl megadja az előfordulás idejét, illetve a forrásközlésre utaló hivatkozást is. 
Néhány, a korai névanyag egy-egy etimológiai csoportjával foglalkozó, természetszerüen teljességre nem törekvő, tudományos igényü feldolgozást említhetünk még a későbbi évtizedekből. Ezek között mindenképpen kiemelendő GOMBOCZ ZOLTÁNnak az Árpád-kori török (GOMBOCZ 1915), illetve BAÁN KÁLMÁNnak az ősi magyar személynevekröl írott, tudományos igényü munkája (BAÁN 1944).

A kezdeti, kudarcra ítélt próbálkozások után a második világháborút követően nyílt reális esély a korai századok teljes személynévtárának létrehozására. BENKŐ LORÁND a névtudomány legközelebbi feladataként 1949-ben a régi magyar személynévanyagnak legalább a családnevek kialakulásának koráig (a 14-15. századig) történő összegyüjtését jelölte meg (1949: 247). BENKÖ felhívását követően a Magyar Tudományos Akadémia 1949-ben létrehozott Nyelvtudományi Intézetében el is kezdődtek a történeti személynévtár munkálatai. Az 1950-es években folyó adatgyüjtés előrehaladott állapotáról PAPP LÁSZLÓ számolt be az 1958-ban tartott első névtani konferencián (PAPP 1960). A készülő Árpád-kori személynévszótárról a szakmabelieken kívül már az érdeklödő nagyközönséget is tájékoztatták különböző napilapok hasábjain. ${ }^{2}$ A nyolc év alatt összegyüjtött 120 ezres cédulaanyag további bővítését ígérték a még kiadatlan oklevelek feldolgozásával, a megjelenés idejét pedig 1967 körülre prognosztizálták. Sajnos mindez csupán terv maradt: a kiadás nem történt meg, az összegyüjtött cédulaanyag további sorsa pedig ismeretlen.

Habár a mű nem készült el, az adatgyűjtés alapelveiről PAPP LÁszLÓ tanulmányaiból (1960, 1961) pontosan értesülhetünk. A gyüjtés általános célja „,a névvel megjelölt Árpád-kori személyek számbavétele volt” (PAPP 1960: 126), azaz a legkorábbi emlékektől kezdve 1301-ig az Árpád-kori Magyarországra kiterjedően (beleértve Szlavóniát is) kívánták a személynévi adatokat feltárni. A legvitatottabb kérdést a személynévi eredetü helynevek szótárazása jelentette. A munkabizottság úgy döntött, hogy az eltérö vélemények ellenére (erre 1. pl. PAIS 1960) nem veszik fel a szótárba a személyneveket tartalmazó helyneveket, egyrészt mert nem mindig problémamentes a személynévi eredet igazolása, másrészt a névtárat egyfajta munkaeszközül szánták etimológiai kérdések megoldásához, névgyakorisági elemzésekhez, a társadalmi megoszlásnak, az öröklődésnek, egyes névalakok funkciójának, területi elterjedésének stb. vizsgálatához, amiben a helynévi adatok zavaróak lettek volna. Véleményük szerint amennyiben olyan adatot is szótáraznának, amely az adott forrás keletkezési idejében már nem élő személy nevéből keletkezett helynév, akkor ,a személynév életére vonatkozóan” félrevezethetik az adat felhasználóját (PAPP 1961: 186).

PAPP érvelését helytállónak kell elfogadnunk, hiszen valóban hitelesebb képet kaphatunk a korai névanyagról, ha a névfajtákat egyértelmüen elkülönítjük egymástól, nem hagyva figyelmen kívül természetesen a kapcsolódási pontokat sem. ${ }^{3} \mathrm{Ma}$ is figyelembe vehetőek az átmeneti névformák (helynévi latin birtokos szerkezetek, helymegjelölések stb.) kapcsán megfogalmazott lexikográfiai érveik. A körvonalazott alapelvek között csupán a bibliai és mondai személyek nevének felvétele ellen emelhetünk elvi kifogást.

${ }^{2}$ Vö. pl. Árpádkori személynévszótár. Dunántúli Napló 15/307: 1, 1958. dec. 31.; Árpád-kori személynévszótár készül a Nyelvtudományi Intézetben. Pest Megyei Hírlap 2/307: 4, 1958. dec. 31.; Árpádkori (!) személynévszótár készül a Nyelvtudományi Intézetben. Szolnok Megyei Néplap 9/308: 4, 1958. dec. 31.

${ }^{3}$ Ilyen esetben megoldás lehet például a vonatkozó helynévi adatok szócikken belüli elkülönítése. 
3. Az Árpád- és Anjou-kori személynévtárak. Az Árpád-kori személynevek összegyüjtése és a kutatás számára elérhetővé tétele terén FEHÉRTÓI KATALIN elévülhetetlen érdemeit kell mindenekelőtt kiemelnünk. Az MTA Nyelvtudományi Intézetében vakvágányra futott munkálatok után hiánypótló jelleggel rendezte sajtó alá az Árpád-kori kis személynévtár anyagát. Az 1983-ban megjelent munka öt, 12-13. századi forrás személynévanyagát tartalmazza. A felhasznált források a következők voltak: 1. 1138/1329: a Dömösi prépostság adománylevele (kb. 1400 szn.), 2. 1202-1203: az Aradi káptalan birtokösszeírása (kb. 400 szn.); 3. 1211: a Tihanyi összeírás (kb. 2000 szn.); 4. 12371240: az Albeus-féle összeírás (a Pannonhalmi apátság birtokösszeírása) (kb. 500 szn.); 5. 1208-1235/1550: a Váradi regestrum (kb. 6800 szn.). A névadatok időrendben, szövegkörnyezettel, forrásjelzéssel, etimológiai magyarázat nélkül követik egymást a névcikkeken belül. A mintegy 11 ezer korai névadatot tartalmazó névtár alapján a kutatók a korábbinál pontosabb képet kaphattak a korai magyar személynévállomány összetételéről, viszont mindez kétségtelenül csupán töredéke volt az 1301 előtti forrásokban fennmaradt Kárpát-medencei névanyagnak.

FEHÉRTÓI mindennek tudatában folytatta a gyüjtőmunkát a „teljes” Árpád-kori személynévanyagra vonatkozóan. A gyüjtés körét elsősorban a nyomtatásban megjelent okleveles forrásanyagban határozta meg. Feldolgozta az Árpád-kori új okmánytár köteteit (ÁÚO.), valamint GYÖRFFY GYÖRGY Árpád-kori történeti földrajzából (Gy.) is kigyüjtötte az ott közölt személyneveket. Viszont nem használta fel a FEJÉR GYÖRGY által összeállított Codex Diplomaticus Hungariae címü legelső oklevélközlő sorozatot (F.) az abban található számos olvasati hiba miatt. A csak kéziratban meglévő, mintegy ezer Árpád-kori oklevelet szintén nem dolgozta fel. Az adatgyüjtés térbeli határát a Magyar Királyságra korlátozta, Szlavónia, Horvátország és Dalmácia személynevei ezért kimaradtak a válogatásból.

FEHÉRTÓI agyaggyűjtésének legvitathatóbb eleme az az eljárás, mely a 14. századi krónikakompozíció Árpád-korra vonatkozó nevein kívül Anonymus Gesta Hungaroruma és Kézai Simon Gesta Hunnorum et Hungarorum címü müvének személyneveit érinti. A nyelv- és történettudomány kutatóinak jelentős része ma már egyetért abban, hogy a geszták szereplőinek és az általuk véghezvitt cselekményeknek a hitelessége több esetben megkérdőjelezhető (vö. pl. TóTH 2013: 236). Tudjuk, hogy a szereplök egy része nem valós (mondai) személy, mások nevét pedig Anonymus helynévből alkotta meg, majd talált ki hozzájuk kapcsolható történetet (bővebben 1. pl. BENKÖ 1994, 1998), észrevéve, majd felhasználva a magyar névadásnak azt a sajátosságát, hogy személynévből formáns nélkül is keletkezhet helynév (elsődlegesen településnév). Munkamódszerének legárulkodóbb esetei azok, amikor idegen (nem személynévi) etimonú (főként szláv) helynevekből is hasonló módszerrel hoz létre fiktív személyneveket (pl. dux Salanus $<$ Szalankamen szláv eredetü településnévből, Laborc vezér < Laborc szláv folyónévből, Zobor vezér < szláv hegynévből). A gesztában előforduló személynevek egy másik csoportjánál a személynévi eredet más, korabeli forrás adatával nem erősíthető meg (pl. Galád - ÁSznt. Glad, Tolma - ÁSznt. Tulma, Gyalu - ÁSznt. Gelou, Kölpén - ÁSznt. Culpun stb. - vö. BENKÖ 1998: 18-24).

A fentiekhez hasonló nevek tulajdonképpen az írói névadás korai példáinak tekinthetők (bővebben 1. FARKAS 2019), így a névtár személynevei között feltüntetve azt a téves képzetet kelthetik az olvasóban, mintha ezek is a korabeli névadás valóságos elemei lettek volna. Természetesen a geszták valós személyek nevét is tartalmazzák, de ezek elkülönítése a fiktívektől további kutatást igényel. FEHÉRTÓI fenti munkamódszerét az sem 
igazolja, hogy a kitalált írói nevek némelyike századokkal később, a romantika korától kezdve bekerülhetett a magyar keresztnévanyagba (pl. Salanus $>$ Zalán).

Hasonlóan problémásnak tekinthető a személynévi eredetünek vélt helynevek (pl. Donkháza, terra Gergen) szótárazása FEHÉRTÓI munkájában. A szerző ebben az esetben nem törekedhetett teljes gyüjtésre, hiszen az szétfeszítette volna a szótár kereteit, csupán azokat a neveket igyekezett összegyüjteni, amelyek személynévként nem adatolhatóak. Ez viszont egy olyan szótár esetében, amely a legkorábbi személynévanyagról kíván hiteles képet adni, nehezen fogadható el, hiszen a helynév személynévi előzményét önmagával a helynévvel nem lehet igazolni (az ellenérveket 1. még fenn). Ezeket a neveket mindenképpen külön lett volna célszerü listázni.

Lexikográfiai szempontból mindenképpen említést érdemel, hogy a szerző mủvéhez mutatóként a nemzetségnevek és a női nevek eredeti helyesírás szerinti listáját csatolta. A morfológiai kutatások megkönnyítése érdekében a kötet a teljes névállomány névvégmutatóját is tartalmazza. Fontos segítséget jelent továbbá a kötet tartalmának $\mathrm{CD}$ mellékleten való elérhetővé tétele is.

FEHÉRTÓI a következőket írja a munkájáról: „Névtáram mutatványnak, reprezentatív felmérésnek tekintendő, azaz nem teljes, mégis a jelzett korszak, az Árpád-kor személyneveiről megközelítőleg hü képet felmutató gyüjtés" (ÁSznt. 8). Az ÁSznt. tehát nem tartalmazza a fennmaradt teljes Árpád-kori személynévanyagot, a gyakori nevek esetében a szerző ugyanis válogatta az adatokat, ez pedig névgyakorisági elemzésre nem teszi alkalmassá a gyüjteményt. A gyakoriságszámítást az is megnehezíti, hogy a névtár nem rendeli egy adott személyhez a többszöri névelöfordulásokat. (PAPP LÁszLóéknál még kimutatható ilyen törekvés, bár ennek a megvalósíthatósága kétségtelenül számos nehézségbe ütközött volna.)

Az ÁSznt. ugyan nem tartalmazza az egyes nevek etimológiai magyarázatát, viszont a címszavasítás, illetve a szócikkek közötti utalások összekapcsolják a FEHÉRTÓI KATALIN szerint összetartozó névalakokat. ${ }^{4} \mathrm{Az}$, hogy ennél tovább nem ment a szerzö, nem róható fel neki, hiszen az etimológiai elemzés hasonló vagy még nagyobb nagyságrendü munkát jelentett volna, mint magának az adatoknak az összegyüjtése. „Amennyire örvendetes tény, hogy a régi magyar személynevek tanulmányozása terén az első fontos akadály (ti. egy filológiai alaposságú adattár megjelentetése) elhárult a névkutatók elől, annyira elszomorító a magyar névtudománynak az a nagy adóssága, amely az Árpád-kori személynévadatok etimológiai vizsgálatának hiánya terén mutatkozik" (N. FODOR 2015: 118). Az egyes névalakok körüli olvasati, illetöleg magyarázati bizonytalanság (különösen a számos egy- vagy kétszótagos név esetében) még inkább fokozza a nehézségeket (erre 1. FODOR 2006, SLÍZ 2011a: 56-67). Mindezek a tényezők, illetve a névanyag nagysága pályázati támogatással végzett kutatócsoporti munkát tenne szükségessé.

BENKÖ LORÁND 70 évvel ezelőtt még bizakodóan írta: „A személynév-etimológiai szótár belátható időn belül való megvalósítása lehetségesnek látszik.” Indoklása szerint: „Ilyen jellegü munkánál korántsem kell, és nem is lehet teljességre törekedni. [...] Egyelőre megelégedhetnénk a keresztnevek, valamint a gyakoribb régi világi eredetü személynevek és családnevek etimológiájának a megadásával" (BENKŐ 1949: 249). A névkutatás adóssága e téren kétségtelen. Az Árpád-kori személynevek etimológiai szótárának elkészítése továbbra is a magyar névkutatás elsődleges feladatai közé tartozik.

${ }^{4}$ Ezek az összekapcsolások sokszor hiányosak, esetlegesek és pontatlanok. Összekapcsol nyilvánvalóan nem összetartozó névalakokat is, illetve az is előfordul, hogy egy személy adatai 3-4 szócikkben vannak szétszórva (erre 1. pl. SLíz MARIANN vizsgálatát a Jolánta név kapcsán; 2017b: 59-63). 
Természetesen nemcsak a magyar írásbeliség első három évszázadának névanyaga fontos számunkra, hanem a későbbi koroké is. Az Anjou-kor névtani szempontból kiemelt jelentőségét az adja, hogy a családnevek előzményei ebben a korszakban kezdtek megjelenni az élő nyelvhasználatban. A korszak fontosságát BERRÁR JOLÁN és FEHÉRTÓI KATALIN is felismerte. BERRÁR a női nevek összegyüjtését kiterjesztette a 14. század végéig (1952). Kötetének jelentőségét növeli, hogy a női neveket etimológiai csoportosításban közli; hasonló munka azóta sem készült az Árpád-kor vonatkozásában. FEHÉRTÓI pedig egy kismonográfiát szentelt a 14. századi, az egyénnév mellé kialakult családnévelőzményeknek, a megkülönböztető neveknek (1969), azonban az átmeneti formáknak tekinthető körülíró névszerkezetek jellemző típusai (a latin de prepozíciós nevek, a filius-os nevek stb.) nem képezték részét az adatfeltárásnak.

A korszak személynévi adatainak szisztematikus gyüjtését és szótárba rendezését SLíz MARIANN kezdte el és részben végezte el az elmúlt évtizedben. Az Anjou-kori személynévtár két kötete (SLÍz 2011, 2017a) 1301-1359 közötti időszakra vonatkozó névadatokat tartalmaz. Az együttesen több mint 20 ezres névállományt (első kötet: 14 000, második kötet: 6600 névadat) magukban foglaló müvek hiánypótlóak, hiszen eddig a korszakból nem rendelkeztünk teljességre törekvő, a különböző névformákra, névszerkezetekre is kiterjedő, nem szelektált névanyagot tartalmazó gyüjteménnyel. SLíz nem követte a korábbi szerzők (főként FEHÉRTÓI) eljárásmódját, az általa felhasznált kiadott és kiadatlan oklevelek névanyagát a maga teljességében vette alapul az anyaggyüjtés során. A korai századok forrásaiban fennmaradt névanyag természetesen így is csupán egy véletlenszerü merítése lehet a ténylegesen létezett neveknek, amely azonban a szelektálással még kevésbé tudna hozzájárulni a korszak személynévtörténeti folyamatainak a feltárásához, ezért a szerző megoldása mindenképpen elismerést érdemel.

Az anyaggyüjtés forrásanyagát az Anjou-kori okmánytár hét kötete, a Hazai oklevéltár, a Héderváry és a Károlyi család oklevéltára, a Zichy család okmánytára és az 1332-1337-es pápai tizedjegyzék, valamint néhány kiadatlan oklevél adta. A vizsgált időintervallum az egyelemü névrendszerből a kételemüvé válás folyamatának kiemelt időszaka. Természetesnek tekinthető, hogy ebben az időszakban még az egyénnevek kapnak kiemelt szerepet, hiszen ezek olyan körülíró névszerkezetekben fordulnak elö, amelyekben a korszak elején még ritkán vannak a kételemü névhasználatra utaló elemek. A zajló folyamatot jól érzékelteti az élő nyelvhasználatra utaló (dictus-os vagy anélküli) megkülönbözető nevek számában mutatkozó eltérés a két kötetben.

A névtárak legnagyobb értékét a névadatok közlésén túl az egyénnév eredetére történő utalások adják. Amellett, hogy a ,jól szerkesztett, lehető legtöbb információt (név- és írásváltozatok, névetimológia, azonosítás, helyhez és társadalmi réteghez kötés stb.) tartalmazó, szövegkörnyezetet is közlö névtár a történeti névtanon túl számos tudományág (történelemtudomány, társadalomtörténet, történeti szociológia, nyelvtörténet, helyesírás-történet stb.) kiváló forrása" (SZENTGYÖRGYI 2015: 480), SLÍZ MARIANN munkái etimológiai magyarázatai által egy majdan létrejövő Árpád-kori személynévetimológiai szótár alapvető mintájául és forrásául is fognak szolgálni, hiszen számos, korábban is előforduló névalak „megfejtését” már tartalmazzák (l. még GULYÁs 2014).

Itt kell kitérnünk arra a nagyszabású nemzetközi szótári programra, amelynek célja a Kr. u. 500 (máshol 600) és 1600 közötti európai forrásokban rögzített, valódi (nem fiktív) keresztnevek dokumentálása. A Dictionary of Medieval Names from European Sources [Középkori nevek szótára európai forrásokból] (DMNES.) online épülö anyagába az adatokat a munkatársak folyamatosan töltik fel. Az első megjelenéskor, 2015-ben mintegy 
1000 név 20 ezer névadatát tették elérhetővé számos európai országból, köztük Magyarországról is. A magyarországi adatok feltöltését a szótár munkálataiba időközben szerkesztő munkatársként becsatlakozott SLíz MARIANN végzi. A folyamatosan bővülő adatbázist negyedévente publikálják. A szótár internetes oldalán megtalálható 2019-es statisztikai kimutatás szerint 7329 különbözö keresztnevet tartalmaz, melyekhez 79218 névadat kapcsolódik, ebböl női név mintegy 15 000, férfinév 53000.

A program elindítója és koncepciójának kidolgozója, SARA L. UCKELMAN célja az, hogy minden keresztnevet adatoljanak, amely Európában elöfordult a fenti időszakban. Ebbe természetesen beletartoznak a különböző nyelvek alakváltozatai is, azaz nem korlátozzák a gyüjtést egyetlen nyelvre vagy régióra. Ez az eljárás lehetővé teszi, hogy egy adott név használatáról időben és térben is „teljes” képet kaphassunk, és az országhatárokon átívelö tendenciák is láthatóvá váljanak. Ez tulajdonképpen egy areális történeti keresztnévszótár létrehozását jelenti.

A térbeliség láthatóan kiemelt szerepet kap a programban, ezért sem teljesen érthető az a történelmietlen eljárás, amely az adatokat a mai országokhoz, illetve országrészekhez köti. Így szerepelhet a középkori adatsorok mellett lokalizációként Belgium, Izrael, Ukrajna stb. Másrészt felmerül a kérdés, hogy például akkor a magyar adatok esetében hogyan lehet elkülöníteni a mai országhatáron belüli és kívüli középkori adatokat. Mitől függ, hogy az adat melyik ország alá kerül? Esetleg a levéltári lelőhely, a forráskiadás vagy netalántán a feltöltő személye határozza meg? Kétségtelenül nehéz, sőt sok esetben lehetetlen az évszázadok határmozgásait követni, mégis szükséges lenne egyértelművé tenni a térbeliség kritériumait is, hogy az összevethetőség valóban megvalósulhasson.

Az sem egyértelmü, hogy az adatok közlését hogyan képzeli a program: vajon az-e a cél, hogy egy név, illetve névalak legalább egyszer adatolt legyen egy adott területen (országban?), igazolva a név meglétét, vagy minden egyes forrásbeli előfordulást össze kíván gyüjteni? A John szócikkét ${ }^{5}$ végignézve inkább az utóbbi rajzolódik ki. A magyarországi adatoknál például az Anjou-kori személynévtár első kötetének (SLÍZ 2011) a Johannes címszó alatti vélhetően összes adata megtalálható. Ha ebből indulunk ki, akkor várhatóan feltöltődnek majd az ÁSznt., SLíz 2017a, esetleg az FTSznSz. vagy KARÁCSONY 1961 stb. adatai is, amely azonban kétségtelenül szétfeszítené és áttekinthetetlenné tenné az adatközlést. Noha igaz, hogy egy ilyen program akár több évtizedig is müködhet, lehetővé téve egy valóban hatalmas adatbázis kialakítását, amely azonban számos közremüködő igen sok munkaóráját fogja igényelni.

A szótár a keresztnevek etimológiai magyarázatát is megadja, valójában ez az egyik legnagyobb pozitívuma a kezdeményezésnek. Egy ilyen adatbázis jelentősen megkönynyítheti bármely nyelv ismeretlen személyneveinek az azonosítását. Az már most is látszik, hogy a DMNES. egy jövőbeni személynév-etimológiai szótárhoz is jól felhasználható lesz (a programról bővebben 1. UCKELMAN-SLíz 2015).

4. Személynévtárak a kései ómagyar és középmagyar korból. A korszak szótárainak a bemutatását jelentőségüknél fogva a családnevekre vonatkozó munkákkal kezdem. A magyar családnevek ,viszonylagos teljességre” törekvő történeti-etimológiai szótárát KÁZMÉR MiKLÓs állította össze és adta ki 1993-ban. A CsnSz. számos hangtani, alaktani,

${ }^{5}$ Itt jegyzem meg, hogy szintén vitatható eljárás a nevek angol nyelvi megfelelöinek címszókénti kiemelése. Mivel középkori névanyagról van szó, a latin nyelvi alakok használata lenne az indokolt. 
morfológiai, valamint ortográfiai névváltozatot tartalmaz, melyeket a szerző lexikográfiai bokrosítással rendez szócikkekbe. Önálló címszavakként a mai köznyelvi kiejtésnek és helyesírásnak megfelelö névformákat emeli ki. A CsnSz. a fülszöveg szerint mintegy 9800 szócikket tartalmaz, azaz ennyi magyar családnév 14-18. századi adatait és eredetét mutatja be. A CsnVégSz. szerint azonban ennél több, alakváltozatok nélkül pontosan 10466 (utalócímszókkal 14 101) címszó található a szótárban (CsnVégSz. 8). ${ }^{6}$ Annak megbecsülése, hogy a szócikkekben szereplő névadatok teljes száma mennyi, majdnem lehetetlennek tűnik. Mivel a szótárnak nem készült digitális változata, az adatok statisztikai kimutatása sem egyszerü. Számításaim szerint a szótárban közölt adatok száma 100 ezer körüli, hozzávetőlegesen 90 és 110 ezer közötti lehet. ${ }^{7}$ Azonban a tetemes adatmenynyiség a szerző által gyüjtött „,milliós nagyságrendü” anyagnak csak egy részét (HAJDú szerint egynyolcadát; vö. ÚCsnT. 7) tartalmazza. Mivel a szerző az adatválogatás hátteréröl szükszavúan csak annyit mond, hogy egy családnév lehetőség szerint sok forrásból, a történeti Magyarország számos földrajzi pontjáról, különböző időpontokból minél több ortográfiai, hangtani és morfológiai változattal legyen képviselve a szótárban (CsnSz. 5), érdemes a források segítségével az adatgyüjtés és -közlés hátterét részletesebben feltárni, mivel ez a felhasználhatóságot is befolyásolhatja. Az alábbiakban példaként a gyüjtési időszak végéhez kapcsolódó reprezentatív metszetet vizsgálom meg.

A szótárban közölt másfél oldalas levéltári forrásjegyzék szerint a szerző a Magyar Királyság 1720-as összeírásának válogatott névanyagát is felhasználta. Az 1715-ben keletkezett első országos összeírás terjedelmes anyagából azonban mindössze Sopron és Tolna megye, valamint Pápa szerepel a kimutatásban (CsnSz. 18-19). Mivel a Conscriptio Regnicolaris összeírásai nem tartalmazzák Erdély névadatait, ezért KÁzMÉR a gyüjtést az Erdélyi Kormányzóság F 49 fondszámú Vegyes conscriptio-k elnevezésü anyagára is kiterjesztette. Az nyilvánvaló, hogy az 1720-as országos összeírás 178 ezres névanyagának csak töredéke szerepelhet a szótárban, hiszen a szerző egyrészt csak a magyar eredetünek vélt neveket listázta, másrészt még ezt a mintegy 80 ezres névállományt is erősen megrostálta. Arról, hogy mi alapján válogatott a magyar eredetü nevek között, a fenti szempontokra (föként az arányos területi lefedettségre és a gyakorisági tényezőkre) való hivatkozáson kívül nem rendelkezünk információval (erre 1. még VÖRÖs 2012: 488). A válogatás módszerének feltárásához összevetettem a CsnSz. adatközlését egy kisebb közigazgatási egységnek, Nagyenyednek az 1713-as erdélyi összeírásban található névanyagával.

Nagyenyed 1713-as adóösszeírásában 183 személy neve szerepel. A családnevek között mindössze 2 nem magyar eredetü található (Olczmán, Váncsa ${ }^{8}$ ). A 181 magyar családnévelöfordulás 131 különböző családnévhez kapcsolódik. Az összevetés alapján megállapítható, hogy KÁZMÉR a gyakori nevek esetében nagy mértékben szelektálta a ren-

${ }^{6}$ VÖRÖS FERENC (2012: 486) 10 465, illetve 14103 címszót számolt össze.

${ }^{7}$ Néhány véletlenszerüen kiválasztott oldalon összeszámoltam a közölt névadatokat, és a következő számokat kaptam: 57, 75, 76, 83, 94, 98, 106, 118 (126, 167, 178). A kimagasló utolsó három szám a Nagy és a Tót név szótári adatközlésének egy-egy lapján olvasható adatszámot jelzi. Az első 8 adat arányait figyelembe véve 88 körüli átlagadatot kapunk oldalanként. A szótári rész 1152 oldal terjedelmü. A csonka oldalakat levonva minimálisan 1100 oldallal számolva az adatszám hozzávetőleges értéke 96800 lesz.

${ }^{8}$ KÁZMÉR a Váncsa nevet felveszi a szótárába, tehát magyar eredetűnek tartja. A név magyar eredete véleményem szerint kétséges. 
delkezésére álló adatokat, de a Nagy esetében például még így is 296 (ebből az 1720as összeírásból 47), a Tót-nál 307 (az 1720-asból 54) adatot közölt. A TMCsA. 1720-as adatbázisában az előző névnek 2722, az utóbbinak 2946 előfordulása van. A szerző az összeírásnak nyilvánvalóan csak egy részét (1,7-1,8\%-át) használta fel, a teljes anyag feltárását nem vállalhatta. Másrészről a gyér adatolású családnevek esetében is előfordulhatott, hogy nem kerültek be a szótárba a KÁzMÉR által vélhetően ismert és kigyüjtött adatok. A nagyenyedi anyagban ilyen például a Balsai, Bodrogi, Murza, Rádai és a Rékasi családnév. A Korponai név esetében pedig a területi elvhez kapcsolódó elvárások nem teljesültek, hiszen a 18. század elejéről egyáltalán nem találunk Erdélyhez köthető adatot a névre a CsnSz.-ben, annak ellenére, hogy Nagyenyeden a név biztosan elöfordult. A vizsgált anyag tanulsága továbbá az, hogy a legtöbb nagyenyedi családnév címszóként megtalálható a szótárban. A 131 családnévből mindössze 10 maradt ki, melyek között négy kéttagú, összetett családnév (Szac? Ötvös, Szász Szabó, Szatmári Szabó, Váradi Szücs), egy pedig bizonytalan olvasatú (Gyipsei). A nagyenyedi nevek elöfordulásainak (172) a felét (86) megtaláljuk a szótárban. Csupán az Agotai, az Andormányi, a Burullyai, ${ }^{9}$ az Imás és az Oci családnév szótárazása nem történt meg. Kimaradásuk oka vélhetően a bizonytalan magyarázatukban és gyér adatolhatóságukban keresendő, bár ez utóbbi szempont az érvelésben inkább a közlés mellett szólna.

A fenti szempontok érvényesítésének eredményeként a nagy mennyiségü adatot közlő szótár gyakorisági számításhoz nem használható, névföldrajzi elemzéshez is csak korlátozottan (vö. pl. ZELLIGER 2010). A szótár felhasználhatóságát nagy mértékben korlátozza továbbá, hogy csak nyomtatott formában érhető el. A tetemes adatmennyiség digitalizált adatbázisba rendezése lehetőséget adna többek között az egyes névváltozatok, a különböző névformások, valamint a névrendszertani jellemzők több szempontú vizsgálatára is.

Ezt a hiányosságot a CsnSz. címszóanyagára épülő a tergo szótár (CsnVégSz.) igyekezett enyhíteni. A szótár szerkezetileg két fö egységből áll: a szótári részből és a névanyag motivációk szerinti jegyzékéből. Az előbbi a címszók mellett megadja a névadás lehetséges motivációinak kódját is. A szótár szerkesztői, FARKAS TAMÁs és F. LÁNCZ ÉVA vállalták, hogy KÁZMÉR szerteágazó motivációtípusait áttekintik és egységes rendszerbe foglalják. A CsnSz. az egyes neveknél ugyanis utal a név közvetlen elözményére (pl. Pesti $<$ pesti $<$ Pest hn. $+-i$; Pestis < pestis 'csoma, dögvész'; Kada $<$ Kada régi világi személynév stb.), valamint megadja a lehetséges névadási magyarázatokat, amelyek néhol következetlenek, illetve hiányosak. (Például néhol csupán a közszói előzmény jelentését találjuk motivációként.) Az, hogy az utóbbiak feltárásában milyen elvet követett a szótáríró, szintén nem derül ki az előszóból. Ezért is volt nehéz feladat a változatos motivációkat rendszerbe illeszteni. A CsnVégSz. második része a teljes címszóanyag motivációk szerinti jegyzékét tartalmazza. (A helynévi eredetű családnevek folyamatos szövegű felsorolása például több mint 9 oldalt tesz ki.) Ezáltal az egyes kategóriák megterheltségének arányai is vizsgálhatók a történeti magyar családnévállomány vonatkozásában (számszerü adataikat 1. CsnVégSz. 12). Az a tergo szótár a CsnSz. alapján közli továbbá a név első előfordulásának az évszámát. ${ }^{10}$

${ }^{9}$ Brulya (Burullya) oltmelléki szász település (vö. KIss 2006: 377).

${ }^{10} \mathrm{Az}$ adatok ellenőrzését azonban érthető módon nem vállalhatták a szerkesztők. MizSER az Asztély név kapcsán például megjegyzi, hogy az Asztélyi családnév 1375-re datált első adata íráshiba eredménye. A helyes évszám: 1735 (MIZSER 2007: 78). Ugyanakkor az ehhez hasonló példák elenyészőek lehetnek a hatalmas anyagban. 
A CsnSz. (és az erre épülő CsnVégSz.) a magyar névkutatás és az érintkező tudományágak számára sok szempontból hasznosítható, fontos alapmunkává váltak az elmúlt évtizedekben. Megfelelő kiindulópontjai lehetnek egy, a Németország digitális családnévszótárához (Digitalen Familiennamenwörterbuch Deutschlands; DFD.) hasonló digitális történeti-etimológiai családnévszótárnak is.

A családnevek kialakulásában kiemelt időszaknak, a Mohács elötti egy és negyed évszázadnak a személynévadásába enged bepillantást a korábban megjelent néhány kisebb névkorpusz (pl. TÖRÖK 1961, MEZÖ 1970) mellett a Felső-Tisza-vidék személynévszótára (FTSznSz.), mely 2010-ben látott napvilágot. Ennek tízezres névállománya primér okleveles anyag névadatait tartalmazza. A szótár adatgyüjtési elve a teljességre törekvés volt, amely ebben az esetben azt jelentette, hogy a személynévi adatok összegyüjtését sem nyelvi (formai), sem pedig külső tényezők (pl. a névviselő társadalmi hovatartozása vagy a forrás hiányosságai) nem korlátozták; a szerző szerint ugyanis a névrendszer hiteles leírása kizárólag a „teljes" (nem szelektált) névanyag feltárása alapján történhet. A szótár az adatközlésen túl etimológiai magyarázatokat és a névadás indítékára történő utalást is tartalmaz a CsnSz. eljárását követve. Az FTSznSz.-ben megtaláljuk az egyes névadatok személyhez rendelését is, ami az egyes nevek variabilitásának vizsgálatát és a statisztikai arányszámítást is lehetővé teszi.

A személynévi adatok közlése mellett a szótár jelzi a névviselők társadalmi státuszát: társadalmi réteghez való tartozását, tisztségét, ritkábban foglalkozását is. A személynévi adatok lokalizációja névföldrajzi következtetések levonását is lehetővé teszi. A szótár az okleveles forrás alapján a jobbágyoknál a lakóhelyre, a nemeseknél a birtokra, az egyházi személyek esetében az egyházi méltóságviselés vagy szolgálattétel helyére utal. Az adatközlés időrendi sorrendben, településenkénti csoportosításban valósul meg, ami lehetővé teszi, hogy egy adott településen említett, azonos megkülönböztető nevü személyek adatai révén a családnevek kialakulására és öröklödésére nézve vonhassunk le következtetéseket.

Lexikográfiai szempontból kiemelendő az egyes névszerkezettípusok önálló közlése a szótárban. A családneveken, családnévelőzményeken kívül, melyek a közreadott adatmennyiség mintegy háromnegyedét teszik ki (vö. FTSznSz. 14), külön jegyzékben találhatók a megkülönböztető nevek latin közszói fordításainak címszavai betürendben (pl. carpentator 'ács', faber 'kovács', rufus 'vörös' stb.), a de prepozíciós helynévi eredetü családnevek (pl. 1413: Emericus de perked), a filius-os nevek (pl. 1446: Michael filius Georgii), az apa vagy ős nevének latin genitívuszos elöfordulásai (pl. 1449: Nicolaus Celementis), illetőleg az egytagú (egyelemü) egyénnevek (pl. 1423: Sebastianum, 1523: Thoma.${ }^{11}$ A szótár használatát az egyesített címszómutató, a címszavak névvégmutatója, valamint a településnév-azonosító is segíti. (Sajnos az egyénnevek keresése a nyomtatott szótárban nem lehetséges.) Névélettani szempontból tanulságosak azok a párhuzamos névadatok, melyek ugyanazt a személyt jelölték különböző oklevelekben. Az adatok összetartozását utalások jelzik (pl. Döge falunál [1445-1448]: Nicolaus Kele = 1449: Nicolaus Celementis, 1468: Elias lanifex $=$ [1468 u.]: Elias Chapo).

A teljességre törekvés elve azt eredményezte, hogy az adatgyüjtés csak észszerü és szükségszerü területi korlátozással (Északkelet-Magyarországra szükítve) volt megvalósítható, ezért a kései ómagyar személynévi adatbázis (az ország más területeire is kiterjedő) bővítése továbbra is az elvégzendő feladatok között tartható számon. ${ }^{12}$

\footnotetext{
${ }^{11}$ Az utóbbiak száma a közölt anyagban már csak mindössze 2,5\%-ot tesz ki.

${ }^{12}$ Erre már történtek lépések a szótár megjelenése óta a TMCsA. kutatási programjához kapcsolódóan. Az FTSznSz. anyagával együtt mintegy 22 000, 1401-1526 közötti személynévadat
} 
A középmagyar korra vonatkozóan még egy egyénnevekhez kapcsolódó munkát említek meg: KARÁCSONY SÁNDOR ZSIGMOND névgyüjteményét (1961). KARÁCSONY a keresztnévadási szokások tanulmányozása érdekében adta közre 16-18. századi forrásokból gyüjtött személynévi anyagát. A szerző szerint gyüjteménye 77210 (68 893 férfi és 8317 nő) személy adatait tartalmazza. Munkája első, szótári részében századokra bontva közli a felgyüjtött keresztnevek és becenévi alakváltozataik időben és földrajzilag arányosan válogatott anyagát. Az adatokat szótári rendben, a szócikkeken belül időrendben, a társadalmi hovatartozás feltüntetésével közli. A kötet másik részében az adattár, illetve a teljes gyüjtés alapján készült feldolgozás kapott helyet. Ebben korszakonként vizsgálja az egyes nevek elterjedtségét, ,a társadalmi, a családi névadás törvényszerüségeit” a földrajzi szempontok figyelembevételével. A ,személynevekkel” kapcsolatos kérdések mellett a „társadalmi névadást” is vizsgálta a szerző. Elmondása szerint ,a megvizsgált anyakönyvek a névtípusoknak (egynevüség, két- és háromelemü nevek, ragadványnevek) oly érdekfeszítő változatosságát nyújtották, hogy ezeket a társadalmi névadás hitelt érdemlö megvilágítása érdekében" nem mellőzhette (KARÁCSONY 1961). A források azonban némi egyenetlenséget mutatnak, mert például a 18. századra vonatkozólag föleg református anyakönyveket, jegyzőkönyveket, valamint Kolozsvár 1750-ből származó adóösszeírását használta fel, így a magyar névhasználat jelentős hányada kimaradt a gyüjtési körből.

5. Újmagyar kori családnévtár és családnév-enciklopédia. Az utolsó korszakból HAJDÚ MIHÁLY két munkáját emelem ki és mutatom be részletesen, eltérve a megjelenés időrendi sorrendjétől.

HAJDÚ utolsó műve egy monumentális névtár(ÚCsnT.), amely a szerző egész munkássága alatt különböző Kárpát-medencei forrásokból (pl. anyakönyvekböl, összeírásokból, név- és címjegyzékekből, sírfeliratokból) gyüjtött családneveket tartalmaz az 1787-2007 közötti időszakra vonatkozóan. Az adatgyüjtés és -közlés „II. József névrendelete évének halotti anyakönyveiböl vett adatokkal kezdődik"13, és a Közigazgatási és Elektronikus Közszolgáltatások Központi Hivatala $(\mathrm{KEKKH)}$ által a szerző rendelkezésére bocsátott, 2007-es teljes magyarországi lakónépesség családnévállományának feldolgozásával zárult. HAJDÚ azokat a családneveket kívánta közreadni, amelyek a történelmi Magyarország területén a fenti időszakban ténylegesen adatolhatóak voltak, ezért nem használta fel azoknak a névgyüjteményeknek az adatait (pl. LENGYEL 1917), amelyekben a valóságos neveken kívül kreált nevek is helyet kaptak (ÚCsnT. 6).

A névtár a szerző számításai szerint 375565 különböző családnévalakot tartalmaz. A KEKKH népesség-nyilvántartási adatai alapján 194 432-féle írásváltozatot különített el. A fennmaradó mintegy 181000 névalak más forrásokból, így HAJDÚ saját és egyetemi hallgatóinak időben és térben kiterjesztett gyüjtéseiből állt össze (ÚCsnT. 19). Azt azonban jóval nehezebb meghatározni, hogy ezek a számadatok pontosan hányféle családnevet rejtenek, így a CsnSz. adataival (1. fenn) való összehasonlításra nincs módunk.

található a TMCsA. középkori adatbázisában. Az NKFIH (OTKA) PD 116414. számú pályázatához kapcsolódó, 2015-2018 közötti forrásfeltárás eredményeként a primér okleveles forrásokból gyüjtött névadatok száma 7255-tel, a nyomtatásban megjelent kiadásokból gyüjtött adatok száma pedig 7470-nel nőtt. Ezek főként a Dunántúl, a Dél-Alföld és Erdély területére lokalizálhatók. Ennek ellenére a korszakra vonatkozó adatgyüjtés és -feldolgozás továbbra sem tekinthető lezártnak.

${ }^{13}$ Ennek némiképp ellentmond az, hogy a forrásjegyzék szerint írott forrásai között 16-17. századi névanyag is előfordul (vö. pl. ÁDÁM 1989, MIKECS 1944). 
A szerző ezt a munkáját a CsnSz. időbeli folytatásaként jellemezte (az ÚCsnT. kéziratban lévő a tergo kötetét pedig a CsnVégSz. folytatásának szánta), hangsúlyozva, hogy más szempontból (tartalom, felépítés, közlésmód) azonban inkább különböznek egymástól (ÚCsnT. 6-7). A továbbiakban magam is néhány különbségre térek ki részletesebben.

Az egyik legfeltünőbb eltérés a két szótár között a hivatkozások kezelése terén látható. Míg a CsnSz. mindig megadja a közölt adat pontos forrását, és ezzel együtt az adatolás idejét, addig az újmagyar kori névtárban a forrásjelzés és az évszám feltüntetése elmarad. Érdekes, de a gyüjtési mód alapján érthető megoldás, hogy az ÚCsnT. kizárólag a KEKKH névadatainál közli a név gyakorisági számát, ebben az esetben a forrás és az idö közvetve hozzárendelhető az adathoz. A névtár ugyan tartalmaz forrásjegyzéket (ÚCsnT. 27-37), de a névanyag másik fele esetében a konkrét forrásra történő utalás elmarad, ami az adatok ellenőrizhetőségét jelentősen korlátozza, a visszakereshetőséget pedig egyáltalán nem teszi lehetővé. A hivatkozások elmaradását HAJDÚ egyrészt a primér források (föként az anyakönyvek, sírfeliratok stb.) esetében a kutatási nehézségekkel, föként a személyiségi jogi és politikai korlátozásokkal magyarázza, másrészt azzal, hogy a kutatók eddig is „,csak elvétve néztek utána az oklevélkiadványokban egyegy adatnak" (ÚCsnT. 8).

A másik lényeges különbség, hogy a CsnSz. röviden kitér a név eredetére, valamint a névadás indítékaira. Ezek az utalások az újmagyar kori névtárból szintén hiányoznak. Az ÚCsnT. az egykor Magyarország területén létezett családnevek listáját adja közre egyéb információk hozzárendelése nélkül. Meg kell azonban jegyeznünk, hogy nem szükségszerü egy szótárnak a két vagy több szempontrendszer (történeti adatközlés, etimológiai magyarázat, névélettan stb.) teljesítését együttesen magára vállalnia.

HAJDÚ MIHÁLY a fenti szempontoknál fontosabbnak tartotta a teljességre törekvő adatközlést. A CsnSz.-ben alkalmazott adatválogató munkamódszerrel nem értett egyet, mivel KÁZMÉr ,a maga kutatta névanyagból kiválogatta az általa magyar eredetünek tartott neveket, a többit mellőzte”, sőt a magyar családnevek „milliós nagyságrendü” adatainak hétnyolcadát sem közölte, ezzel szemben az ÚCsnT. „,minden föllelt név írásváltozatát tartalmazza egyszer, bármilyen eredetü vagy etimológiájú is az" (ÚCsnT. 7; a kiemelés törölve - N. F. J.). Rendezőelve tehát „minél több különböző névalak fölkutatása és közlése" volt, tekintet nélkül a név eredetére.

Az ÚCsnT. tehát egy olyan impozáns névgyüjtemény, amely arról tájékoztat, hogy milyen családnévalakok (helyesírási, hangtani és alakváltozatok) fordulhattak elő a Kárpátmedencében az elmúlt két és fél évszázadban.

HAJDÚ MIHÁLY itt említendő másik munkája a Leggyakoribb mai családneveink alcímet viselö Családnevek enciklopédiája (CsnE.), amely tehát a cím szerint se nem történeti, se nem szótár, ezért némileg kilóg az eddig bemutatott müvek sorából. Hogy mégis ezzel zárom áttekintésemet, azt egyrészt a jelenkori családnévanyagnak a történetiségbe ágyazott volta, másrészt a szerző által ismertetett kutatástörténeti előzmények (1. HAJDÚ 2008) indokolják, melyek szorosan összekapcsolják ezt a müvét az előző munkával. A kapcsolatot a részben közös forrásanyagon túl az adja, hogy a CsnE. névfejtései az újmagyar kori névtár egyfajta etimológiai kiegészítésének tekinthetők, azaz a szerző ebben a kötetben voltaképpen vállalta az ÚCsnT.-ben is megtalálható családnevek egy részének elemzését.

Az enciklopédia HAJDÚ szerint ,e könyv címében azt jelenti, hogy az egyes családnevek bemutatásakor teljességre törekszünk. Igyekszünk mindent leírni az adott névröl, ami a mai kor tudásszínvonalának megfelel és fölkutatható" (CsnE. 7). A kötet fenti megfogalmazása már előrevetíti az olvasó számára, hogy itt elsősorban a nagyközönségnek 
szóló, tudománynépszerüsítő munkáról van szó. Az ugyanis, hogy a családnevek bemutatása a „teljességre törekvés”, illetve a „kor színvonalának tudása” alapján történik, felveti a kérdést, hogy valóban lehet-e egy névről tudományosan teljességre törekvően mindent elmondani, illetve pontosan mit jelent „a kor színvonalának tudása” kritérium. A népszerüsítő jelleget a hivatkozások elmaradása szintén jól jelzi.

HAJDÚ ebben a múvében elég nagy feladatot vállal akkor, amikor az 1000 elöfordulásnál gyakoribb, szám szerint 1230 mai magyarországi családnév teljes körü bemutatását tüzi ki célul. A korpusz alapját az ÚCsnT.-ben is felhasznált névanyag adja (CsnE. 8). A KEKKH által rendelkezésére bocsátott, összesen 10162610 személy családnevét tartalmazó névsorból a szerző gyakorisági listát állított össze. Az ismétlődő névelöfordulásokat összesítve 194 917-féle egyedi családnévalakkal számolhatott. ${ }^{14}$ Az anyagmenynyiség nagyságát természetesen az alakváltozatok száma, illetve az idegen származású magyar állampolgárok eredeti születési neve is befolyásolta. A szerző a feldolgozás határát az 1000 fölötti előfordulásoknál húzta meg, azonban előtte el kellett végeznie az egy családnévhez tartozó helyesírási és ejtésvariánsok összekapcsolását, lemmásítását (egyesítette pl. a Kovács, Kováts, Kovách, Kowács, Kovatch stb. névalakokat a Kovács címszó alatt), általában a leggyakoribb névváltozatot véve alapul (HAJDÚ 2010: 22). A gyakorisági sorrend kialakítása során egyaránt megfelelö címszóhoz kellett rendelnie a kötőjeles, különírt vagy összeforrt kettős családneveket (pl. Ábrahám-Nagy, Ács Nagy, Nagygyőr), illetve a betüragadványnévi elötagúakat (azaz a megkülönböztető betüjeles neveket) is (pl. D. Nagy). HAJDÚ azt a megoldást választotta, hogy az összeforrt, egybeírt neveket nem vette figyelembe az egyes névrészeknél.

Mindenesetre a CsnE. a fenti módszer alapján összesen 6688592 magyarországi személy családnevét mutathatta be, ez pedig Magyaroszág népességének közel kétharmadát, 65,82\%-át érinti (HAJDÚ 2010: 9). A mü nagy érdeme, hogy a magyarországi névanyag a fenti gyakorisági kritériumon túl nem szelektálva, hanem teljességre törekvően jelenik meg, nem hagyva ki a nem magyar eredetű neveket sem. A kötetben ezért a magyarok mellett megtaláljuk a leggyakoribb német (pl. Jung, Klein, Schmidt), szláv (pl. Novák, Gyuricza, Petrovics) és román (Árgyelán, Marosán, Moldován) eredetủ magyarországi családneveket. Érdemes kiemelni, hogy a szerző kategorizációja és számítása szerint az 1230 családnév között 1058 magyar (6 313271 névviselövel), 73 német, 66 szláv, 3 román és 27 bizonytalan etimonú található.

Az adott név teljes körü, átfogó bemutatására való törekvést hivatott tehát kifejezni az enciklopédia elnevezés. A CsnE. ennek szellemében tartalmazza az adott családnév „típusát” (pl. „helynévi eredetü, magyar családnév”, ,apanévi eredetü, magyar vagy délszláv családnév" stb.); a név változatait gyakorisággal együtt; az eredeten belül az alapszó nyelvtörténeti változási folyamatait, valamint a név közszói elözményének a jelentését; emellett utal a név földrajzi elterjedésére; illetőleg 19. századi példákkal szemlélteti a névváltoztatásban játszott szerepét (a kötet jellemzésére 1. még MIZSER 2010, ZÁNTÓ 2010, VÖRÖS 2011). Az eredeti tervezetben még a híres névviselők is szerepeltek (HAJDÚ 2008: 174175, 180-182), de végül ezek az adatok különböző okokból nem kerültek be a kötetbe.

${ }^{14}$ Itt jegyzem meg, hogy a két év különbséggel megjelenő kötetek számadatai között több helyütt eltérések mutatkoznak. A családnévalakok számában jelentkező csökkenés (CsnE. 194917 $\rightarrow$ ÚCsnT. 194 432) a számos rontott és hibás névalak, illetve a -né asszonynévképzős nevek különböző módú számításával magyarázható (vö. ÚCsnT. 19); az egyes névadatok gyakorisági számában mutatkozó növekedés mögött feltehetően szintén hasonló okok állnak (1. pl. Fekete 34 $982 \rightarrow 35$ 019, Ferenc $1008 \rightarrow$ 1016, Fodor $23288 \rightarrow 23$ 297, Lörincz $9705 \rightarrow 9711$ stb.). 
Módszertani problémaként a „gördített” etimologizálás gyakorlatát kell megemlítenünk. HAJDÚ ugyanis - az enciklopédikus jellegre hivatkozva - nem elégszik meg a név tulajdonnévi vagy közszói közvetlen előzményének a bemutatásával és indoklásával, hanem visszavezeti a családnevet alkotó lexémát a kikövetkeztethető legkorábbi előzményre. Például megadja a helynévi eredetü családnevekben szereplő településnevek etimológiai magyarázatát is. A Kalocsai családnév kapcsán például megtudhatjuk, hogy a név (1) az ótörök qal köznév kétféle jelentéséből - 'megmaradt, (élve) maradt', '(anya) jegy az újszülött testén' - elöször (2) személynévvé vált valamelyik ótörök nyelvben, majd (3) ez Kal Kál alakban bekerült a magyar személynévkincsbe, később (4) kiegészült - $S-\sim-c s$ - kicsinyítő képzővel és (5) - a birtokjellel. A Kalocsa személynév tehát 'Kalocsé, azaz Kalocs nevü személy fia' jelentéssel bírt. Ebböl (6) formáns nélkül alakult településnév több vármegyében is, ezek (7) bármelyike megkaphatta az $-i$ 'onnan/oda való' jelentésű melléknévképzőt. Ezek közül azonban csupán az utolsó (7) mozzanat az, amely a családnév-etimológiai magyarázat során figyelembe veendő. A többi az ótörök és Árpád-kori magyar személynévtörténet, valamint a helynévtörténet kérdéskörébe tartozik. Az ilyen típusú magyarázat egy népszerüsítő jellegű munkában azért lehet problémás, mert a laikus olvasó téves következtetéseket vonhat le belöle.

A CsnE.-nek az elöbbinél is problematikusabb megoldása a különböző nyelvek névrendszereihez köthető névalakok egy (általában magyar) családnévlemmához rendelése. A hibás eljárásmódra álljon itt néhány példa! A Lörincz névröl megtudjuk, hogy apanévi eredetü, magyar családnév, melynek ,változatai” között megtaláljuk a Lorencz, Lórencz, Lórenc, Lorenc, Lórenz, Lorenz, Laurencz nem magyar „változatokat” is. A szerző a Németh családnévhez rendeli az egyértelmüen szláv nyelvi hátterü Nemecz, Nemec, Nyemecz, Nyemetz névalakokat is. Bár HAJdú azt feltételezi, hogy ezek a -c végü névalakok is lehetnek magyar nyelvjárási alakváltozatok (CsE. 347), ezt a hipotézist azonban a Nemecz és a Nyemecz névalakok 18. század eleji névföldrajza egyáltalán nem támogatja. ${ }^{15}$ A Pintér változatai között megtaláljuk a Binder, Bínder, Bender családneveket is, melyről a szerző megállapítja, hogy elsősorban német nyelvterületen használatosak. Hasonló példákat még hosszan sorolhatnánk; pl. Angyal: Angyel; Fodor: Feodor, Fiedor, Fedor; Fülöp: Filip(p), Philip(p); Gábor: Gábriel, Gabriel(l), Gábriely, Gábrier; Román: Rimán, Réman; Sándor: Sander, Sánder; Bajor: Bájer, Báyer, Bayer, Pájer, Payer, Peyer, Peier stb. A különbözö névrendszerekhez tartozó névalakok összekeverése ellentmondásos kategorizációt eredményezett. Nem világos, hogy a német eredetü Pintér családnév miért lett magyarnak, a Bajor viszont német családnévnek minősítve, hiszen mindkettő közszói előzménye a magyar szókészlet német eredetü rétegébe tartozik, a különbség csupán az átvétel idejében mutatkozik. Természetesen számos olyan eset lehetséges, ahol az adott névalak több nyelvhez is hozzárendelhető. A fentiekben az egyértelmüen elkülöníthető esetekből vettem példákat.

A mü tartalmaz vitatható vagy téves etimológiai magyarázatokat is. Néhány olyan névnél, amely több nyelvben is létrejöhetett, a magyartól eltérö, más nyelvi eredetre nem történik utalás. A Filó esetében például a szláv eredet homályban marad, pedig 1715-ben az egyetlen somogyi adatot kivéve az összes előfordulás északnyugat-magyarországi vármegyék (Turóc, Trencsén, Zólyom, Hont, Nyitra) szláv többségü területeihez

${ }^{15}$ A TMCsA. 1720-as adatbázisában az alábbi, szláv többségű megyékben vagy vegyes lakosságú megyék szláv többségü járásaiban fordulnak elő (zárójelben az előfordulás száma): Trencsén (9), Pozsony (8), Bars (6), Nyitra (4), Zólyom (4), Vas (4), Liptó (3), Hont (3), Turóc (2), Zala (2), Gömör (2), Szepes (1), Pest-Pilis-Solt (1), Komárom (1), Nógrád (1), Sáros (1). 
köthető. Hasonló megállapítást tehetünk többek között a Gajdos, a Gregus, a Polák név kapcsán is. A hibás etimológiára a Pintye név példáját említem. HAJDÚ szerint olyan „apanévi eredetü, magyar családnévről” van szó, amely „különösen a Hajdúságban, vagyis görögkeleti (pontosabban: görög katolikus - N. F. J.) vallású vidékeken fordul elő" (CsnE. 380-381), azaz a román többségü vidékek szomszédságában. A 21. századi névföldrajzi sajátosságok alapján is gyanítható a Pintye családnév román eredete, amelyet a 18. századi előfordulások még inkább megerősítenek. ${ }^{16}$

Összegzésként elmondható, hogy HAJDÚ MIHÁLY családnév-enciklopédiája egy hosszú és termékeny kutatói pálya eredményeként az érdeklődő nagyközönség igényeit kielégítendő született, ezzel a szerző a tudománymüvelés egyik fontos feladatának, a tudománynépszerüsítésnek tett eleget, ugyanakkor számos kérdésben folyamatosan továbbgondolásra késztetheti a névkutatókat is.

6. Záró gondolatok. A lexikográfiát a kutatók többsége ugyan a nyelvtudomány egyik fontos alkalmazott kutatási területének tartja, azonban a feladatra vállalkozók sokszor az elismertség hiányával kénytelenek szembesülni. A fentiekben bemutatott tudománytörténeti áttekintés - úgy hiszem - jól példázza a szótárkészítés komplex, összetett, felkészültséget igénylő és rendkívül időigényes feladatát, mely a feladat nagyságához mérten általában többek együttmüködését igényelné, és amelyre rendszerint csak kevesen vállalkoznak. A magyarországi történeti személynévszótárak készítésének két évszázada alatt számos alapvető munka látott napvilágot, amelyek fontos segédkönyvül szolgálnak további nyelvészeti és interdiszciplináris kutatásokhoz, bekerültek a tudományos vérkeringésbe, a kutatók rendszeresen használják és hivatkoznak adataikra. A közreadott névtárakkal szemben megfogalmazható kritikák és esetleges hiányosságok ellenére is mindenképpen elismerés illeti azokat, akik egy ilyen nehéz feladatra vállalkoztak (és a jövőben vállalkozni fognak). Hiányosságaik, ellentmondásaik elsősorban azt jelzik, hogy az ösvényt, amelyen jártak, jórészt maguknak kellett kitaposniuk.

A bemutatott munkák „,mintát adó kutatói teljesítményként” (SZENTGYÖRGYI 2015: 481) elörevetítik a történeti személynévtan müvelöire váró további feladatokat is. A történeti személynévanyag gyüjtésének folytatása (főként a kései ómagyar korra vonatkozóan), az Árpád-kori személynevek etimológiai szótárának az elkészítése, a kéziratban lévő munkák (pl. MIZSER é. n.) megjelentetése, a meglévő névanyag digitalizálása és információtechnológiai feldolgozása, a tudományos eredmények közzététele a tudomány képviselői és a nagyközönség számára (nyomtatásban és a világhálón) a jövőre nézve is bőven ad tennivalót a történeti személynevek kutatói számára.

\section{Felhasznált források}

ÁDÁM IMRE 1989. Szabolcs megye Dadai járásának jobbágynevei 1574-böl. Magyar Névtani Dolgozatok 82. ELTE Magyar Nyelvészeti Tanszékcsoport Névkutató Munkaközössége, Budapest.

ÁSznt. = FEHÉRTÓI KATALIn, Árpád-kori személynévtár 1000-1301. Akadémiai Kiadó, Budapest, 2004.

${ }^{16}$ A Pintye Pinte családnév előfordulásai 1715-ben a következők: Szatmár megye (5), Kővárvidék (4), Marosszék (3), Fehér (3), Közép-Szolnok (2), Bihar (2), Máramaros (2), Besztercevidék (1), Torda (19); az 1720-as keresztnévi előfordulások pedig hasonlóan Szatmár, Közép-Szolnok, Kraszna és Máramaros megyékhez köthetők (TMCsA.). 
ÁÚO. = Árpádkori új okmánytár 1-12. Közzéteszi WeNZEL GuSZTÁV. Pest/Budapest, 1860-1874. BAÁN KÁLMÁN 1944. Ösi magyar személynevek. K. n., Budapest.

BERRÁr Jolán 1952. Nöi neveink 1400-ig. A Magyar Nyelvtudományi Társaság Kiadványai 80. Magyar Nyelvtudományi Társaság, Budapest.

CsnE. = HAJDÚ MiHÁLY, Családnevek enciklopédiája. Leggyakoribb mai családneveink. A magyar nyelv kézikönyvei 17. Tinta Könyvkiadó, Budapest, 2010.

CsnSz. = KÁZMÉR MiKLós, Régi magyar családnevek szótára XIV-XVII. század. Magyar Nyelvtudományi Társaság, Budapest, 1993.

CsnVégSz. = Régi magyar családnevek névvégmutató szótára XIV-XVII. század. Szerk. FARKAS TAMÁS - F. LÁNCZ ÉVA ANNA. ELTE Magyar Nyelvtudományi és Finnugor Intézet - Magyar Nyelvtudományi Társaság, Budapest, 2009.

DFD. = Digitales Familiennamenwörterbuch Deutschlands. Hrsg. NÜBlING, DAMARIS - JANICH, NINA. http://www.namenforschung.net/dfd/woerterbuch/liste (2020. 05. 03.)

DMNES. = Dictionary of Medieval Names from European Sources. Főszerk. UCKELMAN, SARA L. http://www.dmnes.org (2020.05. 03.)

F. $=$ Codex diplomaticus Hungariae ecclesiasticus ac civilis 1-11. Studio et opera GEORGII FEJÉR. Typ. Universitatis, Buda, 1829-1844.

FEHÉRTÓI KATALIN 1969. A XIV. századi magyar megkülönböztető nevek. Nyelvtudományi Értekezések 68. Akadémiai Kiadó, Budapest.

FEHÉRTÓI KATALIN 1983. Árpád-kori kis személynévtár. Akadémiai Kiadó, Budapest.

FTSznSz. $=$ N. FODOR JÁNOS, A Felsö-Tisza-vidék késő középkori személyneveinek szótára (1401-1526). Magyar Névtani Értekezések 3. ELTE BTK, Budapest, 2010.

GOMBOCZ ZoLTÁN 1915. Árpádkori török személyneveink. A Magyar Nyelvtudományi Társaság Kiadványai 26. Magyar Nyelvtudományi Társaság, Budapest.

Gy. = GYÖRFFY GYÖRGY, Az Árpád-kori Magyarország történeti földrajza 1-4. Akadémiai Kiadó, Budapest, 1963-1998.

JERNEY JÁNOS 1854a. Magyar nyelvkincsek Árpádék korszakából. K. n., Pest.

JERNEY JÁNOS 1854b. Magyar nyelvkincsek Árpádék korszakából. Második közlemény, mely I. András kir. korabeli 800 éves imádságokat tartalmazza, két réztábla nyomattal. Szent István Társulat, Pest.

KARÁCSONY SÁNDOR ZSIGMOND 1961. Személynevek 1500-tól 1800-ig. Nyelvtudományi Értekezések 28. Akadémiai Kiadó, Budapest.

KuBÍNYI FERENC 1891. Régi magyarok személynevei. Magyar történelmi névtár. Első kötet. Révai Leo Bizománya, Budapest.

LENGYEL ZolTÁN 1917. Magyar névkönyv. Nap Nyomda, Budapest.

MA. = MOLNÁR DE SZENCZ, AlBERT, Dictionarivm Latinovngaricum opus novvm hactenvs nvsqvam editvm - Dictionarivm Vngaricolatinvm. Noriberga, 1604.

MEZÖ ANDRÁs 1970. A Várdai-birtokok jobbágynevei a XV. század közepéröl. A Kisvárdai Vármúzeum Kiadványai 3. Kisvárdai Járási Tanács Végrehajtó Bizottsága, Kisvárda.

MiKeCS LÁsZló 1944. Moldvai katolikusok 1646-47. évi összeirása. Erdélyi Tudományos Füzetek 171. Erdélyi Múzeum-Egyesület, Kolozsvár.

Mizser Lajos é. n. Bereg megyei családnévlexikon. Kézirat. Nyíregyháza.

PPB. = Dictionarium latino-hungaricum, succum et medullam purioris Latinitatis, ejusque genuinam in Lingvam Hungaricam conversionem ... FRANCISCO PÁRIZ PÁPAI ... Accessionibus locupletatum intentione ac labore PETRI BOD de F. Tsernáton, V. D. Ministri M. Igeniensis. Nova huic Editioni nunc primum addita est lingva Germanica in parte posteriori, Szeben, 1767.

SLíz MARIANN 2011. Anjou-kori személynévtár (1301-1342). Históriaantik, Budapest. 
SLíz MARIANN 2017a. Anjou-kori személynévtár (1343-1359). Magyar Nyelvtudományi Társaság, Budapest. https://doi.org/10.26546/5061158

TMCsA. = Történeti magyar családnévatlasz. Szerk. N. FODOR JÁNOS. http://www.csaladnevatlasz. $\underline{\mathrm{hu}}(2020.05 .30$.

TÖRÖK GÁBOR 1961. Ötszáz éves híradás a szlavóniai magyarságról. Magyar Nyelv 57: 236-242, $360-363$.

ÚCsnT. = HAJDÚ MiHÁLY, Újmagyarkori családneveink tára XVIII-XXI. század. I. Adatok. Szerzői kiadás, Budapest, 2012.

\section{Hivatkozott irodalom}

BASKI IMRE 1986. A magyarországi kun eredetü nevek kutatása. (Tudománytörténeti áttekintés.) Forrás 18: 88-94.

BENKÖ LORÁND 1949. A történeti személynévvizsgálat kérdései. Magyar Nyelv 45: 116-124, 244-256.

BENKŐ LORÁND 1994. Anonymus gesztája nyelvészeti revíziójának szükségességéről. Magyar Nyelv 90: 131-137.

BENKÖ LORÁND 1998. Név és történelem. Tanulmányok az Árpád-korról. Akadémiai Kiadó, Budapest.

CSÉPLŐ PÉTER 1872. Magyar Onomasticon I. Vezetéknevek okmányainkban. Századok 6: 269273.

FARKAS TAMÁS 2019. Történelemkonstruálás - névkonstruálás. A honfoglalás, illetve a korai magyar történelem személynevei és az utókor. Névtani Értesitö 41: 75-90. https://doi.org/ $\underline{10.29178 / \mathrm{NevtErt} .2019 .4}$

FEKETE ANTAL 1991. Keresztneveink nyomában. (Bod Péter névjegyzékének vizsgálata.) A Magyar Nyelvtudományi Társaság Kiadványai 191. Magyar Nyelvtudományi Társaság, Budapest.

FODOR ISTVÁN 2006. Fehértói Katalin: Árpád-kori személynévtár (1000-1301). [Recenzió.] Magyar Nyelvör 130: 238-243.

N. FODOR JÁNOS 2015. Történeti személynévkutatás. In: FARKAS TAMÁS - SLÍZ MARIANN szerk., Magyar névkutatás a 21. század elején. Magyar Nyelvtudományi Társaság - ELTE Magyar Nyelvtudományi és Finnugor Intézet, Budapest. 115-144.

GULYÁS LÁSZLÓ SZABOLCS 2014. Nomen est societas? Új monográfiák középkori személyneveinkről és társadalomtörténeti vonatkozásaik. [Recenzió.] Századok 148: 538-543.

HAJdú MiHÁLy 2003. Általános és magyar névtan. Személynevek. Osiris Kiadó, Budapest.

HAJDÚ MIHÁLY 2008. Beszámoló a készülő „Mai családneveink lexikona” munkálatairól. Névtani Értesitö 30: 167-184.

HoRVÁT IsTVÁN 1821. Veszprém Vára Nevéről. A’ Tekéntetes Veszprémi Káptalan Nagy Érdemü Tagaihoz Tisztelet Jeléül. Tudományos Gyüjtemény 5/3: 37-70.

KISS LAJOS 2006. Helynévmagyarázatok. Magyar Nyelv 102: 370-378.

KNIEZSA IsTVÁN 1943/2001². Keletmagyarország helynevei. Kisebbségkutatás Könyvek. Lucidus Kiadó, Budapest.

KRISTÓ GYULA 1976. Szempontok korai helyneveink történeti tipológiájához. Acta Universitatis Szegediensis de Attila József Nominatae. Acta Historica 55: 1-101.

MELICH JÁNOS 1907. Az Árpád-kori becéző keresztnevek egy csoportjáról. Magyar Nyelv 3: 165176.

MiKESY SÁNDOR 1970. Személynévkutatásunk első szakaszához. Magyar Nyelv 66: 197-207. 
MizSER LaJos 2007. Asztély. Magyar Nyelv 103: 78.

MizSER LAJOS 2010. Hajdú Mihály: Családnevek enciklopédiája. Leggyakoribb mai családneveink. [Recenzió.] Névtani Értesítö 32: 200-203.

NAGY GyUla 1872. Magyar Onomasticon III. (A nevek osztályozása.) Századok 6: 488-491.

NAGY IMRE 1872. Magyar „Onomasticon” II. (Észrevételek Cs. P. úrnak az april havi füzetben foglalt czikkére.) Századok 6: 341-345.

PAIS DEZSŐ 1960. Szempontok Árpád-kori személyneveink vizsgálatához. In: PAIS DEZSŐ MiKESY SÁNDOR szerk., Névtudományi vizsgálatok. A Magyar Nyelvtudományi Társaság névtudományi konferenciája, 1958. Akadémiai Kiadó, Budapest. 93-105.

PAPP LÁSZLÓ 1960. Beszámoló az Árpád-kori személynévszótár munkálatairól. In: MiKeSY SÁNDOR - PAIS DEZsŐ szerk., Névtudományi vizsgálatok. A Magyar Nyelvtudományi Társaság névtudományi konferenciája 1958. Akadémiai Kiadó, Budapest. 126-131.

PAPP LÁSZLÓ 1961. Személynevek és helynevek. Az Árpádkori Személynévszótár kérdéseiből. Magyar Nyelv 57: 183-194, 325-331.

SLíz MARIANN 2017b. Személynévtörténeti vizsgálatok a középkori Magyarországról. Magyar Nyelvtudományi Társaság, Budapest. https://doi.org/10.26546/5061134

SzABÓ T. ATTILA 1940. A személynevek helyneveinkben. Magyar Népnyelv 2: 81-123.

SZATHMÁRI ISTVÁN 1997. Szenczi Molnár Albert és a nevek. In: B. GERGELY PIROSKA - HAJdú MıHÁLY szerk., Az V. magyar névtudományi konferencia elöadásai (Miskolc, 1995. augusztus 28-30.) A Magyar Nyelvtudományi Társaság Kiadványai 209. Magyar Nyelvtudományi Társaság - Miskolci Egyetem Bölcsészettudományi Intézet, Budapest-Miskolc. 530-535.

SZATHMÁRI ISTVÁN 1999. Személy- és földrajzi nevek Szenczi Molnár Albert 1621-i magyar-latin szótárában. Névtani Értesitő 21: 270-274.

SZENTGYÖRGYI RUDOLF 2015. Slíz Mariann két könyvéröl. [Recenzió.] Magyar Nyelv 111: 478-481.

TÓTH VALÉRIA 2013. Szempontok a középkori források személynévi adatainak értékeléséhez. Nyelvtudományi Közlemények 109: 227-254.

UCKelman, SARA L. - Slíz MARIANN 2015. Többnyelvü névtani lexikográfia: a Dictionary of Medieval Names from European Sources elnevezésủ nemzetközi szótári projekt. Névtani Értesitö 37: 203-220.

VÖRÖS FERENC 2011. Hajdú Mihály, Családnevek enciklopédiája. Leggyakoribb mai családneveink. [Recenzió.] Magyar Nyelv 107: 200-208.

VÖRÖS FERENC 2012. Farkas Tamás szerk.: Régi magyar családnevek névvégmutató szótára. XIV-XVII. század. ELTE Magyar Nyelvtudományi és Finnugor Intézet - Magyar Nyelvtudományi Társaság, 2009. 192 lap. [Recenzió.] Magyar Nyelvör 136: 485-488.

ZÁNTÓ EDINA 2010. Hajdú Mihály: Családnevek enciklopédiája. Leggyakoribb mai családneveink. [Recenzió.] Magyar Nyelvőr 133: 109-111.

ZELLIGER ERZSÉBET 2010. Név - szó - földrajz Lőrinczétől Lőrinczyig. A családnevek morfológiai kérdései. In: Vörös Ferenc szerk., A nyelvföldrajztól a névföldrajzig. A 2010. június 8-i szombathelyi tanácskozás elöadásai. A Magyar Nyelvtudományi Társaság Kiadványai 234. Magyar Nyelvtudományi Társaság - NyME Savaria Egyetemi Központ, Budapest-Szombathely.

N. FODOR JÁNOS

ORCID: https://orcid.org/0000-0002-0401-3701 ELTE Eötvös Loránd Tudományegyetem Bölcsészettudományi Kar 


\section{JÁNOS N. FODOR, Historical personal name dictionaries}

Over the two hundred years in which Hungarian historical dictionaries of personal names have been created a number of fundamental works have been published that have served and continues to serve as vital reference books for linguistic and interdisciplinary research. (Only the most important of these are listed.) The idea of collecting the anthroponyms from the earliest period of Hungarian literacy, the Árpád Era, was first raised in 1821. However, the Dictionary of personal names from the Árpád Era was only published in 2004 (by Katalin Fehértói), following in the footsteps of exemplary antecedents (e.g. Kubinyi 1891) and failed attempts. Anthroponyms collected from documents written within the borders of historical Hungary between 1000 and 1301 were included in the dictionary. However, the entries were not supported by etymological explanations, thus creating an etymological dictionary of Old Hungarian names remained a task for future researchers. More can be said of name dictionaries compiled from later periods of the Old Hungarian period. The historical-etymological dictionaries examining the period (CsnSz; FTSznSz; Slíz 2011, 2017a) collected and published their data following methodologically sound lexicographic standards. The fundamental ideas of these editions may provide food for thought for the editors and authors of future dictionaries. A dictionary of family names used in the Carpathian Basin over the past two hundred years, including name variants, was published in the ÚCsnT, based on several decades of research conducted by Mihály Hajdú. An etymological dictionary of the most common current family names (CsnE) was also the result of his work. The historical overview aims to highlight the unique expertise required to complete the complex and time-consuming task of creating dictionaries by examining these published works, while noting difficulties and tasks of future research. 
FARKAS TAMÁS - SLÍZ MARIANN szerk., Tulajdonnevek és szótárak. ELTE Magyar Nyelvtudományi és Finnugor Intézet - Magyar Nyelvtudományi Társaság, Budapest, 2020. 165-184. DOI: 10.26546/4892373.10

\section{A laikus keresztnévszótárak*}

1. A laikus keresztnévszótárak típusai és bemutatásuk szempontjai. Írásomban a magyar keresztnévszótárak azon típusát mutatom be, amelynek képviselöit laikus, azaz nyelvészeti, illetve névtudományi képzettséggel nem rendelkező szerzők vagy szerkesztők készítették a 20. század végén vagy a 21. század elején, és jelenleg is hozzáférhetők újonnan, antikváriumi kínálatban vagy az interneten. Manapság ugyan a többség feltehetőleg inkább már az interneten fellelhető számos utónévkeresőből, illetve névszótárból tájékozódik, ezeknek azonban az alább áttekintett müvek szolgálhatnak legfőbb forrásukul. (Ez különösen a parakomparatív névszótárak esetében érhető tetten.)

Természetesen szakmabeliek által készített keresztnévszótárak is elérhetők a nagyközönség számára, habár nem nagy számban (elsősorban FERCSIK-RAÁTZ 2017, KnE., MUnk.), ezekkel azonban a fenti célkitüzésnek megfelelően a továbbiakban nem kívánok foglalkozni; már csak azért sem, mert a (szakmai és a laikus) keresztnévszótárak és utónévportálok általános jellemzőiről már léteznek áttekintések (FARKAS 2006, 2019). Jelen írásom egyfajta továbbgondolása az e munkában a laikus névtárak kapcsán tett megfigyeléseknek. Célom egyrészt az, hogy rámutassak olyan módszertani hibákra és hiányosságokra, amelyeket a laikus névszótárak készítői gyakran elkövetnek; e szakmai kérdések tárgyalása a névkutatók és a lexikográfusok számára sem érdektelen. Másrészt igyekszem felhívni a figyelmet arra, hogy e névszótártípusok nem elhanyagolható mennyiségủ és komolyságú problémát okozhatnak, melyeket a szótártípus ignorálásával nem lehet megoldani.

A laikus keresztnévszótárakat a kiadás célja szerint három főbb kategóriába sorolhatjuk: a) általános jellegủ, ideológiamentes munkák; b) ezoterikus alapokon nyugvók; valamint c) parakomparatívnak nevezhető, vagyis a magyar nyelvrokonságról, illetve nyelvtörténetről a tudományostól eltérő nézeteket hirdető névtárak. (A parakomparativ terminusra 1. HEGEDÜs 2003: 16, 150.) A három kategória között elmosódottak a határok, hiszen szerzőik nyelvtudományi és forráskritikai ismeretek hiányában nem tudnak - és nem is feltétlenül akarnak - különbséget tenni az általuk felhasznált irodalmak között azok tudományos értékét, minőségét illetőleg, és gyakran tetszés, szimpátia alapján választanak az alternatívnak tekintett magyarázatok közül. KLIMENT EMILIA ezoterikus típusba tartozó, Névmágia címü könyve (2005) például a nevek eredetéröl többnyire hiteles információkkal szolgál, időnként azonban egy-egy sumér etimon is feltünik a kötetben. Ezt a bevezetésben meg is

\footnotetext{
${ }^{*}$ Készült az ELTE Bölcsészettudományi Karán a Tématerületi Kiválósági Programnak, a Magyar Tudományos Akadémia Bolyai János Kutatási Ösztöndíjának, valamint az Innovációs és Technológiai Minisztérium ÚNKP-19-4 kódszámú Új Nemzeti Kiválóság Programjának a támogatásával. A tanulmánynak a szótárak általános tulajdonságaira, valamint az ideológiamentes szótárak szerkesztési és etimológiaközlési gyakorlatára vonatkozó témái - részben azonos gondolatmenettel és példaanyaggal, részben további, a kvalitatív elemzést kvantitatív megközelítéssel ötvöző szempontokkal és bővebb adatolással - angolul is olvashatók (SLíz 2020).
} 
indokolja a szerző: „Ösi neveink nagy részének a jelentését nem ismerjük. A rendelkezésre álló magyarázatok puszta találgatások [...]. Ezek az értelmezések nemegyszer mármár mulatságosan képtelenek. Így társították az »Apor« nevet az apó szóhoz, az »Árpád«ot pedig az árpaszemhez. Csupán az az alapvető meggondolás hiányzik: miért neveznének apónak egy újszülött gyermeket, és miért árpaszemnek egy fejedelem utódját? Ma már a nyelvészek és történészek széles tábora bizonyítottnak fogadja el a magyar nyelv és kultúra sumér eredetét. Ezen a vonalon haladva lényegesen hihetőbb és életképesebb névmagyarázatok születtek.” (KLIMENT 2005: 5.) TOLNAI LÁSZLÓ Ösi neveink, aranykincseink címü névtára (2007) ezzel szemben a parakomparatív típust képviseli, de néhol ezoterikus, névmágiás megjegyzések is felfedezhetök a névmagyarázataiban. A Zsuzsanna szócikke végén például ez áll: „Lehetnek izgulósak, ingerlékenyek” (TOLNAI 2007: 481).

A következőkben a szótárakat nem egyesével, hanem az adott kategóriára vagy annak több tagjára jellemző tulajdonságok alapján mutatom be. Először a laikus szótárak közös sajátosságaira hívom fel a figyelmet a következő szempontok szerint: milyen közös külső jegyeik vannak; általában hogyan épülnek fel; milyen forrásokat és szakirodalmat használnak, és ezeket hogyan tüntetik fel. Ezt követően a típusspecifikus jellemzőkre térek ki részletesebben, elsősorban arra koncentrálva, hogy miképpen adják meg a vizsgált névszótárak a nevek eredetét és közszói jelentését.

\section{A laikus keresztnévszótárak közös sajátosságai}

2.1. Külső megjelenés. A bibliográfiából is látható, hogy e névszótárak (típustól függetlenül) gyakran jelennek meg hiányos könyvészeti adatokkal: a címen kívül szinte bármi lemaradhat róluk, némelyik esetében még a (szerző személyét helyettesítő) szerkesztőt is csak nehezen, a könyvkötészeti adatok közé rejtve lehet megtalálni. Borítójuk általában figyelemfelhívó, hiszen a nagyközönség érdeklődésére tartanak számot, ugyanakkor sokszor kevésbé igényes; ugyanez mondható el olykor (különösen a 90-es években megjelent szótárak esetében) a papír és a szövegszerkesztés minőségéről is. Az általános jellegüeken legtöbbször csecsemők vagy kisgyermekek láthatók, már csak azért is, mert a kiadók elsősorban a leendő szülőket tekintik potenciális vásárlóiknak (holott a keresztnevek eredete mást is érdekelhet). Emiatt tipikus színeik a világoskék és a rózsaszín, különösen, ha a férfi- és női nevek (sőt a szóhasználattal is a célközönség igényeihez igazodva: fiú- és lánynevek) gyakorlati, illetve üzleti megfontolásból külön kötetben kapnak helyet. Az ezoterikus kiadványokon jellemzőek a mágiára utaló (jel)képek, a parakomparatív névszótárak borítóján pedig gyakran felfedezhetők a nemzeti színek, valamint (ős)magyarnak tekintett motívumok, rovásírás stb. Némelyik névszótárnak a belső részében is van valamiféle díszítőelem (pl. az oldalak tetején egy gólya, csőrében pelenkába kötött csecsemővel; magenta színü betük).

2.2. Felépítés és járulékos részek. Ami e névszótárak szerkezetét illeti, némelyikben egyáltalán nincsen semmiféle járulékos elem a szótári részen kívül (1. pl. GYERGYEL szerk. é. n., LAIK szerk. 1991), többségükben azonban van rövidebb-hosszabb bevezetés és/vagy utószó, néha több is. Ezek típustól függetlenül legjellemzőbben a névválasztás fontosságát hangsúlyozzák, és néha a névjogi szabályozásról is tájékoztatják az olvasót; többnyire hitelesen, néha azonban - félreértésböl vagy célzatosan - hiteltelen állításokat is közölve. A Névmágia elöszava szerint például ,idegen eredetü személyneveknél mind a magyar fonetika szerinti, mind az eredeti írásmód használata megengedett (például 
Ivett vagy Yvette)" (KLIMENT 2005: 16). E mondatban két félrevezető információ is olvasható: egyrészt maga az állítás sem állja meg a helyét, másrészt a példaként szereplő Yvette sem szerepel az anyakönyvezhető női nevek között. ${ }^{1}$ Nem létezik továbbá a következő rendelkezés sem: „Megkülönböztető betüjel szükséges abban az esetben, ha valakinek a neve megegyezik egy jelenkori ismert személyiség nevével" (KLIMENT 2005: 16). TOLNAI LÁSZLÓ 2007-ben, három évvel a Magyarországi német utónevek jegyzékének (BRENNER-ERB-KNIPF szerk. 2004) és a többi kisebbség keresztneveit tartalmazó Nemzeti és etnikai kisebbségek utónévkönyvének (S. DÁVID szerk. 2004) a megjelenése, vagyis a kisebbségi névadásnak a többségihez hasonló, névlistával való szabályozása után kiadott könyve a következőt állítja: „Míg az első típusú eljárások esetén előfordul, hogy a Magyar Tudományos Akadémia ősi magyar nevet elutasít, és a szülök - beleunva abba, hogy gyermeküknek még mindig nincs születési anyakönyve - más nevet választanak, addig a család a »kisebbségi« jogokra való tekintettel gyermekének akár a Cipöfüzö nevet is adhatja" (TOLNAI 2007: 486). SzEGEDI CSANÁD ezzel szemben a névszótára második kiadásában közölt interjúban a kérelmek elbírálása kapcsán éppen ellenkező, de szintén nem hiteles állítást tett: „,most már csak formaság az egész, hiszen minden névre megadják az engedélyt" (SZEGEDI 2004: 18).

Az ezoterikus és a parakomparatív névszótárak ezek mellett időnként az irányultságuknak megfelelö, speciális témákkal is foglalkoznak (pl. a névmágia müködése, numerológiai alapvetések, „névelemzési” módszerek segédletekkel [pl. TAKÁCs 2006a, 2006b], számmisztikai alapú névválasztó játékok [pl. ifj. KULCSÁR szerk. 1992]; a magyar nyelv nem finnugor eredete, hun, szkíta, sumér stb. rokonsága; a magyar nyelv és nép egyedisége; rovásírás [pl. SzEGEDI 2002]). Az utóbbiakban még olyan, a nyelvtől és a névadástól távol álló témák is elökerülnek, mint a népmüvészet, a népzene vagy a kékfestés (TOLNAI 2007), illetve statisztikai elemzések Magyarország demográfiai helyzetéröl (pl. születésszám, abortuszok száma; SzEGEDI 2004). Mindezen járulékos részek mellett azonban a legritkábban találunk tájékoztatást a szótár tartalmáról és a szócikkek felépítéséről.

Maguknak a neveknek a közlése az egyszerü, mindenféle kísérő információ nélküli névlistáktól (pl. NYERS 1997) a rövidebb-hosszabb, akár egyoldalas szócikkekig terjed (pl. KLIMENT 2005). A szócikkek gyakran irreleváns információkat is tartalmaznak. TöLGYESInél például a nevek alapjául szolgáló közszavak kapcsán néhány helyen hosszabb müvelödéstörténeti ismertetések is szerepelnek. A Bíbor névnél például a következö: „A bíbor a rangot és a gazdagságot mutatta, és már az ókorban a hatalom jelképe volt. A festéket bíborcsigákból nyerték, és a legmagasabb méltóságok ruháját festették vele. Akkoriban tizenkétezer csigából tudtak néhány grammnyit előállítani, ezért a bíbor különösen drága anyag volt." (TÖLGYESI 2006: 12.) A szócikkek rendjének összekeveredése szintén előfordul: a LAIK szerkesztette szótár (1991) például 23 esetben is felcseréli a betürendet, a GYERGYEL szerkesztette szótár (é. n.) pedig - egy korábbi hibára visszavezethetően - a nöi nevek között sorolja fel a Bonaventúrá-t. Hasonlóképpen, SzEGEDI CSANÁDnál (2004) az Agáta férfinév, a nem anyakönyvezhető Pete, valamint az anyakönyvezhetö Petres, a Mike, a Szeverin és a Szilvánusz női név, a Nyeste pedig mindkét nemnél fel van tüntetve. E szótár esetében azonban nem feltétlenül szerkesztési hibára kell gondolnunk, inkább tudatos döntés állhat a háttérben. A szerző ugyanis elutasítja a nevek tudományos etimológiáját, mint azt a vele készült interjúban kifejtette: „Nem

${ }^{1}$ A mindenkori anyakönyvezhető nevek havonta frissülő listáját 1. a Nyelvtudományi Intézet honlapján: http://www.nytud.mta.hu/oszt/nyelvmuvelo/utonevek/index.html. (2020. 04. 20.) 
vagyok híve a délibábos nyelvészkedésnek, ezért olyan dolgokat nem írtam bele[,] ami nem biztos. Csak azok mellé írtam jelentést[,] amit biztosan tudunk." (SzEGEDI 2004: 18.) Ennek megfelelöen a puszta névlistát csak időnként töri meg egy-egy, esetlegesen feltüntetett, a tudományos állásponttól eltérő etimológiai jelentés vagy a hajdani névviselöre vonatkozó információ, így nem derül ki, hogy a szerző milyen etimológiai jelentést tulajdonít az említett neveknek.

A laikus szótárak a szakmaiakhoz hasonlóan tipikusan nemek szerinti bontásban közlik a neveket, de kevésbé tipikus megoldás is előfordul: például nemenként, de azon belül eredet szerint (GYERGYEL szerk. é. n.), vagy pedig a rokon neveket (pl. Pál, Paula és Paulina) közös szócikkbe vonva, nemtöl függetlenül tárgyalják (KLIMENT 2005). A szerkezetet azonban a kiadói szempontok megbonthatják, amint azt a LAIK-féle (szerk. 1991) szótár mutatja. Ebben, bár kezdőbetűnként fejezetekre tagolódik, a nőknél a Cs-vel kezdődő nevek - minden jelzés nélkül - bekerülnek a $C$ fejezetének végére, bizonyára mivel mindössze öt van belőlük. A 16, Cs-vel kezdődö férfinév ugyanakkor elégnek bizonyulhatott ahhoz, hogy külön fejezetet kapjanak. Hasonlóképpen egybekerül az $N$ és az $N y$ (mindkét nemnél), az $U$ és az $\ddot{U}$, valamint a $V$ és az $X$; igaz, a legutóbbi esetben a fejezet címe $(V, X)$ legalább jelzi az összevonást. De a következetlenség nemcsak a fejezetek beosztásában, hanem a szócikkek szerkezetében is felfedezhető e szótárban: míg általában minden név önálló szócikket kap, a Betta és a Bettina, illetve a Szofi és a Szófia egy szócikket képez. Ráadásul az elöbbi szócikkben még jelentés sincs, csupán egy zárójeles utalás - „(Babett, Berta, Erzsébet)"2 - holott egyébként a szótár nem kapcsolja össze utalórendszerrel az egymással rokon neveket.

2.3. A források és a szakirodalom felhasználása. A kiadványok egy részéből (jellemzően a 90-es években kiadottakból) nem derül ki, hogy készítőik mi alapján dolgoztak (vö. FARKAS 2006: 246-247). Ha van bibliográfia, akkor tipikusan szakszerütlen: jellemzőek a hiányzó adatok, a betürend hiánya, a tévesen megadott címek és a hibás névalakok (pl. „Gombóc-Melich: Etymologia szótár”; SZEGEDI 2002: 165). A hivatkozott bibliográfiában még az is elöfordul, hogy két bibliográfiai tétel mindössze a szerzők nevéből áll; ráadásul e két szerző (GÁBORJÁNI SZABÓ MIHÁLY és SZABOLCS) ugyanazon névszótárat jegyzi (GÁBORJÁNI SZABÓ - GÁBORJÁNI SzABÓ 1936; 1. később), tehát külön sorban való feltüntetésük megtévesztő. Ami a felhasznált munkákat illeti, az általános jellegü kötetek többnyire hiteles, de gyakran elavult és nem feltétlenül nyelvészeti müvekre támaszkodnak, a másik két csoport azonban jellemzően keveri a szakmunkákat a hiteltelen írásokkal (gyakran egymásra hivatkozva) és az irodalmi müvekkel (pl. Arany: Buda halála).

2.4. A névanyag anyakönyvezhetősége. Arra, hogy milyen típusú információkat tartalmaznak a vizsgált névszótárak, még visszatérek az egyes típusok alaposabb bemutatásakor; itt csak egy, különösen a parakomparatív típusra jellemzö, de a másik két típus egyes képviselőinél is megfigyelhető sajátosságot emelek ki: annak ellenére, hogy elvileg a szülök dolgának megkönnyítése a céljuk, a névszótárak gyakran nem csak az anyakönyvezhető neveket tartalmazzák. Ez az utónévportálok egy részére is jellemző (vö. FARKAS 2019: 70). Egy Utónevek, keresztnevek, névnapok címü utónévkereső ${ }^{3}$

\footnotetext{
${ }^{2}$ A kurziválás az eredetit követi.

${ }^{3}$ http://www.szuloklapja.hu/utonev-kereso.html (2020. 04. 20.)
} 
például, amely a Szülők lapja.hu, a babák-mamák szakértője elnevezésű honlapon működik, több nem anyakönyvezhető nevet is tartalmaz, és ezek mellé ugyanúgy ad statisztikai megjegyzést, mint a valóban választható nevek mellé. A Csellőke kapcsán például azt olvashatjuk, hogy „nagyon ritkán adott lány név [!] volt 2017-ben”, majd hogy nincs rá adat sem első, sem második névként, sőt a teljes lakosságban sem. ${ }^{4}$ Hogy valójában soha nem adták, mert nem is adhatták e nevet, arra már a szülőnek magának kellene rájönnie. Hasonlóan elöfordulnak - minden jelzés, megkülönböztetés nélkül - nem anyakönyvezhető nevek a Babanet utónévkeresőjében is ${ }^{5}$ (melyben a betürend összekavarodása kissé megnehezíti a lista áttekintését). Jó példa erre az Alattyán, amelynél az említett probléma mellett ráadásul a jelentés helyett megismétlik az eredetet, és - a keresők többségéhez hasonlóan - nem derül ki, honnan származik a magyarázat: „Magyar, török eredetü, férfi név. Jelentése: Az Alattyán valószínüleg török eredetü magyar férfinév."

A vizsgált névszótárak egy része e keresőkkel ellentétben különféle módokon azért legalább utal az adott név hivatalos státuszára. Az internetes Magyar Keresztnevek Tára [a továbbiakban: MKT.] például egy bizonyos ikonnal jelzi öket, a TÖLGYESI GÁBOR szerkesztette, az általános jellegüek közé sorolható kiadvány pedig az előszóban jelzi, hogy az anyakönyvezhető neveket kiemelte (2006: 5). ${ }^{6}$ Azt ugyanakkor nem közli, hogy milyen módon, így az olvasónak magának kell rájönnie, hogy a címszó félkövér szedése utal az anyakönyvezhetőségre. Ezek a jelzések azonban nem feltétlenül megbízhatók. A SZEGEDI-féle névtár 2. kiadásának (2004) közel 8200 nevéből például több mint 7300 , azaz a nevek 90\%-a nem anyakönyvezhető. Az előszók nem utalnak arra, hogy valamiképpen jelölve lenne a nevek státusza ilyen szempontból, ugyanakkor az egyes nevek után álló csillag az anyakönyvezhetöségre látszik utalni. Ezt a következtetést azonban bizonytalanná teszi, hogy 208 anyakönyvezhetö névnél nincsen csillag, 2 nem anyakönyvezhetönél viszont van.?

A hivatalosan el nem fogadott, ennélfogva jelenleg Magyarországon keresztnévnek nem minősülö elemek felvétele az e tényre való figyelmeztetés ellenére is megtévesztő lehet, és gyakorlati problémát okozhat. A szülők ugyanis nem feltétlenül veszik észre a szótárak jelzését (ha van egyáltalán), és gyakran már későn szembesülnek azzal, hogy a választott név nem adható a gyermeknek, sőt esetleg még az Utónévbizottság sem támogatja a kérelmüket. Egyes esetekben e névszótárak vagy utónévportálok eleve fölösleges kérelmezésre késztethetik a szülöket; például amikor tévesen jelölik meg a nemet a név mellett. A törvény szerint ugyanis a gyermek csak a nemének megfelelő nevet kaphat, az Utónévbizottság tehát nyilvánvalóan nem támogathat ezzel ellentétes kérést. Ezt a szülők úgy élhetik meg, hogy az állam, a törvény, az Akadémia stb. korlátozza őket saját identitásuk, érdeklődésük stb. kifejezésében, ráadásul igazságtalanul, hiszen a név létezik, elvégre egy keresztnévkönyvböl vagy internetes névtárból választották.

${ }^{4}$ http://www.szuloklapja.hu/lany-nevek/cselloke.html (2020. 04. 20.)

${ }^{5}$ https://www.babanet.hu/utonevkereso (2020. 04. 20.)

${ }^{6}$ A megfogalmazásban alkalmazott idézőjel ráadásul azt a benyomást keltheti, hogy a szerző megkérdőjelezi az eljárás hivatalos voltát: „Könyvünkben a külön eljárás nélkül adható és a »hivatalosan« elfogadott neveket kiemeltük" (TÖLGYESI 2006: 5).

${ }^{7}$ Mivel a Nyelvtudományi Intézet honlapján elérhető hivatalos listán nem szerepel az elfogadás dátuma, jobb híján a MUnk.-kal vetettem össze a szótár állományát, mivel annak 1998-as kiadása közelebb áll hozzá időben a mai állapotnál. 
A tárgyalt szótárak és portálok ezen eljárása tehát mindenki számára negatív következményekkel járhat: a szülőknek csalódást és frusztrációt okozhat, a hivatalnak és az Utónévbizottságnak fölösleges adminisztrációs terhet és szakmai munkát jelenthet, a társadalom szempontjából pedig azért lehet káros, mert az összeesküvés-elméletek és az előítéletes gondolkodás erősödésével járhat. Álljon itt erre példaként egy idézet egy tipikus internetes írásból: „Elgondolkodtató[,] hogy mekkora elemi erővel igyekeznek ősi kultúránkat, hagyományainkat kitörölni úgy, hogy múltunknak még írmagja se maradjon. [...] A Magyar Tudományos Akadémia pedig nyíltan megtiltotta sok szép magyar keresztnevünk használatát (a héber nevek viszont, [!] furcsa módon nem esnek korlátozás alá)." (LÁSZLÓ 2014.)

3. Az általános jellegű keresztnévszótárak tartalmi jellemzői. A forgalomban lévő vagy antikváriumban, könyvtárakban elérhető, általános jellegü utónévkönyvek közül a továbbiakban ötre koncentrálok részletesebben (GYERGYEL szerk. é. n., GYÖRI szerk. é. n., LAIK szerk. 1991., PÁlfy é. n., TÖlgYESI 2006). Közülük a PÁlfi GYULA szerkesztette névkönyv emelhető ki pozitív példaként, ez ugyanis a szerkesztő laikus volta ellenére szakszerünek nevezhető.

A tartalom kapcsán két kérdést járok körül részletesen: a néveredet, illetve a közszói jelentés megadását. E kettőt a laikus szerzők és szerkesztők gyakran nem tudják szétválasztani, és megfelelő ismeretek hiányában abban sem kompetensek, hogy kiszürjék az általuk felhasznált irodalomban felbukkanó esetleges ellentmondásokat vagy téves információkat. (Ez, mint korábban jeleztem, a másik két típusra is jellemző, azok alkotói azonban speciális céljaikból kifolyólag általában nem is törekednek az általuk elutasított tudományos információk megszerzésére, illetve közvetítésére.) A probléma egyébként, úgy tünik, nem csak a magyarra jellemző (vö. MCCLURE 2015: 275).

3.1. A néveredet megadásának problémái. Az alábbiakban azt mutatom be, milyen tévedéseket és félreértéseket okozhat ennek a meglehetősen bonyolult, a névtani szakirodalomban sem kellően tisztázott problémakörnek a megfelelő elméleti és módszertani háttér nélküli kezelése (vö. FARKAS 2006: 248-249, SLÍz 2017: 57-58).

Több névszótárból is kiderül, hogy szerzőjük vagy szerkesztőjük számára nem világos az eredet terminus jelentése. TÖLGYESI például az előszóban (2006: 5) - ritka és pozitív kivételként - megkísérli meghatározni, pontosan mely névtípusokat sorolja a magyar eredetüek közé. Definíció helyett hét csoportot állít fel; ezek közül kettőnek a meghatározása azonban logikai ellentmondást tartalmaz. Az egyik a régi magyar neveké, amelyekről a következőt olvashatjuk: „Mivel a finnugor időkből írásos emlékek nem maradtak fenn, e nevek elsősorban (ó)török és szláv eredetüek.” E kijelentés tarthatatlansága a laikusok számára is könnyen belátható, hiszen egy magyar eredetű név nem lehet ugyanakkor (ó)török vagy szláv eredetü is. A magyar eredetüek egy másik csoportjába sorolta a szerző azokat a neveket, amelyek megmagyarosodtak, hangalakjuk módosult (pl. Erzsébet). Egy név azonban nyilván csak akkor tud megmagyarosodni, ha idegen eredetü. E logikai bukfencek ellenére a szerzőnek bizonyos szempontból igaza van abban, hogy e két csoport elemeit is magyarnak tekinti, hiszen aligha vitatná bárki is például a Gyula vagy az Erzsébet magyarságát; különbséget kell azonban tennünk a magyar eredetű és a napjainkban magyarnak tartott nevek között. Egy név eredete ugyanis objektív, a névhasználók megítélésétől független nyelvi tény (habár a tudomány aktuális állásától függően változhat a név eredet szerinti kategorizációja), a név adott 
jellegűnek ítélése azonban csak konkrét időben, területen és névhasználó közösségben, számos nyelven kívüli tényezőt figyelembe véve értelmezhető (ugyanerre a családnevek kapcsán vö. FARKAS 2010: 64-68).

A néveredet terminus több jelentésének a szakirodalomban is gyakran önkéntelenül elkövetett összemosása szempontkeveredéses rendszerhez vezet. Ezt a legvilágosabban a GYERGYEL szerkesztette (é. n.) utónévkönyv példáján lehet illusztrálni, ez ugyanis már a neveket is az „eredetük” alapján csoportosítva közli. Csakhogy az egyes, valóban nyelvi eredetet képviselő csoportok mellett egyéb szempontok szerinti kategóriák is felbukkannak. Míg például a nőknél „héber, görög és latin eredetü”, addig a férfiaknál már „ókori eredetü (héber, görög, latin) nevek” szerepelnek, vegyítve az idő és a nyelv szempontját. Ugyanez figyelhető meg az ,újabb keletü, nem magyarban létrejött nevek” csoportja esetében, míg a „müvészi alkotású nevek” és a „becézésből létrejött nevek” kategóriák a névkeletkezés módját helyezik előtérbe.

A következő probléma, hogy a néha már eleve tévesen kialakított rendszerbe a neveket gyakran rosszul sorolják be (nem ritkán annak ellenére, hogy maguk is közlik a név eredetére vonatkozó hiteles információt). Az említett munkában például (GYERGYEL szerk. é. n.) az Ancilla a magyar eredetűek között szerepel, holott szócikke szerint „régi magyar női név a latin ancilla (rabnő, szolgáló) szóból.” A világosan magyar közszóból született Ciklámen, Nefelejcs, Levendula, Öszike, Napsugár, Mátka ezzel szemben az újabb keletủ nem magyarok közé került; a Ferenc pedig az ókori eredetủek között található meg, bár ,az olaszban keletkezett”. A Ramón és a Rodrigó - nyilván a germán eredetü Rajmund-ból, illetve Roderik-böl való származásuk alapján - a germán nevek között szerepel, és még csak utalás sincs arra, hogy a spanyolból vettük át őket.

A több nyelven keresztül vándorló nevek esetében különösen nehéz a döntés, hiszen három lehetőség áll elöttünk: 1 . csak azt a nyelvet adni meg, amelyben a név keletkezett; 2. csak azt, amelyből a magyarba került; 3 . mindkettőt (és esetleg a közbeeső állomásokat is) megadni. A döntés attól is függhet, hogy milyen céllal, milyen korszak neveiről és milyen közönségnek készítjük a névszótárat. A nagyközönségnek szánt, napjaink névkészletét bemutató névszótárak esetében a helyes döntés véleményem szerint a 3 ., azzal a megjegyzéssel, hogy a lényeg a keletkezés és az átadás nyelve, így a közbeeső állomások akár nyugodtan el is hagyhatók. A keletkezés nyelvének megadása ugyanis sokszor megkönnyíti a közszói jelentés közlését, az átadás nyelvének közlése pedig segít elkerülni az olyan feltételezéseket vagy félreértéseket, hogy ha egy adott név akkád vagy kelta eredetủ, akkor az akkád vagy a kelta és a magyar nyelv beszélöi között közvetlen népi kapcsolat, netalán rokonság állt fenn.

Mivel a laikus szerzők nem látják át az eredetmegadás problémáját és annak súlyát, az egyes állomások leírását néhányuk (a vizsgált szótárak készítői közül a legnagyobb arányban LAIK [szerk. 1991], valamivel kisebb számban, kevesebb hibával GYÖRI [szerk. é. n.]) kötőjeles kapcsolatokra rövidíti, minél több információt akarva közölni minél kevesebb helyen. Ez a megoldás azonban számos félreértésre ad lehetőséget. A nyelvek kapcsolata például a diakrónia helyett a szinkróniában is értelmezhető; ezért is különösen problematikus például a nyelvek különbözö történeti korszakainak és területi változatainak, valamint a nyelvcsaládoknak, alapnyelveknek egy szinten kezelése: a Célia ,latin-indoeurópai”, az Erik „alnémet-északgermán”, az Ernella „ófelnémet-olasz”, a Hugó és a Rajmund „germán-német”, a Lél „finnugor-magyar”" (LAIK szerk. 1991).

\footnotetext{
${ }^{8}$ A kis- és nagykötőjeleket az adott szótárt követve alkalmazom.
} 
Ha logikus módon azt feltételezzük, hogy a kötőjel az egyik nyelvből a vele érintkező másikba való átadást jelent, akkor is értelmetlen ez a leírás; erre már HAJDÚ MIHÁLY is utalt a LAIK-féle szótár rövid ismertetésében (vö. HAJDÚ 1998: 135).

Szintén zavaró, ha a nyelvek sorából nem koncepcionálisan, hanem véletlenszerüen marad ki egy vagy több, különösen ha az az átadó nyelv. A Pedró például „görögspanyol" (LAIK szerk. 1991), holott nem a görögböl, hanem a latinból került a spanyolba. Az Egyed ,görög-magyar eredetü, az Aegidius névből” (GYŐRI szerk. é. n.); a latin innen is kimarad, habár az említett Aegidius éppen a név latin változata.

Zavart okoz az időrend esetenkénti felrúgása is: a Dárió például „a latin-perzsagörög eredetű Dárius név olasz változata” (GYÖRI szerk. é. n.), a Berill „,középind-óindangol”, a Cézár ,latin-etruszk” (LAIK szerk. 1991).

További szembetünő hiba, hogy a nyelv helyett néha nép(csoport), vidék vagy állam szerepel; pl. Kisanna: „,héber-székely”, Leonidász: „görög-dór”, Lizander: „spártai-latin”, Muriel: „,kelta-angol-normandiai”, Várkony: „török-avar-magyar” (LAIK szerk. 1991).

Ráadásul egyes leírásokból kiderül, hogy a készítők nem feltétlenül vannak tisztában a nyelvek megnevezésével. LAIK ÁGNES például feltehetőleg az oszmán-törököt és a bolgár-törököt is két-két nyelvként értelmezte, vagy pedig a helyesírásukban hibázott: a Gyula és a Zsombor ,bolgár-török-magyar”, a Ladomér „szláv-bolgár-török”, a Tulipán pedig ,perzsa-olasz-német-ozmán[!]-török-magyar” (LAIK szerk. 1991). Emellett ugyanazon nyelv megnevezésének többféle, akár elavult változatát is használja: a Barabás „,arámi-héber”, a Bartal ,,arámeus-görög-latin”, a Tamás ,,arameus-görög-latin”. E munkában nem létező nyelv is felbukkanhat: a Redmond „tenton germán” eredetű név. (Ez még akkor is tévedés, ha feltételezzük, hogy a tenton a szakirodalomként használt müben szereplő teuton elgépelése, esetleg a forrásként szolgáló írás szkenneléséből fakadó hiba.) Ennél is zavaróbb a GYŐRI szerkesztette szótár (é. n.) következő leírása az Eszmeralda szócikkében: „,szemita-görög-spanyol eredetü”.

Az sem ritka, hogy a szótárak - az eljárás mibenlétét nem ismerve - gördített etimológiával dolgoznak, vagyis a név alapjául szolgáló közszó eredetét is figyelembe veszik, és minden megkülönböztetés nélkül a tulajdonnév eredetét leíró kötőjeles egységhez kapcsolják. A virág nevének végső eredete miatt lesz a Petúnia ,indián-magyar eredetü” (vö. GYÖRI szerk. é. n., LAIK szerk. 1991), a Tulipán pedig, mint fentebb láttuk, ,perzsa-olasz-német-ozmán[!]-török-magyar” (LAIK szerk. 1991). Az Ilma szócikkében egy további probléma is van. Bár a szótár közli, hogy a név „Vörösmarty Mihály irodalmi névalkotása: Ilona + Vilma", a magyar kimarad a nyelvek sorából, s a két, alapul szolgáló név alapján „görög-német” szerepel a leírásban (LAIK szerk. 1991). A Varsány esete részben hasonló, csak itt nem az alapul szolgáló népnév eredete, hanem jelentése miatt szerepel az ,albán-magyar”, habár a varsány nem az albánok, hanem az alánok megnevezése lehetett (LAIK szerk. 1991).

Emellett a homonim nevek eredetének leírásában nem mindig különül el a két név eredete. Így lesz a magyar 'karvaly' jelentésű szóból tulajdonnevesült és a végső soron germán eredetü, átadó nyelve szempontjából bizonytalan (ném. Karl, lat. Carolus) név alakjának egybeesését példázó Károly, germán-latin-magyar” (LAIK szerk. 1991). A Vera, amely egyrészt egy szláv eredetü név, másrészt a latinból átvett Veronika becenevéből alakult, sőt GYÖRI (szerk. é. n.) állítása szerint a német eredetü Veréná-ból is rövidülhetett, így lesz LAIKnál „latin-német-szláv-magyar”.

Ha az eredet megadását rendszerszerűen is megvizsgáljuk egy-egy kiadványon belül, kiderül, hogy az azonos nyelvből eredő vagy egymással etimológiailag összefüggő 
neveknél esetenként következetlenek a névszótárak. A LAIK-féle utónévkönyv (szerk. 1991) szerint például a Vladimír „szláv”, míg a vele azonos szerkezetű, sőt azonos előtagot tartalmazó Vladiszláv már „ószláv” eredetü; vagy a Tatjána „latin-orosz-németmagyar” eredetű, míg a belőle keletkezett Tánya „orosz” (igaz, a kötet nem utal a két név összefüggésére). Hasonlóképpen, a Margit-tal etimológiai kapcsolatban álló neveket szemlélve: a Margaréta „görög”; a Margit, a Margita és a Margó „görög-magyar”; a németből átvett beceneve, a Gréti „,babiloni-görög-német-magyar”; az angolból átvett beceneve, a Peggi pedig ,görög”.

3.2. A közszói jelentés megadásának problémái. E kérdés összefügg az etimológia megadásával, így a gondok egy része a nyelvi eredet megadásának problémáiból vezethető le. Az azonos felépítésű vagy egymással etimológiailag összefüggő nevek esetében például gyakran a közszói jelentés megadása is következetlen vagy téves. Míg az itt tárgyalt névszótárak többsége többé-kevésbé hiteles információkkal szolgál e tekintetben, a LAIK ÁGNES szerkesztette kiadvány (1991) - nemcsak terjedelme, hanem szükségszerü tömörsége okán is - különösen alkalmas az elkövethetö hibák típusainak bemutatására, ezért a következőkben ebből merítem példáimat.

Az ún. ditematikus nevek, amelyek a germánra és a szlávra is jellemzőek, egy elő- és egy utótagból állnak, melyek viszonylagos szabadsággal kombinálhatók. Ezek megadásának leghelyesebb módszere a két tag közszói jelentésének külön-külön való megadása; pl. Vladimir: „hatalom + béke”. Az előzőekben már említett, ugyanígy felépülő Vladiszláv esetében azonban már egy jelzős szerkezet szerepel a névszótárban: „dicsőséges uralkodó". Az efféle szerkezetek létrehozása természetesen nem a szerkesztő egyéni leleménye, hanem a külföldi és magyar keresztnévszótárakban általánosan és tipikusan követett, de tudományos szempontból pontatlan megoldás (MCCLURE 2015: 276). ${ }^{9}$ A gond tehát abból adódik, hogy a szerkesztő nem látta e két név azonos szerkezetü voltát, így a kétféle leírás közti eltérés mint probléma sem merült fel benne (annak ellenére sem, hogy a Vladiszláv közvetlenül a Vladimír alatt áll a lapon). A már szintén említett Tatjána és Tánya esetében még feltünőbb az inkongruencia: míg az előbbihez a névszótár a „Tatius családjához tartozó”, addig az utóbbihoz a „bálkirálynő” leírást kapcsolja. Ezek alapján már szinte bizonyosra vehetjük, hogy a két név eredet szerinti összetartozására azért nincs utalás, mert a szerkesztőnek e tény elkerülte a figyelmét.

A szakmai háttér hiánya miatt nemcsak az eredet megadása lehet pontatlan. Ha egy-egy név eredetéről megoszlik a kutatók véleménye, természetes, hogy a különböző nyelvekben más-más, egymástól eltérő jelentésű etimont feltételeznek. Ezeket azonban módszertani hiba a bizonytalanságra és a feltételezett kiindulási nyelvre való utalás nélkül, egymás mellett megadni, másképp olyan képtelen magyarázatok jönnek létre, mint a Petróniusz: „edzett férfi, ürü” vagy a Szörény: „komoly, szigorú, mormota”. Hasonlóképpen történik ez a homonim nevek esetében is: a Károly például, melynek alakjában, mint fentebb láttuk, egybeesik egy 'karvaly' jelentésü magyar és egy 'férfi' jelentésü, végső etimonját tekintve ófelnémet név, így lesz „legény, fiú, karvaly, turul”.

A nem tudományos irodalom felhasználása értelemszerűen téves közszói jelentések megadásához is vezethet; így lett a tárgyalt kötetben a Lél „kürtös, kürtfúvó”, nyilván nem függetlenül a mondától.

${ }^{9}$ A vizsgált szótárak közül a GYERGYEL-féle (szerk. é.n.) és a GYÖRI-féle (szerk. é. n.) is alkalmazza, bár következetlenül. 
Végül megemlítendő, hogy a szótár a jelentés helyén időnként inkább valamely híres névviselőre utal. Az Amerigó jelentéseként például a következő olvasható: „Amerika felfedezője".

4. Az ezoterikus keresztnévszótárak tartalmi jellemzői. Az e típusba sorolható, ma is elérhető utónévkönyvek közül a továbbiakban négyre (illetve a két TAKÁCSnévszótár összetartozása révén tkp. háromra) koncentrálok részletesebben (ifj. KULCSÁR szerk. 1992; KLIMENT 2005; TAKÁCS 2006a, 2006b; az első kiadvány rövid kritikáját 1. HAJDÚ 1998: 135). Ezeket a fentieknél rövidebben tárgyalom, mivel nyelvészeti-névtani szempontból kevés releváns információt tartalmaznak; inkább csak átfogó képet kívánok nyújtani e szótártípus jellemző tartalmairól.

E munkák alapját az olyan ezoterikus tanok képezik, mint a névmágia, a horoszkóp, a numerológia vagy az asztrológia, melyek segítségével e kiadványok a hétköznapi embereknek is bepillantást engednek a nevek rejtélyesnek hirdetett világába. A kiadványok címei (Névmágia; A keresztnevek titkai; Sorsunk a nevünkben) tökéletesen leírják ,elméleti" kiindulópontjukat: a személyek és nevük között eleve adott, titokzatos kapcsolat van, amely meghatározza a sorsukat; e titok azonban a megfelelő módszerek követésével, illetve a beavatottak segítségével felfedhetö. A keresztnevek titkai címü kiadványban (ifj. KULCSÁR szerk. 1992) közölt táblázatok segítségével például - a kötet szerzője által ajánlott szórakoztató játékként - az anya és az apa születésnapja és horoszkópja alapján kiszámolható a gyermeknek javasolt névnap dátuma, így a név is. Azt pedig, hogy kire milyen tulajdonságok jellemzőek, a születésének időpontja határozza meg, akárcsak a horoszkópok esetében; ezért a könyv harmadik részében nem nevekhez, hanem adott hónap adott napjához tartozó jellemzések olvashatók; a február 26-án születettek például jó diplomáciai érzékkel bírnak, és gyors karriernek örülhetnek. A táblázatok és egyéb segédletek (pl. asztro ABC vagy a névelemzési módszer leírása) a tudományosság látszatát igyekeznek kelteni, összefüggésben azzal is, hogy más ezoterikus témákhoz hasonlóan a keresztnevek kapcsán is léteznek tudományosként kommunikált tanfolyamok. TAKÁCS TIBOR könyveiből például „Nomen est omen” címmel egy füzet formájában kivonat is készült, a borító alján a következtető megjegyzéssel: „A névelemző tanfolyam anyaga” (TAKÁCS é. n.). A Névmágia előszava az esetleges kétségeket is igyekszik eloszlatni: „Ha azonban úgy találjuk, hogy a nevünknél szereplő jellemrajz csak felében-harmadában fedi a valóságot, ennek oka a vezetéknév befolyásoló ereje" (KLIMENT 2005: 7).

E kiadványok a nevekről általában a következő információkkal szolgálnak: eredet és közszói jelentés (az általános jellegüeknél ismertetett problémákkal, pl. Hippia: „göröglatin-magyar eredetü", 1. TAKÁCS 2006b) és névnap. Ezt követik az ezoterikus tartalmak: például numerológiai adatok, a névviselő külső-belső jellemzése horoszkópszerüen (ez az ún. névelemzés), esetleg egy híres névviselö rövidebb-hosszabb életrajza. A névelemzések gyakran a közszói jelentésböl indulnak ki, mint például a Benigna esetében: „(latin) jóságos, kegyes, jóakaró. Feladata megtalálni azt az életterületet[,] ahol szolgálhat.” (TAKÁCS 2006b).

5. A parakomparatív keresztnévszótárak tartalmi jellemzői. A következőkben három nyomtatott (NYERS 1997, SZEGEDI 2002, TOLNAI 2007) és egy internetes szótár (MKT.) alapján mutatom be e típus jellegzetességeit, hozzátéve, hogy a személynevek parakomparatív ideológiákban való szerepét nemcsak az efféle névszótárak tükrözik, hanem számos, ilyen szempontból összeállított névanyagot tartalmazó naptár is (ezekről bővebben 1. SLÍZ 2018). 
5.1. A bemutatott szótárak előzményei. E munkák nyelvi ideológiai, szociológiai, pszichológiai stb. hátteréről bővebben itt nem kívánok szólni, hiszen számosan megtették már korábban. Arra azonban, hogy a parakomparatív ideológiákban milyen jelentős szerep jut a hely- és személyneveknek, illetve hogy ezen ideológiák milyen módon használják fel a neveket céljaik elérése érdekében, csak az utóbbi időben irányult nagyobb figyelem (vö. IMREH 2014, 2015; ZELLIGER 2017; SLíz 2018). Általánosságban elmondható, hogy közös pontjuk a magyar nyelv (és nép, hiszen e kettő között nem tesznek különbséget) finnugor eredetének elutasítása, ezen túlmenően azonban meglehetősen eklektikusak, gyakran különböző szubkultúrák elemei elegyednek bennük szétválaszthatatlanul (sumér rokonságban hívő, hun rokonsággal összefüggő, tengri, Arvisura stb.). Fő jellemzőjük, hogy a neveket az adott ideológiáknak megfelelően átértelmezett történelem, s akár egyfajta kitalált mitológia alapján válogatják és magyarázzák. Forrásaikat ritkán jelölik (ha igen, akkor is leginkább egymásra hivatkoznak), ezért nehéz, sőt néha lehetetlen azonosítani, hogy melyik név melyik ideológiához kötődve, milyen müböl került az adott névszótárba. Biztosan azonosítható névszótári forrás például GÁBORJÁNI SZABÓ MiHÁLY és SzABOLCS református lelkipásztorok 1936-os, Öseredetü magyar személynevek tára címü munkája: a fülszöveg szerint NYERS (1977) névszótára ezen alapul, SzEGEDInél (2002) pedig e szerzők neve is szerepel a bibliográfiában. A következőkben - a 19. századi előzményekre, például HoRVÁT ISTVÁNra nem kitérve csupán három, a 20. század második feléből való munkát mutatok be röviden, amelyek nemcsak névanyagukat tekintve, hanem a mögöttük lévő ideológia szempontjából is lényeges forrásként vagy mintaadóként (többé-kevésbé) azonosíthatók a szótárak bibliográfiája, névanyaga és magyarázatai alapján.

Az egyik ilyen forrás az ún. FÉRAN naptár (PAÁL - KÁLLAY L. [1977]), amely „egy jellegzetesen egyértelmü, ősi névadási-ciklus rendszer. Ez az ősi Melegvizek Birodalmának 8-as szaporodási rendszerén alapult. [...] A Kr. elötti 48 ezer évtől fejlődő, 63 ezer névből készült, napi 24 nevet tartalmazó névadó naptár Ataisz elsüllyedése (Kr.e. 5038) után, Kr.e. 3970-ben újíttatott fel elöször". ${ }^{10}$ Ez a naptár, melynek neve a két nemre utal (fér: 'férfi', an: 'nő, tkp. anya'), az Arvisura nevü, PAÁL ZOLTÁN ózdi kohász által kitalált „mítoszrendszer” része. Ennek alapját az állítólag a hun-magyar törzsek sok ezer éves történelmét és mítoszait magába foglaló, kinyilatkoztatás és a kollektív tudattalannal való kapcsolat révén megismert szövegek képezik (bővebben 1. PAÁL 2009). Ezek köré mára egész szubkultúra épült ki, amelynek saját honlapja is van. ${ }^{11}$ Az említett naptár valójában egyszerü névlista, mely hónaponként ${ }^{12}$ minden naphoz 4-4 állítólagos vagy valós férfi- és női nevet sorol. Ezen, ősi hunnak és magyarnak mondott nevek között - a hun-magyar hagyományból, a magyar történelemböl és mondavilágból, a Gilgames eposzból, 19. századi, fiktív ösmagyar környezetben játszódó romantikus müvekből és még számos forrásból nagy képzelőerővel megalkotott mitológiának megfelelően - elöfordulnak a korai magyar történelemhez kapcsolódó személynevek (pl. Aba, Álmos, Jutas), a középkorból adatolható egyéb nevek (pl. Bors, Kaplony, Lökös), helynevek (pl.

${ }^{10} \mathrm{Az}$ Arvisura naptári rendszere. In: Magyar östörténet, Regevilág, Arvisura. http://www. regevilag-arvisura.eoldal.hu/cikkek/az-arvisura-naptari-rendszere.html (2020. 04. 20.) A naptárra és a névadásra vonatkozó részleteket (1. alább) szintén innen idézem.

${ }^{11}$ Magyar östörténet, Regevilág, Arvisura. http://www.regevilag-arvisura.eoldal.hu (2020. 04. 20.)

${ }^{12}$ A hónapoknak saját nevük van, például az augusztusnak Aranyasszony (Böség hava), a szeptembernek Tigris (Almaszüret), a decembernek Istenfiak (Tárkányok) felel meg. 
Érd, Lippa), a kitalált mitológiában szereplö, közszavakból és valós (de nem kereszt-) nevekből kreált állítólagos személynevek (pl. Abavér, Matyó, Pannon), irodalmi müvekből, a magyar mondavilágból, irodalomból és ókori mitológiákból a kitalált mitológiába beépített nevek (pl. Enéh, Góg, Magóg, Gilgames), köztudottan csak a nyelvújítók által létrehozott nevek (pl. Ernő, Gyözö, Angyalka), egyházi nevek (pl. Antal, Pál, Ágnes, Zsuzsa), valamint indoeurópai nyelvekből származó világi nevek (pl. Artur [!], Gusztáv, Erna) (vö. PAÁL - KÁLLAY L. é. n.). Az utóbbi két kategória elemei a PAÁL-féle laikus újraértelmezésnek köszönhetik a naptárba kerülésüket, ahogy arra a január 7-hez tartozó harmadik férfinév is utal: Artur (Öregur). Fontos megjegyezni, hogy a névadás ezen elképzelés szerint nem a maihoz hasonlóan zajlott: „,a nevek a mindennapi csillagállások szerint képződtek, miután a 24 hun törzsnek kezdetben egy nyelve volt, mely nyelv Agaba idejéből úz nyelvként ismeretes. [...] A nyelv ősisége, rendkívüli rugalmassága, annak ragozhatósága miatt meg lehetett határozni a gyermek nevét abban az esetben is, ha arra a napra csak egytagú név esett. Ugyanis a nevek is kifejezték, hogy hány lelkü a gyermek. Annyi magánhangzós szótagból állt, ahány nagyszülője élt a gyermek születésekor. Például, ha négy nagyszülője élt, de a születésnapján csak egytagú név szerepelt a FÉRAN-ban, a Giz esetén ragozással Gizeh, Gizel, majd további ragozással Gizella, majd végül Gizellácska név felelt meg az újszülött névadásának."

Szintén hatással volt a tárgyalt névszótárak készítőire a magyar nyelv sumér eredetének ma már komoly múltra visszatekintő elképzelése (bővebben 1. KOMORÓCZY 1976); különösen BOBULA IDA Kétezer magyar név sumir eredete (é. n.) című névszótára azonosítható forrásukként. Ebben nemcsak keresztnevek (pl. János, Pál, Erzsébet), hanem családnevek (köztük nyilvánvalóan magyar eredetüek, pl. Juhász, Szabó, Munkácsy) és helynevek (pl. Máramaros) is szerepelnek. A neveket, illetve azok csoportjait a szerző kisebb-nagyobb hangzásbeli hasonlóság alapján egy-egy sumérnak nyilvánított „ősszó"-ra vezeti vissza; ugyanazon ős-szó áll például a Maczkó és a Macskássy családnév, egy másik pedig a Técsö, a Tüszö és a Gyüszü mögött.

A harmadik forrás vagy minta PRÁCZKI ISTVÁN Minek nevezzelek? címü könyve (1998), amely bevallottan SzILÁGYI FERENC Sokféle neveknek magyarázatja (1987) címü, egy-egy ma használatos keresztnév vagy névcsoport eredetét, használatát rövid, olvasmányos fejezetekben bemutató névtani ismeretterjesztő munkájának szerkezetét követi, csak a tudományos magyarázat helyett egyfajta egyedi gyökelmélet és sajátos mitológia alapján. A magyar népnévvel kapcsolatban álló, ezért az elméletben fontos helyet kapó Marianna név kapcsán például a következőt olvashatjuk (rövidítve, de az eredeti kiemeléseket megtartva): ,[...] a mór-gál népeket a szó szoros értelmében kiirtották [...]. Ekkor lett a jogfosztott pária neve $=$ helota $=$ a-halott. [...] A Marianna névnapja november 1-jén, Halottak napján van. [...] A Marianna ugyanis = Mari-Anya, a móri anya, aki tulajdonképpen istennő, mert ő a [...] megölt [...] magyar-mórok anyja. A halottak napján [...] a Mariannák gyászolják megölt gyerekeiket [...].” (PRÁCZKI 1998: 178-180.)

5.2. A parakomparatív keresztnévszótárakban tükröződő nyelvszemlélet és nyelvi ideológiai háttér. Az ismertetett munkák előszavaiból a laikus nyelvszemlélet, valamint a homogenista, konzervatív és nacionalista nyelvi ideológiák számos tipikus jellemzője rajzolódik ki (ezekről bővebben 1. pl. BENÖ-LANSTYÁK 2017). Így szerzőik nem ismerik (vagy nem ismerik el) a nyelvi változás tényét, ezért a névállomány különböző nyelvtörténeti korszakokból származó rétegeit összemossák, és „etimológiai” fejtegetéseikben a nevek jelenlegi hangalakjából indulnak ki. 
Szintén jellemző rájuk a nyelvi elzárkózás, a homogenizmus és a purizmus, vagyis az a két, egymással összefüggő meggyőződés, melyek szerint a nyelvi sokféleség káros, így az idegen szavakhoz hasonlóan az idegen eredetü nevek is ártalmasak a magyarra nézve: „Lássuk meg az előre haladott [!] veszélyt, amikor idegen, jövevény- szavak [!] sáskahada lepi el nyelvünket, amelyek mint a tetszetős külsejü élösdi fagyöngyök telepednek meg, holott nagyon jól tudjuk, a valóságban fáink halálos ellenségei." (NYERS CSABA előszava SzEGEDI CSANÁD szótárához; vö. SzEGEDI 2002: 5.) A különböző parakomparatív elképzelések közös vonásának megfelelően, mely a kereszténységet a pogány magyarság elnyomására felhasznált eszköznek tekinti, az idegen nevek terjesztése más népeknek és az egyháznak a büne: „Volt, amikor latinnal próbálta az egyház megfullasztani [ti. a magyar nyelvet - S. M.], volt kor, mikor némettel akarták helyettesíteni, és van közeli rossz emlékünk arról, hogy oroszt erőszakoltak ránk" (SzEGEDI 2002: 7). Más vélemény szerint az elnyomó hatalmak (és kiszolgálóik, a nyelvtudomány képviselői) nem azzal ártanak, hogy idegen neveket terjesztenek, hanem hogy idegen eredetünek állítják be az ősi magyar neveket: „Áttekintve az elmúlt öt évtizedben megjelent hasonló témájú könyveket, azt látjuk, hogy hozzávetőlegesen sajnos majd' mind azt sugallja, a magyar nyelvet beszélő nép még saját nevekkel sem rendelkezett. Így aztán különböző más, például görög, latin, héber, gót, szláv vagy akár hottentotta nyelvekböl vették át nevüket. Szerencsére ma már egyre többen tudják, hogy ez az elmélet hamis, és az igazság egészen más.” (TOLNAI 2007: 7.)

Ebből a gondolatmenetből logikusan következik az axiologizmus, vagyis az a felfogás, amely a magyar nyelvet (ennélfogva pedig természetesen az ősi magyar neveket is) mint magasabbrendű ideált állítja közönsége elé: „Az újszülött magyar gyermek ősmagyar eredetü neve hirdesse büszkén, hogy a Kárpát-medencében olyan nép él, mely múltjához és áldott ősei emlékéhez, önmagához hü marad, mind e világ végezetéig!" (NYERS-előszó; SzEGEDI 2002: 5); „A magyar nyelv ékesen szóló tündérek betükkel játszadozó meseszép éneke" (SzEGEDI 2002: 7).

Amellett, hogy a nyelvrokonság gondolata e müvekben nem válik el a népek genetikai rokonságától, magának a rokonságnak a felfogása sem tisztázott; időnként ugyanis inkább nyelvi azonosságról esik szó; pl. ,szkíta-hun-magyar azonosság” (TOLNAI 2007).

Az ősi múlt idealizálása a konzervativizmus jegyében többek között a járulékos részek archaizáló nyelvhasználatában is megnyilvánul; (pl.fi- és lyánynevek; vö. SzEGEDI 2002, TOLNAI 2007).

5.3. A parakomparatív névszótárak ősi magyarként közölt névanyagának jellemzői. A kiadványok mögött álló eklektikus ideológiai háttér következtében a névanyaguk is számos típust foglal magában. A következőkben nem valamiféle egységes szempontokon nyugvó rendszerezést kívánok megvalósítani; ez az említett okból nemigen lenne lehetséges. Inkább különböző szempontok (nyelvi eredet, forrás, névfajta, névszerkezet, íráskép, kiejtés) felvonultatásával annak bemutatására törekszem, hogy milyen jellegzetes, a tudományos, illetve névjogi kategorizációtól eltérő típusok lelhetők fel a vizsgált névszótárak ősmagyarként feltüntetett anyagában. Bár az alábbiakban minden név kapcsán hivatkozom a forrásra, megjegyzendö, hogy a nevek többsége két vagy több névszótárban is szerepel.

A forrásokból következőleg több sumér vagy annak állított név fordul elő bennük; pl. Ur-Engur (MKT.); Urami-Van, Uruk-Dargin (SZEGEDI 2002). 
Hasonlóképpen vannak a mondavilágban vagy a krónikahagyományban a magyarok öseiként vagy rokonaiként említett népekhez (hun, szkíta szittya, alán) kötött nevek is; pl. Aszparucs, Atakám (NYERS 1997); Ernakh és Irnek (Attila fiának két névváltozata; MKT.).

A kitalált, akár irodalmi eredetre is visszamenő mitológiában szereplö, körülíró jellegü, névszerütlen alakulatok is fellelhetők bennük; pl. Napfia, Istenfi (SzEGEDI 2002).

19. századi írói névalkotások is gyakran feltünnek ősmondaiként feltüntetve vagy minden megjegyzés nélkül. Az egyébként anyakönyvezhető Ividő például Jókai Bálványosvár című müve révén lett ismert, ő pedig Orbán Balázsnak A Székelyföld leírása címü müvében bukkant rá; a név valójában a Jóidö pataka helynév félreolvasásával keletkezett (vö. MIKESY 1971). Szintén Jókai említett müvéből került az ömagyarnak titulált nevek közé a Szilamér, Gillike, Illangó (NYERS 1997) és a Gidula, Zezárma (TOLNAI 2007). A Vörösmarty-féle Zalán futásából szintén több nevet megtalálunk e nevek között: Habilán, Szömér, Zenedö (MKT.).

Számos jövevénynévvel is találkozunk bennük; ezek köztudottan bibliai, martirológiumi vagy más népek történelméből ismert, tehát semmiképpen sem magyar eredetü, de a névszótárakban esetenként másként magyarázott nevek: Sebestyén, Valentin, Robin, Cézár, Titusz, Gabriella (SzEGEDI 2002).

Keresztnévként beállított helynevek is nagy számban megjelennek bennük; pl. $B a$ ranya, Bihar, Maros, Kikinda (NYERs 1997); Sajószöged, Nyitraszeg, Ondótö (SzEGEDI 2002). Ugyanakkor az Utónévbizottság e típust csak akkor tartja elfogadhatónak, ha a helynév bizonyítottan személynévből származik. ${ }^{13}$ E nevek egy része ráadásul kétrészes, és jellegzetes helynévi névrésszel is bír.

Érdemes elkülöníteni azokat a jelenleg nem anyakönyvezhető neveket, amelyek akár irodalmi müből is eredhetnek, de a fentebbi példáktól eltérően felismerhető a közszó, amelyböl mesterségesen létrehozták öket; pl. Boci, Méhike, Karcsú (NyERS 1997); Felhöcske, Menyétke, Pillangó, Viritó (MKT.).

Szintén mesterségesen hoztak létre a szerzők vagy forrásaik anyakönyvezhető férfinevek mellé női párokat, amelyek jelenleg nem anyakönyvezhetők; pl. Atánka (az Atos párjaként), Ondvér (az Ond párjaként) (MKT.).

A női nevek mesterséges alkotásának másik, a névanyag alapján kirajzolódó módja e névszótárakban, hogy különféle létező és nem létező szavakhoz hozzákapcsolják a szemantikai alapon valamiféle női utótagnak tekintett -lány-t, esetleg egy létező női nevekböl elvont utótagot (pl. a -vér-t a fenti példában, feltehetőleg az Arany alkotta Gyöngyvér alapján) vagy a -ka/-ke képzöt; pl. Nyirlány, Marcilány, Odoslány, Pereglány; Pélyike, Nyákocska (SzEGEDI 2002).

Ezek mellett anyakönyvezhető nevek nem anyakönyvezhető változatai is felfedezhetők az állományban; általánosságban is jellemző, hogy egy-egy névnek több változata is szerepel az anyagban; pl. Kötény (Kötöny helyett), Szömöre (Szemere helyett), Tonúzaba (Tonuzóba helyett) (MKT.).

Az egyik legkülönösebb típus a kötőjeles alakulatoké, nemcsak azért, mert a magyarban a keresztnevek közé nem tehetö kötőjel, hanem az alkotórészek miatt is; pl. CsillagCsebi, Ilona-Gyilyó, Mondo-Csu, Tolma-Dala (SzEGEDI 2002).

Szintén feltünő sok név esetében a magyartól, illetve az anyakönyvezhető alaktól eltérö helyesírás, fonológiai vagy morfológiai felépítés; pl. Bendeguz, Boá (NYERS 1997); Istenfiak, Paléchun, Pandjaleh, Purkay, Shonen (SzEGEDI 2002); Énee, Négyöke (MKT.).

${ }^{13}$ Alapelvek a kérvényezett nevek szakvéleményének elkészítéséhez. http://www.nytud.mta. hu/oszt/nyelvmuvelo/utonevek/alapelvek.html (2020. 04. 20.) 
5.4. Az eredet és a közszói jelentés megadása a parakomparatív névszótárakban. E kérdést módszeresen csupán két névszótár alapján tudom áttekinteni. NYERS (1997) ugyanis csak puszta névlistát közöl; SzEGEDI (2002) a nevek mellett feltünteti a névnapokat (habár azt sehol sem jelzi, hogy e számok a névnapra utalnak), illetve szórványosan és esetlegesen közöl egy-egy információt, hol a közszói jelentésre, hol a névviselöre vonatkozólag. A két fennmaradó névszótár (MKT. és TOLNAI 2007) a nyelvi információk megadásában meglehetősen eltérő stratégiát követ, ezért a következőkben külön-külön tárgyalom őket.

TOLNAIra (2007) a több, egyenrangúan közölt teória jellemző, mint azt a következő példa is mutatja: „Olivér: Általában latin eredetünek tartják, jelentése: olajfaültető. • Lehet germán eredetü, jelentése tündér, manó sereg [!], áradat. [...] Lásd még Olupta nevünknél!" (TOLNAI 2007: 262.) Az utalások gazdagon átszövik a névszótárat, az ezekkel összekapcsolt szócikkek eredetre és közszói jelentésre vonatkozó adatai ennek ellenére semmilyen kapcsolatban sincsenek egymással. Az Olivér-rel összekapcsolt Oluptá-ról például ugyanott ezt olvashatjuk: „Olupta, Olip-tulma, Olup-tolma: A szó jelentése a hő teljessége.” A címszavak, mint látjuk, gyakran nem egy, hanem több (nem feltétlenül anyakönyvezhetö) névből állnak, amelyek az adott név változatai. Az egyes szócikkek egymásra utalása a csak bizonyos szócikkek alatt feltünő szürke keret olvastán nyer értelmet. Az említett példa kapcsán, az Olupta stb. szócikk alatti keretes részben például ez olvasható: „O-LiVér, ó-LiVa. Ó, azaz Ódon, ősi LeVe az életnek, ételnek. Az ősök ó-LeVe az oLiVa mindenre jó. Kívül-belül használatos. Kencének, ételnek, gyógyszernek.” Míg tehát maguk a szócikkek különböző nyelvekböl eredeztetik az adott neveket (az egyes etimológiák és velük kapcsolatos közszói jelentések között meg sem próbálva dönteni, esetleg az etimológia bizonytalanságára utalni), addig a keretes részek egyfajta gyökelmélet alapján, a magyarból magyarázzák a pusztán hangzásuk (pontosabban: általában csupán kezdetük vagy mássalhangzóik részleges, illetve teljes azonossága) alapján azonos eredetünek feltételezett neveket. Ezt egyébként már a szótár egyik járulékos része is megelőlegezi, fontos módszertani elvként hangsúlyozva: ,akkor végre az »egzakt« tárgyalhatóság szintjére kerülnek az olyan, azonos képjelekből kiolvasható szópárok, mint a »Madonna - meddő nő«, [...] »Bertalan - bőrtelen«, [...] »Cygnus (csillagkép) - cigány« [...] stb., amelyeknek szoros egymásra vonatkozása régen közhelynek számít a magyar néphagyománnyal foglalkozó kutatás »alternatív« ágazatában” (TOLNAI 2007: 25).

Az internetes Magyar Keresztnevek Tára ezzel szemben csak egyetlen magyarázattal szolgál nevenként. Ezek között vannak hitelesek is, de nem ritka a történetinek beállított, nem anyakönyvezhető vagy egészen más eredetü név. A jelenleg nem választható, történeti forrásokkal nyilvánvalóan alá nem támasztható és a magyarból le nem vezethető Gabillá-ról például az MKT. azt állítja, hogy „ősmagyar leánynév, jelentése: Istenke, Napocska." Nem kevésbé hiteltelen a szintén nem anyakönyvezhető Mátrá-hoz kapcsolódó leírás: „A Kárpát-medencében Kr.e. több fósámán viselte ezt a nevet, egyikükről kapta a hegység az elnevezését, valószínüleg, [!] mert ott lakott.” Az írott forrásokkal nem rendelkező ősmagyar kor mellett a névszótár időnként még a középkorig visszamenőleg jól adatolt nevek és alaposan feltárt források ellenére is tesz minden alapot nélkülöző állításokat. A Manga például „magyar eredetü női név [...], Árpád-házi Szent Margitnak volt a »pogány« neve. A Margit nevet csak zárdába vonulásakor, illetve fogadalomtételekor kapta, mindaddig Mangának hívták."

Bár a névszótár az ismertebb írói alkotásokat többnyire hitelesen magyarázza, némelyiket szintén történetinek állítja be; például az Arany által a gyöngy és vér összetételével létrehozott Gyöngyvér „,honfoglalás elötti [!] türk-magyar eredetü személynév”. 
Szintén jellemző a nem anyakönyvezhető, csak a névszótár által nevekként feltüntetett magyar közszavak szittya, hun, sumér stb., illetve mondai eredetű magyarázata; pl. Mogyoró: „régi magyar eredetü női név. Jelentése: mogyoró. A szó eredete bizonytalan, lehet Mogor, mint a magyarok mondai őse (Magor), de lehetséges a Megyerből való képzése is."

Végül megemlítendő, hogy a keresztnevekként beállított helyneveket is többféle, a fent felsoroltak mellett jellemzően iráni vagy (ó)török nyelvekből magyarázza a névszótár, helynév voltukra esetleg nem is utalva; pl. Eger: ,,az óiráni a-kara, a szkíta agar és az oszét ägär szavak magas hangrendü formája az eger szavunk. Jelentése: végtelen, határtalan.”

6. Az elemzés tanulságai. A laikus keresztnévszótárak három típusának jellemzőit áttekintve megállapítható, hogy különböző okokból ugyan, de mindegyik jelentős arányban tartalmaz a nagyközönséget félretájékoztató információkat. Az általános jellegüek esetében ez nem célzatosan történik, hanem egyszerüen a szakmai ismeretek hiányából fakad. Ez csak akkor lenne elkerülhető, ha kizárólag nyelvészeti és speciálisan névtudományi háttérrel rendelkező szakemberek készítenének névszótárakat. Míg azonban az többé-kevésbé evidensnek számít, hogy egy orvosi vagy hídépítési témájú kiadvány megírásához komoly szakmai ismeretek szükségesek, addig sokan gondolják, hogy a nyelvészeti kérdésekben való nyilatkozáshoz elegendő az, ha valaki az adott nyelvet bírja, illetve a véletlenszerüen kezébe akadó könyvekből tájékozódik. Bár a nyelvészek generációi hangoztatták már korábban is, hogy a nyelv vizsgálata ugyanúgy tudomány, mint a matematika, és alapelveit, forrásait, szakirodalmát, módszereit ugyanúgy egyetemen kell megismerni, erőfeszítésük mind ez idáig hatástalannak tünik. Ennek egyik legfőbb oka az lehet, hogy a fenti tudományokból az iskolában tanult alapok egy laikus számára is érzékelhetően kevésnek bizonyulnak az adott tudomány müveléséhez, illetve egyes tudományokat (pl. jogi, gazdasági, müszaki ismereteket) nem is tanítanak minden iskolatípusban. Emiatt ezek bonyolultabbnak, komolyabbnak tünnek, mint a nyelvtudomány, amelyet az iskolai nyelvtanórák tapasztalatai alapján a többség a nyelvmủveléssel, a helyesírással vagy a mondatelemzéssel azonosít. A bölcsészettudományok világszerte tapasztalt, régóta tartó leértékelödése a közvetlen hasznot hajtó, ezért értékesebbnek tartott természet-, élet-, jog-, gazdaság- és mérnöki tudományokkal szemben pedig tovább erősíti e felfogást. (Bővebben, a parakomparatív eszmék terjedésének okai kapcsán 1. pl. IMREH 2017.) Abban pedig, hogy laikus szerzők éppen keresztnévszótárakat készítenek viszonylag nagy számban, elsősorban az e nevek iránti egyéni és közérdeklődés, e szótártípus eladhatósága játszik szerepet. Jól látható mindez e szótártípus külső jellemzőiből, melyek legfőbb célja a gyermeket váró szülök figyelmének megragadása, ezáltal pedig az eladott példányszám és a bevétel növelése. A másik két szótártípus (az ezoterikus és a parakomparatív) az általános jellegü keresztnévszótárakkal szemben már célzatosan is félretájékoztatja olvasóit, hiszen ezek az egyébként könnyen elérhető tudományos irodalom teljes mellőzésével, sőt elutasításával, egyfajta ideológia terjesztése érdekében készülnek.

A félretájékoztatásból szakmai és társadalmi problémák egyaránt származhatnak: előfordulhatnak fölöslegesen benyújtott névkérelmek, melyek egyrészt a szülőkre rónak terheket, másrészt az Utónévbizottságra és a mindenkori hivatalra; az elutasításból fakadó elégedetlenség, csalódottság; összeesküvés-elméletek és tévhitek terjesztése; hamis történet- és nemzettudat kialakulása, illetve megerösítése; stb.

A parakomparatív névszótárak kapcsán megjegyzésre érdemes, hogy már a paródiájuk is megszületett SIPOS FERENCnek köszönhetően, akinek Nevében él a nemzett. A magyar keresztnevek részletes eredettörténete címü „névszótára” (2012) mind az eklektikus 
ideológiai hátteret, mind a felépítést, tartalmat és stílust tekintve tökéletesen karikírozza e kiadványokat; vö. pl. az Aurél kapcsán: „A baskíriai ősmagyar törzsek közül legdélebbre, Kis-Ázsiába vándorolt szavárd magyarok keresztény hitet felvett családjaiban jelent meg először ez a patinás keresztnév. [...] A szavárd magyarok a határozott névelők közül nem használják a hosszabb »az« alakot [...]. E furcsaság dacára a mi fülünknek igencsak magasztosan hangzik ez a Jóisten mellett hitet tevő keresztnév: Aurél, vagyis »A Ur él«. [...] Egyes esti egyetemeken nevelkedett, erőltetetten materialista nyelvészkutatók próbáltak profánabb eredettörténetet kreálni a keresztnévnek: olvasták »aura-él«-nek (vagyis a szögletes aura oldallapjainak találkozásaként), »élő aurájúnak«, sőt a »gyáva hitetlen« (Gyaurfél) őskeresztnévből is megpróbálták levezetni, de mindhiába.” (SIPOS 2012: 40.) A paródia azonban csak az értő olvasók számára müködhet, ezért bár a névszótár sokak számára szórakoztató olvasmány, és az egyetemi oktatásban is kiválóan alkalmazható lehet, mégsem a legjobb megoldás a problémák ellensúlyozására. Különösen úgy nem, hogy a kötet maga nem utal paródia voltára, így azok, akik nincsenek kellő mértékben, megfelelő ismeretekkel felvértezve, és nem fognak gyanút egyes, kifejezetten erösre sikerült részek és a humoros borítókép kapcsán sem, akár komolyan is vehetik a benne foglaltakat.

Az említett problémák lehetőség szerinti ellensúlyozására, a téves információk és tévhitek, összeesküvés-elméletek terjedésének ellensúlyozására ezért véleményem szerint más utakat kell keresnünk: az ismeretterjesztésre kellene nagyobb hangsúlyt fektetnünk (a magyar névkutatás társadalmi jelenlétéröl 1. JUHÁsz 2015: 54-57; RAÁTZ 2015, kül. 238-239; a feladat fontosságára 1. már BENKÖ 1981, újabban pl. HOFFMANN 2015: 20). Ebben elsősorban a nyelvészeknek, a névkutatóknak és általában a tudománynak és a közoktatásnak a felelősségét kell hangsúlyozni. Egyrészt érdemes lenne növelni a nyelvtörténet jelenlegi arányát az iskolai tananyagban (minden szinten és iskolatípusban), és a legalapvetőbb névtani ismereteket is be kellene vonni az oktatásba (vö. újabban pl. F. LÁNCZ 2016, IMREH 2017), még ha ez önmagában nyilván nem is oldaná meg a problémát. Emellett a jelenleg nem különösebben aktív névtani ismeretterjesztés erősítésére is szükség lenne (pozitív példaként 1 . a nyest.hu portált, mely számos névtani, valamint a nyelvrokonsággal és az ehhez kapcsolódó tévhitekkel is foglalkozó írást közöl, vö. HAINDRICH 2013; illetve az MTA támogatásával 2018 tavaszán indított tudomany.hu oldalt, mely az áltudományos hírek hatását hivatott ellensúlyozni tudományos ismeretterjesztő írásaival, köztük számos nyelvészetivel is). Az ismeretterjesztéshez az interneten könnyen elérhetö, hiteles névszótárak készítése is hozzátartozik. (Fontos kezdeményezés e szempontból az MTA Nyelvtudományi Intézetének RAÁTZ JUDIT és SASS BÁLINT készítette Utónévkeresője. ${ }^{14}$ ) Mindezekhez azonban támogató akadémiai környezetre is fokozottan szükség van. Jelenleg ugyanis nemhogy a nyelvésztársadalom, de még a névkutatók se nagyon ismerik, illetve ha igen, alábecsülik e névszótárak társadalmi hatását, hiszen még a parakomparatív eszmék ellen fellépő tudósok sem igen fordítanak figyelmet rájuk. A névkutatásnak a magyarországi nyelvtudományban kevéssé megbecsült volta és csak töredékesen létezö intézményrendszere (vö. JUHÁSZ 2015; szemben számos külföldi példával; vö. FARKAS 2015) szintén nem segíti elő a változást, ahogyan a jelenleg uralkodó, az ismeretterjesztést és a szótárkészítést alacsonyan értékelö tudománymetriai felfogás sem.

\footnotetext{
${ }^{14} \mathrm{http}$ ://corpus.nytud.hu/utonevportal (2020. 04. 20.)
} 
Ahhoz tehát, hogy számottevő eredményt lehessen elérni, több, egymással szoros kölcsönhatásban lévő tényezőnek kellene változnia, és ezeknek a jó része fölötte áll az egyes névkutatók befolyásának. Mindenesetre a kezdőlépés a probléma felismerése és a figyelem felhívása; írásommal e célt kívántam elősegíteni.

\section{Felhasznált források}

BOBULA IDA é. n. Kétezer magyar név sumir eredete. Limestone College, h. n.

GÁBORJÁNI SZABÓ MiHÁLY - GÁBORJÁNI SZABÓ SZABOLCS 1936. Őseredetü magyar személynevek tára. Dürer, Gyula.

GYERGYEL ISTVÁN szerk. é. n. Utónévkönyv. Fiúnevek, lánynevek eredete és jelentése. Anno Kiadó, h. n.

GYÖRI ERIKA szerk. é. n. Nagy utónévkönyv. Szalay Könyvkiadó, h. n.

KLIMENT EMILIA 2005. Névmágia. Hogyan befolyásolja a név a személyiségünket. LPI Produkciós Iskola, h. n.

IFJ. KULCSÁR LÁSZLÓ szerk. 1992. A keresztnevek titkai. Új Nap Lap- és Könyvkiadó, h. n.

LAIK ÁGNES szerk. 1991. Utóneveink. Kis magyar utónévkönyv. Bibliotéka, Budapest.

LÁSZLÓ TÜNDE 2014. Adjunk gyermekeinknek ősi magyar nevet! Magyar Nö Magazin. http:// magyarno.com/adjunk-gyermekeinknek-osi-magyar-nevet (2020. 04. 20.)

MKT. = Magyar Keresztnevek Tára. http://magyarnevek.hu (2020. 04. 20.)

NyERS CSABA 1997. Magyar keresztnevek tára. Magyarok Európában Európáért Alapítvány, h. n. PAÁl ZOLTÁN 2009. Arvisura (igazszólás) 1-2. Regék a hun és magyar törzsszövetség rovásírásos krónikájából. Szerk. BOLYKY ÚR JÁNOS. Püski Kiadó, Budapest.

PAÁl ZoltánNÉ - KÁllay L. TARJÁn [1977]. Ös Féran névadó naptár. Kézirat, OSZK, II, 80, [10] fol.

PÁLFY GyUla é. n. Utónévkönyv. Milyen nevet válasszunk? Aranyhal Könyvkiadó, Budapest.

PRÁCZKI ISTVÁN 1998. Minek nevezzelek? Keresztnevek magyarázata (Ösnevek - ösmondák - ösmitoszok). Szerzői kiadás, Budapest.

SIPOS FERENC 2012. Nevében él a nemzett. A magyar keresztnevek részletes eredettörténete. Noran Libro, Budapest.

SZEGEDI CsANÁD 2002. Magyar eredetü keresztnevek teljes tára. K. n., Budapest.

SZEGEDI CsANÁD 2004. Magyar eredetü keresztnevek kincses tára. 2., átdolgozott kiadás. Gyepü Kiadó, Budapest.

TAKÁCS TIBOR 2006a. Sorsunk a nevünkben. 1400 férfi utónév elemzése. Sanoma, Budapest.

TAKÁCS TiBOR 2006b. Sorsunk a nevünkben. 1300 női utónév elemzése. Sanoma, Budapest.

TAKÁCS TIBOR é. n. „,Nomen est omen”. K. n., h. n.

TOLNAI LÁSZLÓ 2007. Ősi neveink, aranykincseink. Allprint Kiadó, Budapest.

TÖLGYESI GÁBOR 2006. Magyar eredetü utónevek. Jaffa Kiadó, Budapest.

Utónevek, keresztnevek, névnapok. In: Szülök lapja.hu, a babák-mamák szakértöje. http://www. szuloklapja.hu/utonev-kereso.html (2020. 04. 20.)

Utónévkereső. In: Babanet. https://www.babanet.hu/utonevkereso (2020. 04. 20.)

\section{Hivatkozott irodalom}

BENŐ ATTLA - LANSTYÁK ISTVÁN 2017. Névideológiák Erdélyben. In: VÖRÖS FERENC szerk., A nyelvföldrajztól a névföldrajzig VIII. A nyelvterület keleti peremén. A 2017. május 30-31-i 
kolozsvári névföldrajzi tanácskozás előadásai. Erdélyi Múzeum-Egyesület - Savaria University Press, Kolozsvár-Szombathely. 13-32.

BENKÖ LORÁND 1981. Megnyitó. In: HAJdÚ MiHÁly - RÁCZ ENDRE szerk., Név és társadalom. A III. Magyar Névtudományi Konferencia elöadásai (Veszprém, 1980. szeptember 22-24.). A Magyar Nyelvtudományi Társaság Kiadványai 160. Magyar Nyelvtudományi Társaság, Budapest. 7-13.

BRENNER KolOMAN - ERB MARIA - KNIPF ERZSÉBET szerk. 2004. Magyarországi német utónevek jegyzéke. Magyarországi Németek Országos Önkormányzata, h. n.

S. DÁVID EMESE szerk. 2004. Nemzeti és etnikai kisebbségek utónévkönyve. Aranyhal Könyvkiadó, Budapest.

FARKAS TAMÁS 2006. Keresztnévkönyvek - keresztnévtárak - keresztnévszótárak Magyarországon. In: MÁRTONFI ATTILA - PAPP KorNÉLIA - Slíz MARIANN szerk., 101 írás Pusztai Ferenc tiszteletére. Argumentum Kiadó, Budapest. 246-252.

FARKAS TAMÁS 2010. A magyar családnévanyag fogalma és struktúrája. Magyar Nyelvjárások 48: 59-75.

FARKAS TAMÁS 2015. A nemzetközi névkutatás és magyar kapcsolatai. In: FARKAS TAMÁS - SLÍZ MARIANN szerk., Magyar névkutatás a 21. század elején. Magyar Nyelvtudományi TársaságELTE Magyar Nyelvtudományi és Finnugor Intézet, Budapest. 23-47.

FARKAS TAMÁS 2019. Keresztnévszótárak és utónévportálok. A magyar keresztnévanyag feldolgozása online és határok nélkül. In: VÖRÖS FERENC szerk., A nyelvföldrajztól a névföldrajzig X. Nevek a nyelvpolitikai küzdötérben. A 2019. június 8-i révkomáromi névföldrajzi tanácskozás elöadásai. Savaria University Press, Szombathely. 63-80.

FERCSIK ERZSÉBET - RAÁTZ JUDIT 2017. Örök névnaptár. A mai magyar keresztnevek legteljesebb gyüjteménye. Müszaki Könyvkiadó, Budapest.

HAJDÚ MiHÁLY 1998. Fercsik Erzsébet - Raátz Judit, Hogy hívnak? Könyv a keresztnevekröl. [Recenzió.] Névtani Értesitö 20: 134-139.

HAINDRICH Helga ANNA 2013. Névtani kérdések a nyest.hu-n. Névtani Értesitő 35: 237-243.

HEGEDŰS JÓZSEF 2003. Hiedelem és valóság. Külföldi és hazai nézetek a magyar nyelv rokonságáról. Akadémiai Kiadó, Budapest.

HOFFMANN IsTVÁN 2015. A névtan és a társtudományok. FARKAS TAMÁS - SLíz MARIANN szerk., Magyar névkutatás a 21. század elején. Magyar Nyelvtudományi Társaság - ELTE Magyar Nyelvtudományi és Finnugor Intézet, Budapest. 11-22.

IMREH RÉKA 2014. A helynevek szerepe az alternatív ideologikus gondolkodásban I. A Piliskultusz esete. Névtani Értesitö 36: 105-120.

IMREH RÉKA 2015. A helynevek szerepe az alternatív ideologikus gondolkodásban II. Tudálékos helynév-etimológiák és új helynevek a Pilis-kultuszból. Névtani Értesitö 37: 119-136.

IMREH RÉKA 2017. A laikus nyelvrokonítási kísérletekkel kapcsolatos oktatásmódszertani kérdések. Anyanyelv-pedagógia 10/3: 22-33. https://doi.org/10.21030/anyp.2017.3.2

JUHÁSZ DEZSŐ 2015. A magyar névkutatás tudományos fórumai, intézményei, társadalmi jelenléte. In: FARKAS TAMÁS - SLíZ MARIANN szerk., Magyar névkutatás a 21. század elején. Magyar Nyelvtudományi Társaság - ELTE Magyar Nyelvtudományi és Finnugor Intézet, Budapest. 49-61.

KnE. = FERCSIK ERZSÉBET - RAÁTZ JUDIT, Keresztnevek enciklopédiája. A leggyakoribb női és férfinevek. A magyar nyelv kézikönyvei 16. Tinta Könyvkiadó, Budapest, 2009.

KOMORÓCZY GÉZA 1976. Sumer és magyar? Magvető, Budapest.

F. LÁNCZ ÉVA 2016. Névtudományi ismeretek a magyar nyelvi órán. Anyanyelv-pedagógia 9/4: 47-61. https://doi.org/10.21030/anyp.2016.4.4 
McClure, Peter 2015. Personal and Surname Dictionaries. In: Durkin, PhiliP ed., The Oxford Handbook of Lexicography. Oxford University Press, Oxford. 271-291. https://doi.org/10.1093/ oxfordhb/9780199691630.013.17

MIKESY SÁNDOR 1971. Egy ritka női keresztnévröl. Ividő. Magyar Nyelv 67: 85-88.

MUnk. = LADÓ JÁNOS - BíRÓ ÁGNES, Magyar utónévkönyv. Vince Kiadó, Budapest, 1998.

RAÁTZ JUdiT 2015. Alkalmazott névtan. In: FARKAS TAMÁs - SLíz MARIANN szerk., Magyar névkutatás a 21. század elején. Magyar Nyelvtudományi Társaság - ELTE Magyar Nyelvtudományi és Finnugor Intézet, Budapest. 227-247.

SLíz MARIANN 2017. Személynévtörténeti vizsgálatok a középkori Magyarországról. Magyar Nyelvtudományi Társaság, Budapest. https://doi.org/10.26546/5061134

SLíz, MARIANN 2018. The legal deficiency of publishing calendars and the problems caused by calendars and dictionaries of given names based on lay ideas in Hungary. Onomastica Uralica 10: 309-315.

SLíz, MARIANN 2020. Hungarian non-professional dictionaries of first names. Methodological problems caused by the lack of lexicographic and onomastic knowledge. International Journal of Lexicography. https://doi.org/10.1093/ijl/ecaa009

SZILÁGYI FERENC 1987. Sokféle neveknek magyarázatja. Névnapi szófejtö az év (majd) minden napjára. RTV-Minerva Kiadó, Budapest.

Unk. = Utónévkereső. Készítette: RAÁTZ JUDIT - SASS BÁLINT. http://corpus.nytud.hu/utonevportal (2020. 04. 20.)

ZELLIGER ERZSÉBET 2017. Földrajzi neveink eredetéről - másképpen. Gondolatok néhány közelmúltban megjelent kötet kapcsán. Névtani Értesitő 39: 183-190.

SLÍZ MARIANN

ORCID: https://orcid.org/0000-0001-5959-1018

ELTE Eötvös Loránd Tudományegyetem

Bölcsészettudományi Kar

\section{MARIANN SLÍz, Non-professional given name dictionaries}

The study presents Hungarian given name dictionaries and digital databases that have been compiled by non-professionals, that is, editors without onomastic knowledge, at the end of the $20^{\text {th }}$ century or beginning of the $21^{\text {st }}$. Its goal is to pinpoint methodological errors, shortcomings, and the ideological nature of two types of name dictionaries. Furthermore, it highlights the social difficulties that these dictionaries can cause. The article categorizes name dictionary publications into the following groups: a) non-ideological works; b) those based on esoteric foundations; c) para-comparative dictionaries that aim to advance unofficial theories about the genealogy of the Hungarian language. The boundaries between the three categories are fuzzy, as their authors - lacking onomastic knowledge - are unable to discern the academic value of the sources used. Dictionaries are presented based on characteristics specific to the given category, such as external characteristics, structure, sources, and referenced literature. The study details the methodological problems of providing the etymological origin or meaning of names, concentrating on ideological influences in the question, especially the category of names published as ancient-Hungarian, and the registration of the published name data. The study concludes that the negative effects of such dictionaries (the spread of misinformation, difficulties with naming regulations connected to unregistrable names, feeding a false national idea, the propagation of nationalistic views) would be counter-balanced by an increase in popular scientific works on onomastics. 


\section{Magyar tulajdonnevek és magyarázataik más nyelvek szótáraiban}



FARKAS TAMÁS - SLÍZ MARIANN szerk., Tulajdonnevek és szótárak. ELTE Magyar Nyelvtudományi és Finnugor Intézet - Magyar Nyelvtudományi Társaság,

Budapest, 2020. 187-197. DOI: 10.26546/4892373.11

\section{Magyar tulajdonnevek a román névszótárakban}

1. Bevezetés. Az utóbbi évtizedekben megjelent román nyelvủ névszótárak szinte mindegyike tartalmaz - nem kevés számban - magyar vonatkozású adatokat, ami egyáltalán nem meglepő, hiszen a több évszázados nyelvi-kulturális érintkezések és az összekapcsolódó történelmi helyzetek kontextusában ez természetesnek tekinthető. A román névszótárakban szereplő magyar vonatkozások, etimológiai és más jellegü információk egy része jól hasznosítható a magyar névtani és kontaktológiai tanulmányok mellett a nyelvtörténeti stúdiumokban is. Tanulmányomban a legfontosabb román névszótárak magyar vonatkozásait mutatom be. A román névszótárak sokfélesége, különösen a földrajzinév-szótárak regionális monográfákban való feldolgozottsága nemcsak a vonatkozó magyar névtani kutatásokat segítheti, hanem módszertani változatosságuk termékenyítöleg hathat a magyar névtani (szak)szótárak további gyarapítására is. A román névszótárak bemutatása az általánosabb jellegü földrajzinév-szótárakra, a helységnévszótárakra, továbbá a család- és keresztneveket bemutató lexikográfiai munkákra terjed ki. A szótárak rövid jellemzése során jelzem a magyar nevekhez kapcsolódó kérdéseket, valamint a megközelítések hiányosságait vagy vitatható aspektusait.

2. Földrajzinév-szótárak, településnév-szótárak. A román névszótárak a földrajzi nevek tekintetben két csoportba sorolhatók: 1. olyan helységnévszótárak, amelyek településnevek (város-, község- és falunevek) adatait jelenítik meg gyakran történelmi, nyelvtörténeti utalásokkal; 2 . általánosabb jellegü, nagyobb (történelmi) régiók földrajzi névanyagát monografikusan bemutató lexikográfiai munkák (amelyek rendszerint földrajzi közneveket is tartalmaznak).

2.1. Helységnévszótárak. A helységnévszótárak körében mindmáig egyedülállónak mondható a Partiummal és a Bánsággal együtt értelmezett Erdély településneveit bemutató kétkötetes szótár: Dicționarul istoric al localităților din Transilvania [Erdélyi települések történelmi szótára] (SUCIU szerk. 1967). Az egyfajta helységnév-azonosító szótárnak tekinthető kiadvány a helységnév-változtatásokat is dokumentálja, és gazdag névváltozat-állományt ismertet. Teljességre törekedve, a ma már nem használatos névalakokat is megjeleníti, és eszerint tagolja a névanyagot két nagy csoportba: létező és eltünt településnevek. A román névalak mellett a települések magyar és német neveit is feltünteti; pl. Bârghiş - Bürkös - Bürgesch. A szótár a névmagyarításokat is kiemeli. Ilyenre utal a szerző szerint a Neagra - Nyágra - Feketevölgy (Fehér megye) névváltozat, ${ }^{1}$ illetve a Măguri - Magura - Szamosfö névkapcsolat. A Szamosfö településnév esetében azonban névmagyarításról nem beszélhetünk, hiszen a település nevét 1724ben említette elöször oklevél Szamosfő néven, és későbbröl van adatunk Magura (1805), Magura (Alpestris-) (1808) és Havasmagura (1861) névváltozatokra. A szótár ennek

\footnotetext{
${ }^{1}$ A település jelenlegi hivatalos román neve: Poiana Vadului.
} 
ellenére 1913-as adatként utal a Szamosfö névre mint fordítás eredményére. A szócikkek explicit etimológiai információkat nem tartalmaznak, ami hiányosságként értelmezhetö, lévén hogy a szótár történelmi távlatban kívánja Erdély településneveit bemutatni. A szótár hasznosítható a helynévkutatásokban, bár pontatlanságokat, azonosítási hibákat is tartalmaz. Így például Sepsiszentgyörgyhöz kapcsolja a marosszéki Szentgyörgy 1412. évi adatát, amint ezt VISTAI ANDRÁS JÁNOS jelzi az Erdélyi helynévkönyvében használt források magyarázatánál (ErdHnK.).

Az utóbbi években megjelent román nyelvü településnév-szótárak egy-egy megye településneveit dolgozzák fel etimológiai vagy történeti szempontból, ahogy ezt gyakran a címükben is jelzik. Ilyen etimológiai településnév-szótárként határozzák magukat a Szilágy és Máramaros megye településneveit bemutató lexikográfiai kiadványok: Dicţionar etimologic al localităţilor din județul Sălaj [Szilágy megyei helységnevek etimológiai szótára] (CHENDE-ROMAN 2006), Dicționar etimologic al localităților din județul Maramureș [Máramaros megyei helységnevek etimológiai szótára] (ȘTEF 2016). Földrajzi-történeti szótárként megjelent megyei településnév-feldolgozások: Dicţionar toponimic şi geografico-istoric al localităţilor din judeţul Timiş [Temes megye településeinek földrajzi-történelmi névszótára] (CREŢAN 2006), Dicţionarul istoric al localităţilor din județul Arad [Arad megye településeinek történelmi szótára] (ROZ-KoVACH 1997), Dicţionarul istoric al localităţilor din judeţul Olt [Olt megye településeinek történelmi szótára] (AVRAM szerk. 2009).

Egyáltalán nem meglepő módon az erdélyi megyék településneveit feldolgozó szótárak számos magyar eredetü nevet vesznek számba. A Máramaros megye településneveit elemző szótár (ȘTEF 2016) például részletekbe menően ismerteti a névforma eredetét, az átvétel és a meghonosodás morfológiai aspektusait. A névalak morfológiai szerkezetét a lexikailag egyszerü és az összetett névalakoknál egyaránt jelöli. Így például a Fărcaşa (m. Farkasaszó) községnév esetében jelzi, hogy a magyar Farkas tulajdonnévből származik, és a román - $a$ helynévképzővel honosodott meg. Hasonlóképpen a szótár a Chechiş (m. Oláhkékes) név leírásánál megjegyzi, hogy a magyar kékes melléknévböl származik, utal a magyar szóalak képzős származék jellegére, és ugyanakkor azt is jelzi, hogy a helységnév víznévi eredetü, a Kékes ('kék színü') pataknévből származik (vö. SEBESTYÉN 2012). A magyar eredetü, részfordítással keletkezett összetett névalakoknál azonban a szerző nem jelzi a közvetett átvétel tényét, az átadó nyelvi modellt, csupán a közvetlen átvételü magyar eredetű névelemre utal. Így a Baia Mare $(<\mathrm{m}$. Nagybánya) városnévről csupán annyit tudhatunk, hogy a baia szó magyar (vagy latin) eredetű (bár a latin eredeztetés erőltetett: TAMÁS 1966), és a 'nagy' jelentésü mare melléknév a latinból származik a románban: „Etimologie: Din s. baie »mină, ocnă« (< lat. *bannea sau magh. bánya) + adj. mare »întins, vast « (lat. mas, maris)”. Hasonlóképpen az Arieşu de Câmpie (<m. Mezőaranyos) településnév elemzésekor csak az Arieşu névelem bizonyul magyar eredetünek, a mező szó câmpie alakban való fordításáról nincs szó: „Etimologie: Din Arieș (< magh. aranyos »aurit $\ll)+$ de $(<$ lat. de $)+$ Câmp $(<$ lat. campus $)$ ". A magyar etimonokra való hivatkozások ellenére a szótár egyetlen magyar forrást sem idéz. ${ }^{2}$

2.2. Regionális földrajzinév-szótárak. Az általánosabb jellegü, nagyobb (történelmi) régiók névanyagát feldolgozó többkötetes szótárak a településnevek mellett vizek,

${ }^{2}$ A szótár elektronikusan a következő honlapon tekinthető meg: https://ro.wikisource.org/wiki/ Dicționar_etimologic_al_localităților_din_județul_Maramureș. (2020.04. 17.) 
domborzati formák, telkek és birtokok neveit is elemzik. Ilyen kezdeményezésnek tekinthető egy befejezetlenül maradt vállalkozás: a Bánság földrajzi neveit bemutató hétkötetes szótár, a Dicţionarul toponimic al Banatului (FRĂȚILĂ-GOLCU-SUFLEȚEL 1984-1994). Ez a lexikográfiai mü több magyar forrásmunkára is hivatkozik (BOROVSZKY SAMU Temesvárról írott monográfiájára [1914], PESTY FRIGYES Krassó vármegyét bemutató müvére [1881-1885] és Magyarország helynevei [1888] címü munkájára, valamint a FNESz.-re). A szótár az egyes névcikkekben a következő információkat jeleníti meg: 1. a név ejtéséhez kötődő helyi norma; 2. a földrajzi nevet alkotó, közszói eredetű névelemek jelentése; 3 . történelmi vonatkozások; 4. földrajzi meghatározás, a földrajzi név típusa; 5. közigazgatási adatok (adott megyéhez, községhez való tartozás). Történelmi források alapján olyan magyar településneveket is megemlít, amelyek ma már nem léteznek a vizsgált régióban, mint például Albertfalva, Aranyfalva. A vizsgált magyar forrásoknak is köszönhetően a kiadvány számos magyar földrajzi nevet rögzít abban a formában, amelyben a korai forrásokban megjelenik, jelölve az első ismert előfordulásának évszámát is. Jól szemlélteti ezt az alsó névelemet tartalmazó nevek listája: Alsoigazfalva (1454), Also-Lupavicza (1747), Also-Kava (1511), Also-kiralymezeje (1511), Also-ohaba (1590), Also-Szekas (1440), Alsobathy (1479), Alsofalw (Alsofalu) (1442), Alsokabolcs (1471), Alsokapolnas (1427), Alsooszthrov (1580), Alsoparth (1471), Alsohalmagh (1429), Alsoweze (1403) (Alsóvece, ma már nem létező település).

Hasonló jellegü szótárnak tekinthetőek a Havasalföld, Olténia vagy Moldva földrajzi névanyagát elemző lexikográfiai kiadványok: Dicţionarul toponimic al Romaniei. Muntenia (SARAMANDU szerk. 2005-2015), Dicţionarul toponimic al României. Oltenia (BOLOCAN szerk. 1993-2007), Tezaurul toponimic al României. Moldova (MoLDOvANU szerk. 1991-2014). A Román Akadémia támogatásával (gyakran akadémiai kutatóintézetekben) készült szótárak egységes szempontokat érvényesítve mutatják be az egyes régiók földrajzi neveit. Így ezek a szótárak rendszerint tartalmazzák a címszóban megjelenített név következő vonatkozásait: 1. a hivatalos vagy leggyakoribb névforma; 2 . a név fonológiai és morfológiai változatai; 3. a jelölt földrajzi objektum meghatározása (rövid földrajzi leírása); 4. a név nyelvtörténeti, történelmi forrásokban való adatolása; 5. a név eredete, etimológiai kérdései. Mindhárom szótárban nyomon követhetők a magyar hatás nyelv- és kultúrtörténeti vonatkozásai. A moldvai régió földrajzinév-szótára (MoldovANU szerk. 1991-2014) például jelzi, hogy az Adjud(ul) településnév a magyar Egyed(halma) összetett név első eleméből származik, és a településről szóló első feljegyzés 1433-ból adatolható Egydhalma formában. A vonatkozó szócikk ugyanakkor arra is utal, hogy a névalak a székelyek 13. századi dél-moldvai betelepülésével van összefüggésben, és a m. $e[\ddot{a}] \sim$ r. $a$ fonémacsere kapcsán megjegyzi, hogy a székely nyelvjárásra jellemző (volt) az e magánhangzó nyíltabb ejtése. Hasonló részletességgel mutatja be a szótár a Pângăraţ pataknév magyar vonatkozásait. A szócikk szerint a román névalak a magyar Pongorác patak-hoz kötődik és személynévi eredetü, a magyar Pongorácz családnévvel van összefüggésben: a történelmi források 1585-ből jeleznek egy Pongorácz János nevü moldvai lakost. A nem magyar eredetü településnevek esetében is megjelenhetnek magyar nyelvi adatok, mint például a Neamţi megyei Roman városnév (németül: Romanvarasch) adatainál láthatjuk, ahol a feltárt magyar névváltozatokat is felsorolja a vonatkozó szócikk: Roman Uasar, Román-Város, Román-Vásár, Romani-Vásár, Romanwäsär, Romaniuasar, Romani-Újvár, Román-Újvár, Uivar. Ma már nem használatos névként külön szócikkben közli a szótár a Hadik János huszártábornokról elnevezett, Suceava megyei Hadikfalva nevét (1919-ig a település hivatalos román neve; akkor 
Dorneştii lett a város megnevezése). ${ }^{3}$ Akárcsak Románvásár esetében, a szótár felsorolja a forrásokból adatolható valamennyi írásváltozatot: Hadicfalva, Hadickfalva, Hadickfalwa, Hadik-falwa, Hadik-falva, Hadicul. A Moldva névanyagát bemutató szótár több magyar forrásmunkára, tanulmányra is hivatkozik: az Erdélyi magyar szótörténeti tárra (SzT.), a FNESz.-re, POZSONY FERENC román nyelvü csángó monográfiájára, BALÁZS LÁSZLÓ, KNIEZSA ISTVÁN és MoÓR ELEMÉR tanulmányaira.

Olténia földrajzi névanyagának monografikus leírásában (BOLOCAN szerk. 19932007) is találunk magyar tulajdonnevekhez kapcsolódó névalakokat. Így két Gorj megyei településnév esetében megemlíti a szerkesztő a magyar etimológiai vonatkozást. Az egyik a Halmagíu (Hălmagíu) pataknév, amely a szótár szerint a magyar Halmágy tulajdonnévből származik, a másik pedig a Hirişeşti (a magyar eredetü hireş melléknév képzős származéka).

Erdély ilyen jellegű román nyelvü földrajzinév-szótára nem készült még el, viszont megjelent két, kisebb erdélyi régiót bemutató szótár: a Szilágy megye (PAVEL-POPROŞIANU-VASILIU 2006) és a Jára völgye névanyagát (LOȘONȚI-VLAD szerk. 2010) feldolgozó munka. Mindkét szótár számos magyar eredetü, magyar mintára keletkezett román földrajzi nevet tartalmaz (egyetlen példa a Szilágy megye névszótárából: NuşfalăuNagyfalu [Szilágynagyfalu]). A Szilágy megyei névszótár azokat a magyar helynévalakokat regisztrálja, amelyek kölcsönzés eredményeként adaptálódtak a román nyelvhez, vagy szinonimikus viszonyban állnak a román névvel (pl. Hósu Máre-Nagy-hoszú), és az etimológiai információk sorában az etimon morfológiai szerkezetét is bemutatja. Így például a Bicateiu román helynév kapcsán megjegyzi, hogy a magyar Bikahely összetett szóból származik, és megadja a bika és a hely névelemek jelentését.

2.3. Speciális földrajzinév-szótár. Külön típust képvisel a román szótárirodalomban a népnyelvi földrajzi köznevek szótára (Dicţionar entopic al limbii române) (BOLOCANŞODOLESCU-SilveSTRU-BuRCI-TOMA szerk. 2009). ${ }^{4}$ Amint az előszóból kiderül, a szerkesztők olyan földrajzi közneveket szótároztak, amelyek 1. népnyelvi szintüek (valamennyi nyelvjárásban megtalálhatóak), 2. csak tájnyelvi szinten ismertek, 3. fogalmi jelentésükben eltérnek a köznyelvi használattól. A szócikkek etimológiai részében számos magyar földrajzi köznévre történik utalás, mivel több magyar eredetü köznév meghonosodott a román népnyelvi változatokban. Ezt szemléltetik az alábbi adatok, amelyek a magyar nevek integrálódásának fonológiai, morfológiai és jelentésbeli sajátosságait is jelzik; pl. r. oaşă 'olyan földterület, ahol tilos vadászni, kaszálni vagy fát kivágni' < m. óvás 'védett terület'; r. ageag 'puszta, terméketlen földterület' < m. agyag; r. ogaş, făgaş 'mély keréknyom a földben' < m. vágás 'hosszú, keskeny bemélyedés; szakadék, vízmosás, mélyút'; r. feredea 'fürdőhely' < m. feredő; r. furgău 'folyóvíztorkolat' < m. forgó; $r$. nadă 'tavi nádas' < m. nád.

A szótár lexikográfiai anyagának összeállításában ebből a célból végzett kérdőíves felméréseket is hasznosítottak a korábbi lexikográfiai kutatások és szakközlemények adatainak felhasználása mellett. A szócikkek a címszó után a következő információkat jelenítik meg: 1. a kérdőíves felmérésből származó adatok (alakváltozatok, jelentések,

${ }^{3}$ A települést Hadik János alapította Erdély gubernátorának parancsára 1783-1786 között a korábban Moldvába menekült székelyek Bukovinába való telepítésével.

4 A szótárból megtekinthető egy részlet a következő honlapon: https://www.scribd.com/ document/383398657/Dictionar-Entopic-Al-Limbii-Romane-Vol-1. (2020. 04. 17.) 
az adatok földrajzi elterjedtsége, szinonimák); 2. más szótárakból és publikációkból származó adatok; 3. az adott név történelmi forrásokból való adatolása, 4. a terminus más nyelvekben való elterjedtsége; 5. a név etimonja és az etimon morfológiai szerkezete. A magyar források vagy szakirodalom idézése azonban teljesen hiányzik a szótárból, pedig a sokféle etimologizálás ezt szükségessé tenné.

2.4. Vitatható etimologizálások a névszótárakban. Földrajzi névi és személynévi adattárnak egyaránt tekinthető PĂTRUȚ 1984-ben megjelent munkája (Nume de persoane şi nume de locuri româneşti [Román személy- és helységnevek]), amely a településnevek és a családnevek összefüggését vizsgálja. A bevezető tanulmány arról tesz bizonyságot, hogy a szerző sajátos módszert dolgozott ki a tulajdonnevek eredetének vizsgálatára, amely sok tekintetben vitatható. Így például nagy számban feltételezi a puszta helynév és puszta személynév egységét, vagyis hogy a helynév és a személynév alakja gyakran teljes mértékben megegyezik, ezekröl pedig azt feltételezi, hogy román névadással keletkeztek. A szerző ilyennek tartja a következő neveket: Turda (m. Torda, amely valójában az ősi magyar Turda személynévből származik), Dej (m. Dés, valójában Árpád-kori magyar személynévből ered), Blaj (Balázsfalva, a név valójában a település Cséry Balázs nevü birtokosára vonatkozik). A románban azonban nincsenek adatok a nominativusban álló, puszta személynév helynévvé válásáról, tehát ez magyar sajátosságnak mondható (NAGY 2015: 229-230). PĂTRUȚ a személynevek felépítését, alaki szerkezetét vizsgálva, ezek összehasonlításából nem élö, feltételezett és igencsak vitatható képzőket vél felfedezni (-og-, -ug-, -ag-, -eg-, -or-, -ai), amint erre utal a monográfia egyik recenzense (VASILIU 1985). Jellemző ebből a szempontból, hogy a nyilvánvalóan magyar eredetü családnevet, a Budai-t román eredetünek tartja: szerinte egy feltételezett -ai képzővel jött létre, miközben több magyar eredetü név hasonló módon honosodott meg, tehát strukturális jelenségröl van szó (pl. m. Cirmai > rom. Ţirmai, m. Sinkai > rom. Şincai, m. Kabai > rom. Cabai, m. Maksai > rom. Macşai) (vö. BENÖ 2013: 171).

A legfrissebb román helynévszótárnak tekinthető ION TOMA 101 nume de locuri [101 helynév] címü munkája (TOMA 2015). A magyar eredetü földrajzi neveket is tartalmazó szótár szakirodalmi jegyzéke egyetlen magyar szerzőre sem hivatkozik. Az egyes névcikkek részletes tájékoztatást nyújtanak a földrajzi nevek változatairól, homonimikus viszonyairól. Így például megtudhatjuk, hogy a magyar eredetü Almaş ( $<$ m. Almás) név 15 falu, 6 patak és két domborzati forma nevében fordul elö egyszerü (Almaş) vagy képzett alakban (Almăşel, Almăjeni), esetleg összetétel elemeként (Almaşu-Sălişte). A magyar vonatkozású etimológiai magyarázatok többnyire összhangban vannak a magyar névtani kutatásokkal, amint ezt az Apahida $(<\mathrm{m}$. Apahida $\leftarrow$ apát + hídja $)$, Ardeal $(<\mathrm{m}$. Erdély), Beclean ( $<\mathrm{m}$. Bethlen), Căpâlna $(<\mathrm{m}$. Kápolna), Hunedoara $(<\mathrm{m}$. Hunyadvára) névcikkek magyarázatai szemléltetik. Vannak azonban olyan etimológiai magyarázatok is, amelyek eltérnek a magyar névtani kutatásokban elfogadottnak tekinthető eredeztetéstöl. Így például a szerző a Făgăraş településnevet románban keletkezett névnek tekinti, amely egy Fagar, Fogar személynévből jött létre a román -aş képzővel, és a magyar név szerinte átvétel a románból. Hasonló módon Torda város román alakját (Turda) románban keletkezett névnek tekinti, PĂTRUȚ (1984) vitatható etimologizálását követve, amely szerint a név a Tur román családnévből keletkezett egy feltételezett - $d$ képző alkalmazásával. KISS LAJOS szerint ezzel szemben a Torda településnév puszta személynévből keletkezett, Torda vármegye első ispánjának nevére utal, a románban pedig magyar átvétel (FNESz.). ION TOMA Temesvár nevét is román eredetünek tartja: a román Timiş név 
átvételével és a vár fönév hozzáadásával jött létre, majd az ily módon keletkezett név került vissza a románba, és honosodott meg Timişoara alakban. A Hordou (magyarul Hordó) településnevet a szerző egy feltételezett szláv *Hordov névre vezeti vissza. A FNESz. szerint ez valószínüleg a régi magyar Hordowkuth (Hordokút) rövidült alakja. Mindez azt mutatja, hogy ebben a kötetben az etimológiai vonatkozások megbízhatósága eltérő: megbízható, tudományosan megalapozott eredeztetések váltakoznak erősen vitatható vagy cáfolható magyarázatokkal.

3. Személynévszótárak. A személynevek szótárai közül máig az egyik leggyakrabban használt román lexikográfiai kézikönyv N. A. CONSTANTINESCU (1963) Dicţionar onomastic românesc [Román névszótár] címü munkája. A több mint félezer oldalas mü egyaránt ismertet kereszt- és családneveket. Külön érdekessége, hogy a személyneveket nem így csoportosítja, hanem keresztény (naptári) és világi nevekre osztja. ${ }^{5}$ A 70 oldalnyi bevezető tanulmányban a szerző részletesen elemzi a román személynevek eredetrétegeit és kialakulásuk formai kérdéseit (meghonosodás, rövidülés, képzős nevek létrejötte). A magyar eredetü családnevek sorából többek között a következőkre utal: Almaş (< Almás), Ciomortan (< Csomortán), Cionca (< Csonka), Coposu (< Kopasz), Delţeg (< Délceg), Farcaş (< Farkas), Frenţ(iu) (< Ferenc), Ghimeş (< Gémes), Habîş (< Habos), Hodoi (< Hód), Horga (< Horgas), Laslău (< László), Lehaci (< léha), Mogoş (< Magas), Reațeş (<Recés, Récés), Suciu (< Szücs), Tarco (< Tarkó). A szerző ugyanakkor azt is kimutatja a leggyakoribb magyar eredetü személynevekkel kapcsolatban, hogy többségük keresztnévi vagy népnévi eredetü: Blaj (< Balázs), Dămăcăuş (<Domokos), Dieniş (<Dénes), Endreş (< András), Gabor (< Gábor), Ianăs (< János), Miclăuş (< Miklós), Şandru (< Sándor), Tămaş (< Tamás); Arvat (< Horvát), Orăş (< Orosz), Raţiu (<Rácz), Tăut (<Tót).

Kizárólag családnevekkel foglalkozik IORGU IORDAN 1983-ban megjelent névszótára (Dicţionar al numelor de familie româneşti [Román családnevek szótára]). Adatai sorában több mint 100 magyar eredetü családnevet jelenít meg. Az etimológiai információk azonban nem mindig megbízhatóak. A magyar eredetủ neveket gyakran a magyar köznévi formára vezeti vissza, olyan esetekben is, amikor az adott közszó nem került át a románba, tehát a magyar tulajdonnevet vették át, és nem az annak alapjául szolgáló köznevet, ahogy ezt a szótár sugallja: r. Naghi $<\mathrm{m}$. nagy, r. Olas $<\mathrm{m}$. olasz, r. Panțel $<\mathrm{m}$. páncél. A névcikkek közlik a bemutatott nevek variánsait, önálló és képzős változatait. Így például megtudhatjuk, hogy a Boros családnév Boroş, Boroșan, Boroşoiu alakban honosodott meg a románban, a Kis névnek pedig Chiș, Chișu, Chișiu változatai vannak. A szótár adatai azt is jelzik, hogy a magyar eredetü képzővel integrálódott névalakok igen nagy alaki változatosságra utalnak: pl. r. Fodorică, Fodoreanu, Fodoruț $\leftarrow$ Fodor $<$ m. Fodor; r. Fărcaşu, Farcaşanu, Farcașiu, Fărcășescu $\leftarrow$ Farcaş < m. Farkas; r. Maricaru, Maricaş, Maricescu $\leftarrow$ Marica $<$ m. Marika.

A morfológiailag összetett névalakok nagy száma lehetővé teszi az alaki integrálódás szabályszerüségeinek tanulmányozását is. Megfigyelhetjük például, hogy az apai névre utaló -escu családnévképző (a magyar - $f$ morféma analóg párja) a magyar eredetü névalakokban is megjelenik, és annyira produktív, hogy a szótárban szereplö, magyar eredetü képzős családnevek mintegy 11\%-a ezzel a képzővel is előfordul másodlagos származékszóként: r. Balintescu $\leftarrow$ Balint $<$ m. Bálint; r. Enășescu $\leftarrow$ Ianoș $<$ m. János;

\footnotetext{
${ }^{5}$ A szótárt magyarul GÁLDI LÁsZLÓ ismertette megjelenésekor (GÁLDI 1964).
} 
r. Fărcășescu $\leftarrow$ Fărcaş < m. Farkas; r. Herășescu $\leftarrow$ Hirăş $<$ m. Híres; r. Lucacescu Lucaci $<$ m. Lukács; r. Maricescu $\leftarrow$ Marica < m. Marika; r. Mezeicescu $\leftarrow$ Mezei $<\mathrm{m}$. Mezei; r. Miclescu $\leftarrow$ Miclea < m. Miklós; r. Nagiescu $\leftarrow$ Naghi < m. Nagy; r. Nemețescu, Nemețescu $\leftarrow$ Nemet $<\mathrm{m}$. Német; r. Tămășescu $\leftarrow$ Tămaș $<\mathrm{m}$. Tamás. (A magyar eredetü családnevek román nyelvi alaki integrálódásáról részletesebben l. BENŐ 2015.)

Figyelemre méltó kísérletnek tekinthető a romániai családnevek gyakorisági szótára: Dicţionar de frecvenţă a numelor de familie din România (OANCĂ 2003). A több kötetesre tervezett kiadványnak eddig csak az első kötete jelent meg, amely az $A$ és $B$ kezdőbetűs családneveket mutatja be. A szótár anyaga a népességnyilvántartási hivatal 1994-es adatait hasznosítja, így a mai Románia egészére kiterjed. Gyakorlatilag minden, az adott évben román állampolgárként nyilvántartott személy családneve megjelenik a szótár alapjául szolgáló adatbázisban, jóllehet a szótár csak azokat a neveket jeleníti meg, amelyeknek az előfordulása 10-nél nagyobb, amint ezt az előszóból megtudhatjuk. Így a szótár nem a román, hanem a romániai családnevek adattára kíván lenni, és értelemszerüen az erdélyi magyar családnevek szinte kivétel nélkül megjelennek vagy meg fognak jelenni benne. (Elvileg csak azok hiányozhatnak, amelyekről kevesebb mint 10 adat van az országos nyilvántartásban.) A szótár történelmi régiók és megyék szerinti felbontásban mutatja be a családnevek elöfordulását. Így például megtudhatjuk, hogy a Balla családnév a leggyakoribb a történelmi Erdélyben (1941 személy viseli ezt a nevet), Körösvidéken (1491 elöfordulás) és Máramarosban (373 névviselő). Más régióban (Dobrudzsa, Moldova, Olténia, Bánság) csak szórványosan, néhány vagy néhány tíz adat jelzi az ottani jelenlétét. A szótár szerint Erdélyben a Balla név Hargita (565), Kolozs (556) és Maros (484) megyében a leggyakoribb. A szótár önálló szócikkekben rögzíti és adatolja a névváltozatokat íráskép szerint: például külön-külön szócikk van a Bakos, Bakoş és Bacoş családnévröl, és mindegyiknek megnézhetjük a régió és megye szerinti gyakoriságát. Mivel hivatalos forrásból nincsenek adataink a romániai (erdélyi) magyar családnevek gyakoriságáról és földrajzi elterjedtségéről, a kiadvány hiánypótló lehet a magyar kutatók számára is, különösen, ha megjelennek a szótár további kötetei is.

A Moldovai Köztársaságban jelentették meg a Dicţionar de prenume si nume de familie purtate de moldoveni [Moldovaiak által viselt család- és keresztnevek szótára] címü kiadványt, amely - méreténél fogva - inkább névjegyzéknek tekinthető (CoSNICEANU 1991). Az egyszerü névlista magyar eredetü családneveket is tartalmaz, és ez egyben azt is jelzi, hogy a magyar családnevek keleti irányban való terjedése túlmutat Románia mai határain. Többek között a következő magyar eredetü, családnévként használt elemek szerepelnek a kiadványban: Bologa (< Balog), Fărcăşseanu (< Farkas), Iănuş (< János), Laslău (< László), Mogoş (< Magas), Şandru (< Sándor), Şuteu (< Sütő), Tomaş (< Tamás), Totu $(<$ Tót).

Újabb keletű CRISTIAN IONESCU névszótára, amely (második, javított kiadásként) 2008-ban jelent meg Dicţionar de onomastică [Névszótár] címen. Ez a lexikográfiai munka az előszó szerint mintegy 4000 keresztnevet mutat be, utalva a név eredetére, történelmi, kultúrtörténeti vonatkozásaira. A szócikkek végén a szerző jelzi, hogy az adott névnek milyen rövidüléses vagy becéző formái vannak a románban, és hogy az adott név különböző nyelvekben milyen alakban használatos. Mindegyik szócikk feltünteti a név magyar megfelelöjét (ha van), és gyakran a magyar név változatait, becéző formáit is felsorolja. Így a Barbara név ismertetésekor megemlíti a szótár, hogy a magyarban ehhez a névhez kapcsolódik a Borbála, Boriska, Boróka. A Benedict szócikkben jelzi a Benedek névböl kialakult névformákat: Bede, Beke, Bence, Bencő, Bende, Bene, Béni, 
Benkö, Benyó. Hasonlóképpen a Gheorghe szócikkben megtaláljuk a név magyar változatait, becéző formáit: György, Dudó, Györi, Györök, Gyura. A szótár összesen több ezer magyar keresztnevet, keresztnévváltozatot említ a különböző nyelvü párhuzamos névformák bemutatásakor. ${ }^{6}$

A névtani kutatásokban jól hasznosítható a DEXonline internetes szótárgyüjtemény, ${ }^{7}$ amely 53 román szótár különböző kiadásaiban keresi a vizsgált szót vagy nevet, és különkülön megjeleníti az egyes szótárakban található szócikkeket. A tulajdonneveket (is) tartalmazó szótárak közül a következők épülnek be az internetes szótárgyüjtemény anyagába: 1. az enciklopédikus jellegü Dicţionar universal al limbii române [A román nyelv általános szótára] (ŞĂINEANU 1929), 2. CONSTANTINESCU (1963) említett személynévszótára és 3. a hétkötetes Dicționarul enciclopedic [Enciklopédikus szótár] (PoPA szerk. 1993-2009). Ha beírjuk például az internetes szótárgyüjtemény keresőjébe a magyar eredetü Fărcaş nevet, megtudhatjuk a Dicţionarul enciclopedic szócikkéből, hogy a név egy Dolj megyei települést is jelöl, CONSTANTINESCU szótárának adataiból pedig azt, hogy családnévként Fărcaș, Fărcaşa, Fărcășeul, Fărcăşești alakban is elöfordul.

4. Összegzés. Összefoglalásképpen megállapítható, hogy a román névszótárak (akárcsak a szlovák és ukrán lexikográfiai munkák; vö. BAUKO 2020, SEBESTYÉN 2020) gazdag magyar vonatkozású névanyagot tartalmaznak, amelyek a névtani kutatások mellett a nyelvtörténeti, a kontaktológiai és a müvelödéstörténeti vizsgálatokban is forrásként szolgálhatnak. Ugyanakkor a szótárakban szereplő etimologizálások megítélése kellő óvatosságot igényel, mert némelykor nem kellően megalapozottak, esetleg mellözik a magyar forrásokat, magyar szerzőket. Mind a földrajzi nevek, mind a személynevek szótárai téves, olykor ideologikusnak minősíthető etimologizálásokat is tartalmaznak. Ez az ideologizálás egyfajta folytonosságot is jelez, ha figyelembe vesszük, hogy IOAN PĂTRUȚ egy-egy, 1984-ben megfogalmazott, tudományosan nem igazolható állítása visszaköszön ION TOMA 2015-ben megjelent névtani munkájában. Pontatlanságként említhetö, hogy régebbi román szótárakban a magyar névalakok ékezetes betüi nemritkán hibásan írva jelennek meg, és az etimológiai magyarázatok néha pontosításra, kiegészítésre szorulnak. Amint azt a megfelelö helyen jeleztem, a román névszótárak részben vagy egészben elektronikusan is elérhetők, és ez megkönnyíti a konkrét névvizsgálatok magyar és román vonatkozásainak ellenőrzését, egybevetését.

\footnotetext{
${ }^{6}$ Sok szempontból vitatható megállapításokat is tartalmaz a legújabb, történészek által kiadott névtörténeti monográfia: Antroponimia în Transilvania medievală (secolele XI-XIV). Evaluare statistică, evoluţie, semnificaţii [Nevek a középkori Erdélyben: XI-XIV. század. Statisztikai értékelések, változásfolyamatok, jelentések] (TURCUŞ főszerk. 2011), amely Erdély 11-14. századi személynévanyagát dolgozza fel a korabeli oklevelek alapján. A tudományos kutatás számára a kiadvány leginkább hasznosítható részei a nevek statisztikai feldolgozásának adatait bemutató táblázatok, diagramok, amelyek többek között a névviselök társadalmi megoszlását is jelzik. A kötet bevezető tanulmánya arról is bizonyságot tesz, hogy a szerzők a román történetírásnak azt a módszertani hagyományát alkalmazzák, amely egy bebizonyítandó elözetes koncepcióra épül: a románok már a 11-14. században többségben voltak Erdélyben. Amint a kötet magyar nyelvű recenzense, NAGY LEVENTE jelzi, a szerzők a „szláv-bizánci keleti alaphoz” sorolnak olyan személyneveket, amelyek a korabeli Magyar Királyságban is a leggyakoribb nevek voltak (NAGY 2015: 223-224).

${ }^{7}$ https://dexonline.ro (2020. 04. 17.)
} 


\section{Felhasznált források}

Avram, Cezar Gabriel szerk. 2009. Dicţionarul istoric al localităţilor din judeţul Olt. Editura Alma, Craiova.

Bolocan, GHeOrGHe szerk. 1993-2007. Dicţionarul toponimic al României. Oltenia 1-7. Editura Universitara, Craiova.

Bolocan, GHeOrghe - Şodolescu-Silvestru, Elena - Burci, Iustina - Toma, Ion szerk. 2009. Dicţionar entopic al limbii române 1-2. Editura Universitaria, Craiova.

Chende-Roman, GHeorghe 2006. Dicţionar etimologic al localităţilor din judetul Sălaj. Editura Caiete Silvane, Zalău.

CONSTANTINESCU, Nicolae A. 1963. Dicţionar onomastic românesc. Editura Academiei Republicii Populare Române, București.

COSNICEANU, MARIA 1991. Dicţionar de prenume si nume de familie purtate de moldoveni. Redacția Principală a Enciclopediei Sovietice Moldovenești, Chișinău.

CREŢAN, REMUS 2006. Dicţionar toponimic şi geografico-istoric al localităţilor din judeţul Timiş. Editura Universităţii de Vest, Timişoara.

FrĂȚILĂ, VASILE - GOLCU, VIORICA - SUFLEȚEL, RodiCA 1984-1994. Dicţionarul toponimic al Banatului 1-7. (A-O). Universitatea din Timişoara, Timişoara.

IONESCU, CRISTIAN 2008. Dicţionar de onomastică. Ediţia a II-a. Editura Elion, Bucureşti.

IORDAN, IORGU 1983. Dicţionar al numelor de familie româneşti. Editura Științifică și Enciclopedică, Bucureşti.

Loșonți, Dumitru - Vlad, SABIN szerk. 2010. Tezaurul toponimic al României. Transilvania. Valea Ierii. Editura Academiei Române, București.

Moldovanu, Dragoş szerk. 1991-2014. Tezaurul toponimic al României. Moldova 1-2. Editura Universităţii „Alexandru Ioan Cuza”, Iaşi.

OANCĂ, TEODOR 2003. Dicţionar de frecvenţă a numelor de familie din România 1. (A-B). Editura Universitaria, Craiova.

PĂTRUȚ, IOAN 1984. Nume de persoane si nume de locuri româneşti. Editura Ştiinţifică şi Enciclopedică, Bucureşti.

Pavel, Eugen - Pop, Augustin - Roşianu, Ion - VAsiliu, Gabriel 2006. Tezaurul toponimic al României. Transilvania. Judeţul Sălaj. Editura Academiei Române, Bucureşti.

PoPA, MARCEL D. szerk. 1993-2009. Dicţionar enciclopedic 1-7. Editura Enciclopedică, Bucureşti.

Roz, Alexandru - Kovach Gheza 1997. Dicţionarul istoric al localităţilor din judeţul Arad. Editura Universităţii „Vasile Goldiş”, Arad.

ŞĂINEANU, LAZĂR 1929. Dicţionarul universal al limbii române. Editura „Scrisul Românesc”, București.

SARAMANDU NiCOLAE szerk. 2005-2015. Dicţionarul toponimic al României. Muntenia 1-6. Editura Academiei Române, București.

ȘTEF, Dorin 2016. Dicționar etimologic al localităților din județul Maramureș. Editura Ethnologica, Baia Mare.

SuCIU, CORIOLAN szerk. 1967. Dicționarul istoric al localităților din Transilvania. Editura Academiei R. S. R., București.

TOMA, ION 2015. 101 nume de locuri. Editura Humanitas, Bucureşti.

TURCUȘ, ȘERBAN föszerk. 2011. Antroponimia în Transilvania medievală (secolele XI-XIV). Evaluare statistică, evoluţie, semnificaţii 1-2. Editura Mega, Cluj-Napoca. 


\section{Hivatkozott irodalom}

BAUKO JÁNOS 2020. Magyar tulajdonnevek a cseh és szlovák névszótárakban. In: FARKAS TAMÁS SLíz MARIANN szerk., Tulajdonnevek és szótárak. ELTE Magyar Nyelvtudományi és Finnugor Intézet - Magyar Nyelvtudományi Társaság, Budapest. 199-207. https://doi.org/10.26546/ 4892373.12

BENŐ ATTILA 2013. Román eredetű családnevek etimológiai és morfológiai kérdései. In: VÖRÖS FERENC szerk., A nyelvföldrajztól a névföldrajzig IV. A nyelvi kölcsönhatások és a személynevek. A 2013. június 8-i dunaszerdahelyi tanácskozás elöadásai. Savaria University Press, Szombathely. 169-176.

BENŐ ATTILA 2015. Román-magyar nyelvi kapcsolatok a családnevek tükrében. In: VöRÖS FERENC - MiSAD KATALIN szerk., A nyelvföldrajztól a névföldrajzig V. Interetnikus kapcsolatok. A 2014. november 20-21-i pozsonyi névföldrajzi tanácskozás elöadásai. Szenczi Molnár Albert Egyesület, Pozsony. 172-183.

BorovszKY SAMU 1914. Magyarország vármegyéi és városai. Temes vármegye és Temesvár. Országos Monográfia Társaság, Budapest.

ErdHnK. = VISTAI ANDRÁS JÁNOS, Erdélyi helynévkönyv 1-3. [Hely és év nélkül, csak a világhálón közzétéve.] https://web.archive.org/web/20110710231100/http://www.fatornyosfalunk.com/ html/erdelyi helynevkonyv.html (2020. 04. 17.)

FNESz. = KISS LAJOS, Földrajzi nevek etimológiai szótára 1-2. 4., bővített és javított kiadás. Akadémiai Kiadó, Budapest, 1988.

GÁldi LÁszló 1964. N. A. Constantinescu, Dicționar onomastic romînesc. [Recenzió.] Nyelvtudományi Közlemények 1: 464-466.

NAGY LEVENTE 2015. Újabb erdélyi román személy- és helynévtörténeti kutatások. [Recenzió.] Névtani Értesitó 37: 221-238.

PESTY FRIGYes 1881-1885. Krassó vármegye története 1-4. Athenaeum, Budapest.

PESTY FRIGYES 1888. Magyarország helynevei történeti, földrajzi és nyelvészeti tekintetben 1. Magyar Tudományos Akadémia Történelmi Bizottsága, Budapest.

POzSONY, FERENC 2006. The Hungarian Csángó of Moldova. Corvinus Publishing, BuffaloToronto.

SEBESTYÉN ZSOLT 2012. Máramaros megye településneveinek etimológiai szótára. Bessenyei Könyvkiadó, Nyíregyháza.

SEBESTYÉN ZSOLT 2020. Magyar tulajdonnevek az ukrán névszótárakban. In: FARKAS TAMÁS - SLÍZ MARIANN szerk., Tulajdonnevek és szótárak. ELTE Magyar Nyelvtudományi és Finnugor IntézetMagyar Nyelvtudományi Társaság, Budapest. 209-219. https://doi.org/10.26546/4892373.13

SzT. = Erdélyi magyar szótörténeti tár 1-14. Föszerk. SzABÓ T. ATTILA etc. Kriterion Könyvkiadó etc., Bukarest etc., 1975-2014.

TAMÁS, LAJOS 1966. Etymologisches-historisches Wörterbuch der ungarischen Elemente im Rumänischen. Akadémiai Kiadó, Budapest.

VASILIU, GABRIEL 1985. Ioan Pătruţ, Nume de persoane şi nume de locuri româneşti. [Recenzió.] Nyelv-és Irodalomtudományi Közlemények 1: 89.

BENÖ ATTILA

ORCID: https://orcid.org/0000-0002-6931-2999

Babeş-Bolyai Tudományegyetem

Bölcsészettudományi Kar 


\section{ATTILA BENŐ, Hungarian proper names in Romanian name dictionaries}

The study presents the Hungarian elements of the most important Romanian place name, family and given name dictionaries. Through a brief overview of the Romanian dictionaries, the author indicates issues regarding Hungarian names, the shortcomings of the approaches employed, and debatable elements of the works. The lexicographical data referenced in the study showcase that Romanian name dictionaries are a rich data source for Hungarian names that should be considered by not only onomastic research but historical linguistics, contact studies, and the history of culture. The article emphasizes that some of the methods used in Romanian dictionaries could be employed in Hungarian lexicography as well. However, the author notes that Romanian name dictionaries should be referenced with caution regarding the etymology of Hungarian names, as the statements made are often unsubstantiated, and lack reference to Hungarian sources or authors. The inaccuracy of etymological information is emphasized by how the diacritics of Hungarian names are often misspelled in older Romanian name dictionaries. Thus the information in them is often in need of review or correction. Both geographic and personal name dictionaries, at times, contain false or even ideological etymologizations. Throughout the overview, the author references the Hungarian reviews of these dictionaries to facilitate detailed evaluation. It should be uniquely helpful to researchers that Romanian name dictionaries, or excerpts of them, are available online, this should facilitate research into names when Romanian and Hungarian factors must both be considered. 

FARKAS TAMÁS - SLÍZ MARIANN szerk., Tulajdonnevek és szótárak. ELTE Magyar Nyelvtudományi és Finnugor Intézet - Magyar Nyelvtudományi Társaság,

Budapest, 2020. 199-207. DOI: 10.26546/4892373.12

\section{Magyar tulajdonnevek a cseh és szlovák névszótárakban"}

1. Bevezetés. A tanulmány arra a kérdésre keresi a választ, hogy a cseh és szlovák névszótárakban szerepelnek-e magyar tulajdonnevek, és ha igen, miként magyarázzák őket; használnak-e magyar szakirodalmat; van-e tendenciaszerüség és időbeli változás a magyarázatokban. Csak azokat a névszótárakat, illetve névszótári részeket tartalmazó publikációkat tárgyaljuk, melyekben találhatók magyar tulajdonnevekkel kapcsolatos névcikkek, névmagyarázatok. Elöbb a magyar tulajdonneveket is tárgyaló cseh és szlovák keresztnév-, majd családnév-, végül pedig helynévszótárakat tekintjük át.

2. Keresztnévszótárak. A legismertebb cseh keresztnévszótárat MiLOSLAVA KNAPPOVÁ írta, a kiadvány a Jak se bude vaše dítě jmenovat? [Hogy hívják majd az Ön gyermekét?] címet viseli. A könyv első kiadása 1978-ban, legutóbbi, átdolgozott és bővített hatodik kiadása 2017-ben jelent meg, s mintegy 17000 keresztnevet tartalmaz (KNAPPOVÁ 2017). Csehországban egy olyan keresztnév bejegyzése érdekében, amely nem található meg az említett névkönyvben, a kérvényezők a Cseh Tudományos Akadémia Nyelvtudományi Intézetének Névtani Osztályához fordulhatnak, ahol szakvélemények készülnek a nevekről.

KNAPPOVÁ (2017) a kiadványban a keresztnevekkel összefüggő általános kérdésekkel is aprólékosan foglalkozik. A szótári részt megelőzően ír a keresztnevek történetéről, a névadást motiváló tényezőkről, a nevek anyakönyvezéséről, a kettős keresztnévadás lehetőségéről, a névválasztással kapcsolatos ajánlásokról, a névdivat változásáról és a névnapokról.

A szótári részben az egyes névcikkekben magyarból átvett keresztnevek is szerepelnek címszóként: a férfinevek közül az Ákos, Aladár, Alajos, Antal, Arpád, Atila, Bálint, Béla, Csaba, Farkas, Ferenc, Gál, Imre, István, Kálmán, Kelemen, Lajos, László, Levente, Lóránt, Nándor, Ödön, Pál, Sándor, Śándor, Tivadar, Vidor, Zoltán, Zsolt; a nöi nevek közül az Aranka, Boglárka, Csilla, Dalma, Enikö, Erzsébet, Hajnal, Hajnalka, Iboja, Ila, Ildika, Ilona, Margit, Marika, Mirtill, Orsolya, Piroska, Réka, Sarolta, Timea, Tünde. A keresztnévszótárban található magyar névcikkek megírásához alapvető forrásul a LADÓ JÁNOS és BíRÓ ÁGNES által kiadott Magyar utónévkönyv szolgált (MUnk. 1998). Egyes névalakok azonban az adott keresztnév cseh nyelvbe való adaptációjáról, névcsehesítésről árulkodnak: Arpád, Atila, Šándor, Iboja, Ildika, Timea. A szótár névcikkeiben KNAPPOVÁ többnyire feltünteti a név eredetét és jelentését, becéző alakváltozatait, idegen nyelvekben szereplő megfelelőit, előfordulásának gyakoriságát és a névnap időpontját. A címszóként álló, magyarból átvett keresztnevek mellett a rövidebb névcikkekben gyakran csak a név eredetét és - ha létezik - cseh megfelelöjét találjuk. A bővebb névcikkekben megfigyelhető a keresztnevekből alkotott becenevek cseh nyelvben való használata is: Antal-Antek, Antalek; Arpád-Arpa, Arpouš(ek), Arp(ád)ek; Atila-Ata,

\footnotetext{
*A tanulmány a Tempus Közalapítvány államközi ösztöndíjának támogatásával készült.
} 
Atík, Atilek; Gál-Galek, Galouš(ek), Galo; Vidor-Vid(ek), Vidorek, Dorek; ZoltánZoltánek, Zolek, Zoli, Tan(ek); Aranka - Arana, Arka, Arin(k)a, Aruška; Dalma - Dalka, Dalmuška, Dalmička; Iboja - Boj(k)a, Ibojka, Ibuš(ka); Ildika - Ilka, Ilda, Ildička, Ildin(k)a, Ildun(k)a; Ilona - Ila, Ilka, Ilča, Ilun(k)a, Iluš(ka), Ilonka; Margit-Margitka, Gita, Gitka, Gituš(ka), Marga, Margo(t); Marika - Marička, Marka, Márinka, Mara, Mája, Májina, Maruna, Majčinka; Timea - Timka, Timča, Timuš(ka), Timečka.

A szlovák keresztnévszótár, melyet a szlovákiai anyakönyvi hivatalokban is használtak, illetve használnak, a MILAN MAJTÁN és MATEJ POVAŽAJ szerzőpárostól származik. A névszótár első kiadása 1983-ban látott napvilágot, a bővített változata pedig 1998-ban, Vyberte si meno pre svoje diet'a [Válasszon keresztnevet gyermekének] címen (MAJTÁN-POVAŽAJ 1998). A szótárban az egyes keresztnevek betürendben találhatók. A keresztnevek mellett rövidítések jelölik a női vagy férfinevet. A névcikkekben a keresztnév eredete és jelentése után a különböző nyelvekben (angol, cseh, francia, magyar, német, olasz, orosz, spanyol, svéd stb.) meglévő névmegfelelők, valamint a keresztnévből származó családnevek szerepelnek. A szótárban a betürendes névlistában fel van tüntetve az összes névváltozat, amely visszakereshető az utaló névcikk alapján; pl. Zsaklin p. Žakelína (p. = pozri 'lásd'), Zsanett p. Žaneta, Zseni p. Eugénia, Zseraldina p. Geraldína, Zsigmond p. Žigmund, Zsófia p. Žofia, Zsóka p. Alžbeta, Zsuzsa p. Zuzana, Zsuzsanna p. Zuzana. A szerzők a magyar névmegfelelők megadásakor LADÓ JÁNOS Magyar utónévkönyv címü kiadványára támaszkodtak (MUnk. 1972).

A szótári részen túl a könyvben olvashatunk a személynevek történetéröl, a kereszténység felvétele előtt használatos régi szláv nevekről, a keresztségben kapott személynevekröl, a keresztnévi eredetü családnevekröl, a névdivatról, a keresztnevek anyakönyvezéséről, a hármas keresztnévadás lehetőségéről, az új keresztnevek létrejöttéről, a névválasztásról és -változtatásról, a női családnevek használatáról, az egyes nevek névnapjának időpontjáról, a keresztnevek becenévi alakváltozatairól. Az 1998-ban megjelent szótár óta nagyban változott a keresztnévdivat, bővült a névállomány Szlovákiában, ezért szükség lenne az említett névszótár bővített kiadására. Tudomásom szerint nincs tervben a könyv újabb kiadása. A szlovákiai anyakönyvi hivatalokban egyéb online névforrásokat használnak: minden olyan keresztnevet bejegyeznek az anyakönyvbe, mely megtalálható bizonyos nemzetközi weboldalak valamelyikén. ${ }^{1}$ Egy újonnan kérvényezett keresztnév bejegyzésével kapcsolatban csak ritkán fordulnak a Szlovák Tudományos Akadémiához tanácsadásért, és szakvélemények sem készülnek a nevekröl. Ez annak is köszönhetö, hogy a vonatkozó törvényekben nincs ezzel kapcsolatos meghatározás, és az anyakönyvvezetők online keresztnévjegyzékeket is használnak, melyek bőséges névadatbázist nyújtanak ugyan, de téves névformákat is tartalmazhatnak.

3. Családnévszótárak. MiloslaVA KNAPPOVÁ Naše a cizí př́ijmení v současné češtině [A mai cseh nyelvben lévő hazai és idegen családnevek] címü családnévkönyve 1992-ben, majd bővített kiadása 2008-ban jelent meg. Nem klasszikus családnévszótárról van szó, a szerző a családneveket általában szövegkörnyezetben tárgyalja, de bizonyos fejezetekben névcikkek is elöfordulnak. A könyv végén található névmutató megkönnyíti az egyes családnevek visszakeresését. A kiadvány a következő fejezetekből áll: a cseh családnevek története, a cseh családnevek eredete és jelentése, a családnevek

1 A használatos weboldalak: www.babynames.com, www.babynameworld.com, www. babynology.com. (2020. 04. 24.) 
alaktani sajátosságai, az idegen (női) családnevek adaptációja a cseh nyelvbe, a családnevek helyesírási sajátosságai, a családnevek átírása egyes idegen nyelvekből, családnévváltoztatások, nemesi családnevek, a családnevek gyakorisága (KNAPPOVÁ 2008).

A szerző a magyar eredetű családnevek értelmezésekor KÁZMÉR MIKLÓs Régi magyar családnevek szótára címü müvére (CsnSz.) támaszkodik. KNAPPOVÁ a magyar családnevek helyesírásával, kiejtésével, a cseh nyelvben való toldalékolásával kapcsolatban is megjegyzéseket tesz. A magyar tulajdonnevek cseh nyelvben megfigyelhetö helytelen kiejtése a két nyelvben előforduló eltérő fonémákkal függ össze. A szerző megemlíti a családnevek helyesírása és cseh nyelvbeli kiejtése közötti különbségeket, genitívuszi alakváltozatát és a női nevekhez kapcsolódó -ová névformánst; pl. Balázs [baláž], -zse - Balázsová [balážová]; Juhász [juhás], -sze - Juhászová [juhásová]; Jankovics [jankovič], -cse - Jankovicsová [jankovičová]. Felhívja a figyelmet továbbá arra is, hogy a kisebbségi nők elhagyhatják a családnév végéről az -ová képzőt: Aranyová [araňová] és Arany [araň]; Nagyová [nad'ová] és Nagy [nad']; Királyová [kirájová] és Király [kiráj]. A kettős családneveknél többféle alakváltozattal is találkozhatunk a nöknél; pl. Dudásová-Vigová, Dudás-Vigová, Dudás-Vig. A magyar családnevek adaptációja a cseh nyelvbe a család- és keresztnév eltérö névsorrendjében, valamint a névforma variábilis használatában is mutatkozik: Kovács Pálné Szabó Katalin $\rightarrow$ Katalin Kovácsová Szabóová (Szabó), Katalin Kovácsová rozená ('született') Szabóová (Szabó); Kovácsné Szabó Katalin $\rightarrow$ Katalin Kovácsová Szabóová (Szabó); Kovácsné Sz. Katalin $\rightarrow$ Katalin Kovácsová, Katalin Sz. Kovácsová; K. Szabó Katalin $\rightarrow$ Katalin K. Szabóová; Kovács Katalin $\rightarrow$ Katalin Kovácsová. A magyar családnevek csehesítését példákkal szemlélteti KNAPPOVÁ: Bárczi - Bárci, Csillag - Čillag, Gergely - Gergej, Kiss - Kǐ̌̌š, Nagy - Nad, Nyíri - Níri, Szatmári - Satmári, Tyúk - Ťúk, Zsolt-Žolt.

MILAN MAJTÁN szlovákiai családnevekről írott, Naše priezviská [Családneveink] című monográfiája 2014-ben jelent meg. A kiadványban névcikkek is találhatók, de a cseh családnévkönyvhöz hasonlóan többnyire a szövegben előforduló felsorolások, adatolások részeként szerepelnek az egyes családnevek. A szerző az első fejezetben a szlovák családnevek kialakulásával, nyelvi eredetével és formájával, gyakoriságával foglalkozik. A második részben a családnévadás indítékairól, a nevek képzésmódjairól olvashatunk. Az egyes családnevek etimológiáját és a köztük lévő összefüggéseket a legterjedelmesebb fejezet tárgyalja, amelyben a következő kérdéseket érinti a szerző: a névadás indítéka, a név nyelvi eredete, müvelödéstörténeti vonatkozásai, történeti forrásokban való megjelenése, területi és számbeli előfordulása, alakváltozatai, idegen nyelvü megfelelői, a névalkotás módja és a nyelvjárások hatása a családnév keletkezésében. A negyedik részben turzófalvai családnevek magyarázata található rövid névcikkek formájában (bövebben 1. MAJTÁN 2011). Az ötödik fejezet a családnévkutatás és a genealógia közötti összefüggésekről számol be. A könyv végén lévő névmutató segíti a névvel kapcsolatos információk keresését (MAJTÁN 2014).

Nagy számban jelennek meg a kötetben magyar nyelvből származó családnevek. Az 1995-ös szlovákiai lakosság-nyilvántartás alapján a Szlovákiában használatos leggyakoribb családnevek között is szerepelnek magyar eredetüek, melyek többsége különféle alakváltozatban fordul elö: Kováč (-áč 15238, -ač 125, -ács 4832, -acs 25), Horváth (-áth 15092, -át 1269, -ath 285, -at 1539), Varga (11699), Tóth (11419), Szabó (Szabó 6818, Szabo 1585, Sabó 395), Nagy (10315) / Nad' (433), Baláž (-áž 7351, -áš 21, -ázs 860, -azs 80), Molnár (-ár 6714, -ar 6), Lukáč (-áč 5132, -ač 134, -ács 740, -acs 49). Egyes családnevek e példasorból szláv családnévadás eredményei is lehetnek. A magyar 
családnevek interpretációjakor HAJDÚ MIHÁLY Családnevek enciklopédiája címü munkáját (CsnE.) vette alapul MAJTÁN. A szerző a névadás indítéka szerint csoportosítja a névanyagot, s magyarból átvett példákat is említ könyvében. Magyar keresztnévalakból származó családnevek: Miklós > Mikla, Mikl’a, Mikle, Miklánek, Mikláš, Miklo, Mikloš, Miklošik, Mikloško, Miklošovič, Miklovič stb.; magyar foglalkozásnevekből származó családnevek: Áč, Barát, Bíro, Doboš, Fazekaš, Kadár, Lakatoš, Lovás, Madarás, Mesároš, Molnár, Sabo, Sakáč, Sekerě̌, Šipoš, Takáč, Vámoš, Varga, Žoldoš stb.; magyar helynévböl alakult családnevek: Arvai, Bartfai, Budaj, Gömöri, Honti, Kaššai, Lévai, Liptai, Nyitrai, Sepeši, Šároši, Turóci, Zólyomi, Žolnai stb.; a népnév magyar megnevezéséből alakult családnevek: Horvát, Lendel, Lengyel, Morvai, Német, Oláh, Oros, Rác, Tót, Török stb.; tulajdonságra utaló ragadványnévböl származó magyar eredetü családnevek: Farkaš, Igaz, Pirošik, Rigo, Sarka, Szarka, Varju, Veréb, Vereš stb. A családnevek lejegyzésében megfigyelhető, hogy a magyar eredetü családnevek java része a névszlovákosítás eredményeképpen szlovákos helyesírással fordul elő.

DANIEL DUDOK Priezviská Slovákov v Juhoslávii [A szlovákok családnevei Jugoszláviában] címü, 1998-ban megjelent könyvében szintén nagyobb számban találkozhatunk magyar családnevekkel. Ez sem hagyományos családnévszótár, a következő főbb részekből áll: a személynevek története, szlovák családnevek és szlovákok által viselt családnevek, a vajdasági és szlovákiai szlovákok családnevei, a vajdasági szlovákok családneveinek lexikális-szemantikai elemzése. A névmutató segíti a családnevek fellelhetőségét a könyvben. A szerző a legterjedelmesebb fejezetben lexikális-szemantikai szempontból osztályozza és névcikkek formájában közli a korpuszt (több mint 4200 családnevet). Az egykori Jugoszláviában élő szlovákok családneveiben a névszlovákosítás a magyar eredetủ családnevek helyesírásában figyelhető meg; pl. Andráš, Baláž, Birkášs, Bizoň, Bordáš, Búzáš, Čásár, Čordáš, Déně̌, Derd' (< György), Doboš, Farkaš, Frideš, Híreš, Ištók, Ištván, Kálman, Láslo, Madarás, Mesároš, Mihál', Nad', Ol’ajoš, Pálinkáš, Sakáč, Sakáloš, Šándor, Tamaši, Vašaš, Vereš, Vilmoš, Žíroš. Az etnikumra utaló Magyar családnév különféle alakváltozatokban fordul elő: Mad'ar, Mad'ara, Mad'arek, Mad'arik. DuDOK a magyar névtani szakirodalomból KNIEZSA ISTVÁN A magyar és szlovák családnevek rendszere (1965) címủ munkáját használta az egyes családnevek etimologizálásakor.

Szótárszerű részek, magyar családnevek magyarázatai is találhatók a magyarországi szlovákok családneveit feldolgozó Čabianske priezviská [Békéscsabai családnevek] és Komlóšske priezviská [Tótkomlósi családnevek] címü kiadványokban (DIVIČANOVÁ et al. 2015, 2017).

4. Helynévszótárak. Nem hagyományos helynévszótár, de szótárszerü részeket, névcikkeket, magyar tulajdonneveket is tartalmaz a cseh VLADIMÍR ŠMILAUER Vodopis starého Slovenska [A régi Szlovákia vízrajza] címü, 1932-ben megjelent munkája, mely behatóan elemzi a szláv, magyar és más eredetü vízneveket. A szerző jól ismeri és szakszerüen használja a korabeli magyar szakirodalmat és a középkori magyarországi okleveleket. A mü bevezető részében ismerteti a történeti forrásokat (1300-ig vizsgálja a névanyagot), a kutatás módszereit és a munka szerkezetét (ix-xliii). Az egyes folyók (Morva, Duna, Dudvág, Vág, Nyitra, Garam, Ipoly, Sajó, Hernád, Bodrog, Poprád) szerint haladva mutatja be a vízneveket. Az adattárban közli a víznevek etimológiai magyarázatát. Az összegyüjtött korpuszt a névadás indítéka szerint rendszerezi: köznévi, személy- és helynévi, ismeretlen és bizonytalan eredetü vízneveket különböztet meg. A magyar eredetű köznévből származó víznevek mellett feltünteti cseh megfelelöjüket, 
jelentésüket, továbbá a történeti forrásokban előforduló magyar névalakokat, melyekben az adott névrész megtalálható. A magyar személy- és helynévből keletkezett vízneveknél szerepel az adott névrész írott forrásokban való előfordulása és a név keletkezésmagyarázata. A könyv befejező részében a történeti forrásokban szereplö nevek magyar nyelvü lejegyzésének sajátosságairól olvashatunk, majd a források értékelése és a nevek jegyzéke következik (ŠMILAUER 1932).

Az utóbbi években újra fellendült a víznevek kutatása, melyet egykor ŠMILAUER kezdeményezett. 2005-ben jelent meg JAROMÍR KRŠKO Spracovanie hydronymie Slovenska [Szlovákia vízneveinek feldolgozása] címü monográfiája, melyben módszertani útmutatót ad a Hydronymia Slovaciae nevezetü projekt keretén belül készülő tanulmányok elkészítéséhez (KRŠKO 2005). Önálló kötetekben a következö folyók vízneveit dolgozták fel a szlovák névtanosok: a Sajó szlovákiai része (SIČÁKOVÁ 1996), Ipoly (MAJTÁN-ŽIGO 1999), Túróc (KRŠKO 2003), Nyitra (HLADKÝ 2004), Árva (MAJTÁN-RYMUT 2006), Garam (KRŠKO 2008), a Vág felső része (KRŠKO 2011), Kiszuca (KRŠKO-VELIČKA 2011), Dudvág (HLADKÝ 2011), a Morva (ZÁVODNÝ 2012) és a Hernád folyók szlovákiai része (GoÓTŠOVÁ-CHOMOVÁ-KRŠKo 2014), Kis-Duna (BELÁKOVÁ 2014, BELÁKOVÁHLADKÝ-ZÁvODNÝ 2018), valamint a Csallóköz víznevei (HLADKÝ-ZÁvODNÝ 2015). A hidronimákat feldolgozó szlovák kiadványokban szótári rész is található, melynek névcikkeiben a címnév után következik az adott helynév pontos lokalizálása, a történeti forrásokban szereplő névalakváltozatok felsorolása, a víznév etimológiájának magyarázata. Az említett kötetekben gyakran találkozhatunk magyar eredetü víznevekkel. A magyar névtani munkák közül a legidézettebb KIsS LAJOS kétkötetes, Földrajzi nevek etimológiai szótára címủ müve (FNESz.).

Magyar településneveket is tárgyaló szlovák helységnévszótár JÁN STANISLAV 1947-ben megjelent, Odkryté mená slovenských miest a dedín [Szlovák városok és falvak feltárt nevei] címü könyve, melyet 2008-ban újranyomtattak. A névcikkekben a címnévként álló helységnév után következik a település lokalizálása, a történeti forrásokban lévő névváltozatok ismertetése, s végül az adott név keletkezésmagyarázata. Egyes névcikkekben a szlovák helységnév magyar névpárjáról (pl. Eperjes, Pozsony, Kassa) bővebb névmagyarázatot olvashatunk (STANISLAV 1947).

Hasonló szerkezetben szerepelnek a névcikkek JÁN STANISLAV 1948-ban kiadott, majd 1999-ben (1. kötet) és 2004-ben (2. kötet) újranyomott Slovenský juh v stredoveku [A szlovák dél a középkorban] címü terjedelmes kétkötetes könyvének második, szótári részében. E névtárban nemcsak helységnevek, hanem egyéb helynévfajták (pl. víznevek, domborzati nevek) etimológiája is megtalálható. A szerző gyakran idézi monográfiájában KNIEZSA ISTVÁN, MELICH JÁNOS és MoÓR ElEMÉR tanulmányait. Az irodalomjegyzék azt mutatja, hogy jól ismerte a korabeli magyar munkákat, forrásokat, nyelvészeti folyóiratokat. A helynévszótár több ezer helynév etimológiáját tartalmazza. STANISLAV számos magyar eredetủ nevet tendenciaszerủen a szlávból magyaráz. Az idők során a névkutatók sok, általa helytelenül etimologizált nevet újraértelmeztek, de számos, elsősorban nem magyar eredetủ helynevekkel kapcsolatos megállapítását elfogadták. A kiadvány második részére gyakran hivatkozik KISS LAJOS a FNESz. egyes névcikkeiben, cáfolva STANISLAV magyar eredetủ helynevekkel kapcsolatos helytelen etimologizálásait.

A cseh helynévszótárakban csak ritkán találkozhatunk magyar nevek magyarázataival, a szláv eredetủ nevek mellett német etimonúak jelennek meg nagy számban a vonatkozó kiadványokban (1. PROFOUS 1947-1960, HOSÁK-ŠRÁMEK 1970-1980, LUTTERER-ŠRÁMEK 2004). Az IVAN LUTTERER, LUUBOŠ KROPÁČEK és VÁCLAV HUŇÁČEK 
szerzőhármas által írt Původ zeměpisných jmen. Etymologický slovník 1000 vlastních jmen zemí, měst a př́rodních objektů [Helynevek eredete. 1000 tulajdonnév - országnév, településnév, természeti objektum - etimológiai szótára] címü, 1976-ban kiadott cseh nyelvü helynévszótár magyar helyneveket is etimologizál. A helynévfajták közül városnevek (Budapest, Debrecen, Esztergom, Györ, Pécs, Szeged, Székesfehérvár, Szolnok, Sopron, Veszprém) és egy-egy folyónév (Tisza), hegynév (Kékes), országnév (Magyarország) eredetmagyarázata fordul elő a publikációban. A magyar névtani irodalomból KÁLMÁN BÉLA A nevek világa címü könyvét (1967) használták a szerzők (LUTTERERKROPÁČEK-HUŇÁČEK 1976).

Az IVAN LUTTERER, MiLAN MAJTÁN és RUdOLF ŠRÁMEK által írt Zeměpisná jména Československa [Csehszlovákia földrajzi nevei] címü 1982-es kiadványban mintegy 1200 helynév (helységnév, hegynév, víznév) etimológiája szerepel névcikkek formájában. Egyes, Szlovákia területén lévő helynevek eredetmagyarázatánál a magyar névpárok (pl. Bártfa, Nagyszombat, Somorja, Tornalja) etimológiája is megtalálható.

A szlovákiai helységnevek jegyzékét és az egyes toponimák 1773-1997 közötti névváltozatait tartalmazza MILAN MAJTÁN több kiadásban megjelent Názvy obcí Slovenskej republiky. Vývin v rokoch 1773-1997 [A Szlovák Köztársaság helységnevei. Változásuk az 1773-1997 közötti években] címü könyve (MAJTÁN 1998). A bevezetőt követi a szótári rész, melyben 2871 névcikk szerepel; ${ }^{2}$ az egyes helységnevek mellett időrendi sorrendben szerepelnek a történeti forrásokban előforduló névalakváltozatok. Az adatok a társadalmi változások névanyagra való hatását, a szlovák-magyar helységnévpárok alakulását és a lejegyzett magyar alakváltozatok variabilitását is mutatják (pl. Hurbanovo - 1773, 1786 O-Gyalla, 1808 Ó-Gyálla, 1863-1913, 1938-1945 Ógyalla, 1920-1938, 1945-1948 Ó-Gyalla). A betürendes névmutatóban az összes névváltozat listája található.

MILAN MAJTÁN irányításával valósult meg 1966-1975 között egy egész Szlovákiára kiterjedő, helyneveket összegyüjtő kérdőíves kutatás, melynek eredményeképpen mintegy 250000 mikrotoponima gyült össze (1. MAJTÁN 1983). Ezen névkorpusz feldolgozása napjainkban a Szlovák Tudományos Akadémia Nyelvtudományi Intézetében zajlik. IVETA VALENTOVÁ, a Névtani Osztály vezetője dolgozik a digitális helynévtáron. Egyelöre az ábécé első betüjéhez tartozó mintegy 2000 helynév feldolgozása készült el a Slovník lexiky slovenských terénnych názvov [A szlovák mikrotoponimák lexikájának szótára] című projekt keretén belül (1. VALENTOVÁ 2009, 2014, 2018; LSTN.). A helynévanyag feldolgozása a cseh és morva mikrotoponimák digitális helynévtárához hasonló módon történik (1. ČIŽMÁROVÁ 2010a, 2010b; OLIVOVÁ-NEZBEDOVÁMALENÍNSKÁ 2000; SPJČ.; SPJMS.). A szlovák digitális helynévtár névcikkeiben szlovák nyelvbe adaptált magyar eredetü helynevekkel (pl. Ajandéky < ajándék, Ad’agaš < agyagos, Almáš < almás, Pod álomášom < állomás), illetve ezek lokalizálásával, etimologizálásával, toldalékolásával, digitális térképre vetítésével is találkozhatunk.

5. Összegzés. A cseh és szlovák keresztnév-, családnév- és helynévszótárakban, illetve névszótári részeket tartalmazó publikációkban található magyar tulajdonnevekkel kapcsolatos névcikkek, névmagyarázatok azt mutatják, hogy az említett cseh és szlovák névtani lexikográfiai munkák többsége elfogadhatóan interpretálja a magyar tulajdonneveket, és hivatkozik - ha viszonylag kis mértékben is - a magyar szakirodalomra is. Egyes magyar

${ }^{2}$ Az egyes településekhez kapcsolódó névcikkeket 1. http://www.juls.savba.sk/nazvy_bci.html. (2020. 04. 24.) 
eredetü tulajdonnevek lejegyzésében megfigyelhető, hogy a név adott nyelvbe való adaptációja a névcsehesítés, illetve névszlovákosítás eredményeképpen csehes, illetve szlovákos helyesírással használatos. A cseh és szlovák névszótárak fontos forrásként szolgálnak a szláv eredetű tulajdonnevek magyarázatát illetően is a magyar névkutatók számára.

\section{Felhasznált források}

BelÁKovÁ, MÁRIA 2014. Hydronymia severnej časti povodia Malého Dunaja. Trnavská univerzita, Trnava.

BelákovÁ, MÁria - HLAdKÝ, Juraj - ZÁvodnÝ, Andrej 2018. Hydronymia Malého Dunaja. Trnavská univerzita, Trnava.

DiviČANOvÁ, ANNA et al. 2015. Čabianske priezviská. Výskumný ústav Slovákov v Mad’arsku, Békešská Čaba.

DiviČANOVÁ, ANNA et al. 2017. Komlóšske priezviská. Vydavatel'stvo Ivan Krasko, Nadlak.

DudoK, DANIEL 1998. Priezviská Slovákov v Juhoslávii. Spolok vojvodinských slovakistov, Nový Sad.

GOÓTŠOVÁ, ANDREA - CHOMOVÁ, ALEXANDRA - KRŠKO, JAROMÍR 2014. Hydronymia slovenskej časti povodia Hornádu. Belianum, Banská Bystrica.

HLAdKÝ, JuRAJ 2004. Hydronymia povodia Nitry. Pedagogická fakulta Trnavskej univerzity, Trnava.

HLADKÝ, JuRAJ 2011. Hydronymia povodia Dudváhu. Pedagogická fakulta Trnavskej univerzity, Trnava.

HLAdKÝ, JuRAJ - ZÁvodnÝ, ANDReJ 2015. Hydronymia Žitného ostrova. Pedagogická fakulta Trnavskej univerzity, Trnava.

HosÁK, LAdislaV - ŠRÁMEK, Rudolf 1970-1980. Místní jména na Moravě a ve Slezsku 1-2. Academia, nakladatelství Československé akademie vied, Praha.

KNAPPOVÁ, Miloslava 1978/2017. Jak se bude vaše dítě jmenovat? Academia, Praha.

KNAPPOVÁ, MiloslaVA 1992/2008. Naše a cizi přijmení v současné češtině. AZ KORT, Liberec.

KRŠKO, JAROMÍR 2003. Hydronymia povodia Turca. Univerzita Mateja Bela, Fakulta humanitných vied, Banská Bystrica.

KRŠKO, JAROMÍR 2008. Hydronymia povodia Hrona. Univerzita Mateja Bela, Banská Bystrica.

KRŠKO, JAROMÍR 2011. Hydronymia horného povodia Váhu (od povodia Rajčianky po pramen̆ Váhu). Univerzita Mateja Bela, Banská Bystrica.

KRŠKO, JAROMÍR - VELIČKA, DRAHOMÍR 2011. Hydronymia povodia Kysuce. Univerzita Mateja Bela, Banská Bystrica.

LSTN. = Lexika slovenských terénnych názvov. https://lstn.juls.savba.sk (2020. 04. 24.)

LUTTERER, IVAN - KROPÁČEK, L'UBOŠ - HuŇÁČEK, VÁCLAV 1976. Původ zemépisných jmen. Etymologický slovník 1000 vlastnich jmen zemí, měst a př́rodnich objektů. Mladá fronta, Praha.

LUTTERER, IVAN - MAJTÁN, MILAN - ŠRÁMEK, RUdOLF 1982. Zeměpisná jména Československa. Mladá fronta, Praha.

LUTTERER, IVAN - ŠRÁMEK, RUDOLF 2004. Zeměpisná jména v Čechách, na Moravě a ve Slezsku. Slovník vybraných zemépisných jmen s výkladem jejich původu a historického vývoje. 2. vydání. Tobiáš, Havlíčkův Brod.

MaJTÁN, MiLAN 1972/1998. Názvy obci Slovenskej republiky (Vývin v rokoch 1773-1997). Veda, Bratislava. 
MaJTÁn, Milan 2011. Slovník turzovských priezvisk. In: GaJdIČIAR, IvAN ed., Turzovské priezviská. Spolok priatel'ov Turzovky, Turzovka. 75-211.

Majtán, Milan 2014. Naše priezviská. Veda, vydavatel'stvo Slovenskej akadémie vied, Bratislava.

MaJTÁn, Milan - PovažAJ, MATEJ 1983/1998. Vyberte si meno pre svoje dieta. Art Area, Bratislava.

MAJTÁn, MiLAN - RYMUt, KAZIMIERZ 2006. Hydronymia povodia Oravy. Veda, Bratislava.

MaJTÁN, Milan - ŽIgo, PAVOL 1999. Hydronymia povodia Ipla. Jazykovedný ústav Luudovíta Štúra SAV, Bratislava.

OLIVOVÁ-NEZBEDOVÁ, LIBUŠE - MALENÍNSKÁ, JiTKA 2000. Slovník pomistních jmen v Čechách. Úvodni svazek. Academia, Praha.

PROFOUS, ANTONín 1947-1960. Místní jména v Čechách. Jejich vznik, pưvodní význam a změny 1-5. Nakladatelství ČSAV, Praha.

SiČÁKOVÁ, ĹUBA 1996. Hydronymia slovenskej časti povodia Slanej. Pedagogická fakulta UPJŠ, Prešov.

ŠMilauer, Vladimír 1932. Vodopis starého Slovenska. Učená společnost Šafaříkova, PrahaBratislava.

SPJČ. $=$ Slovnik pomistnich jmen $v$ Čechách. https://spjc.ujc.cas.cz (2020. 04. 24.)

SPJMS. = Slovník pomístních jmen na Moravě a ve Slezsku. https://spjms.ujc.cas.cz (2020. 04. 24.)

STANISLAV, JÁN 1947/2008. Odkryté mená slovenských miest a dedín. Vydavatel'stvo Matice slovenskej, Martin.

STANISLAV, JÁN 1948/1999/2004. Slovenský juh v stredoveku 1-2. Národné literárne centrum, Bratislava.

VAlENTOVÁ, IVETA 2018. Lexika slovenských terénnych názvov (Koncepcia lexikografického spracovania). Slovak Academic Press, Bratislava.

ZÁvOdNÝ, ANDREJ 2012. Hydronymia slovenskej časti povodia Moravy. Pedagogická fakulta Trnavskej univerzity, Trnava.

\section{Hivatkozott irodalom}

ČIŽMÁROVÁ, LIBUŠE 2010a. Tvorba elektronického slovníku pomístnich jmen na Moravě a ve Slezsku. Acta onomastica 51: 79-93.

ČIŽMÁROVÁ, LiBUŠE 2010b. Ke konstrukci heslových slov ve Slovníku pomístních jmen na Moravě a ve Slezsku. Acta onomastica 51: 94-105.

CsnE. = HAJdú MıHÁLY, Családnevek enciklopédiája. Leggyakoribb mai családneveink. A magyar nyelv kézikönyvei 17. Tinta Könyvkiadó, Budapest, 2010.

CsnSz. = KÁzMÉR MIKLós, Régi magyar családnevek szótára XIV-XVII. század. Magyar Nyelvtudományi Társaság, Budapest, 1993.

FNESz. = KISS LAJOS, Földrajzi nevek etimológiai szótára 1-2. 4., bővített és javított kiadás. Akadémiai Kiadó, Budapest, 1988.

KÁLMÁN BÉLA 1967. A nevek világa. Gondolat Kiadó, Budapest.

KNIEZSA IsTVÁn 1965. A magyar és szlovák családnevek rendszere. Sokszorosított gépirat. Budapest.

KRŠKO, JAROMÍR 2005. Spracovanie hydronymie Slovenska (Metodické pokyny na spracúvanie projektov Hydronymie Slovaciae). Univerzita Mateja Bela, Fakulta humanitných vied, Banská Bystrica. 
MaJTÁN, MiLAN 1983. Slovníkovo-areálové spracovanie lexiky slovenských terénnych názvov. Slovenská reč 48: 199-206.

MUnk. 1972 = LADÓ JÁNOS, Magyar utónévkönyv. 2. kiadás. Akadémiai Kiadó, Budapest, 1972. MUnk. 1998 = LADÓ JÁNOS - Bíró ÁGNES, Magyar utónévkönyv. Vince Kiadó, Budapest, 1998.

VALENTOVÁ, IVETA 2009. Ku koncepcii pripravovaného Slovníka slovenských anojkoným. Slovenská reč 74: 283-291.

VALENTOVÁ, IVETA 2014. Výstavba heslových slov slovníka lexiky slovenských terénnych názvov. In: ONDREJOVIČ, SLAVOMíR - SATINSKÁ, LUCIA - VRÁBL’OVÁ, JÚliA szerk., Śtefan Peciar a moderná lexikografia. Zborník k 100. výročiu narodenia Štefana Peciara. Veda, vydavatel'stvo Slovenskej akadémie vied, Bratislava. 280-296.

BAUKO JÁNOS

ORCID: https://orcid.org/0000-0003-1297-6177

Nyitrai Konstantin Filozófus Egyetem

Közép-európai Tanulmányok Kara

\section{JÁNOS BAUKO, Hungarian proper names in Czech and Slovakian name dictionaries}

The study aims to discern whether Czech and Slovakian name dictionaries list Hungarian proper names, and if yes, how these are defined; is Hungarian scholarly literature referenced; can any tendencies or changes over time be found in their definitions. Only name dictionaries and publications that include name dictionaries that contain entries for Hungarian proper names are discussed. First, the Czech and Slovakian given name dictionaries, then family name dictionaries that contain Hungarian proper names are discussed. Finally, dictionaries of toponyms are also reviewed. The majority of Czech and Slovakian name dictionaries or publications that contain such elements define Hungarian proper names acceptably, and (to a minor degree) reference Hungarian academic literature. The adaptation of the orthography of specific Hungarian proper names can be seen in some cases. As a result, Slovakian or Czech name forms are in use. Czech and Slovakian name dictionaries are also an essential source of information regarding names of Slavic origin in the Hungarian language for Hungarian onomasticians. 

FARKAS TAMÁS - SLÍZ MARIANN szerk., Tulajdonnevek és szótárak. ELTE Magyar Nyelvtudományi és Finnugor Intézet - Magyar Nyelvtudományi Társaság, Budapest, 2020. 209-219. DOI: 10.26546/4892373.13

\section{Magyar tulajdonnevek az ukrán névszótárakban}

1. Bevezetés. Az ukrán névtudomány Ukrajna függetlenné válása (1991) óta jelentős fejlődésen ment keresztül. Az eredményes kutatás intézményi háttere már a szovjet időkben létrejött, a szervezett névtani kutatásokat ugyanis az Ukrán Tudományos Akadémia (UTA) Nyelvtudományi Intézetének (НАН України, Інститут української мови) névtani részlege koordinálja 1960 óta. ${ }^{1}$ Az akadémiai kutatómühely főbb projektjei közé tartozott korábban az ukrajnai víznevek összegyüjtése és szótárazása (SHU.), az oklevelekben előforduló tulajdonnevek etimológiai szótárának az elkészítése, valamint Ukrajna ősszláv névrendszerének a feltárása. Az ország méretei és névgazdagsága miatt nagyobb, országos méretü projektek, névgyüjtések lebonyolítására nem került sor. A hosszútávú tervek között szerepel ugyan Ukrajna helységneveinek történeti-etimológiai vizsgálata, eddig azonban sem a gyüjtö-, sem a feldolgozó munkáról nem jelentek meg írások.

Az UTA mellett az elmúlt évtizedekben több, névtudománnyal foglalkozó központ is létrejött, elsősorban az egyes felsőoktatási intézmények nyelvészeti tanszékein a nagyobb egyetemi városokban, például Lvivben, Rivnében, Ternopilban és Ivano-Frankivszkban. A kutatómunka eredményei a névtani jellegű tanulmányok, monográfiák, regionális helynévgyüjtések, névelméleti munkák, szótárak, egy-egy helynévtípus vizsgálatával foglalkozó monográfiák stb. nagy számában mutatkoznak meg. Az 1855-2000 közötti időszak névtani munkáit listázó, SzVJATOSZLAV VERBICS által szerkesztett, Ukrajinszka onomasztika. Bibliohraficsnij pokazscsik [Ukrán névtudomány. Bibliográfiai mutató] című ukrán névtani bibliográfia (VERBICS 2013) 4534 tételt tartalmaz, zömmel a 20. század második feléből. Emellett 2000 után számos, mérföldkőnek számító etimológiai szótár jelent meg, ami az ukrán onomasztika töretlen fejlődését mutatja.

Az ukrán névszótárak magyar eredetű anyagának vizsgálata kapcsán fontos megemlíteni, hogy az ukrán névtudomány (ellentétben például a szlovák és román nyelvészek vizsgálataival, vö. a jelen kötetben BAUKO JÁNOS [2020] által ismertetett szlovák és a BENÖ ATTILA [2020] által bemutatott román helynévszótárakkal) a kárpátaljai névkincscsel csak a terület Szovjetunióhoz való csatolása után kezdett foglalkozni. Szervezett, kiterjedt névgyüjtések ugyanakkor a mai napig nem történtek, a kutatók figyelme rendszerint egy-egy részkérdésre terjed ki. A kárpátaljai magyar névanyag kutatása még kevesebb figyelmet kap ukrán részről, aminek nyelvi és nyelven kívüli okai egyaránt vannak.

2. Helynévszótárak. Az ukrán névtudományban még nem készült a FNESz.-hez hasonló jellegü és terjedelmű helynév-etimológiai szótár. A kárpátaljai helységnevekről az első (és máig az egyetlen), ukrán nyelven született tudományos munka KIRILO HALASZ 1961-ben készült, Toponimija Zakarpatszkoji oblasztyi (nazvi naszelenih punktiv) [Kárpátontúl megye helynevei (településnevek)] című kandidátusi disszertációja. A dolgozat

${ }^{1}$ http://www1.nas.gov.ua/institutes/ium/Structure/Departments/Department6/Pages/ default.aspx (2020.05. 05.) 
kéziratban maradt, így szélesebb olvasóközönséghez nem jutott el, ugyanakkor az ukrán nyelvü szakirodalomban rendszeresen hivatkoznak rá. A 607 kárpátaljai településnév közül csak néhány tucatról mutatja ki a magyar eredetet, az évszázadokon keresztül használt magyar névalakokkal nem foglalkozik, etimológiáinak nagy része helytelen vagy félremagyarázott.

Egyes kárpátaljai helységnevek etimológiájával azonban két kiadványban is találkozhatunk. Az első, úttörő jelentőségű monográfia MIKOLA JANKO 1998-ban megjelent, Toponimicsnij szlovnik Ukrajini [Ukrajna helynévszótára] című szótára. Ez a kiadvány az Ukrán Oktatási Minisztérium tudománynépszerüsítő programja keretében készült, elsődleges célja a nyelv- és történettudomány eredményeinek szélesebb olvasóközönséghez való eljuttatása. A szótár Ukrajna legfontosabb helységeinek, járási központjainak, ún. városi típusú településeinek, ismertebb falvainak, valamint történelmi, kulturális stb. szempontból fontos helyeinek a nevét tárgyalja etimológiai szempontból. Az elsődleges célközönség a diákok, középiskolások, egyetemisták korosztálya, de például tanárok a helytörténeti, nyelvészeti oktatásban segédkönyvként is használhatják. Ez a cél teljes mértékben meghatározza a szótár szerkezetét, illetve tartalmát. A szócikkek rövidek, kevés információt tartalmaznak, a részletes etimológiai vizsgálatra és bizonyításra a szerző nem fordít megfelelö figyelmet. JANKO eltekint a nevek történelmi adatainak a közlésétől, a hivatalos nevekből kiindulva etimologizál, az esetleges korábbi, történelmi névváltozatokkal - ezáltal az eredeti etimológiákkal - ritkán foglalkozik. Ezt kiemelten fontos figyelembe venni a szótár kárpátaljai névkorpusza kapcsán, ugyanis a hivatalos helységnevek rendszerébe 1946-ban jelentős beavatkozás történt. A szótár mintegy 50 kárpátaljai nevet tartalmaz. A helységnevek közül Beregszász, Nagyberezna, Nagybocskó, Tiszaújlak, Nagyszölös, Volóc, Bátyú, Dombó, Ilosva, Gyertyánliget, Királyháza, Ökörmezö, Munkács, Alsóverecke, Perecseny, Rahó, Szolyva, Szerednye, Aknaszlatina, Taracköz, Ungvár, Királymezö, Huszt, Szentmiklós, Körösmezö hivatalos ukrán nevét vizsgálja.

1. ábra: Beregszász nevének névcikke (JANKO 1998)

\begin{abstract}
Бе́регове - м., рц. Закарпатської обл. Розташоване в долині p. Тиса (бас. Дунаю). Виникло в XI ст., входило до складу Київської Русі. 3 кінця XI ст. під владою Угорщини. Назва від слов. берег «ділянка землі біля води, гора» та суф. -ов(е). Звідси ж назва Берегівські горби - підвищення, розташовані на пд. 3х. Закарпатської, низовини, сх. від м. Берегового.
\end{abstract}

A víznevek köre szinte kizárólag a nagyobb folyókat öleli fel (Fehér-Tisza, Borzsova, Latorca, Nagy-ág, Szinevér, Talabor, Tisza, Túr, Ung, Fekete-Tisza), de egy-két kisebb, kevésbé ismert patak neve is bekerült a szótárba (pl. Bogdán, Bronyka, Sipot). A Kárpátaljára leginkább jellemző hegynevek közül csak a Beszkidek, Bliznica, Gorgánok, Priszlop és a Szinyák nevekről, illetve a legfontosabb hágók nevéröl ír (pl. Vereckeihágó, Volóci-hágó, Ruszkij Puty, Uzsoki-hágó, Tatár-hágó). A szótár a szláv eredetű nevek többé-kevésbé megbízható etimológiáját adja, a magyar vagy magyar vonatkozású nevek esetében azonban hajlamos a tények elferdítésére vagy mellözésére, gyakran esik a népetimológia csapdájába.

Beregszász szükszavú szócikkében például olyan, forrásokkal, adatokkal alá nem támasztott információk olvashatók, miszerint a város a 11. században jött létre, s a Kijevi 
Ruszhoz tartozott, de a század végétől Magyarország uralma alá került. A helységnevet a szl. bereg 'víz melletti földdarab, part, hegy' főnév -ов(e) melléknévképzős származékának tartja, így annak jelentése tkp. 'part menti, hegy melletti'.

A Munkács név magyarázatánál a városról szintén azt írja, hogy bár alapításának ideje bizonytalan, egyértelmü, hogy a 9-10. században a Kijevi Rusz része volt. A település konkrét adatainak hiányában állítja a szerző az ősi szláv államhoz való tartozását. Az 1946-tól hivatalos ukrán Мукачів névalakot magyarázza, a történelmi Munkács névformát megemlíti ugyan, de az etimológia szempontjából nem tartja relevánsnak.

2. ábra: Munkács nevének névcikke (JANKO 1998)

Мука́чеве (Мука́чів) - м., рц. Закарпатської обл. Розташоване на обох бер. р. Латориця (бас. Дунаю), на стику відгорів Вулканічних Карпат і Закарпатської низовини. Час заснування невідомий. Гадають, шо воно виникло в IX-X ст. М. входило до складу Київської Русі. В письмових джерелах уперше згадується в 1196. Походження назви не встановлено. Існує кілька легенд $\mathrm{i}$ народних переказів про її утворення. У хронікальних записах і в науковій літературі зустрічаємо варіанти Мункач, Мункачів, що вказує на можливість походження назви міста від угор. мунка «праця, труд» (пор. 3 укр. Трудовач, Трудниия, Трудолюбівка). Проте найбілыш вірогідне припущення походження назви міста від імені Мукач, утворена присв. суф. -ів. У наш час не виправдано змінено ім. форму назви на прикм.

A szerző által vallott sajátos történelemfelfogás a Kárpátalja névről írt szócikkében is tetten érhető: Kárpátontúli Ukrajna vagy Kárpátontúl ugyanis szerinte történelmi régió, amihez hozzátartozott a mai Kárpátontúli megye, s azon földek részének tekinti, ahol a keleti szlávság létrejött.

3. ábra: Kárpátalja nevének névcikke (JANKO 1998)

Закарпа́тська Украй́на, Закарпаття (Підкарпатська Русь) - історична територія, до складу якої входила суч. Закарпатська обл. Частина земель, на яких створювалося східне слов'янство [УРЕ II, 4, 71]. Назва від розташування за Карпатами. Утворена від основи Карпат- преф. за- і суф. -ськ(а).

A szótárra jellemző az a hivatalos ukrán történelemszemlélet, általánosan elfogadott és tanított dogma, mely szerint a mai Kárpátalja területén a honfoglalást megelőzően keleti szlávok éltek, akiknek - az egyébként nemzetiségként el nem ismert - ruszinok az egyenes ági leszármazottai. A magyarok bejövetele előtt egy feltételezett szláv államot vizionálnak, ami a Kijevi Ruszhoz tartozott, így a területnek a Szovjetunióhoz, majd Ukrajnához való csatolását újraegyesülésként (возз'єднання) értelmezik és tanítják. JANKO szótára ennek szellemében íródott, hiteles adatokkal nem dolgozik, ezért tudományos kutatásra kevésbé alkalmas, a bevezetőben kitüzött népszerüsítő és hazafias gondolkodásra nevelő célt azonban minden bizonnyal megvalósítja. Hasonló szemlélet 
más határon túli régiókban is visszaköszön: a szlovák STANISLAV a kárpátaljai helyneveket szintén a szlávból magyarázza (vö. STANISLAV 1948; a felvidéki nevekhez 1. BAUKO 2020), a román DRĂGANU pedig mindenhol román neveket vél felfedezni (vö. DRĂGANU 1933; az erdélyi névanyaghoz 1. még BENÖ 2020).

A laikus közönség számára készülö, névtant, nyelvészetet népszerüsítő munkák mellett idővel felmerült egy pontosabb, tudományos alapokon nyugvó helynévszótár létrehozásának igénye. A két szempontot kívánja ötvözni, valamint a névtan legfrissebb eredményeit a nagyközönség elé tárni VASZILIJ LUCSIK Etimolohicsnij szlovnik toponimiv Ukrajini [Ukrajna helyneveinek etimológiai szótára] című, 2014-ben megjelent etimológiai szótára. ${ }^{2}$ A szerző az UTA Nyelvtudományi Intézetének munkatársa, évtizedek óta foglalkozik helynévkutatással, elsősorban víznevekkel és földrajzi köznevekkel. A szótár közvetlen elözménye a JANKO-féle kiadvány, a két szótár között mind a szócikkek, mind azok tartalma között jelentős átfedés tapasztalható. Ugyanakkor LUCSIK a hibákat figyelembe véve egy részletesebb és pontosabb szótár elkészítését, a hiányosságok pótlását tüzte ki célul. A kötet 2600 szócikkben mintegy 3700 földrajzi név etimológiáját tárgyalja. Vizsgálata a helynevek minden típusára és Ukrajna teljes területére kiterjed. A szótár elsődleges bázisát a makrotoponimák (víznevek, domborzati és településnevek) alkotják, de foglalkozik például természetvédelmi területek, erdők, dülők elnevezéseivel is. A névkorpuszban mintegy másfélszáz kárpátaljai toponima magyarázata található meg, zömmel önálló szócikkben. A teljesség igénye nélkül a következő nevek magyarázatai szerepelnek a kötetben:

- Helységnevek: Ungvár, Munkács, Csap, Beregszász, Huszt, Nagyszölös, Ilosva, Perecseny, Rahó, Szolyva, Técső, Bátyú, Bustyaháza, Nagyberezna, Nagybocskó, Tiszaújlak, Visk, Volóc, Dombó, Zsdenyova, Kölcsény, Gyertyánliget, Királyháza, Ökörmezö, Szerednye, Aknaszlatina, Taracköz, Királymezö, Szentmiklós, Körösmezö.

- Víznevek: Tisza és mellékágai, Apsica, Apsinec-tó, Bajlova, Bruszturjanka, Horodilovai vízesés, Ilosva, Kerepec, Krivulya, Mokrjanka, Pinye, Pomejnica, Repinka, Szalva, Vicsa stb.

- Hegy- és hágónevek: Berlyaszka, Beszkidek, Gorgánok, Bliznica, Bouvan, Borzsahavas, Brebenyeszkul, Hoverla, Gutin-Tomnatek, Kobila, Popagya, Pop Iván, Priszlop, Rebro, Ruszka, Szvidovec, Jabloncai-hágó, Vereckei-hágó, Uzsoki-hágó, Volóci-hágó, Toronyai-hágó stb.

A szócikkek felépítése már a filológiai igényü etimológiai szótárak szokásos eljárását követi. A hivatalos, ukrán nevek mellett sajnos a népnyelvi adatokat, névvariációkat nem közli a kiadvány, de a lokalizálás után a nevek történeti adatait közreadja. Ez a szerző hangsúlyozott újítása, ugyanis a korábbi etimológiai szótár fő hiányossága éppen ennek a mellőzése volt. Sajnos LUCSIK sem tudja teljes mértékben teljesíteni a célkitüzését. Az eltérő történelmi múlttal rendelkező ukrán területek múltjának dokumentumai, oklevelei főként külföldi (lengyel, magyar, osztrák, román, orosz stb.) levéltárakban vagy nyomtatásban megjelent adattárakban találhatók. Megismerésük és feldolgozásuk ukrán részről a mai napig nem történt meg. Ezzel magyarázható, hogy történeti adat helyett csak egy évszámot vagy még azt sem közöl a szerző. A kárpátaljai településnevek adatait rendszerint HALASZ korábban hivatkozott munkájából (1961), közvetett és kevésbé megbízható forrásból meríti.

\footnotetext{
${ }^{2}$ Részletes ismertetését 1. SEBESTYÉN 2016.
} 
4. ábra: Beregszász nevének névcikke (LUCSIK 2014)

Бе́регове - місто, Закарпат. обл. [АТП, 156]; засн. в XI ст. [ГЕУ 1, 83], сакс. $Z a z=$ угор. Szàsz (1141), Bereg (1214), Lampertszàsz, Lamprechtszàsz, Lam. perthàz, Luprechtszasz (XIII ст.), Beregszàsz [Галас, 58], Бépezoвo (1981) [CЭС, 132]. Суч. ойконім виник унаслідок субстантивації та онімізадії відн. прикм. береговйй фрозміщений, розтапований на прибережних ділянках [СУМ 1, 158] у формі сер. роду, яка узгоджуе ойконім з номенкл. іменем село, поселення, місто; пор. назву нп Берегове в Криму і в різних обл. Укряїви [ATI, 581]. В основі твірного прикм. ГТ бе́рег (днв. Бе́pez), який під пд.слов. та герм. впливом на Закарпатті міг виражати також актуальне знячення "гора" й закріпитися в істор. назвах пос. Bereg і Beregszàsz. Найдавніша форма $\mathrm{Zaz}$, якій відповідає угор. Szàsz, постала семант. способом від етноніма $z a z, s z d \dot{s} z$ "саксонець", що відбився в прізв. закарп. україндів [Чучка, 503]. Композитні сакс. та угор. назви з цим компонентом включають фонет. варіанти герм. антроповіма Ламперт [Галас, 58]. Перевесення наголосу на перший склад ойконіма Бе́регове 3 останнього у твірному береговйй «стос. до бе́реz" зумовлене впливом угор. мови; пор. оронім Бе́регівське горбогір'я, що називає масив плосковершинних вулкав. горбів і розчлевованих силових поверховь побл. м. Береговоzo [ГЕУ 1, 82], суміж. с. Nagy Bereg, укр. Вереги [Галас, 58] і ще 13 ойконімів Берегове в різних регіонах України [ATI, 581].

A teljes magyar vonatkozású névanyag bemutatásától természetesen eltekintek, de érdemes összehasonlítani JANKO és LUCSIK etimológiai szótárának egy-két szócikkét. Beregszász-szal nagyobb terjedelemben foglalkozik, közli a település korábbi névalakjait is (Szász, Lampertszász, Beregszász). Elsődlegesen a mai hivatalos helységnevet (Берегове) etimologizálja, ami szerinte az ukrán береговий 'part melletti helyen telepített (falu, város)' melléknév származéka. Úgy véli azonban, hogy a melléknév alapjául szolgáló берег fönév másodlagos 'hegy' jelentése figyelhető meg a helység régi Bereg és Beregszász nevében, mivel a város hegy lábánál települt. A legkorábbi Szász formát - helyesen - a szász népnévből eredezteti, míg a Lampert nevet személynévi eredetünek tekinti. A magyar településnévhez füzött magyarázatai tehát megfelelnek a valóságnak (vö. FNESz. Beregszász, SEBESTYÉN 2010: 25). A helységnév szláv eredeztetése azonban téves. Példaként megemlíti ugyan a megyének is nevet adó Nagybereg helységet, azzal azonban nincs tisztában, hogy a Bereg- előtag Beregszász nevében a megyére utal, s nem a város melletti hegyre.

Hasonló részletességgel tárgyalja a szerző Munkács nevét. A mai Мукачеве helységnévből indul ki, ami szerinte „ukrán környezetben” keletkezett, s a Mukacs személynév birtoklást kifejező -ове/-еве képzős származéka. Kitér a személynév magyarázatára, amelynek szerinte а мукати 'dörmög, dünnyög' ige az alapja. Úgy véli, hogy az -aч képző különböző víznevek hatására kerülhetett a helységnévbe. A magyar Munkács névalak szerinte másodlagos, létrejöttében szerepet játszhatott az ősszláv munka fönévvel való összecsengése, amit már Anonymus is említ (An. 12). (A név tudományos névfejtését 1. FNESz. Munkács, SEBESTYÉN 2010: 99.) 
5. ábra: Munkács nevének névcikke (LUCSIK 2014)

\begin{abstract}
Мука́qеве - місто, Закарпат. обл. [АТП, 16i] ; відоме з IX ст. [ГЕУ 2, 393], за ін. джерелами - згадується 1196 р. і має варіанти Мука́чів, Мункач, Мункачів [Янко, 237]; Munkács [Галас 1957-a, 204], як відоме з XII ст., Мука́чево (1981) [СЭС, 854]. Суч. ойконім виник в укр. середовищі як посесив на -ове / -еве, варіант -ев / -ів, від антропоніма Мукач з основою дієсл. мукати *мугикати», який відомий у пол. мові як $M u k$-acz 31430 p. [Rymut 2, 124]; пор. серб., хорв. апелятив мукац *жаба-джерелянка i похідний від нъото топонім Mukačije [Галас 1957-a, 204 ] із суф. -ije в посес. функціі. Завдяки суф. - $а ц$ у структурі твірного слова ойконім міг функщіонувати без додаткових афіксів подібно до гідроніків Головач, Рөач, Лукач, Тлумач, Лехач [Трубачев, 225], що відбиває угор. Munkács, у якому звукосп. -иn- постало під впливом запозиченого д.слов. тunka *мука" (< псл. *mpka), на що вказуе у зв'язку з назвою Мукачеве ще Анонім; пор. у Потиссі угор. топонім Mukacs без вос. - un- в основі [Галас 1957-а, 204] i закарп. прізв. Му́нка, Мункач, Мункачі, Мункаш, Мункоєи о таким дифтонгом в угор. джерелах [Чучка, 402].
\end{abstract}

A szerző javára kell írnunk ugyanakkor, hogy több esetben javítja JANKO hibás etimológiáit. A Munkács melletti Szentmiklós ukrán nevéről (Чинadiєвe) adott JANKO-féle népetimológiás magyarázat helyett mind a magyar, mind az ukrán név pontos jelentését közli: az előbbi védőszent nevéből, az utóbbi képzős személynévből ered. Helytálló etimológiái mellett számos esetben tévesen elemzi a helységneveket, amit kevésbé róhatunk fel a szerző hibájaként, ugyanis magyarázatainál elsősorban HALASz (1961) kéziratos munkájára támaszkodik. A Bátyú helységnévnél például az 1995-ig érvényben lévő hivatalos ukrán nevet tárgyalja (Вузлове), illetve az újabb, ukránosított Батеве névalakra is kitér. A hagyományos, történelmi Bátyú névröl azonban szót sem ejt, így a helységnek egy szláv eredetü, képzéssel létrejött nevet kreál, szemben a puszta személynévi eredetü magyar névvel (vö. FNESz. Bátyú, SEBESTYÉN 2010: 22). Hasonló az eljárása a szintén magyar, puszta személynévi Técső névnél is (vö. FNESz. Técsö, SEBESTYÉN 2012: 139), aminek a hivatalos Тячів alakját a Тяч személynév birtoklást kifejező -iв képzős formájának tartja, holott az a magyar név ukrán kiejtéshez igazított adaptációja.

Bár LUCSIK szótára a JANKO-féle kötettel összevetve tudományos szempontból pontosabb, a modern névtudományi elveknek kevésbé felelnek meg a szótárak névcikkei. A szerzők nem vagy csak szórványosan közlik a denotátumok adatait, valamint a névfejtések a szláv eredet ideológiáitól sem mentesek, sőt többször megfigyelhető az adatok értelmezésében az anakronizmus.

3. Személynévszótárak. Az általános helynévszótárakkal ellentétben ukrán nyelven számos személynévszótár jelent meg, bár ezek mind módszerükben, mind a vizsgált névkorpusz tekintetében jelentős eltéréseket mutatnak. Kárpátaljai, illetve magyar vonatkozású névanyag általában ritkán szerepel ezekben a kiadványokban. Az ukrán személynévkutatás legfontosabb szótára azonban teljes mértékben a kárpátaljai személynévkincsre támaszkodik. 2005-ben jelent meg PAVLO CSUCSKA Prizviscsa zakarpatszkih ukrajinciv. Isztoriko-etimolohicsnij szlovnik [A kárpátaljai ukránok családnevei. Történeti-etimológiai szótár] címü, a kárpátaljai ukránok családneveit bemutató történeti-etimológiai szótára. ${ }^{3}$ A szerző az 1970-es évek óta foglalkozott a kárpátaljai ukrán családnevekkel, a 702 oldalas szótár évtizedes gyüjtő- és kutatómunkájának az eredménye. A kötetben jelentős a magyar eredetü nevek aránya, ami azzal magyarázható, hogy ukránnak tekinti a közép-

\footnotetext{
${ }^{3}$ Részletes ismertetését 1. SEBESTYÉN 2009.
} 
korban még a nyelvhatáron fekvő, magyar többségű vagy vegyes lakosságú, de mára elukránosodott települések lakosságát, s az ő neveiket is felveszi a szótárba. CSUCSKA tudományos igénnyel megírt szótára kiemelkedő jelentőséggel bír mind az ukrán, mind a magyar névtudomány számára. A magyar eredetű névkorpusz részletes bemutatására itt nem térek ki, csak két névtípus segítségével bemutatom a szerzőnek a szótárban elöforduló, már-már típushibának tekinthető és vitatható eljárását.

A szótárban elemzett, egyértelműen magyar nevek esetében a szerző rendszerint elsődlegesen nem a magyar, hanem az ukrán nyelvből igyekszik magyarázatot találni a néveredetre. Ez a törekvése a legszembetünőbb módon a foglalkozásnévi eredetű családnevek körében figyelhetö meg. A nyelvi érintkezés nyomán a helyi ukrán nyelvjárásokban ugyanis jövevényszóként számos magyar foglalkozásnév él (vö. CSOPEI 1883). CSUCSKA úgy véli, hogy ezekből a foglalkozásnevekből már az ukrán névadók hoztak létre családneveket, holott családnévvé válásuk valószínüleg még a magyar névadásban történt meg. Ezt a példaként hozott korai történelmi adatok is alátámasztják, amik jellemzően a korábban magyar (vagy részben magyar) településekröl származnak. A Lakatos és Kondás családnevekre példaként Ugocsából említ 1565-ös adatokat (Szászfaluból és Fancsikáról; a két faluban még ma is élnek magyarok), holott ekkor a ruszinok körében - állítása szerint - még nem voltak családnevek. Mindkét esetben magyar jövevényszóból magyarázza az etimológiát. A foglalkozásnévi eredetü családnevek körében szinte kivétel nélkül ezt az irányt követi, mesterségesen „szlávosítva” őket, pl. Сабов (Szabó), Бийреш (Béres), Варта (Varga), Кочіи (Kocsis), Сокач (Szakács).

Ugyancsak több esetben vitathatók a helynévi eredetü családnevekhez füzött magyarázatai. A mind a belső, mind a külső migráció által nagy mértékben érintett területen jelentős a helynevekből létrejött nevek aránya a magyar és a helyi ukrán névadásban. A magyar - $i$ képző ukrán -ський, -цький megfelelöjével számos családnév keletkezett, CSUCSKA azonban az ukrán eredetủek közé sorol olyan családneveket is, amelyek egyértelműen magyar névalkotással jöttek létre. A foglalkozásra utaló neveknél alkalmazott szlávosítás, az ukrán etimológia kényszeredett erőltetésének hatása alól itt sem tudja függetleníteni magát. Ennek példáit hosszasan sorolhatnám, illusztrációként csak egykét jellegzetes nevet emelek ki.

6. ábra: A Lipcse (Lipcsej) családnév névcikke (CSUCSKA 2005)

\footnotetext{
Липче́ї [Личчи́ü], -ея́-Xc, Тч, lp, Мж, Уж. 1542, 1550, 1600: вл. Jo. Lypchey - Липча (Bélay 171); 1550: шл. Sim. Lipchei-Руське Поле (Bćlay 211); 1600: кр.Gc. Lipczei-Буштино (Bélay 132); 1600: землевласник Lipcsei Ferena - Голятнн (Bélay 147); 1726: Лunчей Прода" - Сокирниця (Гаджега-М 75). 1. Укр. патр. 3 суф. -ей від антр. Лйпча. 2. Угор. утворення 3 формантом -i від укр. ойк. Липча (по-угор. - Lipcse, а по-рум. - Lipsa). Останне відбнлося й на деякнх офіційннх запнсах п-щ. Пор. рум. п-ща Lipsa, Lipsci (Iordan 280).
}

A szótárban szerepel a Липчей (Lipcsej) családnév, amely a magyar Lipcsei név ukrán kiejtéshez igazított alakja. A helységnévből keletkezett magyar családnevek ukrán 
adaptációiban gyakran találkozunk a szóvégi magyar -ai/-ei hangkapcsolatok -aŭ/-eŭ megfelelőivel. CSUCSKA azonban a Липчей nevet elsődlegesen személynévi eredetűnek tartja: úgy véli, hogy az az ukrán Липчa személynév -eŭ képzős alakja. Illeszkedéssel viszont a Липчаŭ forma lenne a szabályos. Érezvén az etimológia bizonytalanságát és erőltetettségét, másodlagos magyarázatként megemlíti, hogy a név származhat a máramarosi Lipcse helységnévböl is, magyar - $i$ képzővel (legkorábbi adatát is erröl a településről hozza!). A Бедеŭ (Bedei) családnevet Bedőházáról említi, mely település neve évszázadokon keresztül Bedő alakban volt használatos. A név lehetséges etimológiájaként elsőként ősszláv, majd magyar vagy horvát személynevet hoz, végül harmadik eshetőségként a Bedö helységnév - $i$ képzős származékát is megemlíti. Ezt az eljárást követi még а Бачкай (Bacskai), Добай (Dobai), Добрай (Dobrai), Довгай (Dovhai, de minden történelmi adata Dolhai), Долинай (Dolinai), Левай (Lévai), Мортітай (Margitai), Ревай (Révai), Редей (Rédei), Сіксай (Szikszai) stb. neveknél is. A helynévi eredetü családnevek körében elöforduló tévedéseire részben magyarázat lehet a magyar szakirodalom, illetve a forrásmunkák, történeti helységnévtárak, a történelmi helynévanyag hiányos ismerete.

7. ábra: A Sztritei (Sztritej) családnév névcikke (CSUCSKA 2005)

\section{Cтрітеи †. 1523: Zitrithei Pal - Зняцьово (LehBcr 309). $\triangleleft$ Уrop. п-щс з суф. -і від якогось ойк, на зразок Cmpime.}

Jól illusztrálja ezt a kihaltnak feltüntetett Cmpimeŭ (Sztritei) családnév, melynél szlávosítja az egyetlen, Ignéc faluból származó 1523-as Ztrithei adatot, mert a település ma ukrán lakosságú, holott a középkorban még magyar volt. A nevet egy „valamilyen” Sztrite helységnévből a magyarban képzett alaknak tartja, amire nincsenek adatai. A település azonban nem ismeretlen a kárpátaljai magyar kutatók számára, hiszen az a Csucska szülöfalujától, az ungi Baranyától 10 km-re (!) fekvő mai Szürte (vö. SEBESTYÉN-ÚR 2014: 113-4).

8. ábra: Az Újbári (Ujbarij) családnév névcikke (CSUCSKA 2005)

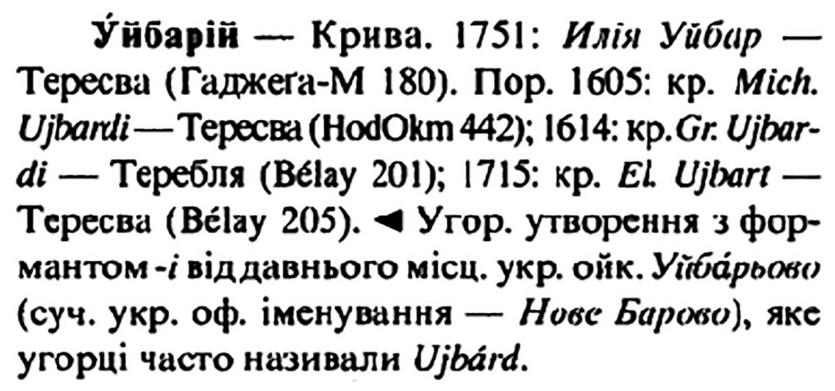

Végezetül még egy jellemző példa a történeti adatok kezelésével és értelmezésével kapcsolatban. Az Уüбаріü (Ujbári) családnévhez hozott történelmi példái: Ujbar, Ujbardi és Ujbart. Más neveknél is gyakran elöfordul, hogy a történelmi formák nem egyeznek meg a vizsgált családnévvel. A nevet ugyan magyar eredetünek tartja, de az szerinte a „régi ukrán Ujbarjovo" helységnév - $i$ képzős alakja, mely helységet a magyarok „gyakran Ujbárd-nak nevezték”. 
CSUCSKA szótára mellett érdemes megemlíteni még egy ukrán nyelvü, de nem Ukrajnában készült kiadványt. 2003-ban jelent meg Eperjesen MiKOLA DUJCSAK Antroponimija Pjasivcsini [Eperjes vidékének személynevei] címü szótára, amely a felvidéki Eperjes környékén élő ukránok családneveit tartalmazza. A gyüjtés 270 szlovákiai, zömmel ukrán nemzetiségü falura terjedt ki, s a településekröl 4278 nevet közöl. Célja a mai családnévanyag összegyüjtése és szótárazása volt. A szerző a személynevek nyelvészeti (etimológiai, szemantikai, alaki) szempontú vizsgálatát tüzi ki elsődleges feladatként, s bár az etimológiai elemzés kiemelt szempontként szerepel a bevezetőben, a nevek eredetének magyarázatára a szerző nem tér ki minden szócikkben.

Az idegen eredetü, magyar, német, román, szlovák családnevek a teljes névállomány mintegy 20\%-át teszik ki. Körülbelül két tucat név esetében jelzi a szerző a közvetlen magyar eredetet: Адзіма (Hagyma?), Андраш (András), Андраші (Andrási), Apвай (Árvai), Барна (Barna), Варга (Varga), Галас (Halász), Гал (Gál), Йуzac (Juhász), Лаката (Lakat), Секела (Székely), Терек (Török), Чікош (Csikós) stb. Ennél nagyobb számban szerepelnek a szótárban ugyanakkor olyan családnevek, amelyek esetében DUJCSAK nem utal a név eredetére, de egyértelmüen magyar származékról van szó: Байус (Bajusz), Бакош (Bakos), Балог (Balog), Бан'ас (Bányász), Барат (Barát), Бочкай (Bocskai), Будай (Budai), Batami (Vágási), Веспремі (Veszprémi), Вірак (Virág), Вісокай (Viszokai), Гетедуш (Hegedüs), Габор (Gábor), Гонос (Gonosz), Добош (Dobos), Ештван (Estvan), Камараш (Kamarás), Корпонай (Kогропаi), Кормош (Kormos), Кочіш (Kocsis), Легін' (Leginy), Мінд’ap (Mingyár), Héмem (Német), H’ертеш (Nyerges), Петровай (Petrovai), Пушкаш (Puskás), Ракоціi (Rákóci), Сабо (Szabó), Фаркаш (Farkas), Чонтош (Csontos) stb.

9. ábra: A Bányász családnév névcikke (DUJCSAK 2003)

'БАН'АС, -А Вд-1/6, Ки-2/9, Мп-5/12. До Бан'аса - Андрій Родак [його отец пристал До Бан'аса] ВП, Бан'аска - Іл’а Бружкына [3 Кожуховец за слоб.] Вк. Banyász, Bañas ПКК Мп. Оф. Ban̆as.

10. ábra: A Kocsis családnév névcikke (DUJCSAK 2003)

КОЧІШ, -А Мц-1/4 [з Гіралтовец], Ок-1/3 [3 Керештвсіัа], Шн-4/13 [гурал'i]. Oф. Kočiš.

Végül, bár nem személynévszótár, de mégsem hagyható ki a felsorolásból CSOPEI LÁSZLÓ ruszin-magyar szótára (CSOPEI 1883). A mü jelentős keresztnévanyagot tartalmaz, ezért egyfajta 19. századi ruszin-magyar névjegyzékként is használható; pl. Абрунъ Ábris, Ábrahám, Акакий Ákos, Алексий Elek, Aндрей András, Andor, Endre, Антоний Antal, Tóni, Apuй Áron, Викторъ Gyözö, Георгий György, Gyuri, Gyurka, Дмитрий Demeter, Döте, Евгений Ödön, Иванъ János, Jancsi, Iván, Илий $\sim$ Illés, Микула Miklós, Петро $\sim$ Péter, Федоръ $\sim$ Tódor stb.; Варвара Borbála, Biri, Гафа Agápia, Ева Éva, Елизавета Erzsébet, Örzsi, Ирина Irén, Irénke, Катерина Katalin, Katica, Kati, Магдалина Magdolna, Одарка Dorottya, Олена Ilona stb. 
CSOPEI nemcsak a személynevek ,hivatalos” formáit közli, hanem szép számmal adatolja a beregi ruszin beceneveket is: Васьо $\sim$ Vaszily kicsinyítve, Грицько $\sim$ Gerö, Gergely, Данко Dániel, Дзуря György, Gyuri, Илько Illés, Леųа Sándor, Луц̧ьо Lukács, Мrъшка Miska, Палий Pál, Pali, Тоний Antal, Tóni, Яиько Jakab stb.; Анияя Anna, Anica, Anikó, Галька Ilka, Ilona, Ilonka, Eржа Erzsi, Örzsi, Örzsébet, Маруня Mariska, Marcsa, Mária, Настя Neszti, Eszti, Oришко Irén stb.

4. Összegzés. Rövid összefoglalásként elmondható, hogy a mai Kárpátalja területén az évszázados ukrán (ruszin) és magyar együttélés nyomán sajátos hely- és személynévkincs jött létre, ami mindkét nemzet névtudósai számára lehetőséget nyújt a kutatásra. A vidék peremterület jellege miatt azonban sajnos általában kiesik a kutatók látóköréből. A röviden bemutatott ukrán hely- és személynévszótárak némelyike a tudományos megközelítés mellett sajnos egyoldalú ideológiai és politikai célokat is szolgál, ami gátolja az objektív következtetések levonását.

\section{Felhasznált források}

CSOPЕI = ЧОПЕЙ, ЛАСЛОВЪ 1883. Русько мадярский словарь. Будапешть.

CSUCSKA 2005. = ЧучКА, ПАВЛО 2005. Прізвища закарпатських украйнців. Історикоетимологічний словник. Видавництво „Світ”, Львів.

DUJCSAK 2003. = ДуйЧАК, МиКОЛА 2003. Антропонімія Пряшівщини. К. п., Пряшів.

HALASZ 1961. = ГАЛАС, КИРИЛО 1961. Топоніміка Закарпатської області (назви населених пунктів). Ужгород. Kézirat.

ЈаNко 1998. = Янко, МиколА 1998. Топонімічний словник України. Словник-довідник. Знання, Київ.

LUCSIK 2014. = ЛучИК, ВАСИль 2014. Етимологічний словник топонімів України. Академія, Київ.

\section{Hivatkozott irodalom}

BAUKO JÁNOS 2020. Magyar tulajdonnevek a cseh és szlovák névszótárakban. In: FARKAS TAMÁS SLíz MARIANN szerk., Tulajdonnevek és szótárak. ELTE Magyar Nyelvtudományi és Finnugor Intézet - Magyar Nyelvtudományi Társaság, Budapest. 199-207. https://doi.org/10.26546/ $\underline{4892373.12}$

BENÖ ATTILA 2020. Magyar tulajdonnevek a román névszótárakban. In: FARKAS TAMÁs - SLíz MARIANN szerk., Tulajdonnevek és szótárak. ELTE Magyar Nyelvtudományi és Finnugor Intézet - Magyar Nyelvtudományi Társaság, Budapest. 187-197. https://doi.org/10.26546/ $\underline{4892373.11}$

Drăganu, Nicolae 1933. Romanii in Veacurile IX-IV. Pe baza toponimiei şi a onomasticei. Academia Română, Bucureşti.

FNESz. = KISS LAJOS, Földrajzi nevek etimológiai szótára 1-2. 4., bővített és javított kiadás. Akadémiai Kiadó, Budapest, 1988.

SEBestyén Zsolt 2009. Pavlo Csucska: Прізвища закарпатських українців. Історикоетимологічний словник. [Recenzió.] Névtani Értesitő 31: 267-271.

SEBESTYÉn ZsOLT 2010. Bereg megye helységneveinek etimológiai szótára. Bessenyei Könyvkiadó, Nyíregyháza. 
SEBESTYÉN ZSOLT 2012. Máramaros megye helységneveinek etimológiai szótára. Bessenyei Könyvkiadó, Nyíregyháza.

SEBESTYÉN ZSOLT 2016. В. В. Лучик: Етимологічний словник топонімів України. [Recenzió.] Névtani Értesitö 38: 255-257.

SEBESTYÉN ZSOLT - ÚR LAJOS 2014. Ung megye helységneveinek etimológiai szótára. K. n., Ungvár. SHU. = Словник гідронимів України . Szerk. НЕПОКУПНИЙ, АНАТОЛИЙ ПАВЛОВИч - СТРИЖАК, ОЛЕКСІй СИЛЬВЕСТРОВИЧ - ЦІЛУЙКО, КИРИЛО КУзЬМОвИч. Наукова Думка, Київ, 1978. StANISLAV, JÁN 1948. Slovenskýjuh v stredoveku 1-2. Matica slovenská, Turčiansky Sv. Martin. VERBICS 2013. = ВЕРБИЧ, СВятОсЛАВ 2013. Українська ономастика. Бібліографічний покажчик. Національна академія наук України Інститут української мови, Київ.

SEBESTYÉN ZSOLT

ORCID: https://orcid.org/0000-0002-1817-424X

Nyíregyházi Egyetem

Nyelv- és Irodalomtudományi Intézet

\section{ZSOLt SEBESTYÉN, Hungarian proper names in Ukrainian name dictionaries}

Ukrainian onomastics has undergone significant development in recent decades. The number of dictionaries and monographs published reflects the productive nature of this research. However, academic interest only turned towards the Transcarpathian name stock in the second half of the $20^{\text {th }}$ century or after the turn of the millennium. Organized, extensive name collections have not taken place in the county to the present day; attention is generally limited to selected sub-issues. The study presents Ukrainian etymological dictionaries of names that contain Hungarian-related data. The historical and ethnic characteristics of the region must be taken into consideration when studying the Transcarpathian name stock. Unfortunately, the Hungarian name stock receives little attention, which is partly due to linguistic reasons but primarily a political decision. The authors of geographical name dictionaries often omit historical Hungarian toponyms from their works, only discussing the Ukrainian names that have been used officially since 1946 . Personal name dictionaries contain an increased number of Hungarian data, but the general tendency to emphasize the Slavic traditions of the region over the linguistic facts of a Hungarian past are apparent in these as well. 



\section{Tulajdonnevekkel összefüggő köznevek a szótárakban}



FARKAS TAMÁS - SLÍZ MARIANN szerk., Tulajdonnevek és szótárak. ELTE Magyar Nyelvtudományi és Finnugor Intézet - Magyar Nyelvtudományi Társaság, Budapest, 2020. 223-230. DOI: 10.26546/4892373.14

\title{
A Magyar földrajzi köznevek táráról
}

\begin{abstract}
1. A Magyar földrajzi köznevek tárának tudománytörténeti háttere és jelentősége. A földrajzi köznevek mint helyet jelölő kifejezések bármely nyelv szókincsének, így a magyarnak is a központi elemkészletébe tartoznak, a helyek fajtájának megjelölésére ugyanis kizárólag ezek az elemek alkalmasak. Érthető tehát, hogy a földrajzi köznevekkel kapcsolatos vizsgálatok a helynevek kutatásában mindenkor fontos szerepet töltöttek be. Ezért természetes az a jelenség is, hogy amikor a helynevekkel összefüggő feladatok a nyelvtudományban elötérbe kerültek, mindig erős figyelem fordult a földrajzi köznevek felé is (HOFFMANN 2000: 64). A szócsoport kutatásának fellendülését ily módon elsősorban a rendszeres helynévgyüjtés megindulásához, vagyis az élőnyelvi helynévi adatok felhalmozódásához köthetjük a magyar és a nemzetközi tudományosságban egyaránt (NEMES 2005: 4). A földrajzi köznevek kérdése mindamellett önmagában, azaz a helynevektől függetlenül is gyakran kerül a nyelvészeti vizsgálatok középpontjába (1. ehhez BÁBA 2016: 11-19).

A földrajzi köznevek tudományos igényü feldolgozásának alapvető feltétele az adott szócsoport adatainak lehető legteljesebb egybeállítása. Ennek köszönhető az, hogy nemcsak a hazai, hanem a nemzetközi névtudományban is fontos célnak tekintik a szakemberek a földrajzi köznevek állományának összegyüjtését és sokféle igényt kielégítő, jól kezelhető formában történő közreadását. Ezen a téren a szláv névkutatók járnak az élen: KISS LAJOS már a IV. Magyar Névtudományi Kongresszuson arról számolhatott be, hogy több szláv nyelv földrajziköznév-szótára is elkészült (KISS 1989). A Finn Névtani Archívum, amely két és fél millió, élőnyelvi gyüjtésből származó helynévadatot tartalmaz, ugyancsak lehetővé teszi a finn földrajzi köznevek együttes elemzését (MIIKKULAINEN 1996: 249). Korán jelentkezik az angol nyelvre vonatkozó földrajziköznév-gyüjtemény is, amelyet SWAYNE nevéhez köthetünk (1956). A magyar nyelvészeti kutatásokban évtizedekkel ezelött ugyancsak megfogalmazódott egy minél teljesebb földrajziköznévszótár összeállításának és közreadásának a gondolata.

A Magyar földrajzi köznevek tára (FKnT.) tehát hiánypótló munkának tekinthető, amely a helynévkutatást segítő gyakorlati hasznossága mellett további kutatási lehetőségeket is kínál. Anyagának felhasználásával mindenekelőtt pontosíthatóvá válik a helynevek helynévfajtákba rendezése, ami a helynévrendszerek nyelvészeti elemzésének alapvető feltétele. Ezt a nyelvi szempontú osztályozást ugyanis akkor végezhetjük el megnyugtatóan, ha ismerjük az ide tartozó elemek jelentéstartalmát, alá-, fölé- és mellérendeltségi

* A tanulmány az Emberi Erőforrások Minisztériuma ÚNKP-17-4 Új Nemzeti Kiválóság Programja és a Debreceni Egyetem támogatásával, az MTA-DE Magyar Nyelv- és Névtörténeti Kutatócsoport programja, valamint az MTA Prémium Posztdoktori Kutatóprogram keretében készült. Az írás alapvetően - célkitüzéséből adódóan - a Magyar földrajzi köznevek tára címü kötet (FKnT.) és a Földrajzi köznevek térben és időben címủ monográfia (Bába 2016) megfelelö egységeire, fejezeteire támaszkodik.
\end{abstract}


viszonyait. A névkutatás szempontjain túl a szótárnak szélesebb felhasználási lehetőségei is bőséggel vannak: a földrajzi köznevek nyelvtörténeti, etimológiai, nyelvföldrajzi célú vizsgálataiban e munkára egyaránt támaszkodhat a tudományos kutatás.

2. A szótár forrásai. A Magyar földrajzi köznevek tárát élönyelvi (táj)szótárként határozhatjuk meg, ezért összeállításakor elsősorban az Új magyar tájszótárt (ÚMTsz.) tekintettük vonatkozási pontnak. Ez a szótár a szélesebb értelemben vett 20. századi magyar nyelvet reprezentálja 1890-1960 közé eső források tájszóanyagának közreadásával. A Magyar földrajzi köznevek tárának bázisanyaga a célba vett szókincsréteg tekintetében azonban gazdagabb ennél, az elmúlt évtizedekben ugyanis regionális tájszótárak és földrajzinév-tárak egész sora látott napvilágot, amelyek így jelentősen kiegészítették az ÚMTsz. anyagát.

A földrajzi köznevek tára e fontos szómező minél teljesebb körü bemutatásával járulhat hozzá a vizsgálatok kiteljesítéséhez. Az ÚMTsz. ugyanis az 1960 előtti időszak nyomtatott, kéziratos, nyelvjárási és néprajzi természetü forrásaiban szétszórtan heverö tájszóanyagot ad közre, a földrajzi köznevek nagy tömegeit felszínre hozó földrajzinévtárak viszont éppen ezt követően láttak egyre bővülő számban napvilágot. Ez a körülmény azzal a fellendüléssel áll kapcsolatban, amely a magyar helynévkutatásban az 1960-as évek közepétől a helynévgyüjtés és a -közzététel terén tapasztalható volt, s amely - noha lendülete egyre inkább apad - máig sem szünt meg teljesen.

A megyénként, illetve járásonként, ritkábban kisebb tájegységenként, településenként közreadott helynévtárak a Somogy megye földrajzi nevei címü munkával (SMFN.) kezdődően rendszerint a területre jellemző földrajzi közneveket is közzéteszik. E szójegyzékeknek - mint maguknak a helynévgyüjteményeknek is - a színvonala azonban igen egyenetlen. Lexikográfiailag pontos, jól szerkesztett, megbízható kis szótárakat éppúgy találunk közöttük, mint olyan listákat, amelyekben érezhető a gyüjtő, a közzétevő bizonytalansága. Ebből adódóan pedig a bennük található adatok forrásértéke sem egyforma. A helynévtárak földrajziköznév-jegyzékeinek eltérő értéke többek között abból adódik, hogy a névgyüjteményeknek a földrajzi köznevek gyüjtésére vonatkozó alapelvei és módszerei sem voltak egységesek.

A Somogy megye földrajzi nevei címü kötet például nem a nevekből kiemelt földrajzi közneveket, hanem külön kérdőíves kikérdezéssel készült szólistát közöl (SMFN. 35-36). A munkát elvégző MARKÓ IMRE LEHEL ugyanis joggal vélte úgy, hogy a nyelvközösség földrajziköznév-anyaga nem feltétlenül fedi a tulajdonnevekben megjelenő földrajzi köznevek állományát. A tulajdonnevek között vannak például mesterségesen alkotott nevek is, amelyek nem az illető nyelvközösségtől származnak, így például a kataszteri térképet készítő mérnök kiegészítő névelemként olyan földrajzi köznevet is használhatott, amelyet az adott nyelvközösség akár nem is ismert. A Somogy megyei kötetben a földrajziköznévlista összeállítóinak törekvése ezért az volt, hogy a nyelvközösség közvetlen nyelvhasználatán alapuló köznevek kerüljenek a listába, ebböl adódóan pedig a földrajzi nevekben megjelenő, de közszói jelentésükben már kihalt elemeket (pl. mál) nem szerepeltették a jegyzékben. Az egyes címszavak értelmezései kapcsán arról is tudomást szerezhetünk a somogyi kötetből, hogy azok mindig a népi értelmezésen alapulnak, tehát semmiféle filológiai segédletet nem vettek hozzá igénybe a szerzők (SMFN. 35-36).

A Somogy megyei kötet elveit követve jelent meg a Tolna megye földrajzi nevei és a Baranya megye földrajzi nevei címü kötetekben is a földrajzi köznevek értelmező szótára (TMFN. 37-47, BMFN. 2: 951-958). Ettől némiképp eltért azonban a Veszprém megye 
földrajzi nevei címü kiadványsorozat munkamódszere. Itt ugyanis a földrajzi nevekben szereplő földrajzi köznevekből előzetesen összeállított listát kérdezték ki bizonyos kutatópontokon (VeMFN. 1: 15, VeMFN. 2: 15, VeMFN. 3: 16, VeMFN. 4: 20). További problémát jelent, hogy egyes földrajzinév-tárakban a földrajzi köznevek jelentésmeghatározása nem feltétlenül a helyi nyelvhasználat, hanem korábbi, máshol közölt definíciók alapján történt (vö. HOFFMANN 2003: 57).

A Magyar földrajzi köznevek tárának legfontosabb feladata az ÚMTsz.-éhez hasonlóan az, hogy a kutatót e szócsoport vizsgálatakor a számos forrás átnézése alól mentesítse, $\mathrm{s}$ a szókincs benne megjelenített elemeit úgy tárja elé, mintha ezt a munkát maga ténylegesen elvégezte volna. Mindez azonban reményeink szerint korántsem jelenti azt, hogy a forrásokhoz való hüség a tárat a mutató szintjére süllyeszti. A Magyar földrajzi köznevek tára csak olyan információt használhat fel, amelyet a forrás közöl, de - ahogyan ez jellemzi az ÚMTsz. gyakorlatát is - a források adta lehetőségeken belül általánosításokat, összevonásokat vagy éppen jelentésekre tagolásokat is megvalósít.

3. A földrajzi köznevek körének meghatározása. Az ÚMTsz. adatfeltárását követő időből több mint hetven további forrást (többségükben szójegyzékeket, kisebb számban tájszótárakból, tanulmányokból kiemelt anyagot) dolgoztunk fel, de beépítettük azoknak az 1960 előtt megjelent kiadványoknak (például a SzamSz.-nak, a SzegSz.-nek stb.) a földrajzi közneveit is, amelyekre az ÚMTsz. az egyes szócikkek végén utalt ugyan, de a konkrét anyagközlés különböző okok miatt elmaradt. Az így egybeállt földrajziköznév-tár csaknem 3500 szócikke több mint 18000 földrajzi köznévi adatot tartalmaz.

A felhasznált forrásokból azonban nem minden adatot vettünk figyelembe: a földrajzi köznevek kapcsán ugyanis komoly elhatárolási nehézségekbe ütközünk. A Magyar földrajzi köznevek tára összeállításakor azt a praktikus alapelvet igyekeztünk szem előtt tartani, hogy földrajzi köznévnek tekinthetünk minden olyan, helyet jelölö lexémát, amely a jelenkori helynevekben fajtajelölö szerepet tölt be, de egyúttal a helynevektöl függetlenül, közszói minőségében is funkcionál.

Az adattárba kizárólag fönévi szófajú elemeket emeltünk be. Nem vettük tehát figyelembe az általunk forrásként felhasznált gyüjtemények adatai között gyakran szereplő „földrajzi jelzőket” (alsó, közép, öreg stb.) és a szótárakban címszóként nemigen használatos szintagmákat (nagy állás, nagy árok stb.). Eljárásunk kapcsán ugyanakkor azt is hangsúlyoznunk kell, hogy elméleti szempontból a földrajzi köznevek fogalmának meghatározásakor nem húzhatunk meg e szócsoportot a nyelv más elemeitől elválasztó merev határokat, hiszen ez általában sem jellemző a nyelv egyes kategóriáira. Ez pedig azt jelenti, hogy a földrajzi köznév ugyan per definitionem fónévi jellegü lexikális elem, de átmenetet mutat más szófajok, illetve a szintagmák irányába (l. ehhez BÁBA 2012).

A földrajzi köznevek körének meghatározása során például az összetételek és a szintagmatikus kapcsolatok elhatárolása nem egy esetben komoly problémát jelent. A megyei és járási kötetek földrajziköznév-jegyzékébe, illetve tájszótárakba igen gyakran kerültek be olyan szintagmatikus formák, amelyek feltehetően gyakoriságuk folytán tünhetnek közszói jellegünek a névgyüjtők számára (vö. HEGEDÜs 2008: 130). NEMES MAGDOLNA doktori értekezésének mellékleteként közölt földrajziköznév-szótárában, amelynek fö forrásai éppen az elmúlt fél évszázadban készült helynévgyüjtemények voltak, csak a nagy jelző 44 különböző alaptaggal fordul elö (nagy árok, nagy lénia, nagy utca, nagy ág, nagy állás, nagy ér, nagy gát, nagy gyep stb.). Ezek gyakoriságát igazolja az a közvetlen tapasztalatunk is, hogy a Magyar Digitális Helynévtár több mint 250000 rekordnyi átvizsgált 
helynévanyagában a nagy híd szintagmatikus szerkezet például 70, a nagy árok 69, a nagy hegy 44 objektum neveként vagy névrészeként fordul elö. A Magyar földrajzi köznevek tárában az ilyen szerkezetü elemek földrajzi köznévi minősítésében fontos szempontként vettük figyelembe azt, hogy az elö- és utótag együttes jelentése egybeesik-e a szintagmatikus szerkezet jelentésével (pl. nagydomb 'nagyobb, magasabb kiemelkedés'), vagy az összetétel és a szerkezet jelentése eltér (pl. nagylegelö 'a falu közös legelöje'). Csak ez utóbbi esetben tekintettük földrajzi köznévnek az adott alakulatot (1. FKnT. 10).

Komolyabb nehézséget jelentenek az olyan, összetételgyanús csoportok, mint például az állatnévi előtagú struktúrák (pl. gulyaállás, gulyajárás), amelyek megítélése még a kiegészítő gyüjtések után is bizonytalan marad (HOFFMANN 2000: 69). A földrajzi nevek helyesírása címü kiadvány (FÁBIÁN-FÖLDI-HÖNYI 1998) ugyan részletes listát közöl a földrajzi köznévként kezelhető szavakról, s ebben a listában az összetett földrajzi köznevek számbavétele is megtörténik, ezek mindegyikének földrajzi köznévként való funkcionálása erősen kétséges (például sárkánygödör, sárkányjárás, ördöglyuk). Másfelöl nyilvánvaló, hogy a listába vett kifejezések analógiája alapján további, eddig nem adatolt összetételek megléte tételezhető fel, kérdéses azonban, hogy a lista kiterjesztése milyen határokon belül müködhet észszerüen. Póczos RITA hívja fel a figyelmet arra, hogy a Dinnyeföld, Csordakút típusú neveket a tipológiai munkák nem egységesen ítélik meg: néhol egyrészes névnek tekintik (mivel összetett földrajzi köznévböl alakult), néhol viszont kétrészes nevekként írják le öket (az utóbbi esetben csak a föld és a kút tartható bennük földrajzi köznévi elemnek). Ha a névadatokat a nyelvi környezetüket is figyelembe véve vizsgáljuk, az gyakran a kétrészesség mellett szól: ezeknek a helyneveknek ugyanis több esetben olyan szinonimáik vannak, amelyekkel utótagjukban megegyeznek, előtagjuk viszont a denotátum egy másik sajátosságát fejezi ki; pl. m. Vásár/tér $\sim$ Kocsmai/tér, Kender/föld Pajta/föld, n. Hanf/Acker Scheune/Acker (Póczos 2010: 59).

Az $-s$ képzős szavak esetében a nyelvhasználat és a nyelvszokás hiányos ismerete miatt szintén problémát jelenthet a földrajzi köznévi jelleg megítélése. Az $-s$ képzős helynevek ugyanis nemcsak földrajzi köznévböl keletkezhettek, hanem a fötag ellipszisével, illetve közvetlenül helynévképzéssel is (HoFFMANN 2000: 69). Az -s képzős köznevek és tulajdonnevek így sok esetben alakilag egybeesnek, és szétválasztásuk azért is különösen nehéz, mert a különböző jelentések etimológiailag is összefüggnek (BÉNYEI 2012: 94). BÉNYEI ÁGNES szerint az - $s$ képzős földrajzi köznevek esetében a gyűjtőnévképzői funkció szerkezeti változás eredményeképpen jött létre: a Nádas-tó-féle szerkezetből a jelző önállósul, és magára veszi az elmaradt fötag jelentését. A később létrejövő $-s$ képzős szavak azonban már nem tapadás útján, hanem a meglévők mintájára, eleve képzővel alakulnak (B. LŐRINCZY 1962: 91, KÁROLY 1970: 303, HOFFMANN 1993: 76, BÉNYEI 2012: 98). A legtöbb ilyen lexikai egység növénynévböl keletkezett (pl. bükkös, füzes, nádas, nyíres), de előfordulhat közöttük állatnévböl alakult is (pl. méhes) (vö. NEMES 2005, BÉNYEI 2012: 98). Ezeknek a lexémáknak a nyelvi státusával kapcsolatos kérdések helyesírási problémaként is jelentkeznek, hiszen az Alsó-nyíres/Alsó-Nyíres, Nagy-bükkös/Nagy-Bükkös nevek utótagjának írásmódját az határozza meg, hogy köznévnek vagy tulajdonnévnek tekintjük-e őket. Hozzá kell tennünk azonban, hogy a névadó és a névhasználó tudatában a földrajzi köznévböl, az ellipszissel, illetve a helynévképzéssel való alakulás nemigen válik el egymástól, így a névrész tulajdonnévi vagy közszói státusa sem lényeges számukra.

A földrajzi köznevek jelentéseinek, fogalmi tartományainak közös jellemzője, hogy helyet jelölnek. Az ebbe a fogalomkörbe való tartozás meghatározása azonban már önmagában sem egyértelmü, mert a helyfogalom igen sok szó jelentésének fontos összetevője. 
Ebben a vonatkozásban kínálhat gyakorlati szempontból hasznos fogódzót az a megközelítés, amely szerint földrajzi köznévnek csak azokat a helyjelölő szavakat tekinthetjük, amelyek - mivel a földrajzi köznevek a helynevek alkotásában lényeges szerepet játszanak a helyek fajtájának megjelölésére - helynévvel is megjelölhető helyfajtákat jelentenek. Kissé leegyszerüsítve pedig mindez azt jelenti, hogy az olyan, helyet jelölö közszavak, amelyek nem szerepelnek helynevekben, nem minősülnek földrajzi köznévnek (ágyás, gyalogjárda, veteményeskert stb.). A szótár anyagának egybeszerkesztésekor nem vettük figyelembe azokat az átvizsgált forrásokban előforduló szavakat sem, amelyek helynevekben viszonylag gyakoriak ugyan, de közszói absztrakciójú 'hely' jelentésük nincs (halesz, kütyü stb.) (HOFFMANN 2000: 71).

A jelentésen alapuló besorolást nehezíti az a körülmény is, hogy a szavak (így a helyet jelölök is) csak ritkán egyjelentésüek. A 'hely' jelentése egyes szavaknak (például az építményt, az intézményt vagy akár a növényt jelölöknek) másodlagosan is kialakulhat, így ezek a lexémák földrajzi köznévi jellegüvé válhatnak. Az épületeket jelölö neveket illetően az egyes helynévtárak sem képviselnek egységes gyakorlatot. A Mátészalkai (MJFN.) és a Nyírbátori járás (NyJFN.), valamint a Baranya megye földrajzi neveit tartalmazó kötetek (BMFN.) ezeknek az elemeknek csak egy részét (pl. a kocsma, csárda szavakat) vették fel a kötetben közreadott földrajziköznév-szótárba, ezzel szemben a Pápai és az Ajkai járás kötetei az autóbuszállomás, mentöállomás, iskola szavakat is tartalmazzák (VeMFN. 2-3; vö. NEMES 1999: 339). ${ }^{1}$ Az olyan lexémáknak, mint például az állomás, kocsma, kultúrház, kétségkívül van 'hely' jelentésük is. Ugyanakkor szemantikai tartalmuk központi magva HoFFMANN ISTVÁN szerint elsősorban más típusú szavakkal (mégpedig az építménynevekkel) füzi öket egy jelentésmezőbe, s az ezeket jelölő tulajdonnevek szintén csak másodlagosan tekinthetők helynévnek (2000: 68). Ezen megfontolások alapján nem tekintettük a földrajzi köznevek körébe tartozónak az olyan, épületet, illetve intézményt jelölö szavakat, mint az iskola, templom, imaház, ispotály, minthogy ezek csak másodlagosan jelölnek helyet. A belölük alkotott tulajdonnevek is elsődlegesen intézménynévnek tekinthetők.

Szintén gondot okozhatnak a földrajzi köznévi jelleg megítélését illetően az olyan épületeket, építményeket jelölő kifejezések, mint a kunyhó, esztena, istálló, akol, hodály stb. Ezek kapcsán ahhoz az alapelvhez tartottuk magunkat, hogy amennyiben az adott építmények egy-egy belterületi telek részét képezik, az azokat jelölö lexémákat nem tekintettük földrajzi köznévnek. Ha ellenben az akol, hodály stb. szavak a települések külterületén levő építményeket jelölik meg, felvettük őket a földrajzi köznevek tárába. Ezt a döntést föképpen az magyarázza, hogy a települések külterületén található építményeket jelölö lexémák igen gyakran részt vesznek a helynevek lexikális felépítésében, elsösorban mint fajtajelölö elemek.

A helynévi kategória egzakt meghatározásának hiánya olyan esetekben is gondot jelenthet, amikor az adott helymegjelölést szemantikai tartalma alapján ugyan a tulajdonnevek közé tartozónak ítélhetjük, azzal kapcsolatban azonban, hogy a kifejezés köznévi vagy tulajdonnévi jellegü-e, sokszor még maguk a névhasználók sem tudnak egyértelmüen állást foglalni; ilyenek például az Egyház földje egyház földje, Dobi Sándor tanyája (HBmHn. 1: 46, 47) stb. kifejezések. Ez a bizonytalanság pedig a helymegjelölésben szereplö földrajzi köznevek státusát is befolyásolja.

${ }^{1}$ Az egyes helyfajták eltérő mértékü képviseltségéről a földrajzinév-tárakban, illetve az ezzel kapcsolatos nehézségekről 1. HOFFMANN 2003: 45. 
A Magyar földrajzi köznevek tára azokat a (táj)szavakat tartalmazza, amelyeket a 20. század folyamán, illetve a mai magyar nyelvhasználatban a beszélők a különböző helyfajták megjelölésére használtak vagy használnak fel. Mivel azonban egy-egy terület élő helynévkincse hosszú történeti fejlődés során alakult olyanná, amilyennek ma ismerjük, természetes jelenség, hogy bármely helynévrendszer nagy számban tartalmaz olyan földrajzi köznévi lexémákat is, amelyek napjainkban már nem élnek közszóként az adott vidéken. Ennek megfelelően az egyes források által kihaló és régi minősítéssel ellátott földrajzi közneveket felvettük a földrajziköznév-tárba, a kihalt jelöléssel ellátottakat viszont mellőztük.

4. Kitekintés. A földrajziköznév-tár létrehozásának elméleti előzményét NEMES MAGDOLNÁnak az adott szókincsréteg jelenkori állományát feldolgozó doktori disszertációja (2005), valamint a történeti földrajziköznév-állomány rendszerszerü áttekintését célul kitűző PhD-értekezésem képezte (BÁBA 2013). A Magyar földrajzi köznevek tára címü kézikönyv közvetlen elözménye pedig az a szótár volt, amelyet doktori értekezéséhez NEMES MAGDOLNA állított egybe. E szótári állomány további források anyagával való kibővítését és megszerkesztését én végeztem el. Minthogy pedig a földrajzi köznevek állománya az egyik legkorábbról és leggazdagabban adatolható szócsoport, a feldolgozás következő fázisát egy olyan analitikus munka jelentheti, amely az egyes szavakra irányítja rá a figyelmet. Ennek a leginkább célszerü formája egy történeti-etimológiai földrajziköznév-szótár lehetne.

\section{Felhasznált források}

BMFN. = Baranya megye földrajzi nevei 1-2. Szerk. Pesti JÁnOs. Baranya Megyei Levéltár, Pécs, 1982.

FKnT. = BÁBA BARBARA - NEMES MAGDOLNA, Magyar földrajzi köznevek tára. A Magyar Névarchívum Kiadványai 32. Debreceni Egyetemi Kiadó, Debrecen, 2014.

HBmHn. = Hajdú-Bihar megye helynevei 1. A Hajdúböszörményi és a Hajdúhadházi járás helynevei. Szerk. BÁBA BARBARA. A Magyar Névarchívum Kiadványai 35. Debreceni Egyetemi Kiadó, Debrecen, 2015.

MJFN. = KÁLNÁSI ÁRPÁD, A mátészalkai járás földrajzi nevei. KLTE Magyar Nyelvészeti Tanszék, Debrecen, 1989.

NyJFN. = JAKAB LÁSZLÓ - KÁLNÁSI ÁRPÁD, A nyírbátori járás földrajzi nevei. Nyírbátor Városi Tanácsa, Nyírbátor, 1987.

SMFN. = Somogy megye földrajzi nevei. Szerk. PAPP LÁsZLÓ - VÉGH JÓZSEF. Akadémiai Kiadó, Budapest, 1974.

SzamSz. = CsÜRY BÁLINT, Szamosháti szótár 1-2. Magyar Nyelvtudományi Társaság, Budapest, 1935-1936.

SzegSz. = BÁLINT SÁNDOR, Szegedi szótár 1-2. Akadémiai Kiadó, Budapest, 1957.

TMFN. = Tolna megye földrajzi nevei. Szerk. ÖRDÖG FERENC - VÉGH JÓZSEF. Akadémiai Kiadó, Budapest, 1981.

ÚMTsz. = Új magyar tájszótár 1-5. Főszerk. B. LŐRINCZY ÉVA. Akadémiai Kiadó, Budapest, 1979-2010.

VeMFN. = Veszprém megye földrajzi nevei 1 -4. Szerk. BALOGH LAJOS - ÖRDÖG FERENC [-VARGA MÁRIA]. A Magyar Nyelvtudományi Társaság Kiadványai 156, 171, 192, 194. Budapest, Magyar Nyelvtudományi Társaság, 1982-2000. 


\section{Hivatkozott irodalom}

BÁBA BARBARA 2012. A földrajzi köznév fogalma. Helynévtörténeti Tanulmányok 8: 121-131.

BÁBA BARBARA 2013. Vizsgálatok a földrajzi köznevek története köréböl. Doktori (PhD) értekezés. Debreceni Egyetem, Debrecen. Kézirat.

BÁBA BARBARA 2016. Földrajzi köznevek térben és időben. A Magyar Névarchívum Kiadványai 39. Debreceni Egyetemi Kiadó, Debrecen.

BÉNYEI ÁGNES 2012. Helynévképzés a magyarban. A Magyar Névarchívum Kiadványai 26. Debreceni Egyetemi Kiadó, Debrecen.

FÁBIÁN PÁL - FÖLDI ERVIN - HŐNYI EDE 1998. A földrajzi nevek helyesírása. Akadémiai Kiadó, Budapest.

HEGEDŰS ATTILA 2008. Jel és jelentés a földrajzi köznevekben. In: GECSÖ TAMÁs - SÁRDi CSILLA szerk., Jel és jelentés. Segédkönyvek a nyelvészet tanulmányozásához 83. Tinta Könyvkiadó, Budapest. 129-133.

HoffMANN IsTVÁn 1993. Helynevek nyelvi elemzése. A Debreceni Kossuth Lajos Tudományegyetem Magyar Nyelvtudományi Intézetének Kiadványai 61. Debreceni Kossuth Lajos Tudományegyetem Magyar Nyelvtudományi Intézet, Debrecen.

HOFFMANN ISTVÁN 2000. Földrajzi közneveink szótáráról. In: SZABÓ GÉZA - MoLNÁR ZOLTÁN szerk., Nép - nyelv - társadalom. Végh József emlékezetére. A Berzsenyi Dániel Főiskola Magyar Nyelvészeti Tanszékének Kiadványai 4. Berzsenyi Dániel Főiskola, Szombathely. 63-73.

HoffMAnN IsTVÁN 2003. Magyar helynévkutatás. 1958-2002. A Magyar Névarchívum Kiadványai 7. Debreceni Egyetem Magyar Nyelvtudományi Tanszék, Debrecen.

KÁROLY SÁNDOR 1970. Általános és magyar jelentéstan. Akadémiai Kiadó, Budapest.

KISS LAJOS 1989. Az európai névtudomány utóbbi másfél évtizede. In: BALOGH LAJOS - ÖRDÖG FERENC szerk., Névtudomány és müvelödéstörténet. A IV. magyar névtudományi konferencia elöadásai Pais Dezső születésének 100. évfordulóján. (Zalaegerszeg, 1986. október 8-10.). A Magyar Nyelvtudományi Társaság Kiadványai 183. Magyar Nyelvtudományi Társaság, Budapest. 18-31.

B. LŐRINCZY ÉVA 1962. Képzö- és névrendszertani vizsgálódások. Az-s -cs képzővel alakult névanyag az ómagyar korban. Nyelvtudományi Értekezések 33. Akadémiai Kiadó, Budapest.

Mitkkulainen, Raija 1996. The Database of Finnish Toponyms. In: Nicolaisen, Wilhelm FrITZ HERMANN ed., Proceedings of the XIXth International Congress of Onomastic Sciences. Aberdeen, August 4-11, 1996. 1-2. University of Aberdeen, Department of English, Aberdeen. 2: $248-255$.

NeMES Magdolna 1999. A földrajzi köznevekröl. Magyar Nyelvjárások 37: 331-340.

Nemes Magdolna 2005. Földrajzi köznevek állományi vizsgálata. Doktori (PhD) értekezés. Debreceni Egyetem, Debrecen. Kézirat.

Póczos RiTA 2010. Nyelvi érintkezés és a helynévrendszerek kölcsönhatása. A Magyar Névarchívum Kiadványai 18. Debreceni Egyetemi Kiadó, Debrecen.

SWAYNE, JAMES COLIN 1956. A concise glossary of geographical terms. George Philip and Son, London.

BÁBA BARBARA

ORCID: https://orcid.org/0000-0002-2381-5216

Debreceni Egyetem

Bölcsészettudományi Kar 


\section{BARBARA BÁBA, On the Dictionary of Hungarian geographical common nouns}

Geographical common nouns as elements that denote places are a central element of the lexicon of any language. The same can be said for Hungarian, as these are the only words suitable to designate the type of a place. Naturally, research into the nature of geographical common nouns has always been central to the study of toponyms. The base of such work is the academic collection of the highest possible number of such common nouns and their publication in an easy to use and accessible form. Projects of this nature have been the focus of both Hungarian and international onomastic research. The Dictionary of Hungarian geographical common nouns is thus a vital work, which not only provides practical support for the study of toponyms but raises unique research questions. 
FARKAS TAMÁS - SLÍZ MARIANN szerk., Tulajdonnevek és szótárak. ELTE Magyar Nyelvtudományi és Finnugor Intézet - Magyar Nyelvtudományi Társaság,

Budapest, 2020. 231-240. DOI: 10.26546/4892373.15

\section{Köznevesült tulajdonnevek szótárainkban*}

1. Bevezetés. Egyetérthetünk PARAPATICS ANDREÁval, aki szerint a magyar szleng szókészletével való foglalkozás rövid időn belül elvezeti a kutatót a köznevesülés jelenségéhez (2012: 159). Ennek a sajátos szóalkotási módnak a vizsgálata valóban kedvelt és gyakori témája mind a szlengkutatásnak és a névkutatásnak, mind pedig a lexikológiának. Gazdag szakirodalmi háttérrel találkozhatunk még akkor is, ha csak a legújabbakat emeljük ki az utóbbi évek részben vagy teljesen e témával foglalkozó szakcikkei közül (PARAPATICS 2012; KEMÉNY 2014; SARHEMAA-SIIVONEN 2015; H. VARGA 2017; RESZEGI 2018; SARHEMAA-TAKÁCS 2018).

A köznevesülés folyamatát általában az élőnyelvi nyelvhasználathoz kötik (TAKÁCS 2002: 123, PARAPATICS 2012: 159), s a konnotáció fontos szerepet kap benne. Az is tény, hogy minél gyakrabban használunk egy tulajdonnevet, minél több asszociáció füződik hozzá, annál nagyobb a valószínűsége a közszói jelentés és használat kialakulásának (vö. TAKÁCS 2003: 605). Úgy vélem azonban, hogy a köznevesülésnek mint jelentésváltozási folyamatnak a beindulásában és lefolyásában egy-egy név esetén a konnotatív jelentés(ek) meglétén és a gyakori használaton kívül számos egyéb ok is közrejátszik, melyeknek bemutatása és feltérképezése sok esetben túlmutat a hagyományos nyelvészeti módszereken.

Tanulmányomban elöször azokat a tényezőket mutatom be röviden, melyek a köznevesülés jelenségének egyértelmü meghatározását nehezítik, illetve a szócsoport azon jellegzetességeit, melyek az ily módon létrejött alakok szótárba szerkesztésekor nehézséget jelenthetnek. Ezt követően az apellativizációval létrejött közszói alakok szóközlésekben és szótárakban való eddigi megjelenését vizsgálom, végül pedig a legfőbb szótári előzményeket mutatom be.

2. A köznevesülésről hagyományos és kognitív keretben. A köznevesülés (apellativizáció) az a jelentésváltozási folyamat, melynek eredményeképpen egy tulajdonnévként használt nyelvi elemet elkezdenek közszóként is használni. A köznevesülés jelentésváltozásként való felfogása azt feltételezi, hogy a kiindulásul szolgáló tulajdonnévnek jelentést tulajdonítunk. Sőt mára elfogadott tény az is, hogy a tulajdonnevek nyelvi (szemantikai-pragmatikai) viselkedése nem is magyarázható mással, mint a köznévinél összetettebb és sokrétübb jelentésszerkezetükkel, arról azonban, hogy ez a folyamat nyelvileg hogyan értelmezhető és miként zajlik le, megoszlanak a vélemények.

A tulajdonnév jelentésével és közszóvá válásával kapcsolatban két markáns elméletkör rajzolódik ki. Az egyik a köznevesülést azzal magyarázza, hogy a jelentésszerkezet összetevőinek aránya, azok hangsúlyai a használat során megváltoznak, míg a másik az emberi gondolkodás általános természetéből fakadó jelenségnek tartja. A továbbiakban ezeket az elméleteket mutatom be röviden.

* A tanulmány megjelenését az EFOP-3.6.1-16-2016-00001 Kutatási kapacitások és szolgáltatások komplex fejlesztése az Eszterházy Károly Egyetemen címú projekt támogatta. 
A tulajdonnévvel kapcsolatban jelentésszerkezetről a magyar szakirodalomban J. SOLTÉSZ KATALIN beszélt először (1979), elemeiként pedig az önkényességet és a motiváltságot, az információtartalmat, a denotációt, a konnotációt, valamint az etimológiai jelentést és e jelentés átláthatóságát nevezte meg. Ezek közül a jelentésváltozás szempontjából legfontosabb elemet, a konnotációt emeljük ki, melyet a névhez kötődö asszociatív értékként értelmezhetünk. J. SolTÉSz (1979: 30) szerint a köznévvé válás oka a tulajdonnév konnotatív jelentésének elötérbe kerülése, illetve az, hogy a metaforikus és metonimikus értelemben használt tulajdonnév jelentésében az asszociatív mozzanatok háttérbe szorítják az elsődleges névviselő tudati képét.

HAJDÚ MIHÁLY (2003: 70-71) a köznevesülésnek egyrészt társadalmi (amikor egy névviselö - legyen az személy, hely vagy más objektum - a többi hasonlónál ismertebbé válik, nevét egyre többen használják, s lassan, fokozatosan fogalommá válik), másrészt pszichológiai okát említi (a tulajdonnév a viselőjének jelentősége miatt szimbólummá válik). Társadalmi okon alapul a cézár, király, mecénás közszavunk létrejötte, a júdás, snejderfáni, fritz, ádámcsutka szó kialakulásának pedig szerinte pszichológiai okai vannak. Úgy vélem azonban, ezeket a köznevesülés általános indítékaként nem fogadhatjuk el.

KIEFER szerint (2007: 162) a tulajdonnevek deskriptív értelmezése konceptuális szinten történik, ahol döntő szerephez jutnak a tulajdonnév hordozójával asszociált mindennapi ismeretek, s a különböző értelmezések alapja az alábbi kognitív elv: bizonyos részek bizonyos jellemzői az egészet jellemezhetik. Ezt elfogadva tudunk a mondanivaló megfogalmazása/feldolgozása során egy név előhívásával hasonlóságon vagy érintkezésen alapuló asszociációk révén valamilyen kapcsolódó köznévi jellegü jelentéstartalmat is aktiválni (vö. RESZEGI 2010).

3. A köznevesült szóanyag megjelentetése. Ha a köznevesülésre kognitív szemlélettel tekintünk, nehezen elképzelhető, hogy nyelvünk szókincsét bemutató szótáraink legtöbbje ne tartalmazna ilyen keletkezésü elemeket is. A következőkben bemutatom mindazokat a kiadványokat (kezdetben szóközléseket és tanulmányokat, később szótárakat is), amelyek mellékesen vagy fő feladatuknak tekintve köznevesült szóanyagot is közölnek. Összefoglalásomban nem elsősorban a jelenséget elméleti szempontból megközelítő munkákra koncentrálok, hanem azokra, melyek a szóanyagot értelmezve, rendszerezve, később pedig szócikkek formájában is megjelentetik.

3.1. A korai források. A 19. század végétől kezdve számos tanulmány gyüjtötte össze és elemezte a nyelvjárásokban és/vagy a köznyelvben közszói jelentéssel bíró tulajdonneveket (pl. SIMONYI 1881; TOLNAI 1899; SZILY 1911; SZENDREY 1936; később pedig többek között LACZKÓ 1956; J. SOLTÉSZ 1959; KÁLMÁN 1967; VITÁNYI 1985, 1997; P. CSIGE 1986; B. LÖRINCZY 1991; LAKATOS 1993; TAKÁCS 2000, 2003; FARKAS 2003; HAJDÚ 2003).

A jelenségről kezdetben átfogó feldolgozás sokáig nem készült, csak a Magyar Nyelv és a Magyar Nyelvőr szóközléseiben, névgyüjteményeiben fordultak elö szórványosan köznevesült tulajdonnevek - kezdettől fogva elsősorban keresztnevek. Ez az időszak nem az analízisé, hanem az adatközléseké volt: nagy mennyiségü, de nem kategorizált, legfeljebb csak szemantikai csoportokba sorolt adatokat találunk ezekben az írásokban. Egy-egy szerző néhol érinti azt a kérdést is, hogy miben különböznek ezek az adatok a tulajdonnevektől, és milyen formális sajátságai vannak a változásnak, de a fó cél még leginkább az adatok összegyüjtése és közlése volt. Az ebben az időben publikált adatok 
közös jellemzője az is, hogy a szerzők teljesen összemossák a magyarban köznevesült és a nyelvünkbe jövevényszóként érkezett, az átadó nyelvben közszóvá vált alakokat. Az első szintézis igényü, már nemcsak adatközlése szorítkozó, hanem elméleti megközelítést is felvállaló munka szerzői közt találjuk TOLNAI VILMOSt, aki Személynevek mint köznevek címü dolgozatában a köznevesülést úgy definiálja, hogy „a közhasználat a személyneveket valamely külön tulajdonsággal ruházza fel, sok esetben jelzőt tesz melléjök és így köznevekké teszi őket" (1898: 1).

3.2. A szótárba emelés problémái. A tulajdonnévi eredetű köznévi szókincs szótárba emelésének problémáira J. SOLTÉSZ KATALIN is utalt a tulajdonnév és köznév határterületeinek vizsgálata kapcsán (1959). A tulajdonneveket ő egyértelműen kizárná értelmező szótárainkból, ha azonban a tulajdonnévnek olyan jelentésével találkozunk, amely már értelmezhető, s használata nem alkalmi, hanem már többé-kevésbé általánosult, nézete szerint „,nem kell visszariadnunk attól, hogy a szótárba felvegyük” (J. SOLTÉSZ 1959: 470). Megközelítése alapján tehát a Petőfi ne kerüljön be az értelmező szótárba, hiába jelent alkalmilag verset, iskolát vagy forradalmi költöt, a teljesen köznevesült pecsovics-ot viszont vegyük fel címszóként. Jogosan teszi fel ugyanakkor a kérdést, hogy hol a határ, milyen objektív kritériumai vannak a tulajdonnévi jelentésnek (J. SOLTÉSZ 1959: 470).

Érdemes ezt a kérdést diakrón szempontból is (bár csak szük 60 évre visszatekintve) megvizsgálni. J. SOLTÉSZ újságcikkek alapján megállapítja, hogy 1958-ban a Moszkvics az 'autó', a Csepel a 'motorkerékpár', a Zetor pedig a 'traktor' fogalmához kapcsolódott (1959: 467), azaz az említett márkanevekhez a tulajdonnévi jelentések mellett ekkor már egy új, közszói jelentést hordozó mikrojegy is kapcsolódott. Ezek közül mára csak a zetor-nak van közszói (bár még egyetlen szótárban sem szereplö) jelentése is, ennek viszont a tulajdonnévi azonosíthatósága vált korlátozottá. Azt tehát, hogy egy folyamatban lévő jelentésváltozás mennyire lesz általános érvényü és tartós, megjósolni nem lehet.

Az általánosult jelentéssel bíró, egyértelmủen közszóvá vált alakoknak J. SoLTÉSz (1959: 468) szerint az egyik legegyértelműbb jele a képzős használat (a szerző példái-

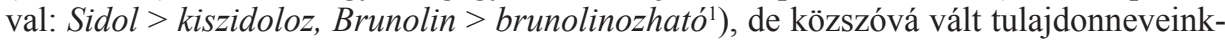
nek csak kis részét érinti a szemantikai mellett ilyen jellegü, egyértelmüen felismerhető alaktani változás is, azaz viszonylag ritkán kapunk ennyire egyértelmü segítséget a szó köznévi csoportba sorolásához. ${ }^{2}$ Szótáraink viszont csak az egyértelmüen besorolható, definíciószerüen megadható jelentéssel bíró közszói adatokat veszik fel szócikként is.

Általában ezt az elméleti megközelítést elfogadva közelítenek a tulajdonnevekhez értelmező szótáraink. Az előbb említett pecsovics-nak például mindkét értelmezését megtaláljuk az ÉrtSz.-ben (rég. gúny. 'a Habsburgok, illetve a kormánypárt szolgai híve' és 'túlzó kormánypárti'), sőt a szócikkben még tulajdonnévhez is kötik (Petsovics István szekszárdi tiszttartó nevéből). Az etimológiát azonban (a szótártípussal kapcsolatos elvárásoknak megfelelöen) nem minden esetben találjuk meg a szóval kapcsolatos információk részeként. Az ismertebb közszói alakok mellett megjelenik, pl. zeppelin 'szivar alakú, igen nagy léghajó' (F. Zeppelin német feltaláló nevéből), bédekker '(részletes) útikalauz, útikönyv' (K. Baedeker lipcsei könyvkiadóról) (ÉKsz. ${ }^{1}$ ); máshol viszont még az egyértelmüen tulajdonnévhez köthető szavak esetében is elmarad, pl. ripacs 'olcsó

${ }^{1}$ Ez utóbbi márkanév közszói használatára (bútorfényesítő neveként) interneten manapság is találunk példát.

${ }^{2}$ A magyarban képzőt kapott alakokból bőven hoz példát HAJDÚ (2002: 55, 2003: 78). 
hatásokra törekvő rossz színész (ritkábban előadó vagy szónok)’ (ÉrtSz., ÉKsz. ${ }^{1}$ ). Úgy tünik, a tulajdonnévi eredet megadása a szó ismertségén és/vagy gyakoriságán kívül egyéb (sokszor szubjektív) tényezőktől is függ.

Etimológiai szótárainkban szinte minden ilyen keletkezésủ szó esetén nagy hangsúly esik a tulajdonnévi eredet feltárására. Utalás van rá például (az ismertebbek közül véve a példákat) az aggastyán, ádámcsutka, pálfordulás, pali, panama, paprikajancsi szócikkben (TESz., ESz.), néha azonban etimológiai szótárban is elmarad a tulajdonnévhez kötés (pl. ripacs), illetve néhány esetben egyes, sokak által ismert tulajdonnevekhez köthető szavak még címszóként sem jelennek meg; pl. bédekker, pecsovics, zeppelin (ESz.).

A köznevesült tulajdonnevek egyes nyelvváltozatokban feltételezhető nagy számára az Új magyar tájszótár anyaga kapcsán már B. LőRINCZY ÉVA (1991) is felhívta a figyelmet (ő elsősorban a nyelvjárásokban való gyakori előfordulásra utalt), ám a szótár még az általa feltételezetteknél is nagyobb gazdagságban tartalmazza a tulajdonnévi (dominánsan keresztnévi) eredetű szókincset. Néhány példát kiemelve közülük: andrástartó 'azok közül a hajótetőt tartó cölöpök közül egy, amelyeken keresztben fekszik a süvegfa', büdöspanna 'poloska', fiúpista 'fiúpecér', böskebab 'babfajta neve', sanyarúfáni 'zsugori, fösvény nö'. B. LŐRINCZY elsősorban a kereszt- és becenévből létrejött adatok nagy számára utal, de természetesen ebben a nyelvváltozatban is - bár jóval kisebb számban - köznevesülnek egyéb tulajdonnévtípusok is; pl. júdásfa 'évelö holdviola' (ÚMTSz.), amerikadohány 'dohányfajta, melyet a bébai dohánykertészek termeltek' (SzegSz.), kanadaranett, sándorcár és biszmark 'almafajta' (a SzegSz. alma címszavánál), virginia 'muzsikaszó, zene' (SzegSz.).

Bár nem hagyományos értelemben vett szótár, hanem az enciklopédikus szótárak közé sorolható (vö. FÁBIÁN 2015), de mindenképpen ide kívánkozik a Hogy hívnak? Könyv a keresztnevekről címü munka (FERCSIK-RAÁTZ 1997). A kötet nemcsak a hagyományos szótárak sorába nem illeszkedik, de a hagyományos utónévkönyvekébe sem: a korábbi (részben hasonló célú) kiadványoktól eltérően nem elégszik meg az anyakönyvezhető keresztnevek betürendes közlésével, de sok közérdeklődésre számot tartó egyéb információt is ad a nevekről: számos hozzájuk kapcsolódó néprajzi, kultúrtörténeti és nyelvészeti információt is megad (vö. HAJDÚ 1998). A szerzők írnak például a személynevek helynevekben és idegen nyelvekben való előfordulásáról, más nevekkel való összefüggéseiről és - ami a maga idejében ilyen típusú kiadványokban úttörő jelentőségü volt - a közszóval való kapcsolatukról, azaz közszóvá válásukról is.

Jellegénél fogva ez a kötet is csak keresztneveket dolgoz fel, csaknem százat azok közül. Az, hogy ez az alapvetően ismeretterjesztőnek szánt kiadvány a névcikkekben a nevekhez hozzákapcsolja a közszói származékokat is, arra utal, hogy a szerzők fontosnak tartják egyértelműen a tulajdonnévhez kötni a már szótárazható jelentéssel is bíró közneveket. Még hangsúlyosabb ez a szemlélet a szerzőpáros Keresztnevek enciklopédiája című kiadványában (KnE.), melyben száz-száz női és férfinév szerepel. A névcikkek szerkezete követi a korábbi munkájuk mintáját (a keresztnévnek a nyelvészetin kívül számos kulturális, néprajzi vonatkozását közli), de sokkal erőteljesebben (tipológiailag is) elkülöníti a nevek jellemzésének egyes szempontjait.

A köznévi előfordulásokat a szócikkek utolsó pontja adja meg. Ezeket áttekintve azt láthatjuk, hogy egy-egy névcikkben csak a nyelvjárási és (a valószínüleg) általánosan ismert köznyelvi adatok jelennek meg, ám a forrásokat itt sem találjuk meg az adatok mellett, s feltünő, hogy a magyarban történt jelentésváltozásokat és a nyelvünkbe már eleve közszói formában érkezett, az átadó nyelvben köznevesült adatokat sem különítik el. Természetesen ennek a kiadványnak nem is a közszói adatok forrásának pontos közlése 
volt a fö célja, de sajnos emiatt a szócikkek kutatási célra nehezen használhatók. A kötetben elsőként álló Ádám név közszói származékai például így jelennek meg (KnE. 39):

A köznyelvi ádámcsutka megnevezése a népnyelvben is Ádám nevéhez kötődik, például ádámalma, ádámbütyök, ádámcsomó, ádámcsont, ádámfalat, ádámgége, ádámgombja, ádámgörcs stb.

Tudjuk, hogy aki ádámkosztümben van, az valójában ruhátlan, pucér. Ismerjük a népmesékből az ádámbüz megnevezést, amely főleg az idegenekre, a házhoz nem tartozó személyekre vonatkoztatva jelöli az emberszagot. De vajon mit csinál az, aki ádám villájával eszik? Tréfásan ezt olyankor mondják, ha az illemet megsértve, evőeszköz nélkül, kézzel eszik valaki. Az adamiták ókori, majd középkori eretnekek voltak. Nevüket a bibliai Ádám nevéből kapták.

A zúzott kővel borított, hengerelt utak, az úgynevezett makadám utak is Ádámra emlékeztetnek. Ezt a burkolatot egy skót mérnök, J. L. MacAdam találta fel a múlt század elején (MacAdam magyarul Ádám fia, azaz Ádámfi). Az ő nevét a magyar nyelv hangsúlyaival ejtve jött létre és vált köznévvé a makadám szavunk.

3.3. A tulajdonnévi eredetü szóanyag forrásai és típusai. A korábbi, szótáralapú szógyüjtések elsősorban a kifejezetten könnyen tulajdonnévhez köthető, az egyéb névtípusokhoz képest egyszerübben felismerhetö köznevesült keresztnevekre koncentráltak, s mára 36 szótár teljes anyagának szókincsét vizsgálták át. Ezek között vannak etimológiai szótárak (SzófSz., TESz.), értelmező szótárak (ÉrtSz., ÉKsz.1), regionális és teljes tájszótárak (pl. Tsz., MTsz., BodrSz., FTsz., KiskSz., SzegSz., SzamSz.), szlengszótárak (pl. JENŐ-VETÖ 1900, KABDEBÓ 1917, FAZAKAS 1991, HOFFMANN 1996) és kisebb, egyegy nyelvi réteg szókincsét felölelö, illetve szak- és regionális szótárak (pl. MNövSz., VÖRÖS 1996). Az említett szótárakban szereplő keresztnévi eredetü korpusz elemzését magam végeztem el (TAKÁCS 2007: 45-97), az újabb szlengszótárak (TIMÁR-FAZAKAS 2003, PARAPATICS 2008, SzŰTS 2008, KÖVECSES 2009) köznevesült személynévi anyagának vizsgálata pedig PARAPATICS ANDREA (2012) munkája.

Tapasztalataim alapján a nyelvjárási szótárakban elsősorban a keresztnévi eredetü szókincs, a szlengszótárakban pedig (föleg a legújabbakban) az egyéb tulajdonnévfajták (elsősorban család- és helynevek) közszói alakjai jelennek meg legnagyobb számban. Néhány példát idézve ezek közül: kádárkolbász 'gumibot', zrínyizik 'fizetés nélkül elmegy, elszökik', blöki 'kutya', nyelesdemalgon 'vodka (üvegböl)' (KöVECSES 2009); rákóczitér 'folyosó a női börtönben' (SZABÓ 2008); balkán 'rendetlenség, zürzavar' (PARAPATICS 2008); antaljózsi 'LSD-vel átitatott bélyeg, kábítószer', csikágó 'veszélyes környék', dzsurasszikpark 'nem dolgozó körlet, rezervátum' (KIS 2015).

Föleg újabb börtönszlengszótárunk (KIS 2015) mutat igen sok köznevesült alakot, amelyek sok esetben analogikus változások alapjául is szolgálnak: egész köznevesült szócsaládok jöttek létre hasonló vagy akár ugyanolyan jelentéssel; pl. mengele, csaucseszku, bubó 'börtönorvos'; terminátor, zsan, mikrobi, kintekunta 'az elítéltek hierarchiájában a legalsó fokon lévő, zárkatársa(i) kiszolgálására kényszerített, megalázott személy, csicska'; dzsémszbandi, geréb, júdás, matahari, donibraszkó 'áruló, besúgó, vamzer'. A börtönszlengben közszóként is használt, különböző típusokból származó tulajdonnevek korpuszát szemantikai és morfológiai szempontból elemeztem (TAKÁCS 2020a, 2020b), 
a magyar és finn szlengben köznevesült keresztneveket pedig a két szócsoport legföbb különbségeinek kiemelésével vizsgáltuk meg (SARHEMAA-TAKÁCS 2018). Úgy vélem, hogy a szlengből származó gazdag szóanyag minél több szempontot felölelö további vizsgálata feltétlenül indokolt, alapvető fontosságú ismeretekkel gazdagíthatja ugyanis tudásunkat az apellativizáció folyamatával, típusaival, mentális hátterével kapcsolatban.

3.4. A magyar deonomasztikon kezdeménye. Olyan magyar nyelvű szótár, mely kizárólag a tulajdonnévi eredetű közszavak állományát tartalmazná, jelenleg nem létezik, bár idegen nyelvekben (az olaszban és a németben) van rá példa (KÖSTER 2012, SCHWEICKARD 1997-2013; ismertetéseiket 1. FÁBIÁN 2014, MÜLlER 2015). A legbővebb ilyen jellegü magyar munka a jelenségről szóló (idáig egyetlen) magyar monográfia (Keresztnevek jelentésváltozása. Egy tulajdonnévtípus közszóvá válásának modellje) névtári része (TAKÁCS 2007: 97-136). Ez a mü az egyik tulajdonnévtípust középpontba állítva mutatja be a változást: 28 magyar kereszt- és becenév közszói származékai szerepelnek benne szócikk formájában.

A kötet 32 szótár teljes anyagából meríti korpuszát, ${ }^{3}$ melyet három (általános, szerkezeti és jelentéstani) szempontból is elemez, a jelenséggel kapcsolatos általános jellemzöket pedig csaknem 400, apellatív alakot is mutató magyar keresztnév kb. 2300 közszói adata alapján fogalmazza meg. A monográfia csak a keresztnévi eredetü példákat és a magyarban közszóvá vált alakokat tartalmazza, tulajdonnévi eredetü jövevényszavakat nem. Terjedelmi okokból azonban a kötet névtári részében a vizsgálat alapjául szolgáló 396 keresztnév közül csak 28-hoz kapcsolódó névcikk kapott helyet.

Az alábbiakban az egyik, tulajdonnévként is ritka használatú és kevés közszói származékot mutató férfinév, az Andor névtárban szereplő szócikkét mutatom be (TAKÁCS 2007: 99):

1. Az András név régi Andorjás formájából rövidült alakja, de lehetett a régi magyar Andornak keresztnév rövidülése is. Az Andornak az Andronicus név magyarosított alakja (Ladó 130, Ladó-Bíró 29). Családnévként 1453-ból adatolható Tomas Andor alakban. A családnév a CsnSz. szerint az András régi egyházi személynév Andorjás változatának rövidült becézőnevéből, az Andor-ból származó apanév. Ennek képzett alakjai (az Andorka, Andorkó) is megjelentek családnévként (OklSz.).

2. Népi gyógyszer neve az andortea (Herba Marubii) (ÚMTsz.).

4. Összegzés. A köznevesült tulajdonnévi adatok megjelenése az általános szótárakban igen esetleges: kiválogatásuk és értelmezésük, illetve a hozzájuk füzött információk (köztük a tulajdonnévi eredet feltárása is) a szótár típusán és céljain túl sok esetben függ a szerkesztő megítélésétől is. Meglátásom szerint mindenképpen szükséges és érdemes lenne ennek a szóanyagnak az önálló szótárba rendezése, egy magyar deonomasztikon létrehozása: ehhez a későbbiekben jó alapot szolgáltathatnak a korábbi szótárak anyagán alapuló eddigi gyüjtések és a jelenségről szóló monográfia névtári része. A mintaként említett olasz és német szótár közül, úgy vélem, célszerü lenne a német mintáját követni: a magyar köznevesült szóanyagot elsődlegesen leíró szempontból, értelmező szótárként lenne érdemes feldolgozni, ám a korpusz kialakítása során fontos a jövevényszavak és a magyar szóalkotások egyértelmü elkülönítése.

\footnotetext{
${ }^{3}$ A teljes egészében és részben feldolgozott szótárak listáját 1. TAKÁCS 2007: 159-161.
} 
Meg kell jegyeznünk, hogy mivel az előzményként használható összes magyar kiadvány jórészt keresztnévi eredetű alakokat közöl, igen lényeges az egyéb névtípusok (helynevek, családnevek stb.) közszói származékainak bevonása és felmutatása is. Az újabb névtípusok beemelésén kívül fontos kérdés a források körének bővítése is: a hagyományos, nyomtatott szótárakon, szógyüjteményeken túl érdemes lenne nyitni az online források (elsősorban szlengszótárak és blogok, illetve a közösségi tereken zajló nyelvhasználat) felé is, hiszen ha a közszóvá válást az élönyelvi névhasználathoz kötjük, az online szótárak kiváló forrásai lehetnek a köznevesüléssel létrejött szóanyagnak.

Az e szempontok alapján kialakított magyar deonomasztikon jól illeszkedne a tanulmányomban is említett, keresztnevekhez kapcsolódó, tudományos igényességgel készült tudománynépszerüsítő névtani kiadványok sorába (KÁLMÁN 1967, FERCSIK-RAÁTZ 1997, KnE.), melyek egyszerre tartanak számot a nyelvészet felé csupán érdeklődéssel fordulók figyelmére, és szolgálnak forrásokként további (szemantikai, alaktani vagy lexikológiai jellegü) névtani kutatások számára is.

\section{Felhasznált források}

BodrSz. = NAGY GÉZA, Bodrogközi tájszótár. Bodrogközi Kastélymúzeum Baráti Köre, Pácin, 1992.

ÉKsz. ${ }^{1}=$ Magyar értelmező kéziszótár. Szerk. JUHÁsz JÓZSEF - SzŐKE ISTVÁN - O. NAGY GÁBOR KovalovszKY MikLós. Akadémiai Kiadó, Budapest, 1972.

ÉrtSz. = A magyar nyelv értelmező szótára 1-7. Főszerk. BÁRCZI GÉZA - ORSZÁGH LÁsZLÓ. Akadémiai Kiadó, Budapest, 1959-1962.

ESz. = Etimológiai szótár. Főszerk. ZAICZ GÁBOR. Tinta Könyvkiadó, Budapest, 2006.

FAZAKAS ISTVÁN 1991. Jasszok, zsarók, cafkavágók. Életképek a vagányvilágból, ó- és új argószótár. Fekete Sas Kiadó, Budapest.

FERCSIK ERZSÉBET - RAÁTZ JUDIT 1997. Hogy hívnak? Könyv a keresztnevekröl. Korona Kiadó, Budapest.

FTsz. = IMRE SAMU, Felsőőri tájszótár. Akadémiai Kiadó, Budapest, 1973.

Hoffmann OtTó 1996. Mini-tini szótár. A mai magyar diáknyelv szótára. Janus Pannonius Tudományegyetem Továbbképző Központ, Pécs.

JENŐ SÁNDOR - VETŐ IMRE 1900. A magyar tolvajnyelv és szótára. Béta Irodalmi Részvénytársaság, Budapest.

KABDEBÓ OsZKÁR 1917. Pesti jassz-szótár. Török Ignác Kiadóvállalata, Mezőtúr.

KIS TAMÁs 2015. Sittesduma. Magyar börtönszlengszótár. Szlengkutatás 9. Debreceni Egyetemi Kiadó, Debrecen.

KiskSz. = MARKÓ IMRE LEHEL, Kiskanizsai szótár. Akadémiai Kiadó, Budapest, 1981.

KnE. = FERCSIK ERZSÉBET - RAÁTZ JUDIT, Keresztnevek enciklopédiája. A leggyakoribb nöi és férfinevek. A magyar nyelv kézikönyvei 16. Tinta Könyvkiadó, Budapest, 2009.

KÖVECSES ZOLTÁn 2009. Magyar szlengszótár. Akadémiai Kiadó, Budapest.

MNövSz. = CSAPODY VERA - PRISZTER SZANISZLÓ, Magyar növénynevek szótára. Mezögazdasági Kiadó, Budapest, 1966.

MTsz. = SZINNYEI JózSEF, Magyar tájszótár 1-2. Hornyánszky, Budapest, 1893-1901.

PARAPATICS ANDREA 2008. Szlengszótár. A mai magyar szleng 2000 szava és kifejezése fogalomköri szinonimamutatóval. Az ékesszólás kiskönyvtára 6. Tinta Könyvkiadó, Budapest. SZABÓ EDINA 2008. A magyar börtönszleng szótára. Kossuth Egyetemi Kiadó, Debrecen. 
SzamSz. = CsÜRY BÁLINT, Szamosháti szótár 1-2. Magyar Nyelvtudományi Társaság, Budapest, 1935-1936.

SzegSz. = BÁLINT SÁNDOR, Szegedi szótár 1-2. Akadémiai Kiadó, Budapest, 1957.

SzófSz. = BÁRCZI GÉZA, Magyar szófejtő szótár. Királyi Magyar Egyetemi Nyomda, Budapest, 1941.

SzŰTs LÁszLó 2008. Diáksóder. Cédrus Művészeti Alapítvány - Napkút Kiadó, Budapest.

TESz. = A magyar nyelv történeti-etimológiai szótára 1-3. Föszerk. BENKÖ LORÁND. Akadémiai Kiadó, Budapest, 1967-1976.

TimÁr GyÖrGY - FAZAKAS IstVÁn 2003. Szleng-szó-szedet. Fekete Sas Kiadó, Budapest.

Tsz. = Magyar tájszótár. A’ Magyar Tudós Társaság, Buda, 1838.

ÚMTsz. = Új magyar tájszótár 1-5. Főszerk. B. LŐRINCZY ÉvA. Akadémiai Kiadó, Budapest, 1979-2010.

VÖRÖS ÉVA 1996. Egzotikus gyümölcsök magyar neveinek történeti-etimológiai szótára. Debrecen.

\section{Hivatkozott irodalom}

P. Csige Katalin 1986. Személynevek frazeológiai egységekben. Magyar Névtani Dolgozatok 62. ELTE, Budapest.

FÁBIÁN ZsUZSANNA 2014. Wolfgang Schweickard szerk.: Deonomasticon Italicum. Dizionario storico dei derivati da nomi geografici e da nomi di persona 1-4. Con supplemento bibliografico. [Recenzió.] Névtani Értesitö 36: 282-285.

FÁBIÁN ZSUZSANNA 2015. A szótár, illetve a lexikon és az enciklopédia megkülönböztetése az „enciklopédikus szótár” müfajának tükrében. In: FÁBIÁN ZSUZSANNA - SZÖLLŐSY ÉVA szerk., Szótár, lexikon, enciklopédia. Kérdések és feladatok. Segédkönyvek a nyelvészet tanulmányozásához 172. Tinta Könyvkiadó, Budapest.

FARKAS TAMÁS 2003. Névkutatás - szlengkutatás: nevek és köznevesülés a katonai szlengben. In: HAJDÚ MiHÁLY - KESZLER BORBÁLA szerk., Köszöntő kötet Kiss Jenö születésnapjára. ELTE, Budapest. 641-650.

HAJDÚ MiHÁLY 1998. Fercsik Erzsébet - Raátz Judit: Hogy hívnak? Könyv a keresztnevekről. [Recenzió.] Névtani Értesitö 20: 134-139.

HAJdÚ MiHÁLY 2002. A tulajdonnevek köznevesülése. In: GRÉCZI-ZSOLDOS ENIKÖ - KovÁCS MÁRIA szerk., Köszöntö kötet B. Gergely Piroska tiszteletére. Miskolci Egyetem Magyar Nyelvtudományi Tanszék, Miskolc. 50-59.

HAJDÚ MiHÁly 2003. Általános és magyar névtan. Személynevek. Osiris Kiadó, Budapest.

KÁLMÁN BÉLA 1967. A nevek világa. Gondolat Kiadó, Budapest.

KEMÉNY GÁBOR 2014. Az antonomázia helye a nyelvi képek családjában. Magyar Nyelv 110 : 257-265, 385-393.

KIEFER FERENC 2007. Jelentéselmélet. 2. kiadás. Corvina Kiadó, Budapest.

KÖSTER, RUdOLF 2012. Eigennamen im deutschen Wortschatz. Ein Lexikon. Walter de Gruyter, Berlin.

LACZKÓ GÉZA 1956. Köznévvé vált tulajdonnevek. In: LÖRINCZE LAJOS szerk., Nyelvmüvelö. Müvelt Nép Könyvkiadó, Budapest. 92-97.

LAKATOS ERIKA 1993. Személynevek az Új Magyar Tájszótár szólásaiban és közmondásaiban. Névtani Értesitö 15: 212-215.

B. LŐRINCZY ÉVA 1991. Jancsi és Juliska. In: HAJdÚ MiHÁLY - KISS JENŐ szerk., Emlékkönyv Benkö Loránd 70. születésnapjára. ELTE, Budapest. 423-426.

MÜLLER MÁRTA 2015. Rudolf Köster: Eigennamen im deutschen Wortschatz. [Recenzió.] Névtani Értesítö 37: 274-277. 
PARAPATICS ANDREA 2012. Közszóvá váló személynevek a mai magyar szlengben. In: PARAPATICS ANDREA főszerk., Doktoranduszok a nyelvtudomány útjain. (A 6. Félúton konferencia, ELTE BTK 2010. október 7-8.). Tálentum Sorozat 2. ELTE Eötvös Kiadó, Budapest. 156-169. RESZEGI KATALIN 2010. A köznevesülésröl. Névtani Értesitő 32: 143-149.

RESZEGI KATALIN 2018. On the proper name-to-apellative transformation. Rivista Italiana di Onomastica 24: 25-46.

SARHEMAa, MARIA - SivOnen, JARI 2015. Suomen ja unkarin slangin appellatiivistuneet etunimiyhdyssanat. Folia Uralica Debreceniensia 22: 191-212.

SARHEMAA, MARIA - TAKÁCS JUDIT 2018. 'Ember' jelentésű köznevesült keresztnevek a finn és a magyar szlengben. Folia Uralica Debreceniensia 25: 211-225.

Schweickard, WolfGang szerk. 1997-2013. Deonomasticon Italicum. Dizionario storico dei derivati da nomi geografici e da nomi di persona 1-4. Con supplemento bibliografico. Niemeyer, Tübingen.

SIMONYI ZSIGMOND 1881. Andalog. Magyar Nyelvör 10: 405-407.

J. SOLTÉSZ KATALIN 1959. Tulajdonnév és köznév határterülete. Magyar Nyelv 55: 461-470.

J. SOltÉSZ KaTAlin 1979. A tulajdonnév funkciója és jelentése. Akadémiai Kiadó, Budapest.

SZENDREY ZSIGMOND 1936. Személynevek mint köznevek. Magyar Nyelv 32: 248-259.

SZILY KÁLMÁN 1911. Régi dolgok új kiadásban. Személy- és helynevekből lett közszók. Magyar Nyelv 7: 90-98, 135-138.

TAKÁCS JUDIT 2000. Bödekata, fagyurka és társaik. Közszóvá vált keresztneveinkröl. Magyar Nyelvjárások 38: 403-409.

TAKÁCS JUDIT 2002. Az igeképzés egy sajátos esete: keresztnévből alkotott igék. In: HofFMANN ISTVÁN - JUHÁSZ DEZSÖ - PÉNTEK JÁNOS szerk., Hungarológia és dimenzionális nyelvszemlélet. Elöadások az V. Nemzetközi Hungarológiai Kongresszuson (Jyväskylä, 2001. augusztus 6-10.). Debreceni Egyetem Magyar Nyelvtudományi Tanszék, Debrecen-Jyväskylä. 121-126.

TAKÁCS JUDIT 2003. Istvánok, Istik, Pistik. Egy keresztnév közszói származékainak vizsgálata. Magyar Nyelvjárások 41: 603-607.

TAKÁCS JUDIT 2007. Keresztnevek jelentésváltozása. Egy tulajdonnévtípus közszóvá válásának modellje. A Debreceni Egyetem Magyar Nyelvtudományi Intézetének Kiadványai 86. Debreceni Egyetem Magyar Nyelvtudományi Intézet, Debrecen.

TAKÁCS JUDIT 2020a. Közszóvá vált tulajdonnevek a börtönszlengben. In: BÖLCSKEI ANDREA HELTAI JÁNOS IMRE szerk., Nyelv, kultúra, identitás. Alkalmazott nyelvészeti kutatások a 21. századi információs térben. IV. Szociolingvisztika, névtan, nyelvtörténet. A MANYE Kongresszusok Előadásai 14. Akadémiai Kiadó, Budapest. Megjelenés előtt.

TAKÁCS JUDIT 2020b. A szleng fekete humora: márkanevek a börtönszlengben. In: A VI. Magyar Interdiszciplináris Humorkonferencia előadásai. Megjelenés előtt.

TOLNAI VILMOS 1899. Személynevek mint köznevek. Magyar Nyelvőr 28: 1-9.

H. VARGA MÁRTA 2017. Bibliai eredetü személynevek köznevesülése. Folia Uralica Debreceniensia 24: 259-274.

VITÁNYI BORBÁLA 1985. Értjük-e a nyelvjárások üzenetét? Édes Anyanyelvünk 7/4: 11-12.

VITÁNYI BORBÁLA 1997. Keresztnevek és becézőnevek népnyelvi mezőben. Magyar Nyelvjárások 121: 39-43.

TAKÁCS JUDIT

ORCID: https://orcid.org/0000-0002-8665-0893

Eszterházy Károly Egyetem Bölcsészettudományi Kar 


\section{JUDIT TAKÁCS, Common nouns derived from proper names in Hungarian dictionaries}

The study first presents the factors that limit the precise definition of the process that results in proper names becoming common nouns and then continues with an overview of common nouns formed through appellativization as listed in dictionaries and the characteristics of the word group that complicate listing these words in dictionaries. Research shows that the inclusion of commons nouns derived from proper names in dictionaries is incidental. Their selection, definition, and further information provided (including their origin from proper names) depend on the goal of the dictionary and often simply the editors' personal judgement. It is the author's view that the word group should be collected into a Hungarian deonomasticon. The databases compiled for previous dictionaries and the word lists attached to a chapter on the phenomenon from a monograph could be used as the bases of such a book. It would be best to process the appellativized common nouns from a primarily descriptive standpoint in a monolingual dictionary. However, particular emphasis should lie on the separation of loan words and words created in Hungarian. Furthermore, it would be vital to bring common nouns derived from different name types (place names, family names) to the fore, alongside common nouns derived from given names, a category which has many wellknown examples. The sources used should also be expanded: beyond traditional dictionaries and word lists, digital sources (slang dictionaries, blogs, language use on social media) should also be exploited. Such a Hungarian deonomasticon would fit in well among the many popular scientific works published on given names, which are not only of interest to those interested in linguistics but are the sources of further (semantic, morphological, or lexicological) onomastic research. 
FARKAS TAMÁS - SLÍZ MARIANN szerk., Tulajdonnevek és szótárak. ELTE Magyar Nyelvtudományi és Finnugor Intézet - Magyar Nyelvtudományi Társaság,

Budapest, 2020. 241-243.

\section{Kötetünk szerzői}

Bába Barbara PhD, egyetemi adjunktus, a Debreceni Egyetem Magyar Nyelvtudományi Tanszékének munkatársa. 2007-től a Debreceni Egyetem oktatója, PhD-értekezését 2013-ban védte meg. A Magyar Nyelvjárások címü folyóirat szerkesztőbizottságának tagja. Fő kutatási területe a névtan, nyelvtörténet, nyelvjárástörténet. Kutatásai jelentős részben a földrajzi köznevek jelenkori és történeti állományának kérdéseivel foglalkoznak, a témában önálló monográfiája és társszerzős földrajziköznév-szótára jelent meg. Ímél: baba.barbara@arts.unideb.hu.

Bauko János PhD, habilitált egyetemi docens, a Nyitrai Konstantin Filozófus Egyetem Középeurópai Tanulmányok Kara Magyar Nyelv- és Irodalomtudományi Intézetének munkatársa, intézetigazgató. 1996-tól a Nyitrai Konstantin Filozófus Egyetem oktatója. PhD-értekezését 2007-ben védte meg, 2017-ben habilitált. 2009-től a Magyar Tudományos Akadémia külső köztestületi tagja. 2012-től a Szlovák Tudományos Akadémia Névtani Bizottságának elnökségi tagja. 2014-től a Névtani Értesítő szerkesztőbizottságának tagja. Fő kutatási területe a névtan, elsősorban a szlovákiai magyarok névhasználatát érintő kérdésekkel foglalkozik. Lexikográfiai munkálatokat is végez, több publikációja tárgyalja az előkészületben lévő magyar-szlovák keresztnévszótár sajátosságait. Ímél: jbauko@ukf.sk.

Benő Attila PhD, habilitált egyetemi tanár, a Babeş-Bolyai Tudományegyetem Magyar és Általános Nyelvészeti Tanszékének munkatársa, tanszékvezető. 1999-től a BBTE oktatója. PhD-értekezését 2000-ben védte meg Kolozsváron, 2013-ban habilitált. A Nyelv- és Irodalomtudományi Közlemények címü folyóirat föszerkesztö-helyettese. Kutatásai a nyelvi érintkezések, a névkontaktusok szociolingvisztikai és lexikográfiai vonatkozásainak feltárására irányulnak. Több tanulmányt közölt ebben a témakörben román-magyar, magyar-román vonatkozásban. Ímél: beno. attila@1ett.ubbcluj.ro.

Fábián Zsuzsanna CSc, habilitált professor emeritus. 1973-1988 között a Szegedi Tudományegyetem Bölcsészettudományi Kara Olasz Tanszékének oktatója, 1988-2019 között az Eötvös Loránd Tudományegyetem Romanisztikai Intézete Olasz Tanszékének munkatársa. Kandidátusi értekezését 1996-ban védte meg, 2007-ben habilitált, 2011-ben nevezték ki egyetemi tanárnak. 2016-tól második ciklusban nem akadémikus közgyülési képviselője az MTA I. Osztályának és tagja az MTA Nyelvtudományi Bizottságának. A Magyar Nyelvtudományi Társaság választmányi tagja (2005-től). Több cikluson keresztül titkára, illetve elnöke volt az MTA I. Osztálya mellett múködő Szótári Munkabizottságnak. Fő kutatási területei: az olasz leíró nyelvtan, a lexikológia és a lexikográfia, valamint a névtan, de oktatott szociolingvisztikát és írástörténetet is. Szerkesztőbizottsági tagja a Nuova Corvina, a Rivista Italiana di Onomastica és a Névtani Értesítő címü folyóiratoknak. Ímél: fabian.zsuzsanna@btk.elte.hu. 
Farkas Tamás PhD, habilitált egyetemi docens, az Eötvös Loránd Tudományegyetem Magyar Nyelvtudományi és Finnugor Intézet Magyar Nyelvtörténeti, Szociolingvisztikai, Dialektológiai Tanszékének munkatársa, tanszékvezető, intézetigazgató-helyettes. 1997-től az ELTE oktatója. PhD-értekezését 2002-ben védte meg, 2013-ban habilitált. A Magyar Nyelvtudományi Társaság titkára, a Magyar Nyelv folyóirat társszerkesztője, a Névtani Értesítő felelős szerkesztője. Fő kutatási területe a névtan, kiemelten a magyar személynévtörténet, az általános, illetve az alkalmazott névtan; kutatásait a dimenzionális nyelvészeti megközelítésmód jellemzi. Több publikációjában foglalkozik a tulajdonnévszótárak, illetve a névlexikográfia egyes kérdéseivel. Ímél: farkas.tamas@btk.elte.hu.

N. Fodor János PhD, egyetemi adjunktus, az Eötvös Loránd Tudományegyetem Magyar Nyelvtudományi és Finnugor Intézet Magyar Nyelvtörténeti, Szociolingvisztikai, Dialektológiai Tanszékének munkatársa. 2001-től az ELTE oktatója, PhD-értekezését 2008-ban védte meg. A Magyar Nyelvtudományi Társaság Csűry-díj Bizottságának tagja, a Magyar Névtani Értekezések sorozat szerkesztője. Fő kutatási területe a névtan, elsősorban a személynévtörténet és a névföldrajz. Publikációinak jelentős része e két kutatási területhez kapcsolódik. A Történeti Magyar Családnévatlasz kutatási program vezetője, egy történeti magyar személynévszótár szerzője. Ímél: nfodor.janos@btk.elte.hu.

Gerstner Károly PhD, az MTA Nyelvtudományi Intézetének tudományos főmunkatársa, a Pázmány Péter Katolikus Egyetem Magyar Nyelvészeti Tanszékének egyetemi docense. 1995-ben szerezte meg a PhD-fokozatot. Kutatói munkáját 1976 óta végzi, oktatói tevékenységet 1978 óta folytat (ELTE, Rijksuniversiteit Groningen, PPKE). 2007-2012-ig az MTA Szótári Munkabizottságának, 2012-2017-ig az MTA Nyelvtudományi Bizottságának titkára. A Lexikográfiai Füzetek, a Magyar Nyelv és a Névtani Értesítő szerkesztőbizottságának tagja. Fő kutatási területe a leíró és történeti lexikológia és lexikográfia. Egyik szerkesztője volt az Etymologisches Wörterbuch des Ungarischen című szótárnak (1993-1995), szótári főmunkatársként pedig részt vesz A magyar nyelv nagyszótára munkálataiban. Ímél: gerstner.karoly@nytud.hu.

Juhász Dezső CSc, egyetemi tanár, az Eötvös Loránd Tudományegyetem Magyar Nyelvtudományi és Finnugor Intézet Magyar Nyelvtörténeti, Szociolingvisztikai, Dialektológiai Tanszékének munkatársa, intézetigazgató. 1979-től az ELTE oktatója. Kandidátusi értekezését 1991-ben védte meg, 2002-ben habilitált. A Magyar Nyelvtudományi Társaság fötitkára, a Magyar Nyelv folyóirat felelős szerkesztője, a Névtani Értesítő szerkesztőbizottságának tagja. Fő kutatási területei: történeti és szinkrón dialektológia, nyelvföldrajz, magyar nyelvtörténet, dimenzionális nyelvészet, névtan. A névtanon belül az általános kérdéseken túl föleg a történeti helynevek, tájnevek világa érdekli; monográfiát írt a magyar tájnévadásról (1988). Ímél: juhasz.dezso@btk.elte.hu.

Kovács Éva PhD, az MTA-DE Magyar Nyelv- és Névtörténeti Kutatócsoportjának tudományos munkatársa. PhD-értekezését 2013-ban védte meg a Debreceni Egyetemen. Fő kutatási területe a magyar nyelvtörténet és a történeti névtan. Elsősorban történeti helynévkutatással foglalkozik. Két fontos szórványemlék helyneveinek a monografikus feldolgozását végezte el. Két névtani tárgyú, angol nyelvü kötet szerkesztője, illetve társszerkesztője. Aktívan közremüködik a Magyar Nemzeti Helynévtár nevű elektronikus adatbázis részeként müködő Magyar Digitális Helynévtár korai moduljának kialakításában, valamint a Korai magyar helynévszótár címủ sorozat munkálataiban. Ímél: kovacs.eva@arts.unideb.hu. 
Mártonfi Attila PhD, nyelvész-informatikus, tagja az MTA Magyar Nyelvi Osztályközi Állandó Bizottságának, valamint a Földrajzinév-bizottságnak. 2002 és 2014 között az MTA Nyelvtudományi Intézetében dolgozott lexikográfusként A magyar nyelv nagyszótárának első hat kötetén. PhD-értekezését 2007-ben védte meg az Eötvös Loránd Tudományegyetemen. Társszerzője, illetve -szerkesztője számos (zömében helyesírási) szótárnak, köztük a széles körben használt Osiris Helyesírásnak. Tanulmányai túlnyomórészt helyesírási és lexikográfiai témákban születtek.

Sebestyén Zsolt PhD, főiskolai docens, a Nyíregyházi Egyetem Nyelv- és Irodalomtudományi Intézetének a munkatársa, a Nyelvészeti Intézeti Tanszék tanszékvezetője, intézetigazgató-helyettes. 2004-től a Nyíregyházi Főiskola (2016-tól Nyíregyházi Egyetem) oktatója. PhD-értekezését 2006ban védte meg. Fő kutatási területe a névtan. Elsődlegesen a történelmi Magyarország északkeleti régiójának, illetve a mai Kárpátalja helység-, víz- és dülőneveinek a gyüjtésével és feldolgozásával foglalkozik. Több monográfiája és szótára jelent meg a régió helységneveinek etimológiájáról, valamint a Felső-Tisza-vidék víz- és dủlőneveiröl. Ímél: sebestyen.zsolt@nye.hu.

Slíz Mariann PhD, habilitált egyetemi docens, az ELTE Eötvös Loránd Tudományegyetem Magyar Nyelvtudományi és Finnugor Intézet Magyar Nyelvtörténeti, Szociolingvisztikai, Dialektológiai Tanszékének munkatársa. 2004-től az ELTE oktatója. PhD-értekezését 2010-ben védte meg, 2016-ban habilitált. A Magyar Nyelvtudományi Társaság Névtani tagozatának titkára, a Névtani Értesítő szerkesztője. Fő kutatási területe a névtan, elsősorban a személynévtörténet, a névelmélet, az alkalmazott névtan és az írói névadás. Írásainak jelentős része történeti személynévkutatással foglalkozik. Két magyar történeti személynévszótár szerzője, a Dictionary of Medieval Names from European Sources címủ nemzetközi online személynévszótár magyar szerkesztője. Ímél: sliz.marianna@btk.elte.hu.

Szilágyi-Kósa Anikó PhD, egyetemi docens, 1998-2007 között a veszprémi Pannon Egyetem Alkalmazott Nyelvészeti Tanszékének, majd Germanisztikai és Fordítástudományi Intézetének, 2007-től pedig a Károli Gáspár Református Egyetem Német Nyelv és Irodalom Tanszékének oktatója. A magyarországi németek névhasználatáról szóló PhD-értekezését 2008-ban védte meg. Fő kutatási területe a névtan, elsősorban a magyarországi német névanyag vizsgálata és kontrasztív névtani kutatások, valamint a kisebbségtudomány (magyarországi németek) és a kontrasztív frazeológia. Ímél: kosa.aniko@kre.hu.

Takács Judit PhD, egyetemi docens, az Eszterházy Károly Egyetem Magyar Nyelvészeti Tanszékének oktatója. 2004-2016 között a Debreceni Egyetem Finnugor Nyelvtudományi Tanszékének, azóta pedig az Eszterházy Károly Egyetem munkatársa. Doktori disszertációját magyar névtanból 2006-ban védte meg. Fő kutatási területe a finnugor nyelvészet terén a magyar nyelv eredetének oktatásmódszertana, névtanból pedig a személynevek jelentésváltozása, az általános és alkalmazott névtan. Publikációiban gyakorlati szempontból is foglalkozik a tulajdonnévből származó apellatív adatok szótárazásának problémájával. Ímél: takacs.judit@uni-eszterhazy.hu. 
A kiadásért az együttmüködő intézmények vezetői felelnek Kiadta az ELTE Magyar Nyelvtudományi és Finnugor Intézete és a Magyar Nyelvtudományi Társaság Címük: 1088 Budapest, Múzeum krt. 4/A

Nyomta és kötötte: Kódex Könyvgyártó Kft., Budapest

Felelős vezető: Marosi Attila 